Ca anduron

Bibliography

of North American

Geology 1949

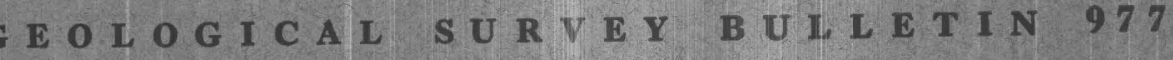

$$
8149
$$
CILIC 


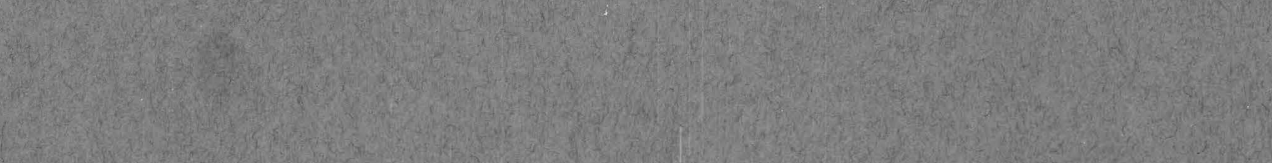

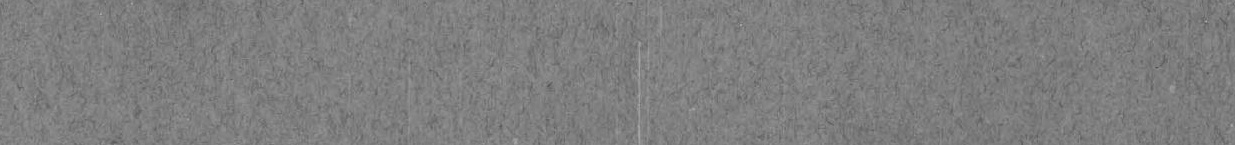

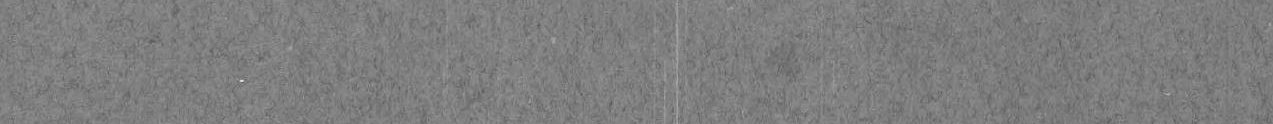

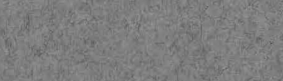

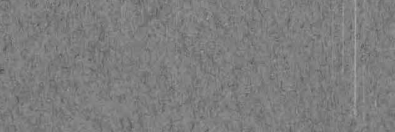

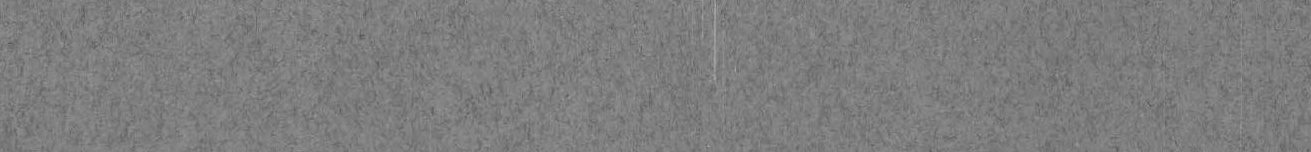
A (1)

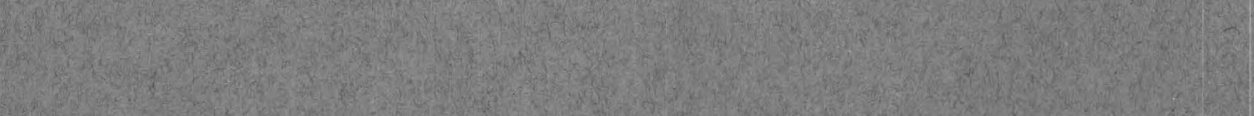

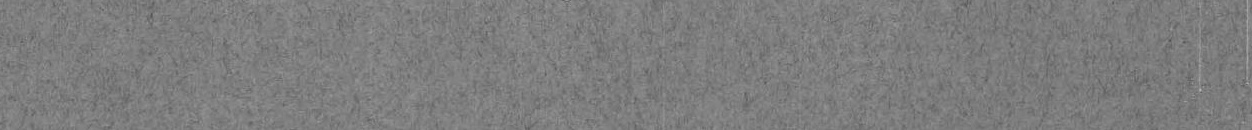
1.5.

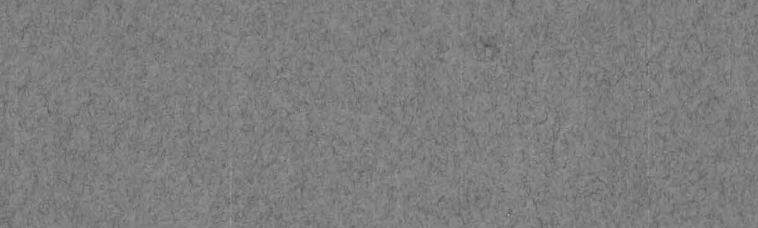

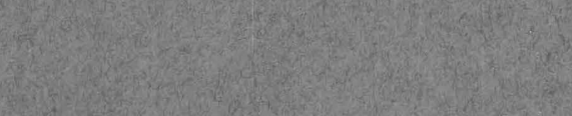

$(x+1)$

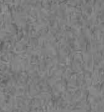

$\left(\frac{1}{10}\right.$

(2)

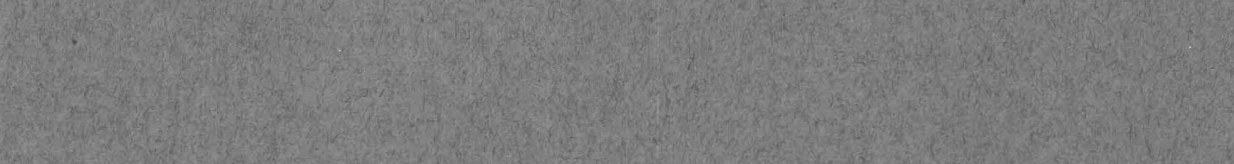
3.

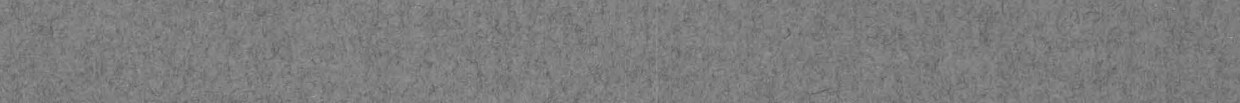

H.

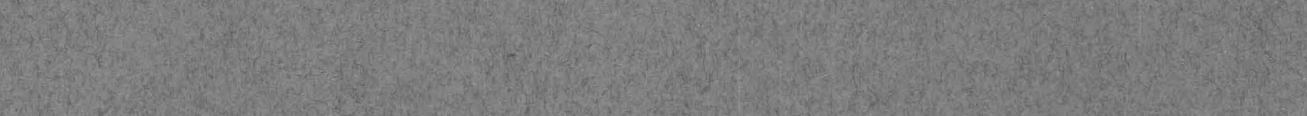
M.

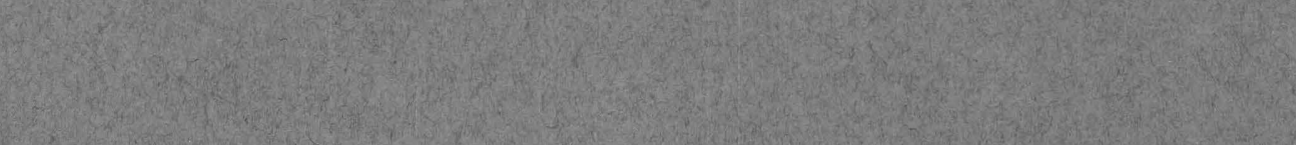

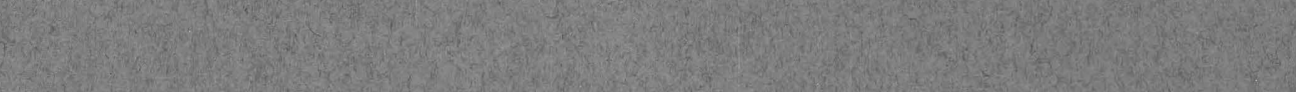

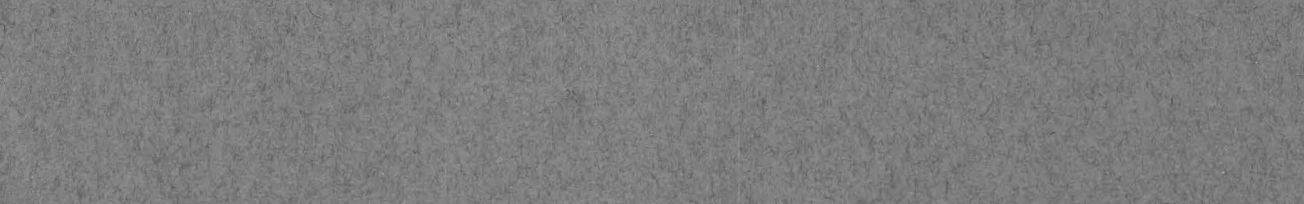

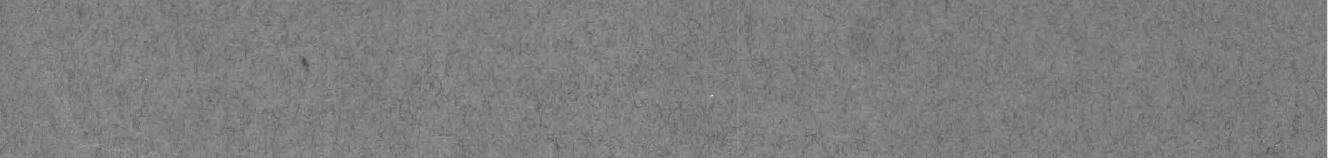




\section{Bibliography}

of North American

\section{Geology 1949}

By EMMA MERTINS THOM, MARJORIE HOOKER and RUTH REECE DUNAVEN

G E O L O G I C A L S U R V E Y B U L L E T I N 977

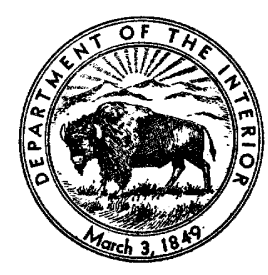




\section{UNITED STATES DEPARTMENT OF THE INTERIOR}

Oscar L. Chapman, Secretary

\section{GEOLOGICAL SURVEY}

W. E. Wrather, Director 


\section{CONTENTS}

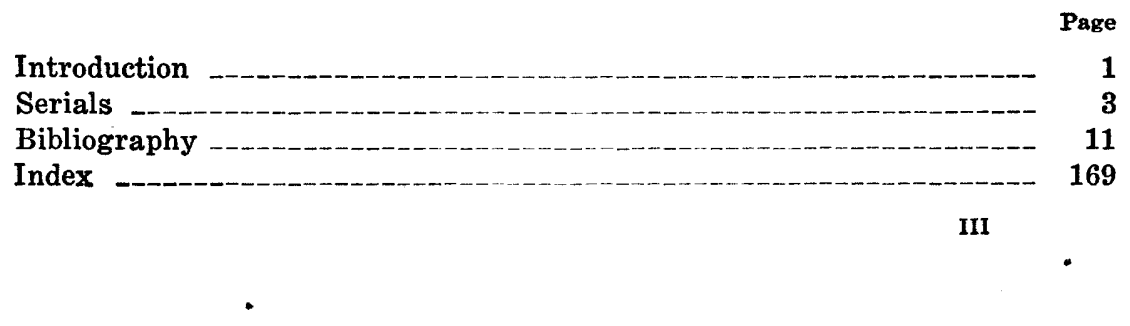





\title{
BIBLIOGRAPHY OF NORTH AMERICAN GEOLOGY
}

\section{9}

\author{
By Emma Mertins Thom, Marjorie Hooker, \\ and \\ Ruth Reece Dunaven

\section{INTRODUCTION}

The bibliography of North American geology, including paleontology, petrology, and mineralogy, for the year 1949, lists publications on the geology of the Continent of North America and adjacent islands and on Panama, the Hawaiian Islands, and the Island of Guam. It includes textbooks and papers of a general character by American authors, but not papers by foreign authors, except those that appear in American publications.

The papers, with full title and medium of publication, are listed under the names of their authors, which are arranged in alphabetical order. The author list is followed by an index to the literature cited.

The bibliography of North American geology to the end of 1947 is contained in the following bulletins of the United States Geological Survey: 746 and 747 (1785-1918) and 823 (1919-28), by John M. Nickles; 937 (1929-39), 938 (1940-41), 949 (1942-43), and 952 (1944-45), by Emma Mertins Thom; 958 (1946-47) and 968 (1948), by Emma Mertins Thom Mariorie Hooker, and Ruth Reece Dunaver 



\section{SERIALS}

The following list gives both the abbreviated citation and the full name of the periodicals and serials which have been examined in the preparation of the bibliography. The place of publication is also given.

Acad. Nac. Cienc. Mem. Rev.-Academia Nacional de Ciencias, Memorias y Revista. Mexico City.

Acad. Nat. Sci. Phila. Notulae Naturae; Proc--Academy of Natural Sciences of Philadelphia Notulae Naturae; Proceedings. Philadelphia, $\mathrm{Pa}$.

Acta Crystallographica-Acta Crystallographica. Cambridge, England.

Ala. Geol. Survey Bull.; Mus. Paper; Spec. Rpt._Alabama Geological Survey Bulletin; Museum Paper; Special Report. University, Ala.

Alaska Dept. Mines Pamph._Alaska Department of Mines Pamphlets. College, Alaska.

Alberta Research Coun. Rpt.-Alberta Research Council Reports. Edmonton, Alberta.

Am. Acad. Arts and Sci. Proc.-American Academy of Arts and Sciences Proceedings. Boston, Mass.

Am. Alpine Jour.-American Alpine Journal. New York.

Am. Antiquity - American Antiquity. Menasha, Wis.

Am. Assoc. Petrol. Geol. Bull.-American Association of Petroleum Geologists Bulletin. Tulsa, Okla.

Am. Ceramic Soc. Bull.; Jour.-American Ceramic Society Bulletin; Journal. Columbus, Ohio.

Am. Geophys. Union Trans.-American Geophysical Union Transactions. Washington.

A. I. M. E. Trans.-American Institute of Mining and Metallurgical Engineers Transactions. New York.

Am. Jour. Botany-American Journal of Botany. Lancaster, Pa.

Am. Jour. Sci.-American Journal of Science. New Haven, Conn.

Am. Midland Naturalist-American Midland Naturalist. Notre Dame, Ind.

Am. Mineralogist American Mineralogist. Ann Arbor, Mich.

Am. Mus. Nat. History Bull.; Novitates-American Museum of Natural History Bulletin; Novitates. New York.

Am. Philos. Soc. Proc.; Trans.-American Philosophical Society Proceedings; Transactions. Philadelphia, Pa.

Am. Sci.-American Scientist. New Haven, Conn.

Am. Water Works Assoc. Jour.-American Water Works Association Journal. New York.

Appalachia-Appalachia. Boston, Mass.

Appalachian Geol. Soc. Bull.-Appalachian Geological Society Bulletin. Charleston, W. Va.

Arctic_-Arctic. Montreal.

Ariz. Bur. Mines Bull., Geol. Ser.; Circ-_-Arizona Bureau of Mines Bulletin, Geologic Series; Circular. Tucson, Ariz.

Ark. Res. Dev. Comm. Div. Geology Bull._-Arkansas Resources and Development Commission, Division of Geology, Bulletin. Little Rock, Ark.

Ark. State Geologist Ann. Rpt.—Arkansas State Geologist, Annual Report. Little Rock, Ark.

Assoc. Am. Geog. Annals-Association of American Geographers Annals. Lancaster, Pa.

Assoc. Canadienne-Française Av. Sci. Annales-Association CanadienneFrançaise pour l'Avancement des Sciences Annales. Montreal. 
Augustana Library Pub._Augustana Library Publications. Rock Island, Ill.

Auk-The Auk. Lancaster, Pa.

Black Hills Eng._-Blacks Hills Engineer. Rapid City, S. Dak.

Bot. Gazette-Botanical Gazette. Chicago.

Bot. Rev.-Botanical Review. Lancaster, Pa.

British Columbia Dept. Mines Ann. Rpt.; Bull._-British Columbia Department of Mines Annual Report; Bulletin. Victoria, B. C.

Buffalo Soc. Nat. Sci. Bull.—Buffalo Society of Natural Sciences Bulletin. Buffalo, N. Y.

Bull. Am. Paleontology-Bulletins of American Paleontology. Ithaca, N. Y.

Butler Univ. Bot. Studies-Butler University Botanical Studies. Indianapolis, Ind.

Calif. Acad. Sci. Proc.-California Academy of Sciences Proceedings. San Francisco, Calif.

Calif. Dept. Nat. Res. Div. Mines Bull.-California Department of Natural Resources, Division of Mines Bulletin. Sacramento, Calif.

Calif. Dept. Public Works, Water Res. Div. Bull. California Department of Public Works, Water Resources Division Bulletin. Sacramento, Calif.

Calif. Jour. Mines and Geology-California Journal of Mines and Geology. Sacramento, Calif.

Calif. Oil Fields-California Oil Fields. San Francisco, Calif.

Calif. Univ. Dept. Geol. Sci. Bull.—California University, Department of Geological Sciences Bulletin. Berkeley, Calif.

Calif. Univ., Pub. in Zoology-California University, Publications in Zoology. Berkeley, Calif.

Calif. Univ. Seismog. Sta. Bull.-California University Seismographic Station Bulletin. Berkeley, Calif.

Calif. Univ. Scripps Inst. Oceanog. Submarine Geology Rpt.-California University, Scripps Institution of Oceanography, Submarine Geology Report. La Jolla, Calif.

Canada Bur. Mines, Mines and Geology Br., Memo. ser.-Canada Bureau of Mines, Mines and Geology Branch, Memorandum series. Ottawa.

Canada Geol. Survey Bull.; Mem.; Paper-Canada Geological Survey Bulletin; Memoir; Paper. Ottawa.

Canada Dominion Óbservatory Pub. - Canada Dominion Observatory Publications. Ottawa.

Canada Natl. Mus. Bull._Canada National Museum Bulletin. Ottawa.

Canadian Alpine Jour.-Canadian Alpine Journal. Banff, Alberta.

Canadian Field-Naturalist_-Canadian Field-Naturalist. Ottawa.

Canadian Geog. Jour.-Canadian Geographical Journal. Montreal.

Canadian Inst. Min. Met. Trans.-Canadian Institute of Mining and Metallurgy Transactions. Montreal.

Canadian Min. Met. Bull._Canadian Mining and Metallurgical Bulletin. Montreal.

Canadian Min. Jour.-Canadian Mining Journal. Gardenvale, Quebec.

Carnegie Inst. Washington Pub.-Carnegie Institution of Washington Publications, Washington.

Carnegie Mus. Annals-Carnegie Museum Annals. Pittsburgh, Pa.

Chicago Acad. Sci. Bull. Chicago Academy of Science Bulletin. Chicago.

Ciencia-Ciencia. Mexico City.

Colo. Sch. Mines Quart._Colorado School of Mines Quarterly. Golden, Colo.

Colo. Sci. Soc. Proc.-Colorado Scientific Society Proceedings. Denver, Colo.

Colo.-Wyo. Acad. Sci. Jour.-Colorado-Wyoming Academy of Science Journal. Boulder, Colo.

Compass-The Compass. Menasha, Wis.

Condor-The Condor. Berkeley, Calif.

Conn. Acad. Arts Sci. Trans.-Connecticut Academy of Arts and Sciences Transactions. New Haven, Conn.

Conn. Geol. Nat. History Survey Bull.; Misc. Ser.-Connecticut Geological and Natural History Survey Bulletin; Miscellaneous Series. Hartford, Conn. 
Crystallographic Soc. Am. Mem.-Crystallographic Society of America Memoirs. Irvington-on-Hudson, N. Y.

Cushman Lab. Foram. Research Contr.; Spec. Pub.-Cushman Laboratory for Foraminiferal Research, Contributions; Special Publications. Sharon, Mass.

Denison Univ. Sci. Lab. Jour.-Denison University Scientific Laboratories Journal. Granville, Ohio.

Desert Mag. - Desert Magazine. El Centro, Calif.

Earth Sci. Digest-Earth Science Digest. Revere, Mass.

Earthquake Notes_-Earthquake Notes. Washington.

Ecol. Mon.-Ecological Monographs. Durham, N. C.

Ecology-Ecology. Brooklyn, N. Y.

Econ. Geology Economic Geology. Urbana, Ill.

Econ. Geology Mon.-Economic Geology Monographs. Urbana, Ill.

Elisha Mitchell Sci. Soc. Jour._Elisha Mitchell Scientific Society Journal. Chapel Hill, N. C.

Eng. Jour.-Engineering Journal. Montreal.

Eng. Min. Jour.-Engineering and Mining Journal. New York.

Evolution-Evolution. Lancaster, $\mathrm{Pa}$.

Field \& Lab.—Field \& Laboratory. Dallas, Texas.

Fieldiana; Botany-Fieldiana; Botany. Chicago.

Fieldiana; Geology_-Fieldiana; Geology. Chicago.

Fieldiana; Zoology_-Fieldiana; Zoology. Chicago.

Fla. Acad. Sci. Quart. Jour._- Florida Academy of Sciences, Quarterly Journal. Gainesville, Fla.

Fla. Geol. Survey Inf. Circ._-Florida Geological Survey Information Circular. Tallahassee, Fla.

Frontiers-Frontiers. Philadelphia, Pa.

Gems and Gemology-Gems and Gemology. Los Angeles.

Geog. Rev.-Geographical Review. New York.

Geol. Soc. Am. Bull.; Interim Proc.; Mem.; Proc.-Geological Society of America Bulletin; Interim Proceedings; Memoir; Proceedings. New York.

Geophysics-Geophysics. Austin, Texas.

Ga. Geol. Survey Bull.-Georgia Geological Survey Bulletin. Atlanta, Ga.

Glacier Nat. History Assoc. Spec. Bull.-Glacier Natural History Association Special Bulletin. Belton, Mont.

Harvard Coll. Mus. Comp. Zoology Bull._-Harvard College Museum of Comparative Zoology Bulletin. Cambridge, Mass.

Harvard Univ. Bot. Mus. Leaflets-Harvard University Botanical Museum Leaflets. Cambridge, Mass.

Hopper-The Hopper. Norman, Okla.

Idaho Bur. Mines and Geology Pamph._- Idaho Bureau of Mines and Geology Pamphlets. Moscow, Idaho.

Ill. State Acad. Sci. Trans.-Illinois State Academy of Science Transactions. Springfield, Ill.

Ill. State Geol. Survey Bull.; Circ.; Ill. Petrol.; Rpt. Inv.-Illinois State Geological Survey Bulletin; Circular; Illinois Petroleum; Report of Investigations. Úrbana, Ill.

Ill. State Mus. Sci. Paper-Illinois State Museum Scientific Papers. Springfield, Ill.

Ill. State Water Survey Div. Rpt. Inv.-Illinois State Water Survey Division Report of Investigations. Urbana, Ill.

Ill. Univ. Eng. Expt. Sta. Circ.-Illinois University Engineering Experiment Station Circular. Urbana, Ill.

Ind. Acad. Sci. Proc.-Indiana Academy of Science Proceedings. Indianapolis, Ind.

Ind. Dept. Conserv. Div. Geology Rpt. Prog.-Indiana Department of Conservation, Division of Geology, Report of Progress. Bloomington, Ind.

Ing. Hidráulica México-Ingeniería Hidráulica en México. Mexico City. 
Iowa Acad. Sci. Proc.-Iowa Academy of Science Proceedings. Des Moines, Iowa.

Iowa Univ. Pubs., Studies Nat. History-_-Iowa University Publications, Studies in Natural History. Iowa City, Iowa.

Jour. Geology_Journal of Geology. Chicago.

Jour. Mammalogy - Journal of Mammalogy. Baltimore, Md.

Jour. Marine Research—Journal of Marine Research. New Haven, Conn.

Jour. Metals-Journal of Metals. New York.

Jour. Paleontology-Journal of Paleontology. Tulsa, Okla.

Jour. Petrol. Tech.—Journal of Petroleum Technology. Dallas, Texas.

Jour. Sed. Petrology_Journal of Sedimentary Petrology. Menasha, Wis.

Kans. Acad. Sci. Trans.-Kansas Academy of Sciences Transactions. Topeka, Kans.

Kans. Univ. Mus. Nat. History-Kansas University Museum of Natural History. Lawrence, Kans.

Kans. Univ. Paleont. Contr.-Kansas University Paleontological Contributions. Lawrence, Kans.

Kans. Univ. Sci. Bull.-Kansas University Science Bulletin. Lawrence, Kans.

Kans. Univ., State Geol. Survey Bull.; Oil and Gas Inv.-Kansas University, State Geological Survey Bulletin; Oil and Gas Investigations. Lawrence, Kans.

Ky. Acad. Sci. Trans.-Kentucky Academy of Science Transactions. Lexington, $\mathrm{Ky}$.

Ky. Univ. Research Club Bull.-Kentucky University Research Club Bulletin. Lexington, $\mathrm{Ky}$.

Los Angeles Mus. Quart.-Los Angeles Museum Quarterly. Los Angeles.

La. Geol. Survey Bull.-Louisiana Geological Survey Bulletin. New Orleans, La.

Maine Geol. Survey Bull.-Maine Geological Survey Bulletin. Augusta, Maine.

Maine State Geologist Rpt._-Maine State Geologist Report. Orono, Maine. Manitoba Dept. Mines and Nat. Res., Mines Br. Bull.; Prelim. Rpt.-Manitoba Department of Mines and Natural Resources, Mines Branch Bulletin; Preliminary Report. Winnipeg, Manitoba.

Md. Dept. Geology, Mines and Water Res. Bull.; County Rpt.-Maryland Department of Geology, Mines and Water Resources Bulletin; County Report. Baltimore, Md.

Maryland Naturalist_-Maryland Naturalist. Baltimore, Md.

Mazama-Mazama. Portland, Oregon.

Meddelelser om Grønland-Meddelelser om Grønland. Copenhagen, Denmark.

Meteor. Soc. Contr.-Meteoritical Society Contributions. Los Angeles, Calif.

México Inst. Nac. Inv. Rec. Miner. Bol.-México Instituto Nacional para la Investigación de los Recursos Minerales de México Boletín. Mexico Gity.

Mich. Acad. Sei. Papers-Michigan Academy of Science, Arts and Letters Papers. Ann Arbor, Mich.

Mich. Geol. Survey Pub., Geol. Ser.; Tech. Rpt.-Michigan Geological Survey Publications, Geological Series; Technical Reports. Lansing, Mich.

Mich. Miner. Soc. Yearb.-Michigan Mineralogical Society Yearbook. Bloomfield Hills, Mich.

Mich. Univ. Mus. Paleontology Contr-_Michigan University Museum of Paleontology Contributions. Ann Arbor, Mich.

Micropaleontologist-The Micropaleontologist. New York.

Mil. Eng.-Military Engineer. Washington.

Mineral Industries-Mineral Industries. State College, Pa.

Mineralogist-The Mineralogist. Portland, Oregon.

Min. Cong. Jour.-Mining Congress Journal. Washington.

Min. Eng. - Mining Engineering. New York. 
Min. Met. Soc. Am. Bull.-_-Mining and Metallurgical Society of America Bulletin. New York.

Mines Mag.-Mines Magazine. Golden, Colo.

Minn. Geol. Survey Bull.-Minnesota Geological Survey Bulletin. Minneapolis, Minn.

Miss. Geol. Soc. Field Trip Guidebook-Mississippi Geological Society Field Trip Guidebooks. Jackson, Miss.

Miss. Geol. Survey Bull._-Mississippi Geological Survey Bulletin. Jackson, Miss.

Mo. Bot. Garden Annals-Missouri Botanical Garden Annals. Fulton, Mo.

Mo. Geol. Survey and Water Res. Inf. Circ.; Rpt. Inv.-Missouri Geological Survey and Water Resources Information Circular; Report of Investigations. Rolla, Mo.

Mo. Univ., Sch. Mines and Metallurgy Bull. Tech. Ser.-Missouri University, School of Mines and Metallurgy Bulletin, Technical Series. Rolla, Mo.

Mo. Univ. Studies-Missouri University Studies. Columbia, Mo.

Mont. Acad. Sci. Proc.-Montana Academy of Sciences Proceedings. Missoula, Mont.

Mont. Bur. Mines and Geology Mem.-Montana Bureau of Mines and Geology Memoirs. Butte, Mont.

Natl. Acad. Sci. Biog. Mem.; Proc.; Sci. Mem.-National Academy of Sciences, Biographical Memoirs; Proceedings; Scientific Memoirs. Washington.

Natl. Research Council, Div. Geol. and Geog.-National Research Council, Division of Geology and Geography. Washington.

Natl. Speleol. Soc. Bull._National Speleological Society Bulletin. Washington.

Nat. History-Natural History. New York.

Naturaliste Canadien.-Le Naturaliste Canadien. Quebec City.

Nature Mag.-Nature Magazine. Washington.

Nautilus - The Nautilus. Philadelphia, Pa.

Nev. State Engineer's Office, Water Res. Bull.-Nevada State Engineer's Office, Water Resources Bulletin. Carson City, Nev.

Nev. Univ. Bull., Geology and Mining Ser.-Nevada University Bulletin, Geology and Mining Series. Reno, Nev.

N. H. State Plan. Dev. Comm. Mineral Res. Survey-New Hampshire State Planning and Development Commission, Mineral Resource Survey. Concord, N. H.

N. J. Dept. Conserv., Geol. Ser. Bull--New Jersey Department of Conservation and Development, Geologic Series Bulletin. Trenton, N. J.

N. Mex. Bur. Mines and Mineral Res. Bull.; Circ.; Ground-water Rpt.-New Mexico Bureau of Mines and Mineral Resources Bulletin; Circular; Ground-water Reports. Socorro, N. Mex.

N. Mex. Univ. Pub. Geology-New Mexico University Publications in Geology, Albuquerque, N. Mex.

N. Y. Acad. Sci. Annals; Trans.-New York Academy of Sciences Annals; Transactions. New York.

N. Y. State Mus. Bull.-New York State Museum Bulletin. Albany, N. Y.

N. Y. State Science Service Rpt. Inv. - New York State Science Service Report of Investigations. Albany, N. Y.

N. Y. Water Power and Control Comm. Bull.-New York Water Power and Control Commission Bulletin. Albany, N. Y.

Newfoundland Geol. Survey Bull.; Inf. Circ.-Newfoundland Geological Survey Bulletin; Information Circular. St. Johns, Newf.

N. C. Dept. Conserv. Dev., Div. Mineral Res. Bull.; Inf. Circ. - North Carolina Department of Conservation and Development, Division of Mineral Resources Bulletin; Information Circular. Raleigh, N. C.

N. Dak. Geol. Survey Bull.; Ground-water Studies; Rpt. Inv.-North Dakota Geological Survey Bulletin; Ground-water Studies; Report of Investigations. Grand Forks, N. Dak.

Northwest Sci. - Northwest Science. Cheney, Wash.

Nova Scotia Dept. Mines Ann. Rpt.-Nova Scotia Department of Mines Annual Report. Halifax, N. S. 
Nova Scotian Inst. Sci. Proc.-Nova Scotian Institute of Science Proceedings. Halifax, N. S.

Ohio Geol. Survey Bull.; Inf. Circ.; Rpt. Inv.-Ohio Geological Survey Bulletin; Information Circular; Report of Investigations. Columbus, Ohio.

Ohio Jour. Sci.—Ohio Journal of Science. Columbus, Ohio.

Ohio State Univ. Eng. Expt. Sta. News-Ohio State University Engineering Experiment Station News. Columbus, Ohio.

Ohio Water Res. Bd. Bull.-Ohio Water Resources Board Bulletin. Columbus, Ohio.

Oil and Gas Jour._-Oil and Gas Journal. Tulsa, Okla.

Okla. Acad. Sci. Proc.-Oklahoma Academy of Science Proceedings. Norman, Okla.

Okla. Geol. Survey Bull.; Circ.; Mineral Rpt.-Oklahoma Geological Survey Bulletin; Circular; Mineral Report. Norman, Okla.

Ontario Dept. Mines Ann. Rpt.; Press Release-Ontario Department of Mines Annual Report; Toronto.

Oreg. Dept. Geology and Mineral Industries Bull.; G.M.I. Short PaperOregon Department of Geology and Mineral Industries Bulletin; G.M.I. Short Paper. Portland, Oreg.

Oreg. State Coll. Studies in Geology-Oregon State College Studies in Geology. Corvallis, Oreg.

Pacific Sci._Pacific Science. Honolulu.

Palaeontographica Americana-Palaeontographica Americana. Ithaca, N. Y.

Peabody Found. Archaeology Papers-Peabody Foundation for Archaeology Papers. Andover, Mass.

Pa. Acad. Sci. Proc.-Pennsylvania Academy of Science Proceedings. Harrisburg, $\mathrm{Pa}$.

Pa. Dept. Int. Affairs Monthly Bull.-Pennsylvania Department of Internal Affairs Monthly Bulletin. Harrisburg, Pa.

Pa. Geol. Survey, 4th ser., Bull. Pennsylvania Geological Survey, 4th series, Bulletin. Harrisburg, Pa.

Pa. State Coll. Mineral Indus. Expt. Sta. Bull.; Circ.; Tech. Paper-Pennsylvania State College Mineral Industries Experiment Station Bulletin; Circular; Technical Paper. State College, Pa.

Pa. State Coll. Sch. Mineral Indus. Tech. Rpt. Pennsylvania State College School of Mineral Industries Technical Report. State College, Pa.

Petroleo Interamericano-Petroleo Interamericano. Tulsa, Okla.

Petrol. Eng.-Petroleum Engineer. Dallas, Texas.

Photogrammetric Engineering-Photogrammetric Engineering. Washington.

Plateau-Plateau. Flagstaff, Ariz.

Pop. Astronomy-Popular Astronomy. Northfield, Minn.

Precambrian - The Precambrian. Winnipeg, Manitoba.

Producers Monthly-Producers Monthly. Bradford, Pa.

Quebec Dept. Mines, Geol. Surveys Br., Geol. Rpt.-Quebec Department of Mines, Geological Surveys Branch, Geological Reports. Quebec City.

Quebec Dept. Mines, Mineral Deposits Br., Prelim. Rpt.-Quebec Department of Mines, Mineral Deposits Branch, Preliminary Reports. Quebec City.

Rev. Soc. Haïtienne Hist. Géog.—-Revue de la Société Haïtienne d'Histoire, de Géographie. Port-au-Prince.

R. I. Port Indus. Dev. Comm. Geol. Bull.; Sci. Contr.-Rhode Island Port and Industrial Development Commission, Geological Bulletin; Scientific Contribution. Providence, R. I.

Rochester Acad. Sci. Proc.-Rochester Academy of Science Proceedings. Rochester, N. Y.

Rocks and Minerals-Rocks and Minerals. Peekskill, N. Y.

Royal Canadian Inst. Proc.; Trans.- Royal Canadian Institute Proceedings; Transactions. Toronto. 
Royal Ontario Mus. Paleontology Contr.-Royal Ontario Museum of Paleontology Contributions. Toronto.

Royal Soc. Canada Proc.; Trans.-Royal Society of Canada Proceedings; Transactions. Ottawa.

Rutgers Univ. Bur. Mineral Research Bull.-Rutgers University Bureau of Mineral Research Bulletin. New Brunswick, N. J.

San Diego Soc. Nat. History Trans.-San Diego Society of Natural History Transactions. San Diego, Calif.

Science-Science. Lancaster, Pa.

Sci. Am.-Scientific American. New York.

Sci. Monthly-Scientific Monthly. New York.

Seismol. Soc. Am. Bull.-Seismological Society of America Bulletin. Berkeley, Calif.

Sierra Club Bull.- Sierra Club Bulletin. San Francisco, Calif.

Smithsonian Inst. Ann. Rpt.; Misc. Coll. Smithsonian Institution Annual Report; Miscellaneous Collection. Washington.

Soc. Cubana Ing. Rev.- Sociedad Cubana de Ingenieros, Revista. Habana.

Soc. Cubana Historia Nat. Mem.-Sociedad Cubana de Historia Natural, Memorias. Habana.

Soc. Geol. Mexicana Bol.- Sociedad Géológica Mexicana Boletín. Mexico City.

Soil Sci. - Soil Science. Baltimore, Md.

S. Dak. Geol. Survey Rpt. Inv.—-South Dakota Geological Survey Report of Investigations. Vermillion, S. Dak.

S. Calif. Acad. Sci. Bull.- Southern California Academy of Sciences Bulletin. Los Angeles, Calif.

Staten Island Inst. Arts Sci. Proc.-Staten Island Institute of Arts and Sciences Proceedings. Staten Island, N. Y.

Tenn. Acad. Sci. Jour.-Tennessee Academy of Science Journal. Nashville, Tenn.

Tenn. Dept. Conserv. Div. Geology Bull.-Tennessee Department of Conservation, Division of Geology Bulletin. Nashville, Tenn.

Texas Arch. Paleont. Soc. Bull.-Texas Archeological and Paleontological Society Bulletin. Abilene, Texas.

Texas Geog. Mag.-Texas Geographic Magazine. Dallas, Texas.

Texas Jour. Sci.-Texas Journal of Science. San Marcos, Texas.

Texas State Bd. Water Eng. [Rpt.] - Texas State Board of Water Engineers [Reports]. Austin, Texas.

Texas Univ. Bur. Econ. Geology Pub.; Rpt. Inv.-Texas University, Bureau of Economic Geology Publications; Report of Investigations. Austin, Texas.

Torreia, Museo Poey, Univ. Habana-Torreia, Museo Poey, Universidad de la Habana. Habana, Cuba.

Torrey Bot. Club Bull.-Torrey Botanical Club Bulletin. Menasha, Wis. Tulsa Geol. Soc. Digest-Tulsa Geological Society Digest. Tulsa, Okla.

U. S. Bur. Mines Bull.; Inf. Circ.; Rpt. Inv.; Tech. Paper-United States Bureau of Mines Bulletin; Information Circular; Report of Investigations; Technical Paper. Washington.

U. S. Bur. Recl. Petrog. Lab. Rpt.-United States Bureau of Reclamation, Petrographic Laboratory Report. Denver, Colo.

U. S. Geol. Survey Bull.; Circ.; Geol. Quad. Map; Geophys. Inv.; Index to Geol. Mapping; Oil and Gas Inv.; Prof. Paper; Water-Supply Paper -United States Geological Survey Bulletin; Circular; Geologic Quadrangle Map; Geophysical Investigations; Index to Geologic Mapping; Oil and Gas Investigations; Professional Paper; Water-Supply Paper. Washington.

U. S. Natl. Mus. Bull.; Proc.-United States National Museum Bulletin; Proceedings. Washington.

Utah Acad. Sci. Proc.-Utah Academy of Sciences, Arts and Letters Proceedings. Provo, Utah.

Utah Dept. Pub. Indus. Dev. Bull.; Circ._Utah Department of Publicity and Industrial Development Bulletin; Circular. Salt Lake City, Utah. 
Utah Geol. Miner. Survey-Utah Geological and Mineralogical Survey.

Utah Geol. Soc. Guidebook-Utah Geological Society Guidebooks. Salt Lake City, Utah.

Va. Acad. Sci. Proc_-Virginia Academy of Science Proceedings. Charlottesville, Va.

Va. Geol. Survey Bull._-Virginia Geological Survey Bulletin. Charlottesville, Va.

Volcano Letter-The Volcano Letter. Honolulu.

Wagner Free Inst. Sci. Bull.-Wagner Free Institute of Science of Philadelphia Bulletin. Philadelphia, Pa.

Washington Azad. Sci. Jour.-Washington Academy of Sciences Journal. Washington.

Wash. Dept. Conserv. Dev. Div. Mines and Geology Bull.; Inf. Circ.; Rpt. Inv. - Washington Department of Conservation and Development, Division of Mines and Geology Bulletin; Information Circular; Report of Investigations. Olympia, Wash.

W. Va. Acad. Sci. Proc. West Virginia Academy of Sciences Proceedings. Morgantown, W. Va.

W. Va. Geol. Survey [Rpt.] —West Virginia Geological Survey [Reports]. Morgantown, W. Va.

West Texas Geol. Soc. Guidebook-West Texas Geological Society Guidebooks.

Western Miner-Western Miner. Vancouver, British Columbia.

World Oil-World Oil. Houston, Texas.

World Petroleum-World Petroleum. New York.

Wyo. Geol. Survey Bull._Wyoming Geological Survey Bulletin. Laramie, Wyo.

Yale Univ. Peabody Mus. Nat. History Bull.__ Yale University, Peabody Museunn of Natural History Bulletin. New Haven, Conn. 


\title{
BIBLIOGRAPHY
}

\author{
[A double dagger $(\ddagger)$ indicates material reproduced by means other than \\ ordinary printing.]
}

\section{Abbott, M. L.}

A paleobotanical pull method [abs.]: Am. Jour. Botany, v. 36, no. 10, p. 817-818, Dec. 1949.

Abernethy, Roy Franklin. See Cooper, H. M., 1, 2.

Ableiter, J. Kenneth.

Obituary, Alfred Paul Dachnowski-Stokes, .1875-1949: Washington Acad. Sci. Jour., v. 39, no. 10, p. 348-349, Oct. 15, 1949.

Adams, C. E. See Tunell, G., 2.

Adamson, John Howard, Jr.

1. (and Graham, Jack Bennett, and Klein, N. H.). Ground-water resources of the valley-fill deposits of Allegheny County, Pennsylvania: Pa. Geol. Survey, 4th ser. Bull. W8, 181 p.(\$), illus., 1949.

2. Ground water significance in Pittsburgh area: Pa. Dept. Int. Affairs Monthly Bull., v. 17, no. 10, p. 26-32, Sept. 1949.

Addington, Arch Rombough.

Miniature cauldrons [abs.]: Geol. Soc. Am. Bull., v. 60, no. 12, pt. 2, p. 1935, Dec. 1949.

Addy, Richard V.

Cambrian stratigraphy of the southern Front Range, Colorado [abs.]: Geol. Soc. Am. Bull., v. 60, no. 12, pt. 2, p. 1959, Dec. 1949.

\section{Agnich, Fred Joseph.}

Geophysical exploration for limestone reefs: Geophysics, v. 14, no. 4, p. $486-500$, illus., Oct. 1949 ; abs., no. 3, p. 447, July 1949; Oil and Gas Jour., v. 47 , no. 46, p. 108, Mar. 17, 1949.

\section{Agocs, W. B.}

1. Sea-bottom slope determination from water sound arrivals: Geophysics, v. 14, no. 2, p. 123-132, illus., Apr. 1949.

2. Curves for the rapid determination of refraction seismograph velocity intervals and critical distances: Geophysics, v. 14 , no. 3, p. 361-368, illus., July.1949.

\section{Aguayo, Carlos Guillermo.}

1. Nuevos moluscos fósiles de la Republica Dominicana: Soc. Malacológica "Carlos de la Torre" Rev., v. 6, no. 3, p. 91-92, illus., June 30, 1949.

2. Nuevos moluscos fósiles de Cuba y Panamá: Soc. Malacológica "Carlos de la Torre" Rev., v. 7, no. 1, p. 11-14, illus., Sept. 30, 1949.

3. Sobre el Miocene de Somorrostro, Habana: Soc. Malacológica "Carlos de la Torre" Rev., v. 7, no. 1, p. 20, Sept. 30, 1949.

\section{Ahlmann, Hans Wilhelmson.}

Glaciological research on the North Atlantic coasts: Royal Feog. Soc., Research ser. no. 1, 83 p., illus. incl. index map, 1948. 
Ahrens, Louis $\mathbf{H}$.

1. Geological age; the extreme antiquity of pegmatites from Manitoba: Nature (London), v. 160, no. 4077, p. 874-875, Dec. 20, 1947.

2. Measuring geologic time by the strontium method: Geol. Soc. Am. Bull., v. 60 , no. 2, p. 217-266, illus., Feb. 1949 .

3. Report to Committee on measurement of geologic time: Natl. Research Council, Div. Geol. and Geog., Rpt. of the Committee on the measurement of geologic time, 1948-1949, Exhibit D, p. 75-78 (\$), Dec. 1949.

Ahrens, Thomas P. See Irwin, W. H., 6.

Akin, Philmore Donald. See Dennis, P. E.

Albanese, John P.

Peridotite body in the Laramie Mountains, Wyoming [abs.]: Geol. Soc. Am. Bull., v. 60 , no. 12 , pt. 2, p. 1959 , Dec: 1949.

Albers, J. P. See Kinkel, A. R., Jr.

Albrecht, Herbert 0.

Comments on limonitic "fulgurites": Rocks and Minerals, v. 24, nos. 11-12, p. 606-607, Nov.-Dec. 1949.

Albritton, Claude Carroll, Jr. See also Smith. J. F., Jr., 1, 2.

1. (and Smith, Joe Fred, Jr.). Sedimentary rocks of Permian age in the northwestern Marfa Basin, Hudspeth County, Texas [abs.]: Geol. Soc. Am. Bull., v. 60, no. 12, pt. 2, p. 1869, Dec. 1949.

2. (and others). Structural features associated with lead and zinc ores of the Goodspring:s district, Nevada [abs.]: Geol. Soc. Am. Bull. v. 60, no. 12 , pt. 2, p. 1869-1870, Dec. 1949.

Alcock, Frederick James. See also Canada Geol. Survey., 9.

1. Geology, in One hundred years of science in Canada: The Royal Canadian Institute Centennial Volume, 1849-1949, p. 61-70, 1949.

2. A classification of gneisses: Royal Soc. Canada Trans. 3d ser., v. 43, sec. 4, p. 1-5, June 1949; abs., Proc. 3d ser., v. 43, p. $239,1949$.

Alexander, Charles Ivan.

Core descriptions [Mississippi-Gulf Oil Company No. 1 Pope, Covington County, Miss.], in Mississippi Geological Society Guidebook, Sixth Field Trip, June 18-20, 1948, p. 49-51 ( $\$), 1948$.

Alexander, Walter Herbert, Jr. See also Broadhurst, W. L., 1.

1. (and Broadhurst, William L., and White, Walter Noy). Progress report on ground, water in the High Plains in Texas: Texas State Bd. Water Eng. [Rpt.] no. 3, 34 p. ( $\ddagger)$, illus., Apr. 1943.

2. (and Lang, Joseph Winford). Ground water in High Plains of Texas, Progress Report No. 5: Texas State Bd. Water Eng. [Rpt.] no. 5, 29 p. (\$), illus., May 1945.

Alkire, Robert Leo.

1. Oil and gas fields of Ohio: Ohio Geol. Survey map. Scale 1 inch to 6 miles. 1948.

2. Deep tests in Ohio: Producers Monthly, v. 13, no. 8, p. 26-28, illus., June 1949.

Allaway, W. H. See Riecken, F. F.

Alldredge, L. R.

(and Keller, Fred, Jr.). Preliminary report on magnetic anomalies between Adak, Alaska, and Kwajalein, Marshall Islands: Am. Geophys. Union Trans., v. 30, no. 4, p. 494-500, illus. incl. index maps, Aug. 1949.

Allen, Henry W. See Pratt, E. S. 
Allen, Maxine W. See Keefer, E. K.; U. S. G. S. 1, no. 107.

Allen, Rhesa McCoy, Jr.

1. Virginia; geology unlimited: Compass, v. 26 , no. 3, p. 233-241, illus., Mar. 1949.

2. A suggested origin for the Shelby County, Alabama, limonite ores: Econ. Geology, v. 44, no. 4, p. 278-285, illus. incl. index, geol. maps, June-July 1949.

Allen, Simeon A. See Ruhl, 0.

Allen, Victor Thomas.

1. (and Frank, Albert J., and Fahey, Joseph John). Mineralogical and bacterial content of some Paleozoic shales of Missouri [abs.]: Oil and Gas Jour., v. 47, no. 46, p. 151, Mar. 17, 1949.

2. Leucoxene problem [abs.]: Geol. Soc. Am. Bull., v. 60, no. 12, pt. 2, p. 1870 , Dec. 1949 .

Allen, William Burrows.

1. (and Jeffords, Russell MacGregor). Ground-water resources in the vicinity of Exeter, Rhode Island: R. I. Port Indus. Dev. Comm., Sci. Contr. 2, 42 p., illus. incl. index map, 1948.

2. Ground-water resources of the Pawtucket quadrangle, Rhode Island and Massachusetts, in The geology and ground-water resources of the Pawtucket quadrangle, Rhode Island: R. I. Indus. Comm., Geol. Bull. 3, p. 38-85, illus. incl. geol. map, 1948.

Allison, Ira Shimmin. See also Emmons, W. H.

Fault pattern of south-central Oregon [abs.]: Geol. Soc. Am. Bull., v. 60, no. 12 , pt. 2, p. 1935 , Dec. 1949.

Allsman, Paul Trekell. See Horton, F. W.

Almond, Hy. See Lakin, H. W.

Alvarez, Manuel, Jr.

Tectonics of México: Am. Assoc. Petrol. Geol. Bull., v. 33, no. 8, p. 13191335, illus., Aug. 1949; abs., v. 32, no. 12, p. 2312, 2314, Dee. 1948; Oil and Ģas Jour., v. 47, no. 25, p. 129, Oct. 21, 1948.

Ambrose, John Willis.

Are the "Bolton" lavas of post-Devonian age? [abs.]: Royal Soc. Canada Proc. 3d ser., v. 43, p. 239, 1949.

American Commission on Stratigraphic Nomenclature.

Report 1, Declaration on naming of subsurface stratigraphic units: Am. Assoc. Petrol. Geol. Bull., v. 33, no. 7, p. 1280-1282, July 1949.

American Institute of Mining and Metallurgical Engineers.

Industrial minerals and rocks (nonmetallics other than fuels). $\mathrm{x}, 1156 \mathrm{p}$, illus. New York, 1949. Contains 51 chapters by specialists in the field of nonmetallic mineral industry.

American Institute of Mining and Metallurgical Engineers, Southwestern New Mexico Section. See West Texas Geological Society, 4 .

American Mining Congress, Coal Division, Committee on Roof Action.

Geologic considerations of roof support: Min. Cong. Jour., v. 35, no. 12, p. 45-48, illus., Dec. 1949.

American Society for Testing Materials.

Symposium on mineral aggregates (1948): Am. Soc. Testing Materials Spec. Tech. Pub. 83, 233 p., illus., Oct. 1948. Contains 15 papers dealing with the distribution, characteristics and uses of mineral aggregates.

$904979^{\circ}-51-2$ 


\section{Ammon, Walter Lamm.}

1. Pennsylvanian reef in Lawson-Chapman area, Haskell County, Texas: Tulsa Geol. Soc. Digest, v. 17, p. 67, 1949.

2. (and Dorbandt, Leslie Winston, and Stovall, John H.). Developments [in oil and gas] in north and west-central Texas in 1948: Am. Assoc. Petrol. Geol. Bull., v. 33, no. 6, p. 935-944, index map, June 1949.

Amsden, Thomas William.

1. Stratigraphy and paleontology of the Brownsport formation (Silurian) of western Tennessee: Yale Univ., Peabody Mus. Nat. History Bull. 5, 138 p., illus., 1949.

2. Two new genera of brachiopods from the Henryhouse formation (Silurian) of Oklahoma: Washington Acad. Sci. Jour., v. 39, no. 6, p. 202-203, June 15, 1949.

\section{Anderson, Alfred Leonard.}

1. Silver-gold deposits of the Yankee Fork district, Custer County, Idaho: Idaho Bur. Mines and Geology Pamph. 83, 37 p., illus. incl. index, geol. maps [Feb. 1949].

2. Monzonite intrusion and mineralization in the Coeur d'Alene district, Idaho: Econ. Geology, v. 44, no. 3, p. 169-185, illus., May 1949; abs., Geol. Soc. Am. Bull., v. 59, no. 12, pt. 2, p. 1308, Dec. 1948.

Anderson, Charles Alfred.

Older Precambrian structure in Arizona [abs.]: Geol. Soc. Am. Bull., v. 60, no. 12 , pt. 2, p. 1870 , Dec. 1949.

\section{Anderson, Eskil.}

1. Mineral occurrences other than gold deposits in northwestern Alaska: Alaska Dept. Mines Pamph. no. 5-R, 48 p., index map, May 1944 (revised Mar. 1947).

2. Asbestos and jade occurrences in the Kobuk River region, Alaska: Alaska Dept. Mines Pamph. no. 3-R, 26 p., illus. incl. index map, May 1945 (revised to Dec. 1945).

\section{Anderson, Judson Lowell.}

1. Explorations for oil and gas in Maryland: Appalachian Geol. Soc. Bull., v. 1, p. $67-70,1949$.

2. Pseudotachylite of the Antietam quartzite [Md.]: Am. Mineralogist, v. 34, nos. 3-4, p. 331-334, illus., Mar.-Apr. 1949.

Anderson, Kenneth F. See Carpenter, C. B.

Anderson, Robert Edwin.

(and Redwine, Lowell Edwin, and McGovney, Paul E.). Geology of northern Santa Rosa Island [Calif.] [abs.]: Am. Assoc. Petrol. Geol. Bull., v. 33, no. 12, p. 2062, Dec. 1949; Oil and Gas Jour., v. 48, no. 29 , p. 140 , Nov. 24,1949 .

Andrews, Henry Nathaniel, Jr. See also Mamay, S. H.

1. Fossil tree ferns of Idaho: Archaeology, v. 1, no. 4, p. 190-195, illus., Winter 1948.

2. Nucellangium, a new genus of fossil seeds previously assigned to Lepidocarpon: Mo. 'Bot. Garden Annals, v. 36, no. 4, p. 479-505, illus., Nov. 1949.

3. A study of the fossils known as Lepidocarpon glabrum [abs.]: Am. Jour. Botany, v. 36, no. 10, p. 818, Dec. 1949.

Antevs, Ernst Valdemar.

1. The Great Basin, with emphasis on glacial and post-glacial times; 3 , Climatic changes and pre-white man: Utah Univ, Bull., v. 38, no. 20 (Biol. ser., v. 10, no. 7), p. 168-191, illus., June 30, 1949.

2. Age of the last pluvial in New Mexico and Texas [abs.]: Geol. Soc. Am. Bull., v. 60, no. 12, pt. 2, p. 1871, Dec. 1949. 
Anthony, Harold Elmer.

Nature's deep freeze: Nat. History, v. 58, no. 7, p. 296-301, illus., Sept. 1949.

Anthony, John W. See Feth, J. H., 1.

Applin, Paul Livingston.

Preliminary report on buried pre-Mesozoic rocks in Florida and adjacent states [abs.] : Am. Assoc. Petrol. Geol. Bull., v. 33, no. 12, p. 20702071, Dec. 1949.

Arellano, Alberto R. V.

1. The Becerra formation (latest Pleistocene) of central Mexico [abs.]: 18th Internat. Geol. Cong., London, Volume of titles and abstracts, p. $74,1948$.

2. (and Azcón, Ernesto). Pre-Equus horses from Goleta (Morelia) Michoacan, Mexico [abs.]: Geol. Soc. Am. Bull., v. 60 , no. 12 , pt. 2 , p. 1871, Dec. 1949.

Argall, George 0., Jr.

Industrial minerals of Colorado: Colo. Sch. Mines Quart., v. 44, no. 2, 477 p., illus., Apr. 1949.

Arkansas Resources and Development Commission, Division of Geology.

Arkansas, oil and gas-wildcat wells and producing areas in the southern half of the state [map]. Scale 1 inch to 3 miles. 1949.

Armstrong, Herbert Stoker. See Satterly, J., 1.

Armstrong, John Edward. See also Canada Geol. Survey, 3, 4.

Fort St. James map-area, Cassiar and Coast districts, British Columbia: Canada Geol. Survey Mem. 252, 210 p., illus. incl. index, geol. map, 1949.

Arnett, G. Ray.

Geology of the Lytle Creek area, California: Compass, v. 26, no. 4, p. 285, 294-304, illus. incl. index, geol. maps, May 1949.

Arnett, R. A. See Heroy, W. B., Jr.

Arnold, Chester Arthur.

1. The fossil fern Osmundites oregonensis [Oreg.]: Mineralogist, v. 17, no. 5, p. 233-235, illus., May 1949.

2. Fossil flora of the Michigan coal basin: Mich. Univ., Mus. Paleontology Contr., v. 7, no. 9, p. 131-269, illus., Dec. 29, 1949.

3. Fruits of Koelreuteria from the John Day series of Oregon [abs.] : Am. Jour. Botany, v. 36, no. 10, p. 818, Dec. 1949.

Arnow, Theodore.

The ground-water resources of Albany County, New York: N. Y. Water Power and Control Comm. Bull. GW-20, 56 p., illus. incl. index, geol. maps, 1949.

Arrhenius, G. See Phleger, F. B., Jr., 1.

Arthur, Marion A.

Method of preserving wet, fragile geologic specimens: Jour. Sed. Petrology, v. 19 , no. 3 , p. $131-134$, illus., Dec. 1949 .

\section{Ashley, George Hall.}

The new coal age: Econ. Geology, v. 44, no. 3, p. 161-168, May 1949; abs., Geol. Soc. Am. Bull., v. 58, no. 12, pt. 2, p. 1164, Dec. 1947.

Atwood, Wallace Walter, 1872-1949.

A geologist looks at the Quetico-Superior area: Canadian Geog. Jour., v. 39, no. 1, p. 36-43, illus. incl. index map, July 1949. 
Aubert de la Rüe, Edgar.

1. Preliminary report on the Lac des Trente-et-un-milles area, Gatineau and Labelle Counties [Quebec]: Quebec Dept. Mines Prelim. Rpt. 196,17 p. (\$), index, geol. maps, 1947.

2. Preliminary report on McGill Township area, Papineau, Labelle and Gatineau Counties [Quebec]: Quebec Dept. Mines Prelim. Rpt. 215, 14 p. (\$), index, geol. maps, 1948 .

Auger, Paul Emile.

1. Preliminary report on Belleterre map-area (Sheet No. 1), Guillet Township, Témiscamingue County [Quebec]: Quebec Dept. Mines Prelim. Rpt. 194, 12 p. $(\ddagger)$, geol. map, 1946.

2. Preliminary report on Belleterre map-area (Sheet No. 2), Guillet Township, Témiscamingue County [Quebec]: Quebec Dept. Mines Prelim. Rpt. 203, 21 p. (\$), geol. map, 1947.

3. Preliminary report on Belleterre map-area (Sheet No. 3), Blondeau Township, Témiscamingue County [Quebec]: Quebec Dept. Mines Prelim. Rpt. 209, 15 p. ( $\ddagger$, geol. map, 1947.

\section{Averitt, Paul.}

1. Analyses of Iowa coals; Iowa coal fields: U. S. Bureau Mines Tech. Paper 706, p. 1-5, geol. map, 1949.

2. Work of the U. S. Geological Survey on coal and coal reserves: Min. Eng., v. 1, no. 6, p. 224-228, discussion, p. 227-228, June 1949; A.I.M.E. Trans. v. 184, 1949.

Axeirod, Daniel. 1 .

1. [Discussion], in Longwell, C. R., chm., Sedimentary facies in geologic history [symposium]: Geol. Soc. Am. Mem. 39, p. 155-164, illus., June 17, 1949.

2. Eocene and Oligocene formations in the western Great Basin [abs.]: Geol. Soc. Am. Bull., v. 60, no. 12, pt. 2, p. 1935-1936, Dec. 1949.

Axelrod, Joseph Meyer.

1. (and Grimaldi, Frank Saverio). Muscovite with small optic axial angle: Am. Mineralogist, v. 34, nos. 7-8, p. 559-572, illus., July-Aug. 1949.

2. (and others). Uranium minerals from the Hillside mine, Yavapai County, Arizona [abs.]: Am. Mineralogist, v. 34, nos. 3-4, p. 274, Mar.-Apr. 1949.

Azcón, Ernesto. See Arellano, A. R. V., 2.

\section{Bader, Henri.}

1. (and Wolfe, Peter Edward). The lime marl deposit of Vincentown, New Jersey: Rutgers Univ. Bur. Mineral Research Bull. 3, 24 p., illus., 1948.

2. A definition of Euclidean geometrical symmetry: Am. Mineralogist, v. 34, nos. 3-4, p. 226-228, Mar.-Apr. 1949.

3. Screw axes of symmetry and their symbols: Am. Mineralogist, v. 34, nos. $9-10$, p. $752-756$, Sept.-Oct. 1949.

Baer, Francis $M$.

(and Martin, William H.). Some new finds of fossil ganoids in the Virginia Triassic: Science, v. 110 , no. 2869 , p. $684-686$, illus. incl. index map, Dec. 23, 1949.

Bailey, Donald A.

A note on the conversion of amorphous silica to quartz: Am. Mineralogist, v. 34, nos. 7-8, p. 601-605, illus., July-Aug. 1949.

Bailey, E. B.

Meteorites or springs as geological agents: Nature (London), v. 154, no. 3908, p. 383-385, illus., Sept. 23, 1944. 
Bailey, Reginald King.

Talc in the salines of the potash field near Carlsbad, Eddy County, New Mexico; Am. Mineralogist, v. 34 , nos. 9-10, p. 757-759, Sept.-Oct. 1949.

Bailey, Sturges W.

Liquid inclusions in granite thermometry: Jour. Geology, v. 57, no. 3, p. 304-307, May 1949.

\section{Bailly, René J.}

(and Holke, Kenneth A.) Microscope and refractometer for infra-red light [abs.]: Geol. Soc. Am. Bull., v. 60 , no. 12, pt. 2, p. 1871-1872, Dec. 1949.

Baker, Arthur Alan.

(and Huddle, John Warfield, and Kinney, Douglas Merrill). Paleozoic geology of north and west sides of Uinta Basin, Utah: Am. Assoc. Petrol. Geol. Bull., v. 33, no. 7, p. 1161-1197, illus. incl. index map, July 1949.

\section{Baker, Manley Benson.}

Dr. E[verend] L[ester] Bruce, [1884-1949]: Canadian Min. Jour., v. 70, no. 12 , p. 76-77, Dec. 1949.

Baldwin, Ewart Merlin.

(and Howell, Paul W.). The Long Tom, a former tributary of the Siuslaw River [Oreg.]: Northwest Sci., v. 23, no. 3, p. 112-124, illus., Aug. 1949: abs., no. 1, p. 42, Feb. 1949.

\section{Baldwin, Ralph B.}

The craters of the moon: Sci. Am., v. 181, no. 1, p. 20-24, illus., July 1949.

Baldwin, Thomas Armet.

San Ardo [oil field, Calif.], a stratigraphic analysis [abs.]: Am. Assoc. Petrol. Geol. Bull., v. 33, no. 12, p. 2058, Dec. 1949; Oil and Gas Jour., v. 48 , no. 29 , p. 134 , Nov. $24,1949$.

Baldwin, Walter Brewster.

A preliminary report on the Sioux quartzite [S. Dak.]: S. Dak. Geol. Survey Rpt. Inv. 63, 34 p. ( $\ddagger)$, illus., Jan. 1949.

\section{Balk, Robert.}

Structure of Grand Saline salt dome, Van Zandt County, Texas: Am. Assoc. Petrol. Geol. Bull., v. 33, no. 11, p. 1791-1829, illus. incl. index map, Nov. 1949.

\section{Ballmer, Gerald Jacob.}

Geology of the Santa Rita area [N. Mex.], in West Texas Geological Society Guidebook Field Trip no. 3, November 6-9, 1949, p. 26-27, geol. map, 1949.

Balsley, James Robinson, Jr.

(and James, Harold Lloyd, and Wier, Kenneth L.). Aeromagnetic survey of parts of Baraga, Iron, and Hudspeth Counties, Michigan, with preliminary geologic interpretation [profiles and text]: U. S. Geol. Survey, Geophys. Inv., 1949.

\section{Bandy, Orville Lee.}

1. Eocene and Oligocene Foraminifera from Little Stave Creek, Clarke County, Alabama: Bull. Am. Paleontology, v. 32, no. 131, 210 p., illus. incl. index map, Mar. 4, 1949.

2. New names for two species of Foraminifera from Little Stave Creek, Clarke Co., Alabama: Jour. Paleontology, v. 23, no. 4, p. 440, July 1949 .

3. Ontogenetic variation in Eponides mexicanus (Cushman) [abs.]: Geol. Soc. Am. Bull., v. 60, no. 12, pt. 2, p. 1949, Dec. 1949. 
Barghoorn, Elso Sterrenberg, Jr. See also Spackman, W., Jr.

1. (and others). The Boylston Street Fishweir II, a study of a site on Stuart Street in the Back Bay district of Boston, Massachusetts: Peabody Foundation for Archaeology Papers, v. 4, no. 1, 133 p., illus., 1949.

2. Paleobotanical studies of the Fishweir and associated deposits [Boston, Mass.]: Peabody Foundation for Archaeology Papers, v. 4, no. 1, p. 49-83, illus., 1949.

3. (and Spackman, William, Jr.). A preliminary study of the flora of the Brandon lignite [Vt.]: Am. Jour. Sci., v. 247, no. 1, p. 33-39, Jan. 1949.

4. Degradation of plant remains in organic sediments: Harvard Univ. Bot. Mus. Leaflets, v. 14, no. 1, 20 p., illus., June 27, 1949; abs., Am. Jour. Botany, v. 36, no. 10, p. 831-832, Dec. 1949.

5. Geological and botanical study of the Brandon [Vt.] lignite and its significance in coal petrology [abs.]: Econ. Geology, v. 44, no. 7, p. 644-645, Nov. 1949; Geol. Soc. Am. Bull., v. 60 , no. 12, pt. 2, p. 1872, Dec. 1949.

Barker, Clarence S. See Fitch, C. A., Jr.

\section{Barksdale, Julian Devreau.}

1. Stratigraphy in the Methow quadrangle, Washington: Northwest Sci., v. 22 , no. 4, p. 164-176, Nov. 1948; abs. with title "Geology of the Methow quadrangle, Washington", Geol. Soc. Am. Bull., v. 58, no. 12 , pt. 2 , p. 1247-1248, Dec. 1947.

2. Volcanic rocks in the Candelaria district, west-central Nevada [abs.]: Geol. Soc. Am. Bull., v. 60, no. 12, pt. 2, p. 1936, Dec. 1949.

Barksdale, William L. See Black, R. F

Barlow, A. C. See Irwin, W. H., 6.

Barnes, Carleton $P$.

W[alter] Elmer Ekblaw, 1882-1949; Assoc. Am. Geog. Annals, v. 39, no. 4, p. 294-295, port., Dec. 1949.

\section{Barnes, Farrell Francis.}

Coal investigations on the southern margin of the Homer district, Kenai coal field, Alaska, in 1947-1948: U. S. Geol. Survey [Mineral deposits of Alaska, short preliminary reports], $12 \mathrm{p} .(\$)$, illus. incl. index, geol. maps, Dec. 1949.

Barnes, Frank C.

1. Structures of the San Juan Basin [Colo.-N. Mex.]: Oil and Gas Jour., v. 47, no. 48, p. 97-100, illus., Mar. 31, 1949.

2. Developments in the San Juan Basin of Colorado and New Mexico: Oil and Gas Jour., v. 48, no. 7 , p. 154, 157, 159, 162, illus. incl. index map, June 23, 1949.

\section{Barnes, Jack Rich.}

(and others). Geology and ground water in the irrigated region of the Southern High Plains in Texas, with a section on Quality of water by Burdge Irelan: Texas State Bd. Water Eng., Prog. Rpt. 7, 51 p. $(\$)$, illus. incl. geol. map, Mar. 1949.

\section{Barnes, Roy Merrill.}

1. George Clark Gester, honorary member: Am. Assoc. Petrol. Geol. Bull., v. 33 , no. 5 , p. 767-769, port., May 1949.

2. Roy Edward Collom (1881-1948) ; Am. Assoc. Petrol. Geol. Bull., v. 33, no. 5, pp. 772-774, port., May 1949. 
Barnes, Virgil Everett. See also Romberg, F., 2.

1. (and Goldich, Samuel Stephen, and Romberg, Frederick), Iron ore in the Llano region, central Texas: Texas Univ., Bur. Econ. Geology Rpt. Inv. 5, 50 p., illus. incl. index, geol. maps, Apr. 1949.

2. (and Mathis, Robert W., and Romberg, Frederick). Gravity prospecting for lead and zinc, New Mexico [abs.]: 18th Internat. Geol. Cong., London, Volume of titles and abstracts, p. 24, 1948; Geophysics, v. 14, no. 3, p. 371, July 1949.

\section{Barnes, William Howard.}

1. The unit cell and space group of childrenite: Am. Mineralogist, v. 34, nos. 1-2, p. 12-18, illus., Jan.-Feb. 1949.

2. The unit cell and space group of probertite: Am. Mineralogist, v. 34, nos. 1-2, p. 19-25, illus., Jan.-Feb. 1949; correction, nos. 7-8, p. 611-612, July-Aug. 1949.

3. The unit cell and space group of lindgrenite: Am. Mineralogist, v. 34, nos. 3-4, p. 163-172, illus., Mar.-Apr. 1949; correction,nos. 7-8, p. 611-612, July-Aug. 1949 .

4. Some comments on the Buerger precession method for the determination of unit cell constants and space groups: Am. Mineralogist, v. 34, nos. 3-4, p. 173-180, illus., Mar.-Apr. 1949.

Barr, Charles R. See Henderson, C. F.

\section{Barret, William Morris}

Exploring the earth with radio waves: World Petroleum, v. 20, no. 4, p. 52-53, illus., Apr. 1949.

\section{Barshad, Isaac.}

The nature of lattice expansion and its relation to hydration in montmorillonite and vermiculite: Am. Mineralogist, v. 34, nos. 9-10, p. 675-684, illus., Sept.-Oct. 1949.

Barth, Thomas Fredrik Weybye. See also Bloss, F. D.

1. The distribution of oxygen in the lithosphere: Jour. Geology, v. 56, no. 1 , p. 41-49, illus., Jan. 1948; abs., Geol. Soc. Am. Bull., v. 58, no. 12 , pt. 2, p. 1166, Dec. 1947; Am. Mineralogist, v. 33, nos. 3-4, p. 193, Mar.-Apr. 1948; discussion by Ivan Th. Rosenqvist, Jour. Geology, v. 57, no. 4, p. 420-423, 425, July 1949; author's reply, p. $423-425$.

2. Oxygen in rocks, a basis for petrographic calculations: Jour. Geology, v. 56, no. 1 , p. 50-60, illus., Jan. 1948; discussion by Ivan Th. Rosenqvist, v. 57, no. 4, p. 420-423, July 1949; author's reply, p. $425-427$.

3. (and Rosenqvist, Terkel). Thermodynamic relations of immiscibility and crystallization of molten silicates: Am. Jour. Sci., v. 247, no. 5, p. 316-323, illus., May 1949.

Bartlett, Z. W.

Salt and sulphur resources of Texas: Texas Acad. Sci. Trans., 1945, v. 29, p. 186-191, 1946.

\section{Bartley, Jerald $H$.}

Simpson group, west Texas and southeastern New Mexico [abs.]: Geol. Soc. Am. Bull., v. 60, no. 12, pt. 2, p. 1872-1873, Dec. 1949.

\section{Bartram, John Greer.}

(and Imbt, William C., and Shea, Edward F.). Occurrence of oil and gas in the Arbuckle and Ellenburger formations [abs.]: Tulsa Geol. Soc. Digest, v. 17, p. 53-57, illus., 1949.

\section{Bartz, Patricia McBride.}

Ground water in California ; the present state of our knowledge: Calif. Univ., Agr. Expt. Sta., Ground Water Studies, no. 1, 67 p. (\$), Sept. 1949. 
Bascom, W. N. See Isaacs, J. D.

Bassler, Ray Smith.

Glacial varved clay concentrations of New England: Smithsonian Inst. Ann. Rpt. 1948, p. 269-276, illus. [1949].

Bastin, Edson Sunderland.

Deposition and resolution of native silver at Gowganda, Ontario: Econ. Geology, v. 44, no. 5, p. 437-444, illus., Aug. 1949.

Bateman, Ernest S.

The famous petrified wood Russell forests of Washington: Rocks and Minerals, v. 24, nos. 1-2, p. 18-23, illus., Jan.-Feb. 1949.

Bateman, John Danvers. See also Jenness, J. L.

1. Prospecting with the Geiger counter: Canadian Min. Met. Bull. no. 445, p. 222-227, illus., May 1949; Canadian Inst. Min. Met. Trans., v. 52 , p. 111-116, 1949 .

2. Permafrost at Giant Yellowknife [Northwest Territories]: Royal Soc. Canada Trans. 3d ser., v. 43, sec. 4, p. 7-11, illus., June 1949; abs., Proc. 3d ser., v. 43, p. 239, 1949.

Bateman, Paul C.

The relationship of contact-metamorphic tungsten deposits to regional geology in the Bishop district, California [abs.]: Econ. Geology, v. 44 , no. 1 , p. 79 , Jan.-Feb. 1949.

Bates, Thomas Fulcher.

1. The electron microscope applied to geological research: N. Y. Acad. Sci. Trans., ser. 2, v. 11, no. 4, p. 100-107, illus., Feb. 1949.

2. (and Hildebrand, Fred A., and Swineford, Ada). Electron microscopy of the kaolin minerals [abs.]: Am. Mineralogist, v. 34, nos. 3-4, p. 274, Mar.-Apr. 1949.

\section{Baulig, Henri.}

La vallée et le delta du Mississippi: Annales Géog. no. 311, 58 ann., p. 220-232, illus., July-Sept. 1949: no. 312, p. 325-334, illus., Oct.Dec. 1949.

\section{Baxter, Robert W.}

Some pteridosperm stems and fructifications with particular reference to the Medullosae: Mo. Bot. Garden Annals, v. 36, no. 3, p. 287-353, illus., Sept. 1949.

\section{Bayles, Robert Ellery.}

Subsurface Upper Devonian sections in southwestern Pennsylvania: Am. Assoc. Petrol. Geol. Bull., v. 33, no. 10, p. 1682-1703, illus. incl. index, geol. sketch maps, Oct. 1949 ; abs., v. 32 , no. 11, p. 2161 , Nov. 1948; Oil and Gas Jour., v. 47, no. 24, p. 90, Oct. 14, 1948.

\section{Beard, Charles Noble.}

Stratigraphy and structure of the Capitola quadrangle, California [abs.]: Geol. Soc. Am. Bull., v. 60, no. 12, pt. 2, p. 1936, Dec. 1949.

Bearman, Charles Henry. See Byrne, F. E., 1, 3.

Beath, Orville Andrew. See Trelease, S. F.

Beck, Carl W.

1. (and La Paz, Lincoln). A preliminary report on the mineralogy of the Norton County, Kansas-Furnas County, Nebraska, achondrite $(1000,400)$ : Pop. Astronomy, v. 57, no. 2, p. 85-88, Feb. 1949; Meteor. Soc. Contr., v. 4, no. 3, p. 176-179, 1949.

2. (and La Paz, Lincoln). The Weatherford, Oklahoma, meteorite $(\mathrm{ECN}=+988,358):$ Pop. Astronomy, v. 57, no. 9, p. 450-454, illus., Nov. 1949; Meteor. Sóc. Contr., v. 4, no. 3, p. 216-220, illus., 1949. 
Beck, Henry Vorhees. See Byrne, F. E., 1, 2.

Beck, William August. See Kline, M. H.

Beebe, Byron Warren.

Geologic responsibility in seismic exploration: Tulsa Geol. Soc. Digest, v. 17 , p. $74-77,1949$, abs., Oil and Gas Jour., v. 48, no. 29, p. 132, Nov. 24, 1949.

Behre, Charles Henry, Jr. See also Stark, J. T.

1. (and Heyl, Allen Van, Jr., and McKnight, Edwin Thor). Zinc and lead deposits of the Mississippi Valley, in Dunham, K. C., ed., Symposium on the geology, paragenesis and reserves of the ores of lead and zinc, 18th Internat. Geol. Cong., London, p. 46-61, illus., 1948; abs., Volume of titles and abstracts, p. 40-41, 1948.

2. Slate, in Industrial minerals and rocks, p. 927-944, illus., 1949.

3. (and others). Patterns of ore deposition in Mexico [abs.]: Econ. Geology, v. 44, no. 7, p. 638-639, Nov. 1949.

4. (and Fries, Carl, Jr.). Gemorphic events of east-central Mexico [abs.]: Geol. Soc. Am. Bull., v. 60, no. 12, pt. 2, p. 1873, Dec. 1949.

Bejnar, Waldemere.

Lithologic control of ore deposits in the San Juan Mountains, Colorado: Compass, v. 26, no. 2, p. 117-130, illus. incl. geol. sketch map, Jan. 1949.

\section{Béland, J.}

Etude de la structure d'une bande de roches métasédimentaires à l'aide de la linéation suivant l'axe $b$ [abs.]: Assoc. Canadienne-Française Av. Sci. Annales v. 15, p. 67-69, 1949.

Béland, René.

1. Preliminary report on Taibi Lake area, Abitibi-East County [Quebec]: Quebec Dept. Mines Prelim. Rpt. 192, 8 p. ( $\$)$, geol. map, 1946.

2. Preliminary report on the Allard River area, Abitibi-East County [Quebec]: Quebec Dept. Mines Prelim. Rpt. 213, 13 p. ( $\$)$, index, geol. maps, 1948.

8. Preliminary report on the Rawdon area, Montcalm and Joliette Counties [Quebec]: Quebec Dept. Mines Prelim. Rpt. 226, 10 p. (\$), index, geol. maps, 1948.

4. Synthèse des argents rouges dans des solutions de sulfures alcalins [abs.]: Assoc. Canadienne-Française Av. Sci. Annales v. 15, p. 72, 1949.

\section{Bell, Alfred Hannam.}

1. (and Leighton, Morris Morgan). Prospects for oil discoveries in Illinois beyond proven areas and from deeper horizons: Ill. State Geol. Survey Circ. 150,5 p. $(\ddagger)$, illus. incl. index, geol. sketch maps, 1949.

2. (and Esarey, Ralph Emerson, and Brooks, Barbara Ellen). Developments [in oil and gas] in Illinois and Indiana in 1948: Am. Assoc. Petrol. Geol. Bull., v. 33, no. 6, p. 866-876, index map, June 1949; reprinted as Ill. State Geol. Survey, Ill. Petrol., no. 59, July 30, 1949.

3. (and Kline, Virginia Harriett). Oil and gas development in Illinois in 1948: Ill. State Geol. Survey, Ill. Petrol. no. 60, 53 p., Oct. 22, 1949.

Bell, Mendell M. See Hansen, G. H.

Bell, Walter Andrew.

Uppermost Cretaceous and Paleocene floras of western Alberta: Canada Geol. Survey Bull. 13, 231 p., illus., 1949. 
Benioff, Hugo. See also Gutenberg, B., 5.

1. Earthquakes and rock creep (continued) [abs.]: Geol. Soc. Am. Bull., v. 60, no. 12, pt. 2, p. 1936-1937, Dec. 1949.

2. Directional characteristics of strain seismograph pairs [abs.]: Geol. Soc. Am. Bull., v. 60 , no. 12 , pt. 2 , p. 1953 , Dec. 1949.

Bennett, William Alfred Glenn. See Glover, S. L., 1.

Benson, William Edward Barnes.

Golden Valley formation of North Dakota [abs.]: Geol. Soc. Am. Bull., v. 60 , no. 12 , pt. 2 , p. $1873-1874$, Dec. 1949.

Berg, John Robert.

Developments [in oil and gas] in north mid-Continent in 1948: Am. Assoc. Petrol. Geol. Bull., v. 33, no. 6, p. 883-891, index map, June 1949.

Bergquist, Harlan Richard.

Geology of the Woodbine formation of Cooke, Grayson, and Fannin Counties, Texas [geologic map and text]: U. S. Geol. Survey Oil and Gas Inv. Prelim. Map 98 (2 sheets). Scale 1 inch to 1 mile. 1949.

Berkey, Charles Peter. See Holland, W. Y., 1.

Berliner, Miles Howard.

Investigation of the Harding tantalum-lithium deposits, Taos County, N. Mex: U. S. Bur. Mines Rpt. Inv. 4607, 7 p. $(\ddagger)$, illus., Dec. 1949.

\section{Berman, Joseph.}

Petrographic examination and strength tests of drill core samples, Angostura dam, Angostura unit [S. Dak.], Missouri Basin project: U. S. Bur. Recl. Petrog. Lab. Rpt. 87, 6 p. (\$), Jan. 3, 1947.

Bermúdez y Hernández, Pedro Joaquín. See also Cushman, J. A., 1, no. 326.

1. Pavoninoides, a new genus of the Miliolidae from Panama: Cushman Lab. Foram. Research Contr., v. 25, pt. 3, no. 328, p. 58, illus., Sept. 1949.

2. Tertiary small Foraminifera of the Dominican Republic: Cushman Lab. Foram. Research Spec. Pub. 25, 322 p., illus., Dec. 21, 1949.

Berry, Edward Willard.

1. Marls and limestones of eastern North Carolina: N. C. Dept. Conserv. Dev., Div. Mineral Res. Bull. 54, 16 p., geol. map, 1947.

2. Fossils from Harrellsville, North Carolina [abs.]: N. C. Acad. Sci. Proc. in Elisha Mitchell Sci. Soc. Jour., v. 65, no. 2, p. 196, Dec. 1949.

3. Fossil plants from Santee Valley, South Carolina [abs.]: Geol. Soc. Am. Bull., v. 60, no. 12, pt. 2, p. 1874, Dec. 1949.

Berry, Leonard Gascoigne.

X-ray measurements on vauquelinite [abs.]: Am. Mineralogist, v. 34, nos. 3-4, p. 275, Mar.-Apr. 1949.

Béthune, Pierre F. de.

Remarques sur la structure du continent Nord-Américain, à propos de la carte tectonique des Etats-Unis du National Research Council: Société Belge de Géologie Bull., tome 54, fasc. 3, p. 185-191, illus., 1945.

\section{Bevan, Arthur Charles.}

1. Memorial to Edward Steidtmann [1881-1948]: Geol. Soc. Am. Proc. 1948 , p. $229-231$, port., May 1949 .

2. Memorial to Lewis Gardner Westgate [1868-1948]: Geol. Soc. Am. Proc. 1948 , p. 243-248, port., May 1949. 
Bieber, Charles Leonard.

Structural trends of the southern flanks of the Wisconsin arch: Ind. Acad. Sci. Proc., v. 58, p. 244-245, illus., 1948.

Bieberman, Doris Franz.

Stratigraphy of three wells in Sullivan and Vigo Counties, Indiana: Ind. Dept. Conserv., Div. Geology, Rpt. Prog. 2, 10 p. $(\$)$, index map, Jan. 1949.

Biemesderfer, George $\mathrm{K}$.

A new tool for plotting points on the equal area net: Pa. Acad. Sci. Proc., v. 23, p. 72-75, illus., 1949.

Bigelow, Henry W., Jr. See Marmer, H. A.

Billings, Marland Pratt.

(and Chidester, Alfred Herman). Geologic maps and structure sections of the Carleton talc quarry, Chester, Vt., Rousseau talc prospect, Cambridge, Vt., and Mad River talc mine, Fayston, Vt.: U. S. Geol. Survey Strategic Minerals Inv., Prelim. Map no. 3-227, 3 sheets. Scales 1 inch to 20 feet and 1 inch to 50 feet. Surveyed, 1945. [1949].

Billingsley, Harold Ray.

A subsurface study of the Sholem Alechem oil field, Stephens and Carter Counties, Oklahoma [abs.]: Tulsa Geol. Soc. Digest, v. 17, p. 107111, map, 1949.

\section{Bimson, Walter $R$.}

Louis D[avidson] Ricketts (1859-1940), mining engineer, geologist, banker, industrialist, and builder of Arizona. 32 p., illus. New York, The Newcomen Society of England, American Branch. 1949.

Bishop, Ottey Manley.

(and Needham, Albert Booth). Investigation of Douglas fluorite property, Pope County, Ill.: U. S. Bur. Mines Rpt. Inv. 4434, 13 p. $(\ddagger)$, illus. incl. index map, Mar. 1949.

\section{Bissell, Harold Joseph.}

The Cretaceous system of Utah, in The oil and gas possibilities of Utah, by G. H. Hansen and M. M. Bell: Utah Geol. Miner. Survey, p. 90100, Dec. 1949.

Black, Robert Foster.

(and Barksdale, William L.). Oriented lakes of northern Alaska: Jour. Geology, v. 57, no. 2, p. 105-118, illus., Mar. 1949; correction, no. 4 , p. 446, July 1949 ; abs., Washington Acad. Sci. Jour., v. 39, no. 3, p. 107-108, Mar. 15, 1949.

Blackstone, Donald LeRoy, Jr.

Structural pattern of the Powder River Basin [Wyo.]: Wyo. Geol. Assoc. Guidebook, Powder River Basin, p. 35-36 ( $\ddagger)$, illus., 1949.

Blackwelder, Eliot.

1. The Great Basin, with emphasis on glacial and postglacial times; 1, The geological background: Utah Univ. Bull., v. 38, no. 20 (Biol. ser., v. 10, no. 7), p. 3-16, illus., June 30, 1948.

2. Pre-Cambrian rocks of Utah, in The oil and gas possibilities of Utah, by G. H. Hansen and M. M. Bell: Utah Geol. Miner. Survey, p. 2530, illus., Dec. 1949.

Blake, Daniel B.

(and Roy, Chalmer John). Unusual stylolites: Am. Jour. Sci., v. 247, no. 11 , p. 779-790, illus., Nov. 1949. 


\section{Bloomer, Robert Oliver.}

Laboratory manual for elementary physical geology. 77 p. (\$), illus. Syracuse, N. Y., L. C. Grandy. 1949.

\section{Bloss, F. Donald.}

(and Barth, Thomas Fredrik Weybye). Observations on some Yellowstone geysers: Geol. Soc. Am. Bull., v. 60 , no. 5, p. 861-886, illus., May 1949.

\section{Boardman, Leona.}

1. (and Brown, Annabel, and Watson, Elaine). Geologic map index of Georgia: U. S. Geol. Survey Index to geologic mapping in the United States. Scale 1:750,000 or approx. 1 inch to 12 miles. 1949.

2. Geologic map index of Idaho: U. S. Geol. Survey Index to geologic mapping in the United States no. 11. Scale 1:750,000 or approx. 1 inch to 12 miles. 1949 .

3. (and Watson, Elaine). Geologic map index of Maine: U. S. Geol. Survey Index to geologic mapping in the United States. Scale 1:750,000 or approx. 1 inch to 12 miles. 1949.

4. (and Brown, Annabel). Geologic map index of Nevada: U. S. Geol. Survey Index to geologic mapping no. 13. Scale $1: 1,000,000$ or approx. 1 inch to 16 miles. 1949.

5. Geologic map index of Ohio: U. S. Geol. Survey Index to geologic mapping in the United States. Scale 1:750,000 or approx. 1 inch to 12 miles. 1949 .

6. (and Brown, Annabel). Geologic map index of Oregon: U. S. Geol. Survey Index to geologic mapping in the United States, no. 12: Scale 1:750,000 or approx. 1 inch to 12 miles. 1949 .

7. Geologic map index of Tennessee: U. S. Geol. Survey Index to geologic mapping in the United States. Scale 1:750,000 or approx. 1 inch to 12 miles. 1949.

8. Geologic map index of Washington: U. S. Geol. Survey Index to geologic mapping in the United States. Scale 1:750,000 or approx. 1 inch to 12 miles. 1949 .

9. (and Watson, Elaine). Geologic map index of West Virginia: U. S. Geol. Survey Index to geologic mapping in the United States. Scale $1: 750,000$ or approx. 1 inch to 12 miles. 1949 .

10. Geologic mapping in the United States: Geol. Soc. Am. Bull., v. 60, no. 7 , p. 1125-1131, illus., July 1949 .

\section{Bock, Wilhelm.}

Triassic chimaeroid egg capsules from the Connecticut Valley: Jour. Paleontology, v. 23, no. 5, p. 515-517, illus., Sept. 1949.

Bolander, Louis Phillip, Jr., 1887-1950.

New type diopside from California: Mineralogist, v. 17, no. 9, p. 403, Sept. 1949.

\section{Bonham, W. M.}

Mineral areas of Yukon: Canadian Min. Jour., v. 70, Pt. 1, no. 4, p. 71-73, illus., Apr. 1949; Pt. 2, no. 5, p. 69-71, illus., May 1949; Pt. 3, no. 6, p. 67-70, illus., June 1949; Pt. 4, no. 9, p. 81-83, illus., Sept. 1949.

Boos, Margaret Fuller. See also Maillot, E. E.

Structure of the Precambrian, Denver Mtn. Parks quadrangle, Colorado [abs.]: Geol. Soc. Am. Bull., v. 60, no. 12, pt. 2, p. 1874, Dec. 1949.

\section{Bostock, Hugh Samuel.}

1. Preliminary map, McQuesten, Yukon Territory (map and descriptive notes): Canada Geol. Survey Paper 48-25, 13 p. (\$), geol. map, 1948.

2. Prospecting in Yukon: Western Miner, v. 22, no. 4, p. 166-168, 170, illus, Apr. 1949.

3. Prospecting in Yukon Territory: Precambrian, v. 22, no. 7, p. 8-11, illus., July 1949. 
Botinelly, Theodore See Denson, N. M., 1, 2; Love, J. D., 2; U. S. G. S. 1, no. $92,102$.

\section{Boucot, Arthur J.}

1. Allanite from Godhaab, South Greenland: Rocks and Minerals, v. 24, nos. 1-2, p. 35, 61, Jan.-Feb. 1949.

2. Notes on the Ecton mine, Montgomery Co., Pa.: Rocks and Minerals, v. 24, nos. 9-10, p. 492-495, illus., Sept.-Oct. 1949 .

\section{Bourret, Weston.}

Aeromagnetic survey of the Allard Lake district, Quebec: Econ. Geology, v. 44, no. 8, p. 732-740, illus., Dec. 1949.

Bowen, Norman Levi. See also Tuttle, O. F., 4.

1. (and Tuttle, Orville Frank). The system $\mathrm{MgO}-\mathrm{SiO}_{2}-\mathrm{H}_{2} \mathrm{O}$ : Geol. Soc. Am. Bull., v. 60 , no. 3 , p. $439-460$, illus., Mar. 1949 ; abs., v. 58, no. 12 , pt. 2, p. 1168 , Dec. 1947; Am. Mineralogist, v. 33, nos. 3-4, p. 193, Mar.-Apr. 1948.

2. Memorial to Rollin Thomas Chamberlin [1881-1948]: Geol. Soc. Am. Proc. 1948, p. 135-143, port., May 1949.

3. (and Tuttle, Orville Frank). Serpentine and talc equilibria [abs.]: 18th Internat. Geol. Cong., London, Volume of titles and abstracts, p. $4,1948$.

4. (and Tuttle, Orville Frank). System $\mathrm{NaAlSi}_{3} \mathrm{O}_{8}-\mathrm{KAlSi}_{3} \mathrm{O}_{8}-\mathrm{H}_{2} \mathrm{O}$ [abs.]: Geol. Soc. Am. Bull., v. 60, no. 12, pt. 2, p. 1874-1875, Dec. 1949.

Bowles, Oliver.

William Clifton Phalen [1877-1949]: Min. Eng., v. 1, no. 9, p. 65, Sept. 1949.

Bowsher, Arthur Leroy. See Laudon, L. R., 1.

Boyé, M. See Malaurie, J. N., 2.

Bradley, H. B. See Plummer, F. B.

Bradley, William Frank. See also Comeforo, J. E.; Grim, R. E., 2, 3.

Alternating layer sequence of rectorite [abs.]: Geol. Soc. Am. Bull., v. 60, no. 12 , pt. 2, p. 1875 , Dec. 1949.

\section{Bradley, Worthen.}

Walter Stalder [1881-1949]: Eng. Min. Jour., v. 150, no. 10, p. 112, Oct. 1949.

\section{Brady, Lionel Francis.}

Oniscoidichnus, new name for Isopodichnus Brady 1947, not Bornemann 1889 [Invertebrate tracks, Coconino sandstone, Arizona]: Jour. Paleontology, v. 23, no. 5, p. 573, Sept. 1949.

\section{Bragg, William Lawrence.}

Acceptance of the Roebling Medal of the Mineralogical Society of America: Am. Mineralogist, v. 34, nos. 3-4, p. 238-241, Mar.-Apr. 1949.

Brajnikov, B. See Guimarães, D.

\section{Branham, C. A.}

A brief commentary on magnetic surveying in the Appalachian area: Appalachian Geol. Soc. Bull., v. 1, p. 275-276, illus., 1949.

Brannock, Walter Wallace. See Byers, F. M., Jr.; White, D. E., 2, 3.

\section{Branson, Delmar 0.}

Blackfoot field, Anderson County, Texas [abs.]: Am. Assoc. Petrol. Geol. Bull., v. 33, no. 12, p. 2068, Dec. 1949; Oil and Gas Jour., v. 48, no. 25, p. 88 , Oct. 27,1949 . 
Branson, Edwin Bayer, 1877-1950.

1. (and Mehl, Maurice Goldsmith). Zonal correlations by means of conodonts [abs.] : 18th Internat. Geol. Cong., London, Volume of titles and abstracts, p. 67, 1948.

2. Old soils at unconformities and their age [abs.]: 18th Internat. Geol. Cong., London, Volume of titles and abstracts, p. 83, 1948.

Braunstein, Jules.

1. Bibliography, Catahoula, Chickasawhay, Vicksburg and Jackson of Mississippi, in Mississippi Geological Society Guidebook, Sixth Field Trip, June 18-20, 1948, p. 37-48, 1948.

2. Bibliography, Paleozoic and pre-Cambrian rocks of north Alabama, northeast Mississippi and west central Tennessee, in Mississippi Geological Society Guidebook, 7th field trip, Aug. 24-27, 1949, p. $72-83,1949$.

Bravais, Auguste.

On the systems formed by points regularly distributed on a plane or in space: Crystallographic Soc. Am. Mem. 1, 113 p., illus., Sept. 1949. Translation by Amos J. Shaler "Sur les systèmes formés par des points distribués régulièrement sur un plan ou dans l'espace," originally published in Journal de l'Ecole Polytechnique, tome 19, cahier 33, p. 1-128, Paris, 1850.

Breger, Irving A.

Depositional environment of source materials forming organic sediments [abs.] : Am. Jour. Botany, v. 36, no. 10, p. 832, Dec. 1949.

Bretz, J Harlen.

1. Carlsbad Caverns and other caves of the Guadalupe block, New Mexico: Jour. Geology, v. 57, no. 5, p. 447-463, illus. incl. index maps; Sept. 1949.

2. (and Horberg, Carl Leland). The Ogallala formation west of the Llano Estacado [N. Mex.]: Jour. Geology, v. 57, no. 5, p. 477-490, illus. incl. geol. sketch map, Sept. 1949.

3. (and Horberg, Carl Leland). Caliche in southeastern New Mexico: Jour. Geology, v. 57, no. 5, p. 491-511, illus. incl. geol. sketch map, Sept. 1949.

\section{British Columbia Department of Mines.}

Metal-mining (lode): British Columbia Dept. Mines Ann. Rpt. 1948, p. 53-170, illus. incl. geol. maps, 1949.

Broadhurst, Samuel Davis.

A general survey of some high silica materials in North Carolina: N. C. Dept. Conserv. Div. Mineral Res. Inf. Circ. 7, 30 p. ( $\ddagger$, June 1949.

Broadhurst, William L. See also Alexander, W. H., Jr., 1.

1. (and Alexander, Walter Herbert, Jr.). Progress report on ground water in the High Plains in Texas: Texas State Bd. Water Eng. [Rpt.] no. 4, 12 p. (\$), illus., May 1944 .

2. A few scientific conceptions of our ground-water resources: Texas Acad. Sci. Trans., 1945, v. 29, p. 173-177, 1946.

3. Ground water in High Plains in Texas, Progress Report no. 6: Texas State Bd. Water Eng., 31 p. (\$), illus., Nov. 1946, with addendum Jan. 1947.

Broderick, Thomas Monteith.

Exploration for ore deposits: Econ. Geology, v. 44, no. 5, p. 357-375, Aug. 1949.

\section{Brodie, Gerson Herzl.}

Origin of shallow structures in west central Texas: World Oil, v. 129, no. 6 , p. 61-62, 64, 66, illus., Sept. 1949 . 
Brokaw, Arnold Leslie. See also Albritton, C. C., Jr., 2.

Geology and mineralogy of the east Tennessee zinc district, in Dunham, K. C., ed., Symposium on the geology, paragenesis and reserves of the ores of lead and zinc, 18th Internat. Geol. Cong., London, p. 62-67, illus., 1948; abs., Volume of titles and abstracts, p. 42, 1948.

Bronniman, $\mathbf{P}$.

Notes on the ecologic interpretation of fossil Globigerina from the West Indies: Micropaleontologist, v. 3, no. 2, p. 23-27 ( $\$)$, Apr. 1949.

Brookhart, J. W.

The water resources of Anne Arundel County; the ground-water resources: Md. Dept. Geology, Mines and Water Res. Bull. 5, p. 28-143, illus., 1949.

Brooks, Barbara Ellen. See Bell, A. H., 2.

Brooks, Benjamin Talbott.

Active-surface catalysts in formation of petroleum [Pt.] 2: Am. Assoc. Petrol. Geol. Bull. v. 33, no. 9, p. 1600-1612, illus., Sept. 1949.

Brooks, Charles Ernest Pelham.

Climate through the ages, $2 \mathrm{~d}$ ed., 395 p., illus. New York, McGraw-Hill Book Co., Inc., 1949.

Brown, Annabel. See Boardman, L., 1, 4, 6.

Brown, Bahngrell W.

A fluorescence study of Wyoming bentonite: Am. Mineralogist, v. 34, nos. 1-2, p. 98-101, illus., Jan.-Feb. 1949.

Brown, Donald Melvin. See Combo, J. X.

\section{Brown, Harrison Scott.}

1. The composition of meteoritic matter and the origin of meteorites: Science, v. 109, no. 2828, p. 251-254, Mar. 11, 1949.

2. (and Goldberg, Edward). The neutron pile as a tool in quantitative analysis; the gallium and palladium content of iron meteorites: Science, v. 109 , no. 2832 , p. 347-353, illus., Apr. 8, 1949.

3. (and Goldberg, Edward). A preliminary report on the distribution of gallium, palladium, gold, and nickel in 45 iron meteorites: Pop. Astronomy, v. 57 , no. 8, p. 398-399, Oct. 1949 ; Meteor. Soc. Contr., v. 4 , no. 3, p. 207-208, 1949 .

\section{Brown, Hart.}

A precision detail gravity survey, Jameson area, Coke County, Texas: Geophysics, v. 14 , no. 4, p. 535-542, illus., Oct. 1949 ; abs., no. 3 , p. 447, July 1949; Oil and Gas Jour., v. 47, no. 46, p. 109, Mar. $17,1949$.

Brown, John Stafford.

An alternative to the hydrothermal theory of ore genesis [abs.]: 18th Internat. Geol. Cong., London, Volume of titles and abstracts. p. 4-5, 1948.

\section{Brown, Roland Wilbur.}

1. Algal pillars miscalled geyser cones: Smithsonian Inst. Ann. Rpt. 1948, p. 277-282, illus. [1949].

2. Paleocene deposits of the Rocky Mountains and Plains [map with descriptive notes]: U. S. Geol. Survey, one sheet, scale 1:1,000,000 or 1 inch to approx. 16 miles, 1949 .

3. Nelson Horatio Darton [1865-1948]: Washington Acad. Sci. Jour., v. 39, no. 3, p. 114, Mar. 15, 1949 .

4. Pliocene plants from Cachee [Cache] Valley, Utah: Washington Acad. Sci. Jour., v. 39, no. 7, p. 224-229, illus., July 15, 1949. 
Browning, James S. See Staley, W. W.

Bruce, Everend Lester, 1884-1949.

(and Ross, J. S.). Relation of the Seine series to granite at East Shoal Lake, Ontario [abs.]: Geol. Soc. Am. Bull., v. 60, no. 12, pt. 2, p. 1875 , Dec. 1949.

\section{Bruet, Edmond.}

1. Le Labrador et le Nouveau-Québec. 346 p., illus. incl. geol. sketch maps, Paris, Payot, 1949. Chapter on geology, p. 122-188.

2. Le batholite granitique de Duverny (Nouveau Québec, Canada) et son cortège de roches associées. Contribution à l'étude des carbonatites [abs.]: 18th Internat. Geol. Cong., London, Volume of titles and abstracts, p. 11, 1948; Rpt. Pt. 3, p. 130, 1950.

\section{Brundall, Laurence.}

1. Methods of photogeologic evaluation in a Tertiary Basin [Wyo.]: Wyo. Geol. Assoc. Guidebook, Powder River Basin, p. 63-68 ( $\ddagger)$, illus., 1949.

2. Photogeology: Tulsa Geol. Soc. Digest, v. 17, p. 94-96, illus., 1949.

Bryan, Kirk, 1888-1950.

The geologic implications of cryopedology: Jour. Geology, v. 57, no. 2, p. 101-104, Mar. 1949.

\section{Bryson, Robert Pearne.}

Distribution, occurrence, and resources of sub-bituminous coal and lignite in the western United States [abs.]: Econ. Geology, v. 44, no. 7, p. 643 , Nov. 1949; Geol. Soc. Am. Bull., v. 60 , no. 12, pt. 2, p. 1875-1876, Dec. 1949.

Buchanan, R. M. See Moorhouse, W. W.

\section{Bucher, Walter Hèrmann.}

Recent results of suboceanic geology and major earth problems [abs.]: Geol. Soc. Am. Bull., v. 60, no. 12, pt. 2, p. 1876, Dec. 1949.

\section{Buddhue, John Davis.}

1. A sieve analysis of crushed sandstone from the Canyon Diablo, Arizona, meteorite crater: Meteor. Soc. Contr., v. 4, no. 2, p. 134-135, 1948.

2. Reduced meteoritic iron oxide: Pop. Astronomy, v. 57, no. 6, p. 293295, June 1949; Meteor. Soc. Contr., v. 4, no. 3, p. 197-199, 1949.

3. Miscellaneous notes on meteorites from Holbrook [Ariz.], Richardton [N. Dak.], Xiquipilco [Mexico], and Mt. Eldon [Ariz.]: Pop. Astronomy, v. 57, no. 8, p. 400-402, illus., Oct. 1949; Meteor. Soc. Contr., v. 4, no. 3, p. 208-210, illus., 1949.

4. Native metals widely distributed: Mineralogist, v. 17 , no. 11, p. 513-515, Nov. 1949.

Buehler, Edward J.

(and Walker, A. C.). Growing quartz crystals: Sci. Monthly, v. 49, no. 3, p. 148-155, illus., Sept. 1949.

\section{Buell, Arthur Whitcomb.}

Porosity and permeability analysis, in Subsurface geologic methods: Colo. Sch. Mines Quart., v. 44, no. 3, p. 168-179, illus., July 1949.

Buerger, Martin Julian. See also Washken, E.

1. Fourier summations for symmetrical crystals: Am. Mineralogist, v. 34, nos. 11-12, p. 771-788, Nov.-Dec. 1949.

2. General aspects of disorder in minerals [abs.]: Geol. Soc. Am. Bull., v. 60 , no. 12 , pt. 2 , p. $1876-1877$, Dec. 1949 . 
Buford, T. B. See Jones, P. H.

Bullock, Kenneth C.

(and Proctor, Paul Dean). Igneous rocks of Utah, in The oil and gas possibilities of Utah, by G. H. Hansen and M. M. Bell: Utah Geol. Miner. Survey, p. 119-126, Dec. 1949.

Bump, James Dye. See Welles, S. P.

Bundy, Paul A.

Cuba has potential tungsten mines: Eng. Min. Jour., v. 150, no. 8, p. 78-79, illus., Aug. 1949.

\section{Bureau, René.}

1. Le musée de minéralogie et de géologie de l'Université Laval: Le naturaliste Canadien, v. 76 , nos. 8-10, p. 205-222, illus., Aug.-Oct. 1949: reprinted as Université Laval Contribution 94, Quebec, 1949.

2. Inventaire des substances minérales de la ville de Québec [abs.]: Assoc. Canadienne-Française Av. Sci. Annales v. 15, p. 64-65, 1949.

3. Note sur certains fossiles silicifiés [abs.]: Assoc. Canadienne-Française Av. Sci. Annales v. 15, p. 65, 1949.

Burgess, Blandford C. See also Warriner, L. P.

Feldspar, in Industrial minerals and rocks, p. 345-373, illus., 1949.

\section{Burleson, Gretchen Lyon.}

A Pliocene pinniped from the San Diego formation of southern California: Calif. Univ. Pub. Zoology, v. 47, no. 10, p. 247-253, illus., Oct. 15, 1948.

Burma, Benjamin H. See also Cline, L. M.

The species concept, a semantic review: Evolution, v. 3, no. 4, p. 369-370, 372-373, Dec. 1949.

\section{Burns, Ken R.}

Prospecting in northwest Arkansas: World Oil, v. 129, no. 2, p. 74, 76, 78, illus., June 1949.

\section{Burns, R. E.}

Geologic map of pegmatites at Pleasant Valley, Custer County, South Dakota: U. S. Geol. Survey Strategic Minerals Inv. Prelim. Map 3-229. Scale 1 inch to 100 feet. Sept. 1948.

\section{Burrill, Meredith Frederic.}

Philip Sidney Smith, 1877-1949: Assoc. Am. Geog. Annals, v. 39, no. 4, p. 293 , Dec. 1949.

\section{Burt, Frederick Arthur.}

1. Pioneers in geology: Am. Assoc. Petrol. Geol. Bull., v. 33, no. 5, p. 720-721, May 1949; discussion by A. O. Woodford, no. 8, p. 1430-1431, Aug. 1949; by W. E. Pratt, no. 12, p. 2039, Dec. 1949.

2. Origins of geologic terms: Sci. Monthly, v. 49, no. 1, p. 20-22, July 1949.

\section{Buss, Walter $\mathbf{R}$.}

Physiography [Utah], in The oil and gas possibilities of Utah, by G. If. Hansen and M. M. Bell: Utah Geol. Miner. Survey, p. 5-9, illus., Dec. 1949.

\section{Butler, Bert Sylvenus.}

Setting of Arizona in Cordilleran structure [abs.]: Geol. Soc. Am. I v. 60 , no. 12 , pt. 2 , p. 1877 , Dec. 1949 . 
Butler, Charles R.

Geology of the northern part of the Sangre de Cristo Mountains, Colo. [abs.]: Geol. Soc. Am. Bull., v. 60, no. 12, pt. 2, p. 1959-1960, Dec. 1949.

\section{Bütler, Heinrich.}

1. Die westgrenze des Devons am Kejser Franz Joseph Fjord in Ostgrönland [The geology at the western margin of the Old Red Sandstone area on Ymer Island and Strindberg Land, Franz Joseph Fiord in East Greenland]: Mitt. Naturforsch. Ges. Schaffhausen, Band $22(1947 / 48)$, p. 73-152, illus. incl. geol. map, 1948. German, with English summary.

2. Uber ein Vorkommen von Quarziten der untern Eleonore Bay Formation an der Nordküste der Wegener Halbinsel in Ostgrönland: Meddelelser om Grønland, Band 150, no. 3, 9 p., illus. incl. geol. sketch map, 1949.

3. Uber das Vorkommen von Mitteldevon im südlichen Teil der GieseckeBerge [Greenland]: Meddelelser om Grønland, Band 150, no. 4, 24 p., illus. incl. index, geol. sketch maps, 1949.

Butner, D. W.

Phosphate rock mining in southeastern Idaho: U. S. Bur. Mines Inf. Circ. 7529,18 p. (\$), illus., Oct. 1949 .

\section{Butterlin, Jacques.}

Structure géologique des grandes Antilles: Revue de la Société Haïtienne Hist. Géog., v. 20, no. 74, p. 75-87, July 1949.

Byerly, Perry. See also Lawson, A. C., 1; Voigt, D. S.

1. (and Mei, Alexis I., and Romney, Carl F.). Dependence on azimuth of the amplitudes of $P$ and PP: Seismol. Soc. Am. Bull., v. 39, no. 4, p. 269-284, illus., Oct. 1949.

2. (and Evernden, J.). First motion from deep and shallow shocks [abs.] : Geol. Soc. Am. Bull., v. 60, no. 12, pt. 2, p. 1953, Dec. 1949.

3. (and Romney, Carl F.). Nevada earthquakes [abs.]: Geol. Soc. Am. Bull., v. 60, no. 12, pt. 2, p. 1953, Dec. 1949.

\section{Byers, Frank Milton, Jr.}

(and Brannock, Walter Wallace). Volcanic activity on Umnak and Great Sitkin Islands, 1946-1948: Am. Geophys. Union Trans., v. 30, no. 5, p. 719-734, illus. incl. index maps, Oct. 1949.

\section{Byrne, Frank Edward.}

1. (and Beck, Henry Vorhees, and Bearman, Charles Henry). Construction materials in Norton County, Kansas: U. S. Geol. Survey Circ. 24, 16 p. ( $\$)$, illus. incl. index, geol. maps, Apr. 1949.

2. (and Beck, Henry Vorhees, and Houston, Max S.). Construction materials in Rooks County, Kansas: U. S. Geol. Survey Circ. 27, 15 p. (\$), illus. incl. index, geol. maps. Apr. 1949.

3. (and Coombs, Vincent Bruce, and Bearman, Charles Henry). Constructions materials in Ellis County, Kansas: U. S. Geol. Survey Circ. 30, 18 p. (\$), illus. incl. index, geol. maps, Apr. 1949.

Cady, George H. See Farrar, R. L., Jr.

\section{Cady, Gilbert Haven.}

Coal geology, an opportunity for research and study: Econ. Geology, v. 44, no. 1, p. 1-12, Jan.-Feb. 1949; Ill. State Geol. Survey Circ. 147, 12 p., 1949; summary, Earth Sci. Digest, v. 3, no. 10, p. 3-10, illus., May 1949.

Cady, John Gilbert. See Wascher, H. L. 
Cady, Wallace Martin. See also Wallace, R. E., 2.

[Discussion], in Longwell, C. R., chm., Sedimentary facies in geologic history [symposium]: Geol. Soc. Am. Mem. 39, p. 137-139, index map, June 17, 1949.

Caillère, Simonne.

(and Kraut, François). Contribution à l'étude des minerais de fer oolithiques de Wabana (Terre-Neuve): Acad. Sci. Paris, Comptes Rendus, tome 228, no. 1, p. 113-115, Jan. 3, 1949.

Cain, Stanley Adair.

The place of pollen analysis in paleoecology: Chronica Botanica, v. 9, nos. 2-3, p. 106-114, Autumn 1945.

Cairnes, Clive Elmore.

Dr. Michael W[alter] Feniak [1914-1949]: Canadian Min. Jour., v. 70, no. 9 , p. 99 , Sept. 1949 .

Caldwell, Joseph M.

Beach erosion: Sci. Monthly, v. 49, no. 4, p. 229-235, illus., Oct. 1949.

California Department of Natural Resources, Division of Mines.

The counties of California: mineral resources and mineral production during 1947: Calif. Dept. Nat. Res., Div. Mines Bull. 142, 197 p., illus., July 1949.

Calver, James Lewis.

1. The glacial and post-glacial history of the Platte and Crystal Lake depressions, Benzie County, Michigan, in Occasional Papers for 1946 on the geology of Michigan: Mich. Geol. Survey Pub. 45, Geol. ser. 38, Pt. 2, 70 p., illus. incl. geol. map [c1947].

2. Florida kaolins and clays: Fla. Geol. Survey Inf. Circ. 2, 59 p. (\$), illus. incl. index map, 1949.

Cameron, E. Lee.

Salt, potash, and phosphate in Manitoba: Manitoba Dept. Mines and Nat. Res., Mines Br. Bull. 48-9, 13 p. $(\ddagger)$, index map, 1949.

\section{Cameron, Eugene Nathan.}

(and others.). Internal structure of granitic pegmatites: Econ. Geology, Mon. 2, 115 p., illus. incl. index, geol. maps, 1949.

\section{Cameron, Harcourt $\mathrm{L}$.}

1. Air photograph interpretation in the Chimney Corner-Cheticamp area, Cape Breton Island, N. S.: Canadian Min. Met. Bull. no. 430, p. 62-68, illus., Feb. 1948; reprinted in Photogrammetric Engineering, v. 15 , no. 2 , p. $238-249$, June 1949.

2. Sub-sea faulting in the Lismore area, Nova Scotia: Canadian Min. Met. Bull. No. 444, p. 168-169, illus., Apr. 1949; Canadian Inst. Min. Met. Trans., v. 52, p. 87-88, 1949.

3. Faulting in Nova Scotia: Royal Soc. Canada Trans., 3d ser., v. 43, sec. 4, p. 13-21, illus., June 1949; abs., Proc. $3 d$ ser., v. 43, p. 237, 1949.

Cameron, J. R. See Leverin, H. A.

\section{Camp, Charles Lewis.}

1. (and Welles, Samuel Paul, and Green, Morton). Bibliography of fossil vertebrates, 1939-1943: Geol. Soc. Am. Mem. 37, 371 p., June 24, 1949.

2. Mesozoic bøundaries and faunal changes [abs.]: Geol. Soc. Am. Bull., v. 60 , no. 12 , pt. 2 , p. $1877-1878$, Dec. 1949 . 
Campbell, Charles Duncan. See also Conybeare, C. E. B., 3.

Favorable ore zones of the Northport district, northeastern Washington [abs.]: Econ. Geology, v. 44, no. 7, p. 639, Nov. 1949; Geol. Soc. Am. Bull., v. 60 , no. 12 , pt. 2, p. 1878 , Dec. 1949.

Campbell, Ian.

Magnesium metasomatism in dolomite from Lucerne Valley, California [abs.]: 18th Internat. Geol. Cong., London, Volume of titles and abstracts, p. 12, 1948.

Campbell, Neil.

[History and geology of] the Con-Rycon mine, Yellowknife, N. W. T. [Northwest Territories]: Canadian Min. Met. Bull,, no. 446, p. 288292, illus. incl. geol. map, June 1949; Canadian Inst. Min. Met. Trans., v. 52, p. 133-147, 1949.

\section{Canada Geological Survey.}

1. Physiography and geology, in Canada's New Northwest, p. 25-42, illus. incl. geol. map. Ottawa, Edmond Cloutier, 1947.

2. Callum Creek, west of Fifth Meridian, Alberta. Geology by George Shaw, 1944, and Robert John Wilson Douglas, 1945. Map 982-A, with descriptive notes by R. J. W. Douglas. Scale 1:63,360 or 1 inch to 1 mile. 1949.

3. Carp Lake, Cariboo District, British Columbia. Geology by John Edward Armstrong, Howard W. Tipper, and John William Hoadley. Geologic Map no. 979-A, with descriptive notes by J. E. Armstrong. Scale $1: 253,440$ or 1 inch to 4 miles. 1949.

4. Surface deposits, Carp Lake, Cariboo District, British Columbia. Geology by John Edward Armstrong and Howard W. Tipper. Geologic Map no. 980-A, with descriptive notes by J. E. Armstrong. Scale $1: 253,440$ or 1 inch to 4 miles. 1949.

5. Gap, west of Fifth Meridian, Alberta. Geology by Robert John Wilson Douglas, 1946-47. Geologic Map 978-A with descriptive notes. Scale $1: 63,360$ or 1 inch to 1 mile. 1949.

6. Kississing, Saskatchewan-Manitoba. Geology by James Merritt Harrison, 1947. Map 970-A, with descriptive notes. Scale $1: 253,440$ or 1 inch to 4 miles. 1949 .

7. Lac de Gras, District of Mackenzie, Northwest Territories. Geology by Robert Edward Folinsbee, 1946, 1947. Map 977-A with descriptive notes. Scale 1:253,440 or 1 inch to 4 miles. 1949.

8. Langford Creek west of Fifth Meridian, Alberta. Geology by George Sherwood Hume, 1940; George Shaw, 1944; and Robert John Wilson Douglas, 1946. Geological compilation and descriptive notes by R. J. W. Douglas. Map 981-A with descriptive notes. Scale $1: 63,360$ or 1 inch to 1 mile. 1949 .

9. Geological map of the Maritime Provinces (New Brunswick, Nova Scotia, and Prince Edward Island). Geology compiled by Frederick James Alcock. Geologic Map 910-A with brief notes and index to recent geological maps in the Provinces. Scale 1:760,320 or 1 inch to 12 miles. 1949.

10. McConnell Creek, Cassiar District, British Columbia. Geology by Clifford Symington Lord, 1941, 1944, and 1945. Geologic Map 962-A with descriptive notes. Scale $1: 253,440$ or one inch to 4 miles. 1949.

11. Moberly Creek, west of Sixth Meridian, Alberta. Geology by Arthur Hamilton Lang, 1946. Map 963-A, with descriptive notes. Scale $1: 63,360$ or 1 inch to 1 mile. 1949 .

12. Moon Creek west of Sixth Meridian, Alberta. Geology by Ernest James Wingett Irish, 1946, 1947. Map 968-A with descriptive notes. Scale $1: 63,360$ or 1 inch to 1 mile. 1949 .

13. Smithers-Fort St. James, British Columbia. Geological information compiled by Harrington Molesworth Anthony Rice ... Map 971-A, with lists of mining properties and placer deposits. : Scale $1: 506,880$ or 1 inch to 8 miles. 1949 . 


\section{Canada Geological Survey-Continued}

14. Stimson Creek, west of Fifth Meridian, Alberta. Geology by George Sherwood Hume, 1936, 1940. Map 934-A, with descriptive notes. Scale $1: 63,360$ or 1 inch to 1 mile. 1949 .

Caran, John. G.

Core analysis; predicting well behavior, in Subsurface geologic methods: Colo. Sch. Mines Quart., v. 44, no. 3, p. 238-264, illus., July 1949.

Carbonneau, Côme.

Glaciation dans les monts Schickshocks, Péninsule de Gaspé: Canadian Min. Jour., v. 70, no. 6, p. 74-81, illus. incl. index map, June 1949.

Carlson, C. E.

Geologic map and structure sections of the Red Fork Powder River area [Wyo.]: Wyo. Geol. Assoc. Guidebook, Powder River Basin, 1949.

Carlson, Roy F.

Church Buttes [gas field, Wyo.]: Oil and Gas Jour., v. 48, no. 7, p. 188, 190-191, illus., June 23, 1949.

\section{Carlston, Charles William.}

Drainage patterns [abs.]: Geol. Soc. Am. Bull., v. 60, no. 12, pt. 2, p. 1967 , Dec. 1949 .

Carpenter, Albert C.

Many forms-selenite crystals: Mineralogist, v. 17 , no. 10, p. 466, 468, 470, 472, 474, illus., Oct. 1949 .

Carpenter, Charles Byron.

(and Anderson, Kenneth F., and Cook, Alton B.). Petroleum-engineering study of the New Hope oil field, Franklin County, Tex.: U. S. Bur. Mines Rpt. Inv. 4594, 88 p. ( $\ddagger)$, illus., Sept. 1949.

Carr, Donald R. See Kulp, J. L., 3.

Carsola, A.

(and Dietz, Robert Sinclair, and Russell, Richard Dana). Submarine geology of two northeast Pacific sea mounts [abs.]: Geol. Soc. Am. Bull., v. 60 , no. 12 , pt. 2, p. 1878 , Dec. 1949 .

Carter, George F.

Evidence for Pleistocene Man in Southern California: Geog. Rev., v. 40, no. 1, p. 84-102, illus., Jan. 1950; abs. with title, Evidence for Pleistocene Man in an alluvial fan at La Jolla, California, Geol. Soc. Am. Bull., v. 59, no. 12, pt. 2, p. 1315, Dec. 1948; abridged paper with title, Evidence for Pleistocene Man at La Jolla, California, N. Y. Acad. Sci. Trans., ser. 2, v. 11, no. 7, p. 254-257, Jan. 1949.

Cary, Allen Stuart.

Natural clay grout in openwork gravel [Wash.] [abs.]: Geol. Soc. Am. Bull., v. 60, no. 12, pt. 2, p. 1878-1879, Dec. 1949.

Casperson, William $\mathbf{C}$.

Minerals: Rocks and Minerals, v. 24, nos. 9-10, p. 476-478, Sept.-Oct. 1949.

Cater, Frederick William, Jr. See Wells, F. G., 2.

Cathcart, James Bachelder, Jr.

Open fracture in langbeinite, International Minerals and Chemical Corporation's potash mine, Eddy County, New Mexico: Min. Eng., v. 1, no. 7 , p. 256-258, illus., July 1949 ; A. I. M. E. Trans., v. 184, 1949.

Cederstrom, Dagfin John. See Cushman, J. A., 2. 
Chadwick, George Halcott.

Glacial molding of the Gulf of Maine [abs.]: Geol. Soc. Am. Bull., v. 60, no. 12 , pt. 2 , p. 1967 , Dec. 1949 .

\section{Chaisson, Ursula.}

Optics of triclinic adularia [abs.]: Geol. Soc. Am. Bull., v. 60, no. 12, pt. 2, p. 1879, Dec. 1949.

Chakrabarty, S. K.

(and Richter, Charles Francis). The Walker Pass earthquakes and structure of the southern Sierra Nevada: Seismol. Soc. Am. Bull., v. 39, no. 2, p. 93-107, illus. incl. index map, Apr. 1949.

Chamberlin, Ralph V.

A new fossil chilopod from the late Cenozoic [Ariz.]: San Diego Soc. Nat. History Trans., v. 11, no. 7, p. 117-120, illus., Apr. 29, 1949.

Chamberlin, Rollin Thomas, 1881-1948.

1. Glacier mechanics: Am. Alpine Jour., v. 4, no. 1, p. 40-53, illus., 1940.

2. Arthur Philemon Coleman, 1852-1939; Am. Alpine Jour., v. 4, no. 1, p. 119-121, portrait, 1940 .

3. Harry Fielding Reid, 1859-1944: Am. Alpine Jour., v. 5, no. 3, p. 413-414, portrait, 1945 .

4. Geological evidence on the evolution of the earth's atmosphere, in Kuiper, G. P., ed., The atmosphere of the earth and planets, p. 250-259, University of Chicago Press, 1949.

Chambers, Lawrence Shiner.

Richard Robbins Crandall (1902-1949) : Am. Assoc. Petrol. Geol. Bull., v. 33, no. 12 , p. 2075-2076, port., Dec. 1949.

\section{Chaney, Ralph Works.}

1. The ancient forests of Oregon. xiv, 56 p., illus. Eugene, Oreg. State System of Higher Education, 1948.

2. Evolutionary trends in the angiosperms, in Jepson, G. L., ed., Genetics, paleontology, and evolution, p. 190-201, 1949 .

3. The Miocene occurrence of Sequoia and related conifers in the John Day Basin [E. Oregon]: Natl. Acad. Sci. Proc., v. 35, no. 3, p. 125-129, Mar. 1949.

4. Early Tertiary ecotones in western North America: Natl. Acad. Sci. Proc., v. 35, no. 7, p. 356-359, July 1949; abs., Science, v. 109, no. 2835, p. 438, Apr. 29, 1949.

Chapin, Theodore C. See Garfias, V. R.

\section{Chapman, L. J.}

(and Putnam, Donald Fulton). The recession of the Wisconsin glacier in southern Ontario: Royal Soc. Canada Trans., 3d ser., v. 43, sec. 4, p. 23-52, illus., June 1949; abs., Proc. 3d ser., v. 43, p. 241, 1949.

\section{Chapman, Randolph Wallace.}

1. The geology of the Percy quadrangle, New Hampshire. 36 p., illus. incl. geol. map. Concord, N. H., State Plan. Dev. Comm. 1949.

2. (and Greenfield, Mildred A.). Spheroidal weathering of igneous rocks: Am. Jour. Sci., v. 247, no. 6, p. 407-429, illus., June 1949.

\section{Chappell, Walter Miller.}

(and Durham, John Wyatt, and Savage, Donald Elvin). Rhinoceros mold in basalt [abs.]: Geol. Soc. Am. Bull., v. 60, no. 12, pt. 2, p. 1949, Dec. 1949.

\section{Chase, James L.}

Surface geology beneath the sea: Petrol. Eng., v. 19, no. 12, p. 102, 104, 106, 108, 112, illus., Aug. 1948. 
Chatterjee, B. See Mackie, W. Z.

Chayes, Felix. See also Fairbairn, H. W., 1.

1. A simple point counter for thin-section analysis: Am. Mineralogist, v. 34, nos. 1-2, p. 1-11, illus., Jan.-Feb. 1949.

2. On ratio correlation in petrography; Jour. Geology, v. 57, no. 3, p. 239-254, illus., May 1949.

3. Some notes on the point counter: Am. Mineralogist, v. 34, nos. 7-8, p. 600-601, July-Aug. 1949.

4. Remains of a gabbro-granite transition in Norfolk County, Massachusetts [abs.]: Am. Mineralogist, v. 34, nos. 3-4, p. 275, Mar.-Apr. 1949.

Chenoweth, Philip A.

Statistical treatment of facies change [abs.]: Geol. Soc. Am. Bull., v. 60 , no. 12, pt. 2, p. 1967 , Dec. 1949.

Chesterman, Charles W.

Dike complex in the Turtle Mountains, eastern San Bernardino County, California [abs.]: Geol. Soc. Am. Bull., v. 60, no. 12, pt. 2, p. 1937, Dec. 1949.

Chidester, Alfred Herman. See Billings, M. P.

Chisholm, E. 0.

1. Preliminary report on the Linklater Lake tin discovery, District of Thunder Bay [Ontario]: Ontario Dept. Mines Press Release 194811,6 p. (\$), illus. incl. geol. maps, Jan. 1949 .

2. The copper-nickel-cobalt occurrences in the Rex-Warner Lakes area, Ontario: Precambrian, v. 22, no. 4, p. 10-15, 53-54, illus. incl. geol. map, Apr. 1949.

Chittenden, Hiram Martin, 1859-1917.

Yellowstone National Park; historical and descriptive. 5th ed. revised by Eleanor Chittenden Cress and Isabelle F. Story. 286 p., illus. Stanford, Calif. Stanford University Press. [c1949].

\section{Christie, A. M.}

1. (and Kesten, S. N.). Goldfields and Martin Lake map-areas, Saskatchewan (preliminary account and two maps): Canada Geol. Survey Paper 49-17, 32 p. ( $\$$, geol. maps, 1949.

2. (and Kesten, S. N.). Pitchblende occurrences of the Goldsfields area, Saskatchewan: Canadian Min. Met. Bull. 452, p. 643-651, illus. incl. geol. sketch maps, Dec. 1949.

Chronic, Byron John, Jr. See Laudon, L. R., 2.

Church, Harry Victor, Jr. See Horberg, C. L., 1.

\section{Chute, Newton Earl.}

1. Surficial geology of the Pawtucket quadrangle, Rhode Island and Massachusetts, in The geology and ground-water resources of the Pawtucket quadrangle, Rhode Island: R. I. Indus. Comm., Geol. Bull. 3 , p. 28-37, geol. map, 1948.

2. Surficial geology, Pawtucket quadrangle, Rhode Island-Massachusetts: U. S. Geol. Survey, Geol. Quad. Map, with text. Scale 1:31,680 or 1 inch to $1 / 2$ mile, 1949.

Clabaugh, Stephen Edmund.

Eudialyte and eucolite from southern New Mexico [abs.]: Geol. Soc. Am. Bull., v. 60, no. 12, pt. 2, p. 1879-1880, Dec. 1949.

Claffy, Esther W.

The polarographic method for determining trace elements in rocks and minerals: Am. Jour. Sci., v. 247, no. 3, p. 187-199, illus., Mar. 1949. 


\section{Clair, Joseph Robinson.}

Lithologic criteria of Mississippian rocks in western Kansas: World Oil, v. 129, no. 8, p. 61-62, 64, 66, illus., Nov. 1949 .

\section{Clark, G. Conrad.}

1. Developments [in oil and gas] in east Texas in 1948: Am. Assoc. Petrol. Geol. Bull., v. 33, no. 6, p. 956-965, index maps, June 1949.

2. Interior salt domes of East Texas [abs.]: Am. Assoc. Petrol. Geol. Bull., v. 33, no. 12, p. 2067-2068, Dec. 1949; Oil and Gas Jour., v. 48 , no. 25 , p. 87 , Oct. $27,1949$.

\section{Clark, Leslie M.}

1. (chairman). Alberta symposium: Am. Assoc. Petrol. Geol. Bull., v. 33, no. 4, p. 487-633, illus., Apr. 1949. Contains papers by E. W. Shaw and S. R. L. Harding, M. B. B. Crockford, Joseph Gleddie, J. Spivak, J. D. Weir, P. S. Warren, D. B. Layer, J. R. McGehee, L. M. Clark.

2. Geology of Rocky Mountain Front Ranges near Bow River, Alberta, in Clark, L. M., chm., Alberta symposium: Am. Assoc. Petrol. Geol. Bull., v. 33, no. 4, p. 614-633, illus. incl. geol. map, Apr. 1949.

\section{Clark, Thomas Henry.}

1. Summary report on the St. Lawrence Lowlands south of the St. Lawrence River [Quebec]: Quebec Dept. Mines Prelim. Rpt. 204, 18 p. (\$), geol. map, 1947 .

2. Preliminary report on the Portneuf map-area, Portneuf and Lotbinière Counties [Quebec]: Quebec Dept. Mines Prelim. Rpt. 225, 10 p. $(\$)$, index, geol. maps, 1948 .

3. New information concerning Logan's line [abs.]: Royal Soc. Canada Proc. 3d ser., v. 43, p. 238, 1949.

\section{Clark, Wallace.}

Danburite locality near Russell, N. Y.: Rocks and Minerals, v. 24, nos. 1-2, p. 36-37, map, Jan.-Feb. 1949.

\section{Claudet, A.}

New method of local and regional correlation using resistivity value from electrical logs [abs.] : Am. Assoc. Petrol. Geol. Bull., v. 33, no. 12, p. 2067, Dec. 1949; Oil and Gas Jour., v. 48, no. 25, p. 87, Oct. 27, 1949.

\section{Claveau, Jacques.}

1. Preliminary report on Iserhoff River area, Abitibi-East County [Quebec]: Quebec Dept. Mines Prelim. Rpt. 197, 12 p. ( $\ddagger)$, index, geol. maps, 1947.

2. Preliminary report on Waswanipi Lake area (west half), Abitibi-East County [Quebec]: Quebec Dept. Mines Prelim. Rpt. 217, 15 p. ( $\$)$, index, geol. maps, 1948.

3. Wakeham Lake area, Saguenay County [Quebec]: Quebec Dept. Mines, Geol. Surveys Br., Geol. Rpt. 37, 58 p. ( $\ddagger)$, illus. incl. index, geol. maps, 1949; also in French ed.

4. Upper Romaine River area, Saguenay County [Quebec]: Quebec Dept. Mines, Geol. Surveys Br., Geol. Rpt. 38, 35 p. ( $\ddagger)$, illus. incl. index, geol. maps, 1949; also in French ed.

5. La fosse du lac Wakeham, précurseur de la fosse labradorienne [abs.] : Assoc. Canadienne-Française Av. Sci. Annales v. 15, p. 69-71, 1949.

\section{Clayton, Austin B.}

(and Sayrs, Richard Lee). Investigation of the Tennessee Zinc Co. property, Bumpus [Bumpass] Cove, Unicoi County, Tenn.: U. S. Bur. Mines Rpt. Inv. 4390,14 p. ( $\$)$, illus. incl. index map, Jan. 1949.

\section{Clayton, Neal.}

Correlation of seismic events with geological horizons: World Oil, v. 129, no. 1, p. $66,69,70$, illus., May 1949 . 
Clement, Paul F.

(and Watson, G. R.). Correlation of gravity anomalies with seismic and geological data in California [abs.]: Oil and Gas Jour., v. 47, no. 46, p. 160, Mar. 17, 1949; Geophysies, v. 14, no. 3, p. 445, July 1949.

Clements, Thomas D.

Leonardo da Vinci as a geologist [abs.]: Geol. Soc. Am. Bull., v. 60, no. 12, pt. 2, p. 1937, Dec. 1949.

Clewell, Dayton Harris.

(and Simon, R. F.). Seismic wave propagation [abs.]: Oil and Gas Jour., v. 47 , no. 46 , p. 158,160 , Mar. 17,1949 ; Geophysics, v. 14, no. 3 , p. 449, July 1949 .

Cline, Lewis Manning.

(and Burma, Benjamin H.). Paleoecological study of the Pennsylvanian Exline limestone of Iowa and Missouri [abs.]: Geol. Soc. Am. Bull., v. 60 , no. 12 , pt. 2 , p. $1880-1881$, Dec. 1949 .

Clippinger, Donn Merrell.

Barite of New Mexico: N. Mex. Bur. Mines and Mineral Res. Circ. 21, 26 p. ( $\$), 1949$.

Cloos, Ernst. See Goddard, E. N., 2.

Cobb, Harrison S.

The Long Creek [Wyo.] jade deposit: Mineralogist, v. 17, no. 1, p. 44, Jan. 1949.

Cohick, Kenneth S.

Correlation possibilities in the Sacramento Valley: Geophysics, v. 14, no. 3, p. 337-340, illus. incl. index map, July 1949.

\section{Colbert, Edwin Harris.}

1. Progressive adaptations as seen in the fossil record, in Jepsen, G. L., ed., Genetics, paleontology, and evolution, p. 390-402, 1949.

2. The ancestors of mammals: Sci. Am., v. 180 , no. 3, p. 40-43, illus., Mar. 1949.

3. Evolutionary growth rates in the dinosaurs: Sci. Monthly, v. 69, no. 2, p. 71-79, illus., Aug. 1949.

\section{Cole, John Wilson.}

1. Investigation of the Electric Point and Gladstone lead-zinc mines, Stevens County, Wash.: UT. S. Bur. Mines Rpt. Inv. 4392, 11 p. $(\ddagger)$, illus. incl. index, geol. maps, Jan. 1949.

2. Core drill testing for base metal mineralization below the Hope silver mine, Granite County, Mont.: U. S. Bur. Mines Rpt. Inv. 4399, 9 p. $(\ddagger)$, illus. incl. index, geol. maps, Feb. 1949.

Cole, Wiliam Storrs.

Upper Eocene larger Foraminifera from the Panama Canal Zone: Jour. Paleontology, v. 23, no. 3, p. 267-275, illus., May 1949.

Coleman, T. L. See Hill, H. B., 2.

Coles, Roswell S.

Early record of the rocks and minerals of Staten Island [N. Y.]: Staten Island Inst. Arts Sci. Proc., v. 12, no. 1, p. 1-9, Oct. 1949: Pt. 2, no. 2, p. 31-36, Jan. 1950.

Collin, Robert L.

(and Lipscomb, William N.). The crystal structure of groutite, $\mathrm{HMnO}_{2}$ : Acta Crystallographica, v. 2, pt. 2, p. 104-106, Apr. 1949.

Collins, Jack Beverly. See Maher, J. C., 1, 4; U. S. G. S. 1, no. 101. 
Collins, Robert Frank.

Volcanic rocks of northeastern New Mexico: Geol. Soc. Am. Bull., v. 60, no. 6, p. 1017-1040, illus. incl. geol. map, June 1949.

Combo, John Xavier.

(and others). Coal resources of Montana: U. S. Geol. Survey Circ. 53, 28 p. ( $\ddagger)$, illus. incl. index maps, Aug. 1949.

Comeforo, Jay Eugene. See also Wilkerson, A. S., 1, 2.

(and Fischer, R. B., and Bradley, William Frank). Mullitization of kaolinite: Am. Ceramic Soc. Jour., v. 31, no. 9, p. 254-259, illus., Sept. $1,1948$.

Conger, Paul Sydney. See also Barghoorn, E. S., Jr., 1.

The diatoms [Boylston Street Fishweir II, Boston, Mass.] : Peabody Foundation for Archaeology Papers, v. 4, no. 1, p. 109-123, 1949.

\section{Conley, J. N:}

Limestone development in Pennsylvanian of eastern Permian basin [Texas] [abs.]: Oil and Gas Jour., v. 47, no. 46, p. 109, Mar. 17, 1949.

Connolly, F. T.

Petrography and paleogeography of McClosky sand in Passport oil pool, Clay County, Illinois [abs.]: Oil and Gas Jour., v. 47, no. 46, p. 151-152, Mar. 17, 1949.

Conybeare, Charles E. B.

1. Stylolites in pre-Cambrian quartzite [Alice Lake area, Saskatchewan]: Jour. Geology, v. 57, no. 1, p. 83-85, illus., Jan. 1949.

2. Genesis and structure of the Athabaska series, Goldfields, Saskatchewan: Northwest Sci., v. 23 , no. 4 , p. 165-174, index, geol. sk. map, Nov. 1949.

3. (and Campbell, Charles Duncan). Petrology of the red radioactive zones north of Goldfields, Saskatchewan [abs.]: Geol. Soc. Am. Bull., v. 60 , no. 12 , pt. 2 , p. 1881 , Dec. 1949 .

Cook, Alton B. See Carpenter, C. B.

Cook, Robert B.

Diatomite in the Palos Verdes Hills, California: Compass, v. 26, no. 4, p. 333-337, illus. incl. index map, p. 285, May 1949.

Cook, Roger $\mathrm{H}$.

(and Zima, L. C.). Petrographic examination of concrete aggregate from Columbia Basin deposits, Columbia Basin project [Wash.]: U. S. Bur. Recl. Petrog. Lab. Rpt. 76, 6 p. (\$), Oct. 1, 1945 .

Cooke, Charles Wythe.

Pygurostoma pasionensis, a Cretaceous echnoid from Guatemala: Am. Mus. Nat. History Novitates, no. 1422, 3 p., illus., July 29, 1949.

Cooke, Harold Caswell.

William Albert Johnston (1874-1949): Royal Soc. Canada Proc. 3d ser. v. 43 , p. $127-131$, port., 1949 .

Coombs, Howard Abbott.

Granitization in the Swauk formation near Wenatchee, Washington [abs.]: Geol. Soc. Am. Bull., v. 60, no. 12, pt. 2, p. 1937-1938, Dec. 1949.

Coombs, Vincent Bruce. See Byrne, F. E., 3.

\section{Cooper, Byron Nelson.}

In memoriam, Roy Jay Holden, 1870-1945: Compass, v. 26, no. 3, p. 246247, port., Mar. 1949. 
Cooper, Harry Mac.

1. (and Abernethy, Roy Franklin). Investigation of coal deposits in the Fairview and Coal City Basins of Coosa field, St. Clair County, Ala. 3. Analyses of samples? U. S. Bur. Mines Tech. Paper 719, p. 28, 97-104, 1949.

2. (and Abernethy, Roy Franklin). Investigation of lower coal beds in Georges Creek and north part of Upper Potomac Basins, Allegany and Garrett Counties, Md., 3. Analyses of drill-core samples: U. S. Bur. Mines Tech. Paper 725, p. 18, 101-115, 1949.

Cortright, W. D.

Complications in basement reflection correlation: Geophysics, v. 14, no. 3, p. 341-345, illus., July 1.949.

Coté, Pierre E.

Preliminary report on the Chertsey map-area, Montcalm, Joliette and Terrebonne Counties [Quebec]: Quebec Dept. Mines Prelim. Rpt. 214, 10 p. (\$), index, geol. maps, 1948.

Cottingham, Kenneth.

The influence of geology in Ohio place-names: Ohio Jour. Sci., v. 49, no. 1, p. 34-40, Jan. 1949 .

\section{Cox, Arthur Hubert.}

A re-interpretation of the geological sequence in the Glacier-Rogers Pass section of the Selkirk Mountains, British Columbia [abs.]: 18th Internat. Geol. Cong., London, Volume of titles and abstracts, p. 85, 1948.

\section{Cox, Benjamin Burton.}

Transformation of organic material into petroleum under geological conditions ("The geological fence") : Am. Assoc. Petrol. Geol. Bull., v. 30, no. 5, p. 645-659, May 1946; reprinted in Appalachian Geol. Soc. Bull., v. 1, p. 11-23, 1949.

Cox, Manning William. See also Eric, J. H., 2; Heyl, G. R., 3.

1. (and Wyant, Donald Gray, and Heyl, George Richard). Geology of the Lilyama and Pioneer mines, El Dorado County, California: Calif. Dept. Nat. Res., Div. Mines Bull. 144, p. 43-47, geol. maps, Dec. 1948.

2. (and Wyant, Donald Gray). La Victoria copper mine, Mariposa County, California: Calif. Dept. Nat. Res., Div. Mines Bull. 144, p. 127-132, illus. incl. index. geol. maps, Dec. 1948.

3. (and Wyant, Donald Gray). The Jesse Belle copper mine, Madera County, California: Calif. Dept. Nat. Res., Div. Mines Bull. 144, p. 151-157, illus. incl. geol. maps, Dec. 1948.

Craig, Lawrence Carey.

Lower Middle Ordovician of south-central Pennsylvania: Geol. Soc. Am. Bull., v. 60, no. 4, p. 707-799, illus. incl. index map, Apr. 1949.

Crain, Harry M. See also LeRoy, L. W., 1.

Reports on subsurface geology, in Subsurface geologic methods: Colo. Sch. Mines Quart., v. 44, no. 3, p. 682-694, July 1949.

\section{Crawford, Arthur Lorenzo.}

Gilsonite and related hydrocarbons of the Uinta basin, Utah, in The oil and gas possibilities of Utah, by G. H. Hansen and M. M. Bell : Utah Geol. Miner. Survey, p. 235-260, illus., Dec. 1949.

\section{Crawford, James Gilmore.}

1. Core and water analyses: Oil and Gas Jour., v. 48, no. 7, p. 178, 180, $183,185,186$, illus., June 23, 1949.

2. Water analysis (characteristics of oil-field waters of Rocky Mountain region), in Subsurface geologic methods: Colo. Sch. Mines Quart., v. 44, no. 3 , p. 188-210, July 1949. 
Creamer, A. S. See Hunt, C. B., 2.

Cressey, George Babcock.

Wallace W[alter] Atwood, 1872-1949: Assoc. Am. Geog. Annals, v. 39, no. 4, p. 296-306, port., Dec. 1949.

Cressman, Luther Sheeleigh.

Odell Lake site, a new paleo-Indian campsite in Oregon: Am. Antiquity, v. 14, no. 1, p. 57-58, illus., July 1949.

\section{Crippen, Richard Aubrey, Jr.}

Nephrite jade and associated rocks of the Cape San Martin region, Monterey County, California [abs.]: Geol. Soc. Am. Bull., v. 60, no. 12, pt. 2, p. 1938, Dec. 1949.

\section{Crockford, Michael Bertram Bray.}

1. Geology of Ribbon Creek area, Alberta: Alberta Research Coun. Rpt. 52, 67 p., illus. incl. index, geol. maps, 1949.

2. Geology of Kootenay coal measures in southwestern Alberta: Canadian Min. Met. Bull., no. 443, p. 122-128, illus. incl. geol. map, Mar. 1949; Canadian Inst. Min. Met. Trans., v. 52, p. 69-75, 1949.

3. Oldman and Foremost formations of southern Alberta, in Clark, L. M., chm., Alberta symposium: Am. Assoc. Petrol. Geol. Bull., v. 33, no. 4, p. 500-510, illus. incl. index, geol. maps, Apr. 1949.

Cromack, G. H. See Sundstrom, R. W.

Crosby, James W., 3d.

Silicification of limestone near Oroville, Washington [abs.]: Northwest Sci., v. 23 , no. 1 , p. 41 , Feb. 1949.

Cross, Aureal T. See also Hoskins, J. H., 1, 2.

1. A comparison of tissue preservation in coalified and silicified logs [abs.]: Am. Jour. Botany, v. 36, no. 10, p. 818, Dec. 1949.

2. (and Hoskins, John Hobart). An unusual sigillaroid stump from southeastern Ohio [abs.]: Am. Jour. Botany, v. 36 , no. 10 , p. 818 , Dec. 1949.

3. Sedimentary cycles in the Dunkard and Monongahela series of Ohio [abs.]: Geol. Soc. Am. Bull., v. 60, no. 12, pt. 2, p. 1881-1882, Dec. 1949 .

Cross, William $\mathbf{P}$.

The relation of geology to dry-weather stream flow in Ohio: Am. Geophys. Union Trans., v. 30, no. 4, p. 563-566, illus. incl. index map, Aug. 1949 ; discussion by R. G. Kazmann and author's reply, v. 31, no. 3, p. 473-474, June 1950 .

Crouch, Robert W.

Pliocene Ostracoda from southern California: Joui. Paleontology, v. 23, no. 6 , p. 594-599, illus., Nov. 1949.

\section{Culberson, olin.}

The oil and gas resources of Texas, their geographical distribution within the State with brief comments on the importance of these resources in the economic life of the citizenship of the State as a whole: Texas Acad. Sci. Trans., 1945, v. 29, p. 177-186, 1946.

Cumming, Jorge L.

El petróleo, su origen, geología y métodos de exploración-reservas nacionales y mundiales: Petroleos Mexicanos, no. 74, p. 13-31, Oct. 1949.

Cummins, Arthur Benson.

(and Mulryan, Henry). Diatomite, in Industrial minerals and rocks, p. 294-312, illus., 1949. 


\section{Curry, H. Donald.}

"Turtlebacks" of central Black Mountains, Death Valley, California [abs.]: Geol. Soc. Am. Bull., v. 60 , no. 12, pt. 2, p. 1882 , Dec. 1949.

\section{Curtin, George.}

The LaBrea Tar Pits [Los Angeles, Calif.] : Compass, v. 26, no. 4, p. 368373, illus., May 1949.

Cushman, Joseph Augustine, 1881-1949.

1. Contributions from the Cushman Laboratory for Foraminiferal Research.

V. 25, Pt. 1, Mar. 1949.

324. Foreign.

325. (and Todd, Margaret Ruth). The genus Sphaeroidina and its species, p. 11-21, illus. [Trinidad].

V. 25, Pt. 2, June 1949.

326. (and Bermúdez y Hernández, Pedro Joaquín). Some Cuban species of Globorotalia, p. 26-45, illus.

V. 25, Pt. 3, Sept. 1949.

327. Foreign.

328. Pavoninoides, a new genus of the Miliolidae from Panama, by Pedro Joaquín Bermúdez y Hernández, p. 58, illus.

329. (and Todd, Margaret Ruth). Species of the genera Allomorphina and Quadrimorphina p. 59-72, illus.

V. 25, Pt. 4, Dec. 1949.

330. Foreign.

331. (and Todd, Margaret Ruth). Species of the genus Chilostomella and related genera, p. 84-99, illus.

332. Homonyms in Foraminifera erected during 1948 and 1949, by Hans Ernst Thalmann, p. 100-103, illus.

Recent literature on the Foraminifera, v. 25 , p. $22-24,45-48,72,103-$ $105,1949$.

2. (and Cederstrom, Dagfin John). An upper Eocene foraminiferal fauna from deep wells in York County, Virginia: Va. Geol. Survey Bull. 67, vii, 58 p., illus., 1945.

3. The foraminiferal fauna of the Upper Cretaceous Arkadelphia marl of Arkansas: U. S. Geol. Survey Prof. Paper 221-A, 19 p., illus., 1949.

4. Robert Tracy Jackson, 1861-1948: Science, v. 109, no. 2822, p. 93-94, Jan. 28, 1949.

5. (and Stewart, Roscoe Emerson, and Stewart, Katherine C.). Quinault Pliocene Foraminifera from western Washington: Oreg. Dept. Geology and Mineral Indus. Bull. 36, pt. 7, p. 148-163, illus., Oct. 1949.

6. (and Stewart, Roscoe Emerson, and Stewart, Katherine C.). Upper Eocene Foraminifera from the Toledo formation, Toledo, Lincoln County, Oregon: Oreg. Dept. Geology and Mineral Indus. Bull. 36, pt. 6 , p. 126-145, illus., Oct. 1949.

\section{Dadson, Alexander S.}

The Giant Yellowknife [Northwest Territories]: Western Miner, v. 22, no. 10, p. 82-90, illus., Oct. 1949.

\section{Dahm, Cornelius George.}

Velocity treatment applicable to southeastern New Mexico [abs.]: Oil and Gas Jour., v. 47, no. 46, p. 161, Mar. 17, 1949; Geophysies, v. 14, no. 3 ; p. 444, July 1949 .

Dake, Henry Carl.

1. Where to collect minerals: Mineralogist, v. 17 , no. 3, p. 119-121, illus., Mar. 1949.

2. Some rare minerals of Oregon: Mineralogist, v. 17, no. 4, p. 171-174, Apr. 1949.

3. Old Texas uranium locality: Mineralogist, v. 17 , no. 9 , p. 410 , illus., Sept. 1949. 
Daly, Reginald Aldworth.

Granite and metasomatism: Am. Jour. Sci., v. 247, no. 11, p. 753-778, Nov. 1949.

Dane, Carle Hamilton.

Coal, oil and gas, and oil-shale investigations in Colorado by the United States Geological Survey: Mining Yearbook, 1949, p. 59, 61, index map. Denver, Colo., Colorado Mining Association.

Danloux-Dumesnils, Maurice.

La géologie, matière d'enseignement supérieur: Revue Trimestrielle Canadienne, v. 29, no. 114, p. 165-196, June 1943.

Dapples, Edward Charles. See also Krumbein, W. C.; Sloss, L. L., 1.

1. Sedimentation, an appropriate field of research in the natural history of coal beds: Econ. Geology, v. 44, no. 7, p. 598-605, illus., Nov. 1949.

2. (and Sloss, Laurence Louis, and Krumbein, William Christian). Organization of sedimentary rocks [abs.]: Oil and Gas Jour., v. 47, no. 46, p. 157, Mar. 17, 1949.

Davidson, Donald Miner.

Mining geology [annual review, 1948]: Min. Eng., v. 1, no. 3, p. 55-60, illus., Mar. 1949.

Davies, James F.

Geology of the Wanipigow Lake area, Rice Lake Division, Manitoba: Manitoba Dept. Mines and Nat. Res., Mines Br. Prelim. Rpt. 48-2, 14 p. $(\ddagger)$, geol. map. Scale $1: 31,680$ or 1 inch to $1 / 2$ mile. 1949 .

Davies, L. M.

Ranikothalia in East and West Indies: Geol. Mag., v. 86, no. 2, p. 113-116, Mar.-Apr. 1949.

Davies, William E.

1. Caverns of West Virginia: W. Va. Geol. Survey [Rpt.], v. 19, 353 p., illus., 1949.

2. Features of cave breakdowns: Natl. Speleol. Soc. Bull. 11, p. 34-35, 72, illus., Nov. 1949.

\section{Daviess, Steven Norman.}

(and Woodford, Alfred Oswald). Geology of the northwestern Puente Hills, Los Angeles County, California: U. S. Geol. Survey Oil and Gas Invs. Prelim. Map no. 83 (2 sheets). Text with map, Stratigraphy and structure of northwestern Puente Hills, California. Scale 1 inch to 1000 feet. 1949.

Davis, D. Dwight.

Comparative anatomy and the evolution of vertebrates, in Jepson, G. L., ed., Genetics, paleontology, and evolution, p. 64-89, 1949.

Davis, Gordon Leslie.

(and Hess, Harry Hammond). Radium content of ultramafic igneous rocks; 2, Geological and chemical implications: Am. Jour. Sci., v. 247, no. 12, p. 856-882, Dec. 1949.

Davis, Joseph Dana. See Toenges, A. L., 2.

Davis, Watson.

Thermoluminescence of rocks may give better radioactivity test: Earth Sci. Digest, v. 3, no. 11, p. 19-20, June 1949 .

Dawson, Arthur S. See also Wing, L. A.

The application of geology in the search for industrial mineral deposits: Canadian Min. Met. Bull. no. 442, p. 49-52, Feb. 1949; Canadian Inst. Min. Met. Trans., v. 52, p. 23-26, 1949. Spanish translation, Bol. Minero (Chile), v. 61, no. 592, p. 378-383, Aug. 1949. 
De Blieux, Charles W.

Photogeology in Gulf Coast exploration: Am. Assoc. Petrol. Geol. Bull., v. 33 , no. 7 , p. 1251-1259, illus. index map, July 1949; abs., no. 1 , p. 110, Jan. 1949; Oil and Gas Jour., v. 47, no. 32, p. 104, Dec. 9, 1948.

Decker, Charles Elijah.

Five new varieties of graptolites from Tennessee and Virginia: Jour. Paleontology, v. 23, no. 2, p. 214-217, illus., Mar. 1949.

DeCoster, George L. See Behre, C. H., Jr., 3.

Deegan, Charles J.

1. Benedum field [Texas] is established as three-pay major reserve: Oil and Gas Jour., v. 48, no. 2, p. 183-184, 401-402, illus., May 19, 1949.

2. Gulf Coast oil: Oil and Gas Jour., v. 48, no. 2, p. 190-192, 326-327, 330, illus., May 19, 1949.

3. Exploration in western Canada today: Oil and Gas Jour., v. 48, no. 7, p. 92-93, 150, illus. incl. index map, June 23, 1949.

\section{Deevey, Edward Smith, Jr.}

Pleistocene research, a review by the members of the committee on interrelations of Pleistocene research, National Research Council; 3, Biogeography of the Pleistocene, Part 1, Europe and North America: Geol. Soc. Am. Bull., v. 60, no. 9, p. 1315-1416, illus. incl. index maps, Sept. 1949.

\section{DeFord, Ronald Kinnison.}

Geologic section in Argo Oil Corporation's Mitchell Bros.-State No. 1 [well], in West Texas Geological Society Guidebook, Fall field trip, Oct. 29-31, 1948, p. 37-39, 1948.

DeGolyer, Everette Lee.

How men find oil: Fortune, v. 40, no. 2, p. 97-100, 103-104, illus., Aug. 1949.

Dehlinger, Martin E.

Report on Ajo quadrangle, Arizona: Compass, v. 26, no. 2, p. 182-188, Jan. 1949.

Deidrick, Elgin. See Laudon, L. R., 3.

Deiss, Charles Frederick.

Phosphate deposits of the Deer Creek-Wells Canyon area, Caribou County, Idaho: U. S. Geol. Survey Bull. 955-C, p. 61-101, illus. incl. index, geol. map, 1949.

Dejnozka, Ladislav. See Strock, L. W., 2.

deLaguna, Wallace.

Geologic correlation of logs of wells in Kings County, New York: N. Y. Water Power and Control Comm. Bull. GW-17, 35 p., illus., 1948.

De la O. Carreño, Alfonso.

Estado actual de la investigación gravimétrica en la República Mexicana: Ciencia, v. 7, nos. 7-8, p. 243-245, illus., index map, Nov. 15, 1946.

Delavault, Robert E. See Warren, H. V., 1, 3, 5.

\section{De Ment, Jack Andrew.}

1. Handbook of fluorescent gems and minerals. 68 p. Portland, Oreg., Mineralogist Pub. Co. 1949.

2. Silicon carbide refractometer: Mineralogist, v. 17, no. 2, p. 99-104, Feb. 1949.

3. Theory and prediction; behavior of volcanoes: Mineralogist, v. 17, no. 4, p. 176-178, Apr. 1949.

4. New elements in earth's crust: Mineralogist, v. 17, no. 6, p. 287-288, June 1949. 
Denis, Bertrand Tyrrell.

Quebec's undeveloped mineral resources: Eng. Jour., v. 32, no. 11, p. 736740, illus., Nov. 1949.

Dennis, Philip Eldon.

(and Akin, Philmore Donald, and Worts, G. F. Jr.). Geology and groundwater resources of parts of Cass and Clay counties, North Dakota and Minnesota: N. Dak. Geol. Survey, Ground-water Studies no. 11, Minn. Ground-water Studies no. 1, 177 p. ( $\$)$, illus. incl. index map, 1949.

Denson, Norman Maclaren. See also Duncan, D. C.; Love, J. D., 2; U. S. G. S. 1 , no. 92,94 .

1. (and Botinelly, Theodore). Geology of the Hartville Uplift, eastern Wyoming: U. S. Geol. Survey Oil and Gas Invs. Prelim. Map no. 102 ( 2 sheets). Text with map, Geology and oil and gas possibilities of the Hartville Uplift and adjacent areas, eastern Wyoming. Scale 1 inch to 4000 feet. 1949 .

2. (and Botinelly, Theodore). Tectonic map of the Hartville Uplift and adjacent areas [Wyo.]: Wyo. Geol. Assoc. Guidebook, Powder River Basin, p. 40, 1949 .

Derry, Duncan Ramsay.

Lithium-bearing pegmatites in northern Quebec [abs.]: Am. Mineralogist, v. 34, nos. 3-4, p. 275, Mar.-Apr. 1949.

De Terra, Hellmut.

1. El hombre fosil de Tepexpan y la estratigrafia del cuaternario en la cuenca de Mexico: Ciencia, v. 8, nos. 6-9, p. 153-156, Nov. 30, 1947.

2. Early Man in Mexico, in Tepexpan Man: Viking Fund Pubs. in Anthropology, no. 11, 160 p., illus. incl. geol. map, 1949.

DeVore, George W. See Newhouse, W. H., 1.

De Witt, Wallace, Jr.

Map of the Berea sand of northern Ohio: U. S. Geol. Survey Oil and Gas Invs. Prelim. Map 99, revision of Prelim. Map 39 (1945), one sheet, map with descriptive notes. Scale 1 inch to 3 miles. 1949.

\section{DeWolf, Frank Walbridge.}

Memorial to H[arry] Foster Bain [1871-1948]: Geol. Soc. Am. Proc. 1948, p. 127-133, port., May 1949.

Diamond, Woodson. See Hunter, C. D.

Dickson, Kathryn 0. See Lonsdale, J. T., 1; Maxwell, R. A., 1.

Dietz, Robert Sinclair. See Carsola, A.; Grim, R. E., 2.

Dietzel, Norman E. See Laurie, A. M.

Dings, McClelland Griffith.

The Gunnison Forks sulfur deposit, Delta County, Colorado: Colo. Sci. Soc. Proc., v. 15, no. 5, p. 237-256, illus. incl. index, geol. maps, 1949.

Dix, Charles Hewitt.

On the minimum oscillatory character of spherical seismic pulses: Geophysics, v. 14, no. 1, p. 17-20, Jan. 1949.

\section{Dobbin, Carroll Edward.}

1. (and Horn, George Henry). Geology of the Mush Creek and Osage oil fields and vicinity [Wyo.] [geologic maps and text]: U. S. Geol. Survey Oil and Gas Invs. Prelim. Map no. 103. Scale 1 inch to 2 miles. 1949.

2. Francis Maurice Van Tuyl, honorary member: Am. Assoc. Petrol. Geol. Bull., v. 33, no. 5, p. 766-767, port., May 1949. 
Dobrovolny, Ernest.

Geology applied to highway design and construction [abs.]: Washington Acad. Sci. Jour., v. 39, no. 3, p. 108, Mar. 15, 1949.

Dodge, Stanley Dalton.

Ralph Hall Brown, 1898-1948: Assoc. Am. Geog. Annals, v. 38, no. 4, p. 305-309, port., Dec. 1948.

Doeglas, D. J.

Loess, an eolian product: Jour. Sed. Petrology, v. 19, no. 3, p. 112-117, illus., Dec. 1949.

Doerr, Arthur H.

Structure and mining in Williamson and Franklin Counties, Illinois: Rocks and Minerals, v. 24 , nos. $7-8$, p. $372-375$, illus. incl. index map, JulyAug. 1949.

Dondlinger, Peter Tracy.

Notes on a happy hobby: [fossil collecting]: Nature Mag., v. 42, no. 2, p. 76-78, illus., Feb. 1949.

Donnay, Gabrielle Hamburger. See also Donnay, J. D. H., 1.

The one-dimensional crystal. 2. A graphical method for computing structure factors: Acta Crystallographica, v. 2, pt. 6, p. 370-371, illus., Dec. 1949.

\section{Donnay, Joseph Désiré Hubert.}

1. (and Donnay, Gabrielle Hamburger). The one-dimensional crystal. 1. General: Acta Crystallographica, v. 2, pt. 6, p. 366-369, illus., Dec. 1949.

2. From the law of rationality to the law of Bravais [abs.]: Am. Mineralogist, v. 34, nos. 3-4, p. 288-289, Mar.-Apr. 1949.

Donnelly, H. F. See Nagelschmidt, G.

Donner, Henry Frederick.

Geology of the McCoy area, Eagle and Routt Counties, Colorado: Geol. Soc. Am. Bull., v. 60 , no. 8, p. 1215-1247, illus. incl. index, geol. map, Aug. 1949.

\section{Donnerstag, Philip.}

Recent petroleum explorations in New York State: Appalachian Geol. Soc. Bull., v. 1, p. 303-306, 1949.

\section{Donohue, John J.}

Shore studies, Stover's Cove, South Harpswell, Maine: Maine State Geologist Rpt. 1947-1948, p. 104-109, index, geol. maps, Mar. 1949.

\section{Donovan, Desmond T.}

Observations on the Mesozoic rocks of Geographical Society $\emptyset$ [Island], East Greenland: Meddelelser om Grønland, Bind 149, nr. 5, 14 p., illus., 1949.

Dorbandt, Leslie Winston. See Ammon, W. L., 2.

\section{Dorn, Conrad L.}

Developments [in oil and gas] in Rocky Mountain region in 1948: Am. Assoc. Petrol. Geol. Bull., v. 33, no. 6, p. 827-836, illus. incl. index maps, June 1949.

Dort, Wakefield, Jr.

Glaciation of the Coeur d'Alene mining district, Idaho [abs.]: Geol. Soc. Am. Bull., v. 60, no. 12, pt. 2, p. 1883-1884, Dec. 1949. 9049790-51-4 
Dott, Robert Henry.

Minerals of Oklahoma, Director's biennial report for 1947-1948: Okla. Geol. Survey, 32 p., illus., Jan. 1949.

Douglas, Edwin B.

Cobalt in Idaho: Mining Yearbook, 1949, p. 150-152. Denver, Colo., Colorado Mining Association.

Douglas, George Vibert.

1. The structure of Ungava: Royal Soc. Canada Trans. 3d ser., v. 43, sec. 4, p. 53-55, illus., June 1949; abs., Proc. 3d ser., v. 43, p. 237, 1949.

2. (and Johnston, J. W. D.). Note on the origin of the Gut of Canso and the Bras D'Or lakes [Nova Scotia]: Royal Soc. Canada Trans. 3d ser., v. 43 , sec. 4 , p. 57-59, illus., June 1949; abs., Proc. $3 d$ ser., v. 43, p. $238,1949$.

Douglas, Robert John Wilson. See Canada Geol. Survey, 2, 5, 8.

Dowd, James Joseph. See Toenges, A. L., 2.

Downs, George Reed.

Mesozoic rocks of the northern Powder River Basin, Wyoming: Wyo. Geol. Assoc. Guidebook, Powder River Basin, p. 46-51 ( $\$)$, illus., 1949.

Downs, Harold Robert. (One and the same as Robert Harold). See Miller, A. K., 5; Younquist, W. L., 2.

\section{Downs, Theodore.}

Pleistocene avifauna from Kansas and its environment [abs.]: Geol. Soc. Am. Bull., v. 60, no. 12, pt. 2, p. 1949-1950, Dec. 1949.

Draisin, Wilburt M. See Larsen, E. S., Jr., 4.

Drake, Robert J.

Mollusk shells found in alluvium at Buell Park, Apache County, Arizona: Plateau, v. 22, no. 2, p. 26-31, Oct. 1949.

Dreyer, Robert Marx. See also Garrels, R. M., 1, 2.

(and Howland, Arthur Lloyd, and Garrels, Robert Minard). Wall rock replacement by oxidized copper minerals [abs.]: Econ. Geology, v. 44 , no. 7, p. 642 , Nov. 1949 ; Geol. Soc. Am. Bull., v. 60, no. 12, pt. 2, p. 1884 , Dec. 1949.

Dubins, Ira M. See Runnels, R. T., 1.

Dufresne, $C$.

Les failles de la plaine du Saint-Laurent [Canada] [abs.] : Assoc. Canadienne-Française Av. Sci. Annales, v. 15, p. 65-67, 1949.

Dunaven, Ruth Reece. See Thom, E. M.

\section{Dunbar, Carl Owen.}

Historical geology. xii, 567 p., illus. New York, John Wiley \& Sons, Inc., ['1949].

Duncan, Donald Cave. See also Lochman, C.

(and Denson, Norman Maclaren). Geology of Naval Oil Shale Reserves 1 and 3 , Garfield County, Colorado [geologic map and text]: U. S. Geol. Survey Oil and Gas Inv. Prelim. Map no. 94 (2 sheets). Scale 1 inch to $1 / 2$ mile. 1949.

\section{Duncan, Helen.}

Genotypes of some Paleozoic Bryozoa: Washington Acad. Sci. Jour., v. 39, no. 4, p. 122-136, Apr. 15, 1949. 
Dunham, Kingsiey Charles.

(editor). Symposium on the geology, paragenesis, and reserves of the ores of lead and zinc: 18th Internat. Geol. Cong., London, 230 p., illus., 1948. Contains 23 papers of which ten concern lead and zinc deposits of Canada, United States, and Mexico. These are by C. $O$. Swanson; T. L. Tanton and J. M. Harrison; C. H. Behre, Jr., A. V. Heyl, Jr., and E. T. McKnight; A. L. Brokaw; A. W. Pinger; P. J. Shenon; R. N. Hunt and H. G. Peacock; S. G. Lasky and A. D. Hoagland; E. B. Young; G. M. Fowler, R. M. Hernon, and E. A. Stone.

Dunn, Orton C., Jr.

Petroliferous formations in southeastern Ohio: Oil and Gas Jour., v. 47, no. 43, p. 131-132, 134, 136, 138, illus., Feb. $24,1949$.

\section{Durham, Forrest.}

Physiographic history of Finger Lakes of central New York: Compass, v. 26, no. 2, p. 138-142, illus., Jan. 1949.

Durham, John Wyatt. See also Chappell, W. M.

1. Dendraster elsmerensis Durham, n. sp.: Am. Jour. Sci., v. 247, no. 1, p. 49-62, illus., Jan. 1949.

2. Ontogenetic stages of some simple corals: Calif. Univ., Dept. Geology Bull., v. 28, no. 6, p. 137-172, illus., Apr. 27, 1949.

3. Pacific Coast Tertiary marine climates [abs.]: Geol. Soc. Am. Bull., v. 60 , no. 12 , pt. 2 , p. 1884 , Dec. 1949 .

\section{Dutton, Carl Evans.}

Geology of the central part of the Iron River district, Iron County, Michigan: U. S. Geol. Survey Circ. 43,9 p. $(\ddagger)$, illus. incl. index, geol. maps, Nov. 1949.

\section{Dysart, Arthur.}

Corkscrew Mountain [Wash.]: Mineralogist v. 17, no. 2, p. 59-61, illus., Feb. 1949.

\section{Dyson, James Lindsay.}

1. Glaciers and glaciation in Glacier National Park [Mont.]: Glacier Nat. History Assoc. Spec. Bull. 2, 24 p., illus., 1948.

2. The geologic story of Glacier National Park [Mont.]: Glacier Nat. History Assoc. Spec. Bull. 3, 24 p., illus., 1949.

Eakin, T. E. See also Maxey, G. B., 3.

(and Maxey, George Burke, and Robinson, Thomas William, Jr.). Ground water in Goshute-Antelope Valley, Elko County, Nevada: Nevada, Office of the State Engineer. 24 p. (\$), illus., 1949.

\section{Eardley, Armand John.}

1. Ancient Arctica; reply to remarks: Jour. Geology, v. 57, no. 3, p. 319320, May 1949.

2. Paleotectonic and paleogeologic maps of central and western North America: Am. Assoc. Petrol. Geol. Bull., v. 33, no. 5, p. 655-682, illus., May 1949.

3. Structural evolution of Utah, in The oil and gas possibilities of Utah, by G. H. Hansen and M. M. Bell: Utah Geol. Miner. Survey, p. 10-23, illus., Dec. 1949.

\section{Earley, J. W.}

Studies of natural and artificial selenides; 1 . Klockmannite, CuSe: Am. Mineralogist, v. 34, nos. 5-6, p. 435-440, illus., May-June 1949. 
Earthquake Notes.

[Short notes, many unsigned, on earthquakes, seismology, apparatus, and abstracts of Proceedings of the Eastern Section, Seismological Society of America]: v. 20, no. 3, p. 21-28 ( $)$, Mar. 1949; no. 4, p. 29-40 ( $)$, June 1949; no. 5-6, p. 41-60 ( $)$, Sept.-Dec. 1949.

Easker, David G.

Geology of the Tokio quadrangle [N. Dak.]: N. Dak. Geol. Survey Bull. 24, ii, 35 p., illus. incl. index, geol. maps, 1949.

Easton, William Heyden.

Mississippian cuneate corals [abs.]: Geol. Soc. Am. Bull., v. 60, no. 12, pt. 2, p. 1950 , Dec. 1949.

Eastwood, G. E. P.

Preliminary map, Snake Rapids, Saskatchewan (map and descriptive notes) : Canada Geol. Survey Paper 49-18, 4 p. (\$), geol. map, 1949.

\section{Ebright, John R.}

(and Fettke, Charles Reinhard, and Ingham, Albert Irwin). East ForkWharton gas field, Potter County, Pennsylvania: Pa. Geol. Survey Bull. M30, 43 p., illus. incl. index map, 1949.

Eckel, Edwin Butt. See also Schwartz, G. M., 2.

1. (and others). Geology and ore deposits of the La Plata district, Colorado: U. S. Geol. Survey Prof. Paper 219, 179 p., illus. incl. index, geol. maps, 1949. Contains sections by James S. Williams; F. W. Galbraith; G. M. Schwartz, D. J. Varnes and E. B. Eckel ; E. N. Goddard (which see); also several mine descriptions by E. N. Goddard.

2. Engineering geology branch, U. S. Geological Survey [abs.]: Geol. Soc. Am. Bull., v. 60 , no. 12 , pt. 2, p. 1884-1885, Dec. $\div 949$.

Eckhardt, Engelhardt August.

Geophysical activity in 1948: Geophysics, v. 14, no. 4, p. 477-485, illus., Oct. 1949 ; abs., no. 3 , p. 446, July 1949 .

Eckis, Rollin.

Geology of Russell Ranch and South Cuyama oil fields, Cuyama Valley, California [abs.]: Am. Assoc. Petrol. Geol. Bull., v. 33, no. 12, p. 2058-2059, Dec. 1949; Oil and Gas Jour., v. 48, no. 29, p. 137, Nov. 24, 1949.

\section{Edinger, Ward $M$.}

Interpretation of core analysis results on cores taken with oil or oil-base mud; Oil and Gas Jour., v. 47, no. 48, p. 104, 108-110, illus., Mar. 31, 1949.

\section{Edwards, Austin B.}

(and Gaskin, A. J.). [Discussion of] Ore and granitization: Econ. Geology, v. 44, no. 3, p. 234-241, May 1949; reply by C. J. Sullivan, no. 4, p. 336-345, June-July 1949 .

Edwards, Richard Archer.

An abandoned valley near High Springs, Florida: Fla. Acad. Sci. Quart. Jour., v. 11, no. 4, p. 125-132, illus., Dec. 1948 (1949).

\section{Ehlers, George Marion.}

1. (and Stumm, Erwin Charles). Corals of the Devonian Traverse group of Michigan. Part 1, Spongophyllum: Mich. Univ. Mus. Paleontology Contr., v. 7 , no. 8, p. 123-130, illus., May 13, 1949; Part 2, Cylindrophyllum, Depasophyllum, Disphyllum, Eridophyllum, and Synaptophyllum, v. 8, no. 3, p. 21-41, illus., Nov. 22, 1949.

2. Pachyphyllum vagabundum, a new coral from the Upper Devonian strata of New York: Mich. Univ. Mus. Paleontology Contr., v. 8, no. 1, p. 1-6, illus., Sept. 26, 1949. 
Eifler, Gus Kearney, Jr.

Geologic map and cross section of Barrilla Mountains, Texas, in West Texas Geol. Soc. Guidebook, Fall field trip, Oct. 29-31, 1948, p. 62-63, 1948 .

Eisenberg, Jerome $M$.

1. The Green River oil shales: Earth Sci. Digest, v. 4, no. 2, p. 13-16, illus., Sept. 1949.

2. Mount Mazama and Crater Lake [Oreg.]: Earth Sci. Digest, v. 4, no. 3, p. 3-9, illus., Oct. 1949.

Ekern, P. C., Jr.

(and Muckenhirn, R. J.). Water drop impact as a force in transporting sand: Soil Sci. Soc. Am. Proc., v. 12, 1947, p. 441-444, illus., 1948.

Ellis, Brooks Fleming.

1. (and Messina, Angelina Rose). Catalogue of Foraminifera (Supplements for 1949, nos. 1, 2, 3) : Am. Mus. Nat. History Spec. Pub., unpaged, illus., 1949 .

2. A new mounting device [microfossils]: Micropaleontologist, v. 3, no. 1, p. 23-25 (\$), illus., Jan. 1949.

Ellis, Miller Ward. See Gordon, M., Jr.

Ellis, W. G. See also Barnes, J. R.

Ground-water resources of Borden County, Texas: Texas State Bd. Water Eng. Rpt., 26 p. ( $\$$, illus. incl. geol. map, Sept. 1949.

Ellison, Samuel Porter, Jr.

1. Miniature stadia rod, a teaching aid: Am. Assoc. Petrol. Geol. Bull., v. 33, no. 11, p. 1902-1903, illus., Nov. 1949.

2. Subsurface Woodford black shale of west Texas and southeast New Mexico [abs.]: Geol. Soc. Am. Bull., v. 60, no. 12, pt. 2, p. 1885, Dec. 1949.

\section{Ellison, Walter David.}

Soil erosion: Soil Sci. Soc. Am. Proc., v. 12, 1947, p. 479-484, illus., 1948.

Ellsworth, Elmer William.

Sherman Alexander Wengerd, recipient of President's Award: Am. Assoc. Petrol. Geol. Bull., v. 33, no. 5, p. 769-771, port., May 1949.

Elms, Morris Allen. See Goldich, S. S., 2, 3.

\section{Emery, Kenneth Orris.}

Topography and sediments of the Arctic Basin: Jour. Geology, v. 57, no. 5, p. 512-521, illus., index map, Sept. 1949.

\section{Emmons, William Harvey, 1876-1948.}

(and others). Geology, principles and processes. 3d ed. x, 502 p., illus. New York, McGraw-Hill Book Co., Inc. 1949.

Engel, Albert Edward John. See also Jahns, R. H., 2.

1. Talc and ground soapstone, in Industrial minerals and rocks, p. 10181041, illus., 1949.

2. New York tales, their geological features, mining, milling, and uses: Min. Eng., v. 1, no. 9, p. 345-348, illus. incl. index map, Sept. 1949; A.I.M.E. Trans., v. 184, 1949.

3. Studies of cleavage in the metasedimentary rocks of the northwest Adirondack Mountains, New York: Am. Geophys. Union Trans., v. 30, no. 5, p. 767-784, illus. incl. geol. map, Oct. 1949.

4. Vein features in the Ouachita mineral province, Arkansas [abs.]: Econ. Geology, v. 44, no. 1, p, 79-80, Jan.-Feb, 1949. 
Erdtman, G.

Suggestions for the classification of fossil and recent pollen grains and spores: Svensk. Bot. Tidskr., Band 41, Häfte 1, p. 104-114, 1947.

Eric, John Howard. See also Heyl, G. R., 2, 3; Jenkins, O. P.

1. Zinc-copper deposits of the Big Bend mine, Butte County, California: Calif. Dept. Nat. Res., Div. Mines Bull. 144, p. 31-42, illus. incl. geol. maps, Dec. 1948.

2. (and Cox, Manning William). Zinc deposits of the American EagleBlue Moon area, Mariposa County, California: Calif. Dept. Nat. Res., Div. Mines Bull. 144, p. 133-150, illus. incl. geol. maps, Dec. 1948.

Ervin, Guy, Jr.

(and Osborn, Elburt Franklin). X-ray data on synthetic melilites: Am. Mineralogist, v. 34, nos. 9-10, p. 717-722, illus., Sept.-Oct. 1949.

Esarey, Ralph Emerson. See Bell, A. H., 2.

Escher, B. G.

Origin of the asymmetrical shape of the earth's surface and its consequences upon volcanism on earth and moon: Geol. Soc. Am. Bull., v. 60, no. 2, p. 352-362, illus., Feb. 1949.

Evans, Glen Louis.

Upper Cenozoic of the High Plains [Texas], in West Texas Geological Society Guidebook Field Trip no. 2, November 6-9, 1949, p. 1-9, illus.g 1949.

\section{Evans, Oren Frank.}

1. Shoreline processes of the continental shelf: World Oil, v. 129, no. 2, p. 80, 82, 84, 85, illus., June 1949 .

2. Ripple marks as an aid in determining depositional environment and rock sequence: Jour. Sed. Petrology, v. 19, no. 2, p. 82-86, illus., Aug. 1949.

3. The origin of the Verden sandstone of Oklahoma: Jour. Sed. Petrology, v. 19 , no. 2, p. 87-94, Aug. 1949.

Everhart, Donald L.

The geologic environment of primary vein deposits of uranium: Mich. Coll. Min. Tech., Conference on radioactive ores, May 6,1949, p. 13-15, 1949.

Everhart, J. 0.

Clays of Ohio; 3, Ceramic minerals distribution: Ohio State Univ., Eng. Expt. Sta. News, v. 21, no. 2, p. 28-34, illus., Apr. 1949.

Evernden, J. See Byerly, P., 2.

Evitt, William Robert, 2d.

Stereophotography as a tool of the paleontologist: Jour. Paleontology, v. 23, no. 5, p. 566-570, illus., Sept. 1949; abs., Geol. Soc. Am. Bull., v. 59 , no. 12 , pt. 2 , p. 1320 , Dec. 1948.

\section{Evrard, Pierre.}

The differentiation of titaniferous magmas: Econ. Geology, v. 44, no. 3, p. 210-232, illus., May 1949.

Ewing, William Maurice. See also Hersey, J. B., 1; Press, F.; Tolstoy, I., 1, 3.

1. (and others). [Short note] Seismic refraction measurements in the Atlantic Ocean Basin, Part 1: Geol. Soc. Am. Bull., v. 60, p. 1303, Aug. 1949.

2. Structure of the Mid-Atlantic Ridge [abs.], in Symposium on the earth's crust: Am. Geophys. Union Trans., v. 30, no. 2, p. 170, Apr. 1949.

3. Seismic studies in ocean basins [abs.]: Geol. Soc. Am. Bull., v. 60, no. 12, pt. 2, p. 1885-1886, Dec. 1949. 
Fahey, Joseph John. See Allen, V. T., 1; Hunt, C. B., 2; Murdoch, J., 2; Pecora, W. T., 2.

\section{Fairbairn, Harold William.}

1. Structural petrology of deformed rocks (with supplementary chapters on statistical analysis by Felix Chayes). $2 \mathrm{~d}$ ed., ix, 344 p., illus. Cambridge, Mass., Addison-Wesley Press, Inc. 1949.

2. Synthetic quartzite [abs.]: Geol. Soc. Am. Bull., v. 60 , no. 12, pt. 2, p. 1886, Dec. 1949 .

Falkenbach, Charles Henry. See Schultz, C. B.

\section{Fancher, George Homer.}

Frederick Byron Plummer [1886-1947] : Texas Acad. Sci. Proc. 1946, v. 30, p. 23-26, 1948.

Farley, W. J.

Geology of the Sherritt Gordon orebody [Manitoba]: Canadian Min. Met. Bull. no. 441, p. 25-30, illus. incl. gaol. map, Jan. 1949.

\section{Farrar, R. L., Jr.}

(and Cady, George H.). Comparison of age with the relative abundance of argon and potassium in rocks: Am. Chem. Soc. Jour., v. 71, ro. 2, p. $742-743$, Feb. 1949.

\section{Fash, Ralph Henry.}

New approach in study of origin of oil: Am. Assoc. Petrol. Geol. Bull., v. 33 , no. 1, p. 99 , Jan. 1949.

\section{Faul, Henry.}

1. (and Sullivan, Geraldine R.). Density correction in beta-ray assaying of rock and mineral samples: Nucleonics, v. 4, no. 1, p. 53-56, illus., Jan. 1949.

2. (and Roberts, Wayne A.). New fossil footprints from Colorado [abs.]: Geol. Soc. Am. Bull., v. 60, no. 12, pt. 2, p. 1886, Dec. 1949.

Faust, Feorge Tobias.

1. Differentiation of aragonite from calcite by differential thermal analysis: Science, v. 110 , no. 2859 , p. 402-403, Oct. 14, 1949.

2. Dedolomitization, and its relation to a possible derivation of a magnesium-rich hydrothermal solution: Am. Mineralogist, v. 34, nos. 11-12, p. 789-823, illus., Nov.-Dec. 1949.

\section{Fawley, Allan P.}

Geology of the Sickle Lake area, Granville Lake Division, Manitoba: Manitoba Dept. Mines and Nat. Res., Mines Br., Rpt. and Map 48-6, 19 p. ( $\ddagger)$, geol. map, 1949.

\section{Feld, Jacob.}

Manhattan schist as a foundation for structures: N. Y. Acad. Sci. Trans., ser. 2, v. 12, no. 1, p. 5-9, Nov. 1949.

Feniak, Michael Walter, 1914-1949.

McAlpine Channel map-area, Northwest Territories (report and map): Canada Geol. Survey Paper 49-19, 14 p. ( $)$, geol. map, 1949.

\section{Fent, Oscar S.}

Use of geologic methods in ground water prospecting: Am. Water Works Assoc. Jour., v. 41, no. 7, p. 590-598, illus., July 1949.

Fenton, Carroll Lane. See also Stumm, E. C., 1.

Are these earth's oldest plants? [Medicine Bow Mts., Wyo.] : Nature Mag., v. 42 , no. 9 , p. 440 , illus., Nov. 1949.

Fenton, Mildred Adams. See Stumm, E. C., 1. 
Fenwick, Willis Henry.

1. A discussion of the application of the gravitational and magnetic methods of exploration to the Powder River Basin [Wyo.]: Wyo. Geol. Assoc. Guidebook, Powder River Basin, p. 52-62 (\$), illus., 1949.

2. Gravitational and magnetic exploration in the Powder River Basin of Wyoming: Mines Mag., v. 39 , no. 12 , p. $73-79,121,126$, illus., Dec. 1949.

\section{Ferguson, Henry Gardiner.}

(and Muller, Siemon William). Structural geology of the Hawthorne and Tonopah quadrangles, Nevada: U. S. Geol. Survey Prof. Paper 216, 55 p., illus. incl. index, geol, maps, 1949.

Ferguson, Robert Bury.

Observations on some aluminium fluoride minerals: Am. Mineralogist, v. 34, nos. 5-6, p. 383-397, May-June 1949; abs., Observations on weberite and jarlite, v. 33, nos. 3-4, p. 195, Mar.-Apr. 1948.

Feth, John Henry.

1. (and Anthony, John W.). Spheroidal structures in Arizona volcanics: Am. Jour. Sci., v. 247, no. 11, p. 791-801, illus., Nov. 1949.

2. Structural reconnaissance of the Red Rock quadrangle, Arizona [abs.]: Geol. Soc. Am. Bull., v. 60, no. 12, pt. 2, p. 1887, Dec. 1949.

Fettke, Charles Reinhard. See also Ebright, J. R.

1. (and Seifert, Wilbur H.). Haskell sand core from the Coryville pool, McKean County, Pennsylvania (Preliminary Report): Pa. Geol. Survey Prog. Rpt. 131, 9 p. ( $\ddagger)$, map, 1946.

2. Developments [in gas and oil] in Pennsylvania in 1948: Am. Assoc. Petrol. Geol. Bull., v. 33, no. 6, p. 841-847, index map, June 1949.

Fidlar, Marion Moore.

Clay Basin gas field, Daggett County, Utah, in The oil and gas possibilities of Utah, by G. H. Hansen and M. M. Bell: Utah Geol. Miner. Survey, p. 261-267, illus., Dec. 1949.

Field, Richard Montgomery.

Geological-geophysical-geochemical significance of geosynclines [abs.]: 18th Internat. Geol. Cong., London, Volume of titles and abstracts, p. 53-54, 1948; Geophysics, v. 14, no. 3, p. 375, July 1949.

Field, V. W.

Clayton Peak, Utah, storehouse of minerals: Mineralogist, v. 17, no. 10, p. $474,476,478$, Oct. 1949 ; reprinted from Am. Mineralogist, v. 6, no. 6 , p. 103-104, June 1921.

Field, William Osgood, Jr.

1. The mountains and glaciers of Prince William Sound, Alaska: Am. Alpine Jour., v. 1, no. 4, p. 445-458, illus., 1932.

2. Glacier observations in the Canadian Rockies, 1948: Canadian Alpine Jour., v. 32, p. 99-114, illus., May 1949.

\section{Fieldner, Arno Carl.}

Solid fuels, in Symposium on fuel reserves in the United States: Oil and Gas Jour., v. 47, no. 46, p. 138-140, 142, 145, illus., Mar. 17, 1949.

Finch, Ruy Herbert. See also Macdonald, G. A., 2, 3.

Volcanic tremor (Part 1) : Seismol. Soc. Am. Bull., v. 39, no. 2, p. 73-78, illus., Apr. 1949.

Fine, Spencer Freeland. See Schwade, I. T.

Finley, Robert, Jr. See Fischer, A. G. 


\section{Finn, Fenton $\mathbf{H}$.}

Geology and occurrence of natural gas in Oriskany sandstone in Pennsylvania and New York: Am. Assoc. Petrol. Geol. Bull., v. 33, no. 3, p. 303-335, illus. incl. index maps, Mar. 1949.

Fischer, Alfred George.

(and Finley, Robert, Jr.). Microstructure of some Pennsylvanian nautiloids [abs.]: Geol. Soc. Am. Bull., v. 60, no. 12, pt. 2, p. 1887, Dec. 1949.

Fischer, R. B. See Comeforo, J. E.

\section{Fischer, Richard Philip.}

1. Simplified geologic map of the vanadium region of southwestern Colorado and southeastern Utah [with descriptive notes]: U. S. Geol. Survey Strategic Minerals Inv. Prelim. Map 3-226. Scale 1 inch to 3 miles. 1944.

2. Origin of the Colorado Plateau vanadium deposits [abs.]: Washington Acad. Sci. Jour., v. 39, no. 3, p. 109, Mar. 15, 1949.

Fishel, Vinton Crews. See Frye, J. C., 2.

Fisher, Daniel Jerome.

1. Changes in the objectives in the teaching of mineralogical crystallography [abs.]: Am. Mineralogist, v. 34, nos. 3-4, p. 289-290, Mar.Apr. 1949.

2. Cone-axis diffraction patterns [abs.]: Geol. Soc. Am. Bull., v. 60, no. 12, pt. 2, p. 1888 , Dec. 1949.

Fisher, Harvey Irvin.

The skulls of the cathartid vultures [recent and fossil]: Condor, v. 46, no. 6 , p. 272-296, illus., Nov.-Dec. 1944.

\section{Fisher, Joel E.}

1. Max Harrison Demorest, 1910-1942: Am. Alpine Jour., v. 5, no. 2, p. 296-297, 1944.

2. Problems in the geology of mountains. 80 p., illus. New York. Privately published. May 1944.

3. The kinetic theory of the origin of mountain-making forces: Am. Alpine Jour., v. 6, no. 1 , p. 69-74, 1946.

4. The pressure melting point of ice and the excavation of cirques and valley steps by glaciers: Am. Alpine Jour., v. 7, no. 1, p. 67-72, Apr. 1948.

Fisher, Lloyd Wellington.

Color photography of minerals: Rocks and Minerals, v. 24, nos. 3-4, p. 115-122, illus., Mar.-Apr. 1949.

Fisk, Harold Norman. See also Turnbull, W. J.

Depositional environments of Mississippi Delta [abs.]: Oil and Gas Jour., v. 47, no. 46, p. 150, Mar. 17, 1949.

Fiteh, Cecil A., Jr.

(and Quigley, James E., and Barker, Clarence S.). Utah's new mining district [Topaz Mtn.] : Eng. Min. Jour., v. 150, no. 3, p. 63-66, illus. incl. index map, Mar. 1949.

Fix, Philip Forsyth.

1. (and Swinney, C. Melvin). Quicksilver deposits of the Oakville district, Napa County, California: Calif. Jour. Mines and Geology, v. 45, no. 1, p. 31-46, illus. incl. index, geol. maps, Jan. 1949.

2. Regularity of Old Faithful Geyser, Yellowstone National Park, Wyoming: Am. Jour. Sci., v. 247, no. 4, p. 246-256, illus., Apr. 1949. 
Flagg, Arthur Leonard.

Fluorescent minerals: Arizona Highways, v. 25, no. 1, p. 30-33, illus., Jan. 1949.

Fleming, John Adam.

Biographical memoir of William Bowie, 1872-1940; Natl. Acad. Sci. Biog. Mem., v. 26, p. 61-78, illus. incl. port., bibliography (with Harry Durward Harradon), p. 79-98, 1949.

Flint, Norman $K$.

Geologic map of Perry County [Ohio]: Ohio Geol. Survey. Scaie 1:62,500 or 1 inch to approx. 1 mile. 1948.

\section{Flint, Richard Foster.}

1. Ups and downs of the Great Lakes: Nat. History, v. 58, no. 4 , p. 180184, illus. incl. index maps, Apr. 1949.

2. Leaching of carbonates in glacial drift and loess as a basis for age correlation: Jour. Geology, v. 57, no. 3, p. 297-303, May 1949.

3. (chairman). Pleistocene research, a review by the members of the committee on interrelations of Pleistocene research, National Research Council: Geol. Soc. Am. Bull., v. 60 , no. 9, p. 1305-1525, illus. incl. index maps, Sept. 1949. Contains papers by R. F. Flint, Henri Bader [Foreign], Edward Smith Deevey, Jr., Claude William Hibbard, Chauncey DePew Holmes, Helmut Landsberg, Hallam L. Movius, Jr. [Foreign], Fred B. Phleger, Jr., Louis Lamy Ray, Harold Theodore Uhr Smith, James Thorp.

4. Pleistocene research, a review by the members of the committee on interrelations of Pleistocene research, National Research Council; 1. Introduction: Geol. Soc. Am. Bull., v. 60, no. 9, p. 1305-1308, Sept. 1949.

Flores, Teodoro.

Geology and structural environment of the iron ore deposits of Mexico [abs.]: 18th Internat. Geol. Cong., London, Volume of titles and abstracts, p. 87, 1948 .

\section{Flower, Rousseau Hayner.}

1. New genera of Devonian nautiloids: Jour. Paleontology, v. 23, no. 1, p. 74-80, illus., Jan. 1949.

2. Phylogeny and stratigraphy [abs.]: Oil and Gas Jour., v. 47, no. 46, p. 157, Mar. 17, 1949 .

3. Structural history of the Hudson Valley [abs.]: Geol. Soc. Am. Bull., v. 60 , no. 12 , pt. 2 , p. 1969 , Dec. 1949.

Foley, Richard. See Keller, W. D., 3.

Folinsbee, Robert Edward. See also Canada G. S., 7.

Determination of reflectivity of the ore minerals: Econ. Geology, v. 44, no. 5, p. 425-436, illus., Aug. 1949.

\section{Folk, Robert L.}

1. Petrography and reservoir potentialities of the Nittany dolomite: Pa. State Coll. Mineral Indus. Expt. Sta. Bull. 52, p. 43-52, illus., Feb. 25, 1949; Producers Monthly, v. 13, no. 7, p. 35-38, illus., May 1949; abs., Oil and Gas Jour., v. 42, no. 26, p. 105, Oct. 28, 1948.

2. Petrology of lower Ordovician cherts in central Pennsylvania [abs.]: Geol. Soc. Am. Bull., v. 60, no. 12, pt. 2, p. 1969, Dec. 1949.

\section{Follett, Clarence R.}

(and White, Walter Noy, and Irelan, Burdge). Occurrence and development of ground water in the Linn-Faysville area, Hidalgo County, Texas: Texas State Bd. Water Eng. Rpt., 43 p. ( $\ddagger)$, illus., Sept. 1949. 
Forbes, Hyde.

Effect of Niles-Irvington section of the Haywards fault: Seismol. Soc. Am. Bull., v. 39, no. 4, p. 243-247, illus., Oct. 1949.

Forman, S. A.

(and Peacock, Martin Alfred). Crystal structure of rickardite, $\mathrm{Cu}_{4-x} \mathrm{Te}_{2}$ : Am. Mineralogist, v. 34, nos. 5-6, p. 441-451, illus., May-June 1949.

Forrester, James Donald.

1. Mining and mineral resources of Missouri: Mo. Univ. Sch. Mines and Metallurgy Bull. Tech. ser. 73, 50 p., illus., Dec. 1948.

2. Mining geology and the engineering aspects of mineral exploration: Econ. Geology, v. 44, no. 6, p. 545-550, Sept.-Oct. 1949.

Forrey, Donald C. See Northup, R. C.

Fortier, Yves Oscar.

Indin Lake map-area (east half), Northwest Territories (report and map) : Canada Geol. Survey Paper 49-10, 28 p. ( $\$)$, geol. map, 1949.

Foshag, William Frederick. See González Reyna, J., 1.

\section{Foster, Wilder DeAyre.}

Petrographic determination of quartz in the presence of claylike minerals: U. S. Bur. Mines Rpt. Inv. 4573, 13 p. ( $\ddagger)$, illus., Nov. 1949.

Foster, Wilfrid Raymond. See also Riddle, F. H.

1. (and Royal, Herbert F.). An intermediate compound in the system $\mathrm{BeO} . \mathrm{Al}_{2} \mathrm{O}_{3}$ (chrysoberyl)- $\mathrm{Al}_{2} \mathrm{O}_{3}$ (corundum): Am. Ceramic Soc. Jour., v. 32, no. 1, p. 26-34, illus., Jan. 1, 1949.

2. Petrographic distinction of xenotime and bastnäsite: Am. Mineralogist, v. 34, nos. 11-12, p. 830-834, Nov.-Dec. 1949.

\section{Foster, William J.}

Mineralogical data in speleological work: Natl. Speleol. Soc. Bull. 11, p. 51-54, Nov. 1949.

Fowler, George Malcolm.

(and Hernon, Robert M., and Stone, Edwin A.). The Taxco mining district, Guerrero [Mexico], in Dunham, K. C., ed., Symposium on the geology, paragenesis and reserves of the ores of lead and zinc, 18th Internat. Geol. Cong., London, p. 107-116, illus. incl. geol. map, 1948; abs., Volume of titles and abstracts, p. 44-45, 1948.

\section{Fowler-Billings, Katharine.}

1. The geology of the Monadnock quadrangle, New Hampshire. $41 \mathrm{p}$., illus. incl. geol. map. Concord, N. H., State Plan. Dev. Comm. 1949.

2. Geology of the Monadnock region of New Hampshire: Geol. Soc. Am. Bull., v. 60, no. 8, p. 1249-1280, illus. incl. index, geol. maps, Aug. 1949 ; abs., v. 57 , no. 12 , pt. 2 , p. 1280 , Dec. 1946.

Frank, Albert J. See Allen, V. T., 1.

Franklin, Virginia. See Wolfe, C. W., 6.

Franz, Harvey. See Hill, J.

\section{Frarey, M. J.}

Preliminary map, Collins Point, Manitoba: Canada Geol. Survey Paper 49-9, geol. map with descriptive notes, 1949.

\section{Fraser, George D.}

Coal Creek quartzite, Jefferson and Boulder Counties, Colorado [abs.]: Geol. Soc. Am. Bull., v. 60, no. 12, pt. 2, p. 1960, Dec. 1949. 
Frautschy, J. D.

Use of a variable-field electromagnetic mineral separator in sedimentary petrography [abs.]: Geol. Soc. Am. Bull., v. 60, no. 12, pt. 2, p. 1888, Dec. 1949.

Frederickson, Edward Arthur, Jr.

1. Trilobite fauna of the Upper Cambrian Honey Creek formation [Okla.] : Jour. Paleontology, v. 23, no. 4, p. 341-363, illus., July 1949; abs, Geol. Soc. Am. Bull., v. 59, no. 12, pt. 2, p. 1323, Dec. 1948.

2. Cyphaspis and other trilobites from Oklahoma [abs.]: Geol. Soc. Am. - Bull., v. 60, no. 12 , pt. 2, p. 1888, Dec. 1949.

Freedman, Jacob. See Wahrhaftig, C., 1.

\section{Freeman, James C.}

Strand-line accumulation of petroleum, Jim Hogg County, Texas: Am. Assoc. Petrol. Geol. Bull., v. 33, no. 7, p. 1260-1270, illus. inel. index map, July 1949.

\section{Freeman, Louise Barton.}

Regional aspects of Cambrian and Ordovician subsurface stratigraphy in Kentucky: Am. Assoc. Petrol. Geol. Bull., v. 33, no. 10, p. 1655-1681, lllus., Oct. 1949; reprinted in Appalachian Geol. Soc. Bull., v. 1, p. 118-165, illus., 1949; abs., Oil and Gas Jour., v. 47, no. 24, p. 90 , Oct. 14, 1948; Am. Assoc. Petrol. Geol. Bull., v. 32, no. 11, p. 2160, Nov. 1948.

Frey, David Grover.

Morphometry and hydrography of some natural lakes of the North Carolina Coastal Plain; the bay lake as a morphometric type: Elisha Mitchell Sci. Soc. Jour., v. 65, no. 1, p. 1-37, illus., June 1949.

\section{Friedman, I. I.}

1. The laboratory growth of quartz: Am. Mineralogist, v. 34, nos. 7-8, p. 583-588, illus., July-Aug. 1949.

2. A proposed method for the measurement of geologic temperatures: Jour. Geology, v. 57, no. 6, p. 618-619, Nov. 1949.

3. Liquid immiscibility in hydrous silicate systems: Econ. Geology, v. 44, no. 8, p. 742-744, illus., Dec. 1949 . Discussion of comments by George W. Morey (v. 44, no. 2, p. 151-154, Mar.-Apr. 1949) on "Transport and deposition of the non-sulphide vein minerals. 3. Phase relations at the pegmatitic stage" by F. Gordon Smith, v. 43, no. 7, p. 535-546, Nov. 1948.

4. Liquid immiscibility in the $\mathrm{Na}_{2} \mathrm{O}-\mathrm{SiO}_{2}-\mathrm{H}_{2} \mathrm{O}$ system; preliminary data on the $\mathrm{Na}_{2} \mathrm{O}-\mathrm{SiO}_{2}-\mathrm{Al}_{2} \mathrm{O}_{3}$ system [abs.]: Geol. Soc. Am. Bull., v. 60, no. 12 , pt. 2 , p. 1889 , Dec. 1949.

Fries, Carl, Jr. See Behre, C. H., Jr., 4.

Frizzell, Donald Leslie.

1. (and Keen, Angeline Myra). On the nomenclature and generic position of Nautilus beccarii Linné (Foraminifera, "Rotaliidae") : Jour. Paleontology, v. 23, no. 1, p. 106-108, Jan. 1949.

2. Rotaliid Foraminifera of the Chapmanininae; their natural distinction and parallelism to the Dictyoconus lineage: Jour. Paleontology, v. 23, no. 5, p. 481-495, illus., Sept. 1949; abs. with title "Morphology and relationships of the foraminiferal genus Chapmanina Silvestri," Geol. Soc. Am. Bull., v. 58, no. 12, pt. 2, p. 1181, Dec. 1947.

Frondel, Clifford.

1. Crystallography of spangolite: Am. Mineralogist, v. 34, nos. 3-4, p. 181-187, illus., Mar.-Apr. 1949.

2. (and Palache, Charles). Retgersite, $\mathrm{NiSO}_{4} \cdot 6 \mathrm{H}_{2} \mathrm{O}$, a new mineral: Am. Mineralogist, v. 34, nos. 3-4, p. 188-194, illus., Mar.-Apr. 1949; abs., p. 276, Mar.-Apr. 1949; Geol. Soc. Am. Bull., v. 59, no. 12, pt. 2, p. 1323-1324, Dec. 1948. 
Frondel, Clifford-Continued

3. The dufrenite problem: Am. Mineralogist, v. 34, nos. 7-8, p. 513-540, July-Aug. 1949.

4. Wolfeite, xanthoxenite, and whitlockite from the Palermo mine, New Hampshire: Am. Mineralogist, v. 34 , nos. 9-10, p. 692-705, illus., Sept.-Oct. 1949.

Frowe, Eugene W.

Offshore exploration with gravity meter and magnetometer; Petroleum Engineer, v. 21, no. 4, p. B92, B95, illus., Apr. 1949.

Frueh, Alfred J., Jr.

Disorder in sulphides [abs.]: Geol. Soc. Am. Bull., v. 60, no. 12, pt. 2, p. 1889 , Dec. 1949.

\section{Fry, Wayne L.}

Cordaitean fructifications [abs.]: Am. Jour. Botany, v. 36, no. 10, p. 818819, Dec. 1949.

\section{Frye, John Chapman.}

1. (and Leonard, Alvin Riley). Geology and groundwater resources of Norton County and northwestern Phillips County, Kansas: Kans. Univ., State Geol. Survey Bull. 81, 144 p., illus. incl. index, geol. maps, 1949.

2. (and Fishel, Vinton Crews). Ground water in southwestern Kansas. 24 p., illus. Lawrence, Kans., Kans. State Geol. Survey, 1949.

3. The Plains Border physiographic section: Kans. Acad. Sci. Trans., v. 52 , p. 71-81, illus., 1949 .

4. Use of fossil soils in Kansas Pleistocene stratigraphy: Kans. Acad. Sci. Trans., v. 52, p. 478-482, 1949.

5. (and others). Ceramic utilization of northern Kansas Pleistocene loesses and fossil soils: Kans. Univ., State Geol. Survey Bull. 82, pt. 3, p. 49-124, illus., Oct. 31,1949 .

6. (and Leonard, Arthur Byron). Pleistocene stratigraphic sequence in northeastern Kansas: Am. Jour. Sci., v. 247, no. 12, p. 883-899, illus., Dec. 1949.

\section{Fuller, Richard Eugene.}

Basaltic fan jointing induced by aqueous chilling [Wash.] [abs.]: Am. Mineralogist, v. 34, nos. 3-4, p. 276, Mar.-Apr. 1949.

Funnell, John E.

Ceramic materials of southwestern Oklahoma: Am. Ceramic Soc. Bull., v. 28 , no. 12 , p. $489-492$, illus., Dec. $15,1949$.

Furcron, Aurelius Sydney.

Staurolite and its occurrence in Georgia: Earth Sci. Digest, v. 3, no. 7, p. 7-12, illus., Feb. 1949.

\section{Gabelman, John W.}

1. Thin-section analysis, in Subsurface geologic methods: Colo. Sch. Mines Quart., v. 44, no. 3, p. 128-135, July 1949.

2. A self potential survey in the Georgetown mining district, Colorado: Mines Mag., v. 39, no. 9, p. 19-22, illus., Sept. 1949; abs. with title "A preliminary report of a self potential survey of the Anglo Saxon vein, Georgetown, Colorado", Colo.-Wyo. Acad. Sci. Jour., v. 3, no. 5, p. 38-39, Mar. 1948.

3. Laramide structure and igneous activity of the Fulford and Brush Creek mining districts, Colorado [abs.]: Geol. Soc. Am. Bull., v. 60, no. 12, pt. 2, p. 1960-1961, Dec. 1949.

Gadd, N. R.

Preliminary map, Brochet, Manitoba (map and descriptive notes) : Canada Geol. Survey Paper 49-12, 7 p. ( $\$), 1949$. 
Gaines, R. V.

Hydrothermal synthesis of enargite and tennantite [abs.]: Am. Mineralogist, v. 34, nos. 3-4, p. 276-277, Mar.-Apr. 1949.

Gair, Jacob E.

Cleavage and the distortion of stratigraphic thicknesses in Appalachian folds: Am. Geophys. Union Trans., v. 30, no. 1, p. 116-118, illus., Feb. 1949.

Galbraith, Frederic William, 3d.

1. Mineralogy, in Geology and ore deposits of the La Plata district, Colorado, by E. B. Eckel: U. S. Geol. Survey Prof. Paper 219, p. 53-63, illus., 1949.

2. Thrust faulting in the Empire Mountains, southeastern Arizona [abs.]: Geol. Soc. Am. Bull., v. 60, no. 12, pt. 2, p. 1889-1890, Dec. 1949.

Galeski, Robert Benjamin. See Johnson, C. H.

García Rojas, Antonio.

1. Exploraciones gravimétricas de tipo industrial: Ciencia, v. 9, nos 1-3, p. 51-65, illus. incl. index maps, Dec. 15, 1948.

2. Mexican oil fields: Am. Assoc. Petrol. Geol. Bull., v. 33, no. 8, p. 13361350 , illus. incl. index maps, Aug. 1949; abs., v. 32, no. 12, p. 2314, Dec. 1948; Oil and Gas Jour., v. 47, no. 25, p. 129, Oct. 21, 1948.

Gardner, Louis W.

Seismograph determination of salt-dome boundary using well detector deep on dome flank: Geophysics, v. 14, no. 1, p. 29-38, illus., Jan 1949.

Garfias, Valentin Richard.

(and Chapin, Theodore C.). Geología de México. 202 p., illus. incl. geol. map. México, Editorial Jus. 1949.

Garrels, Robert Minard. See also Dreyer, R. M.; Howland, A. L.

1. (and Dreyer, Robert Marx, and Howland, Arthur Lloyd). Diffusion of ions through intergranular spaces in water-saturated rocks: Geol. Soc. Am. Bull., v. 60 , no. 12 , pt. 1, p. 1809-1828, illus., Dec. 1949.

2. (and Howland, Arthur Lloyd, and Dreyer, Robert Marx). Precipitation of basic copper [abs.] : Econ. Geology, v. 44, no. 7, p. 641-642, Nov. 1949; Geol. Soc. Am. Bull., v. 60 , no. 12 , pt. 2 , p. 1890 , Dec. 1949.

Gaskin, A. J. See Edwards, A. B.

Gates, George Oscar. See Twenhofel, W. S.

Gates, Olcott.

Geology of the west side of the Gore Range near Radium, Colorado [abs.]: Geol. Soc. Am. Bull., v. 60, no. 12, pt. 2, p. 1962, Dec. 1949.

\section{Gault, Hugh Richard.}

1. (and Joyce, J. E.). Localization of phosphates by contact printing: Pa. Acad. Sci. Proc., v. 23, p. 67-71, 1949.

2. The frequency of twin types in quartz crystals: Am. Mineralogist, v. 34 , nos. 3-4, p. 142-162, illus., Mar.-Apr. 1949.

Gazin, Charles Lewis.

A lepticid insectivore from the middle Eocene Bridger formation of Wyoming: Washington Acad. Sci. Jour., v. 39, no. 7, p. 220-223, illus., July 15, 1949.

Gealy, William K. See Stirton, R. A.

George, William Owsley. See Barnes, J. R. 
Gester, George Clark.

Walter Stalder (1881-1949) : Am. Assoc. Petrol. Geol. Bull., v. 33, no. 7, p. 1310 , July 1949 .

Geyne, A. R.

[Discussion of] Mineral relationships in the ores of Pachuca and Real del Monte, Hidalgo, Mexico: Econ. Geology, v. 44, no. 3, p. 233-234, May 1949.

\section{Gianella, Vincent Paul.}

Verdi, Nevada, earthquake of December 29, 1948 [abs.]: Geol. Soc. Am. Bull., v. 60, no. 12, pt. 2, p. 1938, Dec. 1949.

\section{Gilbert, Charles Merwin.}

1. Cementation of some California Tertiary reservoir sands: Jour. Geology, v. 57, no. 1 , p. 1-17, illus., Jan. 1949.

2. (and Turner, Francis John). Use of the universal stage in sedimentary petrography: Am. Jour. Sci., v. 247, no. 1, p. 1-26, illus., Jan. 1949.

\section{Gilbert, J. E.}

1. Preliminary report on Capsisit Lake area, Abitibi-East County [Quebec]: Quebec Dept. Mines Prelim. Rpt. 210, 10 p. ( $\ddagger)$, index, geol. maps, 1947.

2. Preliminary report on Branssat-Kreighoff area, Abitibi-East County [Quebec]: Quebec Dept. Mines Prelim. Rpt. 221,13 p. $(\ddagger)$, index, geol. maps, 1948.

Giles, Alfred E. See Huffman, G. G., 1.

\section{Gill, Edmund D.}

Prosopon, a term proposed to replace the biologically erroneous term ornament: Jour. Paleontology, v. 23, no. 5, p. 572, Sept. 1949; discussion by C. W. Wright, v. 24, no. 4, p. 497, July 1950.

Gill, James Edward.

1. Natural divisions of the Canadian Shield: Royal Soc. Canada Trans., 3d ser., v. 43, sec. 4, p. 61-69, illus., June 1949; abs., Proc. 3d ser., v. 43 , p. 237,1949 .

2. Mountain building in the Canadian Precambrian Shield [abs.]: 18th Internat. Geol. Cong., London, Volume of titles and abstracts, p. 88, 1948.

\section{Gillies, Norman B.}

Preliminary report on the Canimiti River area, Pontiac County [Quebec]: Quebec Dept. Mines Prelim. Rpt. 212, 11 p. ( $\ddagger)$, index, geol. maps, 1948.

\section{Gillson, Joseph Lincoln.}

Titanium, in Industrial minerals and rocks, p. 1042-1073, 1949.

\section{Gilluly, James.}

1. The Ajo mining district, Arizona: U. S. Geol. Survey Prof. Paper 209 (supplement), 1 p. ( $\ddagger$ ), illus., 1949.

2. (and Grant, Ulysses Simpson, 4th). Subsidence in the Long Beach Harbor area, California: Geol. Soc. Am. Bull., v. 60, no. 3, p. 461529, illus., Mar. 1949 ; abs., v. 58, no. 12 , pt. 2, p. 1251 , Dec. 1947.

3. Distribution of mountain building in geologic time: Geol. Soc. Am. Bull., v. 60, no. 4, p. 561-590, illus., Apr. 1949.

\section{Gilmore, Marion H.}

Relations of microseisms to meteorology (with discussion by B. Gutenberg), in Symposium on the earth's crust: Am. Geophys. Union Trans., v. 30, no. 2, p. 165-169 ( $\ddagger$ ), illus., Apr. 1949. 


\section{Girault, Jean Paul.}

1. Un nouveau procédé pour la mesure de l'indice $n_{p}$ dans les micas et les chlorites [abs.]: Assoc. Canadienne-Française Av. Sci. Annales v. 15, p. 72,1949 .

2. Contribution à l'etude du mica suzorite [abs.]: Assoc. Canadienne-Française Av. Sci. Annales, v. 15, p. 73, 1949.

Glaessner, Martin F.

Foraminifera of Franciscan (California): Am. Assoc. Petrol. Geol. Bull., v. 33, no. 9, p. 1615-1617, Sept. 1949.

Glass, Jewell Jeannette.

(and Vhay, John Stewart). A new locality for ludlamite [Idaho]: Am. Mineralogist, v. 34, nos. 3-4, p. 335-336, Mar.-Apr. 1949.

Gleddie, Joseph.

Upper Cretaceous in western Peace River Plains, Alberta, in Clark, L. M., chm., Alberta symposium: Am. Assoc. Petrol. Geol. Bull., v. 33, no. 4, p. 511-532, illus. incl. index map, Apr. 1949.

Glover, Sheldon Latta.

1. (and Bennett, William Alfred Glenn). Geologic factors of quarrying: Wash. Dept. Conserv. Dev., Div. Mines and Mining, Inf. Circ. 10, 18 p. ( $\ddagger)$, Sept. 1944 .

2. Origin and occurrences of gem stones in Washington: Wash. Dept. Conserv. Dev., Div. Mines and Geology, Rpt. Inv. 16, 32 p., 1949.

Goddard, Edwin Newell. See also Eckel, E. B., 1.

1. Copper deposits of the Bear Creek district, in Geology and ore deposits of the La Plata district, Colorado, by E: B. Eckel: U. S. Geol. Survey Prof. Paper 219, p. 70-72, illus., 1949.

2. (and others). Map symbols used in publications of the United States Geological Survey: Calif. Jour. Mines and Geology, v. 45, no. 1, p. 109-116, Jan. 1949.

Goebel, Lawrence A.

Cairo field, Union County, Arkansas [abs.]: Oil and Gas Jour., v. 48, no. 25 , p. $87-88$, Oct. 27,1949 ; Am. Assoc. Petrol. Geol. Bull., v. 33 , no. 12, p. 2069 , Dec. 1949.

Goldbeck, A. T.

Crushed stone, in Industrial minerals and rocks, p. 245-293, 1949.

Goldberg, Edward. See also Brown, H. S., 2, 3.

Goldich, Samuel Stephen. See also Barnes, V. E., 1.

1. (and Seward, Clay Luzenberg, Jr.). Green Valley-Paradise Valley Field Trip, in West Texas Geological Society Guidebook, Fall Field Trip, Oct. 29-31, 1948, p. 11-36, illus. incl. index, geol. maps, 1948.

2. (and Elms, Morris Allen, and Seward, Clay Luzenberg, Jr.). Green Valley-Paradise Valley Field Trip [Texas], in West Texas Geological Society Guidebook Field Trip no. 1, November 5-9, 1949, p. 63-93, illus. incl. index, geol. maps, 1949.

3. (and Elms, Morris Allen). Stratigraphy and petrology of Buck Hill quadrangle, Texas: Geol. Soc. Am. Bull., v. 60 , no. 7, p. 1133-1182, illus. incl. index, geol. maps, July 1949 ; reprinted as Texas Univ., Bur. Econ. Geology Rpt. Inv. 6, July 1949.

Goldman, Marcus Isaac. See also Hills, J. M.

1. Bauxitization, a tropical disease [abs.]: Washington Acad. Sci. Jour., v. 39, no. 3, p. 107, Mar. 15, 1949.

2. Petrology of bauxite surrounding a boulderlike core of kaolinized nepheline syenite in Arkansas (exhibit) [abs.]: Geol. Soc. Am. Bull., v. 60 , no. 12 , pt. 2 , p. $1890-1891$, Dec. 1949. 


\section{Goldsmith, Julian R.}

1. Some aspects of the system $\mathrm{NaAlSiO}_{4}-\mathrm{CaO} \cdot \mathrm{Al}_{2} \mathrm{O}_{3}$ : Am. Mineralogist, v. 34, nos. 7-8, p. 471-493, illus., July-Aug. 1949; abs., nos. 3-4, p. 277, Mar.-Apr. 1949; Geol. Soc. Am. Bull., v. 59, no. 12, pt. 2, p. 1326, Dec. 1948.

2. Significance of gallium and germanium replacements in synthetic feldspars [abs.]: Geol. Soc. Am. Bull., v. 60, no. 12, pt. 2, p. 1891, Dec. 1949.

\section{Goldthwait, Lawrence.}

Clay survey, 1948: Maine State Geologist Rpt. 1947-1948, p. 63-69, illus. incl. index map, Mar. 1949.

\section{Goldthwait, Richard Parker.}

Artesian wells in New Hampshire: N. H. State Plan. Dev. Comm. Mineral Res. Survey, Part 11, 24 p., illus., 1949.

\section{González Reyna, Jenaro.}

1. (and Foshag, William Frederick, and Pough, Frederick Harvey). Parícutin and Mexico's volcanic area [abs.]: 18th Internat. Geol. Cong., London, Volumes of titles and abstracts, p. 2, 1948.

2. Los criaderos plomo-zincíferos de México [abs.]: 18th Internat. Geol. Cong., London, Volume of titles and abstracts, p. 48-49, 1948.

Good, Stanley Edgar, d. 1949.

(and Pettijohn, Francis John). Magnetic survey and geology of the Stager area, Iron County, Michigan: U. S. Geol. Survey Circ. 55, 4 p. ( $\ddagger)$, illus. incl. index, geol. maps, Aug. 1949.

\section{Goodspeed, George Edward.}

1. Retrogressive alteration following granitization and rheomorphism [Oreg.] [abs.]: Am. Mineralogist, v. 34, nos. 3-4, p. 277, Mar.-Apr. 1949.

2. Rheomorphic breccias [abs.]: Geol. Soc. Am. Bull., v. 60, no. 12, pt. 2, p. 1891 , Dec. 1949.

3. Mineralization related to granitization [abs.]: Geol. Soc. Am. Bull., v. 60 , no. 12 , pt. 2 , p. $1938-1939$, Dec. 1949 .

\section{Goranson, Roy Waldemar.}

Effect of pressure on physical phenomena in the crust, in Symposium on the earth's crust: Am. Geophys. Union Trans., v. 30, no. 2, p. 187-189, illus., Apr. 1949.

\section{Gordon, Mackenzie, Jr.}

(and Tracey, Joshua Irving, Jr., and Ellis, Miller Ward). Field relations of Arkansas bauxite deposits [abs.]: Econ. Geology, v. 44, no. 7 , p. 640-641, Nov. 1949 ; Geol. Soc. Am. Bull., v. 60, no. 12, pt. 2, p. 1891-1892, Dec. 1949 .

\section{Gordon, Samuel George.}

The role of the museum in the teaching of crystallography [abs.]: Am. Mineralogist, v. 34, nos. 3-4, p. 291, Mar.-Apr. 1949.

\section{Goudge, Monson Fraser.}

Limestone at Glen Morrison [Nova Scotia]: Nova Scotia Dept. Mines. Ann. Rpt. 1948, p. 127-135, illus., 1949.

Gould, Donald Boyd. See Stark, J. T.

Graham, A. R.

Artificial pyrrhotite: Am. Mineralogist, v. 34, nos. 5-6, p. 462-464, illus., May-June 1949. 


\section{Graham, Charles E.}

Structure of the western portion of the Lewiston downwarp in southeastern Washington [abs.]: Northwest Sci., v. 23, no. 1, p. 41-42, Feb. 1949.

Graham, Jack Bennett. See Adamson, J. H., Jr., 1.

The stability and significance of magnetism in sedimentary rocks: Jour. Geophys. Research, v. 54, no. 2, p. 131-167, illus., June 1949.

Graham, John W. See also Torreson, O. W.

Graham, Joseph J.

1. A note on the occurrence-of microfossils in the matrix of an Upper Cretaceous plesiosaur from Lake Waco, McLennan County, Texas: Micropaleontologist, v. 3, p. 13 (\$), July 1949.

2. Occurrence of a questionable Elphidium in the early Tertiary of California [abs.]: Geol. Soc. Am. Bull., v. 60, no. 12, pt. 2, p. 1950 , Dec. 1949.

\section{Graham, Robert Bruce.}

1. Preliminary report on Duparquet Lake map-area, west part of $\mathrm{Du}$ parquet Township, Abitibi-West County [Quebec]: Quebec Dept. Mines Prelim. Rpt. 206, 28 p. (\$), index, geol. maps, 1947.

2. Preliminary report on Hébécourt Lake map-area, east part of Hébécourt Township, Abitibi-West County [Quebec]: Quebec Dept. Mines Prelim. Rpt. 216, 25 p. ( $\ddagger$ ), index, geol. maps, 1948.

Graham, Ronald P.

John Ross and meteorites [Greenland] : Canadian Geog. Jour., v. 39, no. 5, p. 222-227, illus., Nov. 1949.

\section{Granger, Arthur Earle.}

Stratigraphic and structural problems in the Basin and Range area of western Utah, in The oil and gas possibilities of Utah, by G. H. Hansen and M. M. Bell: Utah Geol. Miner. Survey, p. 289-295, Dec. 1949.

Grant, Ulysses Simpson, 4th. See Gilluly, J., 2.

\section{Graves, Roy W., Jr.}

Marathon region [Texas], in West Texas Geological Society Guidebook Field Trip no. 1, November 6-9, 1949, p. 3-12, index, geol. maps, 1949.

\section{Grawe, Oliver Rudolph.}

(and Nackowski, M. P.). Strontianite and witherite associated with southern Illinois fluorite: Science, v. 110 , no. 2857 , p. 331, Sept. 30 , 1949.

Gray, John Gardiner.

(and Roliff, William Albert). Developments [in oil and gas] in Canada in 1948: Am. Assoc. Petrol. Geol. Bull., v. 33, no. 6, p. 1012-1028, illus. incl. index, geol. sketch maps, June 1949.

\section{Gray, John H.}

The Comanchean of Fort Worth, Texas: Compass, v. 26, no. 2, p. 179-181, Jan. 1949.

Gray, Stephen Wood. See Lull, R. S.

Green, Morton. See Camp, C. L., 1.

Greene, Kenneth T. See Mielenz, R. C., 16.

Greenfield, Mildred A. See Chapman, R. W., 2. 


\section{Gregory, Herbert Ernest.}

Geologic and geographic reconnaissance of eastern Markagunt Plateau, Utah: Geol. Soc. Am. Bull., v. 60, no. 6, p. 969-997, illus. incl. index, geol. maps, June 1949 ; abs., v. 57 , no. 12 , pt. 2, p. 1253 , Dec. 1946.

Grey, Edwin. See Laudon, L. R., 3.

Gries, John Paul.

Sampling of Helen beryl pegmatite, Custer County, S. Dak.: U. S. Bur. Mines Rpt. Inv. 4396, 14 p. ( $\ddagger)$, illus., Jan. 1949 .

Griffin, Norman J.

Volcanoes from the air [Central America]: Frontiers, v. 13, no. 3, p. 72-73, 96, illus., Feb. 1949.

\section{Griffiths, John Cedric.}

1. Petrographical evaluation of porosity measurement: Pa. State Coll. Mineral Indus. Expt. Sta. Bull. 52, p. 6-30, Feb. 25, 1949; Producers Monthly, v. 13, no. 6, p. 38-46, Apr. 1949; abs., Oil and Gas Jour., v. 42 , no. 26 , p. 105 , Oct. 28,1948 .

2. [Discussion], in Longwell, C. R., chm., Sedimentary facies in geologic history [symposium]: Geol. Soc. Am. Mem. 39, p. 140-141, June 17, 1949.

\section{Griffitts, Mary 0 .}

1. A new rudistid from the Niobrara of Colorado: Jour. Paleontology, v. 23, no. 5, p. 471-472, illus., Sept. 1949.

2. Zones of Pierre formation of Colorado: Am. Assoc. Petrol. Geol. Bull., v. 33, no. 12, p. 2011-2028, illus., Dec. 1949; abs., Geol. Soc. Am. Bull., v. 60 , no. 12 , pt. 2, p. 1961 , Dec. 1949.

\section{Griggs, Roy Lee.}

Geology and ground-water resources of the eastern part of Colfax County, New Mexico [with a section on Geology by R. L. Griggs, Stuart Alvord Northrop, and Gordon H. Wood, Jr.]: N. Mex. Bur. Mines and Mineral Res. Ground-water Rpt. 1, 180 p., illus. incl. index, geol. maps, 1948.

\section{Grim, Ralph Early.}

1. Mineralogical composition in relation to the properties of certain soils: Géotechnique, v. 1, no. 3, p. 139-147, illus., June 1949; reprinted in Ill. State Geol. Survey Rpt. Inv. 146, p. 13-21, illus., 1950.

2. (and Dietz, Robert Sinclair, and Bradley, William Frank). Clay mineral composition of some sediments from the Pacific Ocean off the California coast and the Gulf of California: Geol. Soc. Am. Bull., v. 60 , no. 11 , p. $1785-1808$, illus. incl. index maps, Nov. 1949.

3. (and Bradley, William Frank). The illite clay minerals [abs.]: 18th Internat. Geol. Cong., London, Volume of title and abstracts, p. 127$128,1948$.

Grimaldi, Frank Saverio. See Axelrod, J. M., 1, 2.

\section{Grogan, Robert Mann.}

1. Structures due to volume shrinkage in the bedding-replacement fluorspar deposits of southern Illinois: Econ. Geology, v. 44, no. 7, p. 606-616, illus., Nov. 1949; reprinted as Ill. State Geol. Survey Circ. $158,1949$.

2. Present state of knowledge regarding the pre-Cambrian crystallines of Illinois: Ill. State Acad. Sci. Trans., v. 42, p. 97-102, illus., Dec. 31,1949 ; reprinted in Ill. State Geol. Survey Circ. 157, p. 97-102, illus., 1950.

\section{Grohskopf, John Gustave.}

(and McCracken, Earl). Insoluble residues of some Paleozoic formations of Missouri, their preparation, characteristics, and application: Mo. Geol. Survey and Water Res. Rpt. Inv. 10, 39 p., illus., 1949. 


\section{Grossman, Irving G.}

The sodium sulphate deposits of western North Dakota, a progress report: N. Dak. Geol. Survey, Rpt. Inv. 1, 66 p. (\$), illus. incl. geol. maps, 1949.

\section{Gruver, Robert M.}

(and Henry, Edward Carleton, and Heystek, H.). Suppression of thermal reactions in kaolinite: Am. Mineralogist, v. 34 , nos. 11-12, p. 869 873, illus., Nov.-Dec. 1949.

\section{Gude, Arthur James, 3d.}

Simple method of preparing crystal models [abs.]: Geol. Soc. Am. Bull., v. 60, no. 12 , pt. 2 , p. 1961 , Dec. 1949 .

\section{Guimarães, Djalma.}

(and Brajnikov, B.). Enstenitization in the Palisade sill diabase and its consequences: Inst. Tecnologia Industrial Bol. 7, 30 p., illus., 1948.

\section{Guiza, Reinaldo, Jr.}

Estudio geologica del distrito minero de Guanajuato, Gto. (zona de la Veta Madre): México, Inst. Nac. Inv. Rec. Miner. Bol. 22, 75 p., illus. incl. geol. map, 1949.

\section{Gulley, M. Gordon.}

James Fulton Swain (1903-1948) : Am. Assoc. Petrol. Geol. Bull., v. 33, no. 5 , p. $779-780$, May 1949 .

\section{Gunn, Ross.}

Isostasy—extended: Jour. Geology, v. 57, no. 3, p. 263-279, illus., May 1949.

\section{Gunter, Herman.}

1. Exploration for oil and gas in Florida: Fla. Geol. Survey Inf. Circ. 1 (revised), 106 p. ( $\ddagger$ ), illus. incl. index map, Jan. 1, 1949; supplement, 1949, 38 p. (\$), Jan. 1, 1950.

2. Exploration in Florida: World Oil, v. 129, no. 6, p. 69-70, 72, illus., Sept. 1949.

\section{Gustafson, John David.}

Recent Canadian oil developments: Jour. Petrol. Tech., v. 1, no. 12, p. 8-15, illus., Dec. 1949; abs., no. 9, p. 21, Sept. 1949.

\section{Gustafson, John Kyle.}

Uranium resources: Nucleonics, v. 4, no. 5, p. 23-28, May 1949; Sci. Monthly, v. 49 , no. 2 , p. 115-120, Aug. 1949.

Gutenberg, Beno. See also Gilmore, M. H.

1. Approximations in geophysics: Finnischen Geodätischen Institutes Veröffentlichungen No. 36, p. 41-44, 1949; abs., Geol. Soc. Am. Bull., v. 60 , no. 12 , pt. 2 , p. 1954 , Dec. 1949 .

2. (and Richter, Charles Francis). Seismicity of the earth and associated phenomena. 273 p., illus., Princeton, New" Jersey, Princeton University Press. 1949. Abs., Geol. Soc. Am. Bull., v. 58, no. 12, pt. 2, p. 1252 , Dec. 1947.

3. Earth physics: Physics Today, v. 2, no. 2, p. 14-18, illus., Feb. 1949.

4. Unexplained phases in seismograms: Seismol. Soc. Am. Bull., v. 39, no. 2, p. 79-91, illus., Apr. 1949.

5. (and Richter, Charles Francis, and Benioff, Hugo). Earthquake study in southern California, 1948: Am. Geophys. Union Trans., v. 30, no. 4, p. 595-597, Aug. 1949.

6. Properties of the earth's crust beneath the oceans [abs.] : Geol. Soc. Am. Bull., v. 60 , no. 12 , pt. 2, p. 1892 , Dec. 1949. 
Gutschick, Raymond Charles.

Redwall limestone along the southwest margin of the Colorado Plateau, Arizona [abs.]: Geol. Soc. Am. Bull., v. 60 , no. 12 , pt. 2, p. 1893, Dec. 1949 .

\section{Guyod, Hubert Charles.}

Can resistivity method discover oil directly? Part 1, Theoretiral depthresistivity curves: World Oil, v. 128 , no. 13, p. 69-70, illus., Apr. 1949; Part 2, Actual depth-resistivity curves, v. 129, no. 1, p. 73-74, 77, illus., May 1949.

\section{Guzmán, Eduardo J.}

New petroleum developments by Petróleos Mexicanos in northeastern Mexico: Am. Assoc. Petrol. Geol. Bull., v. 33, no. 8, p. 1351-1384, illus. incl. index map, Aug. 1949 ; abs., v. 32 , no. 12 , p. 2314 , Dec. 1948; Oil and Gas Jour., v. 47 , no. 25 , p. 129 , Oct. 21 , 1948.

\section{Haas, Otto.}

1. Acanthoceratid Ammonoidea from near Greybull, Wyoming: Am. Mus. Nat. History Bull., v. 93, art. 1, 39 p., illus., 1949.

2. Precedence of modern plant names over names based on fossils?: Science, v. 109 , no. 2819 , p. $18-19$, Jan. $7,1949$.

3. Possibility of synonymous homonyms: Jour. Paleontology, v. 23, no. 5, p. 573-574, Sept. 1949.

\section{Hackel, Otto.}

(and Turner, Roy Wilbur). Geology of west slope of Temblor Range between Bitterwater Creek and San Diego Creek [Calif.] [abs.]: Oil and Gas Jour., v. 48, no. 29, p. 139, Nov. 24, 1949; Am. Assoc. Petrol. Geol. Bull., v. 33, no. 12, p. 2058, Dec. 1949.

\section{Hadley, Jarvis Bardwell.}

1. Bedrock geology, Mount Grace quadrangle, Massachusetts: U. S. Geol. Survey, Geol. Quad. Map, with text. Scale 1 inch to $1 / 2$ mile. 1949.

2. Surficial geology, Mount Grace quadrangle, Massachusetts: U. S. Geol. Survey, Geol. Quad. Map, with text. Scale 1 inch to $1 / 2$ mile. 1949.

3. Preliminary report on corundum deposits in the Buck Creek peridotite, Clay County, North Carolina: U. S. Geol. Survey Bull. 948-E, p. 103-128, illus. incl. index, geol. maps, 1949.

4. Geological mapping by the U. S. Geological Survey in the Great Smoky Mountains National Park [abs.]: Geol. Soc. Am. Bull., v. 60, no. 12, pt. 2, p. 1970 , Dec. 1949.

\section{Haff, John Coles.}

1. Memorandum on the results of a petrographic study of the Keswick quartz-diorite and associated rocks in the vicinity of Democrat Mountain, near Redding, California: U. S. Bur. Recl. Petrog. Lab. Rpt. 20,36 p. ( $\ddagger)$, illus., Oct. 8,1938 .

2. Preliminary petrographic study of certain rocks near the western terminus of the Continental Divide tunnel [Colo.]: U. S. Bur. Recl. Petrog. Lab. Rpt. 26, 28 p. (\$), illus., Nov. 10,1941 .

3. Petrographic study of rocks from shear zone in the Continental Divide tunnel [Colo.]: U. S. Bur. Recl. Petrog. Lab. Rpt. 27, 23 p. ( $\ddagger$, illus., Jan. 10, 1942.

4. Petrographic examination of selected Cowlitz River gravel [Wash.]: U. S. Bur. Recl. Petrog. Lab. Rpt. 33, 7 p. ( $\ddagger)$, illus., June 18, 1942.

\section{Hager, Dorsey.}

1. Tectonics of north-central States: Am. Assoc. Petrol. Geol. Bull., v. 33, no. 7 , p. 1198-1205, illus., July 1949 ; abs., v. 32, no. 2, p. 296-297, Feb. 1948.

2. Crater Mound ("Meteor Crater"), Arizona; Is its origin geologic or meteoritic [abs.]: Pop. Astronomy, v. 57, no. 9, p. 457-458, Nov. 1949; Meteor. Soc. Contr., v. 4, no. 3, p. 223-224, 1949. 
Hagner, Arthur Feodor. See Newhouse, W. H., 1, 2.

\section{Halberg, Henry N.}

(and Roberts, Claude Martin). Recovery of ground-water supplies by pumping from watertable ponds [Mass.]: Am. Geophys. Union Trans., v. 30, no. 2, p. 283-292, illus., Apr. 1949.

\section{Hale, Danforth Rawson.}

- (and Hurlbut, Cornelius Searle, Jr.). Quartz sphere grown into a faced crystal: Am. Mineralogist, v. 34, nos. 7-8, p. 596-599, illus., JulyAug. 1949.

\section{Hall, George H.}

The Greenbrier limestone (Big Lime) and its treatment: Appalachian Geol. Soc. Bull., v. 1, p. 329-341, illus., 1949.

\section{Ham, William Eugene.}

1. Geology and dolomite resources, Mill Creek-Ravia area, Johnston County, Oklahoma: Okla. Geol. Survey Circ. 26, 104 p., illus. incl. index, geol. maps, 1949.

2. Cellular products from Oklahoma volcanic ash; geological and petrographical investigations: Okla. Geol. Survey Circ. 27, p. 48-84, illus., 1949.

3. Stratigraphy of the Arbuckle limestone, Arbuckle Mountains, Oklahoma [abs.]: Geol. Soc. Am. Bull., v. 60, no. 12, pt. 2, p. 1893, Dec. 1949.

Hamilton, Daniel Kirk.

Hydrologic investigation of caves: Natl. Speleol. Soc. Bull. 11, p. 8-10, 16, Nov. 1949.

Hamilton, Gordon R. See Ewing, W. M., 1.

\section{Hamilton, Howard V.}

An unusual mineral specimen from near Ravena, N. Y. [quartz]: Rocks and Minerals, v. 24, nos. 9-10, p. 481, illus., Sept.-Oct. 1949.

Hamilton, Peggy Kay. See Behre, C. H., Jr., 3; Kerr, P. F., 1, 3.

Hamilton, Warren B. See Laudon, L. R., 3.

Hammond, Paul.

Geology of Allard Lake ilmenite deposits [Quebec]: Canadian Min. Met. Bull., no. 443, p. 117-121, illus. incl. index map, Mar. 1949; Canadian Inst. Min. Met. Trans., v. 52, p. 64-68, 1949.

Handin, John Walter.

(and Ludwick, John C.). Accretion of beach sand behind a detached breakwater: Calif. Univ., Scripps Inst. Oceanog., Submarine Geology Rpt. No. 8, 15 p. ( ), illus., Dec. 1949.

IIandley, Ernest Jack.

1. Can geophysical reflections be correlated with geological horizons: Oil and Gas Jour., v. 47, no. 44, p. 84, 87, illus., Mar. 3, 1949.

2. Las reflexiones geofisicas-Geophysical reflections: Petroleo Interamericano, v. 7 , no. 12 , p. 54-55, illus., Dec. 1949.

Hanna, G. Dallas.

(and Hertlein, Leo George). Two new species of gastropods from the middle Eocene of California: Jour. Paleontology, v. 23, no. 4, p. 392-394, illus., July 1949.

\section{Hansen, George Henry.}

(and Bell, Mendell M.). The oil and gas possibilities of Utah. 341 p., illus. Salt Lake City, Utah. Utah Geol. Miner. Survey. Dec. 1949. Includes sections by 16 additional authors, cited individually. 


\section{Hansen, Henry Paul.}

1. Postglacial forests in south central Alberta, Canada: Am. Jour. Botany, v. 36 , no. 1 , p. 54-65, illus., Jan. 1949.

2. Postglacial forests in west central Alberta, Canada: Torrey Bot. Club Bull., v. 76, no. 4, p. 278-289, illus., July-Aug. 1949.

3. (and Packard, Earl Leroy). Pollen analysis and the age of proboscidian bones near Silverton, Oregon: Ecology, v. 30, no. 4, p. 461-468, illus., Oct. 1949.

4. (and Mackin, Joseph Hoover). A pre-Wisconsin forest succession in the Puget Lowland, Washington: Am. Jour. Sci., v. 247, no. 12, p. 833-855, illus., Dec. 1949.

\section{Harder, Edmund Cecil.}

1. Bauxite, in Industrial minerals and rocks, p. 95-118, illus., 1949.

2. Stratigraphy and origin of bauxite deposits: Geol. Soc. Am. Bull., v. 60, no. 5, p. 887-907, May 1949; Geol. Assoc. Canada Proc., v. 1, Aug. 1949.

Harder, James 0. See Noble, J. A.

\section{Harding, Richard W.}

Preliminary correlation of the Bradford and Richburg oil sands [N. Y., Pa.]: Producers Monthly, v. 13, no. 8, p. 24-25, illus., June 1949.

Harding, Stanley Russell Lauck. See Shaw, E. W.

\section{Hardy, John A.}

Report on a radioactive diamond: Gems and Gemology, v. 6, no. 6, p. 167170, illus., Summer 1949.

\section{Harradon, Harry Durward. See Fleming, J. A.}

\section{Harrell, David C.}

Crystalline area of Alabama, in Mississippi Geological Society Guidebook, 7th field trip, Aug. 24-27, 1949, p. 22-28, illus. incl. geol. map, 1949.

\section{Harrington, John W.}

Structural analysis of the west border of the Durham Triassic Basin [N. C.] [abs.]: Geol. Soc. Am. Bull., v. 60, no. 12, pt. 2, p. 18931894, Dec. 1949.

\section{Harris, R. Merrill.}

(and Payne, Willard M.). Developments [in oil and gas] in Southeastern States in 1948: Am. Assoc. Petrol. Geol. Bull., v. 33, no. 6, p. 10021010, index map, June 1949.

Harrison, Harold Charles. See Larsen, E. S., Jr., 2.

Harrison, James Merritt. See also Canada Geol. Survey, 6; Tanton, T. L., 1.

1. Geology and mineral deposits of File-Tramping Lakes area, Manitoba: Canada Geol. Survey Mem 250, 92 p., illus. incl. geol. maps, 1949.

2. Structural geology in the Canadian Shield as revealed by air photographs [abs.]: Tulsa Geol. Soc. Digest, v. 17, p. 48-52, illus., 1949.

Hash, Lewis J. See Hunter, C. E.

Haw, V. A. See also Hawley, J. E., 2.

Hawkes, Herbert Edwin, Jr.

1. (and Lakin, Hubert W.). Vestigial zinc in surface residuum associated with primary zinc ore in East Tennessee: Econ. Geology, v. 44, no. 4, p. 286- 295, illus., June-July 1949.

2. Geochemical prospecting for ores; a progress report: Econ. Geology, v. 44, no. 8, p. 706-712, Dec. 1949. 
Hawkins, Alfred Cary.

Distribution of pebbles in a glacial outwash plain: N. Y. Acad. Sci. Trans., ser. 2, v. 12, no. 1, p. 2-3, Nov. 1949.

Hawley, James Edwin.

1. Current research in the geological sciences in Canada: Canadian Min. Met. Bull. no. 445, p. 238-243, May 1949.

2. (and Haw, V. A.). Further studies of the Fe-Ni-S system [abs.]: Royal Soc. Canada Proc. 3d ser., v. 43, p. 240, 1949.

3. (and Wark, W. J.). Spectographic study of Kirkland Lake pyrite [abs.]: Royal Soc. Canada Proc. 3d ser., v. 43, p. 240, 1949.

Hayes, Albert Orion.

1. Geology of the area between Bonavista and Trinity Bays, eastern Newfoundland: Newfoundland Geol. Survey Bull. 32, Pt. 1, p. 1-34 ( $\$)$, illus. incl. geol. map, 1948.

2. Coal possibilities of Newfoundland: Newfoundland Geol. Survey Inf. Circ. 6, 31 p., illus. incl. index, geol. maps, 1949.

Hayes, W. H.

The Bridgewater copper mine [N. J.] from the collector's standpoint: Rocks and Minerals, v. 24, nos. 1-2, p. 27-29, illus., Jan.-Feb. 1949.

\section{Hazen, Scott Wike, Jr.}

Lead-zinc-silver in the Poughkeepsie district and part of the Upper Uncompahgre and Mineral Point districts, Ouray and San Juan Counties, Colo.: U. S. Bur. Mines Rpt. Inv. 4508, 110 p. ( $\ddagger$, illus., Sept. 1949.

Headlee, Alvah John Washington.

The composition and properties of natural gas in the Appalachian fields: Appalachian Geol. Soc. Bull., v. 1, p. 24-33, illus., 1949.

\section{Heald, Weldon F.}

1. Palisade Glacier survey, Sierra Nevada: Am. Alpine Jour., v. 6, no. 3, p. 332-339, illus., 1946.

2. Our vanishing glaciers [western U. S.] : Nature Mag., v. 42, no. 3, p. 115-118, illus., Mar. 1949.

Heaps, H. S.

The sial in compression [abs.]: Royal Soc. Canada Proc. 3d ser., v. 43, p. $237,1949$.

Heide, Harold Elliott.

(and Wright, Wilford Stillman, and Rutledge, Franklin Allen). Investigations of the Kobuk River asbestos deposits, Kobuk district northwestern Alaska: U. S. Bur. Mines Rpt. Inv. 4414, $25 \mathrm{p} \mathrm{(})$, illus. incl. index map, Mar. 1949.

Heilborn, George.

Cosmic sediments: Rocks and Minerals, v. 24, nos. 3-4, p. 136, Mar.-Apr. 1949.

\section{Heinrich, Eberhardt William.}

1. Pegmatite mineral deposits in Montana: Mont. Bur. Mines ard Geology Mem. 28, 56 p. ( $¥$ ), illus. incl. index, geol. maps, 1949.

2. Pegmatites of Montana: Econ. Geology, v. 44, no. 4, p. 307-335, illus., June-July 1949.

3. Pre-Beltian rocks near Dillon, Montana [abs.]: Am. Mineralogist, v. 34, nos. 3-4, p. 278, Mar.-Apr. 1949.

\section{Heinrich, Ross $\mathbf{R}$.}

Three Ozark earthquakes: Seismol. Soc. Am. Bull., v. 39, no. 1, p. 1-8, illus., Jan. 1949. 
Heisey, E. L.

(and Lawson, D. E., and Weimer, R. J.). Geology of Whiskey Gap-Muddy Gap and Ferris Mountains region, Wyoming [abs.]: Geol. Soc. Am. Bull., v. 60, no. 12, pt. 2, p. 1961, Dec. 1949.

Heiskanen, W.

William Bowie as an isostasist and as a man [1872-1940]: Am. Geophys. Union Trans., v. 30 , no. 5, p. $629-635$, illus. incl. port., Oct. 1949.

\section{Henbest, Lloyd George.}

Significance of explosive evolution for diastrophic division of earth history [abs.]: Geol. Soc. Am. Bull., v. 60, no. 12, pt. 2, p. 1894-1895, Dec. 1949.

\section{Henderson, Charles Frederick.}

(and Barr, Charles R.). Developments [in oil and gas] in west Texas and southeast New Mexico in 1948: Am. Assoc. Petrol. Geol. Bull., v. 33, no. 6, p. 908-930, index maps, June 1949.

Henderson, Edward Porter. See also Hess, H. H., 1; Reberholt, B. 0.

1. American meteorites and the National Collection: Smithsonian Inst. Ann. Rpt. 1948, p. 257-268, illus. [1949].

2. (and Perry, Stuart Hoffman). The Pima County (Arizona) meteorite: U. S. Natl. Mus. Proc., v. 99, no. 3241, p. 353-355, illus., 1949.

3. (and Perry, Stuart Hoffman). The Linwood (Nebraska) meteorite: U. S. Natl. Mus. Proc., v. 99, no. 3242, p. 357-360, illus., 1949.

4. (and Perry, Stuart Hoffman). The Wathena, Doniphan Co. Kansas, meteorite: Am. Mineralogist, v. 34, nos. 1-2, p. 102-103, Jan.-Feb. 1949.

5. The Aggie Creek meteorite from Seward Peninsula, Alaska: Am. Mineralogist, v. 34, nos. 3-4, p. 229-232, illus., Mar.-Apr. 1949.

6. Some unusual formations in Skyline Caverns, Va.: Natl. Speleol. Soc. Bull. 11, p. 31-34, illus., Nov. 1949.

Henderson, James Fenwick.

1. Pitchblende occurrences between Beaverlodge and Hottah Lakes, Northwest Territories: Canada Geol. Survey Paper 49-16, 17 p. (\$), geol. maps, 1949.

2. (and Lord, Clifford Symington, and Wilson, John Tuzo). Discussion of "Some aspects of geophysics in Canada with special reference to structural research in the Canadian Shield (Part 2: An approach to the structure of the Canadian Shield)": Am. Geophys. Union Trans., v. 30 , no. 3, p. 448-451, June 1949.

Henderson, Roland George.

(and Zietz, Isidore). The computation of second vertical derivatives of geomagnetic fields: Geophysies, v. 14 , no. 4, p. 508-534, illus., Oct. 1949 : abs., no. 3 , p. 449 , July 1949 .

Hendricks, Leo.

Recognition of the Lower Ordovician formations in the subsurface of central Texas [abs.]: Geol. Soc. Am. Bull., v. 60, no, 12, pt. 2, p. 1895, Dec. 1949.

\section{Hendy, William J.}

Notes on the stratigraphy of northeastern Wayne County, Mississippi, in Mississippi Geological Society Guidebook, Sixth Field Trip, June 18-20, 1948, p. 25-31 ( $), 1948$.

Henry, Edward Carleton. See Gruver, R. M.

\section{Herdlick, Jared Albert.}

Investigation of the Big Ben molybdenum deposit, Neihart district, Cascade County, Mont.: U. S. Bur. Mines Rpt. Inv. 4406, 22 p. ( (), illus. incl. index, geol. map, Feb. 1949. 
Hermance, H. P.

(and Sanford, Robert Stills,on). Investigation of Parker and Webb zinc deposits, St. Lawrence County, N. Y.: U. S. Bur. Mines Rpt. Inv. 4417, 31 p. $(\ddagger)$, illus. incl. index, geol. maps, Feb. 1949.

Hernon, Robert M. See also Fowler, G. M.

Geology and ore deposits, Silver City region, New Mexico, in West Texas Geological Society Guidebook Field Trip no. 3, November 6-9, 1949, p. 4-6, illus., 1949.

Heroy, William Bayard, Jr.

(and Arnett, R. A.). Seismic surveying: Appalachian Geol. Soc. Bull., v. 1, p. 265-274, illus., 1949.

\section{Herrick, Stephen Marion.}

(and Legrand, Harry E.). Geology and ground-water resources of the Atlanta area, Georgia: Ga. Dept. Mines, Mining and Geology, Bull. 55, 124 p., illus. incl. geol. map, 1949.

Hersey, J. B. See also Ewing, W. M., 1.

1. (and Ewing, William Maurice). Seismic reflections from beneath the ocean floor: Am. Geophys. Union Trans., v. 30, no. 1, p. 5-14, illus., Feb. 1949.

2. (and Press, Frank). Seismic studies of geologic structure of the ocean floor [abs.], in Symposium on the earth's crust: Am. Geophys. Union Trans., v. 30, no. 2, p. 171, Apr. 1949.

Hertlein, Leo George. See Hanna, G. D.

Hess, Harry Hammond. See also Davis, G. L.

1. (and Henderson, Edward Porter). The Moore County [N. C.] meteorite; a further study with comment on its primordial environment: Am. Mineralogist, v. 34, nos. 7-8, p. 494-507, iHus., July-Aug. 1949; abs., nos. 3-4, p. 278, Mar.-Apr. 1949; Geol. Soc. Am. Bull., v. 59, no. 12 , pt. 2 , p. 1330 , Dec. 1948 .

2. Chemical composition and optical properties of common clinopyroxenes, Part 1: Am. Mineralogist, v. 34, nos. 9-10, p. 621-666, illus., Sept.Oct. 1949; abs., v. 33, nos. 3-4, p. 199, Mar.-Apr. 1948; Geol. Soc. Am. Bull., v. 58, no. 12 , pt. 2, p. 1192 , Dec. 1947.

\section{Hewett, Donnel Foster.}

Kingston thrust fault, Inyo, San Bernardino Counties, California [abs.]: Geol. Soc. Am. Bull., v. 60, no. 12, pt. 2, p. 1895-1896, Dec. 1949.

Hewitt, D. F. See Satterly, J., 4.

Heyl, Allen Van, Jr. See Behre, C. H., Jr., 1.

Heyl, George Richard. See also Cox, M. W., 1.

1. Foothill copper-zinc belt of the Sierra Nevada, California: Calif. Dept. Nat. Res., Div. Mines Bull. 144, p. 11-29, geol. map, Dec. 1948.

2. (and Eric, John Howard). Newton copper mine, Amador County, California: Calif. Dept. Nat. Res., Div. Mines Bull. 144, p. 49-60, illus. incl. geol. maps, Dec. 1948.

3. (and Cox, Manning William, and Eric, John Howard). Penn zinc-copper mine, Calaveras County, California: Calif. Dept. Nat. Res., Div. Mines Bull. 144, p. 61-84, illus. incl. geol. maps, Dec. 1948.

4. The Grayhouse area, Amador County, California: Calif. Dept. Nat. Res., Div. Mines Bull. 144, p. 85-91, illus. incl. geol. map, Dec. 1948.

5. Ore deposits of Copperopolis, Calaveras County, California: Calif. Dept. Nat. Res., Div. Mines Bull. 144, p. 93-110, illus. incl. index, geol. maps, Dec. 1948.

6. The zinc-copper mines of the Quail Hill area, Calaveras County, California: Calif. Dept. Nat. Res., Div. Mines Bull. 144, p. 111-126, illus. incl. geol. maps, Dec. 1948. 
Heyl, George Richard-Continued

7. (and Wiese, John Herbert). Geology of limestone near Sonora, Tuolumne County, California: Calif. Jour. Mines and Geology, v. 45, no. 4, p. 509-513, geol. maps, Oct. 1949.

8. (and Walker, George Walton). Geology of limestone near Gazelle, Siskiyou County, California: Calif. Jour. Mines and Geology, v. 45, no. 4, p. 514-520, illus. incl. index, geol. maps, Oct. 1949.

Heystek, H. See Gruver, R. M.

\section{Hibbard, Claude William.}

1. Pleistocene stratigraphy and paleontology of Meade County, Kansas: Mich. Univ. Mus. Paleontology Contr., v. 7, no. 4, p. 63-90, illus. incl. index map, Mar. 2, 1949.

2. Pliocene Saw Rock Canyon fauna in Kansas: Mich. Univ. Mus. Paleontology Contr., v. 7, no. 5, p. 91-105, illus., Mar. 2, 1949.

3. (and Riggs, Elmer Samuel). Upper Pliocene vertebrates from Keefe Canyon, Meade County, Kansas: Geol. Soc. Am. Bull., v. 60, no. 5, p. 829-860, illus., May 1949.

4. Pleistocene research, a review by the members of the committee on interrelations of Pleistocene research, National Research Council; 4, Pleistocene vertebrate paleontology in North America: Geol. Soc. Am. Bull., v. 60 , no. 9, p. 1417-1428, index maps, Sept. 1949.

5. Techniques of collecting microvertebrate fossils: Mich. Univ. Mus. Paleontology Contr., v. 8, no. 2, p. 7-19, illus., Oct. 20, 1949.

\section{Hicks, Forrest.}

Halite stalactites [Bristol Dry Lake cave, Calif.]: Compass, v. 26, no. 4, p. 338-341, illus. incl. index map p. 285, May 1949.

Hiestand, Thomas Cleon. See Summerford, H. E., 1, 2.

\section{Higazy, Riad A.}

Petrogenesis of perthite pegmatites in the Black Hills, South Dakota: Jour. Geology, v. 57, no. 6, p. 555-581, illus. incl. index map, Nov. 1949.

Higgins, G. E.

A note on multiple reflections: Geophysics, v. 14 , no. 3 , p. $356-360$, illus., July 1949.

Higginson, Elmo C. See Mielenz, R. C., 6.

\section{Higgs, Donald V.}

Quantitative areal geology of the United States: Am. Jour. Sci., v. 247, no. 8, p. 575-583, illus., Aug. 1949.

Hildebrand, Fred A. See also Bates, T. F., 2.

Orbicular tinguaite dikes near Bryant, Saline County, Arkansas [abs.]: Geol. Soc. Am. Bull., v. 60, no. 12, pt. 2, p. 1896, Dec. 1949.

\section{Hill, Harry Blackburn.}

1. (and Vogel, Felix A., Jr.). Petroleum-engineering study of Sheridan field, Colorado County, Tex.: U. S. Bur. Mines Rpt. Inv. 4367, 94 p. (\$), illus. incl. index map, Mar. 1949.

2. (and others). Petroleum-engineering study of the West Red River field, Tillman County, Okla.: U. S. Bur. Mines Rpt. Inv. 4450, $97 \mathrm{p}$. $(\ddagger)$, illus. incl. index map, Mar. 1949 .

\section{Hill, Jeff.}

(and Franz, Harvey). A second report on unusual limonite forms from Van Buren County, Michigan: Rocks and lMinerals, v. 24, nos. 9-10, p. 458-461, illus., Sept.-Oct. 1949. 
Hills, John Moore.

Sampling and examination of well cuttings: Am. Assoc. Petrol. Geol. Bull., v. 33 , no. 1 , p. $73-91$, illus., Jan. 1949 ; reprinted in Petroleum Engineer, v. 21, no. 8, p. B40-B58 incl. ads, illus., July 1949: also in A symposium on subsurface logging techniques, p. 49-60, illus., Univ. Book Exchange, Norman, Okla., 1949. Discussion by M. I. Goldman, Am. Assoc. Petrol. Geol. Bull., v. 33, no. 12, p. 2039, Dec. 1949.

Hintze, Ferdinand Frilis.

1. Silurian of Utah, in The oil and gas possibilities of Utah, by G. H. Hansen and M. M. Bell: Utah Geol. Miner. Survey, p. 55-57, Dec. 1949.

2. Devonian of Utah, in The oil and gas possibilities of Utah, by G. H. Hansen and M. M. Bell: Utah Geol. Miner. Survey, p. 58-66, Dec. 1949.

Hintze, Lehi F.

Ordovician system of Utah, in The oil and gas possibilities of Utah, by G. H. Hansen and M. M. Bell: Utah Geol. Miner. Survey, p. 38-54, Dec. 1949.

Hitchcoek, Harold B.

Caves in eastern Canada: Natl. Speleol. Soc. Bull. 11, p. 60-63, 72, illus., Nov. 1949.

Hladik, William B. See Frye, J. C., 5.

Hoadley, John William. See Canada Geol. Survey, 3.

Hoagland, A. D. See Lasky, S. G., 1.

Hoare, Joseph M. See Wallace, R. E., 2.

Hobbs, Samuel Warren. See Pecora, W. T., 1.

\section{Hobbs, William Herbert.}

1. American and Eurasian glaciers of the past, a picture based on existing ones: Sci. Monthly, v. 46, no. 2, p. 99-106, illus. incl. index maps, Feb. 1948.

2. Crustal movement in the Great Lakes area, a discussion: Jour. Geology, v. 57, no. 3, p. 312-314, index map, May 1949.

3. The glacio-fluvial and glacio-eolian deposits of continental glaciers [abs.]: 18th Internat. Geol. Cong., London, Volume of titles and abstracts, p. 92, 1948.

4. The initial continental glaciations of Europe and North America [abs.] : 18th Internat. Geol. Cong., London, Volume of titles and abstracts, p. $92,1948$.

5. The Pleistocene history of the Mississippi River [abs.]: Assoc. Am. Geog. Annals, v. 39, no. 1, p. 64, Mar. 1949.

Holbrooke, G. L.

Geology and ore position of the Dickenson Red Lake gold mine: Precambrian, v. 22, no 3 , p. 12-16, 18, illus. incl. geol. map, Mar. 1949.

Holden, Roy Jay, 1870-1945.

The "Punch" Jones and other Appalachian diamonds: Va. Poly. Inst. Eng. Expt. Sta. ser. Bull. 56, 32 p., illus. incl. index map, Feb. 1944; reprinted in Compass, v. 26, no. 3 , p. 197-224, illus. incl. index map, Mar. 1949.

Holdredge, Claire Parker.

Geological problems connected with flood control projects in the Central Valley of California [abs.]: Geol. Soc. Am. Bull., v. 60, no. 12, pt. 2, p. 1939 , Dec. 1949.

Holke, Kenneth A. See Bailly, R. J. 


\section{Holland, Charles T.}

Structure of mine roof: Min. Cong. Jour., v. 35, no. 3, p. 29-31, illus., Mar. 1949.

\section{Holland, Heinrich D.}

(and Kulp, John Laurence). The distribution of accessory elements in pegmatites; 1 . Theory: Am. Mineralogist, v. 34, nos. 1-2, p. 35-60, illus., Jan.-Feb. 1949; abs., nos. 3-4, p. 278, Mar.-Apr. 1949; Geol. Soc. Am. Bull., v. 59, no. 12, pt. 2, p. 1331, Dec. 1948.

Holland, William Y. See also Mielenz, R. C., 17.

1. Petrography of the Brett Pit aggregate [Coulee Dam, Wash.]: U. S. Bur. Recl. Petrog. Lab. Rpt. 13,46 p. ( $\ddagger)$, illus., Jan. 2, 1936. Includes section by Charles P. Berkey, Geological notes concerning the sand and gravel deposits at Grand Coulee damsite, p. 37-46.

2. Petrography of the Hamilton Dam aggregates [Texas]: U. S. Bur. Recl. Petrog. Lab. Rpt. 14, 10 p. (†), illus., Mar. 25, 1936.

3. Petrography of the Chickamauga limestone [Tenn.]: U. S. Bur. Recl. Petrog. Lab. Rpt. 15, 37 p. ( $\$$ ), illus., June 29, 1936.

4. Petrography of the aggregate from the Graysville area, TVA [Tenn.] : U. S. Bur. Recl. Petrog. Lab. Rpt. 16, 5 p. (\$), illus., Jan. 7, 1937.

5. Petrography of aggregates from the Tennessee Valley Authority: U. S. Bur. Recl. Petrog. Lab. Rpt. 17, 14 p. (\$), illus., Jan. 13, 1937.

6. A compilation of petrographic studies of aggregate for Marshall Ford dam [Texas]: U. S. Bur. Recl. Petrog. Lab. Rpt. 18, 31 p. ( $¥)$, illus., Mar. 22, 1937.

7. Petrographic examination of concrete aggregate from Pasco, Washington: U. S. Bur. Recl. Petrog. Lab. Rpt. 42, 3 p. ( $\ddagger)$, Apr. 7, 1943.

8. (and King, Myrle E.). Petrographic characteristics of loess, Trenton dam, Frenchman-Cambridge Division [Nebr.], Missouri River Basin project: U. S. Bur. Recl. Petrog. Lab. Rpt. 93, 7 p. (\$), illus., July $19,1949$.

Holmberg, Clyde Laurence. See Zinner, P.

Holmes, Arthur.

The oldest known minerals and rocks: Edinburgh Geol. Soc. Trans., v. 14, pt. 2, p. 176-194, illus., 1948.

Holmes, Chauncey DePew.

1. Introduction to college geology. $\mathrm{xxi}, 429$ p., illus., New York, The Macmillan Co. 1949.

2. Pleistocene research, a review by the members of the committee on interrelations of Pleistocene research, National Research Council; 5, Glacial erosion and sedimentation: Geol. Soc. Am. Bull., v. 60, no. 9, p. 1429-1436, Sept. 1949.

\section{Holmes, G. William.}

Glacial geology of the west-central Wind River Mountains, Wyoming [abs.]: Geol. Soc. Am. Bull., v. 60, no. 12, pt. 2, p. 1896-1897, Dec. 1949.

Holmes, Ralph Jerome. See Kulp, J. L., 1.

Holt, Stephen Philip. See Ruhl, 0.

\section{Holtedahl, $\mathbf{H}$.}

En vulkan blir til [a volcano comes into being; Parícutin, Mexico]: Naturen, v. 73, no. 9, p. 257-267, illus., Sept. 1949. Norwegian.

\section{Holwerda, James.}

Summer field course, University of Southern California: Compass, v. 26, no. 4, p. 348-354, illus. incl. index map, p. 285, May 1949. 


\section{Honkala, Fred S.}

1. The geologic section at Sheep Mountain, Fremont Co., Wyoming: Compass, v. 26, no. 2, p. 130-137, illus. incl. index map, Jan. 1949.

2. A geologic section on the West Fork of the Madison River, Beaverhead and Madison Counties, Montana [abs.] : Northwest Sci., v. 23, no. 1, p. 42-43, Feb. 1949.

3. Stratigraphy of the Centennial region, Beaverhead County, Montana [abs.]: Geol. Soc. Am. Bull., v. 60, no. 12, pt. 2, p. 1897, Dec. 1949.

Hooker, Marjorie. See Thom, E. M.

Hoover, W. Farrin.

Insoluble residue zones of Ste. Genevieve formation in Illinois and adjacent states [abs.]: Oil and Gas Jour., v. 47, no. 46, p. 152, Mar. 17, 1949.

\section{Hopkins, David Moody.}

Thaw lakes and thaw sinks in the Imuruk Lake area, Seward Peninsula, Alaska: Jour. Geology, v. 57, no. 2, p. 119-131, illus., Mar. 1949.

\section{Hopkins, Harold.}

Structure at Kirkland Lake, Ontario, Canada: Geol. Soc. Am. Bull., v. 60, no. 5, p. 909-922, illus. incl. index, geol. maps, May 1949; Geol. Assoc. Canada Proc., v. 1, Aug. 1949.

Horberg, Carl Leland. See also Bretz, J H., $2,3$.

1. (and Nelson, Vincent Edward, and Church, Harry Victor, Jr.). Structural trends in central western Wyoming: Geol. Soc. Am. Bull., v. 60 , no. 1 , p. 183-215, illus. incl. index, geol. maps, Jan. 1949.

2. A possible fossil ice wedge in Bureau County, Illinois: Jour. Geology, v. 57, no. 2, p. 132-136, illus., Mar. 1949.

3. Geomorphic history of the Carlsbad Caverns area, New Mexico: Jour. Geology, v. 57, no. 5, p. 464-476, illus. incl. index map, Sept. 1949.

4. Intersecting minor ridges on the Lake Agassiz plain, North Dakota [abs.]: Geol. Soc. Am. Bull., v. 60, no. 12, pt. 2, p. 1970, Dec. 1949.

Horn, George Henry. See Dobbin, C. E., 1; U. S. G. S. 1, no. 103.

Horton, F. W.

(and Allsman, Paul Trekell). Investigation of Casper Mountain chromite deposits, Natrona County, Wyo.: U. S. Bur. Mines Rpt. Inv. 4512, 26 p. (\$), illus. incl. index, geol. sk. map, Aug. 1949.

Hoskins, John Hobart. See also Cross, A. T., 2.

1. (and Cross, Aureal T.). The present status and correlation of the New Albany shale flora [abs.]: Ind. Acad. Sci. Proc., v. 58, p. 161$162,1948$.

2. (and Cross, Aureal T.). Plants of the Devonian-Mississippian black shales; lycopods [abs.]: Am. Jour. Botany, v. 36, no. 10, p. 819, Dec. 1949.

Hotchkiss, William Otis.

Memorial to Rolland Craten Allen [1881-1948]: Geol. Soc. Am. Proc. 1948, p. 111-116, port., May 1949.

Hotz, Preston Enslow. See Wells, F. G., 2.

\section{Hough, Jean Ringier.}

The subspecies of Hoplophoneus, a statistical study: Jour. Paleontology, v. 23, no. 5, p. 536-555, illus., Sept. 1949.

Housner, George William.

(and McCann, G. D.). The analysis of strong-motion earthquake records with the electric analog computor: Seismol. Soc. Am. Bull., v. 39, no. 1, p. 47-56, illus., Jan. 1949.

Houston, Max S. See Byrne, F. E., 2. 
Howard, Hildegarde. See also Miller, L. H.

1. Avian fossils from the marine Pleistocene of southern California: Condor, v. 51, no. 1, Jan.-Feb., p. 20-28, Feb. 2, 1949.

2. New avian records for the Pliocene of California: Carnegie Inst. Wash. Pub. 584, Contr. Paleontology, p. 177-199, illus., June 22, 1949.

\section{Howell, Benjamin Franklin.}

1. Cambrian correlation between China and North America: Geol. Soc. China Bull., v. 27, p. 141-162, Nov. 1947.

2. New hydrozoan and brachiopod and new genus of worms from the Ordovician Schenectady formation of New York: Wagner Free Inst. Sci. Bull., v. 24, no. 1, p. 1-10, illus., Feb. 1949.

3. (and Richards, Horace Gardiner). New Paleozoic linguloid brachiopod from Florida: Wagner Free Inst. Sci. Bull., v. 24, no. 4, p. 35-37, illus., Nov. 1949.

Howell, Benjamin Franklin, Jr.

Ground vibrations near explosions: Seismol. Soc. Am. Bull., v. 39, no. 4, p. 285-310, illus., Oct. 1949 ; abs., Geol. Soc. Am. Bull., v. 60, no. 12, pt. 2, p. 1954-1955, Dec. 1949.

Howell, Paul W. See Baldwin, E. M.

Howland, Arthur Lloyd. See also Dreyer, R. M.; Garrels, R. M., 1, 2; Stark, J. T.

(and Garrels, Robert Minard, and Jones, William Richard). Chromite deposits of Boulder River area, Sweetgrass County, Montana: U. S. Geol. Survey Bull. 948-C, p. 63-82, illus. incl. index, geol. maps, 1949.

Hoylman, H. Wayne.

Airborne magnetometer profiles: Oil and Gas Jour., v. 48, no. 34, p. 55-57, 77-78, illus., Dec. 29, 1949.

\section{Hseung, Yi.}

(and Yeh, Chih Cheng). Note on the fluorescence test of bentonite: Am. Mineralogist, v. 34, nos. 11-12, p. 896-897, Nov.-Dec. 1949.

Hubbs, Carl Leavitt.

(and Miller, Robert Rush). The Great Basin, with emphasis on glacial and postglacial times; 2 , The zoological evidence; Correlation between fish distribution and hydrographic history in the desert basins of western United States: Utah Univ. Bull., v. 38, no. 20 (Biol. ser., v. 10 , no. 7), p. 18-166, illus. incl. index map, June $30,1949$.

Huddle, John Warfield. See Baker, A. A.

Huff man, George Garrett.

1. (and Giles, Alfred E.). Geology of the Strake and Squire field area, Duval County, Texas: World Oil, v. 129 , no. 7, p. $68,70,72,76$, illus., Oct. 1949.

2. (and Price, William Armstrong). Clay dune formation near Corpus Christi, Texas: Jour. Sed. Petrology, v. 19, no. 3, p. 118-127, illus., Dec. 1949.

Hughes, Aden Wayne. See Regan, L. J., Jr.

Hughes, Paul W.

History of the Supai formation in Black Mesa, Yavapai County, Arizona: Plateau, v. 22, no. 2, p. 32-36, index map, Oct. 1949.

Humbert, Roger Paul. See Wascher, H. L.

Hume, George Sherwood. See Canada Geol. Survey, 8, 14. 
Hummel, Floyd A. See also Morgan, R. A.

Properties of some substances isostructural with silica: Am. Ceramic Soc. Jour., v. 32 , no. 10 , p. $320-326$, illus., Oct. 1, 1949.

\section{Humphrey, Fred LaSalle.}

Some observations on geological structures in eastern Nevada [abs.]: Oil and Gas Jour., v. 48, no. 29, p. 139, Nov. 24, 1949; Am. Assoc. Petrol. Geol. Bull., v. 33, no. 12, p. 2063, Dec. 1949.

\section{Humphrey, William Elliott.}

Geology of the Sierra de los Muertos area, Mexico (with descriptions of Aptian cephalopods from the La Peña formation): Geol. Soc. Am. Bull., v. 60, no. 1, p. 89-176, illus. incl. index, geol. maps, Jan. 1949.

\section{Hundhausen, Robert John.}

Investigation of Henderson Gulch tungsten deposit, Granite County, Mont.: U. S. Bur. Mines Rpt. Inv. 4513, 8 p. ( $\ddagger)$, illus. incl. index, geol. maps, July 1949.

\section{Hunt, Charles Butler.}

1. Some geological aspects of the problems of soil genesis and soil classification: Second Int. Conf. Soil Mechanics and Found. Eng., Rotterdam, Proc. v. 3, p. 6-7 ( $), 1948$.

2. (and Creamer, A. S., and Fahey, Joseph John). A newly discovered type of clay deposit in Utah: Washington Acad. Sci. Jour., v. 39, no. 4, p. 120-122, illus., Apr. 15, 1949.

Hunt, Richard N.

(and Peacock, H. G.). Lead and lead-zinc of the Bingham district, Utah, in Dunham, K. C., ed., Symposium on the geology, paragenesis and reserves of the ores of lead and zinc, 18th Internat. Geol. Cong., London, p. 81-85, illus. incl. geol. sketch map, 1948; abs., Volume of titles and abstracts, p. 45-46, 1948.

Hunter, Charles Eugene.

(and Hash, Lewis J.). Halloysite deposits of western North Carolina: N. C. Dept. Conserv. Dev., Div. Mineral Res. Bull. 58, 32 p., illus. incl. index map, Mar. 1949.

\section{Hunter, Coleman Dillard.}

(and Diamond, Woodson). Geological notes and statistics on oil and gas development of south-central Kentucky: Appalachian Geol. Soc. Bull., v. 1, p. 185-191, illus., 1949.

Huntting, Marshall Tower.

Perlite and other volcanic glass occurrences in Washington: Wash. Dept. Conserv. Dev., Div. Mines and Geology, Rpt. Inv. 17, 77 p., illus., 1949.

Hurlbut, Cornelius Searle, Jr. See also Hale, D. R.

1. Minerals and how to study them, by Edward Salisbury Dana. 3d ed. revised by C. S. Hurlbut, Jr. x, 323 p., illus. New York, John Wiley \& Sons, Inc. [ [1949].

2. Causes of color in gemstones: Gems and gemology, v. 6, no. 6, p. 171173,178 , Summer 1949.

3. Beryl at Mt. Mica, Maine [abs.]: Geol. Soc. Am. Bull., v. 60, no. 12, pt. 2, p. 1897-1898, Dec. 1949.

\section{Hurley, Patrick Mason.}

1. Age of Canada's principal gold-producing belt: Science, v. 110, no. 2845, p. 49-50, July 8, 1949.

2. Airborne magnetic survey in Maine: Eng. Min. Jour., v. 150, no. 8, p. $52-55$, illus. incl. geol. sketch map, Aug. 1949; summary with map, World Oil, v. 130, no, 4, p. 66-67, Mar. 1950. 


\section{Hurley, Patrick Mason-Continued}

3. Some problems of age measurements on eastern North American magnetites: Natl. Research Councll, Div. Geol. and Geog., Rpt. of the Committee on the measurement of geologic time, 1948-1949, Exhibit E, p. 79-82 ( $\$)$, Dec. 1949 . Comments by J. P. Marble.

\section{Hurst, Macleod Ewart.}

IIereward Clarence Horwood (1905-1948): Royal Soc. Canada Proc. 3d ser. v. 43, p. 121-125, port., 1949.

\section{Hussey, Keith Morgan.}

Louisiana Cane River Eocene Foraminifera: Jour. Paleontology, v. 23, no. 2, p. 109-144, illus., Mar. 1949.

Hussey, Russell Claudius. See Landes, K. K., 1.

Huston, Charles Coombs.

Hereward Clarence Horwood [1905-1948]: Eng. Min. Jour., v. 150, no. 1, p. 108-109, Jan. 1949; Min. Eng., v. 1, no. 2, p. 44, Feb. 1949.

Hutchinson, George Evelyn.

A note on two aspects of the geochemistry of carbon: Am. Jour. Sci., v. 247, no. 1, p. 27-32, Jan. 1949.

Hutton, Curtis E.

Studies of loess-derived soils in southwestern Iowa: Soil Sci. Soc. Am. Proc., v. 12,1947 , p. $424-431$, illus., 1948.

Imbault, Paul E.

1. Preliminary report on Olga Lake area, Abitibi-East County [Quebec]: Quebec Dept. Mines Prelim. Rpt. 207, 11 p ( $\ddagger)$, geol. map, 1947.

2. Preliminary report on Goéland Lake area, Abitibi-East County [Quebec]: Quebec Dept. Mines Prelim. Rpt. 218, 11 p. ( $\ddagger)$, index, geol. maps, 1948.

Imbt, Robert Floyd.

(and McCollum, S. V.). Pennsylvanian reef at Todd field, Crockett County, Texas [abs.]: Oil and Gas Jour., v. 47, no. 46, p. 109, Mar. 17, 1949.

Imbt, William C. See Bartram, J. G.

Imperial Oil, Ltd., staff. See Layer, D. B.

Ingersoll, Alfred C. See Ingersoll, L. R.

\section{Ingersoll, Leonard Rose.}

(and Zobel, Otto J., and Ingersoll, Alfred C.). Heat conduction; with engineering and geological applications. xii, 278 p., illus. New York, McGraw-Hill Book Co., Inc. 1948.

Ingham, Albert Irwin. See also Ebright, J. R.

1. The McDonald oil field, Allegheny and Washington Counties, Pennsylvania: Producers Monthly, v. 13, no. 4, p. 29-39, illus., Feb. 1949.

2. Slide rule for computing car odometer mileage from road logs: Am. Assoc. Petrol. Geol. Bull., v. 33, no. 9, p. 1613-1614, illus., Sept. 1949.

\section{Ingram, Roy Lee.}

The breaking characteristics of argilutites [abs.]: N. C. Acad. Sci. Proc. in Elisha Mitchell Sci. Soc. Jour., v. 65, no. 2, p. 196, Dec. 1949.

\section{Inman, Douglas L.}

1. Sorting of sediments in the light of fluid mechanics: Calif. Univ., Scripps Inst. Oceanog., Submarine Geology Rpt. no. 3, 31 p. ( $\ddagger)$, illus., Nov. 1948; Jour. Sed. Petrology, v. 19, no. 2, p. 51-70, illus., Aug. 1949: abs., Geol. Soc. Am. Bull., v. 60, no. 12, pt. 2, p. 1940, Dec. 1949. 
Inman, Douglas L.-Continued

2. Report on beach study in the vicinity of Mugu Lagoon, California: Galif. Univ., Scripps Inst. Oceanog. Submarine Geology Rpt. no. 5, 30 p. $(\ddagger)$, illus., June 1949; Beach Erosion Board Tech. Memo. no. 14, 47 p., illus., Mar. 1950.

Innes, M. J. S.

An investigation of the applicability of gravimetric and magnetometric methods of geophysical prospecting: Canadian Min. Met. Bull. no. 448, p. 378-384, illus., Aug. 1949; Canadian Inst. Min. Met. Trans., v. 52 , p. $168-174,1949$; reprinted as Canada Dominion Observatory Pub., v. 11, no. 10, p. 355-361, illus. [1949].

Irelan, Burdge. See Barnes, J. R.; Follett, C. R.; Scalapino, R. A.

\section{Ireland, Hubert Andrew.}

1. Insoluble residues, in Subsurface geologic methods: Colo. Sch. Mines Quart., v. 44, no. 3, p. 111-128, illus., July 1949.

2. Pleistocene physiography and sedimentation in the Caddo canyons of Oklahoma [abs.]: Geol. Soc. Am. Bull., v. 60, no. 12, pt. 2, p. 1898, Dec. 1949.

Irish, Ernest James Wingett. See also Canada Geol. Survey, 12.

A la Pêche map-area, Alberta (report and map): Canada Geol. Survey Paper 49-7, 23 p. ( $\$$ ), geol. map, 1949.

Irish, Ruth I. See Warren, H. V., 3.

Irwin, William Harold. See also McConnell, D., 3.

1. Examination of drill-core samples-proposed Granby tunnel and pumping plant, Colorado-Big Thompson project, Colorado: U. S. Bur. Recl. Petrog. Lab. Rpt. 43, 7 p. ( $\ddagger)$, illus., July 15, 1943.

2. Physical tests and petrographic study of rock cores from the foundation of Hiwassee Dam (TVA), North Carolina: U. S. Bur. Recl. Petrog. Lab. Rpt. 49, 7 p. (市), illus., Aug. 14, 1943.

3. Résumé of petrographic examinations made on basalt and shale specimens, North Dam site area, Grand Coulee Reservoir, Columbia Basin project, Washington: U. S. Bur. Recl. Petrog. Lab. Rpt. 53, 5 p. $(\$)$, Oct. 8, 1943 .

4. Laboratory examination of rock from Anderson rock pit proposed for use as riprap, Newton Dam, Newton project, Utah: U. S. Bur. Recl. Petrog. Lab. Rpt. 57, 5 p. ( $\ddagger$, illus., Dec. 10, 1943.

5. Tests of earth materials, Tucumcari project, New Mexico: U. S. Bur. Recl. Petrog. Lab. Rpt. 59, 13 p. ( $\ddagger)$, Feb. 7, 1944.

6. (and others). Development and use of multiple packers by the Bureau of Reclamation for ground-water observation in engineering geology [abs.]: Geol. Soc. Am. Bull., v. 60, no. 12, pt. 2, p. 1898, Dec. 1949.

Isaacs, J. D.

(and Bascom, W. N.). Water-table elevations in some Pacific Coast beaches: Am. Geophys. Union Trans., v. 30, no. 2, p. 293-294 ( $\ddagger)$, illus., Apr. 1949.

Isfort, Louise $G$.

Geography, geology, and fossils, in A partial bibliography of natural history in the Chicago [Illinois] region: Am. Midland Naturalist, v. 42 , no. 2, p. 413-423, Sept. 1949.

\section{Israelsky, Merle Cathcart.}

1. Oscillation chart [from Foraminifera in oil well, Terrebonne Parish, La.]: Am. Assoc. Petrol. Geol. Bull., v. 33, no. 1, p. 92-98, illus., Jan. 1949.

2. Names of some subsurface stratigraphic units in Texas: Am. Assoc. Petrol. Geol. Bull., v. 33, no. 11, p. 1904-1906, Nov. 1949. 
Jackson, M. Lucille. See Mackie, W. Z.; Pennington, R. P.; Tanner C. B.; Willis, A. L.

Jackson, Neil A.

A subsurface study of the lower Pennsylvanian rocks of east central Oklahoma [abs.]: Tulsa Geol. Soc. Digest, v. 17, p. 112-114, 1949.

Jacobs, Elbridge Churchill.

Physical features of Vermont [abs.]: Geol. Soc. Am. Bull., v. 60, no. 12, pt. 2, 1970-1971, Dec. 1949.

\section{Jacobsen, Clyone Lynn.}

1. (and Reed, Edwin William). Ground-water supplies in the Oklahoma City area, Oklahoma: Okla. Geol. Survey, Mineral Rpt. 20, 21 p. (\$), illus., 1949 .

2. Structural relations on the east flank of the Anadarko Basin, Cleveland and McClain Counties, Oklahoma: Am. Assoc. Petrol. Geol. Bull., v. 33 , no. 5 , p. $695-719$, illus. incl. index, geol. maps, May 1949 ; abs., Tulsa Geol. Soc. Digest, v. 17, p. 66, 1949; discussion by Robert R. Wheeler and reply by author, Am. Assoc. Petrol. Geol. Bull., v. 34, no. 1 , p. 139-146, illus., Jan. 1950.

Jacobson, E. C.

Official oil and gas fields of the State of Kansas [map]. Scale 1 inch to 8 miles. 516 Mayo Building, Tulsa, Okla. 1949.

\section{Jaffe, Howard William.}

1. Visual arc spectroscopic detection of halogens, rare earths, and other elements by use of molecular spectra: Am. Mineralogist, v. 34, nos. 9-10, p. 667-674, illus., Sept.-Oct. 1949.

2. Role of yttrium and other minor elements in the garnet group [abs.]: Geol. Soc. Am. Bull., v. 60, no. 12, pt. 2, p. 1899, Dec. 1949.

Jaggar, Thomas Augustus.

Steam blast volcanic eruptions, a study of Mount Pelée in Martinique as type volcano: Hawaiian Volcano Observatory, Spec. Rpt. 4, 137 p., illus., 1949.

Jahn, Alfred.

Studies on jointing of rocks and glacial micro-relief in Western Greenland: Lublin, Annales Univ. Mariae Curie-Sklodowska, v. 2, sec. B, p. 47-99, illus., 1947 [Polish, with English summary]; abs., Acad. Polonaise des Sci. Letters, Comptes Rendus Classe Sci. Math. Nat. nos. 1-10, p. 32-33, Nov. 1946 [English].

Jahns, Richard Henry. See also Cameron, E. N.

1. Lithium-bearing pegmatites near Wickenburg, Arizona [abs.]: Geol. Soc. Am. Bull., v. 60, no. 12, pt. 2, p. 1899, Dec. 1949.

2. (and Engel, Albert Edward John). Pliocene breccias in the Avawatz Mountains, San Bernardino County, California [abs.]: Geol. Soc. Am. Bull., v. 60, no. 12 , pt. 2, p. 1940 , Dec. 1949.

Jakosky, John Jay.

The economics of geophysics in mining exploration: Min. Eng., v. 1, no. 9, p. 326-330, Sept. 1949; A.I.M.E. Trans., v. 184, 1949.

James, C. C.

The Paricutin eruption [Mexico]: Royal Geol. Soc. Cornwall Trans., v. 17, (1947), pt. 7, p. 368-379, 1948.

Jamès, Harold Lloyd. See also Balsley, J. R., Jr.

Iron formation and associated rocks of the Iron River district, Michigan [abs.]: Geol. Soc. Am. Bull., v. 60. no. 12, pt. 2, p. 1899-1900, Dec. 1949 . 
James, Jack A.

Geologic relationships of the ore deposits in the Frederickstown area, Missouri: Mo. Geol. Survey and Water Res., Rpt. Inv. 8, 25 p., illus., 1949.

Jameson, C. H. See Maxey, G. B., 1.

Jeffords, Russell MacGregor. See Allen, W. B., 1.

Jeffries, Charles D.

1. The mineralogical approach to some soil problems: Soil Sci., v. 63, no. 4 , p. 315-320, June 1947.

2. The use of the $X$-ray spectrometer in the determination of the essential minerals in soils: Soil Sci. Soc. Am. Proc., v. 12, 1947, p. 135-140, illus., 1948.

Jeletzky, Jurij A.

Scaphites morrowi, new name for Scaphites pygmaeus Morrow 1935, non Holzapfel 1888: Jour. Paleontology, v. 23, no. 3, p. 330, May 1949.

Jenkins, Olaf Pitt.

(and others). Copper in California: Calif. Dept. Nat. Res., Div. Mines Bull. 144,429 p., illus. incl. index, geol. maps, Dec. 1948 . Includes Economic mineral map of California No. 6-Copper. Scale 1: $1,000,000$ or 1 inch to approx. 16 miles. 1948.

Jenness, John L.

Permafrost in Canada: Arctic, v. 2, no. 1, p. 13-27, illus., May 1949; discussion by J. D. Bateman, no. 3, p. 203-204, illus., Dec. 1949.

\section{Jensen, Homer.}

1. Airborne magnetic profile above 40th parallel, eastern Colorado to western Indiana: Geophysics, v. 14, no. 1, p. 57, illus., Jan. 1949.

2. Geophysical exploration with the airborne magnetometer: Earth Sci. Digest, v. 4, no. 4, p. 3-11, illus., Nov. 1949.

\section{Jepson, Glenn Lowell.}

1. (and Mayr, Ernst, and Simpson, George Gaylord) (editors). Genetics, paleontology, and evolution. [Report of National Research Council Committee on Common problems of genetics, paleontology and systematics]. xiv, 474 p. illus. Princeton, N. J. Princeton Univ. Press, 1949.

2. Memorial to William Berryman Scott [1858-1947]: Geol. Soc. Am. Proc. 1948, p. 211-227, port., May 1949.

3. Selection "orthogenesis", and the fossil record: Am. Philos. Soc. Proc., v. 93 , no. 6 , p. $479-500$, Dec. $29,1949$.

Jérémine, Elisabeth.

Sur quelques roches intrusives et métamorphiques de la province de Québec: Société Vaudoise des Sciences Naturelles Mém., v. 9, no. 2, p. 163-193, illus. incl. geol. map, 1949.

Jewett, John Mark. See also Ver Wiebe, W. A., 2.

1. Oil and gas in eastern Kansas, with special reference to developments from 1944 to 1948: Kans. Univ., State Geol. Survey Bull. 77, 308 p., illus., July 1949 .

2. (and Smith, R. Kenneth). Oil-bearing rocks in Kansas: Mines Mag., v. 39 , no. 12 , p. 85-90, 100, illus., Dec. 1949.

\section{Jillson, Willard Rouse.}

1. Notes on excavations for big bones at Lower Blue Licks Spring [Ky.]: Filson Club History Quart., v. 20, no. 1, p. 3-9, illus., Jan. 1946.

2. Discovery of Pleistocene vertebrates at Lower Blue Licks [Ky.], 17851946. 30 p., illus., Frankfort, Ky. Roberts Printing Co. 1949. 
Jillson, Willard Rouse-Continued

3. Geologic reconnaissance through Kentucky, Ohio, Pennsylvania, and New York. 32 p., illus. Frankfort, Ky, Roberts Printing Co. 1949.

4. Geology of Owen County, Kentucky. 43 p., illus. Frankfort, Ky. Roberts Printing Co. 1949.

5. Geology of the Jessamine Creek disturbance; observations on the physiography, stratigraphy, and structure of a faulted area in central Kentucky. 33 p., illus. Frankfort, Ky. Roberts Printing Co. 1949.

6. Edestus minor an extinct shark from the Allegheny series of western Kentucky. 16 p., illus. Frankfort, Ky., Roberts Printing Co., [Jan. 10] 1949.

7. The piracy of Eagle Creek; a study in Pliocene drainage modification in northern Kentucky. 32 p., index map. Frankfort, Ky., Roberts Printing Co. [June 23] 1949.

Joesting, Henry Rochambeau.

(and Keller, Fred, Jr., and King, Elizabeth). Geologic implications of aeromagnetic survey of Clearfield-Philipsburg area, Pennsylvania: Am. Assoc. Petrol. Geol. Bull., v. 33, no. 10, p. 1747-1766, illus. incl. geol. maps, Oct. 1949.

Johnson, Curtis Herman.

(and Galeski, Robert Benjamin). Offshore seismic problems affecting geologic evaluation [abs.]: Am. Assoc. Petrol. Geol. Bull., v. 33, no. 12, p. 2059-2060, Dec. 1949; Oil and Gas Jour., v. 48, no. 29, p. 140, Nov. 24, 1949.

Johnson, Dorothy.

(and Lowman, Shepard Wetmore, and Rouse, John Thomas). Directory of geology departments of educational institutions in the United States and Canada. 126 p., Am. Assoc. Petrol. Geol., Mar. 1949. [Tulsa, Okla.].

Johnson, E. A.

Pre-history of the earth's magnetic field [abs.], in Symposium on the earth's crust: Am, Geophys. Union Trans., v. 30, no. 2, p. 169-170, Apr. 1949.

Johnson, Frederick. See also Barghoorn, E. S., Jr., 1.

Summary [Boylston Street Fishweir II Studies, Boston, Mass.]: Peabody Foundation for Archaeology Papers, v. 4, no. 1, p. 124-127, 1949.

Johnson, Jesse Harlan. See also LeRoy, L. W., 4; Stark, J. T.

1. An introduction to the study of organic limestones: Colo. Sch. Mines Quart., v. 44, no. 4, 139 p., illus., Oct. 1949.

2. Permian calcareous algae from the Apache Mountains, Texas [abs.]: Geol. Soc. Am. Bull., v. 60, no. 12, pt. 2, p. 1900, Dec. 1949.

Johnson, Robert $B$.

Upper Devonian ophiurans in central New York [abs.]: Geol. Soc. Am. Bull., v. 60, no. 12, pt. 2, p. 1971, Dec. 1949.

Johnson, Vard Hayes. See also Toenges, A._L., 2.

Geology of the Helvetia mining district, Pima County, Arizona [abs.]: Econ. Geology, v. 44, no. 7, p. 639-640, Nov. 1949; Geol. Soc. Am. Bull., v. 60 , no. 12 , pt. 2 , p. $1900-1901$, Dec. 1949.

Johnston, H. F.

The cooperative ground-water program in West Virginia: W. Va. Acad. Sci. Proc., v. 19, Morgantown meeting (1947), W. Va. Univ. Bull. ser. 49, no. 8-I, p. 146-151, 1949.

Johnston, J. W. D. See Douglas, G. V., 2. 
Johnston, Kenneth Howard. See Hill, H. B., 2.

Johnston, William Drumm, Jr.

(and Thayer, Thomas Prence). Chromite, in Industrial minerals and rocks, p. 194-206, illus., 1949.

Jolley, Theodore Roosevelt. See Toenges, A. L., 1, 4.

Jolliffe, Alfred Walton.

The northwestern part of the Canadian Shield [abs.]: 18th Internat. Geol. Cong., London, Volume of titles and abstracts, p. 93, 1948.

Jonas, Edward C. See Rowland, R. A.

Jones, Paul Hastings. See also Maher, J. C., 3.

(and Buford, T. B.). Application of electric logging to ground-water exploration [abs.]: Oil and Gas Jour., v. 48, no. 29, p. 132, 134, Nov. 24, 1949 .

Jones, Waldo $\mathrm{H}$.

1. Rare minerals of old Virginia: Mineralogist, v. 17, no. 2, p. 62-63, Feb. 1949.

2. Pegmatites of Spruce Pine district, North Carolina: Mineralogist, v. 17, no. 6, p. 283-285, June 1949.

3. The monazite bearing sands of the Atlantic beaches: Mineralogist, v. 17, no. 10 , p. $457-459$, illus., Oct. 1949 .

Jones, Walter Bryan.

Eugene Allen Smith [1841-1927]: Ala. Geol. Survey Bull. 60, p. 19-21, 1948.

Jones, William Richard. See Howland, A. L.

Jooste, R. F.

Preliminary report on the Bourget area, Chicoutimi County [Quebec]: Quebec Dept. Mines Prelim. Rpt. 222, 16 p. ( $\$)$, index, geol. maps, 1948.

Jordan, George F.

Harold Watson Murray [1906-1948]: Washington Acad. Sci. Jour., v. 39, no. 3 , p. 116, Mar. 15,1949 .

Jordan, Richard H.

A Florida landslide: Jour. Geology, v. 57, no. 4, p. 418-419, illus., July 1949.

Joubin, Francis Renault.

Likely occurrences of uranium: Western Miner, v. 22, no. 5, p. 39-41, illus., May 1949.

Joyce, J. E. See Gault, H. R., 1.

Judson, S. Sheldon, Jr. See also Barghoorn, E. S., Jr., 1.

The Pleistocene stratigraphy of Boston, Massachusetts and its relation to the Boylston Street Fishweir: Peabody Foundation for Archaeology Papers, v. 4, no. 1, p. 7-48, illus. incl. index map, 1949.

Just, Theodore Karl.

Some aspects of plant morphology and evolution, in Jepson, G. L., ed., Genetics, paleontology, and evolution, p. 90-100, 1949.

Kaiman, S.

Lattice spacings for glancing angles with iron $x$-radiation: Am. Mineralogist, v. 34, nos. 5-6, p. 465-468, May-June 1949. 
Kalliokoski, J.

Preliminary map, Weldon Bay, Manitoba (map and descriptive notes): Canada Geol. Survey Paper 49-5, 9 p. (\$), 1949.

Kansas Geological Society.

Guidebook, Lower Kansas River valley field conference, June 17-18, 1949. 32 p. ( $\ddagger)$, illus., June 1949.

Karlstrom, Thor N. V.

Geology and ore deposits of the Hecla mining district, Beaverhead County, Montana: Mont. Bur. Mines and Geology, Mem. 25, 87 p. ( $\ddagger)$, illus. incl. geol. maps, 1948.

Kastrop, J. E.

The Poulter method of geophysical seismic exploration: World Oil, v. 128, no. 9, p. 53-60, incl. ads., illus., Jan. 1949.

\section{Kay, George Marshall.}

1. [Discussion], in Longwell, C. R., chm., Sedimentary facies in geologic history [symposium]: Geol. Soc. Am. Mem. 39, p. 134-137, June $17,1949$.

2. Paleozoic North American geosynclines and island arcs [abs.]: 18th Internat. Geol. Cong., London, Volume of titles and abstracts, p. 93,1948 .

3. Pleistocene lakes in the Mohawk Valley, New York [abs.]: Geol. Soc. Am. Bull., v. 60, no. 12, pt. 2, p. 1971, Dec. 1949.

\section{Kay, James LeRoy.}

The Tertiary of Utah, in The oil and gas possibilities of Utah, by G. H. Hansen and M. M. Bell: Utah Geol. Miner. Survey, p. 102-108, Dec. 1949.

Kazmann, Raphael Gabriel. See also Cross, W. P.

The utilization of induced stream infiltration and natural aquifer storage at Canton, Ohio: Econ. Geology, v. 44, no. 6, p. 514-524, illus., Sept.-Oct. 1949: abs., no. 1, p. 84, Jan.-Feb. 1949.

\section{Keating, B. J.}

The basal conglomerates of Nova Scotia: Nova Scotia Dept. Mines Ann. Rpt. 1948, p. 136-142, 1949.

\section{Keefer, Eleanor K.}

(and others). Map of Wyoming showing test wells for oil and gas, anticlinal axes, oil and gas fields, pipelines, unit areas, and land district boundaries: U. S. Geol. Survey, Oil and Gas Invs. Prelim. Map 107, 2 sheets. Scale 1:500,000 or approx. 1 inch to 8 miles. 1949.

Keen, Angeline Myra. See Frizzell, D. L., 1; Schenk, E. T.

Keevil, Norman Bell. See also Larsen, E. S., Jr., 2.

(and Wilson, John Tuzo). Radioactivity of rocks in eastern Ontario [abs.]: Royal Soc. Canada Proc. 3d ser., v. 43, p. 211, 1949.

\section{Keith, Mackenzie Lawrence.}

Sandstone as a source of silica sands in southeastern Ontario: Ont. Dept. Mines Ann. Rpt., v. 55, pt. 5, 1946, 36 p., illus. incl. index, geol. maps, 1949.

Keith, Scott. See Linehan, Daniel.

Keller, Fred, Jr. See Alldredge, L. R.; Joesting, H. R. 


\section{Keller, Walter David.}

1. The rock cycle: Earth Sci. Digest, v. 3, no. 9, p. 17, illus., Apr. 1949.

2. Higher alumina content of oak leaves and twigs growing over clay pits: Econ. Geology, v. 44, no. 5, p. 451-454, Aug. 1949.

3. (and Foley, Richard). Missouri River sediments in river water, ocean water, and sodium oxalate solution: Jour. Sed. Petrology, v. 19, no. 2, p. 78-81, illus., Aug. 1949.

4. (and Pickett, E. E.). Absorption of infrared radiation by powdered silica minerals: Am. Mineralogist, v. 34, nos. 11-12, p. 855-868, illus., Nov.-Dec. 1949.

5. Absorption of infra-red radiation by clay minerals [abs.]: Am. Mineralogist, v. 34, nos. 3-4, p. 278, Mar.-Apr. 1949.

6. (and Pickett, E. E.). Hydroxyl in minerals [abs.]: Geol. Soc. Am. Bull., v. 60, no. 12 , pt. 2, p. 1901, Dec. 1949 .

\section{Kelley, Vincent Cooper.}

Geology and economics of New Mexico iron-ore deposits: N. Mex. Univ. Pubs. Geology no. 2, 246 p., illus. incl. index, geol. maps, 1949.

\section{Kelly, Sherwin Finch.}

Geophysics in the exploration, exploitation and conservation of water: Mines Mag., v. 39, no. 11, p. 13-21, 38, illus., Nov. 1949.

\section{Kelsey, Martin Cyrus.}

Studies in fault detection with the reflection seismograph: Geophysic: v. 14, no. 1, p. 21-28, illus., Jan. 1949.

\section{Kemp, C. Ernest.}

Geiger counter reconnaissance in Upper Michigan, 1948: Mich. Coll. Min. Tech., Conference on radioactive ores, May 6, 1949, p. 25-26, 1949.

\section{Kerr, Lillian B.}

1. Bibliography of coal, oil, natural gas, and industrial minerals in the post-Cambrian region of southern Manitoba to 1945: 25 p. ( $\ddagger$ ), Winnipeg, Manitoba Dept. Mines and Nat. Res., Mines Br., 1949.

2. The stratigraphy of Manitoba with reference to oil and natural gas possibilities: Manitoba Dept. Mines and Nat. Res., Mines Br. Pub. 49-1, 132 p., illus. incl. geol. map, 1949.

Kerr, Paul Francis. See also Kulp, J. L., 2.

1. (and Hamilton, Peggy Kay). Glossary of clay mineral names: Am. Petrol. Inst. Project 49, Clay Mineral Standards, Prelim. Rpt. 1, 68 p. (\$), Feb. 1949 .

2. (and Kulp, John Laurence). Refer nnce clay localities, United States: Am. Petrol. Inst. Project 49, Clay Mineral Standards, Prelim. Rpt. 2, 101 p. (\$), illus. incl. index maps, Feb. 1949.

3. (and Kulp, John Laurence, and Hamilton, Peggy Kay). Differential thermal analyses of reference clay mineral specimens: Am. Petrol. Inst. Project 49, Clay Mineral Standards, Prelim. Rpt. 3, 48 p. (\$), illus., May 1949 .

4. (and Kulp, John Laurence). Multiple differential thermal analysis, in Subsuríace geologic methods; Colo. Sch. Mines Quart., v. 44, no. 3, p. 264-295, illus., July 1949 ; reprinted from Am. Mineralogist, v. 33 , nos. $7-8$, p. $387-419$, illus., July-Aug. 1948.

5. Mineralogical methods in mineral exploration: Min. Eng., v. 1, no. 8, p. 22-25, illus., Aug. 1949.

6. Alteration features at Silver Bell, Arizona [abs.]: Geol. Soc. Am. Bull., v. 60 , no. 12 , pt. 2 , p. 1901 , Dec. 1949.

Kerwin, Larkin.

Use of the broadcast band in geologic mapping: Jour. Applied Physics, v. 18 , no. 4 , p. $407-413$, illus., Apr. 1947 . 
Kesler, Thomas Lingle.

Occurrence and exploration of barite deposits at Cartersville, Georgia: Min. Eng., v. 1, no. 10, p. 371-375, illus., Oct. 1949; A. I. M. E. Trans., v. 184, 1949.

Kesten, S. N. See Christie, A. M., 1, 2.

Keulegan, Garbis $\mathbf{H}$.

(and Krumbein, William Christian). Stable configuration of bottom slope in a shallow sea and its bearing on geological processes: Am. Geophys. Union Trans., v. 30, no. 6, p. 855-861, illus., Dec. 1949.

Kidd, Donald J. See Smith, F. G., 2.

Kiersch, George A.

1. Structural control and mineralization at the Seventy Nine mine, Gila County, Arizona: Econ. Geology, v. 44, no. 1, p. 24-39, illus. incl. geol. map, Jan.-Feb. 1949.

2. Some geologic factors in subterranean construction [abs.]: Geol. Soc. Am. Bull., v. 60 , no. 12 , pt. 2, p. 1940-1941, Dec. 1949.

\section{Kindle, Cecil Haldane.}

1. The Cretaceous crab Raninella testacea in New Jersey: N. Y. Acad. Sci. Trans., ser. 2, v. 12, no. 1, p. 16-17, illus., Nov. 1949.

2. The Croton Point [N. Y.] moraine: Rocks and Minerals, v. 24, nos. 11-12, p. 563-568, illus., Nov.-Dec. 1949.

King, Elizabeth. See Joesting, H. R.

King, Myrle E. See Holland, W. Y., 8; Mielenz, R. C., 16, 17.

\section{King, Philip Burke.}

1. Regional geologic map of parts of Culberson and Hudspeth Counties, Texas [with text]: U. S. Geol. Survey Oil and Gas Invs. Prelim. Map no. 90 . Scale 1 inch to 12,000 feet. 1949.

2. The floor of the Shenandoah Valley [Va.]: Am. Jour. Sci., v. 247, no. 2, p. 73-93, illus., Feb. 1949.

3. Memorial to Nelson Horatio Darton [1865-1948]: Geol. Soc. Am. Proc. 1948 , p. $145-169$, port., May 1949 .

4. Memorial to George Rogers Mansfield [1875-1947]: Geol. Soc. Am. Proc. 1948, p. 187-196, port., May 1949.

5. [Discussion], in Longwell, C. R., chm., Sedimentary facies in geologic history [symposium]: Geol. Soc. Am. Mem. 39, p. 167-171, illus., June 17, 1949 .

6. The base of the Cambrian in the southern Appalachians, Part 1: Am. Jour. Sci., v. 247, no. 8, p. 514-530, illus. incl. geol. sketch map, Aug. 1949; Part 2, no. 9, p. 622-645, illus. incl. geol. sketch map, Sept. 1949 .

Kinkel, A. R., Jr.

(and Albers, J. P.). The geology of the massive sulfide deposits at Iron Mountain, Shasta County, California [abs.]: Econ. Geology, v. 44, no. 1, p. 81-82, Jan.-Feb. 1949.

Kinney, Douglas Merrill. See Baker, A. A.

\section{Kirk, Howard M.}

Robert Hastings Palmer (1882-1949) : Am. Assoc. Petrol. Geol. Bull., v. 33, no. 7, p. 1313-1314, July 1949 .

\section{Kirkham, Don.}

Studies of hillside seepage in the Iowan drift area [Howard Co., Iowa]: Soil Sci. Soc. Am. Proc., v. 12, 1947, p. 73-80, illus., 1948. 
Kirschner, Charles Elbert.

(and Minard, David Lee). Geology of the Iniskin Peninsula, Alaska [geologic map and text]: U. S. Geol. Survey Oil and Gas Invs. Prelim. Map no. 95. Scale 1 inch to 4000 feet. 1948.

Kjellesvig-Waering, Erik N.

The Mazon Creek eurypterid; a revision of the genus Lepidoderma: Ill. State Mus., Sci. Papers, v. 3, no. 4, 48 p., illus., 1948.

Klein, N. H. See Adamson, J. H., Jr., 1.

Kline, Mitchell Heeney.

(and Beck, William August). Investigation of Chestatee copper and pyrite project, Lumpkin County, Ga.: U. S. Bur. Mines Rpt. Inv. 4397, 12 p. (\$), illus. incl. index map, Jan. 1949.

Kline, Virginia Harriett. See Bell, A. H., 3.

Knechtel, Maxwell McMichael. See Oakes, M. C.

Knodle, Robert $\mathbf{D}$.

Factors affecting laboratory measurement of permeability of unconsolidated glacial material: Ill. State Acad. Sci. Trans., v. 42, p. 103112, illus., Dec. 31, 1949: reprinted in Ill. State Geol. Survey Circ. 157 , p. 103-112, illus., 1950.

Knopf, Adolph.

Time in earth history, in Jepson, G. L., ed., Genetics, paleontology, and evolution, p. 1-9, 1949.

Knopf, Eleanora Bliss.

Fabric changes in Yule marble after deformation in compression, Part 1: Am. Jour. Sci., v. 247 , no. 7 , p. 433-461, illus., July 1949; Part 2, no. 8, p. 537-569, illus., Aug. 1949.

Knox, Arthur Stewart.

Fossil pollen and paleoclimatology [abs.], in Symposium on the earth's crust: Am. Geophys. Union Trans., v. 30, no. 2, p. 182, Apr. 1949.

Köhler, Alexander.

Recent results of investigations on the feldspars: Jour. Geology, v. 57, no. 6, p. 592-599, Nov. 1949 .

Kosanke, Robert $M$.

Review of coal research, 1948-1949 [abs.]: Econ. Geology, v. 44, no. 7, p. 646 , Nov. 1949 ; Geol. Soc. Am. Bull., v. 60 , no. 12 , pt. 2, p. 1901-1902, Dec. 1949.

Koschmann, Albert Herbert.

1. Structural control of the gold deposits of the Cripple Creek district, Teller County, Colorado: U. S. Geol. Survey Bull. 955-B, p. 19-60, illus. incl. geol. map, 1949.

2. Addition to symposium on "Geophysics in mining": Geophysics, v. 14, no. 1 , p. 67-69, illus., Jan. 1949.

3. A career in geology: Engineers' Bull., v. 33, no. 12, p. 17-19, Dec. 1949.

Kotick, Ottmar Frank.

Geology and problems of exploring for oil in northern Alaska [abs.]: Am. Assoc. Petrol. Geol. Bull., v. 33, no. 12, p. 2059, Dec. 1949.

Krampert, Edward Walter.

Commercial oil in Cambrian beds, Lost Soldier field, Carbon and Sweetwater Counties, Wyoming: Am. Assoc. Petrol. Geol. Bull., v. 33, no. 12, p. 1998-2010, illus., Dec. 1949; abs., Oil and Gas Jour., v. 47 , no. 46 , p. $152-153$, Mar. $17,1949$. 
Kraut, François. See Caillère, S.

Krinitzsky, Ellis Louis.

Origin of pimple mounds: Am. Jour. Sci., v. 247, no. 10, p. 706-714, illus., Oct. 1949.

\section{Kruger, Frederick Christian.}

A device for calculating stoping values from assays of narrow veins: Econ. Geology, v. 44, no. 5, p. 445-448, illus., Aug. 1949.

Krumbein, William Christian. See also Dapples, E. C., 2; Keulegan, G. H.; Sloss, L. L., 1.

(and Sloss, Laurence Louis, and Dapples, Edward Charles). Sedimentary tectonics and sedimentary environments: Am. Assoc. Petrol. Geol. Bull., v. 33, no. 11, p. 1859-1891, illus., Nov. 1949; abs., Oil and Gas Jour., v. 47, no. 46, p. 157, Mar. 17, 1949; discussion entitled "Diastrophism and sedimentation" by Franklyn B. Van Houten, v. 34 , no. 2, p. 314-316, Feb. 1950 ; authors' reply, p. 316-318, Feb. 1950.

\section{Krusekopf, H. H.}

Gumbotil; its formation and relation to overlying soils with claypan subsoils: Soil Sci. Soc. Am. Proc., v. 12, 1947, p. 413-414, 1948.

\section{Krynine, Paul Dimitri.}

1. Mineralogical research on oil reservoirs: Mineral Industries, v. 18, no. 4, p. 1-3, Jan. 1949 .

2. The origin of red beds: N. Y. Acad. Sci. Trans., ser. 2, v. 11, no. 3, p. 60-68, illus., Jan. 1949 .

3. Current mineralogical research in oil finding: Pa. State Coll. Mineral Indus. Expt. Sta. Bull. 52, p. 1-5, Feb. 25, 1949; Producers Monthly, v. 13, no. 6, p. 36-37, Apr. 1949; abs., Oil and Gas Jour., v. 42, no. 26 , p. 105 , Oct. $28,1948$.

\section{Kuehn, Harald.}

The moonscar upon the earth, Pt. 1: Earth Sci. Digest, v. 3, r.o. 7, p. 3-6, illus., Feb. 1949; Pt. 2, v. 3, no. 8, p. 3-6, illus., Mar. 1949.

\section{Kuhn, Truman Howard.}

Subsurface methods as applied in mining geology, in Subsurface geologic methods: Colo. Sch. Mines Quart., v. 44, no. 3, p. 770-789, illus., July 1949.

Kulp, John Laurence. See also Holland, H. D.; Kerr, P. F., 2, 3, 4.

1. (and Wright, Harold D., and Holmes, Ralph Jerome). Thermal study of rhodochrosite: Am. Mineralogist, v. 34, nos. 3-4, p. 195-219, illus., Mar.-Apr. 1949; abs., p. 285, Mar.-Apr. 1949; Geol. Soc. Am. Bull., v. 59 , no. 12 , pt. 2 , p. 1365 , Dec. 1948.

2. (and Kerr, Paul Francis). Improved differential thermal analysis apparatus: Am. Mineralogist, v. 34 , nos. $11-12$, p. $839-845$, illus., Nov.-Dec. 1949.

3. (and Carr, Donald R.). Surface area of deep-sea sediments [abs.]: Geol. Soc. Am. Bull., v. 60, no. 12, pt. 2, p. 1902, Dec. 1949.

\section{Ladd, Harry Stephen.}

1. (and Tracey, Joshua Irving, Jr.). The problem of coral reefs: Sci. Monthly, v. 69, no. 5, p. 297-305, Nov. 1949.

2. Modern reefs [abs.]: Oil and Gas Jour., v. 47, no. 46, p. 108, Mar. 17, 1949 . 
Lafferty, Robert C., Jr.

Central basin of Appalachian geosyncline: Am. Assoc. Petrol. Geol. Bull., v. 25, no. 5, p. 781-825, illus., May 1941; reprinted in Appalachian Geol. Soc. Bull., v. 1, p. 202-238, illus., 1949; abs. with title "Some observations concerning the sedimentary history of the central part of the Appalachian basin", Oil and Gas Jour., v. 38, no. 48, p. 52, Apr. 11, 1940.

Lahee, Frederic Henry.

1. Exploratory drilling [for oil and gas] in 1948: Am. Assoc. Petrol. Geol. Bull., v. 33, no. 6, p. 783-804, illus. incl. index maps, June 1949; correction, v. 33, no. 8, p. 1438, Aug. 1949.

2. Overlap and non-conformity: Am. Assoc. Petrol. Geol. Bull., v. 33, no. 11, p. 1901, Nov. 1949.

Laird, Wilson Morrow.

1. Stratigraphy of North Dakota with reference to oil possibilities: N. Dak. Geol. Survey Rpt. Inv. 2, two sheets, maps and descriptive text, 1949.

2. State geological surveys: Calif. Jour. Mines and Geology, v. 45, no. 2, p. 300-317, Apr. 1949.

Lakin, Hubert W. See also Hawkes, H. E., Jr., 1; Reichen, L. E.; Stevens, R. E.

(and Stevens, Rollin Elbert, and Almond, Hy). Field method for the determination of zinc in soils: Econ. Geology, v. 44, no. 4, p. 296306, illus., June-July 1949.

\section{Lalicker, Cecil Gordon.}

Principles of petroleum geology. xii, 377 p., illus. New York, AppletonCentury-Crofts, Inc. ['1949].

\section{Lamborn, Raymond Ellwood.}

1. Geologic map of Coshocton County [Ohio]: Ohio Geol. Survey. Scale $1: 62,500$ or 1 inch to approx. 1 mile. 1948 .

2. Gas and oil, in Geology of Holmes County [Ohio], by G. W. White: Ohio Geol. Survey, 4th ser., Bull. 47, p. 261-284, illus., 1949.

\section{LaMoreaux, Philip Elmer.}

1. Fluoride in the ground water of the Tertiary area of Alabama: Ala. Geol. Survey Bull. 59, 77 p., index maps, 1948.

2. Geology [of southeastern Alabama], in Water resources and hydrology of southeastern Alabama: Ala. Geol. Survey Spec. Rpt. 20, p. 28-33, geol. map, 1949.

3. Ground water in southeast Alabama, in Water resources and hydrology of southeastern Alabama: Ala. Geol. Survey Spec. Rpt. 20, p. 200-237, illus., 1949.

\section{Lance, John Franklin.}

Phylogenetic significance of some Pliocene horses from Mexico [abs.]: Geol. Soc. Am. Bull., v. 60 , no. 12, pt. 2, p. 1950, Dec. 1949.

\section{Landes, Kenneth Knight.}

1. (and Hussey, Russell Claudius). Geology and man. ix, 518 p., illus. New York, Prentice-Hall, Inc. 1948.

2. Physical geology and man. ix, 414 p., illus. New York, Prentice-Hall, Inc., 1948. A briefer edition of Landes and Hussey, Geology and man, 1948, omitting the section on Earth history, p. 351-447.

3. Scenic Kansas: Kans. Univ., State Geol. Survey, $2 d$ ed., 16 p., illus. incl. index map [194y] : summary, Earth Sci. Digest, v. 3, no. 12, p. 3-12, illus., July 1949.

4. Metallurgical limestone reserves [abs.]: Econ. Geology, v. 44, no. 7, p. 641 , Nov. 1949 ; Geol. Soc. Am. Bull., v. 60 , no. 12 , pt. 2, p. 19021903, Dec. 1949. 


\section{Landsberg, Helmut.}

Pleistocene research, a review by the members of the committee on interrelations of Pleistocene research, National Research Council; 6, Climatology of the Pleistocene: Geol. Soc. Am. Bull., v. 60, no. 9, p. 1437-1442, Sept. 1949.

Lang, Arthur Hamilton. See also Canada Geol. Survey, 11.

1. Notes on prospecting for uranium in Canada: Canada Geol. Survey Paper 49-4, 22 p. (\$), 1949.

2. The Camray uranium discovery [Ontario]: Canadian Min. Met. Bull. no. 442 , p. 68-72, illus., Feb. 1949; Canadian Inst. Min. Met. Trans., v. 52 , p. $42-46$, illus., 1949 .

3. Uranium deposits of the Canadian Shield with emphasis on the Theano Point, Ontario, discoveries: Mich. Coll. Min. Tech., Conference on radioactive ores, May 6, 1949, p. 16-24, 1949.

Lang, Joseph Winford. See Alexander, W. H., Jr., 2.

Lang, Walter Theodore Barnes.

Cycle of deposition in the Salado formation of the Permian of New Mexico and Texas [abs.]: Geol. Soc. Am. Bull., v. 60, no. 12, pt. 2, p. 1903, Dec. 1949.

\section{Lang, William Albert.}

The fuel reserves of Alberta: Canadian Min. Met. Bull. no. 441, p. 1724, illus., Jan. 1949; Canadian Inst. Min. Met. Trans., v. 52, p. 15$22,1949$.

Langston, Wann, Jr.

1. A new species of Paleorhinus from the Triassic of Texas: Am. Jour. Sci., v. 247, no. 5, p. 324-341, illus., May 1949.

2. Permian amphibians from the Abo formation of New Mexico [abs.]: Geol. Soc. Am. Bull., v. 60, no. 12, pt. 2, p. 1903, Dec. 1949.

La Paz, Lincoln. See also Beck, C. W., 1, 2.

A possible meteorite crater in northeastern New Mexico: Pop. Astronomy, v. 57, no. 3, p. 136-137, illus., Mar. 1949: Meteor. Soc. Contr., v. 4, no. 3 , p. 186-187, illus., 1949.

\section{La Rocque, Aurèle.}

1. Post-Pleistocene connection between James Bay and the Gulf of St. Lawrence: Geol. Soc. Am. Bull., v. 60 , no. 2, p. 363-380, illus., Feb. 1949.

2. New uncoiled gastropods from the Middle Devonian of Michigan and Manitoba: Mich. Univ. Mus. Paleontology Contr., v. 7, no. 7, p. 113122, illus., May 13, 1949.

Larsen, Esper Signius, Jr.

1. Memorial of Alfred Church Lane [1863-1948]: Am. Mineralogist, v. 34, nos. 3-4, p. 249-252, port., Mar.-Apr. 1949.

2. (and Keevil, Norman Bell, and Harrison, Harold Charles). Preliminary report on determining the age of rocks by the lead-uranium ratio of zircon, apatite, and sphene from the rocks using alpha counting and spectrographic methods: Natl. Research Council, Div. Geol. and Geog., Rpt. of the Committee on the measurement of geologic time, 1947-1948, Exhibit E, p. 27-28 (\$), June 1949.

3. The relation between earth movements and volcanism in the San Juan Mountains of Colorado: Am. Geophys. Union Trans., v. 30, no. 6, p. 862-866, illus., Dec. 1949.

4. (and Draisin, Wilburt M.). Composition of the minerals in the rocks of the southern California batholith [abs.]: 18th Internat. Geol. Cong., London, Volume of titles and abstracts, p. 6, 1948.

Larsen, Raymond M. See Keefer, E. K.; U. S. G. S. 1, no. 107. 
Larson, Thurston Eric. See also Smith, H. F.

Geologic correlation and hydrologic interpretation of water analyses: Ill. State Water Survey Circ. 27,8 p., illus. incl. index maps, 1949.

\section{Lasky, Samuel Grossman.}

1. (and Hoagland, A. D.). Central mining district, New Mexico, in Dunham, K. C., ed., Symposium on the geology, paragenesis and reserves of the ores of lead and zinc, 18th Internat. Geol. Cong., London, p. 86-97, illus. incl. geol. map, 1948; abs., Volume of titles and abstracts, p. 46-47, 1948. Reprinted in West Texas Geol. Soc. Guidebook, Field Trip no. 3, November 6-9, 1949, p. 7-24, illus. incl. geol. map, 1949.

2. (and Webber, Benjamin N.). Manganese resources of the Artillery Mountains region, Mohave County, Arizona: U. S. Geol. Survey Bull. 961, 86 p., illus. incl. index, geol. maps, 1949.

3. National mineral resource appraisal: Min. Congress Jour., v. 35, no. 1, p. 35-37, illus., Jan. 1949 ; abs., Econ. Geology, v. 44, no. 1, p. 82-83, Jan.-Feb. 1949.

Latta, Bruce Ferrell.

Ground-water conditions in the Smoky Hill Valley in Saline, Dickinson, and Geary Counties, Kansas: Kans. Univ., State Geol. Survey Bull. 84, 152 p., illus. incl. index, geol. maps, Oct. 1949.

\section{Laudon, Lowell Robert.}

1. (and Bowsher, Arthur Leroy). Mississippian formations of southwestern New Mexico: Geol. Soc. Am. Bull., v. 60 , no. 1, p. 1-87, illus. incl. index maps, Jan. 1949.

2. (and Chronic, Byron John, Jr.). Paleozoic stratigraphy along Alaska Highway in northeastern British Columbia: Am. Assoc. Petrol. Geol. Bull., v. 33, no. 2, p. 189-222, illus. incl. index maps, Feb. 1949.

3. (and others). Devonian and Mississippian stratigraphy, Wapiti Lake area, British Columbia, Canada: Am. Assoc. Petrol. Geol. Bull., v. 33 , no. 9 , p. 1502-1552, illus. incl. index, geol. maps, Sept. 1949; abs., Oil and Gas Jour., v. 47, no. 46, p. 153-154, Mar. 17, 1949.

Laurie, A. M.

(and Dietzel, Norman E.). Geology of the Devil's Punchbowl area [Calif.]: Compass, v. 26, no. 4, p. 305-314, illus., May 1949.

\section{Laverdière, Joseph Willie.}

Bedded limestones in the Lévis formation [Quebec]: Royal Soc. Canada Trans. 3d ser., v. 43, sec. 4, p. 71-83, illus., June 1949; abs. with title, "Middle Cambrian limestones near Lévis, Quebec," Proc. 3d ser., v. 43, p. $239,1949$.

Laves, Fritz.

Geometry of triclinic adularia [abs.]: Geol. Soc. Am. Bull., v. 60, no. 12, pt. 2, p. 1903-1904, Dec. 1949.

Lawson, Andrew Cowper.

1. (and Byerly, Perry). Biographical memoir of Harry Fielding Reid, 1859-1944: Natl. Acad. Sci. Biog. Mem., v. 26, p. 1-12, port., 1949.

2. [Discussion], in Longwell, C. R., chm., Sedimentary facies in geologic history [symposium]: Geol. Soc. Am. Mem. 39, p. 133-134, June 17, 1949.

Lawson, D. E. See Heisey, E. L.

Layer, Douglas Bruce.

(and Imperial Oil, Ltd. staff.). Leduc oil field, Alberta, a Devonian coralreef discovery in Clark, L. M., chm., Alberta symposium: Am. Assoc. Petrol. Geol. Bull., v. 33, no. 4, p. 572-602, illus. incl. index maps, Apr. 1949. 
Lee, Wallace.

Subsurface geologic cross section from Barber County to Saline County, Kansas: Kans. Univ., State Geol. Survey Oil and Gas Inv. no. 8, 16 p., illus., 1949.

Leet, Lewis IIon.

1. Vibrations from delay blasting: Seismol. Soc. Am. Bull., v. 39, no. 1, p. 9-20, illus., Jan. 1949.

2. Discussion of tripartite microseismic measurements: Seismol. Soc. Am. Bull, v. 39, no. 4, p. 239-255, illus., Oct. 1949 ; abs., Geol. Soc. Am. Bull, v. 60, no. 12, pt. 2, p. 1955, Dec. 1949.

Leggat, E. R. See Barnes, J. R.

Leggette, Ralph Maxwell. See Taylor, G. H.

Legrand, Harry E. See also Herrick, S. M.

Sheet structure, a major factor in the occurrence of ground water in the grarites of Georgia: Econ. Geology, v. 44, no. 2, p. 110-118, illus., Mar.-Apr. 1949.

Le Grand, J. R. See Van Horn, E. C., 2.

Leighton, Morris Morgan. See also Bell, A. H., 1.

1. (and Willman, Harold Bowen). Itinerary of field conference; Late Cenozoic geology of Mississippi Valley, southeastern Iowa to central Lou siana, June 12-25, 1949. 86 p. $(\ddagger)$, illus., [1949].

2. (and Shaffer, Paul R.). Newly discovered extension of the Labradorean ice sheet into eastern Iowa during the Tazewell substage of the Wisconsin stage [abs.]: Geol. Soc. Am. Bull., v. 60, no. 12, pt. 2, p. 1904:, Dec. 1949.

3. (and Willman, Harold Bowen). Loess formations of Mississippi Valley [absi.] : Geol. Soc. Am. Bull., v. 60, no. 12, pt. 2, p. 1904-1905, Dec. 1949.

Leith, Carlton J.

Oolitic facies of Middle Mississippian Ste. Genevieve formation in Indiana [abss.]: Oil and Gas Jour., v. 47, no. 46, p. 152, Mar. 17, 1949.

Leith, Edward Isaac.

Fossil elephants of Manitoba: Canadian Field-Naturalist, v. 63, no. 4, p. 135-137, illus. incl. index map, July-Aug. 1949.

Lemoine, Rémy C. See Taylor, G. C., Jr., 1, 2.

Leonard, Alvin Riley. See Frye, J. C., 1.

Leonard, Arthur Byron. See Frye, J. C., 6.

Leonard, Frederick Charles.

On naming new subclasses of meteorites: Pop. Astronomy, v. 57, no. 3, p. 137-138, Mar. 1949; Meteor. Soc. Contr., v. 4, no. 3, p. 187-188, 1949.

Lepper, Henry A., Jr.

Compression tests on oriented specimens of Yule marble: Am. Jour. Sci., v. 247 , no. 8, p. 570-574, illus., Aug. 1949.

LeRoy, Leslie Walter.

1. (and Crain, Harry M.) (editol's). Subsurface geologic methods (a symposium) : Colo. Sch. Mines Quart., v. 44, no. 3, 826 p., illus., July 1949. Contains 46 articles by specialists on various methods and techniques used in subsurface geologic exploration.

2. Introdvction to Subsurface geologic methods: Colo. Sch. Mines Quart., v. 4:4, no. 3, p. 1-25, illus., July 1949 . 
LeRoy, Leslie Walter-Continued

3. Stratigraphic, structural, and correlation considerations, in Subsurface geologic methods: Colo. Sch. Mines Quart., v. 44, no. 3, p. 26-57, illus., July 1949.

4. Micropaleontologic analysis [with a section on Calcareous Algae by $\mathrm{J}$. Harlan Johnson], in Subsurface geologic methods: Colo. Sch. Mines Quart., v. 44, no. 3, p. 58-86, illus., July 1949.

5. Screen analysis, in Subsurface geologic methods: Colo. Sch. Mines Quart., v. 44, no. 3, p. 151-160, illus., July 1949.

6. Settling analysis, in Subsurface geologic methods: Colo. Sch. Mines Quart., v. 44, no. 3, p. 160, July 1949.

7. Stain analysis, in Subsurface geologic methods: Colo. Sch. Mines Quart., v. 44, no. 3 , p. 160-166, illus., July 1949 .

8. Shape analysis, in Subsurface geologic methods: Colo. Sch. Mines Quart., v. 44, no. 3, p. 167-168, July 1949 .

9. Subsurface graphic representations, in Subsurface geologic methods: Colo. Sch. Mines Quart., v. 44, no. 3, p. 595-626, illus., July 1949.

\section{Leuchs, Kurt.}

Charles Schuchert [1858-1942]: Almanach für das Jahr 1947, Jahrg. 97, p. 317-320, Vienna, Osterreichische Akademie der Wissenschaften, 1948.

Leverin, H. A.

(and Cameron, J. R.). Peat and peat mosses in Nova Scotia, Pt. 2: Nova Scotia Dept. Mines Ann. Rpt. 1948, p. 143-174, index maps, 1949.

\section{Levin, S. Benedict.}

1. (and Mosier, McHenry). Investigation of Blister mica mine, Cheshire County, N. H.: U. S. Bur. Mines Rpt. Inv. 4409, 12 p. ( $\$)$, illus. incl. index, geol. maps, Feb. 1949.

2. (and Mosier, McHenry). Investigation of Big mica mine, Cheshire County, N. H.: U. S. Bur. Mines Rpt. Inv. 4410, 16 p. ( $\$)$, illus. incl. index map, Feb. 1949.

3. Garnet evidence in Adirondack petrogeny [N. Y.]: N. Y. Acad. Sci. Trans., ser. 2, v. 11, no. 5, p. 156-162, Mar. 1949.

4. The physical analysis of polycomponent garnet [abs.]: Am. Mineralogist, v. 34, nos. 3-4, p. 279, Mar.-Apr. 1949: Geol. Soc. Am. Bull., v. 60 , no. 12 , pt. 2 , p. 1905 , Dec. 1949 .

Levings, William Stephen. See Van Tuyl, F. M., 1.

\section{Levorsen, Arville Irving.}

1. Estimates of undiscovered petroleum reserves: Mines Mag., v. 39, no. 12, p. 47-51, illus., Dec. 1949.

2. Time of oil and gas accumulation [abs.] : Am. Assoc. Petrol. Geol. Bull., v. 33 , no. 12 , p. 2063 , Dec. 1949 ; Oil and Gas Jour., v. 48, no. 29, p. 134, Nov. 24, 1949.

Lewis, Paul J. See Laudon, L. R., 3.

Lewis, W. V.

The function of meltwater in cirque formation; a reply: Geog. Rev., v. 39, no. 1 , p. 110-128, illus., Jan. 1949 .

Ley, Willy.

How man began to understand fossils: Frontiers, v. 10, no. 1, p. 8-9, 30-32, illus., Oct. 1945.

\section{Liddell, Donald M.}

1. Sydney Hobart Ball [1877-1949]: Min. Eng., v. 1, no. 6, p. 216-217, June 1949.

2. Sydney Hobart Ball [1877-1949]: Eng. Min Jour.. v 150, no. 8, p. 106107, Aug. 1949. 


\section{Lindberg, Marie Louise Lange.}

1. Frondelite and the frondelite-rockbridgeite series: Am. Mineralogist, v. $3 \varepsilon$, nos. 7-8, p. 541-549, July-Aug. 1949.

2. Arrojadite and graftonite from the Nickel Plate mine, South Dakota [abs.]: Am. Mineralogist, v. 34, nos. 3-4, p. 279-280, Mar.-Apr. 1949 .

\section{Linehan, Daniel.}

(and Keith, Scott). Seismic reconnaissance for ground-water development: New England Water Works Assoc. Jour., v. 63, no. 1, p. 7695, illus., Mar. 1949.

\section{Link, Theodore August.}

1. Leduc oil field, Alberta, Canada (An example of transgressive and regressive bioherm growth) : Geol. Soc. Am. Bull., v. 60, no. 3, p. 381402, illus. incl. index, geol. maps, Mar. 1949; Geol. Assoc. Canada Proc., v. 1, Aug. 1949 ; Geol. Soc. Am. Bull., abs., v. 58, no. 12, pt. 2, p. 1202-1203, Dec. 1947.

2. Canada's coral-reefs point to big potential: Oil Forum, v. 3, no. 4, p. 159-163, 170, illus., Apr. 1949 ; no. 5, p. 211-213, illus., May 1949; no. 6, p. 256-257, illus., June 1949.

3. Interpretations of Foothills structures, Alberta, Canada: Am. Assoc. Petrol. Geol. Bull., v. 33, no. 9, p. 1475-1501, illus., Sept. 1949.

4. Oil and gas possibilities in western Canada: Canadian Min. Met. Bull., no. 450, p. 532-542, illus., Oct. 1949; Canadian Inst. Min. Met. Trans., v. 52, p. 220-230, 1949.

5. The. western Canada sedimentary basin area: World Oil, v. 129, no. 9, p. 230-231, 234, 236, 238, 240, 242, 244, 246, 248, illus., Dec. 1949.

6. Theory of transgressive and regressive reef (bioherm) development and origin of oil within them [abs.]: Oil and Gas Jour., v. 47, no. 46, p. 108, Mar. 17, 1949; Am. Assoc. Petrol. Geol. Bull., v. 33, no. 12, p. 2060-2061, Dec. 1949.

\section{Link, Walter Karl.}

Approach to origin of oil: Am. Assoc. Petrol. Geol. Bull., v. 33, no. 10, p. 1767-1769, Oct. 10, 1949.

Lipscomb, William N. See Collin, R. L.

\section{Lisle. T. Orchard.}

Record size [quartz] crystals at Prospect Park, N. J.: Rocks and Minerals, v. 24, nos. 7-8, p. 384, July-Aug. 1949.

\section{Little, H. W.}

1. Preliminary map, Nelson (west half), British Columbia [with descriptive notes]: Canada Geol. Survey Paper 49-22, 1949.

2. The ultrabasic rocks of Middle River Range, B. C.: Am. Jour. Sci., v. 247 , no. 11, p. 802-823, illus. incl. index, geol. maps, Nov. 1949.

\section{Littleton, Robert Thomas.}

Geology and ground-water hydrology of the Angostura irrigation project, South Dakota (with a section on the mineral quality of waters by Herbert A. Swenson) : U. S. Geol. Survey Circ. 54, 96 p. ( $\ddagger)$, illus. incl. index, geol. maps, July 1949.

Livermore, John Sealy. See Wells, F. G., 1.

\section{Lloyd, Edwin Russell.}

Pre-San Andres stratigraphy and oil-producing zones in southeastern New Mexico, a progress report: N. Mex. Bur. Mines and Mineral Res. Bull. 29,79 p., illus. incl. index map, 1949. 
Lobeck, Armin Kohl.

1. Historical geology of the United States. Set of ten maps with notes. Revised ed., New York, Columbia University, The Geographical Press. 1947.

2. Geological diorama of the United States. One sheet, brief text. New York, Columbia University, The Geographical Press. 1948.

\section{Lochman, Christina.}

(and Duncan, Donald Cave). Homonyms and synonyms in "Early Upper Cambrian faunas of central Montana": Jour. Paleontology, v. 23, no. 4, p. 439-440, July 1949 .

\section{Lockett, John Robert.}

Introduction to the petroleum geology of the Clinton sand in Ohio: Appalachian Geol. Soc. Bull., v. 1, p. 79-93, 1949.

Loeblich, Alfred Richard, Jr.

1. (and Tappan, Helen Nina). New Kansas Lower Cretaceous Foraminifera: Washington Acad. Sci. Jour., v. 39, no. 3, p. 90-92, Mar. 15, 1949.

2. (and Tappan, Helen Nina). Foraminifera from the Walnut formation (Lower Cretaceous) of northern Texas and southern Oklahoma: Jour. Paleontology, v. 23, no. 3, p. 245-266, illus., May 1949.

Loeltz, Omar Joseph.

(and Phoenix, David Allen, and Robinson, Thomas William, Jr.) Ground water in Paradise Valley, Humboldt County, Nevada: Nev. State Engineer's Office, Water Res. Bull. 10, 61 p., illús. incl. index map, 1949 .

Logan, Clarence August.

Mines and mineral resources of Tuolumne County, California: Calif. Jour. Mines and Geology, v. 45 , no. 1, p. $47-83$, illus. incl. index map, Jan. 1949.

Lohman, Stanley William. See Wiliams, C. C.

\section{Longley, William Warren.}

1. Preliminary report on Bachelor Lake area, Abitibi-East County [Quebec]: Quebec Dept. Mines Prelim. Rpt. 198, 8 p. ( $\ddagger)$, index, geol. maps, 1947.

2. Forget Lake area, Saguenay County [Quebec]: Quebec Dept. Mines, Geol. Surveys Br., Geol. Rpt. 36, 25 p. ( $\ddagger)$, illus. incl. geol. map, 1948; also in French ed.

\section{Longwell, Chester Ray.}

1. Structure of the northern Muddy Mountain area, Nevada: Geol. Soc. Am. Bull., v. 60, no. 5, p. 923-967, illus. incl. index, geol. maps, May 1949.

2. (chairman). Sedimentary facies in geologic history [symposium]: Geol. Soc. Am. Mem. 39, 171 p., illus., June 17, 1949. Contains papers by Raymond C. Moore; Edwin D. McKee; Siemon W. Muller; Edmund M. Spieker; Horace E. Wood, 2d; and Lawrence L. Sloss, William C. Krumbein, and Edward C. Dapples. Discussion by the authors and Shepard W. Lowman, John Rodgers, Andrew C. Lawson, Marshall Kay, Wallace M. Cady, John C. Griffiths, Robert I. Roth, Franklyn B. Van Houten, Daniel I. Axelrod, and Philip B. King.

3. Structure in the Arizona-Nevada boundary area [abs.]: Geol. Soc. Am. Bull., v. 60, no. 12 , pt. 2 , p. 1905-1906, Dec. 1949 . 
Lonsdale, John Tipton. See also Maxwell, R. A., 1, 2.

1. (and Dickson, Kathrvn O.). Analcime suite of igneous rocks, Brewster County, Texas [abs.]: Am. Mineralogist, v. 34, nos. 3-4, p. 280, Mar.-Apr. 1949.

2. (and Maxweli, Ross Allan). Petrology of Big Bend National Park, Texas [abs.]: Geol. Soc. Am. Bull., v. 60, no. 12, pt. 2, p. 1906, Dec. 1949.

Loofbourow, John Stewart, Jr.

Recent development at Guijarral Hills [oil field, Calif.] [abs.]: Oil and Gas Jour., v. 48, no. 29, p. 134, Nov. 24, 1949; Am. Assoc. Petrol. Geol. Bull., v. 33, no. 12, p. 2062, Dec. 1949.

Loomis, Benjamin Franklin, 1857-1935.

Pictorial history of the Lassen Volcano [California], revised by Loomis Museum Association. 109 p. (\$), illus. incl. index map. Lassen Volcanic Natl. Park, Mineral, Calif. 1948.

Lord, Clifford Symington. See also Canada G. S., 10; Henderson, J. F., 2.

1. McConnell Creek map-area, Cassiar district, British Columbia: Canada Geol. Survey Mem. 251, 72 p., illus., incl. index, geol. maps, 1948.

2. Preliminary map, Aylmer Lake, Northwest Territories: Canada Geol. Survey Paper 49-2, map with descriptive notes, 1949.

Love, John David. See also Keefer, E. K.; Thompson, Raymond M.; U. S. G. S. 1 , no. $107 ; 2$, no. 36.

1. (and Weitz, Joseph Leonard). Geologic map of the Powder River Basin, Wyoming: Wyo. Geol. Assoc. Guidebook, Powder River Basin, 1949.

2. (and Denson, Norman Maclaren, and Botinelly, Theodore). Geology of the Glendo area, Wyoming: U. S. Geol. Survey Oil and Gas Invs. Prelim. Map 92 (2 sheets). Text with map, Geology and oil and gas possibilities of the Glendo area, eastern Wyoming. Scale 1 inch to 4000 feet. 1949.

Lovell, A. P. R. See Parrott, W. T.

\section{Lovering, Thomas Seward.}

1. Rock alteration as a guide to ore-East Tintic district, Utah: Econ. Geology, Monograph 1, 65 p., illus., 1949.

2. William Harvey Emmons [1876-1948]: Washington Acad. Sci. Jour., v. 39 , no. 6 , p. 215-216, June 15, 1949.

Low, Julian W.

Subsurface maps and illustrations, in Subsurface geologic methods: Colo. Sch. Mines Quart., v. 44, no. 3, p. 627-681, illus., July 1949.

\section{Lowe, Kurt E.}

The granite problem in the Hudson Highlands $\bullet$ N. Y.]: N. Y. Acad. Sci. Trans., ser. 2, v. 12, no. 2, p. 49-54, illus., Dec. 1949.

\section{Lowenstam, Heinz A.}

1. Niagaran reefs in Illinois and their relation to oil accumulation: Ill. State Geol. Survey Rpt. Inv. 145, 36 p., illus., 1949.

2. Facies analyses of the Niagaran rocks in Illinois: Ill. State Acad. Sci. Trans., v. 42, p. 113-115, Dec. 31, 1949, reprinted in Ill. State Geol. Survey Circ. 157, p. 113-115, 1950.

Lowman, Shepard Wetmore. See also Johnson, D.

1. [Discussion], in Longwell, C. R., chm., Sedimentary facies in geologic history [symposium]: Geol. Soc. Am. Mem. 39, p. 125-130, illus.; p. 145-151, illus., June 17, 1949 .

2. Sedimentary facies in Gulf Coast: Am. Assoc. Petrol. Geol. Bull., v. 33, no. 12 , p. 1939-1997, illus., Dec. 1949 ; abs., Oil and Gas Jour., v. 47, no. 46, p. 109, Mar. $17,1949$. 
Ludwick, John C. See Handin, J. W.

Lukert, Louis $\mathbf{H}$.

Subsurface cross sections from Marion County, Kansas, to Osage County, Oklahoma: Am. Assoc. Petrol. Geol. Bull., v. 33, no. 2, p. 131-152, illus. incl. index map, Feb. 1949.

Lukesh, Joseph Stevens.

Note on the structure of uranium: Acta Crystallographica, v. 2, pt. 6, p. 420 , Dec. 1949.

Lull, Richard Swann.

(and Gray, Stephen Wood). Growth patterns in the Ceratopsia: Am. Jour. Sci., v. 247, no. 7, p. 492-503, illus., July 1949 .

\section{Lundblad, Britta.}

A selaginelloid strobilus from East Greenland (Triassic) : Meddelelser fra Dansk Geologisk Forening, Bind 11, Hefte 3, p. 351-363, illus., 1948.

\section{Lundelius, Ernest.}

Note on a neural spine of a Permian armored amphibian [abs.]: Geol. Soc. Am. Bull., v. 60 , no. 12, pt. 2, p. 1906, Dec. 1949.

\section{Lusch, Ruth.}

Alexander W[inifred] Scott [1868-1949]: Eng. Min. Jour., v. 150, no. 10, p. 112, Oct. 1949.

Lynn, Ralph D. See Ricker, N. H., 2.

\section{Lynott, W. J.}

Petrology of metamorphic rocks, migmatite, quartz diorite, and mineral deposits, Warn Bay-Tofino Inlet area, west coast Vancouver Island, British Columbia [abs.]: Geol. Soc. Am. Bull., v. 60. no. 12, pt. 2, p. 1907 , Dec. 1949.

McBee, William Salton, Jr. See also Laudon,- L. R., 3.

(and Orchard, Paul Joseph). Developments [in oil and gas] in Louisiana Gulf Coast in 1948: Am. Assoc. Petrol. Geol. Bull., v. 33, no. 6, p. 979-989, index map, June 1949.

\section{McBride, George B.}

The Comstock Lode [Nev.]: Compass, v. 26, no. 2, p. 173-179, Jan. 1949.

McCamey, A. R. See Tollefison, E. H.

McCann, G. D. See Housner, G. W.

\section{MeCanne, Rolland W.}

Lance Creek, East Lance Creek, and Little Buck Creek oil fields, Niobrara County, Wyoming: Wyo. Geol. Assoc. Guidebook, Powder River Basin, p. 85-87 ( $\$)$, illus., 1949.

\section{McCartney, J. T.}

Electron microscopy of coal: Econ. Geology, v. 44, no. 7, p. 617-620, illus., Nov. 1949.

\section{McClain, A. H.}

Stratigraphic accumulation in Jackson-Kanawha Counties area of West Virginia: Am. Assoc. Petrol. Geol. Bull., v. 33, no. 3, p. 336-345, illus., Mar. 1949; reprinted in Appalachian Geol. Soc. Bull., v. 1, p. 192-201, illus., 1949.

MeClelland, W. R.

Notes on lead occurrences in Canada: Canada Bur. Mines Memo. ser. no. $99,27$ p. ( $\ddagger)$, Oct. 1948 . 
MacClintock, Paul.

(and Peltier, Louis Cook). Wisconsin glacial stadia in New Jersey [abs.]: Geol. Soc. Am. Bull., v. 60, no. 12, pt. 2, p. 1971, Dec. 1949.

McCollum, S. V. See Imbt, R. F.

MeConnell, Duncan.

1. Petrographic examination of right abutment rock from Ross dam, city of Seattle [Wash.] : U. S. Bur. Recl. Petrog. Lab. Rpt. 40, 5 p. (\$), illus., Feb. 3, 1943 .

2. Laboratory investigations on clays to be inundated by the proposed Wagon Wheel Gap reservoir [Colo.]: U. S. Bur. Recl. Petrog. Lab. Rpt. 46,9 p. $(\ddagger)$, illus., July $6,1943$.

3. (and Irwin, William Harold). Petrographic examination of argillaceous sediments from Tiber damsite, Lower Marias unit [Mont.]; Missouri Basin project: U. S. Bur. Recl. Petrog. Lab. Rpt. 85, 5 p. ( $\ddagger$, July 18, 1946 .

4. Notes on properties and testing of bentonites: U. S. Bur. Recl. Petrog. Lab. Rpt. 44C, 9 p. (†), Apr. 16, 1947.

McCracken, Earl. See Grohskopf, J. G.

\section{McCutchen, Wilmot R.}

The behavior of rocks and rock masses in relation to military geology: Colo. Sch. Mines Quart., v. 44, no. 1, p. 5-76, illus., Jan. 1949.

MacDonald, Donald Francis, 1875-1942.

Panama Canal slides: Panama Canal Dept. Operation and Maintenance, Spec. Er.g. Div., 73 p. (\$), illus. incl. index, geol. maps, Aug. 1947 .

\section{Macdonald, Gordon Andrew.}

1. Petrography of the Island of Hawaii: U. S. Geol. Survey Prof. Paper 214-D, p. 51-96, illus. incl. geol. map, 1949.

2. (and Finch, Ruy Herbert). The Mauna Loa [Hawaii] eruption of January, 1949: Volcano Letter no. 503, 8 p., illus., Jan.-Mar. 1949.

3. (and Finch, Ruy Herbert). Activity of Mauna Loa [Hawaii] during April, May and June, 1949: Volcano Letter no. 504, 6 p., illus., Apr.June 1949.

4. Hawaiian petrographic province: Geol. Soc. Am. Bull., v. 60, no. 10, p. 1541-1595, illus. incl. index, geol. maps, Oct. 1949.

\section{Macdonald, James $R$.}

1. A new Clarendonian fauna from northeastern Nevada: Calif. Univ., Dept. Geol. Sci. Bull., v. 28, no. 7, p. 173-194, illus. incl. index map, Oct. $19,1949$.

2. Correlation of the Pliocene mammalian faunas of Nevada [abs.]: Geol. Soc. Am. Bull., v. 60, no. 12, pt. 2, p. 1951, Dec. 1949.

\section{McGee, Dean Alexander.}

Continental shelf exploration off Louisiana and Texas [abs.]: Oil and Gas Jour., v. 47, no. 46, p. 109, Mar. 17, 1949.

\section{McGehee, J. Rex.}

Pre-Waterwayss Paleozoic stratigraphy of Alberta Plains, in Clark, L. M., chm., Alberta symposium: Am. Assoc. Petrol. Geol. Bull., v. 33, no. 4, p. 60 s -613 , illus. incl. index map, Apr. 1949.

MeGlamery, Winifred.

Truman H[eminway] Aldrich [1848-1932]: Ala. Geol. Survey Bull. 60, p. $38-40,1948$.

McGlothlin, John Thomas, Jr.

Facies changes in Gulf Cretaceous beds in Mississippi [abs.]: Am. Assoc. Petrol. (Geol. Bull., v. 33, no. 12, p. 2069, Dec. 1949.

McGovney, Paul E. See Anderson, R. E. 
McGrain, Preston.

1. Geological features of the proposed Cagle's Mill flood control reservoir: Ind. Acad. Sci. Proc., v. 58, p. 163-172, illus. incl. index map, 1948.

2. Ground water resources of Henry County, Indiana: Ind. Acad. Sci. Proc., v. 58, p. 173-187, illus., 1948.

McGrew, Paul Orman.

An Osteoborus from Honduras: Field Mus. Nat. Hist., Geol. ser., v. 8, no. 12, p. 75-77, illus., Aug. 14, 1944.

McGuinness, Charles Lee.

(and Poindexter, O. Floyd, and Otton, Edmond George). Ground-water supplies of the Ypsilanti area, Michigan: U. S. Geol. Survey Water Supply Paper 1078, 105 p., illus. incl. geol. map, 1949.

MeGuire, Philip J.

Charles Erb Wuensch [1893-1949]: Min. Eng., v. 1, no. 11, p. 60, Nov. 1949.

McIntosh, Arthur Clem.

A botanical survey of the Black Hills of South Dakota: Black Hills Eng., v. 28, no. 4, p. 2-74, illus. incl. index map, Apr. 1949.

Mackay, Bertram Reid.

1. James Smith Stewart (1883-1948): Royal Soc. Canada Proc. 3d ser. v. 43 , p. 133-139, port., 1949.

2. Geological map of southern Saskatchewan showing lignite occurrences and location of coal mines. Canada Geol. Survey. Scale 1:760,320 or 1 inch to 12 miles. 1949.

3. Canada's resources of low-rank coals [abs.] : Econ. Geology, v. 44, no. 7, p. 644 , Nov. 1949 .

McKee, Edwin Dinwiddie.

1. Facies changes in the Colorado Plateau, in Longwell, C. R., chm., Sedimentary facies in geologic history [symposium]: Geol. Soc. Am. Mem. 39, p. 35-48, illus., discussion, p. 132-133, June 17, 1949.

2. Sedimentary basins of Arizona and adjoining areas [abs.]: Geol. Soc. Am. Bull., v. 60, no. 12 , pt. 2, p. 1908-1909, Dec. 1949.

3. Ripple marks of the Triassic Moenkopi formation [abs.] : Geol. Soc. Am. Bull., v. 60 , no. 12 , pt. 2 , p. 1941 , Dec. 1949.

Mackee, Pedro Verastegui. See Read, C. B.; U. S. G. S. 1, no. 96.

McKelvey, Vincent Ellis.

Geological studies of the western phosphate field, in Symposium on western phosphate mining: Min. Eng., v. 1, no. 8, p. 270-279, illus., Aug. 1949 ; A.I.M.E. Trans., v. 184, 1949.

Mackie, W.Z.

(and Chatterjee, B., and Jackson, M. Lucille). Mineral crystal forms in soils observed in the electron microscope; 1 , single-component clays and synthetic mixtures: Soil Sci. Soc. Am. Proc., v. 12, 1947, p. 176179, illus., 1948.

Mackin, Joseph Hoover. See also Hansen, H. P., 4.

Some structural features of the intrusions in the Iron Springs district [Utah]: Utah Geol. Soc. Guidebook no. 2,62 p., illus. incl. index, geol. maps, 1947; abs. with title "Structural control for mineralization in the Iron Springs district, southwestern Utah," Geol. Soc. Am. Bull., v. 57 , no. 12 , pt. 2, p. 1255 , Dec. 1946 .

McKinstry, Hugh Exton.

1. (and Ohle, Ernest Linwood, Jr.). Ribbon structure in gold-quartz veins: Econ. Geology, v. 44, no. 2, p. 87-109, illus., Mar.-Apr. 1949.

2. Mineral isograds in southeastern Pennsylvania: Am. Mineralogist, v. 34, nos. 11-12, p. 874-892, illus. incl. geol. sk. maps, Nov.-Dec. 1949. 
McKnight, Edwin Thor. See Behre, C. H., Jr., 1.

\section{McLaren, D. J.}

(and Sutherland, P. K.). Lithostrotion from northeast British Columbia and its bearing on the genomorph concept: Jour. Paleontology, v. 23, no. 6 , p. $625-634$, illus., Nov. 1949 .

McLaughlin, Dean Benjamin.

(and Willard, Bradford). Triassic facies in the Delaware Valley: Pa. Acad. Sci. Proc., v. 23, p. 34-44, illus. incl. geol. map, 1949.

McLaughlin, Donald Hamilton.

The Homestake mine [S. Dak.]: Canadian Min. Jour., v. 70, no. 12, p. 49-53, Dec. 1949.

McLaughlin, Thad Gerald.

Geology and ground-water resources of Pawnee and Edwards Counties, Kansas (with analyses by Howard A. Stoltenberg): Kans. Univ. State Geol. Survey Bull. 80, 189 p., illus. incl. index, geol. maps, Mar. 1949.

\section{McLearn, Frank Harris.}

Jurassic formations of Maude Island and Alliford Bay, Skidegate Inlet, Queen Charlotte Islands, British Columbia: Canada Geol. Survey Bull. 12, 19 p., index, geol. maps, 1949.

McMacken, Joseph G.

Geological implications of wells in Spokane [and] Rathdrum valleys; permafrost [abs.]: Northwest Sci., v. 23, no. 1, p. 37-38, Feb. 1949.

McMahon, C. See Senftle, F. E.

McMasters, John Herbert. See Schenk, E. T.

\section{McMillan, William Duncan.}

Investigation of Montezuma and Chinati zinc-lead deposits, Shafter district, Presidio County, Tex.: U. S. Bur. Mines Rpt. Inv. 4506, 26 p. ( $)$, illus. incl. index, geol. maps, July 1949.

MeMurray, Lynn Lloyd. See Van Horn, E. C., 2.

McNair, Andrew Hamilton. See also Cameron, E. N.

1. The geologic story of Franconia Notch and the Flume. 14 p., illus. Concord, N. H., State Plan. Dev. Comm. 1949.

2. The geology story of Kinsman Notch and Lost River. 14 p., illus. Concord, N. H., State Plan. Dev. Comm. 1949.

MacPherson, A. R.

Silica in Canada: Canada Bur. Mines Memo. ser. no. 104, 22 p. ( $\$$ ), Aug. 1949.

Mahard, Richard Harold.

Late Cenozoic chronology of the Upper Verde Valley, Arizona: Denison Univ., Sci. Lab. Jour., v. 41, art. 7, p. 97-127, illus. incl. geol. sketch map, Aug. 1949; abs., Geol. Soc. Am. Bull., v. 59, no. 12, pt. 2, p. 1339, Dec. 1948.

Maher, John Charles.

1. (and Collins, Jack Beverly). Pre-Pennsylvanian geology of southwestern Kansas, southeastern Colorado, and the Oklahoma Panhandle [geologic maps and text]: U. S. Geol. Survey Oil and Gas Invs. Prelim. Map 101 (4 sheets). Scale 1 inch to 14 miles. 1949; summary, Tulsa Geol. Soc. Digest, v. 17, p. 43-47, illus., 1949.

2. Lyons sandstone of Colorado Front Range: Am. Assoc. Petrol. Geol. Bull., v. 33, no. 4, p. 636, Apr. 1949. 


\section{Maher, John Charles-Continued}

3. (and Jones, Paul Hastings). Ground-water exploration in the Natchitoches area, Louisiana: U. S. Geol. Survey Water-Supply Paper 968-D, p. 159-211, illus. incl. index map, [Aug.] 1949.

4. (and Collins, Jack Beverly). Pre-Pennsylvanian geology of the Anadarko Basin's Hugoton Embayment: World Oil, v. 129, no. 9, p. 6162, 64, 68, 70, illus., Dec. 1949.

Maillot, E. E.

(and Boos, Margaret Fuller, and Mosier, McHenry). Investigation of Black Mountain beryl deposit, Oxford County, Maine: U. S. Bur. Mines Rpt. Inv. 4412, 10 p. ( $\ddagger)$, illus. incl. index map, Feb. 1949.

Malaurie, Jean N.

1. Sur des sols structuraux sous-marins de la côte Ouest du Groenland: Acad. Sci. Paris Comptes Rendus, tome 228, no. 3, p. 259-260, Jan. $17,1949$.

2. (and Boyé, M.). Sur le Pré-cambrien de Qapiarfik, Baie de Disko, Groenland occidental: Acad. Sci. Paris Comptes Rendus, tome 228, no. 16, p. 1348-1349, index map, Apr. 20, 1949.

Maldonado-Koerdell, Manuel.

1. Los vertebrados fósiles del Cuaternario en Mexico: Soc. Mex. Hist. Nat. Rev., tomo 9, nos. 1-2, p. 1-36, June 1948.

2. Peces fósiles de Mexico. 1. Elasmobranquios: Soc. Mex. Hist. Nat. Rev., tomo 9, nos. 1-2, p. 127-136, June 1948; Adiciones a "Peces fósiles de Mexico. 1. Elasmabranquios", nos. 3-4, p. 295-300, map, Dec. 1948.

3. Nuevos datos geológicos paleontológicos sobre el Triásico de Zacatecas [Mexico]: Anales Escuela Nac. Cien. Biol., v. 5, nos. 3-4, p. 291306, illus., Dec. 25, 1948.

Malkin, Doris Sarah.

Partial bibliography on ecology and paleoecology as related to micropaleontology: Micropaleontologist, v. 3, no. 4, p. 2-5 (\$), Oct. 1949.

Mallory, Robert William.

The Salt Creek oil field [Wyo.]: Wyo. Geol. Assoc. Guidebook, Powder River Basin, p. 89-91 (\$), illus., 1949.

Mallory, William Wyman.

1. Pennsylvanian stratigraphy and structure of the Velma pool, Stephens County, Oklahoma: Am. Assoc. Petrol. Geol. Bull., v. 32, no. 10, p. 1948-1979, illus., Oct. 1948; summary, Tulsa Geol. Soc. Digest, v. 1', p. 120-125, illus., 1949.

2. Rocky Mountain type structure at Velma pool, Stephens County, Oklahoma: World Oil, v. 129 , no. 3 , p. $68-70,72,74,76,78$, illus. incl. index map, July 1949.

Malott, Clyde Arnett, 1887-1950.

1. Hudelson cavern, a stormwater route of underground Lost River, Orange County, Indiana: Ind. Acad. Sci. Proc., v. 58, p. 236-243, illus., 1948.

2. A stormwater cavern in the Lost River region of Orange County, Indiana: Natl. Speleol. Soc. Bull. 11, p. 64-68, illus., Nov. 1949.

3. Indiana geologists before 1900 [abs.]: Ind. Acad. Sci. Proc., v. 58, p. 250-251, 1948.

Mamay, Sergius H.

(and Andrews, Henry Nathaniel, Jr.). A new species of Botryopteris from Illinois [abs.]: Am. Jour. Botany, v. 36, no. 10, p. 819, Dec. 1949.

\section{Mandra, York T.}

A new species of Mytilus from the Pliocene of Humboldt County, California: Jour. Paleontology, v. 23, no. 1, p. 104-105, illus., Jan. 1949. 
Mann, John F., Jr.

Bottom sample profiles of Lake Elsinore, California: Compass, v. 26, no. 4, p. 320-326, illus. incl. index map, p. 285, May 1949.

Marble, John Putnam. See also Hurley, P. M., 3.

1. (chairman). Report of the Committee on the measurement of geologic time, 1947-1948: Natl. Research Council Ann. Rpt., Div. Geol. and Geog., 77 p. (\$), June 1949.

2. Annotated bibliography of articles relating to the measurement of geologic time: Natl. Research Council, Div. Geol. and Geog., Rpt. of the Committee on the measurement of geologic time, 1947-1948, Exhibit F, p. 29-76 ( $)$, June 1949.

3. (chairman). Report of the Committee on the measurement of geologic time, 1948-1949: Natl. Research Council Ann. Rpt., Div. Geol. and Geog., 139 p. ( ), Dec. 1949.

4. Annotated bibliography of articles relating to the measurement of geologic time: Natl. Research Council, Div. Geol. and Geog., Rpt. of the Committee on the measurement of geologic time, 1948-1949, Exhibit F, p. 83-138 (\$), Dec. 1949 .

5. Some applications of autoradiography [abs.] : 18th Internat. Geol. Cong., London, Volume of titles and abstracts, p. 6-7, 1948.

6. Accuracy of the lead method for the absolute measurement of geologic ages [abs.]: Geol. Soc. Am. Bull., v. 60, no. 12, pt. 2, p. 1907, Dec. 1949.

Marden, Douglas W. See Wilpolt, R. H.; U. S. G. S. 2, no. 38.

\section{Marks, Jay Glenn.}

Nomenclatural units and tropical American Miocene species of the gastropod family Cancellariidae: Jour. Paleontology, v. 23, no. 5, p. 453464, illus., Sept. 1949.

\section{Marmer, Harry Aaron.}

Sea level changes along the coasts of the United States in recent years, in Symposium on the earth's crust: Am. Geophys. Union Trans., v. 30, no. 2, p. 201-204, illus., Apr. 1949; discussion by Henry W. Bigelow, Jr., no. 6, p. 918, illus., Dec. 1949.

\section{Marsell, Ray E.}

1. The Quaternary system of Utah, in The oil and gas possibilities of Utah, by G. H. Hansen and M. M. Bell: Utah Geol. Miner. Survey, p. 109118, Dec. 1949.

2. Basin range faulting near Salt Lake City, Utah [abs.]: Geol. Soc. Am. Bull., v. 60, no. 12, pt. 2, p. 1941, Dec. 1949.

\section{Marshall, Charles Edmund.}

The colloid chemistry of the silicate minerals. Agronomy Monograph, volume 1. ix, 195 p., illus. New York, Academic Press, Inc. 1949.

\section{Martens, James Hart Curry.}

(and Truscott, Frederick W.). West Virginia Geological Survey collection of drill cuttings: Am. Assoc. Petrol. Geol. Bull., v. 30, no. 3, p. 350352, Mar. 1946; reprinted in Appalachian Geol. Soc. Bull., v. 1, p. 181-183, 1949.

Martin, Gerald P. R.

Gas-Ausbrüche der Lava am neuen Vulkan Paricutin in Mexiko: Natur u. Volk, Band 79, Heft 11-12, p. 290-295, illus., Dec. 15. 1949.

\section{Martin, Lewis.}

Giant oysters from the upper Miocene of California: Compass, v. 26, no. 4, p. 359, 367, illus. incl. index map, p. 285, May 1949.

Martin, William H. See Baer, F. M. 
Mason, Brian Harold.

1. Oxidation in geochemistry: Jour. Geology, v. 57, no. 1, p. 62-72, illus., Jan. 1949.

2. (and Vitaliano, Charles J.). Preliminary account of the naturally occurring antimony oxides [abs.]: Geol. Soc. Am. Bull., v. 60, no. 12, pt. 2, p. 1907, Dec. 1949 .

Mason, Herbert Louis.

Evidence for the genetic submergence of Pinus remorata, in Jepson, G. L., ed., Genetics, paleontology, and evolution, p. 356-362, 1949.

Massé, Lucien.

Sur la nécessité des recherches en géophysique: Naturaliste Canadien, v. 76 , nos. 5-7, p. 137-141, May-June 1949.

Matheson, Chester R. See Warren, H. V., 4.

Mathews, Asa A. Lee.

Applications of some biogenetic laws to stratigraphy: Texas Jour. Sci., v. 1 , no. 3, p. 78-81, Sept. 30, 1949.

Mathews, William Henry.

Subglacial streams and extrusion flow: Jour. Glaciology, v. 1, no. 5, p. 284, illus., Mar. 1949.

Mathis, Robert W. See Barnes, V. E., 2.

Mauffette, Pierre.

Preliminary report on Val des Bois map-area, Papineau and Gatineau Counties [Quebec]: Quebec Dept. Mines Prelim. Rpt. 223, 18 p. ( $\ddagger)$, index, geol. maps, 1949.

Maurice, Ovide D.

1. Preliminary report on the Razilly map-area, Abitibi-East County [Quebec]: Quebec Dept. Mines Prelim. Rpt. 201, 7 p. ( $\ddagger)$, index, geol. maps, 1946.

2. Transport and deposition of the non-sulphide vein minerals. 5. Zirconium minerals: Econ. Geology, v. 44, no. 8, p. 721-731, illus., Dec. 1949.

Maxey, George Burke. See also Eakin, T. E.

1. (and Jameson, C. H.). Progress report on the ground-water resources of the Las Vegas artesian basin, Nevada: Nev. State Engineer's Office [Water Res. Bull. 1], 36 p. ( $\ddagger$ ), illus., 1945.

2. General ground-water conditions in Las Vegas Valley [Nev.]: Nev. State Engineer's Office, Water Res. Bull. 3, p. 9-15, 1947.

3. (and Eakin, T. E.). Ground water in White River Valley, White Pine, Nye, and Lincoln Counties, Nevada: Nev. State Engineer's Office, Water Res. Bull. 8, 59 p., illus. incl. index, geol. maps, 1949.

Maxson, John Haviland.

Geology of the Bright Angel quadrangle, Arizona [abs.]: Geol. Soc. Am. Bull., v. 60 , no. 12 , pt. 2 , p. $1963-1964$, Dec. 1949 .

Maxwell, Ross Allan. See also Lonsdale, J. T., 2.

1. (and Lonsdale, John Tipton, and Dickson, Kathryn 0.). The Big Bend region [Texas], in West Texas Geological Society Guidebook Field Trip no. 1 , November $6-9,1949$, p. 13-62, illus. incl. index, geol. maps, 1949.

2. (and Lonsdale, John Tipton). General geology of Big Bend National Park, Texas [abs.]: Geol. Soc. Am. Bull., v. 60, no. 12, pt. 2, p. 1908, Dec. 1949.

Mayfield, William W. See Tollefson, E. H. 


\section{Maync, Wolf.}

1. On the pre-Permian basement of the Giesecke Mountains (Gauss Peninsula), northern East Greenland: Meddelelser om Grønland, Bind 114 nr. 2, 65 p., illus. incl. index map, 1949; abs., 18th Internat. Geol. Cong., London, Volume of titles and abstracts, p. 96-97, 1948.

2. Ancient Arctica; remarks and supplement: Jour. Geology, v. 57, no. 3, p. 314-319, illus. incl. paleogeog. map, May 1949.

3. Jurassic stratigraphy of northern East Greenland [abs.] : 18th Internat. Geol. Cong., London, Volume of titles and abstracts, p. 97, 1948.

4. Cretaceous stratigraphy of North-east Greenland [abs.]: 18th Internat. Geol. Cong., London, Volume of titles and abstracts, p. 97-98, 1948.

Mayr, Ernst. See also Jepson, G. L., 1.

1. Speciation and systematics, in Jepson, G. L., ed., Genetics, paleontology, and evolution, p. 281-298, illus., 1949.

2. The species concept, semantics versus semantics: Evolution, v. 3, no. 4, p. 371-372, Dec. 1949.

Meeker, John E. See Romney, C. F., 1, 2, 3.

Mehl, Maurice Goldsmith. See Branson, E. B., 1.

Mei, Alexis I. See Byerly, P., 1.

Melander, Axel Leonard.

A report on some Miocene diptera from Florissant, Colorado: Am. Mus. Nat. History Novitates no. 1407, 63 p., illus., Feb. 3, 1949.

Mellen, Frederic Francis. See also Thompson, M. L.

General geology of Mississippi: Petroleum Engineer, v. 21, no. 10, p. B-7-B-12, illus., Sept. 1949 .

Melvin, John Harper.

1. Memorial of Lewis Gardner Westgate [1868-1948]: Am. Mineralogist, v. 34, nos. 3-4, p. 256-260, port., Mar.-Apr. 1949 .

2. Directory of State Geological Surveys: Ohio State Univ. Eng. Expt. Sta. News, v. 21, no. 2, p. 13-16, Apr. 1949.

Menard, Henry W., Jr.

Synthesis of sand mixtures: Jour. Sed. Petrology, vo 19, no. 2, p. 71-77, illus., Aug. 1949.

\section{Merriam, Charles Warren.}

1. Geology of the Cerro Gordo mine area, Inyo County, California [abs.]: Econ. Geology, v. 44, no. 1, p. 82, Jan.-Feb. 1949.

2. Paleozoic rocks of Antelope Valley, Eureka County, Nevada [abs.]: Geol. Soc. Am. Bull., v. 60, no. 12, pt. 2, p. 1942, Dec. 1949.

Merrill, William M. See Sturgeon, M. T., 1.

\section{Merritt, Phillip Leonidas.}

Pitchblende, the primary source of uranium: Mich. Coll. Min. Tech., Conference on radioactive ores, May 6, 1949, p. 8-12, 1949 .

Mertie, John Beaver, Jr.

Charting five and six variables on the bounding tetrahedra of hypertetrahedra: Am. Mineralogist, v. 34, nos. 9-10, p. 706-716, illus., Sept.Oct. 1949; abs., nos. 3-4, p. 280-281, Mar.-Apr. 1949; Geol. Soc. Am. Bull., v. 59, no. 12, pt. 2, p. 1340-1341, Dec. 1948.

Messina, Angelina Rose. See Ellis, B. F., 1.

\section{Mettner, Francis Edwin.}

Developments [in oil and gas] in upper Gulf Coast of Texas in 1948: Am. Assoc. Petrol. Geol. Bull., v. 33, no. 6, p. 966-978, index map, June 1949 . 
Meyer, Charles. See Sales, R. H.

Mielenz, Richard Childs. See also Rhoades, R. F., $2,6$.

1. Comparison of the petrographic characters of the Eaglenest Creek aggregates with those of Deposit no. 3 [Wyo.]: U. S. Bur. Recl. Petrog. Lab. Rpt. 25, 5 p. ( $\$)$, Nov. 12, 1941.

2. (and Rhoades, Roger Farnsworth). Description of certain rock specimens from the East Portal of the Continental Divide tunnel [Colo.]: U. S. Bur. Recl. Petrog. Lab. Rpt. 30, 10 p. (\$), illus., Apr. 10, 1942.

3. (and Rhoades, Roger Farnsworth). Petrographic examination of earth dam materials, Anderson Ranch dam, Boise project, Idaho: U. S. Bur. Recl. Petrog. Lab. Rpt. 31, 8 p. ( $)$, Apr. 22, 1942.

4. (and Rhoades, Roger Farnsworth). Petrographic examination of rock material from test pit no. 8, Winona dam site, Merlin project, Rogue River investigations, Oregon: U. S. Bur. Recl. Petrog. Lab. Rpt. 34, 3 p. (\$), Aug. 4, 1942.

5. Petrographic examination of rock core and surface samples in connection with geologic studies, Bridge Canyon investigations [Ariz.]: U. S. Bur. Recl. Petrog. Lab. Rpt. 37, 7 p. ( $\$)$, illus., Dec. 15, 1942.

6. (and Higginson, Elmo C.). Petrographic examination of concrete aggregates from the Columbia Basin deposits, Columbia Basin project [Wash.]: U. S. Bur. Recl. Petrog. Lab. Rpt. 56, 7 p. ( $\$)$, Nov. 10, 1943.

7. Results of petrographic examination of six samples of concrete aggre- gate proposed for use at Peterson field, Colorado: U. S. Bur. Recl. Petrog. Lab. Rpt. 58, 9 p. ( $\ddagger)$, Dec. 6, 1943.

8. Petrographic examination of concrete aggregate from deposit $\mathrm{CO}, \mathrm{Co}-$ lumbia Basin gravel investigations, Columbia Basin project [Wash.] : U. S. Bur. Recl. Petrog. Lab. Rpt. 56A, 7 p. ( $\$)$, Dec. 22, 1943.

9. Petrographic examinations and tests on rock samples from Big Cut and Tunnel no. 1, North Unit Main Canal, Deschutes Project [Oreg.]: U. S. Bur. Recl. Petrog. Lab. Rpt. 69, 10 p. ( $\$)$, illus., May 10, 1945.

10. A mineralogic and textural classification of igneous rocks; description of a rock chart: U. S. Bur. Recl. Petrog. Lab. Rpt. 77, 5 p. ( $\$)$, Nov. $23,1945$.

11. Petrographic classification and description of materials excavated during construction of Main Canal and Lateral M-37, Deschutes project [Oreg.]: U. S. Bur. Recl. Petrog. Lab. Rpt. 78, 5 p. ( $\ddagger$ ), Jan. 22, 1946.

12. Petrographic description and correlation of samples of meta-andesite, Canyon Ferry dam site, Canyon Ferry project [Mont.]; Missouri River Basin investigations: U. S. Bur. Recl. Petrog. Lab. Rpt. 79, 5 p. (\$), Jan. $31,1946$.

13. Petrographic description and classification of samples of rock and rock core, Canyon Ferry dam site, Canyon Ferry project [Mont.], Missouri River Basin investigations: U. S. Bur. Recl. Petrog. Lab. Rpt. $81,14$ p. ( $\ddagger)$, Mar. 13, 1946 .

14. Petrographic examination of samples of pumice, Friant dam, Central Valley project, California: U. S. Bur. Recl. Petrog. Lab. Rpt. 82, 7 p. ( $¥)$, June $4,1946$.

15. Petrographic examination of drill core samples, Palisades dam site, Palisades project [Idaho]: U. S. Bur. Recl. Petrog. Lab. Rpt. 83, 9 p. (\$), July 5, 1946.

16. (and others). Materials for pozzolan; a report for the engineering geologist: U. S. Bur. Recl. Petrog. Lab. Rpt. 90A, 25. p. ( $\$$, Apr. 4, 1949 ; abs., Geol. Soc. Am. Bull., v. 60 , no. 12 , pt 2, p. 1964, Dec. 1949.

17. (and Holland, William Y., and King, Myrle E.). Engineering petrography of loess [abs.]: Geol. Soc. Am. Bull., v. 60 , no. 12, pt. 2, p. 1909, Dec. 1949. 
Miller, Arthur K. See also Youngquist, W. L., 4.

1. (and Youngquist, Walter Lewellyn). The Maquoketa coquina of cephalopods [Iowa]: Jour. Paleontology, v. 23, no. 2, p. 199-204, illus., Mar. 1949.

2. (and Youngquist, Walter Lewellyn). American Permian nautiloids: Geol. Soc. Am. Mem. 41, 218 p., illus., June 28, 1949.

3. A giant scaphopod from the Pennsylvanian of Texas: Jour. Paleontology, v. 23, no. 4, p. 387-391, illus., July 1949.

4. The last surge of the nautiloid cephalopods: Evolution, v. 3, no. 3, p. - 231-238, illus., Sept. 1949.

5. (and Downs, Harold Robert, and Youngquist, Walter Lewellyn). Some Mississippian cephalopods from central and western United States: Jour. Paleontology, v. 23, no. 6, p. 600-612, illus., Nov. 1949.

\section{Miller, Horace P.}

The problems of coal geochemistry: Econ. Geology, v. 44, no. 8, p. 649-662, illus., Dec. 1949 .

\section{Miller, Loye Holmes.}

(and Howard, Hildegarde). The flightless Pliocene bird Mancalla: Carnegie Inst. Wash. Pub. 584, Contr. Paleontology, p. 201-228, illus., June 22, 1949.

\section{Miller, Maynard M.}

Alaskan glacier studies, 1946: Am. Alpine Jour., v. 6, no. 3, p. 339-343, illus., 1946.

\section{Miller, Murray L.}

Preliminary map, Carp Lakes, Northwest Territories [geologic map with descriptive notes]: Canada Geol. Survey Paper 49-8. Scale $1: 253$,440 or 1 inch to 4 miles. 1949.

\section{Miller, Robert L.}

An application of the analysis of variance to paleontology: Jour. Paleontology, v. 23, no. 6, p. 635-640, illus., Nov. 1949.

Miller, Robert Rush. See Hubbs, C. L.

\section{Miller, William John.}

An introduction to physical geology with special reference to North America. 5th ed., ix, 482 p., illus. New York, D. Van Nostrand Co. 1949.

\section{Millis, John B.}

Ground water as a source of industrial supply: Oil and Gas Jour., v, 47, no. 43, p. 175-176, 179-180, index map, Feb. 24, 1949.

\section{Mills, John R.}

(and Taylor, Russel N.). Silurian-Devonian relationships in Schuylkill County, Pa.: Pa. Acad. Sci. Proc., v. 23, p. 49-57, illus., 1949.

\section{Milne, I. H.}

Chloritoid from Megantic County, Quebec: Am. Mineralogist, v. 34, nos. 5-6, p. 422-434, illus., May-June 1949.

Milne, W. G.

1. Bibliography of seismology: Canada Dominion Observatory Bib. Seismol. v. 14 , no. 4, Items $6858-7003$, July-Dec. 1948,95 p., 1949; no. 5, Items 7004-7131, Jan.-June 1949, 133 p., 1950.

2. The location of the Cornwall-Massena earthquake, September 5, 1944: Canada Dominion Observatory Pubs., v. 7, no. 9, p. 345-362, illus., 1949. 


\section{Milthers, Keld.}

Glacialgeologisk rekognoscering i Holsteinsborg distrikt [Glacial geological reconnaissance in the Holsteinsborg district, Greenland]: Meddelelser fra Dansk Geologisk Forening, Bind 11, Hefte 3, p. 393-395, illus., 1948.

Milton, Charles. See also Axelrod, J. M., 2.

1. (and Myers, Alfred Tennyson). Bodenbenderite, a discredited species: Am. Mineralogist, v. 34, nos. 7-8, p. 608-611, illus., July-Aug. 1949.

2. Nickel-copper-gold mineralogy at the Mackinaw mine, Snohomish County, Washington [abs.]: Geol. Soc. Am. Bull., v. 60, no. 12, pt. 2, p. 1909 , Dec. 1949.

Minard, David Lee. See Kirschner, C. E.; U. S. G. S. 1, no. 95.

\section{Misch, Peter.}

1. Metasomatic granitization of batholithic dimensions; Part 3, Relationships of synkinematic and static granitization: Am. Jour. Sci., v. 247 , no. 10 , p. $673-705$, illus., Oct. 1949 .

2. Directions of orogenic stress [abs.]: Geol. Soc. Am. Bull., v. 60, no. 12, pt. 2, p. 1909-1910, Dec. 1949 .

3. Structure, metamorphism, and granitization in part of Okanogan County, north-central Washington [abs.]: Geol. Soc. Am. Bull., v. 60, no. 12, pt. 2, p. 1942, Dec. 1949.

\section{Misener, Austin Donald.}

Temperature gradients in the Canadian Shield: Canadian Min. Met. Bull. no. 446, p. 280-287, illus., June 1949; Canadian Inst. Min. Met. Trans., v. 52, p. 125-132, illus., 1949; abs., Royal Soc. Canada Proc. 3d ser., v. 43, p. 213, 1949.

\section{Mississippi Geological Society.}

1. Guidebook, Sixth Field Trip, June 18, 19, 20, 1948, Upper Eocene, Oligocene, and lower Miocene of central Mississippi. $74 \mathrm{p}$. ( $\ddagger)$, illus. [Jackson, Miss., 1948].

2. Guidebook, Seventh field trip, August 24-27, 1949; Pre-Cambrian and Paleozoic rocks of northern Alabama and south-central Tennessee. 89 p., illus. [Jackson, Miss., 1949].

\section{Yoffit, Fred Howard.}

[Philip Sidney Smith, 1877-1949]: Washington Acad. Sci. Jour., v. 39, no. 9, p. 315-316, Sept. 15, 1949.

\section{Monette, Hector $\mathrm{H}$.}

Geological outline of Pickle Crow [Ontario] : Canadian Min. Jour., v. 70, no. 11 , p. 99-105, illus. incl. geol. sketch maps, Nov. 1949.

\section{Moneymaker, Berlen Clifford.}

Limestone solution in the Papaloapan Basin, Mexico: Tenn. Acad. Sci. Jour., v. 24, no. 2, p. 117-122, illus. incl. index, geol. sketch map, Apr. 1949.

\section{Monroe, Watson Hiner.}

Nelson Horatio Darton (1865-1948) : Am. Assoc. Petrol. Geol. Bull., v. 33, no. 1 , p. 116-123, port., Jan. 1949.

\section{Monsour, Eli T.}

Generalized stratigraphic discussion of post-Claiborne sediments in Mississippi and correlation with equivalent age sediments in the Gulf Coast province, in Mississippi Geological Society Guidebook, Sixth Field Trip, June 18-20, 1948, p. 3-16 (\$), 1948. 


\section{Moody, Clarence Lemuel.}

Mesozoic igneous rocks of northern Gulf Coastal Plain: Am. Assoc. Petrol. Geol. Bull., v. 33 , no. 8, p. 1410-1428, illus. incl. index, geol. maps, Aug. 1949; abs., v. 30, no. 11, p. 1966, Nov. 1946; Oil and Gas Jour., v. 45 , no. 25 , p. 113 , Oct. 26,1946 .

Moody, Graham B.

Developments [in oil and gas] in California in 1948: Am. Assoc. Petrol. Geol. Bull., v. 33, no. 6, p. 805-826, illus. incl. index maps, June 1949.

Mooney, Rose C. L.

Crystal structure of tetragonal bismuth arsenate, $\mathrm{BiAsO}_{4}$ : Acta Crystallographica, v. 1, pt. 4, p. 163-165, Sept. 1948.

\section{Moore, Carl Allphin.}

Electron-microscopic analysis; some geologic applications in correlation work, in Subsurface geologic methods: Colo. Sch. Mines Quart., v. 44, no. 3, p. 179-187, illus., July 1949.

\section{Moore, Charles Henkel, Jr.}

Formation and properties of single crystals of synthetic rutile: Min. Eng., v. 1 , no. 6 , p. 194-199, illus., June 1949 ; A.I.M.E. Trans., v. 184, 1949.

\section{Moore, George Emerson, Jr.}

1. The geology of the Keene-Brattleboro quadrangle, New Hampshire and Vermont. 29 p., illus. incl. geol. map. Concord, N. H., State Plan. Dev. Comm. 1949.

2. Structure and metamorphism of the Keene-Brattleboro area, New Hampshire-Vermont: Geol. Soc. Am. Bull., v. 60, no. 10, p. 1613-1669, illus. incl. index, geol. maps, Oct. 1949.

\section{Moore, Hastings.}

Merigale-Paul field, Wood County, Texas [abs.]: Am. Assoc. Petrol. Geol. Bull., v. 33, no. 12, p. 2068, Dec. 1949; Oil and Gas Jour., v. 48, no. 25, p. 88 , Oct. 27,1949 .

\section{Moore, Raymond Cecil.}

1. Introduction to historical geology. 1st ed., ix, 582 p., illus. New York, McGraw-Hill Book Company, Inc. 1949.

2. Rocks of Permian (?) age in the Colorado River Valley, north-central Texas [geologic map and text]: U. S. Geol. Survey Oil and Gas Invs. Prelim. Map 80 (2 sheets). Scale 1 inch to 1 mile. 1949.

3. (and Thompson, Marcus Luther). Main divisions of Pennsylvanian period and system: Am. Assoc. Petrol. Geol. Bull., v. 33, no. 3, p. 275-302, illus., Mar. 1949.

4. Meaning of facies, in Longwell, C. R., chm., Sedimentary facies in geologic history [symposium]: Geol. Soc. Am. Mem. 39, p. 1-34, illus., discussion, p. 164-165, June 17, 1949.

5. (chairman, Stratigraphic Commission). The Pliocene-Pleistocene boundary: Am. Assoc. Petrol. Geol. Bull., v. 33, no. 7, p. 1276-1280, illus., July 1949 .

6. Divisions of the Pennsylvanian system in Kansas: Kans. Univ., State Geol. Survey Bull. 83, 203 p., illus. incl. geol. sketch maps, Nov. 1949.

7. Late Paleozoic cyclic sedimentation in central United States [abs.]: 18th Internat. Geol. Cong., London, Volume of titles and abstracts, p. 21, 1948.

8. Evolution of the crinoidea in relation to major paleogeographic changes in earth history [abs.]: 18th Internat. Geol. Cong., London, Volume of titles and abstracts, p. 77-78, 1948.

\section{Moorhouse, Walter Wilson.}

(and Peach, P. A., and Buchanan, R. M.). The paragenesis of accessory minerals in igneous rocks [abs.]: Econ. Geology, v. 44, no. 7, p. 642, Nov. 1949. 
Morcom, A. J. See Nagelschmidt, G.

Morey, George Washington. See also Smith, F. G., 6.

The isothermal polybaric saturation curve at $400^{\circ}$ in the system $\mathrm{H}_{2} \mathrm{O}$ $\mathrm{Na}_{2} \mathrm{O}-\mathrm{SiO}_{2}$ [abs.]: Am. Mineralogist, v. 34, nos. 3-4, p. 281, Mar.Apr. 1949 .

Morgan, R. A.

(and Hummel, Floyd A.). Reactions of $\mathrm{BeO}$ and $\mathrm{SiO}_{2}$; synthesis and decomposition of phenacite: Am. Ceramic Soc. Jour., v. 32, no. 8, p. 250-255, illus., Aug. 1, 1949.

Morin, Léo G.

Cent ans de géologie au Canada: Revue Trimestrielle Canadienne, v. 29, no. 113, p. 19-36, March 1943.

Moritz, Carl A. See also Sloss, L. L., 3.

(and Sloss, Laurence Louis). Mesozoic stratigraphy of southwestern Montana [abs.]: Geol. Soc. Am. Bull., v. 60, no. 12, pt. 2, p. 1910, Dec. 1949.

\section{Morley, Russell A.}

The mineralogy and origin of josephinite: Pop. Astronomy, v. 57, no. 2, p. 93-94, Feb. 1949; Meteor. Soc. Contr., v. 4, no. 3, p. 184-185, 1949.

Morris, Frederick Kuhne.

Cause of an ice age [abs.]: Geol. Soc. Am. Bull., v. 60, no. 12, pt. 2, p. 1910-1911, Dec. 1949.

\section{Morrison, Roger B.}

Ground-water resources of the Big Sandy Valley, Mohave County, Arizona. 6 p. ( $\$)$, tables, illus. incl. geol. map. [U. S. Geol. Survey], Dec. 30,1940 .

\section{Morrow, Harold F.}

The geology of Hard Rock gold mine's quartz stringer ore zones: Precambrian, v. 22, no. 9, p. 10-15, 39, illus., Sept. 1949.

Mosier, McHenry. See Levin, S. B., 1, 2; Maillot, E. E.

\section{Moss, John Hall.}

1. Evidence for the climatic origin of the lower Susquehanna River terraces at Highspire [Pa.]: Pa. Acad. Sci. Proc., v. 23, p. 63-66, 1949.

2. Glaciation in the southern Wind River Mountains, Wyoming [abs.]: Geol. Soc. Am. Bull., v. 60, no. 12, pt. 2, p. 1911, Dec. 1949.

3. Possible new glacial substage in the middle Rocky Mountains [abs.]: Geol. Soc. Am. Bull., v. 60, no. 12, pt. 2, p. 1972, Dec. 1949.

Mott, G. P.

Aerial mapping for oil: World Petroleum, v. 20, no. 3, p. 66-70, illus., Mar. 1949.

Moulton, Gail Francis.

Oil prospects in basin areas: World Oil, v. 128, no. 12, p. 61-62, 64, 66, illus., Mar. 1949.

\section{Moyd, Louis.}

1. Petrology of the nepheline and corundum rocks of southeastern Ontario: Am. Mineralogist, v. 34, nos. 9-10, p. 736-751, Sept.-Oct. 1949.

2. A simple method for making stereoscopic photographs and micrographs: Min. Eng., v. 1, no. 11, p. 383-384, illus., Nov. 1949; A.I.M.E. Trans., v. 184,1949 .

Muckenhirn, R. J. See Ekern, P. C., Jr. 
Mudd, Henry T.

Fluorspar and cryolite, in Industrial minerals and rocks, p. 381-403, illus., 1949.

Muench, Josef. See Muench, J. R.

Muench, Joyce Rockwood.

(and Meunch, Josef). Thermal wonders of Yellowstone: Nat. History, v. 58, no. 7, p. 312-315, illus., Sept. 1949.

Muilenberg, Garrett A.

Notes on uranium: Mo. Geol. Survey and Water Res. Inf. Circ. 5, 18 p., 1949.

Muller, J. E.

1. Preliminary maps, Minto, New Brunswick (two maps) [geologic map and coal deposits, both with descriptive notes]: Canada Geol. Survey Paper 49-13, 1949.

2. Preliminary maps, Chipman, New Brunswick (two maps) [geologic map and coal deposits, both with descriptive notes]: Canada Geol. Survey Paper 49-21, 1949.

Muller, Siemon William. See also Ferguson, H. G.; Schenk, E. T.

Sedimentary facies and geologic structures in the Basin and Range province, in Longwell, C. R., chm., Sedimentary facies in geologic history [symposium] : Geol. Soc. Am. Mem. 39, p. 49-54, illus., discussion, p. 171, June 17, 1949.

Mullerried, Frederick Karl Gustav.

1. Peculiaridad orogénica de la Sierra Madre Oriental de México: Ciencia, v. 7, nos. 7-8, p. 229-231, illus. incl. index map, Nov. 15, 1946.

2. [El hombre de Tepexpan], in El hombre de Tepexpan, los huesos de Hernán Cortés y las pinturas de Bonampak, by César Lizardi Ramos: Acad. Nac. Cien. Mem. Rev., tomo 56, nos. 2-3, p. 354-360, 1948.

3. El genero Ptychomya en México: Ciencia, v. 8, nos. 10-12, p. 269-280, illus., Jan. 31, 1948.

4. Dos fósiles interesantes del Cretacico de Nuevo León: Soc. Mex. Hist. Nat. Rev., tomo 9, nos. 1-2, p. 121-125, illus., June 1948.

5. Un rudista de terrenos de Tabasco [México]: Soc. Mex. Hist. Nat. Rev., tomo 9, nos. 3-4, p. 279-294, illus., Dec. 1948.

6. Formas particulares de erosión en el sur de Chiapas (México) : Ciencia, v. 9, nos. 1-3, p. 26-28, illus. incl. index map, Dec. 15, 1948.

7. Rectificacion de la estratigrafía del Mesozoico en el noroeste de America Central (del Istmo de Tehuantepec a Nicaragua): Ciencia, v. 9, nos. 7-10, p. 219-223, 1949.

8. Las zonas sifonales en el genero Coralliochama: Ciencia, v. 9, nos. 4-6, p. 143-146, illus., Apr. 1, 1949.

9. Las facies de fauna y flora del Mesozoico superior y la correlación de sus zonas en México [abs.]: 18th Internat. Geol. Cong., London, Volume of titles and abstracts, p. 70, 1948.

10. Las facies de fauna y flora del Mesozoico en el noroeste de la América central (del Istmo de Tehuantepec a Nicaragua) [abs.]: 18th Internat. Geol. Cong., London, Volume of titles and abstracts, p. 71, 1948.

Mulyran, Henry. See Cummins, A. B.

\section{Mundorff, Maurice John.}

Ground water in the Yadkin-Pee Dee River Basin, North Carolina, in Hydrologic data on the Yadkin-Pee Dee River Basin, 1866-1945: N. C. Dept. Conserv. Dev., Div. Water Res. and Eng., p. 140-172, illus. incl. geol. maps, 1948.

Murata, Kiguma Jack. See Axelrod, J. M., 2; Pecora, W. T., 1.

$904979^{\circ}-51-8$ 
Murdoch, Joseph.

1. Minerals of California-Supplement No. 1 to Bulletin 136: Calif. Jour. Mines and Geology, v. 45, no. 4, p. 521-540, Oct. 1949.

2. (and Fahey, Joseph John). Geikielite, a new find from California : Am. Mineralogist, v. 34 , nos. $11-12$, p. $835-838$, Nov.-Dec. 1949 ; abs., Am. Mineralogist, v. 34, nos. 3-4, p. 281, Mar.-Apr. 1949.

3. Perovskite from California [abs.]: Geol. Soc. Am. Bull., v. 60, no. 12, pt. 2, p. 1911, Dec. 1949.

Murphy, Thomas. See Torreson, 0 . W.

Murray, Albert Nelson.

The gilsonite deposits of the Uinta Basin, Utah: Tulsa Geol. Soc. Digest, v. 17, p. 104-106, index map, 1949.

Murray, Grover Elmer, Jr.

1. Geology of De Soto and Red River Parishes [La.]: La. Geol. Survey Bull. 25, xvii, 312 p., illus. incl. index, geol. maps, sep. folder of maps, June 1948.

2. Geosynclinal sedimentation in central Gulf region of United States [abs.]: Am. Assoc. Petrol. Geol. Bull., v. 33, no. 12, p. 2067, Dec. 1949; Oil and Gas Jour., v. 48, no. 25, p. 87, Oct. 27, 1949.

Murray, Harrison Frank.

Pennsylvanian stratigraphy of the McCoy area, Colorado [abs.]: Geol. Soc. Am. Bull, v. 60, no. 12, pt. 2, p. 1965, Dec. 1949.

Myers, Alfred Tennyson. See Milton, C., 1.

\section{Myers, Richmond Elmore.}

Possible drainage changes in the Lehigh Valley as suggested by'an investigation into the origin of Leibert's gap in the Reading Hills [Pa.]: Rocks. and Minerals, v. 24, nos. 1-2, p. 9-17, illus., Jan.-Feb. 1949.

Nackowski, M. P. See Grawe, O. R.

Nagelschmidt, Gunter.

(and Donnelly, H. F., and Morcom, A. J.). On the occurrence of anatase in sedimentary kaolin [Georgia]: Mineralogical Mag., v. 28, no. 204, p. 492-495, illus., Mar. 1949.

Nauss, Arthur William.

Gas prospects in northern Alberta: World Oil, v. 129, no. 9, p. 270, 272, 276, 278, 280, 282, illus., Dec. 1949.

Neal, E. P.

Southeast Ceres field, Noble County, Oklahoma: Tulsa Geol. Soc. Digest, v. 17, p. 97-99, illus., 1949 .

Needham, Albert Booth. See Bishop, O. M.

Neilson, James M.

Preliminary report on Albanel Lake map-area, Misstassini Territory [Quebec]: Quebec Dept. Mines Prelim. Rpt. 224, 13 p. (\$), index, geol. maps, 1948.

Nelson, Vincent Edward. See Horberg, C. L., 1.

\section{Nettleton, Lewis Lomax.}

Geophysics, geology, and oil finding: Geophysics, v. 14, no. 3, p. 273-289, illus., July 1949; abridged without illustrations, Am. Assoc. Petrol. Geol. Bull., v. 33, no. 7, p. 1154-1160, July 1949; summary, Oil and Gas Jour., v. 47, no. 46, p. 103, Mar. 17, 1949; abs., Geophysics, v. 14, no. 3 , p. 446, July 1949 . 


\section{Neuerburg, George Joseph.}

A second note on the exclusively meteoritic minerals: Pop. Astronomy, v. 57, no. 7, p. 342-343, Aug. 1949; Meteor. Soc. Contr., v. 4, no. 3, p. 202-203, 1949.

Nevin, Charles Merrick.

1. Origin of petroleum-a method of approach; Am. Assoc. Petrol. Geol. Bull., v. 29, no. 3, p. 285-288, index map, Mar. 1945; Appalachian Geol. Soc. Bull., v. 1, p. 8-10, 1949; Spanish translation, Bol. Minas y Petroleo, v. 16, no. 6, p. 29-31, June 1945.

2. Principles of structural geology. 4th ed., xiii, 410 p., illus. New York, John Wiley \& Sons, Inc., 1949.

New Mexico Geological Society. See West Texas Geological Society.

Newell, Norman Dennis.

1. Types and hypodigms: Am. Jour. Sci., v. 247, no. 2, p. 134-142, Feb. 1949.

2. Comments on paleogeography and nomenclature [discussion of "Paleogeography and Nomenclature" by Eugene S. Richardson, Jr.]: Jour. Paleontology, v. 23, no. 2, p. 220-223, Mar. 1949.

3. Phyletic size increase, an important trend illustrated by fossil invertebrates: Evolution, v. 3, no. 2, p. 103-124, illus., June 1949.

4. Periodicity in invertebrate evolution [abs.]: Geol: Soc. Am. Bull., v. 60, no. 12, pt. 2, p. 1911-1912, Dec. 1949.

Newhouse, Walter Harry.

1. (and Hagner, Arthur Feodor, and DeVore, George W.). Structural control in the formation of gneisses and metamorphic rocks [Wyo.]: Science, v. 109, no. 2825, p. 168-169, Feb. 18, 1949.

2. (and Hagner, Arthur Feodor). Cordierite deposits of the Laramie Range, Albany County, Wyoming: Wyo. Geol. Survey Bull. 41, 18 p., illus. incl. index, geol. maps, Sept. 1949.

Nichols, Robert Leslie.

Recent shoreline changes at Shirley Gut, Boston Harbor [Mass.]: Jour. Geology, v. 57, no. 1, p. 85-89, illus., Jan. 1949.

\section{Nielsen, Eigil.}

1. Geologiske Iagttagelser paa Kap Stosch Kysten, Østgrønland [Geological observations along the Cape Stosch Coast, East Greenland]: Meddelelser fra Dansk Geologisk Forening, Bind 11, Hefte 3, p. 391, 1948. Danish.

2. On some trails from the Triassic beds of East Greenland: Meddelelser om Grønland, Band 149, no. 4, 44 p., illus., 1949.

\section{Nininger, Harvey Harlow.}

1. Kansas meteorite discoveries, 1873-1948: Kans. Acad. Sci. Trans., v. 52, p. 110-112, 1949.

2. Significance of the Norton, Kansas, meteorite: Kans. Acad. Sci. Trans., v. 52, p. $113-115,1949$.

3. A new type of magnetometer survey at Barringer meteorite crater [Ariz.]: Pop. Astronomy, v. 57, no. 1, p. 17-21, Jan. 1949.

4. Meteorites in as well as on the crater rim [Barringer meteorite crater, Arizona ]: Pop. Astronomy, v. 57, no. 7, p. 333-334, Aug. 1949.

Nixon, Earl K. See Ver Wiebe, W. A., 2.

Noble, James Alexander.

(and Harder, James O., and Slaughter, Archibald L.). Structure of a part of the northern Black Hills and the Homestake mine, Lead, South Dakota: Geol. Soc. Am. Bull., v. 60, no. 2, p. 321-352, illus., Feb. 1949.

Noe-Nygaard, Arne.

A new orogenic epoch in the Precambrian of Greenland [abs.]: 18th Internat. Geol. Cong., London, Volume of titles and abstracts, p. 100, 1948. 
Nolting, John P., Jr. See Price, P. H., 2.

Norbisrath, Hans. See Vokes, H. E., 1; U. S. G. S. 1, no. 88.

Northrop, Stuart Alvord. See also Griggs, R. L.

A glossary of scientific names (chiefly of fossil invertebrates). v, $71 \mathrm{p}$. Albuquerque, New Mexico. 1949.

Northup, Richard C.

(and Forrey, Donald C.). Oil and gas map of New Mexico. N. Mex. Bur. Mines and Mineral Res., Socorro, N. Mex. Scale 1:660,000. 1949.

Novelly, Walter 0.

Seismic exploration with surface shots: World Petroleum, v. 20, no. 3, p. 56-59, illus., Mar. 1949.

Nuffield, Edward Wilfrid. See Phoenix, $\mathrm{R}$.

Oakes, Malcolm Christie.

(and Knechtel, Maxwell McMichael). Geology and mineral resources of Haskell County, Oklahoma: Okla. Geol. Survey Bull. 67, 134 p., illus. incl. index, geol. maps, 1948.

Oakeshott, Gordon Blaisdell. See also Tucker, W. B.

Titanomagnetite rocks of the western San Gabriel Mountains, Calif. [abs.] : Geol. Soc. Am. Bull., v. 60, no. 12, pt. 2, p. 1942-1943, Dec. 1949.

Oberfell, George Grover.

Natural gas, in Symposium on fuel reserves in the United States: Oil and Gas Jour., v. 47, no. 46, p. 118, 122, 125, 126, 129, 133, 137, illus., Mar. $17,1949$.

O'Brien, J. C.

Mines and mineral resources of Butte County, California: Calif. Jour. Mines and Geology, v. 45, no. 3, p. 417-454, illus., July 1949.

O'Connor, Howard G.

Notes on the ground-water resources of Chase County, Kansas: Kans. Acad. Sci. Trans., v. 52, p. 399-405, illus. incl. index map, 1949.

Odell, Noel Ewart.

1. Stagnant glacier in British Columbia: Jour. Glaciology, v. 1, no. 4, p. 191, Oct. 1948.

2. Exploration of the Lloyd George Mountains in British Columbia: Canadian Geog. Jour., v. 38, no. 2, p. 49-63, illus. incl. index map, Feb. 1949; brief preliminary account with title, "Exploration of the Lloyd George Mts. in the northern Canadian Rockies," Nature (London), v. 161 , no. 4087 , p. 327 , Feb. $28,1948$.

Oder, Charles Rollin Lorain.

The Mascot formation [abs.]: Tenn. Acad. Sci. Jour., v. 24, no. 2, p. 101, Apr: 1949.

O'Donnell, Hugh John. See Smith, H. L., 1, 2.

Ohle, Ernest Linwood, Jr. See McKinstry, H. E., 1.

Okulitch, Vladimir Joseph. See also Stumm, E. C., 1.

Geology of part of the Selkirk Mountains in the vicinity of the main line of the Canadian Pacific Railway, British Columbia: Canada Geol. Survey Bull. 14, 26 p., illus. incl. geol. sketch map, 1949.

Oliver, Thomas A.

Ore minerals of the Berens River mine [Ontario]: Canadian Min. Jour., v. 70 , no. 6, p. 83-86, illus., June 1949. 


\section{Olivier, Charles P.}

Supplementary note on the Aggie Creek meteorite [Alaska]: Am. Mineralogist, v. 34, nos. 3-4, p. 232-233, Mar.-Apr. 1949.

\section{Ontario Dept. Mines.}

Progress report on drilling to determine stratigraphical succession in Sanborn township, District of Cochrane: Ontario Dept. Mines Press Release 1949-1, 5 p. ( ), Feb. 1949.

Orchard, Paul Joseph. See McBee, W. S., Jr.

Oriel, Steven S.

Definitions of arkoses: Am. Jour. Sci., v. 247, no. 11, p. 824-829, Nov. 1949.

Orwig, Eugene R., Jr.

Vaqueros formation west of Santa Barbara, California [abs.]: Am. Assoc. Petrol. Geol. Bull., v. 33, no. 12, p. 2061-2062, Dec. 1949; Oil and Gas Jour., v. 48 , no. 29 , p. 139-140, Nov. 24, 1949.

Osborn, Elburt Franklin. See also Ervin, G., Jr.; Roy R., 2, 3.

Cellular structures in glass as related to structures in lava: Jour. Geology, v. 57, no. 1, p. 73-78, illus, Jan. 1949; reprinted as Pa. State Coll. Mineral Indus. Expt. Sta. Tech. paper 145, 1949.

Osborne, Freleigh Fitz. See also Wahl, W. G., 1.

Coronite, labradorite, anorthosite, and dykes of andesine anorthosite, New Glasgow, P. Q.: Royal Soc. Canada Trans., 3d ser., v. 43, sec. 4, p. 85-112, illus. incl. geol. sk. map, June 1949; abs., Proc. 3d ser., v. 43, p. $238,1949$.

\section{Osterwald, Frank W.}

1. Structure of the Tongue River area, Bighorn Mountains, Wyoming: Wyo. Geol. Assoc. Guidebook, Powder River Basin, p. 37-39, illus. incl. geol. map, 1949.

2. Relation of structure to petrology in the northern Bighorn Mountains, Wyoming [abs.]: Geol. Soc. Am. Bull., v. 60, no. 12, pt. 2, p. 1965, Dèc. 1949.

Otton, Edmond George. See McGuinness, C. L.

\section{Overbeck, Robert Milton.}

Investigations in the subsurface geology of the Maryland coastal plain [abs.]: Geol. Soc. Am. Bull., v. 60, no. 12, pt. 2, p. 1972, Dec. 1949.

Owen, E. B.

Pleistocene deposits of O'Leary map-area, Prince County, Prince Edward Island (report and map): Canada Geol. Survey Paper 49-6, 11 p. $(\ddagger)$, geol. map, 1949.

Packard, Earl Leroy. See Hansen, H. P., 3.

Page, Benjamin Markham.

Structure of the Candelaria district, Mineral County, Nevada [abs.]: Geol. Soc. Am. Bull., v. 60, no. 12, pt. 2, p. 1943, Dec. 1949.

Page, Lincoln Ridler. See Cameron, E. N.

Palache, Charles. See also Frondel, C., 2.

The Fitchburg [Mass.] rollstone: Rocks and Minerals, v. 24, nos. 7-8, p. 347-349, illus., July-Aug. 1949.

\section{Pallister, Hugh Davidson.}

1. Henry McCalley [1852-1904]: Ala. Geol. Survey Bull. 60, p. 22-24, 1948.

2. William Battle Phillips [1857-1918] : Ala. Geol. Survey Bull. 60, p. 25$27,1948$.

3. Dr. William Frederick Prouty [1879-1949]: Ala. Geol. Survey Bull. 60, p. 28-30, 1948. 
Parker, John Mason, 3d.

Outlier near Raleigh, North Carolina [abs.]: N. C. Acad. Sci. Proc. in Elisha Mitchell Sci. Soc. Jour., v. 65, no. 2, p. 195, Dec. 1949.

Parker, Pierre E.

Fossil and recent species of the pelecypod genera Chione and Securella from the Pacific Coast: Jour. Paleontology, v. 23, no. 6, p. 577-593, illus., Nov. 1949.

Parks, Bryan C.

1. Petrographic analysis of coal by the particle count method: Econ. Geology, v. 44, no. 5, p. 376-424, illus., Aug. 1949; reprinted as Ill. Sta'ie Geol. Survey Rpt. Inv. 143, 1949.

2. Petrography of American lignites [abs.]: Econ. Geology, v. 44, no. 7, p. 645 , Nov. 1949; Geol. Soc. Am. Bull., v. 60 , no. 12 , pt. 2, p. 1912, Dec. 1949.

\section{Parrott, William T.}

(and Lovell, A. P. R.). Geologic construction materials in Alleghany County, Virginia: Va. Dept. Highways, 13 p. (\$), illus. incl. geol. map, [1949].

Parry V. F.

Production, classification, and utilization of western U. S. coals [abs.]: Econ. Geology, v. 44, no. 7, p. 643-644, Nov. 1949; Geol. Soc. Am. Bull., v. 60 , no. 12 , pt. 2, p. 1912-1913, Dec. 1949.

\section{Parvis, Merle.}

Status of drainage mapping from airphotos in Indiana: Purdue Univ. Eng. Bull., Ext. ser. no. 69, p. 174-191, illus., Sept. 1949.

Patmore, W. H.

Lead Empire (Omineca) group [British Columbia]: Western Miner, v. 22, no. 2, p. 39-43, illus. incl. index, geol. sketch maps, Feb. 1949.

\section{Patterson, Bryan.}

1. Rates of evolution in taeniodonts, in Jepsen, G. L., ed., Geneties, paleontology, and evolution, p. 243-278, illus., 1949.

2. A new genus of taeniodonts from the late Paleocene [Colo.]: Fieldiana; Geology, v. 10, no. 6, Pub. 623, p. 41-42, Mar. 31, 1949.

Patterson, S. H. See Youngquist, W. L., 1.

Patton, John B.

Crushed stone in Indiana: Ind. Dept. Conserv., Div. Geology, Rpt. Prog. 3, 47 p. ( $\ddagger)$, map, Apr. 1949.

\section{Patton, Leroy Thompson.}

Igneous rocks of the Capitan quadrangle, New Mexico [abs.]: Am. Mineralogist, v. 34, nos. 3-4, p. 281, Mar.-Apr. 1949.

\section{Patton, Murray M.}

Geologic effect of brush fires [Calif.]: Compass, v. 26, no. 4, p. 327-332, illus. incl. index map, p. 285, May 1949.

Pauly, Hans.

Calcite and skarn minerals in the gneisses of the Holsteinsborg District, West Greenland: Meddelelser fra Dansk Geologisk Forening, Bind 11, Hefte 3, p. 328-350, illus., 1948; reprinted as Min. Geol. Mus. Copenhagen Univ. Contr. Mineralogy no. 38, 1948.

Payne, Willard M. See Harris, R. M.

\section{Peabody, Frank E.}

Mid-Pennsylvanian pelycosaurs from Kansas [abs.]: Geol. Soc. Am. Bull., v. 60, no. 12 , pt. 2 , p. 1913 , Dec. 1949. 
Peach, P. A. See also Moorhouse, W. W.; Smith, F. G., 3, 4.

1. A decrepitation geothermometer: Am. Mineralogist, v. 34, nos. 5-6, p. 413-421, illus., May-June 1949.

2. Liquid inclusions in geothermometry: Am. Mineralogist, v. 34, nos. 5-6, p. 460-462, May-June 1949.

Peacock, H. G. See Hunt, R. N.

Peacock, Martin Alfred, 1898-1950. See also Forman, S. A.

1. Prospect of mineralogy: Am. Mineralogist, v. 34, nos. 3-4, p. 135-141, Mar.-Apr. 1949.

2. The teaching of morphological crystallography [abs.]: Am. Mineralogist, v. 34, nos. 3-4, p. 291-292, Mar.-Apr. 1949.

3. Hauchecornite [abs.]: Geol. Soc. Am. Bull, v. 60 , no. 12, pt. 2, p. 1913, Dec. 1949.

\section{Pecora, William Thomas.}

1. (and Hobbs, Samuel Warren, and Murata, Kiguma Jack). Variations in garnierite from the nickel deposit near Riddle, Oregon: Econ. Geology, v. 44 , no. 1, p. 13-23, illus. incl. index map, Jan.-Feb. 1949.

2. (and Fahey, Joseph John). Scorzalite from South Dakota, a new occurrence: Am. Mineralogist, v. 34, nos. 9-10, p. 685-687, Sept.-Oct. 1949; abs., nos. 3-4, p. 282, Mar.-Apr. 1949; Geol. Soc. Am. Bull., v. 59 , no. 12 , pt. 2 , p. 1344 , Dec. 1948 .

3. Origin of ruptured Eocene cobbles in the Bearpaw Mountains, Montana [abs.]: Geol. Soc. Am. Bull., v. 60, no. 12, pt. 2, p. 1913-1914, Dec. 1949.

Peltier, Louis Cook. See also MacClintock, $P$.

Pleistocene terraces of the Susquehanna River, Pennsylvania: Pa. Geol. Survey, 4th ser., Bull. G23, 158 p., illus., 1949.

Pemberton, J. R.

Frank Rieber (1891-1948): Am. Assoc. Petrol. Geol. Bull., v. 33, no. 1, p. 123-124, Jan. 1949.

Pence, Forrest K. See also Plummer, F. B.

1. Texas white firing bentonite: Min. Eng., v. 1, no. 1, p. 27-32, illus. incl. index map, Jan. 1949; A. I. M. E. Trans., v. 184, 1949.

2. Ceramic resources of Texas: Am. Ceramic Soc. Bull., v. 28, no. 12, p. 492-494, geol. sketch map, Dec. 15, 1949.

Pennington, R. P. See also Willis, A. L.

(and Jackson, M. Lucille). Segregation of the clay minerals of poiycomponent soil clays: Soil Sci. Soc. Am. Proc., v. 12, 1947, p. 452-457, illus., 1948.

Pennsylvania State College.

[Index map] Known sources of primary wealth, plants, animals, minerals, fundamental products of Mother Earth. Scale approx. 1 inch to 10 miles. School of Mineral Indus., Jan. 1, 1948.

\section{Penny, John S.}

Studies on the conifers of the Magothy flora [eastern U. S.]: Am. Jour. Botany, v. 34, no. 5, p. 281-296, illus., May 1947.

\section{Perkins, Alfred M.}

South-central New Mexico's sink-holes and craters: Earth Sci. Digest, v. 4, no. 5, p. 3-11, illus., Dec. 1949.

\section{Perkins, Alfred Thomas.}

Reactions of muscovite, bentonite, and their treated residues: Soil Sci., v. 67, no. 1, p. 41-46, Jan. 1949. 
Perrin, René.

(and Roubault, Marcel). On the granite problem: Jour. Geology, v. 57, no. 4, p. 357-379, July 1949 .

Perrine, Charles Dillon.

Periods in earthquake activity: Seismol. Soc. Am. Bull., v. 39, no. 2, p. 109-115, illus., Apr. 1949.

\section{Perry, Eugene Sheridan.}

1. Gypsum, lime, and limestone in Montana: Mont. Bur. Mines and Geology Mem. 29, 45 p. ( $\ddagger)$, illus. incl. geol. maps, 1949.

2. Pre-Jurassic pattern of geology in central Montana: De Re Metallica, v. 14, no. 4, p. 3-6, illus., Apr. 1949.

Perry, Stuart Hoffman. See Henderson, E. P., 2, 3, 4.

Pesonen, Paul E.

1. (and Tullis, Edward Langdon, and Zinner, Paul). Missouri Valley manganese deposits, S. Dak.; Pt. 1, General investigations, stratigraphic studies, and tonnage and grade estimates: U. S. Bur. Mines Rpt. Inv. $4375,90$ p. ( $\ddagger)$, illus. incl. index maps, Feb. 1949; Pt. 2, Drill-hole logs and sections, Rpt. Inv. 4428, 63 p. ( $\ddagger$ ), illus., Mar. 1949.

2. Investigation of the Waukon iron deposit, Allamakee County, Iowa: U. S. Bur. Mines Rpt. Inv. 4479, 22 p. ( $\ddagger)$, illus., June 1949.

\section{Peters, Jack Warren.}

The role of the magnetometer in petroleum exploration: Mines Mag., v. 39, no. 7, p. 11-15, 44, illus., July 1949.

\section{Peters, Leo James.}

The direct approach to magnetic interpretation and its practical application: Geophysics, v. 14, no. 3, p. 290-320, illus., July 1949; abs., p. 448, July 1949; Oil and Gas Jour., v. 47, no. 46, p. 157, Mar. 17, 1949.

\section{Petrunkevitch, Alexander.}

A study of the structure, classification and relationships of the Paleozoic Arachnida based on the collections of the British Museum: Conn. Acad. Arts Sci. Trans. v. 37, p. 69-315, xi, illus., Jan. 1949.

\section{Petsch, Bruno Carl.}

North part of the Whitewood anticline [S. Dak.]: S. Dak. Geol. Survey Rpt. Inv. 65,30 p. ( $¥)$, illus. incl. index, geol. maps, Apr. 1949.

Pettijohn, Francis John. See also Good, S. E.

Sedimentary rocks. xv, 526 p. illus. New York, Harper \& Bros. ['1949].

Péwé, Troy Lewis.

Preliminary report of permafrost investigations in the Dunbar area, Alaska: U. S. Geol. Survey Circ. 42, 3 p. ( $\ddagger$, illus. incl. index map, Feb. 1949.

Phleger, Fred B., Jr. See also Barghoorn, E. S., Jr., 1.

1. Foraminifera of a submarine core from the Caribbean Sea: Oceanografiska Inst. Göteborg Meddelanden 16, 9 p., illus., 1948; discussion by G. Arrhenius, Science, v. 111, no. 2881 , p. 288 , Mar. $17,1950$.

2. The Foraminifera [Boylston Street Fishweir II, Boston, Mass.]: Peabody Foundation for Archaeology Papers, v. 4, no. 1, p. 99-108, illus., 1949.

3. Origin and deposition of deep sea sediments, in Symposium on the earth's crust: Am. Geophys. Union Trans., v. 30, no. 2, p. 180-182, Apr. 1949.

4. Pleistocene research, a review by the members of the committee on interrelations of Pleistocene research, National Research Council; 8, Submarine geology and Pleistocene research: Geol. Soc. Am. Bull., v. 60 , no. 9 , p. $1457-1461$, Sept. 1949 . 
Phoenix, David Allen. See Albritton, C. C., Jr., 2; Loeltz, O. J.

Phoenix, R.

(and Nuffield, Edward Wilfrid). Cancrinite from Blue Mountain, Ontario: Am. Mineralogist, v. 34, nos. 5-6, p. 452-455, May-June 1949.

\section{Picher, Rodolphe Hector.}

Road building rocks and gravels in Prince Edward Island: Cánada Bur. Mines Memo. ser. no. 101, 21 p. ( $\ddagger)$, map, Nov. 1948.

Pickett, E. E. See Keller, W. D., 4, 6.

\section{Pierce, William Dwight.}

1. A modern asphalt seep tells a story [Calif.]: Los Angeles County Mus. Quart., v. 7, no. 3, p. 12-17, illus., Spring 1949.

2. Fossil arthropods of California; 17, The silphid burying beetles in the asphalt deposits: S. Calif. Acad. Sci. Bull., v. 48, pt. 2, p. 54-70, illus., May-Aug. 1949 (issued Nov. 4, 1949).

\section{Pincus, Howard J.}

Quantitative comparative study of fractures in gneisses and overlying sediments of northern New Jersey [abs.]: Geol. Soc. Am. Bull., v. 60, no. 12 , pt. 2, p. 1977 , Dec. 1949.

\section{Pinger, Allen W.}

Geology of the Franklin-Sterling area, Sussex County, New Jersey, in Dunham, K. C., ed., Symposium on the geology, paragenesis and reserves of the ores of lead and zinc, 18th Internat. Geol. Cong., London, p. 68-77, illus. incl. geol. sketch map, 1948; abs., Volume of titles and abstracts, p. 43, 1948.

\section{Pittsburgh Geological Society.}

Geology of the northerr portion of the Appalachian Basin: Guidebook, American Association of Petroleum Geologists, Field Conference, Oct. 4-9, 1948. 121. p., illus. incl. index, geol. maps, 1948.

Plummer, Frederick Byron, 1886-1947.

(and Bradley, H. B., anc. Pence, Forrest K.). Clay deposits of the Cisco group of north-central Texas: Texas Univ. Bur. Econ. Geology Pub. 4915, 44 p., illus. incl. geol. maps, Aug. 1, 1949.

Plummer, Norman Vincen. See Frye, J. C., 5.

Poindexter, O. Floyd, 1898-1.944. See McGuinness, C. L.

Pope, David E.

Occurrence of Harang fauna of the eastern Louisiana coastal parishes: La. Geol. Survey Bull. 26, p. 3-22, 74-76, illus., July 1948.

\section{Popenoe, Willis Parkison.}

(and Weir, Gordon). Cretaceous, Baja California [abs.]: Geol. Soc. Am. Bull., v. 60 , no. 12 , pt. 2, p. 1943 , Dec. 1949.

2. Genetic lines in California Cretaceous mollusks [abs.]: Geol. Soc. Am. Bull., v. 60, no. 12, pt. 2, p. 1951, Dec. 1949.

\section{Popoff, Constantine C.}

1. Investigation of limestone deposits near Arlington, Snohomish County, Wash.: U. S. Bur. Mines Rpt. Inv. 4393, 7 p. ( $\ddagger$, illus. incl. index map, Jan. 1949.

2. Investigation of silica deposits near the Skagit River, Skagit County, Wash.: U. S. Bur. Mines Rpt. Inv. 4472, 16 p. (\$), illus. incl. index, geol. sketch maps, June 1949. 
Potzger, John Ernest.

1. A contribution to the forest history of Quebec [abs.]: Am. Jour. Botany, v. 36 , no. 10 , p. 819 , Dec. 1949.

2. Pollen study in the Quetico-Superior Memorial Forest (A preliminary report) [abs.]: Am. Jour. Botany, v. 36, no. 10, p. 819, Dec. 1949.

Pough, Frederick Harvey. See also González Reyna, J., 1.

1. Memorial of Herbert Percy Whitlock [1868-1948]: Am. Mineralogist, v. 34, nos. 3-4, p. 261-266, port., Mar.-Apr. 1949.

3. Memorial to Herbert Percy Whitlock [1868-1948]: Geol. Soc. Am. Proc. 1948, p. 249-251, port., May 1949.

Poulter, Thomas Charles.

New system of seismic exploration [abs.]: Oil and Gas Jour., v. 47, no. 46, p. 158, Mar. 17, 1949; Geophysics, v. 14 , no. 3, p. 446, July 1949.

Powers, William Edwards. See Stark, J. T.

Pratt, Elbert S.

(and Allen, Henry W.). A reconnaissance survey of limestones in Franklin County, Maine: Maine State Geologist Rpt. 1947-1948, p. 23-29, geol. map, Mar. 1949.

Pratt, Wallace Everette. See also Burt, F. A., 1.

Petroleum, in Symposium on fuel reserves in the United States: Oil and Gas Jour., v. 47, no. 46, p. 112, 115-117, Mar. 17, 1949.

Pray, Lloyd C.

Pre-Abo deformation in the Sacramento Mountains, New Mexico [abs.]: Geol. Soc. Am. Bull., v. 60, no. 12, pt. 2, p. 1914-1915, Dec. 1949.

Press, Frank. See also Ewing, W. M., 1; Hersey, J. B., 2; Tolstoy, I., 3.

(and Ewing, William Maurice, and Tolstoy, Ivan). Airy phase of shallow-focus submarine earthquakes [abs.]: Geol. Soc. Am. Bull., v. 60 , no. 12 , pt. 2 , p. 1956 , Dec. 1949.

Prest, Victor Kent.

The Pleistocene geology of the Vermilion River system near Capreol, District of Sudbury, Ontario (with special reference to placer gold) : Ontario Dept. Mines Press Release 1949-2, 8 p. ( $)$, geol. map, Jan. 1949.

Prewitt-Hopkins, Joan.

X-ray study of holdenite, mooreite, and torreyite: Am. Mineralogist, v. 34, nos. 7-8, p. 589-595, illus., July-Aug. 1949.

Price, Paul Holland.

1. (and Tucker, Rietz Courtney). Present results and future prospects of oil and gas from deeper drilling and new areas in West Virginia: Appalachian Geol. Soc. Bull., v. 1, p. 57-66, illus., 1949.

2. (and Nolting, John P., Jr.). Salt resources of West Virginia: Min. Eng., v. 1, no. 7, p. 259-263, illus., July 1949; A. I. M. E. Trans., v. 184,1949 .

Price, William Armstrong. See also Huffman, G. G., 2.

1. Pocket gophers as architects of mima (pimple) mounds of the western United States: Texas Jour. Sci., v. 1, no. 1, p. 1-17, illus., Mar. 31, 1949.

2. Correlation of Pliocene Ogallala caprock caliche with Reynosa caliche of Gulf Coastal Plain [abs.]: Geol. Soc. Am. Bull., v. 60, no. 12, pt. 2, p. 1915, Dec. 1949 .

Price, William E., Jr.

The Moenkopi formation at Sycamore Canyon [Ariz.] : :Plateau, v. 21, no. 4, p. 49-54, index map, sections, Apr. 1949. 


\section{Prince, Alan Theodore.}

The sampling and examination of clay and shale deposits: Canada Bur. Mines Memo. ser. no. 95, 8 p. ( $\$$ ), Oct. 1947.

Proctor, Paul Dean. See Bullock, K. C.

Prouty, William Frederick, 1879-1949.

Ellipticity of Carolina Bay's [N. C., S. C.]. [abs.]: N. C. Acad. Sci. Proc. in Elisha Mitchell Sici. Soc. Jour., v. 65, no. 2, p. 195-196, Dec. 1949.

Pulver, Helen F. See Combo, J. X.

Pusey, Lewis Barron. See Goddard, E. N., 2.

Putnam, Donald Fulton. See Chapman, L. J.

\section{Putnam, William Clement.}

Quaternary geology of the June Lake district, California: Geol. Soc. Am. Bull., v. 60, no. 8, p. 1281-1302, illus. incl. index, geol. maps, Aug. 1949 ; abs. with title "Quaternary geology of part of the eastcentral Sierra Nevada, California," v. 59 , no. 12, pt. 2, p. 1345-1346, Dec. 1948.

Quarles, Miller Winthrop, Jr.

Fault interpretation in southwest Texas [abs.]: Oil and Gas Jour., v. 47, no. 46 , p. 161 , Mar. 17,1949 ; Geophysics, v. 14 , no. 3 , p. 444-445, July 1949.

Quigley, James E. See Fitch, C. A., Jr.

\section{Quinn, Alonzo Wallace.}

1. (and Ray, Richard Godfrey, and Seymour, W. L.). Bedrock geology of the Pawtucket quadrangle, Rhode Island and Massachusetts, in The geology and ground-water resources of the Pawtucket quadrangle, Rhode Island: R. I. Indus. Comm., Geol. Bull. 3, p. 9-27, index, geol. maps, 2948 .

2. (and Ray, Richard Godfrey, and Seymour, W. L.). Bedrock geology, Pawtucket quadrangle, Rhode Island-Massachusetts: U. S. Geol. Survey, Geol. Quad. Map, with text. Scale 1 inch to $1 / 2 \mathrm{mile}$. 1949.

3. Pre-Pennsylvanian rocks of northern Rhode Island [abs.]: Geol. Soc. Am. Bull., v. 60, no. 12, pt. 2, p. 1972-1973, Dec. 1949 .

Rabbitt, Mary C.

(and Skitsky, Vsevolod Lawrovitch, and Vesselowsky, Sergius Theodore). Geophysical abstracts 137 , April-June 1949: 'U. S. Geol. Survey Bull. 966-B, p. 95-164, 1949; 138, July-September 1949, Bull. 966-C, p. $167-251,1949 ; 139$, October-December 1949, Bull. 966-D, p. 253$333,1950$.

Raitt, Russell W.

Studies of ocean-bottom structure off southern California with explosive waves [abs.]: Geol. Soc. Am, Bull., v. 60 , no, 12, pt. 2, p. 1915, Dec. 1949.

\section{Rall, Cleo Griffith.}

(and Taliaferro, David Ben). A Bureau of Mines method for determining porosity; a list of porosities of oil sands: U. S. Bur. Mines Rpt. Inv. 4548, 28 p. (\$), illus., Sept. 1949 .

\section{Rama Rao, Lakshmeswar.}

Paleontologist-biologist and/or geologist: Jour. Paleontology, v. 23, no. 6, p. 677-679, illus., Nov. 1949. 
Ramberg, Hans.

1. On the petrogenesis of the gneiss complexes between Sukkertoppen and Christianshaab, West Greenland: Meddelelser fra Dansk Geologisk Forening, Bind 11, Hefte 3, p. 312-327, illus., 1948.

2. The facies classification of rocks, a clue to the origin of quartzo-feldspathic massifs and veins: Jour. Geology, v. 57, no. 1, p. 18-54, illus., Jan. 1949.

3. Albite-water system in the gravitational field, a comment: Jour. Geology, v. 57, no. 4, p. 429-431, July 1949.

\section{Ramdohr, Paul.}

Las especias mineralogicas guanajuatita y paraguanajuatita [Guanajuato, México]: México Com. Dir. Inv. Rec. Miner. Bol. no. 20, 15 p., illus., 1948. [Translation by Gustavo Schulze].

\section{Rand, Frederick V.}

[Albert Fred Woods, 1866-1948]: Washington Acad. Sci. Jour., v. 39, no. 9, p. 313-315, Sept. 15, 1949.

\section{Rankama, Kaarlo Kalervo.}

A note on the geochemistry of thallium: Jour. Geology, v. 57, no. 6, p. 608-613, Nov. 1949.

Rau, Weldon Willis.

Miocene Foraminifera from southwest Washington [abs.]: Northwest Sci., v. 23 , no. 1, p. 42 , Feb. 1949.

\section{Raw, Frank.}

Facial sutures in the (hypoparian) trilobites Loganopeltoides and Loganopeltis, and the validity of these genera: Jour. Paleontology, v. 23, no. 5, p. 510-514, illus., Sept. 1949.

\section{Ray, Cyrus Newton.}

Ancient man in Texas: Texas Acad. Sci. Trans., v. 30, 1946, p. 152-154, 1948.

\section{Ray, Louis Lamy.}

1. François Emile Matthes [1874-1948]: Washington Acad. Sci. Jour., v. 39, no. 4, p. 146-147, Apr. 15, 1949.

2. Pleistocene research, a review by the members of the committee on interrelations of Pleistocene research, National Research Council; 9, Problems of Pleistocene stratigraphy: Geol. Soc. Am. Bull., v. 60, no. 9, p. 1463-1473, Sept. 1949.

3. Pleistocene research, a review by the members of the committee on interrelations of Pleistocene research, National Research Council; 10, Alpine glaciation: Geol. Soc. Am. Bull., v. 60, no. 9, p. 1475-1484, Sept. 1949.

Ray, Richard Godfrey. See Quinn, A. W., 1, 2.

\section{Read, Charles Brian.}

(and others). Stratigraphy and geologic structure in the Piedra River Canyon, Archuleta County, Colorado [geologic map and text]: U. S. Geol. Survey Oil and Gas. Invs. Prelim. Map 96. Scale approx. 1 inch to 1 mile. 1949.

Reberholt, B. 0.

(and Henderson, Edward Porter).. An improved method of etching iron meteorites: Am. Mineralogist, v. 34, nos. 7-8, p. 606-608, JulyAug. 1949.

Redmond, C. D.

What is the genus Eponides: Micropaleontologist, v. 3, no. 4, p. 18-21 (\$), illus., Oct. 1949.

Redwine, Lowell Edwin. See Anderson, R. E. 
Reed, Edwin William. See Jacobsen, C. L., 1.

Reed, F. R. Cowper, 1869-1946.

1. West Indies; Chapter 8 in Geology of the British Empire, 2d ed., p. 248-293, illus., London, Edward Arnold \& Co. 1949.

2. Canada and Newfoundland; Chapter 9 in Geology of the British Empire, 2d ed., p. 294-409, illus., incl. geol. map, London, Edward Arnold \& Co. 1949.

\section{Reed, Fredda Doris.}

1. Notes on the anatomy of two Carboniferous plants, Sphenophyllum and Psaronius: Bot. Gazette, v. 110, no. 3, p. 501-510, illus., Mar. 1949.

2. A new calamite from American coal fields [Ind.] [abs.]: Am. Jour. Botany, v. 36 , no. 10 , p. $819-820$, Dec. 1949 .

\section{Reed, Glenn Cornelius.}

Investigation of the Sheep Creek iron deposits, Meagher County, Mont.: U. S. Bur. Mines Rpt. Inv. 4400,9 p. ( $\ddagger)$, illus. incl. index map, Jan. 1949.

Reed, John Calvin. See also Twenhofel, W. S.

1. Obituary, Philip Sidney Smith, 1877-1949: Arctic, v. 2, no. 2, p. 131, port., Sept. 1949.

2. Alaska and the [U. S.] Geological Survey: Sci. Monthly, v. 69, no. 4, p. 242-248, illus., Oct. 1949.

3. The [U. S.] Geological Survey in Alaska; field season of 1949: Arctic, v. 2 , no. 3 , p. 174-182, illus., Dec. 1949 .

Reed, M. F.

The thunder egg: Mineralogist, v. 17, no. 10, p. 492, 494, Oct. 1949.

Reedy, Milton Frank, Jr.

Stratigraphy of Frio formation, Orange and Jefferson Counties, Texas: Am. Assoc. Petrol. Geol. Bull., v. 33, no. 11, p. 1830-1858, illus. incl. index map, Nov. 1949 .

\section{Regan, Louis J., Jr.}

(and Hughes, Aden Wayne). Fractured reservoirs of Santa Maria district, California: Am. Assoc. Petrol. Geol. Bull., v. 33, no. 1, p. 32-51, illus. incl. index maps, Jan. 1949.

\section{Reiche, Parry.}

Geology of the Manzanita and North Manzano Mountains, New Mexico: Geol. Soc. Am. Bull., v. 60 , no. 7, p. 1183-1212, illus. incl. index, geol. maps, July 1949 ; abs., v. 57 , no. 12 , pt. 2 , p. 1257 , Dec. 1946.

Reichen, Laura E.

(and Lakin, Hubert W.). Field method for the determination of zinc in plants: U. S. Geol. Survey Circ. 41, 4 p. (\$), illus., Feb. 1949.

Reinemund, John Adam. See also Albritton, C. C., Jr., 2.

Geology of the Deep River coal field, Chatham, Lee, and Moore Counties, North Carolina [two sheets, geologic map and text]: U. S. Geol. Survey. Scale 1 inch to 2000 feet. 1949.

\section{Reinhardt, Elmer V.}

Can a study of topography locate undiscovered mineralized areas?: Eng. Min. Jour., v. 150, no. 9, p. 90-93, illus., Sept. 1949.

\section{Renfroe, Charles Albert.}

Petroleum exploration in eastern Arkansas with selected well logs: Ark. Res. Dev. Comm., Div. Geology Bull. 14, 159 p., illus. incl. index map, 1949; abs., Am. Assoc. Petrol. Geol. Bull., v. 33, no. 12, p. 2068-2069, Dec. 1949; Oil and Gas Jour., v. 48, no. 25, p. 87, Oct. $27,1949$. 
Rhoades, E. D. See Irwin, W. H., 6.

Rhoades, Roger Farnsworth. See also Mielenz, R. C., 2, 3, 4.

1. Examination of proposed concrete aggregate deposits for Davis dam [Colorado River]: U. S. Bur. Recl. Petrog. Lab. Rpt. 23, 7 p. (\$), illus., Aug. 26, 1941.

2. '(and Mielenz, Richard Childs). Petrographic study of volcanic tuff proposed for use in pervious zone of Newton dam [Utah]: U. S. Bur. Recl. Petrog. Lab. Rpt. 28, 7 p. ( $\ddagger)$, Jan. 30, 1942.

3. Investigation of concrete aggregate from the Pasco district [Wash.]: U. S. Bur. Recl. Petrog. Lab. Rpt. 32, 17 p. (\$), May 8, 1942.

4. Digest of petrographic and related information on Shasta and Friant aggregate and concrete [Calif.]: U. S. Bur. Recl. Petrog. Lab. Rpt. 35, 13 p. (\$), illus., Sept. 21, 1942.

5. Laboratory studies of displacements of Malheur Siphon, Owyhee project [Oreg.]: U. S. Bur. Recl. Petrog. Lab. Rpt. 47, 14 p. ( $\ddagger)$, July. 31, 1943 .

6. (and Mielenz, Richard Childs). Petrographic and mineralogic characteristics of aggregates, in Symposium on mineral aggregates (1948): Am. Soc. Testing Materials Spec. Tech. Pub. 83, p. 20-48, illus., 1948.

\section{Riccio, Joseph F.}

Lower Cambrian fauna of the Marble Mountains, California: Compass, v. 26, no. 4, p. 354-359, index map, p. 285, May 1949.

Rice, Harington Molesworth Anthony. See Canada Geol. Survey, 13.

Rich, John Lyon.

1. Tectonic history of compressional mountain ranges as indicating crustal sliding due to radioactive heating [abs.] : 18th Internat. Geol. Cong., London, Volume of titles and abstracts, p. 102, 1948.

2. Critical environments and deposition, shelf, slope, and bottom, and criteria for their recognition [abs.]: Geol. Soc. Am. Bull., v. 60, no. 12 , pt. 2 , p. 1916 , Dec. 1949.

Richards, Arthur. See Albritton, C. C., Jr., 2.

Richards, Horace Gardiner. See also Howell, B. F., 3; Stock, C., 2; Straley, H. W., 3d, 2.

1. The occurrence of Triassic rocks in the subsurface of the Atlantic Coastal Plain: Pa. Acad. Sci. Proc., v. 23, p. 45-48, 1949.

2. Hunting fossils in the Arctic with the aid of a "seek seek": Earth Sci. Digest, v. 3, no. 12, p. 18-19, illus., July 1949.

Richardson, Eugene Stanley, Jr.

1. A new Silurian trilobite, Dalmanites oklahomae: Fieldiana; Geology, v. 10 , no. 7 , p. 43-45, illus., June 6, 1949.

2. Some Lower Huronian stromatolites of northern Michigan: Fieldiana; Geology, v. 10, no. 8, p. 47-62, illus., Aug. 26, 1949.

\section{Richmond, Gerald Martin.}

Stone nets, stone stripes, and soil stripes in the Wind River Mountains, Wyoming: Jour. Geology, v. 57, no. 2, p. 143-153, illus. incl. index map, Mar. 1949; abs., Colorado-Wyoming Acad. Sci. Jour., v. 3, no. 6, p. 28, Sept. 1948.

Richter, Charles Francis. See also Chakrabarty, S. K.; Gutenberg, B., 2, 5.

Desert Hot Springs earthquake of December 4, 1948 [abs.]: Geol. Soc. Am. Bull., v. 60, no. 12, pt. 2, p. 1956, Dec. 1949. 


\section{Ricker, Norman Hurd.}

1. Attenuations and amplitudes of seismic waves, in Symposium on the earth's crust: Am. Geophys. Union Trans., v. 30, no. 2, p. 184-186, illus., Apr. 1949.

2. (and Lynn, Ralph D.). Composite reflections [abs.]: Oil and Gas Jour., v. 47 , no. 46 , p. 160 , Mar. 17,1949 ; Geophysics, v. 14 , no. 3 , p. 448 , July 1949.

Riddle, Frank Harwood.

(and Foster, Wilfrid Raymond). The sillimanite group; andalusite, kyanite, sillimanite, dumortierite, topaz, in Industrial minerals and rocks, p. 893-926, illus., 1949.

\section{Ridge, John Drew.}

Replacement and the equating of volume and weight: Jour. Geology, v. 57, no. 5, p. 522-550, Sept. 1949 .

\section{Ridland, George Carman.}

Development and geology at the Caribou mine, Consolidated Caribou Silver Mines, Inc. [Colo.]: Min. Yearb., 1949, p. 35, illus., Denver, Colo., Colorado Mining Association.

\section{Riecken, F. F.}

(and Allaway, W. H., and Smith, Guy Donald). Some soil classification and mapping problems in the Wisconsin drift area of Iowa: Soil Sci. Soc. Am. Proc., v. 12, 1947 , p. $432-440$, illus. incl. index map, 1948.

\section{Ries, Heinrich.}

1. Clay, in Industrial minerals and rocks, p. 207-244, illus., 1949.

2. The examination of sands: Econ. Geology, v. 44, no. 8, p. 741, Dec. 1949.

3. (chairman). Report of the Committee on geologic surveys: Am. Ceramic Soc. Bull., v. 28, no. 12, p. 498-510, illus., Dec. 15, 1949.

\section{Riggs, Calvin Harold.}

Peroleum-engineering study of Atlanta oil field, Columbia County, Ark.: U. S. Bur. Mines Rpt. Inv. 4455, 55 p. ( June 1949.

Riggs, Elmer Samuel. See Hibbard, C. W., 3.

\section{Riley, Christopher.}

Finding new ore deposits in British Columbia: Western Miner, v. 22, no. 10, p. 72-76, illus., Oct. 1949.

\section{Rinker, George C.}

Tremarctotherium from the Pleistocene of Meade County, Kansas: Mich. Univ. Mus. Paleontology, Contr., v. 7, no. 6, p. 107-112, illus., Apr. 7, 1949.

\section{Rittenhouse, Gordon.}

1. Early Silurian rocks of the northern Appalachian Basin: U. S. Geol. Survey Oil and Gas Invs. Prelim. Map 100. One sheet, maps with descriptive notes. - Scale 1 inch to 40 miles. 1949.

2. The distribution and thickness of the Queenston shale in the northern Appalachian basin: Producers Monthly, v. 13, no. 5, p. 29-30, illus., Mar. 1949.

3. Detrital mineralogy, in Subsurface geologic methods: Colo. Sch. Mines Quart., v. 44, no. 3, p. 87-11!, illus., July 1949.

4. Interpretive petrology of sedimentary rocks: World Oil, v. 129, no. 7, p. 61-62, 64, 66, illus., Oct. 1949. 
Rittenhouse, Gordon-Continued

5. Petrology and paleogeography of Greenbrier formation [W. Va.]: Am. Assoc. Petrol. Geol. Bull., v. 33, no. 10, p. 1704-1730, illus. incl. index maps, Oct. 1949.

6. Sedimentary facies in early Silurian rocks of northern Appalachian Basin [abs.]: Oil and Gas Jour., v. 47, no. 46, p. 154, Mar. 17, 1949.

Robb, George L.

1. Geologic techniques in civil engineering, in Subsurface geologic methods: Colo. Sch. Mines Quart., v. 44, no. 3, p. 790-819, illus., July 1949.

2. Red bed coloration: Jour. Sed. Petrology, v. 19 , no. 3, p. 99-103, illus., Dec. 1949.

Roberts, Carroll N.

Differential polish as an aid in distinguishing halite and sylvite: Compass, v. 26 , no. 2, p. 155-157, illus., Jan. 1949.

Roberts, Claude Martin. See Halberg, H. N.

Roberts, Ralph Jackson.

Structure and stratigraphy of the Antler Peak quadrangle, north-central Nevada [abs.]: Geol. Soc. Am. Bull., v. 60, no. 12, pt. 2, p. 1917, Dec. 1949.

Roberts, Wayne A. See Faul, H., 2.

Robertson, D. A.

(and Schwartz, C. M., and Trowbridge, A. H.). Surface and subsurface correlation of Wilcox formation in west-central Louisiana [abs.]: Am. Assoc. Petrol. Geol. Bull., v. 33, no. 12, p. 2069, Dec. 1949.

Robertson, David Struan.

Preliminary map, Moody Lake, Manitoba [with descriptive notes]: Canada Geol. Survey Paper 49-20, 1949.

Robertson, Forbes Smith.

(and Tolman, Carl). High potash volcanic rocks, St. Francois Mountains, Missouri [abs.]: Am. Mineralogist, v. 34, nos. 3-4, p. 282, Mar.-Apr. 1949.

Robinson, Stephen Clive.

Owyheeite: Am. Mineralogist, v. 34, nos. 5-6, p. 398-402, May-June 1949.

Robinson, Thomas William, Jr. See Eakin, T. E.; Loeltz, O. J.

Rocha, Victor S. See Wilson, I. F., 1.

Rockwood, Nathan C.

Lime, in Industrial minerals and rocks, p. 467-512, illus., 1949.

\section{Rodgers, John.}

1. [Discussion], in Longwell, C. R., chm., Sedimentary facies in geologic history [symposium]: Geol. Soc. Am. Mem. 39, p. 130-132, June 17,1949 .

2. Evolution of thought on structure of middle and southern Appalachians : Am. Assoc. Petrol: Geol. Bull., v. 33, no. 10, p. 1643-1654, illus. index map, Oct. 1949.

Rodriguez Cabo, Jose, Jr.

(and Trask, Parker Davies). Los yacimientos de manganeso de la Republica Mexicana: México Com. Dir. Inv. Rec. Miner. Bol. no. 19, vii, 162 p., index map, 1948; Spanish translation of U. S. Geol. Survey Bull. 954-F, 1948. 
Roe, Walter B.

Geological features of North Dakota lignites [abs.]: Econ. Geology, v. 44, no. 7, p. 644, Nov. 1949 ; Geol. Soc. Am. Bull., v. 60, no. 12, pt. 2, p. 1917 , Dec. 1949.

Roedder, Edwin W.

1. The system $\mathrm{K}_{2} \mathrm{O}-\mathrm{MgO}-\mathrm{SiO}_{2}$ [abs.]: Am. Mineralogist, v. 34, nos. 3-4, p. 282, Mar.-Apr. 1949.

2. Preliminary report on the system, leucite-SiO2-FeO ([abs].: Geol. Soc. Am. Bull., v. 60 , no. 12 , pt. 2 , p. 1917 , Dec. 1949.

\section{Roehm, John Christian.}

Some high calcium limestone deposits in southeastern Alaska: Alaska Dept. Mines Pamph. no. 6, 85 p., illus., Mar. 1946.

Rogers, Austin Flint.

1. Dolomite crystals of teruel habit from Lake Arthur, Chavez County, New Mexico [abs.]: Geol. Soc. Am. Bull., v. 60, no. 12, pt. 2, p. 1943, Dec. 1949.

2. Chemical formula of kempite [abs.]: Geol. Soc. Am. Bull., v. 60, no. 12, pt. 2, p. 1944, Dec. 1949.

\section{Rogers, D. H.}

The application of phase contrast microscopy to the study of pleochroic haloes [abs]: Royal Soc. Canada Proc. 3d ser., v. 43, p. 211, 1949.

Rojas, Luis E. See Torre Mandrazo, R. de la.

Roliff, William Albert. See also Gray, J. G.

1. Salina-Guelph fields of southwestern Ontario: Am. Assoc. Petrol. Geol. Bull., v. 33, no. 2, p. 153-188, illus. incl. geol. maps, Feb. 1949.

2. Memorial, James Smith Stewart (1883-1948) : Am. Assoc. Petrol. Geol. Bull., v. 33, no. 3, p. 485, Mar. 1949.

Romberg, Frederick. See also Barnes, V. E., 1, 2.

1. Gravity meter survey leads to ore discovery [New Mexico]: Eng. Min. Jour., v. 150 , no. 3 , p. 52-55, illus. incl. geol. sketch map, Mar. 1949.

2. (and Barnes, Virgil Everett). Correlation of gravity observations with the geology of the Coal Creek serpentine mass, Blanco and Gillespie Counties, Texas: Geophysics, v. 14 , no. 2 , p. 151-161, illus. incl. geol. map, Apr. 1949; reprinted as Texas Univ., Bur. Econ. Geology Rpt. Inv. 4, Apr. 1949.

\section{Romer, Alfred Sherwood.}

1. Time series and trends in animal evolution, in Jepson, G. L., ed., Genetics, paleontology, and evolution, p. 103-120, illus., 1949.

2. Louis Agassiz [1826-1873]: Sci. Am., v. 181, no. 1, p. 48-51, illus., July 1949.

Romney, Carl F. See also Byerly, P., 1, 3.

1. (and Meeker, John E.). Earthquakes in northern California and the registration of earthquakes at Berkeley-Mount Hamilton-Palo AltoSan Francisco-Ferndale-Fresno-Mineral, from January 1, 1948, to March 31, 1948: Calif. Univ., Seismog. Sta. Bull., v. 18, no. 1, p. 1-89 (¥), 1949.

2. (and Meeker, John E.). Earthquakes in northern California and the registration of earthquakes at Berkeley-Mount Hamilton-Palo AltoSan Francisco-Ferndale-Fresno-Mineral, from April 1, 1948, to June 30, 1948: Calif. Univ., Seismog. Sta. Bull., v. 18, no. 2, p. 93-180 $(\ddagger), 1949$.

3. (and Meeker, John E.). Earthquakes in northern California and the registration of earthquakes at Berkeley-Mount Hamilton-Palo AltoSan Francisco-Ferndale-Fresno-Mineral-Arcata, from July 1, 1948, to September 30, 1948: Calif. Univ., Seismog. Sta. Bull., v. 18, no. 3,

- p. 184-278 (\$), 1949 . 


\section{Rosalsky, Maurice B.}

A study of minor beach features at Fire Island, Long Island, New York: N. Y. Acad. Sci. Trans., ser. 2, v. 12, no. 1, p. 9-16, illus., Nov. 1949.

Rose, E. R.

Geology of the area between Bonavista, Trinity, and Placentia Bays, eastern Newfoundland: Newfoundland Geol. Survey Bull. 32, pt. 2, p. 39-49 (†), illus. incl. gaol. map, 1948.

Rosenfeld, Melvin Arthur.

Some aspects of porosity and cementation: Pa. State Coll. Mineral Indus. Expt. Sta. Bull. 52, p. 31-42, illus., Feb. 25, 1949; Producers Monthly, v. 13, no. 7, p. 39-42, illus., May 1949; abs., Oil and Gas Jour., v. 42 , no. 26, p. 105 , Oct. 28,1948 .

Rosenholtz, Joseph Leon.

(and Smith, Dudley Thompson). Linear thermal expansion of calcite, var. Iceland spar, and Yule marble: Am. Mineralogist, v. 34, nos. 11-12, p. 846-854, illus., Nov.-Dec. 1949.

Rosenkrantz, Alfred.

Krogbaerende Cephalopoder fra Østgrønlands Perm [Hook-bearing cepha!opods of East Greenland Permian]: Meddelelser fra Dansk Geologisk, Forening, Bind 11, Hefte 1, p. 160-161, illus., 1946.

Rosenqvist, Ivan Th. See Barth, T. F. W., 1, 2.

Rosenqvist, Terkel. See Barth, T. F. W., 3.

Ross, Clarence Samuel.

Obituary, Charles Whitman Cross, 1854-1949: Washington Acad. Sci. Jour., v. 39 , no. 10, p. $347-348$, Oct. 15, 1949.

Ross, Clyde Polhemus.

The Belt problem [Mont.] [abs.]: Washington Acad. Sci. Jour., v. 39, no. 3, p. 111-113, Mar. 15, 1949.

Ross, J. S. See Bruce, E. L.

Ross, Mary Harvey.

Source and correlation of the Deepkill conglomerates [abs.]: Geol. Soc. Am. Bull., v. 60, no. 12, pt. 2, p. 1973, Dec. 1949.

Ross, Reuben J., Jr.

Stratigraphy and trilobite faunal zones of the Garden City formation, northeastern Utah: Am. Jour. Sci., v. 247, no. 7, p. 472-491, illus. incl. index map, July 1949.

Ross, Stewart Hamilton.

Geological reconnaissance of Peribonca River from Passe Dangereuse to Onistagan Lake, Roberval and Chicoutimi Counties [Quebec]: Quebec Dept. Mines, Geol. Surveys Br., Geol. Rpt. 39, 20 p., illus. incl. geol. sk. maps, 1949. Also in French ed.

Roth, Robert Ingersol.

1. [Discussion], in Longwell C. R., chm., Sedimentary facies in geologic history [symposium]: Geol. Soc. Am. Mem. 39, p. 141-142, June 17, 1949.

2. Paleogeology of the Panhandle of Texas: Geol. Soc. Am. Bull., v. 60, no. 10 , p. 1671-1687, illus. incl. geol. sketch maps, Oct. 1949.

\section{Rothrock, Edgar Paul.}

Structures south of the Black Hills [S. Dak.]: S. Dak. Geol. Survey Rpt. Inv. 62,52 p. (\$), illus. incl. index map, Mar. 1949. 


\section{Rothrock, Howard Eugene.}

1. Investigation of coal deposits in the Fairview and Coal City Basins of Coosa field, St. Clair County, Ala. 5. Geology of area: U. S. Bur. Mines Tech. Paper 719, p. 42-50, illus., 1949.

2. Geology and coal resources of the northeast part of the Coosa coal field, St. Clair County, Alabama: Ala. Geol. Survey Bull. 61, Pts. 1 and 2, 163 p., illus. incl. geol. map, 1949.

3. Mayfield pool, Cuyahoga County, Ohio: Am. Assoc. Petrol. Geol. Bull., v. 33 , no. 10 , p. 1731-1746, illus. incl. geol. map, Oct. 1949.

4. Study of the Pennsylvania anthracite fields [abs.]: Geol. Soc. Am. Bull., v. 60 , no. 12 , pt. 2, p. 1973-1974, Dec. 1949.

Rothwell, William Thomas, Jr.

Preliminary report of Ostracoda in bottom samples and cores of northwestern Gulf of Mexico [abs.]: Geol. Soc. Am. Bull., v. 60, no. 12, pt. 2, p. 1918, Dec. 1949.

Roubault, Marcel. See Perrin, R.

Rouse, John Thomas. See Johnson, D.

Rowland, Richards Atwell.

(and Jonas, Edward C.). Variations in differential thermal analysis curves of siderite: Am. Mineralogist, v. 34, nos. 7-8, p. 550-558, illus., July-Aug. 1949; abs., nos. 3-4, p. 282, Mar.-Apr. 1949; Geol. Soc. Am. Bull., v. 59, no. 12, pt. 2, p. 1348, Dec 1948.

Roy, Chalmer John. See Blake, D. B.

Roy, Della M. See Roy, R., 2, 3.

Roy, Rustum.

1. Decomposition and resynthesis of the micas: Am. Ceramic Soc. Jour., v. 32, no. 6, p. 202-209, illus., June 1, 1949; reprinted in Pa. State Coll. Mineral Indus. Expt. Sta. Tech. Paper 150, 1949.

2. (and Roy, Della M., and Osborn, Elburt Franklin). Structural and compositional relationships of the lithium aluminosilicates-eucryptite, spodumene, and petalite: Pa. State Coll. Sch. Mineral Indus. Tech. Rpt. 1, 17 p. $(\$)$, illus., June 10, 1949.

3. (and Roy, Della M., and Osborn, Elburt Franklin). Studies in the system $\mathrm{Al}_{2} \mathrm{O}_{3}-\mathrm{SiO}_{2}-\mathrm{H}_{2} \mathrm{O}$ : Pa. State Coll., Sch. Mineral Indus. Tech. Rpt. 2, 30 p. ( $\ddagger)$, illus., Aug. 1, 1949.

Roy, Sharat Kumar.

1. (and Wyant, Robert Kriss). The Mapleton meteorite: Field Mus. Nat. History, Geol. ser., v. 7, no. 7, p. 99-111, illus., July 29, 1949.

2. (and Wyant, Robert Kriss). The Navajo meteorite [Ariz.]: Field Mus. Nat. History, Geol. ser., v. 7, no. 8, p. 113-127, illus., Aug. 30, 1949.

Royal, Herbert F. See Foster, W. R., 1.

Rubey, William Walden. See Goddard, E. N., 2.

\section{Rubio, Angel.}

Notas sobre geología de Panama. 183 p., illus. Panama, Depto. Cultura y Publicaciones del Ministerio de Educación. 1949.

Ruhe, Robert V.

Some notes on the Pleistocene geology of Shelby County, Iowa: Iowa Acad. Sci. Proc., v. 55, p. 281-286, illus., 1948.

Ruhl, Otto.

(and Allen, Simeon A., and Holt, Stephen Philip). Zinc-lead ore reserves of the Tri-State district, Missouri-hansas-Oklahoma: U. S. Bur. Mines Rpt. Inv. 4490, 59 p. ( $\$)$, illus. incl. index map, July 1949. 
Runnels, Russell T. See also Frye, J. C., 5.

1. (and Dubins, Ira M.). Chemical and petrographic studies of the Fort Hays chalk in Kansas: Kans. Univ., State Geol. Survey Bull. 82, pt. 1, 36 p., illus. incl. index map, 1949.

2. Preliminary report on phosphate-bearing shales in eastern Kansas: Kans. Univ., State Geol. Survey Bull. 82, pt. 2, p. 37-48, illus., 1949.

\section{Russell, George A.}

1. Geology of the English Brook area, Rice Lake Division, Manitoba: Manitoba Dept. Mines and Nat. Res., Mines Br. Prelim. Rpt. and Map 48-3, 22 p. (\$), geol. map, 1949.

2. Field use of aerial photographs in the Canadian Shield [Part I]: Precambrian, v. 22 , no. 10 , p. $10-17$, illus., Oct. 1949 ; Pt. II, no. 11 , p. 8-14, illus., Nov. 1949.

\section{Russell, Loris Shano.}

1. Preliminary report on the stratigraphy of the Gaspe limestone series, Forillon Peninsula, Cap des Rosiers Township, County of Gaspé South [Quebec]: Quebec Dept. Mines Prelim. Rpt. 195, 14 p. ( $\ddagger)$, geol. sketch map, 1946.

2. The relationships of the Alberta Cretaceous dinosaur "Laosaurus" minimus Gilmore: Jour. Paleontology, v. 23, no. 5, p. 518-520, Sept. 1949.

Russell, Richard Dana. See also Carsola, A.

Trends in sedimentology: Am. Assoc. Petrol. Geol. Bull., v. 33, no. 7, p. 1145-1153, July 1949.

\section{Russell, Richard Joel.}

1. Coast of Louisiana: Société Belge Géologie Bull., v. 57, fasc. 2, p. 380394, illus., Dec. 5, 1948.

2. Pliocene-Pleistocene boundary in Louisiana [abs.]: 18th Internat. Geol. Cong., London, Volume of titles and abstracts, p. $63,1948$.

Rutledge, Franklin Allen. See Heide, H. E.

Rutten, Louis Martin Rokert, 1884-1946.

Frequency and periodicity of orogenetic movements: Geol. Soc. Am. Bull., v. 60 , no. 11, p. $1755-1770$, illus., Nov. 1949.

\section{Ryder, Harry Moyer.}

Character of pores in oil sand, in Subsurface geologic methods: Colo. Sch. Mines Quart., v. 44, no. 3, p. 583-594, illus., July 1949.

Rynearson, Garn Arthur. See Wells, F. G., 1.

\section{Sahama, Thure G.}

1. (and Torgeson, D. R.). Thermochemical study of the stability relation of geikielite and ilmenite in rocks: U. S. Bur. Mines Rpt. Inv. 4407, 14 p. ( $\ddagger)$, illus., Feb. 1949.

2. (and Torgeson, D. R.). Thermochemical study of the olivines and orthopyroxenes: U. S. Bur. Mines Rpt. Inv. 4408, 24 p. ( $\ddagger)$, illus., Feb. 1949.

3. (and Torgeson, D. R.). Some examples of the application of thermochemistry to petrology: Jour. Geology, v. 57, no. 3, p. 255-262, illus., May 1949 .

St. John, Harold. See White, S. E., 1.

\section{Salas, Guillermo P.}

Geology and development of Poza Rica oil field, Veracruz, Mexico: Am. Assoc. Petrol. Geol. Bull., v. 33, no. 8, p. 1385-1409, illus. incl. index, geol. maps, Aug. 1949; abs., v. 32 , no. 12 , p. 2314 , Dec. 1948 ; Oil and Gas Jour., v. 47, no. 25, p. 129, Oct. 21, 1948. 
Sales, Reno Haber.

(and Meyer, Charles). Results from preliminary studies of vein formation at Butte, Montana: Econ. Geology, v. 44, no. 6, p. 465-484, illus., Sept.-Oct. 1949.

Sampson, Edward.

A method for polishing sections of ores: Econ. Geology, v. 44, no. 2, p. 119-127, illus., Mar.-Apr. 1949.

Sampson, Reid J. See Tucker, W. B.

Sandberg, Clarence Harold. See White, D. E., 2.

Sandell, Ernest Birger.

The gallium content of igneous rocks: Am. Jour. Sci., v. 247, no. 1, p. 4048, Jan. 1949.

Sanford, Robert Stillson. See also Hermance, H. P.

Investigation of certain high-alumina clays of central Pennsylvania: U. S. Bur. Mines Rpt. Inv. 4427, 12 p. (\$), illus. incl. index map, Mar. 1949.

Satterly, Jack.

1. (and Armstrong, Herbert Stoker). Geology of Beatty Township [Ontario]: Ontario Dept. Mines, Ann. Rpt., v. 56, pt. 7, 1947, 34 p., illus. incl. index, geol. maps, 1949.

2. Geology of Michaud Township [Ontario]: Ontario Dept. Mines, Ann. Rpt., v. 57, pt. 4, 1948, 27 p., illus. incl. index, geol. maps, 1949.

3. Geology of Garrison Township [Ontario]: Ontario Dept. Mines, Ann. Rpt., v. 58, pt. 4, 33 p., illus. incl. geol. map, 1949.

4. (and Hewitt, D. F.). A pitchblende occurrence at Theano Point, Lake Superior, Ontario: Canadian Min. Jour., v. 70, no. 1, p. 88-90, illus., Jan. 1949.

Savage, Donald Elvin. See also Chappell, W. M.

Subdivision of the late Cenozoic of the San Francisco Bay region [abs.]: Geol. Soc. Am. Bull., v. 60, no. 12, pt. 2, p. 1951, Dec. 1949.

Savage, William S.

The search for uranium: Pt. 1, Earth Sci. Digest, v. 3, no. 11, p. 3-7, illus., June 1949; Pt. 2, v. 3, no. 12, p. 13-17, illus., July 1949; Pt. 3, v. 4, no. 1, p. 7-11, illus., Aug. 1949.

\section{Sayre, Albert Nelson.}

1. Oscar Edward Meinzer [1876-1948]: Washington Acad. Sci. Jour., v. 39 , no. 4, p. 147-148, Apr. $15,1949$.

2. Memorial to Oscar Edward Meinzer [1876-1948]: Geol. Soc. Am. Proc. 1948 , p. 197-206, port., May 1949.

3. Ground-water resources of the El Paso region [Texas] [abs.]: Econ. Geology, v. 44, no. 7, p. 638, Nov. 1949.

Sayrs, Richard Lee. See Clayton, A. B.

Scalapino, R. A. See also Barnes, J. R.

Ground-water resources of the El Paso area, Texas (Progress Report no. 6, with a section on quality of water by Burdge Irelan): Texas State Bd. Water Eng. Rpt., 22 p. ( $\ddagger)$, illus., Oct. 1949.

Schaefer, Vincent $\mathbf{J}$.

The formation of ice crystals in the laboratory and the atmosphere: Chem. Reviews, v. 44, no. 2, p. 291-320, illus., Apr. 1949.

Schaeffer, Bobb.

A teleost from the Livingston formation of Montana: Am. Mus. Nat. History Novitates no. 1427, 16 p., illus., Oct. 7, 1949. 


\section{Schafer, J. P.}

1. Some periglacial features in central Montana: Jour. Geology, v. 57, no. 2, p. 154-174, illus. incl. index map, Mar. 1949.

2. Pleistocene geology of the Upper Teton River, central Montana [abs.]: Geol. Soc. Am. Bull., v. 60, no. 12, pt. 2, p. 1974-1975, Dec. 1949.

Schairer, John Frank.

Phase equilibrium relations in the quaternary system $\mathrm{K}_{2} \mathrm{O}-\mathrm{MgO}-\mathrm{Al}_{2} \mathrm{O}_{3}-\mathrm{SiO}_{2}$ [abs.]: Am. Mineralogist, v. 34, nos. 3-4, p. 283, Mar.-Apr. 1949.

Schemel, Mart P.

Spore assemblages of coals near the Cherokee-Marmaton boundary in Missouri [abs.]: Am. Jour. Botany, v. 36, no. 10, p. 820, Dec. 1949.

Schenk, Edward Theodore.

(and McMasters, John Herbert). Procedure in taxonomy. Revised ed., enlarged and in part rewritten by Angeline Myra Keen and Siemon William Muller, vii, 93 p., Stanford, Calif., Stanford Univ. Press, 1948.

Schieck, Emmett E. See Summerford, H. E., 1, 2.

Schiefer, H. V.

Some gems of Ohio: Mineralogist, v. 17, no. 4, p. 192, 194, 196, 198, 200, Apr. 1949.

Schieltz, N. Cyril. See also Mielenz, R. C., 16.

$\mathrm{X}$-ray analysis, in Subsurface geologic methods: Colo. Sch. Mines Quart., v. 44, no. 3, p. 211-238, illus., July 1949.

Schlocker, Julius.

Petrographic descriptions of Minnewasta and Chickamauga-limestones [S. Dak., Tenn.]: U. S. Bur. Recl. Petrog. Lab. Rpt: 89, 9 p. ( $\ddagger)$, illus., May $15,1947$.

Schmitt, Harrison Ashley.

1. Uniformitarianism and the ideal vein [abs.]: Econ. Geology, v. 44, no. 1, p. 80, Jan.-Feb. 1949.

2. Origin of the epithermal mineral deposits [abs.]: Econ. Geology, v. 44, no. 7 , p. 641, Nov. 1949; Geol. Soc. Am. Bull., v. 60, no. 12, pt. 2, p. 1918 , Dec. 1949.

Schneider, Hyrum.

Summary of the Cambrian stratigraphy of Utah, in The oil and gas possibilities of Utah, by G. H. Hansen and M. M. Bell: Utah Geol. Miner. Survey, p. 31-37, illus., Dec. 1949.

\section{Schneider, Robert.}

A hypothesis on the origin of a limonitic layer in beds of Eocene age in Fayette County, Tennessee: Econ. Geology, v. 44, no. 7, p. 621-623, Nov. 1949.

Schoellhamer, J. E.

(and Woodford, Alfred Oswald). Floor of the Los Angeles Basin [abs.]: Am. Assoc. Petrol. Geol. Bull., v. 33, no. 12, p. 2060, Dec. 1949; Oil and Gas Jour., v. 48, no. 29, p. 137, Nov. 24, 1949.

Schoewe, Walter Henry.

The geography of Kansas: Kans. Acad. Sci. Trans., v. 52, p. 261-333, illus. incl. geol. map, 1949.

\section{Schoff, Stuart Leeson.}

Ground water in Kingfisher County, Oklahoma: Okla. Geol. Survey, Mineral Rpt. 19, 21 p. (\$), geol. map, Feb. 1949. 


\section{Schopf, James Morton.}

1. Botanical aspects of coal petrology; Coal from the Coos Bay field in southwestern Oregon: Am. Jour. Botany, v. 34, no. 6, p. 335-345, illus., June 1947; abs., v. 33, no. 10, p. 833, Dec. 1946.

2. Pteridosperm male fructifications; American species of Dolerotheca, with notes regarding certain allied forms: Jour. Paleontology, v. 22, no. 6, p 681-724, illus., Nov. 1948; reprinted as Ill. Geol. Survey Rpt. Inv. $142,1949$.

3. Naturally briquetted coal from a bed in western Pennsylvania: Jour. Geology, v. 57, no. 1, p. 79-82, illus., Jan. 1949.

4. Cannel, boghead, torbanite, oil shale: Econ. Geology, v. 44, no. 1, p. 68-71, Jan.-Feb. 1949.

5. Research in coal paleobotany since 1943: Econ. Geology, v. 44, no. 6, p. 492-513, illus., Sept.-Oct. 1949.

\section{Schreiber, Joseph F., Jr.}

Geologic sketches_pot-holes: Maryland Naturalist, v. 19, no. 3; p. 48, Summer 1949.

\section{Schroeder, Melvin C.}

The Tertiary rocks of southern Pend Oreille County, Washington [abs.]: Northwest Sci., v. 23, no. 1, p. 39-40, Feb. 1949.

\section{Schultz, Charles Bertrand.}

(and Falkenbach, Charles Henry). Promerycochoerinae, a new family of oreodonts: Am. Mus. Nat. History Bull., v. 93, art. 3, p. 69-198, illus., May 20, 1949.

\section{Schwade, Irving T.}

(and Fine, Spencer Freeland). Geology of the North Sulphur Mountain field, Ventura County [Calif.] [abs.]: Am. Assoc. Petrol. Geol. Bull., v. 33 , no. 12 , p. 2061 , Dec. 1949 ; Oil and Gas Jour., v. 48, no. 29, p. 137, Nov. 24, 1949.

Schwartz, C. M. See Robertson, D. A.

\section{Schwartz, George Melvin.}

1. The geology of the Duluth metropolitan area [Minn.]: Minn. Geol. Survey Bull. 33, 136 p., illus. incl. index, geol. maps, 1949.

2. (and Varnes, David Joseph, and Eckel, Edwin Butt). Disseminated chalcopyrite with platinum and palladium, in Geology and ore deposits of the La Plata district, Colorado, by E. B. Eckel: U. S. Geol. Survey Prof. Paper 219, p. 63-66, 1949.

3. Oxidation and enrichment in the San Manuel copper deposit, Arizona: Econ. Geology, v. 44, no. 4, p. 253-277, illus., June-July 1949; abs., no. 1, p. 81, Jan.-Feb. 1949.

\section{Schweers, Richard Henry.}

Connell sandstone, Oil Creek formation, Simpson group, West Texas: Am. Assoc. Petrol. Geol. Bull., v. 33, no. 12, p. 2029-2036, illus., Dec. 1949.

\section{Scott, Glenn $\mathbf{R}$.}

1. Unconformities: Compass, v. 26, no. 2, p. 158-164, Jan. 1949.

2. Cross-bedding: Compass, v. 26, no. 2, p. 165-172, illus., Jan. 1949.

3. Geodes at Garden Park, Colo.: Rocks and Minerals, v. 24, nos. 3-4, p. 142-143, illus., Mar.-Apr. 1949.

Scott, W. Frank. See Wheeler, H. E.

\section{Scrafford, John Bruce.}

Developments [in oil and gas] in south Texas in 1948: Am. Assoc. Petrol. Geol. Bull., v. 33, no. 6, p. 945-955, illus. incl. index map, June 1949. 
Seaman, David Martin.

Some recent [mineral] finds in Maine and New Hampshire: Rocks and Minerals, v. 24, nos. 11-12, p. 608-609, Nov.-Dec. 1949.

\section{Sears, Paul M.}

The man who grabbed a shooting star [Willamette meteorite]: Nat. History, v. 58, no. 4, p. 166-167, 191, illus., Apr. 1949.

Seel, Charles. See Behre, C. H., Jr., 3.

Seifert, Wilbur H. See Fettke, C. R., 1 .

Selk, Erwin L.

Problem of the "Mayes" in Oklahoma: Jour. Geology, v. 56, no. 4, p. 303307, illus. incl. index map, July 1948; summary, Tulsa Geol. Soc. Digest, v. 17 , p. 100-103, map, 1949.

Senftle, Frank E.

(and McMahon, C.). Determination of uranium in ores by field analysis: Canadian Min. Met. Bull. no. 451, p. 618-621, illus., Nov. 1949; Canada Bur. Mines Memo. ser. no. 96, 11 p. ( $\ddagger)$, illus., May 1949.

Seward, Clay Luzenberg, Jr. See Goldich, S. S., 1, 2.

Seward, J. M. See Hill, H. B., 2.

Seymour, W. L. See Quinn, A. W., 1, 2.

Shaffer, Paul R. See Leighton, M. M., 2.

Shainin, Vincent Everett, 1921-1950.

1. Economic geology of some pegmatites in Topsham, Maine: Maine Geol. Survey Bull. 5, 32 p., illus. incl. index, geol. map, Dec 1, 1948.

2. Preliminary report of the pegmatites on Red Hill, Rumford, Maine: Maine State Geologist Rpt. 1947-1948, p. 90-102, illus. incl. index, geol. maps, Mar. 1949.

3. Age determinations of pegmatites in Topsham, Maine: Geol. Soc. Am. Bull., v. 60 , no. 10 , p. 1727 , Oct. 1949.

Shand, Samuel James.

Rocks of the Mid-Atlantic Ridge: Jour. Geology, v. 57, no. 1, p. 89-92, Jan. 1949.

Sharp, Robert Phillip.

1. The constitution of valley glaciers: Jour. Glaciology, v. 1, no. 4, p. 182189 , illus., Oct. 1948; abs., Geol. Soc. Am. Bull., v. 59, no. 12, pt. 2, p. 1381-1382, Dec. 1948.

2. Project "Snow Cornice": Engineering and Science Monthly, v. 12, no. 2, p. 6-10, illus. incl. index map, Nov. 1948.

3. Pleistocene ventifacts east of the Big Horn Mountains, Wyoming: Jour. Geology, v. 57, no. 2, p. 175-195, illus. incl. index map, Mar. 1949.

4. Studies of superglacial debris on valley glaciers: Am. Jour. Sci., v. 247, no. 5, p. 289-315, illus. incl. index map, May 1949.

5. Features of the Seward firn field, St. Elias Range, Canada [abs.]: Geol. Soc. Am. Bull., v. 60, no. 12, pt. 2, p. 1918-1919, Dec. 1949.

Shatsky, N. S.

A comparative study of tectonics of North America and the European platform: Acad. Sci. U.S.S.R., Bull., Geol. ser., 1945, no. 4, p. 10-26, illus., 1945. Russian, with English summary.

Shaub, Benjamin Martin.

1. Do stylolites develop before or after the hardening of the enclosing rock?: Jour. Sed. Petrology, v. 19, no. 1, p. 26-36, illus., Apr. 1949.

2. Magnetic anomalies of the Russell, N. Y., quadrangle (Preliminary Report) : N. Y. State Science Service, Rpt. Inv. 2,9 p. ( $\ddagger)$, illus., May 1949. 


\section{Shaub, Benjamin Martin-Continued}

3. Paragenesis of the garnet and associated minerals of the Barton mine near North Creek, New York: Am. Mineralogist, v. 34, nos. 7-8, p. 573-582, illus., July-Aug. 1949; abs., v. 33, nos. 3-4, p. 208, Mar.Apr. 1948; Geol. Soc. Am. Bull., v. 58, no. 12, pt. 2, p. 1226-1227, Dec. 1947.

\section{Shaw, Ernest William.}

(and Harding, Stanley Russell Lauck). Lea Park and Belly River formations of east-central Alberta, in Clark, L. M., chm., Alberta symposium: Am. Assoc. Petrol. Geol. Bull., v. 33, no. 4, p. 487-499, illus. incl. index map, Apr. 1949.

Shaw, George. See Canada Geol. Survey, 2, 8.

Shea, Edward F. See Bartram, J. G.

\section{Shenon, Philip John.}

Lead and zinc deposits of the Coeur d'Alene district, Idaho, in Dunham, K. C., ed., Symposium on the geology, paragenesis and reserves of the ores of lead and zinc, 18th Internat. Geol. Cong., London, p. 7880 , illus., 1948; abs., Volume of titles and abstracts, p. 50, 1948.

\section{Shepard, Francis Parker.}

1. Investigation of head of Monterey submarine canyon [Calif.]: Calif. Univ., Scripps Inst. Oceanog., Submarine Geology Rpt. No. 1, 15 p. (\$), illus., Mar. 1948.

2. Submarine canyons: Sci. Am., v. 180, no. 4, p. 40-43, illus., Apr. 1949.

3. Longshore-bars and longshore-troughs: Calif. Univ., Scripps Inst. Oceanog., Submarine Geology Rpt. No. 6, 35 p. (\$), illus., Sept. 1949: Beach Erosion Board Tech. Memo. no. 15, 32 p., illus., Jan. 1950.

4. Terrestrial topography of submarine canyons revealed by diving [La Jolla area, Calif.]: Geol. Soc. Am. Bull., v. 60, no. 10, p. 1597-1611, illus. incl. index maps, Oct. 1949.

5. Submarine geology and stratigraphy: World Oil, v. 129, no. 9, p. 72, 74, 76-77, illus., Dec. 1949.

6. Significance of depth changes in submarine canyon heads [abs.]: Geol. Soc. Am. Bull., v. 60, no. 12, pt. 2, p. 1945, Dec. 1949.

\section{Shepherd, George Frederick.}

A structural interpretation, Arick field [Texas]: Petrol. Eng., v. 21, no. 12, p. B-11-B-14, B-16, illus., Nov. 1949.

\section{Sherwin, Melville William.}

La Grange oil field, Adams County, Mississippi [abs.]: Am. Assoc. Petrol. Geol. Bull., v. 33, no. 12, p. 2070, Dec. 1949; Oil and Gas Jour., v. 48, no. 25 , p. 88 , Oct. $27,1949$.

Shields, Joseph John. See Toenges, A. L., 1.

Shreve port Geological Society.

Guidebook, 15th Annual Field Trip, February 1-2, 1947, Upper and lower Cretaceous of southwestern Arkansas, 26 p. ( $\$)$, illus., 1947.

\section{Shrode, Raymond S.}

Physical characteristies of the oolite grains of the Ste. Genevieve formation: Ill. State Acad. Sci. Trans., v. 42, p. 116-119, illus., Dec. 31, 1949: reprinted in Ill. State Geol. Survey Circ. 157, p. 116-119, illus., 1950.

\section{Siever, Raymond.}

Trivoli sandstone of Williamson County, Ill.: Jour. Geology, v. 57, no. 6, p. 614-618, illus. incl. index map, Nov. 1949 . 


\section{Sigafoos, Robert S.}

The effects of frost action and processes of cryoplanation upon the development of tundra vegetation, Seward Peninsula, Alaska [abs.]: Am. Jour. Botany, v. 36, no. 10, p. 832, Dec. 1949.

Simon, R. F. See Clewell, D. H.

Simpson, E. S.

Buried preglacial ground water channels in the Albany-Schenectady area in New York: Econ. Geology, v. 44, no. 8, p. 713-720, illus., Dec. 1949; reprinted as N. Y. Water Power and Control Comm. Bull. GW-20A, 1949.

Simpson, George Gaylord. See also Jepson, G. L., 1.

1. Biographical memoir of William Berryman Scott, 1857-1947: Natl. Acad. Sci. Biog. Mem., v. 25, p. 175-203, port., 1949.

2. Continents in the age of mammals: Tulsa Geol. Soc. Digest, v. 17, p. 5865 , illus., 1949.

3. The meaning of evolution, a study of the history of life and of its sigsificance for man. xv, 364 p., illus. New Haven, Yale Univ. Press, 1949.

4. Rates of evolution in animals, in Jepson, G. L., ed., Genetics, paleontology, and evolution, p. 205-228, 1949.

5. A fossil deposit in a cave in St. Louis [Mo.]: Am. Mus. Nat. History Novitates no. 1408,46 p., illus., Feb. 4, 1949.

6. Essay-review of recent works on evolutionary theory by Rensch, Zimmermann, and Schindewolf: Evolution, v. 3, no. 2, p. 178-184, June 1949.

7. Periodicity in vertebrate evolution [abs.]: Geol. Soc. Am. Bull., v. 60, no. 12 , pt. 2, p. 1919-1920, Dec. 1949 .

\section{Sinclair, George Winston.}

1. The Ordovician trilobite Eobronteus [North America and Europe]: Jour. Paleontology, v. 23, no. 1, p. 45-56, illus., Jan. 1949; correction, Footnotes to Eobronteus, no. 5, p. 571-572, Sept. 1949.

2. Raymondella, Bancroftina, Reedaspis [brachiopod nomenclature]: Jour. Paleontology, v. 23, no. 4, p. 438-439, July 1949.

Singewald, Joseph Theophilus, Jr.

The shore erosion problem [Md.]: Md. Dept. Geology, Mines and Water Res. Bull. 6, p. 1-18, illus., 1949.

Skeels, Dorr Covell.

(and Watson, Robert James). Derivation of magnetic and gravitational quantities by surface integration: Geophysics, v. 14 , no. 2, p. 133150, illus., Apr. 1949.

Skillman, Margaret W. See also Woyski, Margaret Skillman.

Pre-upper Cambrian sediments of Vernon County, Missouri: Mo. Geol. Survey and Water Res. Rpt. Inv. 7, 18 p. ( $\$)$, illus., 1948.

Skinner, W. S. See Stevenson, R. E., 3.

Skitsky, Vsevolod Lawrovitch. See also Rabbitt, M. C.

(and Vesselowsky, Sergius Theodore). Geophysical abstracts 135, OctoberDecember 1948: U. S. Geol. Survey Bull. 959-D, p. 263-388, 1949; 136, January-March 1949, Bull. 966-A, p. 1-93, 1949.

\section{Slack, Howard A.}

Radioactivity measurements in the Kirkland Lake area, northern Ontario: Am. Geophys. Union Trans., v. 30, no. 6, p. 867-874, illus. incl. geol. sketch map, Dec. 1949.

Slaughter, Archibald L. See Noble, J. A. 
Slaughter, Turbit $\mathbf{H}$.

The shore erosion measurements [Md.]: Md. Dept. Geology, Mines and Water Res. Bull. 6, p. 19-118, illus., 1949.

Sloss, Laurence Louis. See also Dapples, E. C., 2; Krumbein, W. C.; Moritz, C. A.

1. (and Krumbein, William Christian, and Dapples, Edward Charles). Integrated facies analysis, in Longwell, C. R., chm., Sedimentary facies in geologic history [symposium]: Geol. Soc. Am. Mem. 39, p. 91-123, illus.; discussion by W. C. Krumbein, p. 142-145; by L. L. Sloss, p. 154, June 17, 1949.

2. Rates of evolution and measurement of geologic time [abs.]: Oil and Gas Jour., v. 47, no. 46, p. 154, 157, Mar. 17, 1949.

3. (and Moritz, Carl A.). Paleozoic stratigraphy of southwestern Montana [abs.]: Geol. Soc. Am. Bull., v. 60, no. 12, pt. 2, p. 1920, Dec. 1949 .

Smith, Burnett.

Holotype of Mytilarca (Plethomytilus) knappi Hall with a note on Ezra Babcock Knapp: Bull. Am. Paleontology, v. 32, no. 132, 10 p., illus., Mar. 20, 1949.

Smith, Clay Taylor. See Wells, F. G., 1.

Smith, D. Jeter.

Miocene Foraminifera of the "Harang sediments" of southern Louisiana: La. Geol. Survey Bull. 26, p. 23-76, illus. incl. index map, July 1948.

Smith, Dudley Thompson. See Rosenholtz, J. L.

\section{Smith, Frederick Gordon.}

1. Transport and deposition of the non-sulphide vein minerals. 4. Tourmaline: Econ. Geology, v. 44, no. 3, p. 186-192, illus., May 1949.

2. (and Kidd, Donald J.). Hematite-goethite relations in neutral and alkaline solutions under pressure: Am. Mineralogist, v. 34, nos. 5-6, p. 403-412, illus., May-June 1949.

3. (and Peach, P. A.). Recent advances in the laboratory study of ore: Canadian Min. Met. Bull. no. 447, p. 351-353, illus., July 1949.

4. (and Peach, P. A.). Apparatus for the recording of decrepitation in minerals: Econ. Geology, v. 44, no. 5, p. 449-451, illus., Aug. 1949.

5. Laboratory testing of "pneumatolytic" deposits: Econ. Geology, v. 44, no. 7 , p. 624-625, Nov. 1949.

6. Transport and deposition of the non-sulphide vein minerals. 3. Phase relations at the pegmatitic stage: Econ. Geology, v. 44, no. 8, p. 741742, Dec. 1949. Reply to discussion of Smith's original paper (v. 43, no. 7, p. 535-546, Nov. 1948) by George W. Morey, v. 44, p. 151154, Mar.-Apr. 1949.

Smith, Guy Donald. See also Riecken, F. F.

Illinois loess; variations in its properties and distribution, a pedologic interpretation: Ill. Univ. Agric. Expt. Sta. Bull. 490, p. 139-184, illus., July 1942.

\section{Smith, H. F.}

(and Larson, Thurston Eric). Groundwater resources in Winnebago County with specific reference to conditions at Rockford: Ill. Dept. Registration and Educ., State Water Survey Div., Rpt. Inv. 2, 35 p. ( $\ddagger$, illus., 1948.

Smith, Harold Theodore Uhr. See also Thorp, J., 2.

1. Periglacial features in the Driftless Area of southern Wisconsin: Jour. Geology, v. 57, no. 2, p. 196-215, illus. incl. index map, Mar. 1949; abs., Geol. Soc. Am. Bull., v. 52, no. 12, pt. 2, p. 1934, Dec. 1941. 
Smith, Harold Theodore Uhr-Continued

2. Pleistocene research, a review by the members of the committee on interrelations of Pleistocene research, National Research Council; 11, Physical ffects of Pleistocene climate changes in nonglaciated areas; eolian phenomena, frost action, and stream terracing: Geol. Soc. Am. Bull., v. 60 , no. 9, p. $1485-1515$, illus., Sept. 1949 .

3. Dune forms in western Nebraska [abs.]: Geol. Soc. Am. Bull., v. 60, no. 12, pt. 2, p. 1920, Dec. 1949.

Smith, Henry Landiss. See also Toenges, A. L., 2.

1. (and O'Donnell, Hugh John). Investigation of coal deposits in the Fairview and Coal City Basins of Coosa field, St. Clair County, Ala. 2. Petrographic study of Fairview coal bed: U. S. Bur. Mines Tech. Paper 719, p. 21-27, illus., 1949.

2. (and O'Donnell, Hugh John). Investigation of lower coal beds in Georges Creek and north part of Upper Potomac Basins, Allegany and Garrett Counties, Md., 2. Petrographic examination of coal cores: U. S. Bur Mines Tech. Paper 725, p. 15-18, 1949.

Smith, Howard Ira.

Potash, in Industrial minerals and rocks, p. 684-713, illus., 1949.

Smith, J. E.

Arthur Gilbertson Hutchison (1902-1949) : Am. Assoc. Petrol. Geol. Bull., v. 33, no. 12, p. 2076-2077, Dec. 1949.

Smith, Joe Fred, Jr. See also Albritton, C. C., Jr., 1.

1. (and Albritton, Claude Carroll, Jr.). Sierra Blanca field trip [Texas], in West Texas Geological Society Guidebook Field Trip no. 1, November 6-9, 1949, p. 95-108, illus. incl. index, geol. maps, 1949.

2. (and Albritton, Claude Carroll, Jr.). Conglomerates of western TransPecos Texas and their relation to a tectonic boundary [abs.]: Geol. Soc. Am. Bull., v. 60, no. 12, pt. 2, p. 1921, Dec. 1949.

Smith, Philip Sidney, 1877-1949.

Stephen Reid Capps [1881-1949]: Washington Acad. Sci. Jour., v. 39, no. 5, p. 179-180, May 15, 1949 .

Smith, R. Kenneth. See Jewett, J. M., 2.

Smith, William H.

Sand and gravel resources in northern Ohio: Ohio Geol. Survey Rpt. Inv. no. 6, 24 p., index map, 1949.

Snavely, Parke Detweiler, Jr. See also U. S. G. S., 1, no. 88; Vokes, H. E., 1.

(and Vokes, Harold Ernest). Geology of the coastal area between Cape Kiwanda and Cape Foulweather, Oregon [geologic map with text]: U. S. Geol. Survey Oil and Gas Invs. Prelim. Map no. 97. Scale 1 inch to 1 mile. 1949.

Socolow, Arthur A.

Geology of the Irwin district of Colorado [abs.]: Geol. Soc. Am. Bull., v. 60 , no. 12 , pt. 2 , p. 1921 , Dec. 1949 .

Sohn, Israel Gregory.

1. Use of sketchmaster in compilation of geologic maps from air-photo enlargements: Econ. Geology, v. 44, no. 6, p. 551-553, illus., Sept.-Oct. 1949.

2. Hinge mechanism of Paleozoic ostracodes: Jour. Paleontology, v. 23, no. 6, p. 691, Nov. 1949.

Sokoloff, Vladimir Petrovich.

Engineering map units in Fairfax quadrangle, Virginia [abs.]: Washingtion Acad. Sci. Jour., v. 39, no. 3, p. 109-110, Mar. 15, 1949. 
Sonnenberg, Frank P.

The Greenbrier formation in eastern Kentucky: Appalachian Geol. Soc. Bull., v. 1, p. 342-356, illus., 1949.

Sorensen, Andrew.

Some observations on Haliotidae (abalones) and their world distribucion: Nautilus, v. 62, no. 4, p. 138-142, Apr. 1949.

\section{Soske, Joshua Lawrence.}

Offshore seismic prospecting augmented by radio surveying: Mines Mag., v. 39, no. 12, p. 91-96, 103, 123, illus., Dec. 1949.

\section{Southeastern Geological Society, Mesozoic Committee.}

1. Mesozoic cross section, A-A', Walton County to Monroe County, Florida. One sheet. Scale 1 inch to 10 miles. Sept. 1949.

2. Mesozoic cross section, B-B', Beaufort, S. C., to Highlands County, Fla.; D-D', Dixie County to Nassau County, Florida. One sheet. Scale 1 inch to 10 miles. Sept. 1949.

3. Mesozoic cross section, C-C', Toombs County, Ga. to Volusia County, Fla. One sheet. Scale 1 inch to 10 miles. Sept. 1949.

4. Mesozoic cross section, E-E', Bullock County, Ala. to Franklin County, Fla. One sheet. Scale 1 inch to 10 miles. Sept. 1949.

\section{Southworth, John S.}

The geological aspects of the Matilija Dam controversy [Calif.]: Mines Mag., v. 39, no. 9, p. 17-18, 22, 39, illus., Sept. 1949.

Spackman, William, Jr. See also Barghoorn, E. S., Jr., 3.

(and Barghoorn, Elso Sterrenberg, Jr.). The geology and flora of the Brandon lignite [Vt.] [abs.]: Am. Jour. Botany, v. 36, no. 10, p. 820, Dec. 1949.

\section{Spieker, Edmund Maute.}

Sedimentary facies and associated diastrophism in the upper Cretaceous of central and eastern Utah, in Longwell, C. R., chm., Sedimentary facies in geologic history [symposium] : Geol. Soc. Am. Mem. 39, p. 55-81, illus. incl. index map, June 17, 1949.

\section{Spitznas, Roger L.}

1. The Bryce Canyon National Park [Utah]: Earth Sci. Digest, v. 3, no. 7, p. 17-21, illus., Feb. 1949.

2. Petroliferous geodes, their occurrence and origin; [Tyson Creek area, Ill.]: Earth Sci. Digest, v. 3, no. 11, p. 15-18, illus., June 1949.

\section{Spivak, Joseph.}

Jurassic sections in foothills of Alberta and northeastern British Columbia; in Clark, L. M., chm., Alberta symposium: Am. Assoc. Petrol. Geol. Bull., v. 33, no. 4, p. 533-546, illus. incl. index map, Apr. 1949.

Spreng, A. C. See Laudon, L. R., 3.

Springer, G. D.

1. Geology of the Cat Lake-Winnipeg River area, Lac du Bonnet Division, Manitoba: Manitoba Dept. Mines and Nat. Res., Mines Br. Prelim. Rpt. 48-7, 15 p. ( $\ddagger)$, geol. map, 1949.

2. Geology and mineral deposits of a part of southeastern Manitoba: Precambrian, v. 22, no. 8, p. 8-10, 35, illus., Aug. 1949.

Sprotte, E. C.

The San Andreas and San Jacinto rift zones [Calif.]: Compass, v. 26, no. 4 , p. 315-319, illus. incl. index map, p. 285, May 1949.

\section{Stainforth, Robert Masterman.}

1. Further notes on fossil Globigerina oozes: Micropaleontologist, v. 3, no. 3, p. 12-13 ( $\$)$, July 1949 .

2. Nomenclatural notes on Pullenia and Cibicides [Foraminifera]: Jour. Paleontology, v. 23, no. 4, p. 436-438, July 1949. 
Staley, William Wesley.

(and Browning, James S.). Preliminary investigation of concentrating certain minerals in Idaho placer sand: Idaho Bur. Mines and Geology Pamph. 87, 23 p. (\$), illus., June 1949.

Stanley, George Mahon. See also Stuart, W. T.

1. Glacial geology study in the Iron River district, Michigan, in Groundwater problems of the Iron River district: Mich. Geol. Survey Tech. Rpt. 2, p. 6-18 ( $\$$ ), illus., June 1948 .

2. Elevations of some Lake Lahontan shore lines [abs.]: Geol. Soc. Am. Bull., v. 60 , no. 12 , pt. 2, p. 1945 , Dec. 1949.

Stanton, Gilman S.

Memorial of James Greenfield Manchester [1871-1948]: Am. Mineralogist, v. 34, nos. 3-4, p. 253-255, port., Mar.-Apr. 1949.

\section{Stanton, Michael Stuart.}

Geology of the Dunphy Lakes area, Granville Lake division, Manitoba: Manitoba Dept. Mines and Nat. Res., Mines Br. Rpt. and Map 48-4, 34 p. (\$), geol. map, 1949 .

\section{Staples, Lloyd William.}

1. The occurrence of priceite in Oregon: Northwest Sci., v. 22, no. 2, p. 69-77, illus., May 1948.

2. Cubic pseudomorphs of quartz after halite in petrified wood [Oreg.] [abs.]: Geol. Soc. Am. Bull., v. 60, no. 12, pt. 2, p. 1945-1946, Dec. 1949.

Stark, John Thomas.

(and others). Geology and origin of South Park, Colo.: Geol. Soc. Am. Mem. 33, viii, 188 p., illus. incl. index, geol. maps, Jan. 10, 1949.

Starr, Charles C.

Leaf samples as an aid to prospecting for zinc: Western Miner, v. 22, no. 1, p. 43, illus., Jan. 1949.

Stauffer, Clinton Raymond. See Emmons, W. H.

Stead, Frank Walter.

Prospecting for uranium with portable Geiger-Mueller equipment: Mich. Coll. Min. Tech., Conference on radioactive ores, May 6, 1949, p. 27-28, 1949.

Stebbins, George Ledyard, Jr.

Fates of evolution in plants, in Jepson, G. L., ed., Genetics, paleontology, and evolution, p. 229-242, 1949.

Stechschulte, Victor Cyril.

Method of obtaining a travel-time curve within a stripped earth [abs.]: Geol. Soc. Am. Bull., v. 60 , no. 12, pt. 2, p. 1957 , Dec. 1949.

Stelek, Charles Richard. See Warren, P. S., 2.

Stensiö, Erik Andersson.

On the placodermi of the Upper Devonian of East Greenland, 2, Antiarchi, subfamily Bothriolepinae: Meddelelser om Grønland, Bind 139, 622 p., illus., 1948.

\section{Stenzel, Henryk Bronislaw.}

1. Successional speciation in paleontology; the case of the oysters of the sellaeformis stock: Evolution, v. 3, no. 1, p. 34-50, illus., Mar. 1949; reprinted as Texas Univ., Bur. Econ. Geol. Rpt. Inv. no. 3, 1949.

2. Coals of Texas [abs.]: Econ. Geology, v. 44, no. 7, p. 638, Nov. 1949.

Stetson, Henry Crosby.

Sediments of western half of the Gulf of Mexico [abs.]: Oil and Gas Jour., v. 47 , no. 46, p. 150, Mar. 17, 1949. 


\section{Steven, Thomas August.}

Geology and fluorspar deposits of the St. Peters dome district, Colorado: Colo. Sci. Soc. Proc., v. 15, no. 6, p. 259-284, illus. incl. index, geol. maps, 1949.

Stevens, J. C.

Variations in airphoto patterns of Illinoian drift in southern Indiana: Purdue Univ. Eng. Bull., Ext. ser. no. 69, p. 120-140, illus. incl. index map, Sept. 1949.

Stevens, Rollin Elbert. See also Lakin, H. W.

(and Lakin, Hubert W.). The chromograph, a new analytical tool for laboratory and field use: U. S. Geol. Survey Circ. 63, 11 p. (\$), illus., Dec. 1949.

Stevenson, John Sinclair.

Prospecting for uranium [British Columbia]: Western Miner, v. 22, no. 3, p. 42-45, illus., Mar. 1949.

\section{Stevenson, Robert Evan.}

1. Geologic structures of the Middle Devonian rocks of Otsego County [N. Y.] (Progress Report): N. Y. State Science Service, Rpt. Inv. 1, 12 p. ( ), illus., Feb. 1948; Addenda, Rpt. Inv. 3, p. 15-16, May 1949 .

2. Geologic structures of the Lower Devonian rocks of central New York (Progress Report) : N. Y. State Science Service, Rpt. Inv. 3, 16 p. (\$), illus., May 1949. Contains addenda to Rpt. Inv. 1, Feb. 1948.

3. (and Skinner, W. S.). The Tully clastics of New York and Pennsylvania: Pa. Acad. Sci. Proc., v. 23, p. 29-33, illus., 1949.

\section{Stewart, David P.}

The surface geology of Wexford County, Michigan: Mich. Acad. Sci. Arts: and Letters, Papers, v. 33 (1947), p. 233-242, illus. incl. geol. map, 1949.

Stewart, Katherine C. See Cushman, J. A., 5, 6; Stewart, R. E.

Stewart, Ralph Bentley.

Lower Tertiary stratigraphy of Mount Diablo, Marysville Buttes, and west border of Lower Central Valley of California: U. S. Geol. Survey Oil and Gas Invs. Prelim. Chart 34 (2 sheets). Text, geologic sections. 1949 .

Stewart, Roscoe Emerson. See also Cushman, J. A., 5, 6.

(and Stewart, Katherine C.). Local relationships of the Mollusca of the Wildcat coast section, Humboldt County, California, with related data on the Foraminifera and Ostracoda: Oreg. Dept. Geology and Mineral Indus. Bull. 36 , pt. 8, p. 166-208, illus. incl. index maps, Oct. 1949.

\section{Stewart, W. Alan.}

Meaning and importance of unconformities in stratigraphic rocks: Mines Mag., v. 39, no. 4, p. 19-24, illus., Apr. 1949.

\section{Stirton, Ruben Arthur.}

(and Gealy, William K.). Reconnaissance geology and vertebrate paleontology of El Salvador, Central America: Geol. Soc. Am. Bull., v. 60, no. 11, p. 1731-1753, illus. incl. index map, Nov. 1949.

\section{Stobbe, Helen Ruth.}

1. Petrology of volcanic rocks of northeastern New Mexico: Geol. Soc. Am. Bull., v. 60, no. 6, p. 1041-1095, illus. incl. index map, June 1949; abs., v. 59, no. 12, pt. 2, p. 1354-1355, Dec. 1948; Am. Mineralogist, v. 34, nos. 3-4, p. 283 , Mar.-Apr. 1949. 


\section{Stobbe, Helen Ruth-Continued}

2. The Gillette quarry, Haddam Neck, Connecticut: Rocks ánd Minerals, v. 24, nos. 9-10, p. 496-502, illus. incl. index, geol. sketch maps, Sept.-Oct. 1949.

3. Dacites from Laughlin Peak, Colfax County, New Mexico [abs.]: Geol. Soc. Am. Bull., v. 60, no. 12, pt. 2, p. 1922, Dec. 1949.

Stock, Chester, 1892-1950.

1. Mammalian fauna from the Titus Canyon formation, California: Carnegie Inst. Wash. Pub. 584, Contr. Paleontology, p. 229-244, illus., June 22, 1949.

2. (and Richards, Horace Gardiner). A Megalonyx tooth from the Northwest Territories, Canada: Science, v. 110 , no. 2870 , p. $709-710$, illus., Dec. 30, 1949.

\section{Stockdale, Paris Buell.}

Problems in Mississippian stratigraphy of the southern Appalachians [abs.] : Tenn. Acad. Sci. Jour., v. 24, no. 2, p. 101, Apr. 1949.

\section{Stokes, William Lee.}

1. Dinosaur National Monument, past and present. 20 p., illus. Washington, D. C. U. S. Gov't Printing Office. 1949.

2. Triassic and Jurassic rocks of Utah, in The oil and gas possibilities of Utah, by G. H. Hansen and M. M. Bell: Utah Geol. Miner. Survey, p. 79-89, illus., Dec. 1949.

Stoltenberg, Howard A. See McLaughlin, T. G.

\section{Stommel, Harrison Edfred.}

Subsurface methods as applied in geophysics, in Subsurface geologic methods: Colo. Sch. Mines Quart., v. 44, no. 3, p. 695-769, illus., July 1949.

Stone, Edwin A. See Fowler, G. M.

\section{Stone, Ralph Walter.}

Origin of caves: Natl. Speleol. Soc. Bull. 11, p. 3-7, illus., Nov. 1949.

\section{Stone, Solon W.}

Rocks and minerals of Connecticut: Conn. Geol. Nat. History Survey, Misc. ser. no. 1, 16 p., June 1949.

Stoneburner, Roger. See Laudon, L. R., 3.

\section{Stormont, D. H.}

Scurry County, West Texas limestone-reef development: Oil and Gas Jour., v. 48 , no. 9, p. 54-57, 87, illus. incl. index map, July 7, 1949.

Stose, Anna Isabel Jonas. See Stose, G. W., 1.

\section{Stose, George Willis.}

1. (and Stose, Anna Isabel Jonas). Ocoee series of the southern Appalachians: Geol. Soc. Am. Bull., v. 60, no. 2, p. 267-320, illus. incl. geol. maps, Feb. 1949.

2. The fault at the west edge of the Triassic in southern Pennsylvania: Am. Jour. Sci., v. 247, no. 8, p. 531-536, illus. incl. geol. sketch map, Aug. 1949.

3. Obituary, Bailey Willis, 1857-1949: Washington Acad. Sci. Jour., v. 39, no. 10, p. 346-347, Oct. 15, 1949.

\section{Stout, Wilber Elihu.}

The Blue Hole, Ohio's most unusual natural spring: Watew Works Eng., v. 102 , no. 2 , p. 138 , Feb. 1949 . 
Stovall, John H. See Ammon, W. L., 2.

Stoyanow, Alexander Alexander.

1. Lower Cretaceous stratigraphy in southeastern Arizona: Geol. Soc. Am. Mem. 38, 169 p., illus. incl. index, geol. maps, July 8, 1949.

2. Sequence of Cambrian trilobite faunas in southeastern Arizona [abs.]: Geol. Soc. Am. Bull., v. 60, no. 12, pt. 2, p. 1922, Dec. 1949.

3. Occurrence of Texan Permian ammonoids in Arizona [abs.]: Geol. Soc. Am. Bull., v. 60, no. 12, pt. 2, p. 1946, Dec. 1949.

Strachan, Clyde G.

The geology at Spavinaw [Okla.]: Tulsa Geol. Soc. Digest, v. 17, p. 126$127,1949$.

\section{Strahler, Arthur Newell.}

1. Recent developments in quantitative analysis of erosional landforms [abs.]: Assoc. Am. Geog. Annals, v. 39, no. 1, p. 65, Mar. 1949.

2. Frequency-distribution analysis of slopes [abs.]: Geol. Soc. Am. Bull., v. 60 , no. 12 , pt. 2 , p. 1975 , Dec. 1949 .

Straley, Harrison Wilson, $3 d$.

1. How deep-seated are Appalachian anticlines?: W. Va. Acad. Sci. Proc., v. 20, p. 103-105, Mar. 1949; abs. with title "Is the basement complex involved in Appalachian folding?", 18th Internat. Geol. Cong., London, Volume of titles and abstracts, p. 29, 1948; Geophysics, v. 14, no. 3, p. 374, July 1949.

2. (and Richards, Horace Gardiner). The Atlantic Coastal Plain [abs.]: 18th Internat. Geol. Cong., London, Volume of titles and abstracts, p. $35,1948$.

\section{Strimple, Harrell LeRoy.}

1. Mooreocrinus bowsheri, new species from the Chester series of northeastern Oklahoma: Am. Jour. Sci., v. 247, no. 2, p. 128-131, illus., Feb. 1949.

2. (and Watkins, William T.) Hybocrinus crinerensis, new species from the Ordovician of Oklahoma: Am. Jour. Sei., v. 247, no. 2, p. 131133, illus., Feb. 1949.

3. Evolution of Delocrinus to Paradelocrinus, and description of Stuartwellercrinus argentinei sp. nov.: Geol. Mag., v. 86, no. 2, p. 123-127, illus., Mar.-Apr. 1949.

4. Crinoid studies; Pt. 3, Apographiocrinus arcuatus, new species from the Missouri series of Oklahoma; Pt. 4, Exocrinus, new genus from the Pennsylvanian of Oklahoma, Pt. 5, Allosocrinus, a new crinoid genus from the Pensylvanian of Oklahoma; Pt. 6, Allagecrinus copani, a new species from the Pennsylvanian of Oklahoma; Pt. 7, New species of crinoids from southeastern Kansas: Bull. Am. Paleontology, v. 32, no. 133, 42 p., illus., Apr. 28, 1949.

5. A group of Pennsylvanian crinoids from the Ardmore Basin [Okla.]: Palaeontographica Americana, v. 3, no. 23, pt. 1, p. 5-22, illus., May $20,1949$.

6. Delocrinids of the Brownville formation of Oklahoma: Paleontographica Americana, v. 3, no. 23, pt. 2, p. 22-23, illus., May 20, 1949.

7. Description of two new cromyocrinids from the Pennsylvanian of $\mathrm{Ne}-$ braska: Palaeontographica Americana, v. 3 , no. 23, pt. 3, p. 24-27, illus., May 20, 1949.

8. On new species of Alcimocrinus and Ulrichocrinus from the Fayetteville formation of Oklahoma: Palaeontographica Americana, v. 3, no. 23, pt. 4, p. 27-30, illus., May 20, 1949.

9. Two new species of Acrocrinus from the Pennsylvanian of Oklahoma: Am. Jour. Sci., v. 247, no. 12, p. 900-904, illus., Dec. 1949.

Stringham, Bronson Ferrin.

(and Taylor, Allen O.). Nontronite at Bingham, Utah [abs.]: Geol. Soc. Am. Bull., v. 60, no. 12 , pt. 2, p. 1923 , Dec. 1949.

9049790- $51-10$ 


\section{Strock, Lester William.}

1. The analysis of rock-forming minerals by spectrochemical methods in petrological research [abs.]: Am. Mineralogist, v. 34, nos. 3-4, p. 284, Mar.-Apr. 1949.

2. (and Dejnozka, Ladislav). Spectrochemical analysis of rocks [abs.]: Geol. Soc. Am. Bull., v. 60, no. 12, pt. 2, p. 1975, Dec. 1949.

\section{Stuart, Wilbur Tennant.}

(and Theis, Charles Vernon, and Stanley, George Mahon). Ground-water problems of the Iron River district [Mich.]: Mich. Geol. Survey, Tech. Rpt. 2, 59 p. (\$), illus. incl. index map, June 1948.

\section{Stuckey, Jasper Leonidas.}

Talc and soapstone in North Carolina [abs.]: N. C. Acad. Sci. Proc., in Elisha Mitchell Sci. Soc. Jour., v. 65, no. 2, p. 195, Dec. 1949.

Stumm, Erwin Charles. See also Ehlers, G. M., 1.

1. (and others). Tabulata, Favositidae [Unit 1-E, pt. B], in Type invertebrate fossils of North America (Devonian): Wagner Free Inst. Sci., Cards 115-260, 1949.

2. Revision of the families and genera of the Devonian tetracorals: Geol. Soc. Am. Mem. 40, viii, 92 p., illus., July 1, 1949.

3. Three new Devonian species of Microcyclus from Michigan and Ontario: Jour. Paleontology, v. 23, no. 5, p. 507-509, illus., Sept. 1949.

Sturgeon, Myron Thomas.

1. (and Merrill, William M.). An additional fossiliferous member in the Allegheny formation (Pennsylvanian) of Ohio: Ohio Jour. Sci., v.' 49 , no. 1 , p. 1-11, illus., Jan. 1949 ; reprinted as Ohio Geol. Survey Inf. Circ. 5, 1949.

2. (and Youngquist, Walter Lewellyn). Allegheny conodonts from eastern Ohio: Jour. Paleontology, v. 23, no. 4, p. 380-386, illus., July 1949.

Sullivan, C. J. See Edwards, A. B.

Sullivan, Geraldine R. See Faul, H., 1.

Summerford, H. Edgar.

1. (and Schieck, Emmett E. and Hiestand, Thomas Cleon). Newcastle sandstone, Upper Cretaceous, Wyoming: Wyo. Geol. Assoc. Guidebook, Powder River Basin, p. 69-79 ( $\$)$, illus., 1949.

2. (and Schieck, Emmett E., and Hiestand, Thomas Cleon). Lithofacies problems, Newcastle sandstone, Mush Creek and Skull Creek area, Weston County, Wyoming [abs.]: Geol. Soc. Am. Bull., v. 60, no. 12, pt. 2, p. 1965-1966, Dec. 1949 .

Summerson, Charles Henry.

The use of aerial photographs in geology: Ohio State Univ. Eng. Expt. Sta. News, v. 21, no. 1, p. 35-39, Feb. 1949.

Sundstrom, Raymond W.

(and Cromack, G. H., and West, N. N.). Ground-water resources of Matagorda County, Texas: Texas State Bd. Water Eng., 39 p. ( $\$)$, index, geol. maps, Apr. 1949.

Sutherland, P. K. See McLaren, D. J.

Swain, Frederick Morrill.

1. Early Tertiary Ostracoda from the western interior United States: Jour. Paleont., v. 23, no. 2, p. 172-181, illus., Mar. 1949.

2. Onlap, offlap, overstep, and overlap: Am. Assoc. Petrol. Geol. Bull., v. 33, no. 4, p. 634-636, Apr. 1949.

3. Upper Jurassic of northeastern Texas: Am. Assoc. Petrol. Geol. Bull., v. 33, no. 7 , p. 1206-1250, illus. incl. geol. map, July 1949. 


\section{Swan, Bird Glenn.}

Index of wells shot for velocity (Second Supplement) : Geophysics, v. 14, no. 1, p. 58-66, Jan. 1949.

\section{Swanson, Clarence Otto.}

1. The Sullivan mine, Kimberley, B. C., in Dunham, K. C., ed., Symposium on the geology, paragenesis and reserves of the ores of lead and zinc, 18th Internat. Geol. Cong., London, p. 36-41, illus., 1948; abs., Volume of titles and abstracts, p. 51, 1948.

2. A perspective on mining geology: Canadian Min. Met. Bull. no. 444, p. 170-173, Apr. 1949; Canadian Inst. Min. Met. Trans., v. 52, p. 89-92, 1949.

\section{Swartz, Frank MeKim.}

1. General characters of the Paleozoic sediments from western to central Pennsylvania and to western New York, in Pittsburgh Geological Society, Guidebook to the geology of the northern portion of the Appalachian Basin, p. 91-115, illus., 1948.

2. Muscle marks, hinge and overlap features, and classification of some Leperditiidae: Jour. Paleontology, v. 23, no. 3, p. 306-327, illus., May 1949.

3. Subsurface projection of Cambro-Ordovician sediments in the Pennsylvania-New York region and relation to oil and gas possibilities: Producers Monthly, v. 13, no. 11, p. 25-32, illus., Sept. 1949; Pt. 2, no. 12 , p. $28-31$, illus., Oct. 1949 ; Pt. 3 , v. 14 , no. 1 , p. 25-31, illus., Nov. 1949 ; Pt. 4, v. 14, no. 2, p. 34-39, illus., Dec. 1949.

Swartzman, E.

Analysis directory of Canadian coals: Canada Bur. Mines Memo ser. no. 100, 199 p. ( $¥)$, illus., Apr. 1948.

\section{Swenson, Frank Albert.}

Geology of the northwest fiank of the Gros Ventre Mountains, Wyoming: Augustana Library Pubs. no. 21, 75 p., illus. incl. index, geol. maps, 1949.

Swenson, Herbert A. See Littleton, R. T.; Waite, H. A.

Swineford, Ada. See also Bates, T. F., 2.

Source area of Great Plains Pleistocene volcanic ash: Jour. Geology, v. 57, no. 3, p. 307-311, index map, May 1949.

\section{Swinnerton, Allyn Coats.}

1. Hydrology and physiography of limestone terranes, Appendix A to Report of the committee on ground water, 1946-48: Am. Geophys. Union Trans., v. 30, no. 4, p. 600-601, Aug. 1949.

2. Artificial quartz by hydrothermal methods [abs.]: Am. Mineralogist, v. 34, nos. 3-4, p. 284, Mar.-Apr. 1949.

Swinney, C. Melvin. See Fix, P. F., 1.

\section{Swirezynski, R. P.}

The geology of the Northwest Sulphur pool, Murray County, Oklahoma: Tulsa Geol. Soc. Digest, v. 17, p. 89-93, illus., 1949.

\section{Switzer, George.}

Svanbergite from Nevada: Am. Mineralogist, v. 34, nos. 1-2, p. 104-108, illus., Jan.-Feb. 1949.

\section{Tague, Glenn Charles.}

The post-glacial geology of the Grand Marais Embayment in Berrien County, Michigan, in Occasional Papers for 1946 on the geology of Michigan; Mich. Geol. Survey Pub. 45, Geol. ser. 38, pt. 1, 82 p., illus. incl. index, geol. maps [ $\left.{ }^{\mathrm{c}} 1947\right]$. 
Taliaferro, David Ben. See Rall, C. G.

Tallman, Sefton L.

Sandstone types, their abundance and cernenting agents: Jour. Geology, v. 57, no. 6 , p. 582-591, Nov. 1949 .

Tanner, C. B.

(and Jackson, M. Lucille). Nomographs of sedimentation times for soil particles under gravity or centrifugal acceleration: Soil Sci. Soc. Am. Proc., v. 12, 1947, p. 60-65, illus., 1948.

Tanton, Thomas Leslie.

1. (and Harrison, James Merritt). The Flin Flon and Sherritt Gordon mines [Manitoba-Saskatchewan], in Dunham, K. C., ed., Symposium on the geology, paragenesis and reserves of the ores of lead and zinc, 18th Inernat. Geol. Cong., London, p. 42-45, illus., 1948; abs., Volume of titles and abstracts, p. 51, 1948.

2. Observations on concentrations of manganese ore minerals in Ungava [Canada] and Keonjhar [India]: Royal Soc. Canada Trans. 3d ser., v. 43 , sec. 4 , p. 113-117, illus., June 1949; abs., Proc. $3 d$ ser., v. 43, p. 239,1949 .

Tappan, Helen Nina. See Loeblich, A. R., Jr., 1, 2.

Tasch, Paul.

A new fossil locality in the Lower Cambrian Monkton formation of Vermont: Canadian Field-Naturalist, v. 63, no. 5, p. 210-211, illus., Sept.-Oct. 1949.

\section{Tator, Benjamin A.}

1. Valley widening processes in the Colorado Rockies: Geol. Soc. Am. Bull., v. 60 , no. 11 , p. 1771-1783, illus. incl. index maps, Nov. 1949.

2. University instruction in photogeology: Photogrammetric Engineering, v. 15 , no. 4 , p. 603-614, Dec. 1949 .

Tatum, James L.

Oil and gas exploration in the "Four Corners" area of Arizona, Colorado, New Mexico and Utah: World Oil, v. 129, no. 8, p. 69-70, 72, 74, 76, illus., Nov. 1949.

Taylor, Allen 0. See Stringham, B. F.

Taylor, Dorothy Ann. See Combo, J. X.

Taylor, George Carroll, Jr.

1. (and Lemoine, Rémy C.). Les rivières et les sources de la Plaine du Cul-de-Sac [Haïti]: Rev. Soc. Haïtienne Hist. Géog., v. 20, no. 75 , p. 1-7, Oct. 1949 .

2. (and Lemoine, Rémy C.). Les eaux souterraines "dans la plaine des Gonaives, Haïti: Rev. Soc. Haïtienne Hist. Géog., v. 20, no. 75, p. 8-33, geol. map, Oct. 1949.

Taylor, George Holmes.

(and Leggette, Ralph Maxwell). Ground water in the Jordan Valley, Utah: U. S. Geol. Survey Water-Supply Paper 1029, 356 p., illus. 1949.

Taylor, Russel N. See Mills, J. R.

\section{Taylor, Walter $\mathbf{P}$.}

The biotic community concept as applied in historical geology: Texas Jour. Sci., v. 1, no. 1, p. 34-40, Mar. 31, 1949.

Teichert, Curt.

Permian crinoid Calceolispongia: Geol. Soc. Am. Mem. 34, 132 p., illus., Feb. 10, 1949. 
Teller, James David.

Louis Agassiz, scientist and teacher. xi, 145 p., Columbus, Ohio. The Ohio State University Press, Graduate School Studies, Education series, no. 2. 1947.

\section{Terry, Ben E.}

Interpretation of seismic data: Mines Mag., v. 39, no. 12, p. 42-43, 51, 64, Dec. 1949.

Terry, Owen W. See Zinner, P.

\section{Tetrick, Paul Roderick.}

Glacial geology of the Oberon quadrangle [N. Dak.]: North Dakota Geol. Survey Bull. 23, 35 p., illus. incl. geol. map, 1949.

\section{Teufel, Virgil W.}

Offshore seismic exploration in Gulf [of Mexico]: Petrol. Eng., v. 21, no. 4, p. B7-B10, illus., Apr. 1949.

\section{Thacker, Edison.}

Squaw Peak [copper] mine [Ariz.]: Rocks and Minerals, v. 24, nos. 7-8, p. 376-377, index map, July-Aug. 1949.

\section{Thalmann, Hans Ernst.}

1. Homonyms of Foraminifera erected in 1947: Micropaleontologist, v. 3, no. 2, p. 28 ( $\ddagger)$, Apr. 1949.

2. Bibliography and index to new genera, species, and varieties of Foraminifera for the year 1947: Jour.. Paleontology, v. 23, no. 4, p. 395-418, July 1949 .

3. Bibliography and index to Foraminifera (Supplements and corrections for the period 1931 to 1947): Jour. Paleontology, v. 23, no. 5, p. 498-506, Sept. 1949 .

4. Bibliography and index to new genera, species, and varieties of Foraminifera for the year 1948: Jour. Paleontology, v. 23, no. 6, p. 641-668, Nov. 1949 .

5. Homonyms in Foraminifera erected during 1948 and 1949: Cushman Lab. Foram. Research Contr., v. 25 , pt. 4, no. 332, p. 100-103, illus., Dec. 1949.

6. The task of the micropaleontologist in petroleum geology [abs.] : 18th Internat. Geol. Cong., London, Volume of titles and abstracts, p. 36, 1948.

7. Foraminiferal evidence for Pliocene-Pleistocene boundary [abs.]: 18th Internat. Geol. Cong., London, Volume of titles and abstracts, p. 64, 1948.

Thayer, Thomas Prence. See Johnston, W. D., Jr.

Theis, Charles Vernon. See Stuart, W. T.

Thiel, George Alfred. See Emmons, W. H.

Thoenen, John Roy.

(and Warne, John David). Titanium minerals in central and northeastern Florida: U. S. Bur. Mines Kpt. Inv. 45i5, 62 p. ( $\ddagger)$, illus., Sept. 1949.

Thom, Emma Mertins.

(and Hooker, Marjorie, and Dunaven, Ruth Reece). Bibliography of North American geology, 1946 and 1947: U. S. Geol. Survey Bull. 958,658 p., 1949.

Thomas, Blakemore E.

Ore deposits of the Wallapai district, Arizona: Econ. Geology, v. 44, no. 8, p. 663-705, illus. incl. index, geol. maps, Dec. 1949. 
Thomas, Emil Paul.

The Jackson (Eocene) and younger beds of west-central Mississippi, in Mississippi Geological Society Guidebook, Sixth Field Trip, June 1820, 1948, p. 17-21 ( $), 1948$.

Thomas, Harold Edgar.

Ground water in Tooele Valley, Tooele County, Utah: Utah State Eng. Tech. Pub. 4, in Utah State Eng. 25th Bienn. Rpt., p. 91-238, illus. incl. index, geol. map, 1946.

\section{Thomas, Horace Davis.}

1. Geology and petroleum resources of Wyoming: Petrol. Eng., v. 20, no. 2, p. $128,130,134,136,138,188$, illus., Nov. 1948; reprinted as Wyo. Geol. Survey Contr., 9 p., illus. [1948].

2. Summary of Paleozoic stratigraphy of the Powder River Basin [Wyo.]: Wyo. Geol. Assoc. Guidebook, Powder River Basin, p. 43-45, 1949.

3. The geological history and geological structure of Wyoming: Wyo. Geol. Survey Bull. 42,28 p., illus., Oct. 1949; abs. with title "Regional stratigraphy and structure of Wyoming", Oil and Gas Jour., v. 46, no. 52, p. 113, Apr. 29, 1948.

Thomas, Leo A.

Devonian-Mississippian formations of southeast Iowa: Geol. Soc. Am. Bull., v. 60 , no. 3 , p. $403-437$, illus., Mar. 1949.

\section{Thomas, Ralph Nelson.}

Salt sands of eastern Kentucky: Appalachian Geol. Soc. Bull., v. 1, p. 167180, illus. incl. index map, 1949.

Thompson, George Albert See White, D. E., 3; Yates, R. G.

\section{Thompson, Henry Dewey.}

1. Drainage evolution in the Appalachians of Pennsylvania; N. Y. Acad. Sci. Annals, v. 52, art. 2, p. 31-62, illus., Aug. 12,1949 ; abs., N. Y. Acad. Sci. Trans., ser. 2, v. 11, no. 3, p. 97, Jan. 1949.

2. Structure-drainage relations in the Appalachian Mountains: N. Y. Acad. Sci. Trans., ser. 2 , v. 12 , no. 1 , p. 3-5, Nov. 1949.

Thompson, Marcus Luther. See also Moore, R. C., 3.

(and Mellen, Frederic Francis). Foraminifers in the Black Warrior Basin of Mississippi and Alabama, in Mississippi Geological Society Guidebook, 7th field trip, Aug. 24-27, 1949, p. 44-54, illus., 1949.

\section{Thompson, Raymond Melvin.}

(and Love, John Bavid, and Tourtelot, Harry Allison). Stratigraphic sections of pre-Cody Upper Cretaceous rocks in central Wyoming [with text]; U. S. Geol. Survey Oil and Gas Invs. Prelim. Chart no. 36 (2 sheets), 1949.

Thompson, Robert Mitchell. See also Warren, H. V., 2.

1. The telluride minerals and their occurrence in Canada: Am. Mineralogist, v. 34, nos. 5-6, p. 342-382, illus., May-June 1949.

2. Goongarrite and warthaite discredited: Am. Mineralogist, v. 34, nos. 5-6, p. 459-460, May-June 1949.

Thompson, Thomas Francis. See Woodring, W. P., 1.

Thompson, Thomas L. See Wheeler, H. E.

Thompson, Warren C.

Ocean floor investigations along Santa Barbara County coast [Calif.] [abs.]: Am. Assoc. Petrol. Geol. Bull., v. 33, no. 12, p. 2062, Dec. 1949; Oil and Gas Jour., v. 48, no. 29, p. 139 , Nov. $24,1949$. 
Thompson, Warren Osborne.

Lyons sandstone of Colorado Front Range: Am. Assoc. Petrol. Geol. Bull., v. 33 , no. 1, p. 52-72, illus., Jan. 1949.

\section{Thomson, James Edgar.}

Geology of Hearst and McFadden townships [Ontario]: Ontario Dept. Mines Ann. Rpt., v. 56, pt. 8, 1947, 34 p., illus. incl. index, geol. maps, 1949.

\section{Thorp, James.}

1. Pleistocene research, a review by the members of the committee on interrelations of Pleistocene research, National Research Council; 12, Interrelations of Pleistocene geology and soil science: Geol. Soc. Am. Bull., v. 60 , no. 9, p. 1517-1525, Sept. 1949.

2. (and Smith, Harold Theodore Uhr). Map of eolian deposits in North America [abs.]: Geol. Soc. Am. Bull., v. 60 , no. 12, pt. 2, p. 1923, Dec. 1949.

\section{Thurston, Anthony W.}

Reviewing the Narragansett Basin [Mass.-R. I.]: Rocks and Minerals, v. 24, nos. 5-6, p. 262-266, illus., May-June 1949.

\section{Thurston, William Robert.}

The Daisy fluorspar deposit near Beatty, Nye County, Nevada: U. S. Geol. Survey, Strategic Mineral Invs. Prelim. Rpt. 3-209, 10 p. ( $)$, illus. incl. index, geol. maps [1949].

\section{Thwaites, Fredrik Turville.}

Geomorphology of the basin of Lake Michigan: Mich. Acad. Sci. Arts and Letters, Papers, v. 33 (1947), p. 243-251, illus., 1949.

Tigert, T. T.

Geology of Central Patricia mine [Ontario]: Canadian Min. Jour., v. 70, no. 11 , p. 72-75, illus. incl. geol. sketch map, Nov. 1949.

\section{Tiphane, Marcel.}

Preliminary report on e Chaste map-area, Abitibi-East County [Quebec]: Quebec Dept. Mines Prelim. Rpt. 219, 10 p. (\$), index, geol. maps, 1948.

Tipper, Howard W. See Canada Geol. Survey, 3,4 .

\section{Tixier, M. P.}

Evaluation of permeability from electric-log resistivity gradient: Oil and Gas Jour., v. 48, no. 6, p. 113, 117, 118, 120, 122, 123, June 16, 1949; summary, Tulsa Geol. Soc. Digest, v. 17, p. 69-73, 1949.

Todd, Margaret Ruth. See also Cushman, J. A., 1, nos. 325, 329, 331.

Joseph A [ugustine] Cushman 1881-1949: Micropaleontologist, v. 3, no. 3, p. 15-18 (†), port., July 1949.

\section{Toenges, Albert Louis.}

1. (and others). Investigation of coal deposits in the Fairview and Coal City Basins of Coosa field, St. Clair County, Ala. 1. Investigation of field and estimated reserves: U. S. Bur. Mines Tech. Paper 719, p. 2-21, illus., 1949.

2. (and others). Reserves, petrographic and chemical characteristics, and carbonizing properties of coal occurring south of Dry Fork of Minnesota Creek, Gunnison County, near Paonia, Colo., and the geology of the area: U. S. Bur. Mines Tech. Paper 721, 48 p., illus. incl. index maps, 1949. 
Toenges, Albert Louis-Continued

3. (and Turnbull, Louis Allan, and Williams, Lloyd). Investigation of lower coal beds in Georges Creek and north part of Upper Potomac Basins, Allegany and Garrett Counties, Md., 1. Investigation of field and estimated reserves: U. S. Bur. Mines Tech. Paper 725, p. 3-14, illus., 1949.

4. (and Jolley, Theodore Roosevelt). Investigation of coal deposits in south central Alaska and the Kenai Peninsula: U. S. Bur. Mines Rpt. Inv. 4520, 37 p. ( $\ddagger)$, illus. incl. index map, May 1949 .

Tollefson, Everett Harold.

(and Mayfield, William W., and McCamey, A. R.). A report on new gas developments in southern West Virginia: Oil and Gas Jour., v. 47, no. 14, p. $82,85-86,89-91$, illus., Aug. 5, 1948; reprinted in Appalachian Geol. Soc. Bull., v. 1, p. 239-247, illus., 1949.

Tolman, Carl. See also Robertson, F. S.

Mining geology and geophysics: Min. Congress Jour., v. 35, no. 2, p. 88-91, illus., Feb. 1949.

Tolstoy, Ivan. See also Press, F.

1. (and Ewing, William Maurice). North Atlantic hydrography and the Mid-Atlantic Ridge: Geol. Soc. Am. Bull., v. 60, no. 10, p. 1527-1540, illus. incl. index maps, Oct. 1949 .

2. Submarine topography in the north Atlantic [abs.]: Geol. Soc. Am. Bull., v. 60 , no. 12 , pt. 2 , p. 1924 , Dec. 1949.

3. (and Ewing, William Maurice, and Press, Frank). " $T$ " phase of shallowfocus submarine earthquakes [abs.]: Geol. Soc. Am. Bull., v. 60, no. 12 , pt. 2, p. 1957 , Dec. 1949 .

Tomlinson, W. Harold.

Assimilation (?) of micaceous schist by diabase [abs.]: Geol. Soc. Am. Bull., v. 60, no. 12 , pt. 2 , p. 1924-1925, Dec. 1949.

Torgeson, D. R. See Sahama, T. G., 1, 2, 3.

Torre Mandrazo, Ricardo de la.

(and Rojas, Luis E.). Una nueva especie y dos subespecies de icthyosauria del Jurasico de Viñales, Cuba: Soc. Cubana Historia Nat. Mem. Museo Poey, v. 19, no. 2, p. 197-202, illus., Nov. 1949.

Torreson, $\mathbf{0}$. W.

(and Murphy, Thomas, and Graham, John W.). Magnetic polarization of sedimentary rocks and the earth's magnetic history: Jour. Geophys. Research, v. 54, no. 2, p. 111-129, illus., June 1949.

Tourtelot, Harry Allison. See Thompson, Raymond M.; U. S. G. S. 2, no. 36.

Tousignant, Constance.

Analyse spectrographique d'une série de roches du canton Landrienne [Quebec] [abs.]: Assoc. Canadienne-Française Av. Sci. Annales v. 15 , p. 72,1949 .

\section{Townsend, Helen Gertrude.}

Annotated bibliography of economic geology for 1948, v. 21, no. 1, p. 1-96, Jan. 1949 ; no. 2 , p. $97-191$, A pr. 1949 ; for 1949 , v. 22 , no. 1 , p. 1117, Oct. 1949; no. 2, p. 118-252, Apr. 1950.

Tracey, Joshua Irving, Jr. See Gordon, M., Jr.; Ladd, H. S., 1.

Trask, Parker Davies. See also Rodriguez Cabo, J., Jr.

Recent sediments in Gulf of Mexico as source beds of petroleum [abs.]: Oil and Gas Jour., v. 47, no. 46, p. 109, Mar. 17, 1949. 
Treadwell, T. K., Jr.

Submarine topography of the continental slope of the northwest of Mexico: Calif. Univ., Scripps Inst. Oceanog., Submarine Geology Rpt. No. 7, 7 p. (\$), map; Sept. 1949.

\section{Treasher, Raymond Clarence.}

1. Engineering geology of the Isabella project, California [abs.]: Geol. Soc. Am. Bull., v. 60, no. 12, pt. 2, p. 1946, Dec. 1949.

2. Kern County fault, Kern County, California [abs.]: Geol. Soc. Am. Bull., v. 60, no. 12 , pt. 2, p. 1958, Dec. 1949.

\section{Trefethen, Joseph Muzzy.}

1. Geology for engineers. xi, 620 p., illus. New York. D. Van Nostrand Co. Inc. [ ${ }^{\mathrm{C}} 1949$ ].

2. Review of the Aroostook County [Maine] manganese deposits: Maine State Geologist Rpt. 1947-1948, p. 8-10, Mar. 1949.

3. Notes on ground water conditions in Maine: Maine State Geologist Rpt. 1947-1948, p. 11-19, illus., Mar. 1949.

4. The Desert of Maine, Freeport, Maine: Maine State Geologist Rpt. 19471948 , p. 20-22, illus., Mar. 1949.

5. Geology for civil engineers: Jour. Eng. Education, v. 39, no. 7, p. 383385, Mar. 1949; reprinted as Maine Univ., Technology Expt. Sta. Paper 56, June 1949.

\section{Trelease, Sam Farlow.}

(and Beath, Orville Andrew). Selenium; its geological occurrence and its biological effects in relation to botany, chemistry, agriculture, nutrition, and medicine. 292 p., illus. Published by the authors, Box 42, Schermerhorn Hall, Columbia University, N. Y. 1949.

\section{Troelsen, Johannes C.}

Contributions to the geology of the area round Jørgen Brønlunds Fjord, Peary Land, North Greenland: Meddelelser om Grønland, Bind 149, no. 2, 28 p., illus. incl. index, geol. map, 1949; Copenhague Univ. Mus Minér. Géol., Commun. Géol. no. 34, 1949.

\section{Tromp, Soleo Walle.}

Additional information on the so-called "Middle Tertiary Orbulina surface": Micropaleontologist, v. 3, no. 3, p. $14(\ddagger)$, July 1949.

Trowbridge, A. H. See Robertson, D. A.

Truscott, Frederick W. See Martens, J. H. C.

Tucker, Rietz Courtney. See Price, P. H., 1.

Tucker, William Burling, 1880-1948.

(and Sampson, Reid J., and Oakeshott, Gordon Blaisdell). Mineral resources of Kern County [Calif.]: Calif. Jour. Mines and Geology, v. 45, no. 2, p. 203-297, illus., Apr. 1949.

Tullis, Edward Langdon. See Pesonen, P. E., 1.

\section{Tunell, George.}

1. Presentation of the Roebling Medal of the Mineralogical Society of America to William Laurence Bragg: Am. Mineralogist, v. 34, nos. 3-4, p. 235-237, Mar.-A pr. 1949.

2. (and Adams, C. E.). On the symmetry and crystal structure of bornite: Am. Mineralogist, v. 34, nos. 11-12, p. 824-829, illus., Nov.-Dec. 1949 .

3. The teaching of X-ray crystallography [abs.]: Am. Mineralogist, v. 34, nos. 3-4, p. 292, Mar.-Apr. 1949. 
Turnbull, Louis Allan. See Toenges, A. L., 1, 2, 3.

Turnbull, William Jay.

(and Fisk, Harold Norman). Relation of soil mechanies and geology in foundation exploration, lower Mississippi Valley: 2d Internat. Conf. Soil Mechanics and Foundation Eng., Rotterdam, Proc. v. 3, p. 3-5 $(\ddagger), 1948$.

Turner, Daniel S.

Development of a new thermal feature in Yellowstone National Park: Am. Geophys. Union Trans., v. 30, no. 4, p. 526-527, Aug. 1949.

Turner, Francis John. See also Gilbert, C. M., 2.

Preferred orientation of calcite in Yule marble: Am. Jour. Sci., v. 247, no. 9, p. 593-621, illus., Sept. 1949.

Turner, Roy Wilbur. See Hackel, 0.

Tuttle, Orville Frank. See also Bowen, N. L., 1, 3, 4.

1. Structural petrology of planes of liquid inclusions: Jour. Geology, v. 57 , no. 4, p. 331-356, illus., July 1949; abs. with title "Structural relations of planes of liquid inclusions in the crystalline rocks of the Washington (D. C.) area", Am. Geophys. Union Trans., v. 26, no. 2, p. 301 , Oct. 1945.

2. The variable inversion temperature of quartz as a possible geologic thermometer: Am. Mineralogist, v. 34, nos. 9-10, p. 723-730, illus., Sept.Oct. 1949: abs., nos. 3-4, p. 284, Mar.-Apr. 1949; Geol. Soc. Am. Bull., v. 59, no. 12 , pt. 2, p. 1359 , Dec. 1948.

3. Two pressure vessels for silicate-water studies: Geol. Soc. Am. Bull., v. 60 , no. 10 , p. $1727-1729$, illus., Oct. 1949.

4. (and Bowen, Norman Levi). High-temperature albite [abs.]: Geol. Soc. Am. Bull., v. 60, no. 12, pt. 2, p. 1925 , Dec. 1949.

Twenhofel, William Henry.

Characteristics and geologic distribution of coral and other organic reefs: World Oil, v. 129, no. 3, p. 61-62, 64, illus., July 1949.

Twenhofel, William Stephens.

(and Reed, John Calvin, and Gates, George Oscar). Some mineral investigations in southeastern Alaska: U. S. Geol. Survey Bull. 963-A, 44 p., illus. incl. index map, 1949.

Tweto, Ogden L.

Stratigraphy of the Pando area, Eagle County, Colorado: Colo. Sci. Soc. Proc., v. 15, no. 4, p. 149-235, illus. incl. index, geol. map, 1949.

Tyler, Paul McIntosh.

The mineral needs of New Jersey industries: Rutgers Univ. Bur. Mineral Research Bull. 4, 62 p., illus., 1948.

Tyler, Stanley Allen.

Development of Lake Superior soft iron ores from metamorphosed iron formation: Geol. Soc. Am. Bull., v. 60, no. 7, p. 1101-1124, illus., July 1949; abs., v. 58, no. 12 , pt. 2, p. 1235, Dec. 1947.

United States Atomic Energy Commission.

(and United States Geological Survey). Prospecting for uranium. 123 p., illus., Washington, D. C. Government Printing Office, 1949.

United States Geological Survey. See also U. S. Atomic Energy Commission.

1. Oil and gas investigations, preliminary maps:

No. 80. Rocks of Permian (?) age in the Colorado River Valley, northcentral Texas [geologic map and text], by Raymond Cecil Moore. Two sheets. Scale 1 inch to 1 mile. 1949. 
United States Geological Survey-Continued

No. 83. Geology of the northwestern Puente Hills, Los Angeles County, California, by Steven Norman Daviess and Alfred Oswald Woodford. Text with map, Stratigraphy and structure of northwestern Puente Hills, California. Two sheets. Scale 1 inch to 1000 feet. 1949.

No. 88. Geology of the Newport-Waldport area, Lincoln County, Oregon [geologic map and text], by Harold Ernest Vokes, Hans Norbisrath, and Parke Detweiler Snavely, Jr. Scale 1 inch to 1 mile. 1949.

No. 90. Regional geologic map of parts of Culberson and Hudspeth Counties, Texas [with text], by Philip Burke King. Scale 1 inch to 12,000 feet. 1949.

No. 92. Geology of the Glendo area, Wyoming, by John David Love, Norman Maclaren Denson, and Theodore Botinelly. Text with map, Geology and oil and gas possibilities of the Glendo area, eastern Wyoming. Scale 1 inch to 4000 feet. 1949.

No. 94. Geology of Naval Oil Shale Reserves 1 and 3, Garfield County, Colorado [geologic map and text], by Donald Cave Duncan and Norman Maclaren Denson. Two sheets. Scale 1 inch to $1 / 2$ mile. 1949.

No. 95. Geology of the Iniskin Peninsula, Alaska [geologic map and text], by Charles Elbert Kirschner and David Lee Minard. Scale 1 inch to 4000 feet. 1948.

No. 96. Stratigraphy and geologic structure in the Piedra River Canyon, Archuleta County, Colorado [geologic map and text], by Charles Brian Read, Gordon $\mathrm{H}$. Wood, Jr., Alexander Andrew Wanek, and Pedro Verastegui Mackee. Scale approx. 1 inch to 1 mile. 1949.

No. 97. Geology of the coastal area between Cape Kiwanda and Cape Foulweather, Oregon [geologic map with text], by Parke Detweiler Snavely, Jr. and Harold Ernest Vokes. Scale 1 inch to 1 mile. 1949.

No. 98. Geology of the Woodbine formation of Cooke, Grayson, and Fannin Counties, Texas [geologic map and text], by Harlan Richard Bergquist. Scale 1 inch to 1 mile. Two sheets. 1949.

No. 99. Map of the Berea sand of northern Ohio [with descriptive notes], by Wallace de Witt, Jr. Revision of Prelim. Map no. 39 (1945). Scale 1 inch to 3 miles. 1949.

No. 100. Early Silurian rocks of the northern Appalachian Basin, by Gordon Rittenhouse. One sheet, maps with descriptive notes. Scale 1 inch to 40 miles. 1949.

No. 101. Pre-Pennsylvanian geology of southwestern Kansas, southeastern Colorado, and the Oklahoma Panhandle [geologic maps and text], by John Charles Maher and Jack Beverly Collins. Four sheets. Scale 1 inch to 14 miles. 1949.

No. 102. Geology of the Hartville Uplift, eastern Wyoming, by Norman Maclaren Denson and Theodore Botinelly. Text with map, Geology and oil and gas possibilities of the Hartville Uplift and adjacent areas, eastern Wyoming. Two sheets. Scale 1 inch to 4000 feet. 1949 .

No. 103. Geology of the Mush Creek and Osage oil fields and vicinity [Wyo.] [geologic maps and text], by Carroll Edward Dobbin and George Henry Horn. Scale 1 inch to 2 miles. 1949.

No. 107. Map of Wyoming showing test wells for oil and gas, anticlinal axes, oil and gas fields, pipelines, unit areas, and land district boundaries, by Eleanor K. Keefer, Maxine W. Allen, Raymond M. Larsen, and John D. Love. Scale 1:500,000 or approx. 1 inch to 8 miles. 1949.

No. 109. Geology and coal resources of the Durango area, La Plata and Montezuma Counties, Colorado [geologic map with text], by Alfred Dexter Zapp. Two sheets. Scale 1 inch to 2 miles. 1949.

2. Oil and gas investigations, preliminary charts:

No. 34. Lower Tertiary stratigraphy of Mount Diablo, Marysville Buttes, and west border of Lower Central Valley of California [text, geologic sections], by Ralph Bentley Stewart. Two sheets. 1949. 


\section{United States Geological Survey-Continued}

No. 36. Stratigraphic sections of pre-Cody Upper Cretaceous rocks in central Wyoming [with text], by Raymond Melvin Thompson, John David Love, and Harry Alison Tourtelot. Two sheets. 1949.

No. 38. Upper Mississippian rocks of southwestern Virginia, southern West Virginia, and eastern Kentucky, by Ralph Henry Wilpolt and Douglas W. Marden. Three sheets with descriptive text. 1949.

3. Total intensity aeromagnetic map of Benton County, Indiana. Scale 1 inch to 1 mile. 1949.

4. Total intensity aeromagnetic map of Fulton County, Indiana. Scale 1 inch to 1 mile, 1949 .

5. Total intensity aeromagnetic map of Jasper County, Indiana. Scale 1 inch to 1 mile. 1949.

6. Total intensity aeromagnetic map of Lake County, Indiana. Scale 1 inch to 1 mile. 1949 .

7. Total intensity aeromagnetic map of La Porte County, Indiana. Scale 1 inch to 1 mile. 1949 .

8. Total intensity aeromagnetic map of Newton County, Indiana. Scale 1 inch to 1 mile. 1949 .

9. Total intensity aeromagnetic map of Posey County, Indiana. Scale 1 inch to 1 mile. 1949 .

10. Total intensity aeromagnetic map of Pulaski County, Indiana. Scale 1 inch to 1 mile. 1949.

11. Total intensity aeromagnetic map of Starke County, Indiana. Scale 1 inch to 1 mile. 1949.

12. Total intensity aeromagnetic map of White County, Indiana. Scale 1 inch to 1 mile. 1949 .

13. Total intensity aeromagnetic profiles of the southern part of Beltrami County, Minnesota, traverses 32-49, 50-67. Two sheets. Scale 1 inch to 2 miles. 1949 .

14. Total intensity aeromagnetic map of the central part of Cass County, Minnesota. Scale 1 inch to 1 mile. 1949.

15. Total intensity aeromagnetic profiles of the central part of Cass County, Minnesota, traverses 1-42. Scale 1 inch to 2 miles. 1949.

16. Total intensity aeromagnetic profiles of the northern part of Cass County, Minnesota, traverses 1-42. Scale 1 inch to 2 miles. 1949.

17. Total intensity aeromagnetic map of the southern part of Cass County, Minnesota. Scale 1 inch to 1 mile. 1949.

18. Total intensity aeromagnetic profiles of the southern part of Cass County, Minnesota, traverses 25-48. Scale 1 inch to 2 miles. 1949.

19. Total intensity aeromagnetic map of the northern part of Crow Wing County and part of Cass County, Minnesota. Scale 1 inch to 1 mile. 1949.

20. Total intensity aeromagnetic profiles of the northern part of Crow Wing County and part of Cass County, Minnesota, traverses 1-27. Scale 1 inch to 2 miles. 1949.

21. Total intensity aeromagnetic map of the southern part of Crow Wing County, Minnesota. Scale 1 inch to 1 mile. 1949.

22. Total intensity aeromagnetic profiles of the southern part of Crow Wing County, Minnesota, traverses 3-29. Scale 1 inch to 2 miles. 1949 .

23. Total intensity aeromagnetic map of part of Hubbard County, Minnesota. Scale 1 inch to 1 mile. 1949 .

24. Total intensity aeromagnetic profiles of part of Hubbard County, Minnesota, traverses 43-67. Scale 1 inch to 2 miles. 1949.

25. Total intensity aeromagnetic map of Wadena County and part of Hubbard County, Minnesota. Scale 1 inch to 1 mile. 1949.

26. Total intensity aeromagnetic profiles of Wadena County and part of Hubbard County, Minnesota, traverses 43-66. Scale 1 inch to 2 miles. 1949.

27. Total intensity aeromagnetic map of the western part of Itasca County, Minnesota. Scale 1 inch to 1 mile. 1949.

28. Total intensity aeromagnetic profiles of the western part of Itasca County, Minnesota, traverses 1-31. Scale 1 inch to 2 miles. 1949. 


\section{United States Geological Survey-Continued}

29. Total intensity aeromagnetic map of the eastern part of Morrison County, Minnesota. Scale 1 inch to 1 mile. 1949.

30. Total intensity profiles of the eastern part of Morrison County, Minnesota, traverses 1-29. Scale 1 inch to 2 miles. 1949.

31. Total intensity aeromagnetic map of the western part of Morrison County, Minnesota. Scale 1 inch to 1 mile. 1949.

32. Total intensity aeromagnetic map of Todd County, Minnesota. Scale 1 inch to 1 mile. 1949 .

33. Total intensity aeromagnetic profiles of Todd County, Minnesota, traverses 43-66. Scale 1 inch to 2 miles. 1949.

34. Total intensity aeromagnetic map of Coldwater quadrangle, Missouri. Scale 1 inch to 2 miles. 1949 .

35. Total intensity aeromagnetic map of Des Arc quadrangle, Missouri. Scale 1 inch to $1 / 2$ mile. 1949.

36. Total intensity aeromagnetic map of De Soto quadrangle, Missouri. Scale 1 inch to 2 miles. 1949.

37. Total intensity aeromagnetic map of Farmington quadrangle and part of Crystal City quadrangle, Missouri. Scale 1 inch to $1 / 2$ mile. 1949 .

38. Total intensity aeromagnetic map of Fredericktown quadrangle, Missouri. Scale 1 inch to $1 / 2$ mile. 1949.

39. Water resources and hydrology of southeastern Alabama: Ala. Geol. Survey Spec. Rpt. 20, 265 p., illus. incl. geol. map, 1949. Contains papers by Fhilip E. LalMoreaux and others.

40. Interpreting ground conditions from geologic maps: U. S. Geol. Survey Circ. 46,10 p. ( $\ddagger)$, illus., geol. maps, May 1949 .

Unklesbay, Athel Glyde.

An unusual specimen of the genus Athyris [Mo.]: Jour. Paleontology, v. 23 , no. 3, p. 328-329, illus., May 1949.

Untermann, Billy R. See Untermann, G. E., 1, 2.

Untermann, George E.

1. (and Untermann, Billy R.). Geology of Green and Yampa River Canyons and vicinity, Dinosaur National Monument, Utah and Colorado: Am. Assoc. Petrol. Geol. Bull., v. 33, no. 5, p. 683-694, illus. incl. index map, May 1949 .

2. (and Untermann, Billy R.). The Morgan formation of Whirlpool Canyon, Green River Dinosaur National Monument, Uintah County, Utah, in The oil and gas possibilities of Utah, by G. H. Hansen and M. M. Bell: Utah Geol. Miner. Survey, p. 219-234, illus., Dec. 1949.

Upson, Joseph E.

1. Late Pleistocene and Recent changes of sea level along the coast of Santa Barbara County, California: Am. Jour. Sci., v. 247, no. 2, p. 94-115, illus. incl. index map, Feb. 1949.

2. Former marine shore lines of the Gaviota quadrangle, Santa Barbara County, California [abs.]: Geol. Soc. Am. Bull., v. 60, no. 12, pt. 2, p. 1925-1926, Dec. 1949 .

Urey, Farold C.

A hypothesis regarding the origin of the movements of the earth's crust [abs.]: Science, v. 110 , no. 2861 , p. 445-446, Oct. $28,1949$.

\section{Urry, William Donald.}

Significance of radioactivity in geophysics; thermal history of the earth, in Symposium on the earth's crust: Am. Geophys. Union Trans., v. 30, no. 2, p. 171-180, illus., Apr. 1949.

\section{Valentine, Grant M.}

Inventory of Washington minerals; Part 1, Nonmetallic minerals: Wash. Dept. Conserv. Dev., Div. Mines and Geology Bull. 37, 113 p., maps, 1949. 


\section{Vance, Louis W.}

Collecting apatite crystals at Durango, Mexico: Rocks and Minerals, v, 24, nos. 7-8, p. 368-371, illus., July-Aug. 1949.

\section{Van Horn, Earl C.}

1. Talc deposits of the Murphy marble belt: N. C. Dept. Conserv. Dev., Div. Mineral Res. Bull. 56, 54 p., illus. incl. geol. maps, 1948.

2. (and Le Grand, J. R., and McMurray, Lynn Lloyd). Geology and preliminary ore dressing studies of the Carolina barite belt: N. C. Dept. Conserv. Dev., Div. Mineral Res. Bull. 57, 25 p., illus., 1949.

3. New barite possibilities revealed in the Carolinas: Eng. Min. Jour., v. 150 , no. 7 , p. $76-78$, illus. incl. index map, Jan. 1949.

\section{Van Houten, Franklyn Bosworth.}

[Discussion], in Longwell, C. R., chm., Sedimentary facies in geologic history [symposium]: Geol. Soc. Am. Mem. 39, p. 152-154, June 17, 1949 .

\section{Van Tuyl, Francis Maurice.}

1. (and Levings, William Stephen). Pliocene Ogallala algal limestone in Union County, New Mexico: Am. Assoc. Petrol. Geol. Bull., v. 33, no. 8, p. 1429-1430, Aug. 1949.

2. Geological engineering at the Colorado School of Mines: Mines Mag., v. 39 , no. 12 , p. $37-41,100$, illus., Dec. 1949.

\section{Van Valkenburg, Samuel.}

Wallace W[alter] Atwood [1872-1949]: Geog. Rev., v. 39, no. 4, p. 675676, Oct. 1949.

Varnes, David Joseph. See Schwartz, G. M., 2.

\section{Vernon, Robert Orion.}

Stratigraphic, structural, and correlation studies of Florida Tertiary [abs.]: Am. Assoc. Petrol. Geol. Bull., v. 33, no. 12, p. 2070, Dec. 1949 ; Oil and Gas Jour., v. 48, no. 25, p. 87, Oct. 27, 1949.

Ver Wiebe, Walter August.

1. Oil fields in North America. iv, 251 p. (\$), illus. Wichita, Kans., Edwards Bros. 1949.

2. (and Jewett, John Mark, and Nixon, Earl K.). Oil and gas developments in Kansas during 1948: Kans. Univ., State Geol. Survey Bull. 78, 186 p., illus., Sept. 1949.

Vesselowsky, Sergius Theodore. See Rabbitt, M. C.; Skitsky, V. L.

Veytia, Mario. See Wilson, I. F., 2.

Vhay, John Stewart. See Glass, J. J.

Visher, Stephen Sargent.

1. François Emile Matthes, 1874-1948: Assoc. Am. Geog. Annals, v. 38, no. 4, p. 301-304, port., Dec. 1948.

2. Bailey Willis, 1857-1949: Assoc. Am. Geog. Annals, v. 39, no. 4, p. 291292, Dec. 1949.

Vitaliano, Charles J. See Mason, B. H., 2.

Vogel, Felix A., Jr. See Hill, H. B., 1.

Voigt, Dorothy Stanley.

(and Byerly, Perry). The intensity of earthquakes as rated from questionnaires: Seismal. Soc. Am. Bull., v. 39, no. 1, p. 21-26, Jan. 1949. 
Vokes, Harold Ernest. See also Snavely, P. D., Jr.; U. S. G. S. 1, no. 97.

1. (and Norbisrath, Hans, and Snavely, Park Detweiler, Jr.). Geology of the Newport-Waldport area, Lincoln County, Oregon [geologic map and text]: U. S. Geol. Survey Oil and Gas Invs. Prelim. Map no. 88. Scale 1 inch to 1 mile. 1949.

2. Maryland dinosaurs: Maryland Naturalist, v. 19 , no. 3, p. 38-46, illus., Summer 1949.

3. The hinge and marginal pectinations of Nuculoidea opima (Hall), type of Nuculoidea Williams and Breger: Washington Acad. Sci. Jour., v. 39 , no. 11 , p. 361-363, illus., Nov. $15,1949$.

Von Gliszczynski, Siegfried.

Gems from the sky [tektites] : Earth Sci. Digest, v. 3, no. 6, p. 18-20, Jan. 1949.

\section{von Huene, Rudolf.}

1. Grain-thin sections and other teaching aids in optical mineralogy: Am. Mineralogist, v. 34, nos. 1-2, p. 121-125, Jan.-Feb. 1949.

2. Notes on Lakeside No. 70 transparent cement: Am. Mineralogist, v. 34, nos. 1-2, p. 125-127, Jan.-Feb. 1949.

\section{Waage, Karl Mensch.}

Investigation of lower coal beds in Georges Creek and north part of Upper Potomac Basins, Allegany and Garrett Counties, Md., 4. Stratigraphy of Georges Creek coal basin: U. S. Bur. Mines Tech. Paper 725 , p. 19-26, illus., 1949 .

\section{Wade, Frank Bertram.}

Another rough diamond found in Indiana: Gems and Gemology, v. 6, no. 8, p. 249-250, illus., Winter 1949-50.

\section{Waesche, Hugh Henry.}

Importance and application of piezoelectric minerals: Min. Eng., v. 1, no. 1, p. 12-16, Jan. 1949; A.I.M.E., Trans., v. 184, 1949.

\section{Wager, Lawrence Rickard.}

The mountains of East Greenland and their origin [abs.]: Royal Philos. Soc. Glasgow Proc., v. 71, p. 91-92, 1946.

\section{Wagner, Warren Richard.}

1. The geology of part of the south slope of the St. Joe Mountains, Shoshone County, Idaho: Idaho Bur. Mines and Geology Pamph. 82, 48 p., illus. incl. index, geol. maps, Feb. 1949.

2. Petrofabric analysis, in Subsurface geologic methods: Colo. Sch. Mines Quart., v. 44, no. 3, p. 135-150, illus., July 1949.

\section{Wahl, Walter.}

Isostasy and the origin of sial and sima and of parental rock magmas: Am. Jour. Sci., v. 247, no. 3, p. 145-167, Mar. 1949.

\section{Wahl, William G.}

1. (and Osborne, Freleigh Fitz). Preliminary report on the Cawatose area, Pontiac County [Quebec]: Quebec Dept. Mines Prelim. Rpt. 202, 8 p. ( $\ddagger)$, index, geol. maps, 1947.

2. Preliminary report on Témiscamie River map-area, Mistassini Territory [Quebec]: Quebec Dept. Mines Prelim. Rpt. 211, 13 p. ( $\$)$, index, geol. maps, 1947.

\section{Wahlstrom, Ernest Eugene.}

Melonite from Boulder County, Colorado [abs.]: Geol. Soc. Am. Bull., v 60, no. 12 , pt. 2 , p. 1926 , Dec. 1949. 


\section{Wahrhaftig, Clyde.}

1. (and Freedman, Jacob). Coal deposits in the valley of the Healy River, Alaska: U. S. Geol. Survey, 11 p. ( $\ddagger)$, illus. incl. index, geol. maps, 1945.

2. The frost-moved rubbles of Jumbo Dome and their significance in the Pleistocene chronology of Alaska: Jour. Geology, v. 57, no. 2, p. 216231, iilus. incl. index, geol. maps, Mar. 1949.

\section{Waite, Herbert Ames.}

(and others). Progress report on the geology and ground-water hydrology of the Lower Platte River valley, Nebraska, with a section on the chemical quality of the ground water by Herbert A. Swenson: U. S. Geol. Survey Circ. 20, 211 p. $(\ddagger)$, illus. incl. index map, Jan. 1949.

\section{Wales, Donald B.}

Cambrian strata on the southern shore of Devon Island in the Arctic Archipelago: Jour. Geology, v. 57, no. 3, p. 330, May 1949.

Walker, A. C. See Buehler, E. J.

Walker, George Walton. See Heyl, G. R., 8.

Walkom, A. B.

Memorial to Ernest Clayton Andrews [1870-1948]: Geol. Soc. Am. Proc. 1948 , p. 117-126, port., May 1949.

Wallace, Louis. See Wheeler, R. R., 1.

Wallace, Robert Earl.

1. Structure of a portion of the San Andreas rift in southern California: Geol. Soc. Am. Bull., v. 60, no. 4, p. 781-806, illus. incl. index, geol. maps, Apr. 1949; abs., v. 59, no. 12, pt. 2, p. 1384, Dec. 1948; Northwest Sci., v. 22, no. 1, p. 21-22, Feb. 1948.

2. (and others). Thermal metamorphism in the central Kuskokwim region, southwestern Alaska [abs.]: Geol. Soc. Am. Bull., v. 60, no. 12, pt. 2, p. 1946-1947, Dec. 1949.

Walthier, Thomas Nash.

1. Geology and mineral deposits of the area between Corner Brook and Stephenville, western Newfoundland: Newfoundland Geol. Survey Bull. 35, pt. 1, p. 1-62, illus. incl. geol. maps, 1949.

2. Geology and mineral deposits of the area between Lewis Hills and Bay St. George, western Newfoundland: Newfoundland Geol. Survey Bull. 35, pt. 2, p. 63-87, illus. incl. geol. map, 1949.

Walton, Matt Savage. See Winchell, $\mathrm{H}$.

Wanek, Alexander Andrew. See Read, C. B.; U. S. G. S. 1, no. 96.

Wang, Y.

Maquoketa Brachiopoda of Iowa: Geol. Soc. Am. Mem. 42, 55 p., illus., Dec. $28,1949$.

\section{Wanless, Harold Rollin.}

Late Paleozoic cycles of sedimentation in the United States [abs.]: 18th Internat. Geol. Cong., London, Volume of titles and abstracts, p. 22- $\quad 23,1948$.

Wantland, Dart.

Some possibilities of mining geophysics in Colorado: Mines Mag., v. 39, no. 4, p. 27-31, 42, illus., Apr. 1949.

Waring, Gerald Ashley.

Statistical data on glacial boulders [N. and S. Dak.] : Science, v. 109, no. 2829, p. 283-284, illus., Mar. 18, 1949. 
Wark, W. J. See Hawley, J. E., 3.

Warne, John David. See Thoenen, J. R.

Warner, S. E.

Report of field investigation of Coachella Valley earthquake on December 4, 1948 [abs.]: Geol. Soc. Am. Bull., v. 60, no. 12, pt. 2, p. 1958, Dec. 1949.

\section{Warren, Charles R.}

Probable Illinoian age of part of the Missouri River [abs.]: Geol. Soc. Am. Bull., v. 60, no. 12, pt. 2, p. 1926, Dec. 1949.

\section{Warren, Harry Verney.}

1. (and Delavault, Robert E.). Further studies in biogeochemistry: Geol. Soc. Am. Bull., v. 60, no. 3, p. 531-559, illus., Mar. 1949.

2. (and Thompson, Robert Mitchell). Further occurrences of antimony and tellurium minerals in western Canada: Am. Mineralogist, v. 34, nos. 5-6, p. 458-459, May-June 1949.

3. (and Delavault, Robert E., and Irish, Ruth I.). Biogeochemical researches on copper in British Columbia: Royal Soc. Canada Trans., $3 \mathrm{~d}$ ser., v. 43 , sec. 4 , p. 119-137, June 1949 ; abs. with title, "Biogeochemical researches in British Columbia" by $H$. V. Warren and R. E. Delavault, Proc. 3d ser., v. 43, p. 240, 1949.

4. (and Matheson, Chester R.). Some relationships between geology and forest growth: Western Miner, v. 22, no. 6, p. 52-54, illus., June 1949.

5. (and Delavault, Robert E.). Gold and silver content of some trees and horsetails in British Columbia [abs.]: Geol. Soc. Am. Bull., v. 60, no. 12, pt. 2, p. 1947 , Dec. 1949.

\section{Warren, Percival Sidney.}

1. Fossil zones of Devonian of Alberta, in Clark, L. M., chm., Alberta symposium: Am. Assoc. Petrol. Geol. Bull., v. 33, no. 4, p. 564-571, illus., Apr. 1949.

2. (and Stelck, Charles Richard). The late middle Devonian unconformity in northwestern Canada: Royal Soc. Canada Trans., 3d ser., v. 43, sec. 4, p. 139-148, illus., June 1949.

\section{Warriner, Lendall $P$.}

(and Burgess, Blandford C.). The pegmatites of Jasper County, Georgia: Min. Eng., v. 1, no. 10, p. 376-380, illus. incl. index, geol. sketch map, Oct. 1949; A.I.M.E. Trans., v. 184, 1949.

\section{Warthin, Aldred Scott.}

Wax and wane of species in Paleozoic Ostracoda [abs.]: Geol. Soc. Am. Bull., v. 60 , no. 12 , pt. 2, p. 1926 , Dec. 1949 .

\section{Wascher, Herman $L$.}

(and Humbert, Roger Paul, and Cady, John Gilbert). Loess in the southern Mississippi Valley; Identification and distribution of the loess sheets: Soil Sci. Soc. Am. Proc., v. 12, 1947, p. 389-399, illus. index map, 1948.

\section{Wasem, Adam Richard.}

Petroleum photogeology: Photogrammetric Engineering, v. 15, no. 4, p. 579-589, illus., Dec. 1949.

\section{Washken, Edward.}

(and Buerger, Martin Julian). Effect of potassium on the nephelinecarnegieite transformation [abs.]: Geol. Soc. Am. Bull., v. 60, no. 12, pt. 2, p. 1927, Dec. 1949. 
Wasserstein, $\mathbf{B}$.

Observations on two precision lattice measurements of pyrite from Leadville, Colorado: Am. Mineralogist, v. 34, nos. 9-10, p. 731-735, Sept.Oct. 1949.

Waters, James Alton.

Joseph Augustine Cushman (1881-1949) : Am. Assoc. Petrol. Geol. Bull., v. 33 , no. 8 , p. 1457-1465, port., Aug. 1949 .

\section{Waterways Experiment Station.}

Geological investigation of gravel deposits in the Lower Mississippi Valley and adjacent uplands: Waterways Expt. Sta. [Vicksburg, Miss.] Tech. Mem. no. 3-273, 58 p. ( $\$)$, illus., May 1949 .

Watkins, William T. See Strimple, H. L., 2.

\section{Watson, David Meredith Sears.}

1. Dr. J [ohn] C [ampbell] Merriam [1869-1945]: Nature (London), v. 156, no. 3971 , p. 683 , Dec. 8,1945 .

2. The evidence afforded by fossil vertebrates on the nature of evolution, in Jepson, G. L., ed., Genetics, paleontology, and evolution, p. 45-63, 1949.

Watson, Elaine. See Boardman, L., 1, 3, 9.

Watson, G. R. See Clement, P. F.

Watson, Robert James. See Skeels, D. C.

Weaver, Charles Edwin.

Geology of the Coast Ranges immediately north of the San Francisco Bay region, California: Geol. Soc. Am. Mem. 35, ix, 242 p., illus. incl. index, geol. maps, Oct. 20, 1949, summarized as Calif.' Dept. Nat. Res. Div. Mines Bull. 149, 135 p., illus. incl. index, geol. maps, Sept. 1949.

Weaver, Paul.

Geological interpretation of exploratory wells: Am. Assoc. Petrol. Geol. Bull., v. 33, no. 7, p. 1135-1144, illus., July 1949; summary, Oil and Gas Jour., v. 47, no. 46, p. 102, 104, Mar. 17, 1949.

Webber, Benjamin N. See Lasky, S. G., 2.

Webber, Edward Joseph. See Wallace, R. E., 2.

Weber, W. W.

Preliminary report on part of Duverny Township, Abitibi-East County [Quebec]: Quebec Dept. Mines Prelim. Rpt. 200, 23 p. (\$), index, geol. maps, 1947.

Weeks, Ludlow Jackson.

Bridgeville limonite deposits [Nova Scotia]: Nova Scotia Dept. Mines Ann. Rpt. 1948, p. 121-125, map, 1949.

Wegmann, C. Eugène.

Geological tests of the hypothesis of continental drift in the Arctic regions; scientific planning: Meddelelser om Grønland, Bind 144, Nr. 7, 48 p., illus., 1948.

\section{Weight, Harold 0.}

1. Geodes and the palms in the Kofa country [Ariz.]: Desert Mag., v. 12, no. 6, p. 17-22, illus. incl. index map, Apr. 1949.

2. Magic rocks of the Saucedas [Mountains, Ariz.]: Desert Mag., v. 12, no. 7 , p. 14-19, illus. incl. index map, May 1949.

3. Fossil shells from a vanished sea: Desert Mag., v. 12, p. 21-26, illus. incl. index map, Oct. 1949. 
Weimer, R. J. See Heisey, E. L.

Weingeist, Leo.

The ostracode genus Eucytherura and its species from the Cretaceous and Tertiary of the Gulf Coast [U.S.]: Jour. Paleontology, v. 23, no. 4, p. 364-379, illus., July 1949.

Weir, Gordon. See Popenoe, W. P., 1.

Weir, James Donald.

Marine Jurassic formations of southern Alberta Plains, in Clark, L. M., chm., Alberta symposium: Am. Assoc. Petrol. Geol. Bull., v. 33, no. 4, p. 547-563, illus. incl. index map, Apr. 1949.

Weiss, Judith.

Wissahickon schist at Philadelphia, Pennsylvania: Geol. Soc. Am. Bull., v. 60 , no. 10 , p. 1689-1726, illus. incl. geol. maps, Oct. 1949.

Weitz, Joseph Leonard. See Love, J. D., 1.

Weller, James Marvin.

Paleontologic classification: Jour. Paleontology, v. 23, no. 6, p. 680-690, illus., Nov. 1949.

Welles, Samuel Paul. See also Camp, C. L., 1.

(and Bump, James Dye). Alzadasaums pembertoni, a new elasmosaur from the Upper Cretaceous of South Dakota: Jour. Paleontology, v. 23 , no. 5, p. 521-535, illus., Sept. 1949.

Wellman, Dean Caster.

Developments [in oil and gas] in Oklahoma in 1948: Am. Assoc. Petrol. Geol. Bull., v. 33, no. 6, p. 892-904, index maps, June 1949.

Wells, Bertram Whittier.

Origin of the Carolina Bays; evidence from some peat profiles [abs.]: N. C. Acad. Sci. Proc. in Elisha Mitchell Sci. Soc. Jour., v. 65, no. 2, p. 185 , Dec. 1949.

Wells, Clayton J.

Hickory Valley phosphate deposit in Independence County, Arkansas, with especial reference to economic possibilities of North Arkansas phosphate region: Ark. Res. Dev. Comm. Div. Geol. Bull. 15, 37 p., illus. incl. index, geol. maps, 1949.

Wells, Francis Gerritt.

1. (and others). Chromite deposits near Seiad and McGuffy Creeks, Siskiyou County, California: U. S. Geol. Survey Bull. 948-B, p. 19-62 $(\ddagger)$, illus. incl. index, geol. maps, 1949 .

2. (and Hotz, Preston Enslow, and Cater, Frederick William, Jr.). Preliminary description of the geology of the Kerby quadrangle, Oregon: Oreg. Dept. Geology and Mineral Industries Bull. 40, 23 p. ( $\$$ ), geol. map, 1949.

3. Ensimatic and ensialic geosynclines [abs.]: Geol. Soc. Am. Rull., v. 60, no. 12 , pt. 2 , p. 1927 , Dec. 1949 .

\section{Wells, Robert J.}

Well velocity shooting in California: Geophysics, v. 14, no. 3, p. 346-356, illus., July 1949.

Wells, Roger Clark, 1877-1944.

Antimonial silver ore from Cobalt, Ontario: Am. Mineralogist, v. 34, nos. 5-6, p. 456-457, illus., May-June 1949.

Wengerd, Sherman Alexander.

Correlation of specific gravity and lithology in Viola rocks [Okla.] [abs.]: Oil and Gas Jour., v. 47, no. 46, p. 154, Mar. 17, 1949. 


\section{Wertz, Jacques B.}

Logarithmic pattern in river placer deposits: Econ. Geology, v. 44, no. 3, p. 193-209, illus., May 1949.

West, N. N. See Sundstrom, R. W.

West Texas Geological Society.

1. [Guidebook] Fall field trip, October 29-31, 1948, Green Valley and Paradise Valley; Wire Gap and The Solitario; Limpia Canyon and Barilla Mts. 67 p. ( $\ddagger)$, illus. [1948].

2. Guidebook, Field Trip no. 1, Marathon region; Big Bend region; Green Valley-Paradise Valley region; Sierra Blanca region, Texas, November 6-9, 1949 . 111 p. (\$), illus. incl. index, geol. maps, 1949.

3. (and New Mexico Geological Society). Guidebook Field Trip no. 2, Cenozoic geology of the Llano Estacado and Rio Grande Valley [Texas], November 6-9, 1949. 79 p. (\$), illus. incl. index, geol. maps, 1949.

4. (and A.I.M.E., Southwestern New Mexico Section). Guidebook Field Trip no. 3, Geology and ore deposits of Silver City region, New Mexico, November 6-9, 1949. 45 p. (\$), illus. incl. index, geol. maps, 1949.

5. Guidebook Field Trip no. 4, The Permian rocks of the trans-Pecos region [Texas], November $6-9,1949.94$ p. (\$), illus. incl. geol. maps, 1949.

6. Guidebook Field Trip no. 5, Pre-Permian rocks of trans-Pecos area [Texas] and southern New Mexico, November 6-9, 1949. 67 p. ( $\ddagger)$, illus. incl. geol. maps, 1949.

\section{West Texas Geological Society, Stratigraphic Problems Committee.}

East-west cross section through southern Permian Basin of West Texas, Fisher County through El Paso County, with text. 34 p. ( $\ddagger)$, Sept. 1949: abs., Geol. Soc. Am. Bull., v. 60. no. 12, pt. 2, p. 1928, Dec. 1949.

\section{Westoll, Thomas Stanley.}

On the evolution of the Dipnoi, in Jepson, G. L., ed., Genetics, paleontology, and evolution, p. 121-184, illus., 1949.

\section{Wheeler, Harry Elugene.}

(and Scott, W. Frank, and Thompson, Thomas L.). Permian-Mesozoic stratigraphy in northeastern Nevada [abs.]: Geol. Soc. Am. Bull., v. 60 , no. 12 , pt. 2 , p. 1928 , Dec. 1949.

Wheeler, Robert Reid. See also Jacobsen, C. L., 2.

1. (and Wallace, Louis). Geological significance of world's deepest well bore [Okla.]: World Oil, v. 128, no. 10, p. 53-54, 56, 60, illus., Feb. 1, 1949; abs., 18th Internat. Geol. Cong., London, Volume of titles and abstracts, p. 37-38, 1948.

2. Stratigraphic convergence [abs.]: 18th Internat. Geol. Cong., London, Volume of titles and abstracts, p. 38, 1948.

3. Guadalupian folding and facies, trans-Pecos Texas and New Mexico [abs.]: 18th Internat. Geol. Cong., London, Vólume of titles and abstracts, p. 38-39, 1948.

Whipple, Fred Lawrence.

The theory of micrometeorites [abs.]: Science, v. 110, no. 2861, p. 438, Oct. 28,1949 ; Meteor. Soc. Contr., v. 4, no. 3, p. 236-237, 1949 .

White, David J.

Radioactive ores the prospector should know: Oreg. Dept. Geology and Mineral Industries, GMI Short Paper 18, 14 p. $(\ddagger)$, illus. incl. index map, 1949. 
White, Donald Edward.

1. Antimony deposits of Soyatal district, State of Queretaro, Mexico: U. S. Geol. Survey Bull. 960-B, p. 35-86, illus. incl. index, geol. maps, 1948. Spanish translation by Salvador Cardenas published as México Inst. Nac. Invs. Rec. Min. Bol. num. 21, 78 p., illus., 1949.

2. (and Sandberg, Clarence Harold, and Brannock, Walter Wallace). Geochemical and geophysical approaches to the problem of utilization of hot spring water and heat: Nev. Water Conf., 3d, Carson City, Nev., Nov. 4-5, 1948, Proc., p. 112-124, discussion, p. 122-124 [1949]..

3. (and Thompson, George Albert, and Brannock, Walter Wallace). Thermal springs and their possible significance in the future discovery of ore deposits [abs.]: Econ. Geology, v. 44, no. 1, p. 83, Jan.-Feb. 1949 .

White, George Willard.

1. Geology of Holmes County [Ohio]: Ohio Geol. Survey, 4th ser., Bull. 47, 373 p., illus. incl. index, geol. maps, 1949. Includes chapter on "Gas and oil" by Raymond E. Lamborn, p. 261-284.

2. Memorial to James Walter Goldthwait [1880-1948]: Geol. Soc. Am. Proc. 1948, p. 171-182, port., May 1949.

White, Sydney E.

1. Processes of erosion on steep slopes of Oahu, Hawaii: Am. Jour. Sci., v. 247 , no. 3 , p. 168-186, illus. incl. index map, Mar. 1949; discussion by Harold St. John and reply by the author, v. 248 , no. 7, p. 508514 , July 1950.

2. Preliminary report on geology of Popacatepetl, Mexico [abs.]: Geol. Soc. Am. Bull., v. 60, no. 12 , pt. 2, p. 1976, Dec. 1949.

White, W. Arthur.

Atterberg plastic limits of clay minerals: Am. Mineralogist, v. 34, nos. 7-8, p. 508-512, July-Aug. 1949; reprinted as Ill. State Geol. Survey Rpt. Inv. 144, 1949 .

White, Walter Noy. See Alexander, W. H., Jr., 1; Follett, C. R.

White, Walter Stanley.

Cleavage in east-central Vermont: Am. Geophys. Union Trans., v. 30, no. 4, p. 587-594, illus. incl. geol. map, Aug. 1949.

Whiteside, E. P.

Preliminary X-ray studies of loess deposits in Illinois: Soil Sci. Soc. Am. Proc., v. 12, 1947, p. 415-419, illus., 1948.

Whittington, Harry Blackmore.

Dolichoharpes and the origin of the harpid fringe: Am. Jour. Sci., v. 247, no. 4, p. 276-285, illus., Apr. 1949.

Wicher, Carl A.

On the age of the higher Upper Cretaceous of the Tampico embayment area in Mexico, as an example of the worldwide existence of microfossils and the practical consequences arising from this: Mus. Hist. Nat. Pays Serbe, Bull., ser. A, lv. 2, p. 49-75 (in Serbian), 76-105 (in English), illus., 1949.

Wickenden, Robert Thomas Daubigny.

Some Cretaceous sections along Athabaska River from the mouth of Calling River to below Grand Rapids, Alberta: Canada Geol. Survey Paper $49-15,31 \mathrm{p}$. (†), index map, 1949.

Wickwire, Grant Townsend.

Underground water and glacial geology of Scottsburg, Indiana, and vicinity : Ind. Acad. Sci. Proc., v. 58, p. 188-195, illus., 1948. 
Wier, Kenneth L. See Balsley, J. R., Jr.

Wiese, John Herbert. See Heyl, G. R., 7.

Wilkerson, Albert Samuel.

1. (and Comeforo, Jay Eugene). Some New Jersey glass sands: Rutgers Univ. Bur. Mineral Research Bull. 1, 155 p., illus., 1948.

2. (and Comeforo, Jay Eugene). Some glass sands from New Jersey: Econ. Geology, v. 44, no. 1, p. 63-67, index map, Jan.-Feb. 1949.

Willard, Bradford. See also McLaughlin, D. B.

1. An Eden faunule in New Jersey: Jour. Paleontology, v. 23, no. 2, p. 218-220, index map, Mar. 1949.

2. Paleozoic continental phases of sedimentation in the northern Appalachians [abs.]: 18th Internat. Geol. Cong., London, Volume of titles and abstracts, p. 23, 1948.

3. Cambrian stratigraphic nomenclature in eastern Pennsylvania [abs.]: Geol. Soc. Am. Bull., v. 60, no. 12, pt. 2, p. 1976-1977, Dec. 1949.

\section{Williams, Charles Coburn.}

(and Lohman, Stanley William). Geology and ground-water resources of a part of south-central Kansas, with special reference to the Wichita municipal water supply: Kans. Univ., State Geol. Survey Bull. 79, 455 p., illus. incl. index, geol. maps, July 1949.

Williams, Edwin P.

Preliminary map, Cardston, Alberta [with descriptive notes]: Canada Geol. Survey Paper 49-3, 1949.

\section{Williams, Howel.}

Geology of Shasta Valley and the adjacent Cascades, northeastern California [abs.]: Geol. Soc. Am. Bull., v. 60, no. 12, pt. 2, p. 1947, Dec. 1949.

Williams, James Steele.

1. Paleontology of the Leadville, Hermosa, and Rico formation, in Geology and ore deposits of the La Plata district, Colorado, by E. B. Eckel: U. S. Geol. Survey Prof. Paper 219, p. 17-24, 1949.

2. Diverse concepts of the Amsden formation [abs.]: Geol. Soc. Am. Bull., v. 60 , no. 12 , pt. 2 , p. $1928-1929$, Dec. 1949 .

Williams, James Stewart.

1. Geologic studies in Utah. 24 p., illus. Logan, Utah, Utah State Agric. Coll. Faculty Assoc., 1948.

2. Carboniferous and Permian rocks [Utah], in The oil and gas possibilities of Utah, by G. H. Hansen and M. M. Bell: Utah Geol. Miner. Survey, p. 67-78, Dec. 1949.

\section{Williams, John Raynesford.}

Development [in oil and gas] in Arkansas and north Louisiana in 1948: Am. Assoc. Petrol. Geol. Bull., v. 33, no. 6, p. 990-1001, index map, June 1949.

Williams, Joseph E.

Chemical weathering at low temperatures: Geog. Rev., v. 39, no. 1, p. 129135, illus., Jan. 1949.

Williams, Lloyd. See Toenges, A. L., 3.

\section{Williams, Merton Yarwood.}

Whence the oil of the Athabaska tar sands [Canada]: Royal Soc. Canada Trans. 3d ser., v. 43, sec. 4, p. 149-156, June 1949; abs., Proc. 3d ser., v. 43, p. $238,1949$. 
Wiliamson, W. 0 .

Ceramic products: their geological interest and analogies: Am. Jour. Sci., v. 247 , no. 10 , p. $715-749$, Oct. 1949.

Willis, A. L.

(and Pennington, R. P., and Jackson, M. Lucille). Mineral standards for quantitative $\mathrm{X}$-ray diffraction analysis of soil clays; 1 , Abridgement of component percentages based on weathering sequence: Soil Sci. Soc. Am. Proc., v. 12, 1947, p. 400-406, illus., 1948.

\section{Willis, Robin.}

Geology of Placerita Canyon oil field [Calif.] [abs.]: Am. Assoc. Petrol. Geol. Bull., v. 33, no. 12, p. 2061, Dec. 1949; Oil and Gas Jour., v. 48 , no. 29 , p. 137 , Nov. $24,1949$.

Willman, Harold Bowen. See Leighton, M. M., 1, 3.

Wilpolt, Ralph Henry.

(and Marden, Douglas W.). Upper Mississippian rocks of southwestern Virginia, southern West Virginia, and eastern Kentucky: U. S. Geol. Survey Oil and Gas Invs. Prelim. Chart no. 38, 3 sheets with descriptive text, 1949 .

Wilson, Charles William, Jr.

Pre-Chattanooga stratigraphy in central Tennessee: Tenn. Dept. Conserv. Div. Geology Bull. 56, xviii, 407 p., illus. incl. index, geol. maps, 1949.

Wilson, Eldred Dewey.

Structure in Arizona [abs.]: Geol. Soc. Am. Bull., v. 60, no. 12, pt. 2, p. 1929 , Dec. 1949.

Wilson, Ivan Franklin.

1. (and Rocha, Victor S.). Coal deposits of the Santa Clara district near Tonichi, Sonora, Mexico: U. S. Geol. Survey Bull. 962-A, 80 p., illus. incl. index, geol. maps, 1949.

2. (and Veytia Mario). Geology and manganese deposits of the Lucifer district northwest of Santa Rosalia, Baja California, Mexico: U. S. Geol. Survey Bull. 960-F, p. 177-233, illus. incl. index, geol. maps, 1949.

Wilson, James Lee.

1. The trilobite fauna of the Elvinia zone in the basal Wilberns limestone of Texas: Jour. Paleontology, v. 23, no. 1, p. 25-44, illus, incl. index map, Jan. 1949.

2. Stratigraphy and faunal relationships of the upper Cambrian in the central Appalachians [abs.]: Geol. Soc. Am. Bull., v. 60, no. 12, pt. 2, p. 1929-1930, Dec. 1949.

Wilson, John Andrew.

Indications of a large coelacanth fish in the Permian Vale formation of Texas [abs.]: Geol. Soc. Am. Bull., v. 60, no. 12, pt. 2, p. 1930, Dec. 1949.

Wilson, John Tuzo. See also Henderson, J. F., 2; Keevil, N. B.

1. The origin of continents and Precambrian history: Royal Soc. Canada Trans., 3d ser., v. 43, sec. 4, p. 157-184, illus., June 1949.

2. Some major structures of the Canadian Shield: Canadian Min. Met. Bull., no. 450, p. 543-554, illus., Oct. 1949; Canadian Inst Min. Met. Trans., v. 52, p. 231-242, 1949.

3. The origin of continents and growth of North America [abs.]: Royal Soc. Canada Proc. 3d ser., v. 43, p. 237, 1949. 
Wilson, Leonard Richard. See also Barghoorn, E. S., Jr., 1.

1. A microfossil analysis of the Lower Peat and associated sediments at the John Hancock Fishweir site [Boston, Mass.]: Peabody Foundation for Archaeology Papers, v. 4, no. 1, p. 84-98, illus., 1949.

2. Plant microfossil studies of early Tertiary deposits in the Western Interior of the United States [abs.]: 18th Internat. Geol. Cong., London, Volume of titles and abstracts, p. 72, 1948.

\section{Wilson, Robert Warren.}

1. Additional Eocene rodent material from southern California: Carnegie Inst. Wash. Pub. 584, Contr. Paleontology, p. 1-25, illus., June 22, 1949.

2. On some White River fossil rodents [Colo.]: Carnegie Inst. Wash. Pub. 584, Contr. Paleontology, p. 27-50, illus., June 22, 1949.

3. Rodents and lagomorphs of the upper Sespe [Calif.]: Carnegie Inst. Wash. Pub. 584, Contr. Paleontology, p. 51-65, illus., June 22, 1949.

4. Early Tertiary rodents of North America: Carnegie Inst. Wash. Pub. 584, Contr. Paleontology, p. 67-164, illus., June 22, 1949.

5. Rodents of the Rincon fauna, western Chihuahua, Mexico: Carnegie Inst. Wash. Pub. 584, Contr. Paleontology, p. 165-176, illus., June $22,1949$.

6. Preliminary report on a Torrejonian faunule from near Angels Peak, San Juan Basin, New Mexico [abs.]: Geol. Soc. Am. Bull., v. 60, no. 12, pt. 2, p. 1930-1931, Dec. 1949.

\section{Wilson, Walter Byron.}

1. Some aspects of petroleum migration [abs.] : 18th Internat. Geol. Cong., London, Volume of titles and abstracts, p. 39, 1948.

2. Reef definition [abs.]: Oil and Gas Jour., v. 47, no. 46, p. 108, Mar. 17, 1949.

\section{Winchell, Alexander Newton.}

What is a mineral?: Am. Mineralogist, v. 34, nos. 3-4, p. 220-225, Mar.Apr. 1949; abs., p. 284, Mar.-Apr. 1949; Geol. Soc. Am. Bull., v. 59, no. 12 , pt. 2 , p. 1364 , Dec. 1948.

Winchell, Horace.

(and Walton, Matt Savage) An inexpensive petrographic microscope: Am. Mineralogist, v. 34, nos. 9-10, p. 688-691, illus., Sept.-Oct. 1949.

Windes, Stephen L.

Physical properties of mine rock, Part 1: U. S. Bur. Mines Rpt. Inv. 4459, 79 p. (\$), illus., Mar. 1949.

Wing, Lawrence $A$.

(and Dawson, Arthur S.). Preliminary report on asbestos and associated rocks of northwestern Maine: Maine State Geologist Rpt. 1947-1948, p. 30-62, index, geol. sketch map, Mar. 1949.

\section{Winton, Will McLain.}

Memorial to Gayle Scott [1894-1948]: Geol. Soc. Am. Proc. 1948, p. 207210, port., May 1949 .

\section{Wolfe, Caleb Wroe.}

1. Ludlamite from the Palermo mine, North Groton, New Hampshire: Am. Mineralogist, v. 34, nos. 1-2, p. 94-97, Jan.-Feb. 1949.

2. Surface geology at the border of an ice sheet: Earth Sci. Digest, v. 3, no. 9, p. 3-8, illus., Apr. 1949.

3. The blister hypothesis and the orogenic cycle: N. Y. Acad. Sci. Trans., ser. 2, v. 11, no. 6, p. 188-195, illus., Apr. 1949; abs., Geol. Soc. Am. Bull., v. 59, no. 12, pt. 2, p. 1364 , Dec. 1948.

4. The blister hypothesis: Sci. Am., v. 180, no. 6, p. 16-21, illus., June 1949. 
Wolfe, Caleb Wroe-Continued

5. The blister hypothesis and geological problems: Earth Sci. Digest, v. 4, no. 2, p. 3-11, illus., Sept. 1949.

6. (and Franklin, Virginia). Refractive indices of high index liquids by the prism method on the two-circle goniometer: Am. Mineralogist, v. 34 , nos. 11-12, p. 893-895, illus., Nov.-Dec. 1949 .

Wolfe, Peter Edward. See also Bader, H., 1.

1. Geology and soils of the West Bay area, Port au Port Peninsula, Newfoundland: Newfoundland Dept. Nat. Res. Soil Survey Bull. 2, 24 p., illus. incl. geol. map, July 1942.

2. Geology and soils of the Upper Humber Valley, Newfoundland: Newfoundland Dept. Nat. Res. Soil Survey Bull. 3, 43 p., illus., June 1944.

3. Agricultural mineral resources of New Jersey: Rutgers Univ. Bur. Mineral Research Bull. 2, 79 p., illus., 1948.

4. Land exploration and land planning through geological methods in Newfoundland [abs.]: 18th Internat. Geol. Cong., London, Volume of titles and abstracts, p. 108, 1948.

Wolfson, Albert.

Biogeography and the nature of continents [abs.]: Geol. Soc. Am. Bull., v. 60 , no. 12 , pt. 2 , p. 1931 , Dec. 1949.

Womack, Robert, Jr.

Brookhaven field, Lincoln County, Mississippi [abs.]: Am. Assoc. Petrol. Geol. Bull., v. 33, no. 12, p. 2069, Dec. 1949; Oil and Gas Jour., v. 48, no. 25, p. 88 , Oct. 27,1949 .

Wood, Albert Elmer.

Small mammals from the uppermost Eocene (Duchesnian) near Badwater, Wyoming: Jour. Paleontology, v. 23, no. 5, p. 556-565, illus., Sept. 1949.

Wood, E. Boyne.

Developments [in oil and gas] in Kentucky in 1948: Am. Assoc. Petrol. Geol. Bull., v. 33, no. 6, p. 853-862, illus. incl. index maps, June 1949.

Wood, Gordon H., Jr. See also Griggs, R. L.; Read, C. B.; U. S. G. S. 1, no. 96.

Stratigraphy of Paleozoic and Mesozoic rocks in the Piedra River Canyon, Archuleta County, Colorado [abs.]: Geol. Soc. Am. Bull., v. 60, no. 12, pt. 2, p. 1931, Dec. 1949.

Wood, Horace Elmer, 2d.

1. Evolutionary rates and trends in rhinoceroses, in Jepson, G. L., ed., Genetics, paleontology, and evolution, p. 185-189, 1949.

2. Oligocene faunas, facies, and formations, in Longwell, C. R., chm., Sedimentary facies in geologic history [symposium]: Geol. Soc. Am. Mem. 39, p. 83-90, index map; discussion, p. 154-155, June 17, 1949.

Woodford, Alfred Oswald. See Burt, F. A., 1; Daviess, S. N.; Schoellhamer, J. E.; U. S. G. S. 1 , no. 83.

Woodring, Wendell Phillips.

1. (and Thompson, Thomas Francis). Tertiary formations of Panama Canal Zone and adjoining parts of Panama: Am. Assoc. Petrol. Geol. Bull., v. 33, no. 2, p. 223-247, illus. incl. index map, Feb. 1949.

2. The Panama land bridge [abs.]: Science, v. 109, no. 2835, p. 437, Apr. 29, 1949.

Woods, Kenneth Brady.

Distribution of mineral aggregates, in Symposium on mineral aggregates (1948) : Am. Soc. Testing Materials Spec. Tech. Pub. 83, p. 4-19, 1948. 


\section{Woodward, Herbert Preston.}

Cambrian and Ordovician stratigraphy and oil and gas possibilities in West Virginia: Appalachian Geol. Soc. Bull., v. 1, p. 107-116, 1949.

Woollard, George Prior.

1. Gravity anomalies and the nature of the earth's crust, in Symposium on the earth's crust: Am. Geophys. Union Trans., v. 30, no. 2, p. 189-201, illus., Apr. 1949.

2. Regional gravity study of the Appalachian Mountain system [abs.]: Geol. Soc. Am. Bull., v. 60, no. 12, pt. 2, p. 1932, Dec. 1949.

Worts, G. F., Jr. See Dennis, P. E.

Worzel, John Lamar. See Ewing, W. M., 1.

Woyski, Margaret Skillman. See also Skillman, Margaret W.

Intrusives of central Minnesota: Geol. Soc. Am. Bull., v. 60, no. 6, p. 9991016, geol. map, June 1949.

Wrather, William Embry.

The [U.S.] Geological Survey: Earth Sci. Digest, v. 3, no. 8, p. 11-17, illus., Mar. 1949.

Wright, Claud William. See Gill, E. D.

Wright, Harold D. See Kulp, J. L., 1.

\section{Wright, Lauren Albert.}

1. Geology of the Silver Lake talc area, San Bernardino County, California [abs.]: Geol. Soc. Am. Bull., v. 60, no. 12, pt. 2, p. 1932, Dec. 1949.

2. Crystal Spring formation, southern Death Valley area, California [abs.]: Geol. Soc. Am. Bull., v. 60, no. 12, pt. 2, p. 1948, Dec. 1949.

Wright, Wilford Stillman. See Heide, H. E.

\section{Wuerker, Rudolph G.}

Sedimentary strata experience can aid in rockburst study: Eng. Min. Jour., v. 150 , no. 6, p. 60-64, illus., June 1949 .

Wyant, Donald Gray. See Cox, M. W., 1,2, 3.

Wyant, Robert Kriss. See Roy, S. K., 1, 2.

Wyllie, M. R. J.

Statistical study of accuracy of some connate-water resistivity determinations made from self-potential $\log$ data: Am. Assoc. Petrol. Geol. Bull., v. 33, no. 11, p. 1892-1900, illus., Nov. 1949.

Wyoming Geological Association.

Guidebook fourth annual field conference in the Powder River Basin [Wyo.], Aug. 9-13, 1949. 102 p. ( $\$)$, illus. incl. index, geol. maps, 1949.

\section{Yagoda, Herman.}

Activity measurements of microradioactive inclusions [abs.] : Am. Mineralogist, v. 34, nos. 3-4, p. 285, Mar.-Apr. 1949.

Yardley, Donald Homer.

Preliminary map, Wecho River (east half), Northwest Territories [with descriptive notes]: Canada Geol. Survey Paper 49-14, 1949.

\section{Yates, Robert Giertz.}

(and Thompson, George Albert). Origin of the mercury minerals of the Terlingua district, Brewster and Presidio Counties, Texas [abs.]: Econ. Geology, v. 44, no. 7, p. 640, Nov. 1949.

Yeh, Chih Cheng. See Hseung, Y. 
Yen, Teng-Chien.

1. Review of the Lower Cretaceous fresh-water molluscan faunas of North America: Jour. Paleontology, v. 23, no. 5, p. 465-470, Sept. 1949.

2. A new name for Carinorbis Yen: Jour. Paleontology, v. 23, no. 5, p. 573, Sept. 1949.

3. Freshwater molluscan faunas and their importance in stratigraphy [abs.]: 18th Internat. Geol. Cong., London, Volume of titles and abstracts, p. 72-73, 1948.

4. On the molluscan faunas of the Morrison and Purbeck formations [North America, Europe] [abs.]: 18th Internat. Geol. Cong., London, Volume of titles and abstracts, p. 73, 1948.

Yenne, Keith Austin.

Pedioceras, a synonym of Crioceras (Pseudocrioceras) : Jour. Paleontology, v. 23 , no. 6, p. 623-624, Nov. 1949 .

Yoder, Hatten Schuyler, Jr.

Jadeite problem [abs.]: Geol. Soc. Am. Bull., v. 60, no. 12, pt. 2, p. 1933, Dec. 1949.

\section{Young, David Marion.}

Geology and occurrence of natural gas in the Big Six sandstone of southeastern Magoffin County, Kentucky: Appalachian Geol. Soc. Bull., v. 1, p. 34-56, illus., 1949 .

\section{Young, Earl B.}

The Pioche district [Nevada], in Dunham, K. C., ed., Symposium on the geology, paragenesis and reserves of the ores of lead and zinc, 18th Internat. Geol. Cong., London, p. 98-106, illus. incl. geol. maps, 1948; abs., Volume of titles and abstracts, p. 51, 1948.

Youngquist, Walter Lewellyn. See also Miller, A. K., 1, 2, 5; Sturgeon, M. T., 2.

1. (and Patterson, S. H.). Conodonts from the Lower Mississippian Prospect Hill sandstone of Iowa: Jour. Paleontology, v. 23, no. 1, p. 5773 , illus., Jan. 1949.

2. (and Downs, Harold Robert). Additional conodonts from the Pennsylvanian of Iowa: Jour. Paleontology, v. 23, no. 2, p. 161-171, illus., Mar. 1949.

3. The cephalopod fauna of the White Pine shale of Nevada: Jour. Paleontollogy, v. 23, no. 3, p. 276-305, illus., May 1949; supplement, no. 6, p. 613-616, illus., Nov. 1949.

4. (and Miller, Arthur K.). Conodonts from the Late Mississippian Pella beds of south-central Iowa: Jour. Paleontology, v. 23, no. 6, p. 617622, illus., Nov. 1949.

\section{Zangerl, Rainer.}

Wyoming quarries yield rare fossils: Mineralogist, v. 17 , nos. 7-8, p. 370, 372, July-Aug. 1949.

\section{Zapp, Alfred Dexter.}

Geology and coal resources of the Durango area, La Plata and Montezuma Counties, Colorado [geologic map with text]: U. S. Geol. Survey Oil and Gas. Invs. Prelim. Map 109 (2 sheets). Scale 1 inch to 2 miles. 1949 .

Zietz, Isidore. See Henderson, R. G.

Zima, L. C. See Cook, R. H.

Zinner, Paul. See also Pesonen, P. E., 1.

(and Holmberg, Clyde Laurence, and Terry, Owen W.). Investigation of the iron-bearing formation of Iron County, Mich., utilizing geophysical and other methods: U. S. Bur. Mines Rpt. Inv. 4583, 40 p. ( $\ddagger)$, illus., Nov. 1949. 
Zobel, Otto J. See Ingersoll, L. R.

ZoBell, Claude E.

Part played by bacteria in petroleum formation [abs.]: Am. Jour. Botany, v. 36 , no. 10 , p. 832 , Dec. 1949.

\section{Anonymous.}

1. Sydney Hobart Ball [1877-1949]: Gems and Gemology, v. 6, no. 5, p. p. 160-161, port., Spring 1949.

2. Salt mine test proves earth penetration by radio waves: World Petroleum, v. 20, no. 3, p. 62-63, illus., Mar. 1949.

3. Inside of rocks shown in movies [rock slicing and photographing apparatus]: Petroleum Engineer, v. 21, no. 4, p. B68, illus., Apr. 1949.

4. Biographical sketch, Thomas [D.] Clements: Compass, v. 26, no. 4, p. 373-375, port., May 1949.

5. Aleutian volcano erupts [Akutan Volcano]: Earth Sci. Digest, v. 3, no. 11, p. 13, June 1949.

6. Retirement of $\mathrm{H}$ [arold] C[aswell] Cooke: Canadian Min. Met. Bull., no. 446, p. 310 , June 1949 .

7. Ernest Clayton Andrews [1870-1948]: Washington Acad. Sci. Jour., v. 39 , no. 6, p. 214-215, June 15,1949 .

8. The meteorite farm [Kimberly Ranch, Kans.]: Mineralogist, v. 17, nos. $7-8$, p. 347, illus., July-Aug. 1949 .

9. Opal, color composite of all gems: Mineralogist, v. 17, nos. 7-8, p. 352, 354, 356, 358, 360, July-Aug. 1949.

10. The late Arthur B [erkeley] Yates [1901-1949]: Canadian Min. Met. Bull. no. 448, p. 390-391, Aug. 1949 .

11. W[alter] Elmer Ekblaw [1882-1949]: Geog. Rev., v. 39, no. 4, p. 677, Oct. 1949.

12. E[verend] L[ester] Bruce, [1884-1949] : Canadian Min. Met. Bull. no. 451 , p. 631-632, Nov. 1949.

13. Everend Lester Bruce [1884-1949]: Western Miner, v. 22, no. 11, p. 104, Nov. 1949.

14. In Memoriam [William Frederick Prouty, 1879-1949]: Compass, v. 27, no. 1 , p. $112-113$, port., Nov. 1949 .

15. Oil and gas fields of Alberta and Saskatchewan, western Canada [map]: World Oil, v. 129, no. 9, Dec. 1949. 


\section{INDEX}

[The numbers refer to entries in the bibliography]

Addresses.

Ancient forests of Oregon: Chaney, R. W., 1.

Blister hypothesis and orogenic cycle: Wolfe, C. W., 3.

Canada, history of geology, 1841-1941: Morin, L. G.

Causes of color in gemstones: Hurlbut, C. S., Jr., 2.

Distribution of mountain building in geologic time: Gilluly, J., 3.

Electron microscope applied to geological research: Bates, T. F., 1.

Evidence for Pleistocene Man at La Jolla, California: Carter, G. F.

Exploration for ore deposits: Broderick, T. $\mathbf{M}$.

Garnet evidence in Adirondack petrogeny: Levin, S. B., 3.

Geological history and geological structure of Wyoming: Thomas, H. D., 3 .

Geological interpretation of exploratory wells: Weaver, $\mathbf{P}$.

Geological studies in Utah: Williams, J. Stewart, 1.

Geophysics, geology, and oil finding: Nettleton, L. L.

New coal age: Ashley, G. H.

Origin of red beds: Krynine, P. D., 2.

Pre-Jurassic geology of Montana: Perry, E. S., 2.

Prospect of mineralogy: Peacock, M. A., 1.

Roebling Medal acceptance: Bragg, W. L.

Roebling Medal presentation: Tunell, G., 1.

Sedimentology, trends: Russell, R. D.

Selenite crystals: Carpenter, A. C.

Aerial photography.

Canadian Shield, prospecting, use: Russell, G. A., 1.

Structure: Harrison, J. M., 2.

Geologic use: Summerson, C. H.

Indiana, airphoto patterns, Illinoian drift: Stevens, J. C.

Drainage mapping from airphotos: Parvis, $M$.

Nova Scotia, Cape Breton Island: Cameron, H. L., 1.

Petroleum exploration: Mott, G. P.

Photogeology: Brundall, L., 2.

Structure interpretation: Wasem, A, R.

University instruction: Tator, B. A., 2.

Wyoming, Powder River Basin: Brundall, L., 1.

Age of the earth. See Geologic time.

Agricultural minerals.

New Jersey: Wolfe, P. E., 3.

Alabama.

Bibliography, northern, Paleozoic, pre-Cambrian: Braunstein, J., 2.

Economic geology.

Coal, Coosa field: Rothrock, H. E., 2.

Analyses: Cooper, H. M., 1.

Reserves: Toenges, A. L., 1.

Limonite ores, Shelby, origin: Allen, R. M., Jr., 2.

Natural gas, development, 1948: Harris, R. M.

Petroleum, development, 1948: Harris, R. M.

Water resources, southeastern: U. S. G. S., 39.

Geologic maps.

Coosa coal field: Rothrock, H. E., 2.

Northeast, crystalline area: Harrell, D. C.

Shelby limonite area: Allen, R. M., Jr., 2.

Southeast, Upper Cretaceous, Tertiary: LaMoreaux, P. E., 2; U. S. G. S., 39.

Ground water.

Fluoride in ground water, Tertiary area: LaMoreaux, P. E., 1.

Southeast: LaMoreaux, P. E., 3.

Resources: U. S. G. S., 39.

Historical geology.

Coosa coal field: Rothrock, H. E., 1, 2.

Cretaceous, southeast: LaMoreaux, P. E., 2.

Little Stave Creek, Tertiary: Bandy, O. L., 1.

Mesozoic, cross section: Southeastern Geol. Soc., Mesozoic Comm., 4.

Northeast, crystalline area: Harrell, D. C.

Paleozoic, northern: Mississippi Geol. Soc., 2.

Pre-Cambrian, northern: Mississippi Geol. Soc., 2.

Pre-Mesozoic, subsurface: Applin, P. L.

Tertiary: LaMoreaux, P. E., 1.

Southeast: LaMoreaux, P. E., 2.

Paleontology.

Foraminifera, Black Warrior Basin, Mississippian: Thompson, M. L.

Little Stave Creek, Tertiary: Bandy, $O$. L., 1, 2.

Petrology.

Fairview coal, coosa field, petrography: Smith, H. L., 1. 
Alabama-Continued

Petrology-Continued

Gilbertsville aggregate, petrography: Holland, W. Y., 5.

Guntersville aggregate, petrography: Holland, W. Y., 5.

Wheeler aggregate, petrography: Holland, W. Y., 5.

Alaska.

Magnetic anomalies, Adak Island: Alldredge, L. R.

U. S. Geological Survey work: Reed, J. C., $2,3$.

Economic geology.

Asbestos, Kobuk River area: Anderson, E., 2; Heide, H. E.

Chichagof Island: Twenhofel, W. S.

Coal, Healy River Valley: Wahrhaftig; C., 1.

Kenai field: Barnes, F. F.

Kenai Peninsula: Toenges, A. L., 4. South central: Toenges, A. L., 4.

Iniskin Peninsula: Kirschner, C. E.; U. S. G. S., 1 , no. 95 .

Jade, Kobuk River area: Anderson, E., 2. Kuiu Island: Twenhofel, W. S.

Limestone deposits, southeastern: Roehm, J. C.

Mineral deposits, northwestern: Anderson, E., 1.

Southeastern: Twenhofel, W. S.

Petroleum, exploration: Kotick, O. F.

Fields: Ver Wiebe, W. A., 1.

Prince of Wales Island: Twenhofel, W. S.

Geologic maps.

Coal, Healy River Valley: Wahrhaftig, C., 1.

Iniskin Peninsula: Kirschner, C. E.; U. S. G. S., 1, no. 95 .

Jumbo Dome: Wahrhaftig, C., 2.

Kenai coal field, southern: Barnes, F. F.

Historical geology.

Healy River Valley: Wahrhaftig, C., 1.

Iniskin Peninsula: Kirschner, C. E.; U. S. G. S., 1, no. 95 .

Kuskokwim area, geosynclinal deposition: Cady, W. M.

Northern: Kotick, O. F.

Mineralogy.

Aggie Creek meteorite, Seward Peninsula: Henderson, E. P., 5; Olivier, C. P.

Paleontology.

Mammoth, frozen, Pleistocene: Anthony, H. E.

Petrology.

Kuskokwim region, thermal metamorphism: Wallace, R. E., 2.

Physical geology.

Akutan Volcano eruption, Apr. 29, 1949: Anonymous, 5.

Dunbar area, permafrost: Péwé, T. L.

Great Sitkin Island, volcanic activity: Byers, F. M., Jr.

Seward Peninsula, frost action and vegetation: Sigafoos, R. S.
Alaska-Continued

Physical geology-Continued

Umnak Island, volcanic activity: Byers, F. M., Jr.

Physiographic geology.

Glacier studies: Miller, M. M.

Jumbo Dome, rubble deposits: Wahrhaftig, C., 2.

Oriented lakes, origin: Black, R. F.

Prince William Sound, glaciers: Field, W. o., Jr., 1.

Thaw lakes and sinks, Seward Peninsula: Hopkins, D. M.

Alberta.

Economic geology.

Coal, Kootenay coal measures: Crockford, M. B. B., 2.

Ribbon Creek area: Crockford, M. B. B., 1.

Foothills structures: Link, T. A., 3.

Fuel reserves: Lang, W. A.

Natural gas, fields, map: Anonymous, 15. Northern: Nauss, A. W.

Petroleum, fields, map: Anonymous, 15. Leduc field: Layer, D. B.

Geologic maps.

A la Pêche area: Irish, E. J. W.

Bow River-Crowsnest Pass area: Crockford, M. B. B., 2.

Callum Creek, West of Fifth Meridian: Canada G. S., 2.

Cardston area: Williams, E. P.

Gap, West of Fifth Meridian: Canada G. S., 5.

Langford Creek area: Canada G. S., 8 .

Leduc oil field: Link, T. A., 1.

Moberly Creek, West of Sixth Meridian: Canada G. S., 11.

Moon Creek area, West of Sixth Meridian: Canada G. S., 12.

Oldman and Foremost formations: Crockford, M. B. B., 3.

Ribbon Creek area: Crockford, M. B. B., 1.

Stimson Creek, West of Fifth Meridian: Canada G. S., 14.

Historical geology.

A la Pêche area: Irish, E. J. W.

Athabaska River, sections, Cretaceous: Wickenden, R. T. D.

Belly River formation: Shaw, E. W.

Callum Creek, West of Fifth Meridian: Canada G. S., 2.

Cardston area: Williams, E. P.

Devonian: Warren, P. S., 1.

Foremost formation: Crockford, M. B. B., 3.

Gap, West of Fifth Meridian: Canada G. S., 5 .

Jurassic, foothills: Spivak, J.

Southern plains: Weir, J. D.

Kootenay coal measures: Crockford, M. B. B., 2.

Langford Creek area: Canada G. S., 8.

Lea Park formation: Shaw, E. W.

Leduc oil field: Layer, D. B.

Bioherm development: Link, T. A., 1. 
A:berta-Continued

Historical geology-Continued

Moberly Creek, West of Sixth Meridian: Canada, G. S., 11.

Moon Creek area, West of Sixth Meridian: Canada G. S., 12.

Northern: Nauss, A. W.

Oldman formation: Crockford, M. B. B., 3.

Paleozoic pre-Waterways strata, Plains area: McGehee, J. R.

Peace River Plains, Upper Cretaceous: Gleddie, J.

Ribbon Creek area: Crockford, M. B. B., 1.

Rocky Mtn. Front Ranges, Bow River area: Clark, L. M., 2.

Stimson Creek, West of Fifth Medidian: Canada G. S., 14.

Symposium: Clark, L. M., 1.

Paleontology.

Athabaska River, Cretaceous, fossil lists: Wickenden, R. T. D.

Fossil zones, Devonian: Warren, P. S., 1.

Flora, Cretaceous: Bell, W. A.

Paleocene: Bell, W. A.

"Laosaurus" minimus Gilmore, dinosaur: Russell, L. S., 2.

Leduc oil field: Layer, D. B.

Bioherm development: Link, T. A., 1.

Peace River Plains, Upper Cretaceous: Gleddie, J.

Peat bogs, pollen analysis: Hansen, H. P., 2.

Postglacial forests: Hansen, H. P., 1.

Physical geology.

Foothills structures: Link, T. A., 3.

Langford Creek area: Canada G. S., 8.

Moon Creek area, West of Sixth Meridian: Canada G. S., 12 .

Rocky Mtn. Front Ranges, Bow River area: Clark, L. M., 2.

Stimson Creek, West of Fifth Meridian: Canada G. S., 14.

Algae.

Algal pillars, Wyoming: Brown, R. W., 1.

Limestones, organic: Johnson, J. H., 1.

Massachusetts, Boylston Street Fishweir II, Pleistocene: Conger, P. S.

Michigan, stromatolites, Lower Huronian: Richardson, E. S., Jr., 2.

Texas, Apache Mts., Permian: Johnson, J. H., 2.

Wyoming, Medicine Bow Mts.: Fenton, C. L.

Algonkian. See Pre-Cambrian.

Alluvial fans.

California, La Jolla: Carter, G. F'.

Alteration, ore guide, East Tintic district, Utah: Lovering, T. S., 1.

Alumina.

Oak leaves: Keller, W. D., 2.

Amethyst. See Gems and gem materials.

Ammonoidea. See Cephalopoda.

Amphibia.

New Mexico, Abo formation, Permian: Langston, W., Jr., 2.

Texas, spine, Permian: Lundelius, E.
Analyses.

Clinopyroxenes: Hess, H. H., 2.

Coal, petrographic: Parks, B. C., 1.

Limestone: Rockwood, N. C.

Oil field cores: Crawford, J. G., 1.

Oil field waters: Crawford, J. G., 1.

Potsdam sandstone, Ontario: Keith, M. L.

Titanium: Gillson, J. L.

Anthozoa.

British Columbia, Wapiti Lake area, faunal lists: Laudon, L. R., 3.

Coral reefs, problem: Ladd, H. S., 1.

Favositidae, Devonian, types: Stumm, E. C., 1.

Lithostrotion, Mississippian, British Columbia: McLaren, D. J.

Michigan, Traverse group, Devonian: Ehlers, G. M., 1.

Microcyclus, Devonian, Michigan, Ontario: Stumm, E. C., 3.

Ontogenetic stages: Durham, J. W., 2.

Pachyphyllum vagabundum, New York, Upper Devonian: Ehlers, G. M., 2.

Tetracorals, Devonian, revision: Stumm, E. C., 2.

Anticlines.

Appalachians, depth: Straley, H. W., 1.

Mexico, Sierra Madre: Mullerried, F. K. G., 1.

South Dakota, Whitewood: Petsch, B. C.

Antimony.

Mexico, Soyatal district: White, D. E., 1.

Oxides: Mason, B. H., 2.

Apatite, Mexico, Durango, collecting: Vance, L. W.

Appalachian Basin.

Northern: Pittsburgh Geol. Soc.

Early Silurian: Rittenhouse, G., 1; U. S. G. S., 1, no. 100 .

Paleogeography, Silurian: Rittenhouse, G., 6.

Paleozoic sediments: Swartz, F. M., 1.

Queenston shale: Rittenhouse, G., 2.

Appalachians.

Anticlines, depth: Straley, H. W., 1.

Cambrian, upper, stratigraphy and paleontology: Wilson, J. L., 2.

Cyclic sedimentation, Paleozoic: Willard, B., 2.

Diamond occurrences: Holden, R. J.

Diastrophism, effect on bedding thickness: Gair, J. E.

Drainage, evolution: Thompson, H. D., 1.

Relation to structure: Thompson, H. D., 2.

Geosyncline, stratigraphy and structure: Lafferty, R. C., Jr.

Gravity study: Woollard, G. P., 2.

Magnetic surveying: Branham, C. A.

Mississippian stratigraphy, problems: Stockdale, P. B.

Natural gas, composition, properties: Headlee, A. J. W.

Southern, Cambrian: King, P. B., 6.

Structure: Rodgers, J., 2.

Tectonics: Shatsky, N, S, 
Apparatus.

Chromograph, element determination: Stevens, R. E.

Decrepitation geothermometer: Peach, P. A., 1.

Differential thermal analysis: Kulp, J. L., 2.

Electron microscope, use in geology: Moore, C. A.

Microscope, for infrared light: Bailly, R. J.

Petrographic: Winchell, $\mathbf{H}$.

Polished sections of ores: Sampson, E.

Refractometer, for infrared light: Bailly, R. J.

Silicon carbide: De Ment, J. A., 2. Aquifer. See Ground water.

Arachnida, Paleozoic: Petrunkevitch, A.

Archean. See Pre-Cambrian.

Arctic America.

Arctic Basin, sediments: Emery, K. 0.

Topography: Emery, K. O.

Continental drift, investigations: Wegmann, C. E.

Devon Island, Aretic Archipelago, Cambrian: Wales, D. B.

Paleogeography: Eardley, A. J., 1; Maync, W., 2.

Permafrost: Bryan, K.

Arizona.

Barringer meteorite crater: Nininger, $H$. H., 4.

Magnetometer survey: Nininger, H. H., 3.

Canyon Diablo meteorite, iron oxide, oxygen content: Buddhue, J. D., 2.

Holbrook meteorite: Buddhue, J. D., 3.

Economic geology.

Aggregate, Davis dam: Rhoades, R. F., 1.

Ajo mining district: Gilluly, J., 1.

Ajo quadrangle: Dehlinger, $M$. E.

Copper, San Manuel, mineralization: Schwartz, G. M., 3.

Squaw Peak mine: Thacker, E.

Wallapai district: Thomas, B. E.

Helvetia mining district: Johnson, V. H.

Manganese, Artillery Mts.: Lasky, S. G., 2.

Seventy Nine mine: Kiersch, G. A., 1.

Geologic maps.

Artillery Mts.: Lasky, S. G., 2.

Chloride district: Thomas, B. E.

Ninety One Hills area: Stoyanow, A., 1. Seventy Nine mine area: Kiersch, G. A., 1.

Ground water.

Big Sandy Valley: Morrison, R. B.

Historical geology.

Artillery Mts.: Lasky, S. G., 2.

Bright Angel quadrangle: Maxson, J. H.

Moenkopi formation, ripple marks: McKee, E. D., 3.

Sycamore Canyon: Price, W. E., Jr.

Pre-Cambrian: Anderson, C. A.

Red Rock quadrangle: Feth, J. H., 2.

Redwall limestone, Mississippian: Gutschick, R. C.

Sedimentary basins: McKee, E. D., 2.
Arizona-Continued

Historical geology-Continued

Southeastern, Lower Cretaceous: Stoyanow, A., 1.

Supai formation, Black Mesa: Hughes, P. W.

Mineralogy.

Chalcedony, geodes, Sauceda Mts.: Weight, H. O., 2.

Geodes, Kofa area: Weight, H. O., 1.

Mt. Eldon meteorite: Buddhue, J. D., 3.

Navajo meteorite: Roy, S. K., 2.

Pegmatite minerals, Wickenburg: Jahns, R. H., 1.

Pima County, meteorite: Henderson, E. P., 2.

Squaw Peak copper mine: Thacker, E.

Uranium minerals, Hillside mine: Axelrod, J. M., 2.

Paleontology.

Ammonoids, Permian, Mustang Mts.: Stoyanow, A. A., 3.

Calciphilus, Black Mesa, Quaternary: Chamberlin, R. V.

Mollusca, Lower Cretaceous, southeastern: Stoyanow, A., 1.

Nonmarine, Recent, Buell Park: Drake, R. J.

Oniscoidichnus for Isopodichnus Brady, 1947: Brady, L. F.

Trilobita, Cambrian: Stoyanow, A. A., 2. Petrology.

Bridge Canyon rock cores, petrography: Mielenz, R. C., 5.

Pegmatites, Wickenburg: Jahns, R. H., 1.

San Manuel copper deposit: Schwartz, G. M., 3 ,

Sandstone, Canyon Diablo meteorite crater, size analysis: Buddhue, J. D., 1.

Silver Bell area, hydrothermal alteration: Kerr, P. F., 6.

Tuff, spheroidal structures, Canelo Hills: Feth, J. H., 1.

Physical geology.

Bright Angel quadrangle, faulting: Maxson, J. H.

Cordilleran structure: Butler, B. S.

Empire Mts., thrust faults: Galbraith, F. W., 3d., 2.

Pre-Cambrian structure: Anderson, C. A.

Red Rock quadrangle: Feth, J. H., 2.

Seventy Nine mine: Kiersch, G. A., 1.

Structure: Longwell, C. R., 3; Wilson, E. D.

Physiographic geology.

Crater Mound, origin: Hager, D., 2.

Upper Verde Valley, Cenozoic history: Mahard, R. H.

Arkansas.

Economic geology.

Bauxite: Gordon, M., Jr.

Natural gas, developments, 1948: Williams, J. R.

Map: Ark. Res. Dev. Comm., Div. Geology. 
Arkansas-Continued

Economic geology-Continued

Petroleum, Atlanta field: Riggs, C. H. Cairo field: Goebel, L. A.

Developments, 1948: Williams, J. R. Exploration, eastern: Renfroe, C. A. Northwest: Burns, K. R.

Map: Ark. Res. Dev. Comm., Div. Geology.

Phosphate, Hickory Valley: Welis, C. J. Geologic maps.

Batesville manganese district: Wells, C. J. Historical geology.

Cretaceous, southwestern: Shreveport Geol. Soc.

Hickory Valley: Wells, C. J.

Paleontology.

Foraminifera, Arkadelphia marl, Upper Petrology. Cretaceous: Cushman, J. A., 3.

Bauxite formation: Goldman, M. I., 2.

Ouachita Mts., veins: Engel, A. E. J., 4.

Tinguaite dikes: Hildebrand, F. A.

Arkose, definition: Oriel, S. S.

Artesian waters and wells.

New Hampshire: Goldthwait, R. P.

Wyoming, Glendo area: Love, J. D., 2; U. S. G. S. 1, no. 92 .

Arthropoda.

Arachnida: Petrunkevitch, A.

Arizona, Calciphilus, Black Mesa: Chamberlin, $R$. V.

Artificial minerals.

$\mathrm{Al}_{2} \mathrm{O}_{3}-\mathrm{SiO}_{2}-\mathrm{H}_{2} \mathrm{O}$ system: Roy, R., 3 .

Albite: Tuttle, O. F., 4.

Aluminum orthophosphate, structure: Hummel, F. A.

BeO.3A12 $\mathrm{O}_{3}$ : Foster, W. R., 1.

Carnegieite: Hummel, F. A.

Ceramic: Williamson, W. 0.

Enargite, hydrothermal synthesis: Gaines, R. $\mathbf{V}$.

Eucryptite: Roy, R., 2.

Klockmannite: Earley, J. W.

Melilites, x-ray data: Ervin, G., Jr.

Petalite: Roy, R., 2.

Phenacite, synthesis: Morgan, R. A.

Pyrrhotite: Graham, A. R.

Quartz, hydrothermal synthesis: Swinnerton, A. C., 2.

Rickardite: Forman, S. A.

Rutile: Moore, C. H., Jr.

Silicates, magnesian, hydrothermal synthesis: Bowen, N. L., 1.

Silver minerals, synthesis: Béland, R., 4. Spodumene: Roy, R., 2.

Tennantite, hydrothermal synthesis: Gaines, R. V.

Asbestos.

Alaska, Kobuk River area: Anderson, E., 2; Heide, H. E.

Maine, northwestern: Wing, L. A.

Asphalt. See also Bituminous rocks.

California, La Brea tar pits: Curtin, G.

McKittrick fossil pit: Pierce, W. D., 1.
Atlantic Coast.

Monazite sand: Jones, W. H., 3.

Petroleum: Straley, H. W., 3.

Triassic, subsurface: Richards, H. G., 1.

Aves. See also Vertebrata.

California, La Brea tar pits, Los Angeles: Curtin, G.

Mancalla, Pliocene: Miller, L. H.

Marine Pleistocene: Howard, H., 1.

San Diego area, Pliocene: Howard, H., 2.

Skulls of cathartid vultures: Fisher, H. I. Kansas, Pleistocene: Downs, T.

Barbados, Globigerina oozes, ages: Stainforth, R. M., 1.

Barite.

Georgia, Cartersville: Kesler, T. L.

New Mexico: Clippinger, D. M.

North Carolina: Van Horn, E. C., 2.

Kings Mtn. area: Van Horn, E. C., 3.

South Carolina, Kings Mtn. area: Van Horn, E. C., 3.

Bars.

Characteristics: Shepard, F. P., 3.

Formation: Shepard, F. P., 3. Basalt.

New Mexico, northeastern: Collins, R. F.; Stobbe, H. R., 1.

Washington, North Dam, Grand Coulee, petrography: Irwin, W. H., 3.

Rock Island, jointing: Fuller, R. E. Basins.

California, Los Angeles, floor: Schoellhamer, J. E.

Petroleum, exploration, reserves: Moulton, G. F.

Batholiths. See also Intrusions.

California, Southern California batholith, minerals: Larsen, E. S., Jr., 4.

Ontario, radioactivity: Slack, H. A.

Quebec, Duverny : Bruet, E., 2. Bauxite.

Arkansas: Gordon, M., Jr.

General: Harder, E. C., 1.

Origin: Goldman, M. I., 1, 2; Harder, E. C., 2.

Stratigraphy of deposits: Harder, E. C., 2. Beaches. See also Changes of level; Glacial lakes; Shore lines; Terraces.

California, Mugu Lagoon area: Inman, D. L., 2.

Santa Monica: Handin, J. W.

Erosion: Caldwell, J. M.

Greenland, west coast, submarine deposit: Malaurie, J. N., 1.

New York, Fire Island: Rosalsky, M. B.

Pacific Coast, ground water level: Isaacs, J. D.

Benches. See Terraces.

Bentonite.

Fluorescence: Hseung, $\mathbf{Y}$.

Grinding reaction: Perkins, A. T.

Properties: McConnell, D., 4.

South Dakota, Missouri Valley: Pesonen, P. E., 1. 
Bentonite-Continued

Texas, Jackson group, Eocene: Pence, F. K., 1 . Beryl.

Wyoming, fluorescence: Brown, B. W.

Maine, Black Mountain pegmatite: Maillot, E. E.

Mt. Mica: Hurlbut, C. S., Jr., 3.

South Dakota, Helen pegmatite: Gries, J. P.

Beryllium.

BeO. $\mathrm{Al}_{2} \mathrm{O}_{3}-\mathrm{Al}_{2} \mathrm{O}_{3}$ system, new compound: Foster, W. R., 1.

Bibliography.

Alabama, northern, Paleozoic, pre-Cambrian: Braunstein, J., 2.

Alberta, Jurassic: Spivak, J.

Ribbon Creek area: Crockford, M. B. B., 1.

Peace River Plains, Cretaceous: Gleddie, J.

Allen, R. C.: Hotchkiss, W. 0 .

Alpine glaciation: Ray, L. L., 3.

Arizona, Wallapai district: Thomas, B. E.

Atwood, W. W.: Cressey, G. B.

Bain, H. F.: DeWolf, F. W.

Bauxite: Harder, E. C., 1, 2.

Biogeography, Pleistocene, Europe and North America: Deevey, E. S., Jr.

Bowie, William: Fleming, J. A.

British Columbia, Jurassic: Spivak, J.

Wapiti Lake area: Laudon, L. R., 3.

Brown, R. H.: Dodge, S. D.

Bryozoa, Paleozoic: Duncan, $\mathbf{H}$.

California minerals: Murdoch, J., 1.

Cellular structures in glass and lavas: Osborn, E. F.

Ceramic materials: Ries, H., 3.

Chamberlin, R. T.: Bowen, N. L., 2.

Chromite: Johnston, W. D., Jr.

Clay: Ries, H., 1.

Coal geochemistry: Miller, H. P.

Coal paleobotany since 1943: Schopf, J. M., 5.

Colorado, South Park: Stark, J. T.

Continental drift: Wegmann, C. E.

Coral reefs: Ladd, H. S., 1.

Crushed stone: Goldbeck, A. T.

Cryolite: Mudd, H. T.

Darton, N. H.: King, P. B., 3.

Diatomite: Cummins, A. B.

Economic geology: Townsend, H. G.

Eurypterida, Upper Paleozoic: KjellesvigWaering, E. N.

Evolution: Jepson, G. L., 3.

Feldspar: Burgess, B. C.

Fluorite: Mudd, H. T.

Foraminifera: Thalmann, H. E., 2, 3, 4.

Walnut formation, Lower Cretaceous, Texas, Oklahoma: Loeblich, A. R., Jr., 2.

Geochemical prospecting: Hawkes, H. E., Jr., 2.

Geologic time, measurement: Marble, J. P., 2,4 .

Glacial debris: Sharp, R. P., 4.
Bibliography-Continued

Glacial erosion, sedimentation: Holmes, C. D., 2.

Goldthwait, J. W.: White, G. W., 2.

Granite, origin: Perrin, $\mathbf{R}$.

Great Basin, climatic changes: Antevs, E. V., 1.

Fish distribution and Pleistocene hydrography: Hubbs, C. L.

Greenland, ancient: Maync, W., 2.

Franz Joseph Fiord area: Bütler, H., 1.

Hawaii, volcanics: Macdonald, G. A., 4.

Illinois, Chicago region: Isfort, L. G.

Industrial minerals: Am. Inst. Min. Met. Eng.: Ries, H., 3.

Kansas, Edwards County: McLaughlin, T. G.

Oil and gas: Jewett, J. M., 2.

Pawnee County: McLaughlin, T. G.

Physiography: Schoewe, W. H.

Lane, A. C.: Larsen, E. S., Jr., 1.

Limestone: Rockwood, N. C.

Lithostrotion and genomorph concept: McLaren, D. J.

Louisiana, De Soto, Red River Parishes: Murray, G. E., Jr., 1.

Foraminifera, Harang formation, Miocene: Smith, D. J.

Harang fauna, Miocene: Pope, D. E.

Mammalia, early Tertiary, North America: Wilson, R. W., 4.

Manitoba, File-Tramping Lakes area: Harrison, J. M., 1.

Nonmetallic mineral resources: Kerr, L. B., 1.

Mansfield, G. R.: King, P. B., 4.

Massachusetts, Boston area, Boylston Street Fishweir II, Pleistocene: Barghoorn, E. S., Jr., 1.

Matthes, F. E.: Visher, S. S., 1.

Meinzer, O. E.: Sayre, A. N., 1.

Mexico, geology: Garfias, V. R.

Manganese deposits: Rodriguez Cabo, J., Jr.

Tectonics: Alvarez, M., Jr.

Tepexpan man: De Terra, H., 2.

Mineral aggregates, distribution: Woods, K. B.

Minnesota, Duluth area: Schwartz, G. M.,

Mississippi, northeastern, Paleozoic, preCambrian: Braunstein, J., 2.

Tertiary: Braunstein, J., 1.

Montana, coal resources: Combo, J. X.

Mountain building distribution in geologic time: Gilluly, J., 3.

New Mexico, southeastern, caliche: Bretz, J. H., 3.

Southwest, Mississippian: Laudon, L. R., 1.

Newfoundland: Hayes, A. O., 1.

North America, 1946-47: Thom, E. M.

Oklahoma, oil and gas developments, 1948: Wellman, D. C.

Oregon, Kerby quadrangle: Wells, F. G., 2. 
Bibliography-Continued

Orogeny, frequency and periodicity: Rutten, L. M. R.

Orthogenesis: Jepson, G. L., 3.

Ostracoda: Crouch, R. W.

Leperditiidae: Swartz, F. M., 2.

Oysters, giant, Miocene: Martin, L.

Paleocology: Malkin, D. S.

Pegmatites: Cameron, E. N.

Montana: Heinrich, E. W., 2.

Petroleum, origin: Cox, B. B.

Plant morphology, evolution: Just, T. K.

Pleistocene, climate: Landsberg, H.; Smith,

H. T. U., 2.

Geology and soil science: Thorp, J., 1 .

Research: Flint, R. F., 3.

Stratigraphy: Ray, L. L., 2.

Vertebrata: Hibbard, C. W., 4.

Potash: Smith, H. I.

Quartz twinning: Gault, H. R., 2.

Salt dome structures: Balk, $R$.

Scott, Gayle: Winton, W. M.

Scott, W. B.: Jepsen, G. L., 2; Simpson, G. G., 1.

Seismology: Milne, W. G., 1.

Sillimanite group: Riddle, F. H.

Size increase in fossil invertebrates: Newell, N. D., 3.

Slate: Behre, C. H., Jr., 2.

South Dakota, Black Hills pegmatites: Higazy, R. A.

Steidtmann, Edward: Bevan, A. C., 1.

Structural petrology: Fairbairn, H. W., 1.

Talc: Engel, A. E. J., 1.

Telluride minerals: Thompson, Robert M., 1.

Tennessee, west-central, Paleozoic, preCambrian: Braunstein, J., 2.

Texas, Permian Basin: West Texas Geol. Soc., Strat. Prob. Comm.

Southwest: West Texas Geol. Soc., 2, 3. Thallium, geochemistry: Rankama, K. K. Titaniferous ores: Evrard, P.

Titanium: Gillson, J. L.

Ventifacts: Sharp, R. P., 3.

Vertebrates, fossil, 1939-43: Camp, C. L. 1.

West Indies: Reed, F. R. C., 1.

Westgate, L. G.: Bevan, A. C., 2; Melvin, J. H., 1 .

Whitlock, H. P.: Pough, F. H., 1, 2.

Wyoming, Powder River Basin: Wyo. Geol. Assoc.

Biogeography, Pleistocene, Europe and North America: Deevey, E. S., Jr.

Biography.

Agassiz, Louis: Romer, A. S., 2; Teller, J. D.

Aldrich, T. H.: McGlamery, W.

Allen, R. C.: Hotchkiss, W. 0 .

Andrews, E. C.: Walkom, A. B.; Anonymous, 7.

Atwood, W. W.: Cressey, G. B.; Van Valkenburg, $\mathbf{S}$.

Bain, H. F.: DeWolf, F. W.
Biography-Continued

Eail, S. H.: Liddell, D. M., 1, 2; Anonymous, 1 .

Bowie, William: Fleming, J. A.; Heiskanen, $W$.

Brown, R. H.: Dodge, S. D.

Bruce, E. L.: Baker, M. B.; Anonymous, $12,13$.

Capps, S. R.: Smith, P. S.

Chamberlin, R. T.: Bowen, N. L., 2.

Clements, T. D.: Anonymous, 4.

Coleman, A. P.: Chamberlin, R. T., 2.

Collom, R. E.: Barnes, R. M., 2.

Cooke, H. S.: Anonymous, 6.

Crandall, R. R.: Chambers, L. S.

Cross, C. W.: Ross, C. S.

Cushman, J. A.: Todd, M. R.; Waters, J. A.

Dachnowski-Stokes, A. P.: Ableiter, J. K.

Darton, N. H.: Brown, R. W., 3; King, P. B., 3; Monroe, W. H.

Demorest, M. H.: Fisher, J. E., 1.

Ekblaw, W. E.: Barnes, C. P.; Anonymous, 11 .

Emmons, W. H.: Lovering, T. S., 2.

Feniak, M. W.: Cairnes, C. E.

Gester, G. C.: Barnes, R. M., 1.

Goldthwait, J. W.: White, G. W., 2.

Holden, R. J.: Cooper, B. N.

Horwood, H. C.: Hurst, M. E.; Huston, C. C.

Hutchison, A. G.: Smith, J. E.

Jackson, R. T.: Cushman, J. A., 4.

Johnston, W. A.: Cooke, H. C.

Knapp, E. B.: Smith, B.

Lane, A. C.: Larsen, E. S., Jr., 1.

Leonardo da Vinci: Clements, T. D.

Manchester, J. G.: Stanton, G. S.

Mansfield, G. R.: King, P. B., 4.

Matthes, F. E.: Ray, L. L., 1; Visher, S. S., 1.

McCalley, Henry: Pallister, H. D., 1.

Meinzer, O. E.: Sayre, A. N., 1, 2.

Merriam, J. C.: Watson, D. M. S., 1.

Murray, H. W.: Jordan, G. F.

Palmer, R. H.: Kirk, H. M.

Phalen, W. C.: Bowles, O.

Phillips, W. B.: Pallister, H. D., 2.

Plummer, F. B.: Fancher, G. H.

Prouty, W. F.: Pallister, H. D., 3; Anonymous, 14 .

Reid, H. F.: Chamberlin, R. T., 3; Lawson, A. C., 1.

Ricketts, L. D.: Bimson, W. R.

Rieber, Frank: Pemberton, J. R.

Schuchert, Charles: Leuchs, $\mathrm{K}$.

Scott, A. W.: Lusch, R.

Scott, Gayle: Winton, W. M.

Scott, W. B.: Jepsen, G. L., 2; Simpson, G. G., 1 .

Smith, E. A.: Jones, W. B.

Smith, P. S.: Burrill, M. F.; Moffit, F. H.; Reed, J. C., 1.

Stalder, Walter: Bradley, W.; Gester, G. C. Steidtmann, Edward: Bevan, A. C., 1. 
Biography-Continued

Stewart, J. S.: Mackay, B. R., 1; Roliff, W. A., 2.

Swain, J. F.: Gulley, M. G.

Van Tuyl, F. M.: Dobbin, C. E., 2.

Wengard, S. A.: Ellsworth, E. W.

Westgate, L. G.: Bevan, A. C., 2; Melvin, J. H., 1.

Whitlock, H. P.: Pough, F. H., 1, 2.

Willis, Bailey: Stose, G. W., 3; Visher, S. S., 2.

Woods, A. F.: Rand, F. V.

Wuensch, C. E.: McGuire, P. J.

Yates, A. B.: Anonymous, 10.

Bioherms. See also Reefs.

Alberta, Leduc oil fields: Link, T. A., 1.

Petroleum, origin: Link, T. A., 6.

Birds. See Aves.

Bituminous rocks. See also Oil shale.

Classification: Schopf, J. M., 4.

Facies: Roth, R. I., 1.

Mid-continent, Missouri series, Pennsylvanian: Roth, R. I., 1.

Northwest Territories, Athabaska tar sands: Williams, M. Y.

Texas, Word series, Permian: Roth, R. I., 1.

Utah, hydrocarbons: Crawford, A. L.

Blastoidea. See Echinodermata.

Block diagrams, Colorado, Lyons sandstone, Front Range: Thompson, W. $O$.

Bogs. See also Paleobotany; Peat; Pollen analysis.

Alberta: Hansen, H. P., 1, 2.

Ontario, paleobotany: Potzger, J. E., 2.

Pollen analysis and paleoecology: Cain, S. A.

Quebec, paleobotany: Potzger, J. E., 1.

Botany, fossil. See Paleobotany.

Boulders.

Massachusetts, Fitchburg rollstone: Palache, $C$.

North Dakota, glacial: Waring, G. A.

South Dakota, glacial: Waring, G. A.

Brachiopoda. See also Invertebrata.

Bancroftina, revision: Sinclair, G. W., 2.

British Columbia, Wapiti Lake area, faunal lists: Laudon, L. R., 3.

California, Lower Cambrian, Marble Mts.: Ridge, J. D.

Florida, Lingulepis floridaensis, early $\mathrm{Pa}-$ leozoic: Howell, B. F., 3.

Iowa, Maquoketa, Ordovician: Wang, $\mathbf{Y}$.

Limestones, organic: Johnson, J. H., 1.

Mexico, La Peña formation, Sierra de los Muertos: Humphrey, W. E.

Zacatecas: Maldonado-Koerdell, M., 3.

Missouri, Athyris, Burlington limestone: Unklesbay, A. G.

New York, Schenectady formation, new species, Ordovician: Howell, B. F., 2.

Oklahoma, Henryhouse formation, Silurian: Amsden, T. W., 2.

Raymondella, revision: Sinclair, G. W., 2.

Reedaspis, revision: Sinclair, G. W., 2.

Breccia.

California, Avawatz Mts., Pliocene: Jahns, R. H., 2.

New Mexico, southeastern, caliche: Bretz, J. H., 3.

Rheomorphic: Goodspeed, G. E., 2. British Columbia.

Correlations of geological and forestry maps: Warren, H. V., 4.

Areas described.

McConnell Creek map-area: Lord, C. S., 1.

Economic geology.

Fort St. James area: Armstrong, J. E.

Geochemical investigations, copper: Warren, H. V., 3.

Gold and silver in plants: Warren, $\mathbf{H}$. V., 5.

Mine areas: Warren, H. V., 1.

Lead Empire group: Patmore, W. H.

Lead-zinc, Sullivan mine: Swanson, C. O., 1.

McConnell Creek map-area: Lord, C. S., 1.

Metal mining areas: British Columbia Dept. Mines.

Nelson area, Kootenay district: Little, H. W., 1.

Ore exploration: Riley, C.

Smithers-Fort St. James area: Canada G. S., 13.

Uranium, prospecting: Stevenson, J. S.

Geologic maps.

Alliford Bay area, Queen Charlotte Islands, Jurassic: McLearn, F. H.

Carp Lake area: Canada G. S., 3. Surface deposits: Canada G. S., 4.

Fort St. James area: Armstrong, J. E.

Glacier Park area, sketch map: Okulitch, V. J.

Lead Empire group: Patmore, W. H.

Maude Island, eastern, Jurassic: McLearn, F. $\mathbf{H}$.

McConnell Creek map-area: Canada G. S., 10; Lord, C. S., 1.

Metal mining areas: British Columbia Dept. Mines.

Middle River Range: Little, H. W., 2.

Nelson area, Kootenay district: Little, H. W., 1.

Smithers-Fort St. James area: Canada G. S., 13.

Wapiti Lake area: Laudon, L. R., 3. Historical geology.

Alliford Bay area, Queen Charlotte Islands, Jurassic: McLearn, F. H.

Carp Lake area: Canada G. S., 3.

Fort St. James area: Armstrong, J. E.

Glacier-Rogers Pass area, Selkirk Mts.: Cox, A. H.

Jurassic sections: Spivak, J.

McConnell Creek area: Canada G. S., 10; Lord, C. S., 1.

Nelson area, Kootenay district: Little, H. W., 1.

Paleozoic strata, Alaska Highway: Laudon, L. R., 2.

Selkirk Mts.: Okulitch, V. J 
British Columbia-Continued

Historical geology-Continued

Smithers-Fort St. James area: Canada G. S., 13 .

Wapiti Lake area, Devonian, Mississippian: Laudon, L. R., 3.

Mineralogy.

Antimony minerals: Warren, H. V., 2.

Tellurium minerals: Warren, H. V., 2.

Paleontology.

Lithostrotion, Mississippian: McLaren, D. J.

Petrology.

Fort St. James area: Armstrons; J. E.

Middle River Range, ultrabasics: Little, H. W., 2.

Warn Bay-Tofino Inlet area: Lynott, W. J.

Physiographic geology.

Carp Lake area: Canada G. S., 3, 4.

Lloyd George Mts.: Odell, N. E., 2.

Sentinel Glacier: Mathews, W. H.

Stagnant glacier, Lloyd George Mts.: Odell, N. E., 1.

Brush fires, geologic effect: Patton, M. M.

Bryozoa.

Genotypes, Paleozoic: Duncan, $\mathbf{H}$.

Limestones, organic: Johnson, J. H., 1.

Building stone. See Construction materials; Granite; Limestone; Sandstone.

Calcite.

Thermal expansion: Rosenholtz, J. L.

Caliche.

Correlation: Price, W. A., 2.

New Mexico, southeastern: Bretz, J H., 3. California.

Engineering geology, Isabella project: Treasher, R. C., 1.

Gravity anomalies, San Joaquin valley: Clement, P. F.

Lake Elsinore, bottom sampling: Mann, J. F., Jr.

Matilija Dam, Ventura County: Southworth, J. S.

Magnetic profiles, Cuyama Valley: Hoylman, H. W.

Seismic investigations, offshore: Johnson, C. $\mathbf{H}$.

Seismic surveys, reflection correlation, Sacramento Valley: Cohick, K. S.

Stream studies, engineering projects: Holdredge, C. $\mathbf{P}$.

Well velocity shooting, seismic data: Wells, R. J.

Economic geology.

Chromite, Siskiyou County: Wells, F. G., 1.

Copper: Jenkins, O. P.

Big Bend mine, Butte County: Eric, J. H., 1.

Copperopolis, Calaveras County: Heyl, G. R., 5.

Foothill copper-zinc belt, Sierra Nevada: Heyl, G. R., 1.

Jesse Belle mine, Madera County: Cox, M. W., 3.
California-Continued

Economic geology-Continued

La Victoria mine, Mariposa County: Cox, M. W., 2.

Lilyama mine, EI Dorado County: Cox, M. W., 1.

Newton mine, Amador County: Heyl, G. R., 2 .

Penn mine, Calaveras County: Heyl, G. R., 3 .

Pioneer mine, El Dorado County: Cox, M. W., 1 .

Quail Hill mines, Calaveras County: Heyl, G. R., 6.

Diatomite, Lompoc area: Cook, R. B.

Iron Mtn. mine, Redding: Kinkel, A. R., Jr.

Lead, Cerro Gordo mine area: Merriam, C. W., 1.

Limestone, Gazelle region: Heyl, G. R., 8. Sonora region: Heyl, G. R., 7.

Mercury, Oakville district, Napa County: Fix, P. F., 1.

Mineral resources: Calif. Dept. Nat. Res., Div. Mines.

Butte County: O'Brien, J. C.

Kern County: Tucker, W. B.

Tuolumne County: Logan, C. A.

Natural gas, developments, 1948: Moody, G. B.

Petroleum, Cuyama field: Eckis, $\boldsymbol{R}$.

Developments, 1948: Moody, G. B.

Guijarral Hills field: Loofbourow, J. S., Jr.

North Sulphur Mtn. field: Schwade, I. T. Placerita Canyon field: Willis, $R$.

Russell Ranch field: Eckis, R.

San Ardo field: Baldwin, T. A.

Santa Maria district, fractured oil reservoirs: Regan, L. J., Jr.

Puente Hills, NW., Los Angeles Co.: Daviess, S. N.; U. S. G. S., 1, no. 83 .

Talc, Silver Lake area: Wright, L. A., 1. Tungsten, Bishop district: Bateman, P. C. Zinc, American Eagle-Blue Moon area: Eric, J. H., 2.

Big Bend mine, Butte County: Eric, J. H., 1.

Foothill copper-zinc belt, Sierra Nevada: Heyl, G. R., 1.

Penn mine, Calaveras County: Heyl, G. R., 3.

Quail Hill mines, Calaveras County: Heyl, G. R., 6.

Geologic maps.

Antioch quadrangle: Weaver, C. E.

Carquinez quadrangle: Weaver, C. E.

Chromite deposits, Siskiyou County: Wells, F. G., 1 .

Copper deposits: Jenkins, O. P.

Copperopolis area, Calaveras Co.: Heyl, G. R., 5 .

Foothill copper-zinc belt, Sierra Nevada: Heyl, G. R., 1.

Gazelle region, limestone; Heyl, G. R., 8. 
California-Continued

Geologic maps-Continued

Grayhouse area, Amador Co.: Heyl, G. R., 4.

Jesse Belle copper mine, Madera Co.: Cox, M. W., 3.

June Lake district: Putnam, W. C.

La Victoria copper mine, Mariposa Co.: Cox, M. W., 2.

Lilyama and Pioneer copper mines, El Dorado Co.: Cox, M. W., 1.

Mare Island quadrangle: Weaver, C. E.

Mt. Vaca quadrangle: Weaver, C. E.

Newton copper mine, Amador Co.: Heyl, G. R., 2.

Oakville district mercury mines: Fix, $P$. F., 1.

Penn zinc-copper mine, Calaveras Co.: Heyl, G. R., 3.

Petaluma quadrangle: Weaver, C. E.

Point Reyes quadrangle: Weaver, C. E.

Puente Hills, Los Angeles Co.: Daviess, S. N.; U. S. G. S., 1, no. 83.

Quail Hill area mines, Calaveras Co.: Heyl, G. R, 6.

San Andreas rift area, southern: Wallace, R. E., 1.

Santa Rosa quadrangle: Weaver, C. E.

Sonoma quadrangle: Weaver, C. E.

Sonora region, limestone: Heyl, G. R., 7.

Vacaville quadrangle: Weaver, C. E.

Zine deposits, American Eagle-Blue Moon area, Mariposa Co.: Eric, J. H., 2.

Zinc-copper deposits, Big Bend mine, Butte Co.: Eric, J. H., 1.

Ground water.

General: Bartz, P. M.

Haywards fault, impounding effect: Forbes, $\mathbf{H}$

Historical geology.

Capitola quadrangle: Beard, C. N.

Coast Ranges, San Francisco Bay area: Weaver, C. E.

Copper deposits: Jenkins, O. P.

Crystal Spring formation: Wright, L. A., 2.

Devil's Punchbowl area: Laurie, A. M.

Foothill copper-zine belt, Sierra Nevada: Heyl, G. R., 1.

June Lake district: Putnam, W. C.

Los Angeles basin: Schoellhamer, J. E.

Lytle Creek area: Arnett, G. R.

Mount Diablo, Marysville Butte area, Lower Tertiary: Stewart, R. B.; U. S. G. S., 2, no. 34

Pliocene breccias, Avawatz Mts.: Jahns, R. H., 2.

Puente Hills, Los Angeles Co.: Daviess, S. N.; U. S. G. S., 1, no. 83.

San Andreas rift area, southern: Wallace, R. E., 1.

Santa Rosa Island, northern: Anderson, R. E.

Shasta Valley: Williams, $\mathbf{H}$.

Temblor Range: Hackel, $\mathbf{0}$.
California-Continued

Historical geology-Continued

Vaqueros formation, Miocene, Santa Barbara area: Orwig, E. R., Jr.

Wildcat series, Tertiary: Stewart, R. E.

Wilmington oil field: Gilluly, J., 2.

Zinc deposits, American Eagle-Blue Moon area, Mariposa Co.: Eric, J. H., 2.

Zinc-copper deposits, Big Bend mine, Butte Co.: Eric, J. H., 1.

Mineralogy.

Cementation, Tertiary reservoir sands: Gilbert, C. M., 1.

Clay minerals, Pacific bottom sediments: Grim, R. E., 2.

Copper deposits, Copperopolis, Calaveras Co.: Heyl, G. R., 5.

Diopside, San Benito County: Bolander, L. P., Jr.

Geikielite, Riverside: Murdoch, J., 2.

Grayhouse area, Amador Co.: Heyl, G. R., 4.

Jesse Belle copper mine, Madera Co.: Cox, M. W.; 3.

La Victoria copper mine, Mariposa Co.: Cox, M. W., 2.

Mineral occurrences: Murdoch, J., 1.

Penn zinc-copper mine, Calaveras Co.: Heyl, G. R., 3.

Perovskite, Crestmore: Murdoch, J., 3.

Southern California batholith, minerals: Larsen, E. S., Jr., 4.

Zine deposits, American Eagle-Blue Moon area, Mariposa Co.: Eric, J. H., 2.

\section{Paleontology.}

Aves, marine Pleistocene: Howard, H., 1.

Pliocene, San Diego area: Howard, H., 2.

Skulls, cathartid vultures: Fisher, H. I. Dendraster elsmerensis, Pliocene: Durham, J. W., 1.

Faunal lists, Lower Tertiary, west central: Stewart, R. B.; U. S. G. S., 2, no. 34 .

Foraminifera, Meganos formation, Tertiary: Graham, J. J., 2.

Puente Hills, Tertiary, Quaternary: Daviess, S. N.; U. S. G. S., 1, no. 83.

Santa Clara County, Franciscan age: Glaessner, M. F.

Wildcat coast section, Pliocene: Stewart, R. E.

Fossil shell collecting, Alverson canyon: Weight, H. O., 3.

Gastropoda, Eocene, Kern Co.: Hanna, G. D.

Insecta, Silphidae, asphalt deposits: Piérce, W. D., 2.

La Brea tar pits, fauna, Los Angeles: Curtin, $G$.

Mammalia, Titus Canyon formation: Stock, C., 1.

Mancalla, Pliocene flightless bird: Miller, L. $\mathbf{H}$.

Marble Mts., Lower Cambrian fauna: Riccio, J. F.

McKittrick asphalt pit: Pierce, W. D., 1. 
California-Continued

Paleontology-Continued

Mollusca, Cretaceous, genetic lines: Popenoe, W. P., 2.

Mytilus, Pliocene, Humboldt Co.: Mandra, Y. T.

Wildcat coast section, Pliocene: Stewart, R. E.

Ostracoda, Pliocene: Crouch, R. W.

Wildcat coast section, Pliocene: Stewart, R. E.

Oysters, giant, Miocene; Shell Peak: Martin, $\mathbf{L}$.

Pinniped, San Diego formation, Pliocene: Burleson, G. L.

Pinus remorata, Pleistocene: Mason, H. L. Pleistocene Man, La Jolla: Carter, G. F.

Rodents, Eocene: Wilson, R. W., 1.

Lagomorphs, upper Sespe: Wilson, R. W., 3.

San Francisco Bay area: Weaver, C. E.

Vertebrates, Pliocene, Pleistocene: Savage, D. E.

\section{Petrology.}

Cape San Martin region, nephrite: Crippen, R. A., Jr.

Cementation, Tertiary reservoir sands: Gilbert, C. M., 1.

Coast Ranges, San Francisco Bay area: Weaver, C. E.

Friant dam, aggregate, petrography: Rhoades, R. F., 4.

Pumice, petrography: Mielenz, R. C., 14.

Keswick quartz diorite, near Redding, petrography: Haff, J. C., 1.

Magnesium metasomatism, Lucerne Valley: Campbell, $\mathrm{I}$.

Metamorphic rocks, Bishop district: Bateman, P. C.

Shasta dam, aggregate, petrography: Rhoades, R. F., 4.

Silver Lake talc-tremolite area: Wright, L. A., 1.

Titanomagnetites, San Gabriel Mts.: Gakeshott, G. B.

Turtle Mts., dikes: Chesterman, C. W.

Physical geology.

Bristol Dry Lakes cave, halite stalactites: Hicks, F.

Brush fires, geologic effect: Patton, M. M.

Coast Ranges, San Francisco Bay area: Weaver, C. E.

Devil's Punchbowl area: Laurie, A. M.

Earthquake study, southern: Gutenberg, B., 5.

Earthquakes: Richter, C. F.

Northern: Romney, C. F., 1, 2, 3.

Southern: Warner, S. E.

Kern County fault: Treasher, R. C., 2.

Kingston thrust fault, southern: Hewett, D. F.

Lassen Volcano eruptions: Loomis, B. F.

Long Beach Harbor area, subsidence: Gilluly, J., 2.

Lytle Creek area: Arnett, G. R.
California-Continued

Physical geology-Continued

Offshore ocean-bottom structure: Raitt, R. W.

Puente Hills, Los Angeles Co.: Daviess, S. N.; U. S. G. S., 1, no. 83.

San Andreas rift, southern, structure: Wallace, R. E., 1.

San Andreas-San Jacinto rift zones: Sprotte, E. C.

Santa Maria district, fractured oil reservoirs: Regan, L. J., Jr.

Turtlebacks, Black Mts.: Curry, H. D.

Walker Pass earthquakes, southern Sierra Nevada: Chakrabarty, S. K.

Physiographic geology.

Alluvial fan, La Jolla: Carter, G. F.

Beach sedimentation, Santa Monica: Han$\operatorname{din}$, J. W.

Beaches, Mugu Lagoon area: Inman, D. L.. 2.

Coastal changes, Santa Barbara, Quaternary: Upson, J. E., 1

Gaviota quadrangle, shore lines: Upson, J. E., 2.

Palisade Glacier: Heald, W. F., 1.

Submarine canyons: Shepard, F. P., 2.

La Jolla area: Shepard, F. P., 4.

Monterey: Shepard, F. P., 1.

Submarine topography, Santa Barbara coast: Thompson, W. C.

Cambrian. See also Paleontology, Cambrian.

Alberta, Paleozoic pre-Waterways strata, Plains area: McGehee, J. R.

Rocky Mtn. Front Ranges, Bow River area: Clark, L. M., 2.

Appalachians, southern: King, P. B., 6. Stratigraphy and paleontology: Wilson, J. L., 2.

Arctic America, Devon Island, Aretic Archipelago: Wales, D. B.

British Columbia, Glacier-Rogers Pass area: Cox, A. H.

Correlation, North America and China: Howell, B. F., 1.

Greenland, Jørgen Brønlunds Fjord area: Troelsen, J. C.

Kentucky, subsurface: Freeman, L. B.

Missouri, Vernon County, pre-upper Cambrian: Skillman, M. W.

New York, Hudson Valley: Flower, R. H., 3.

Subsurface: Swartz, F. M., 3.

Newfoundland, eastern: Hayes, A. O., 1.

Pennsylvania, eastern, terminology: Willard, B., 3.

Subsurface: Swartz, F. M., 3.

Quebec, Lévis: Laverdière, J. W.

Utah: Schneider, $\mathbf{H}$.

West Virginia: Woodward, H. P.

Canada. See also the various provinces.

Canadian Shield, aerial photographs, use: Russell, G. A., 2.

Geologic time, measurement, Ontario-Manitoba gold belt: Hurley, P. M., 1. 
Canada-Continued

Geologic research projects: Hawley, J. E. 1.

History of geology, 1841-1941: Morin, L. G.

1849-1949: Alcock, F. J., 1.,

Permafrost, origin, distribution: Jenness, J. L.

Economic geology.

Coal, analyses: Swartzman, $\mathbf{E}$.

Reserves: Mackay, B. R., 3.

Lead, occurrences: McClelland, W. R.

Natural gas, developments: Gray, J. G.

Western: Link, T. A., 4.

North Pacific region: Canada G. S., 1.

Petroleum: Link, T. A., 2.

Development: Gray, J. G.; Gustafson, J. D.

Exploration, western: Deegan, C. J., 3.

Fields: Ver Wiebe, W. A., 1.

Western: Link, T. A., 4.

Silica deposits: MacPherson, A. R.

Uranium prospecting: Lang, A. H., 1; Savage, W. S.

Geologic maps.

General: Reed, F. R. C., 2.

Maritime Provinces: Canada G. S., 9.

North Pacific region: Canada G. S., 1.

Historical geology.

Canadian Shield, northwestern: Jolliffe, A. W.

Churchill, paleogeography: Richards, H. G., 2.

Devonian, northwestern: Warren, P. S., 2.

General: Reed, F. R. C., 2.

Labrador, pre-Cambrian: Bruet, E., 1.

North Pacific region: Canada G. S., 1.

Quebec, northern, pre-Cambrian: Bruet, E., 1.

Western, Interior Plains, stratigraphy and structure: Link, T. A., 5 .

Mineralogy.

Tellurides: Thompson, Robert M., 1.

Paleontology.

Collecting, Churchill area: Richards, H. G., 2.

Petrology.

Canadian Shield, northwestern: Jolliffe, A. W.

Physical geology.

Canadian Shield, orogeny: Gill, J. E., 2.

Structural provinces: Gill, J. E., 1.

Structure: Harrison, J. M., 2.; Wilson, J. T., 2.

Faults, St. Lawrence Lowland: Dufresne, c.

Labrador, synclinal structure: Douglas, G. V., 1.

Physiographic geology.

Caves, eastern: Hitcheock, H. B.

Glaciers, Canadian Rockies, 1948: Field, W. O., Jr., 2.

North Pacific region: Canada $\dot{G}$. S., 1

Post-Pleistocene seaway, James Bay-Gulf of St. Lawrence: La Rocque, A., 1.

Seward firn field: Sharp, R. P., 5.
Canadian Shield.

Age: Wilson, J. T., 2.

Exploration, use of aerial photographs: Russell, G. A., 2

Geothermal gradients: Misener, A. D.

Northwestern, provinces: Jolliffe, A. W.

Origin: Wilson, J. T., 1, 3.

Orogeny: Gill, J. E., 2.

Provinces: Gill, J. E., 1.

Structure: Wilson, J. T., 1, 2.

Geophysical investigation: Henderson, J. F., 2.

Shown by air photography: Harrison, J. M., 2.

Uranium deposits: Lang, A. H., 3.

Canal Zone. See Panama.

Carbon, geochemistry: Hutchinson, G. E.

Carboniferous. See also Paleontology, Carboniferous.

Alabama, Coosa coal field: Rothrock, H. E., 2.

Alberta, Moon Creek area, west of Sixth Meridian: Canada G. S., 12.

Rocky Mtn. Front Ranges, Bow River area: Clark, L. M., 2.

Appalachians, southern, Mississippian stratigraphy: Stockdale, P. B.

British Columbia, Alaska Highway, Mississippian: Laudon, L. R., 2.

Carp Lake area: Canada G. S., 3.

Wapiti Lake area: Laudon, L. R., 3.

Colorado, McCoy area, Pennsylvanian: Murray, H. F.

Pando area: Tweto, O. L.

Illinois, southern: Doerr, A. H.

Trivoli sandstone, Williamson County: Siever, $\mathbf{R}$.

Iowa, coal fields: Averitt, P., 1.

Southeast, Mississippian: Thomas, L. A.

Kansas, lithology: Clair, J. R.

Pennsylvanian system: Moore, R. C., 6.

Kansas-Oklahoma, subsurface cross sections: Lukert, L. H.

Kentucky, eastern, Upper Mississippian: Wilpolt, R. H.; U. S. G. S., 2, no. 38.

Greenbrier formation, Mississippian: Sonnenberg, F. P.

Salt sand (Pottsville conglomerate), Pennsylvanian: Thomas, R. N.

Maine, Topsham, pegmatite age determination: Shainin, V. E., 3.

New Mexico, southwest, Mississippian: Laudon, L. R., 1.

North America, paleotectonic, paleogeologic maps: Eardley, A. J., 2.

Nova Scotia: Keating, B. J.

Ohio, Allegheny formation, Dorr Run shale: Sturgeon, M. T., 1.

Oklahoma, Anadarko Basin: Wheeler, $\mathbf{R}$. R., 1.

Des Moines series: Jackson, N. A.

Haskell County: Oakes, M. C.

Mayes formation, Mississippian: Selk, E. L.

Morrow series: Jackson, N. A. 
Carboniferous-Continued

Velma pool, Pennsylvanian: Mallory, W. W., 2.

Pennsylvanian system, divisions: Moore, R. C., 3.

Texas, Cisco group clays, Pennsylvanian: Plummer, F. B.

Lawson-Chapman area, Pennsylvanian reef: Ammon, W. L., 1.

Pennsylvanian, limestone distribution: Conley, J. N.

Utah: Williams, J. Stewart, 2.

Morgan formation, Pennsylvanian: Untermann, G. E., 2.

Virginia, southwestern, Upper Mississippian: Wilpolt, R. H.; U. S. G. S., 2, no. 38.

West Virginia, Greenbrier formation: Rittenhouse, G., 5.

Southern, Upper Mississippian: Wilpolt, R. H.; U. S. G. S., 2, no. 38 .

Cartography.

Aerial photographs, geologic use: Summerson, C. H.

Symbols for geologic maps: Goddard, E. N., 2.

Catalog.

Foraminifera, descriptions: Ellis, B. F., 1. Cauldrons, stream: Addington, A. R.

Caves.

Breakdown: Davies, W. E., 2.

Cayada, eastern: Hitchcock, H. B.

Hydrology: Hamilton, D. K.

Indiana, Hudelson cavern: Malott, C. A., $1,2$.

Minerals : Foster, W. J.

Missouri, St. Louis, Cherokee cave: Simpson, G. G., 5 .

New Mexico, Carlsbad Caverns: Horberg, C. L., 3.

Origin: Bretz, J H., 1.

Guadalupe Range, origin: Bretz, J. H., 1.

Origin: Stone, R. W.

Virginia, Skyline Caverns: Henderson, E. P., 6.

West Virginia: Davies, W. E., 1.

Cenozoic.

Arizona, Upper Verde Valley development: Mahard, R. H.

Mississippi Valley, field conference: Leighton, M. M., 1.

New York, Long Island, Kings County: deLaguna, W.

Texas, High Plains: Evans, G. L.

Central America. See also the various countries.

Facies, Mesozoic: Mullerried, F. K. G., 10.

Historical geology: Rubio, A.

Volcanoes: Griffin, N. J.

Cephalopoda. See also Mollusca.

Alberta, Peace River Plains, faunal lists: Gleddie, J.

Arizona, ammonoids, Permian, Mustang Mts.: Stoyanow, A. A., 3.
Cephalopoda-Continued

Greenland, Permoteuthis groenlandica, Permian: Rosenkrantz, A.

Iowa, Maquoketa shale, Ordovician: Miller, A. K., 1.

Mexico, La Peña formation, Sierra de los Muertos: Humphrey, W. E.

Nautiloids, development: Miller, A. K., 4. Devonian: Flower, R. H., 1.

Permian: Miller, A. K., 2.

Nevada, White, Pine shale, Mississippian: Youngquist, W. L., 3.

Oklahoma, Pennsylvanian, microstructure: Fischer, A. G.

Pedioceras, synonym of Crioceras (Pseudocrioceras) : Yenne, K. A.

Scaphites morrowi, nomenclature: Jeletzsky, J. A.

United States, central and western: Miller, A. K., 5.

Wyoming, Ammonoidea, Greybull area, Upper Cretaceous: Haas, O., 1.

Ceramic materials.

Analogy to geologic processes: Williamson, W. 0 .

Kansas, Pleistocene loess: Frye, J. C., 5.

New Jersey, glass sand: Wilkerson, A. S., $1,2$.

Ohio: Everhart, J. O.

Oklahoma, southwestern: Funnell, J. E.

Texas: Pence, F. K., 2.

United States, bibliography: Ries, H., 3.

Occurrence: Ries, H., 3.

Chalk, Kansas, Fort Hays: Runnels, R. T., 1.

Changes of level. See also Beaches; Shore lines; Terraces.

California, La Jolla: Carter, G. F.

Long Beach Harbor area: Gilluly, J., 2.

Santa Barbara, Quaternary: Upson, J. E., 1.

Determination by pollen analysis: Knox, A. S.

Great Lakes area, crustal movement: Hobbs, W. H., 2.

Greenland, ancient: Eardley, A. J., 1.

Franz Joseph Fiord area: Bütler, H., 1.

United States, coastal area, sea level: Marmer, H. A.

Chert.

Pennsylvania, Ordovician, petrology: Folk, R. L., 2.

Chlorite.

Index of refraction measurement: Girault,

$$
\text { J. P., } 1 .
$$

Chromite.

California, Siskiyou County: Wells, F. G., 1.

General: Johnston, W. D., Jr.

Montana, Boulder River area: Howland, A. L.

Wyoming, Casper Mtn.: Horton, F. W. Cirques.

Alpine glaciation: Ray, L. L., 3.

Excavation: Fisher, J. E., 4.

Formation, meltwater function: Lewis, W. V. 
Classification.

Bryozoa, Paleozoic, genotypes: Duncan, $\mathbf{H}$. Carbonaceous rocks: Sehopf, J. M., 4. Geosynclines: Wells, F. G., 3.

Gneiss: Alcock, F. J., 2.

Igneous rocks: Mielenz, R. C., 10.

Iowa, soils, Wisconsin drift area: Riecken, F. F.

Oil shale: Schopf, J. M., 4.

Ostracoda, Leperditiidae: Swartz, F. M., 2.

Paleontologic: Weller, J. M.

Pollen grains and spores: Erdtman, G.

Rocks, by facies: Ramberg, H., 2.

Sandstone, cementing agents: Tallman, S. L.

Sedimentary rocks: Dapples, E. C., 2.

Stratigraphic units, subsurface: American Comm. Strat. Nomenclature.

Texas, Colorado River Valley Permian(?) rocks: Moore, R. C., 2; U. S. G. S., 1, no. 80.

Unconformities: Scott, G. R., 1 . Clay.

Atterberg plastic limits: White, W. A.

Bentonite, properties: McDonnell, D., 4.

Bottom sediments, Gulf of California: Grim, R. E., 2.

Pacific Ocean: Grim, R. E., 2.

Colorado, Wagon Wheel Gap area, petrography: McConnell, D., 2.

Crystal forms, electron microscope: Mackie, W. Z.

Electron microscopy: Bates, T. F., 2.

Florida: Calver, J. L., 2.

Fracture, characteristics: Ingram, R. I.

General: Ries, H., 1.

Grinding reaction: Perkins, A. T.

Illite group: Grim, R. E., 3.

Infrared radiation, absorption: Keller, W. D., 5 .

Iowa, Wisconsin drift area soils: Riecken, F. F.

Kaolinite, crystal structure, thermal behavior: Comeforo, J. E.

Thermal analysis: Gruver, R. M.

Maine: Goldthwait, L.

Mineral names, glossary: Kerr, P. F., 1.

Minerals, structure, optics: Marshall, C. E.

Missouri, alumina in oak leaves over clay pits: Keller, W. D., 2.

Gumbotil, formation, relation to overlying loess: Krusekopf, $\mathrm{H}$. $\mathrm{H}$.

Paleozoic shales: Allen, V. T., 1.

North Carolina, western, halloysite: Hunter, C. E.

Pennsylvania, high-alumina: Sanford, $\mathbf{R}$. s.

Sampling procedure: Prince, A. T.

Segregation of minerals, soils: Pennington, R. P.

Soils, weathering sequence and $\mathrm{X}$-ray diffraction analysis: Willis, A. L.

Stain analysis: LeRoy, L. W., 7.

Clay-Continued

Texas, Cisco group, Pennsylvanian: Plummer, F. B.

Thermal analysis: Kerr, P. F., 4.

Referenee specimens: Kerr, P. F., 3.

United States, reference localities: Kerr, P. F., 2.

Reference specimens, thermal analysis: Kerr, P. F., 3.

Utah, Bingham, nontronite: Stringham, B. F.

Pre-Bonneville deposits: Hunt, C. B., 2.

Washington, Columbia River: Cary, A. S. Cleavage.

Appalachian folds: Gair, J. E.

New York, Adirondack Mts., Grenville series: Engel, A. E. J., 3.

Vermont, east-central: White, W. S.

Coal. See also Lignite.

Alabama, Coosa field: Rothrock, H. E., 2. Analyses: Cooper, H. M., 1.

Fairview coal, petrography: Smith, H. L., 1.

Reserves: Toenges, A. L., 1.

Stratigraphy: Rothrock, H. E., 1.

Alaska, Healy River Valley: Wahrhaftig, C., 1.

Kenai field: Barnes, F. F.

Kenai Peninsula: Toenges, A. L., 4.

South central: Toenges, A. L., 4.

Alberta, Moberly Creek, West of Sixth Meridian: Canada G. S., 11.

Reserves: Lang, W. A.

Ribbon Creek area: Crockford, M. B. B., 1.

Southwestern, Kootenay strata: Crockford, M. B. B., 2.

Stimson Creek West of Fifth Meridian: Canada G. S., 14.

Canada, analyses: Swartzman, E.

Reserves: Mackay, B. R., 3.

Colorado, Durango area: U. S. G. S., 1, no. 109; Zapp, A. D.

Minnesota Creek area: Toenges, A. L., 2.

U. S. Geological Survey, investigations: Dane, C. $H$.

Degradation of plant remains in organic sediments: Barghoorn, E. S., Jr., 4.

Electron microscopy: McCartney, J. T.

Geochemistry: Miller, H. P.

Illinois, petrographic analysis: Parks, B. C.

Southern: Doerr, A. H.

Iowa fields: Averitt, P., 1.

Manitoba, bibliography: Kerr, L. B., 1.

Maryland, Georges Creek basin, analyses: Cooper, H. M., 2.

Petrography: Smith, H. L., 2.

Reserves: Toenges, A. L., 3. Stratigraphy: Waage, K. M.

Upper Potomac basin, analyses: Cooper, H. M., 2.

Petrography: Smith, H. L., 2. Reserves: Toenges, A. L., 3 . 
Coal-Continued

Mexico, Santa Clara district, Sonora: Wilson, I. F., 1.

Mining geology, roof characteristics: Am. Min. Cong., Coal Div., Comm. on Roof Action.

Montana, reserves: Combo, J. X.

New Brunswick, Chipman area, map: Muller, J. E., 2.

Minto area, map: Muller, J. E., 1.

New coal age: Ashley, G. H.

Newfoundland: Hayes, A. O., 2.

North Carolina, Deep River coal field: Reinemund, J. A.

Ohio, Holmes County: White, G. W., 1.

Oklahoma, Haskell County: Oakes, M. C.

Oregon, Coos Bay field, paleobotany: Schopf, J. M., 1.

Paleobotany research since 1943: Schopf, J. M., 5.

Pennsylvania, natural briquettes: Schopf, J. M., 3.

U. S. Geological Survey work: Rothrock, H. E., 4.

Petrographic analysis: Parks, B. C.

Research, fields: Cady, G. H.

1948-1949: Kosanke, R. M.

Reserves, U. S. Geol. Survey Work: Averitt, P., 2.

Resources: Ashley, G. H.

Saskatchewan, southern, map: MacKay, B. R., 2.

Sedimentation, research: Dapples, E. C., 1. Texas: Stenzel, H. B., 2.

United States, reserves: Fieldner, A. C. Western: Parry, V. F.

Reserves: Bryson, R. P.

\section{Coal balls.}

Sphenophyllum, Psaronius, Carboniferous: Cobalt. Reed, F. D., 1.

Idaho, Blackbird district: Douglas, E. B.

Ontario, Rex-Werner Lakes area: Chisholm, E. O., 2.

Coelenterata. See also Anthozoa; Hydrozoa; Invertebrata.

Cuneate corals, Mississippian: Easton, W. $\mathbf{H}$.

Limestones, organic: Johnson, J. H., 1. Ccllections.

Meteorites, U. S. National Museum: Henderson, E. P., 1.

Color photography, minerals: Fisher, I. W.

Color, gemstones: Hurlbut, C. S., Jr., 2.

Colorado.

Colorado School of Mines, geological engineering: Van Tuy, F. M., 2.

Areas described.

La Plata district: Eckel, E. B., 1.

South Park: Stark, J. T.

Economic geology.

Coal, Durango area: U. S. G. S., 1, no. 109; Zapp, A. D.

Minnesota Creek area: Toenges, A. L., 2.
Colorado-Continued

Economic geology-Continued

U. S. Geological Survey investigations: Dane, C. $\mathrm{H}$.

Construction materials: Argall, G. O., Jr. Copper, Bear Creek district: Goddard, E. N., 1.

La Plata district: Schwartz, G. M., 2.

Fluorite, St. Peters Dome area: Steven, T. A.

Georgetown district, Anglo Saxon vein, self potential survey: Gabelman, J. W., 2.

Gold, Cripple Creek area, structural control: Koschmann, A. H., 1.

Industrial minerals: Argall, G. O., Jr.

La Plata district, ores: Eckel, E. B., 1.

Lead-zinc-silver, Mineral Point district: Hazen, S. W., Jr.

Poughkeepsie district: Hazen, S. W., Jr.

Mineral belt, geophysical exploration: Koschmann, A. H., 2.

Mining geophysics, scope: Wantland, $\mathbf{D}$.

Naval Oil Shale Reserves 1 and 3, Garfield Co.: Duncan, D. C.; U. S. G. S., 1 , no. 94 .

Oil and gas investigations, U. S. Geological Survey: Dane, C. $\mathrm{H}$.

Oil shales, Green River: 'Eisenberg, J. M., 1.

Petroleum, Dodge City Basin: Maher, J. C., 1; U. S. G. S., 1, no. 101 .

San Juan Basin: Barnes, F. C., 2.

Piedra River Canyon, Archuleta Co.: Read, C. B.; U. S. G. S., 1, no. 96 .

San Juan Mts.: Bejnar, W.

Silver, Caribou mine: Ridland, G. C.

Sulfur, Gunnison Forks deposit: Dings, M. G.

Vanadium, origin, Colorado Plateau: Fischer, R. P., 2.

Geologic maps.

Cripple Creek area: Koschmann, A. H., 1.

Dodge City Basin, pre-Pennsylvanian: Maher, J. C., I; U. S. G. S., 1, no. 101.

Durango area: U. S. G. S., 1, no. 109; Zapp, A. D.

Gunnison Forks sulfur deposit: Dings, M. G.

La Plata district: Eckel, E. B., 1.

McCoy area: Donner, H. F.

Naval Oil Shale Reserves 1 and 3, Garfield County: Duncan, D. C.; U. S. G. S., 1, no. 94 .

Pando area: Tweto, O. L.

Piedra River Canyon, Archuleta Co.: Read, C. B.; U. S. G. S., 1 no. 96.

St. Peters Dome area: Steven, T. A.

San Juan Mtn. area: Bejnar, W.

South Park: Stark, J. T.

Southwestern, vanadium region: Fischer, R. P., 1.

Historical geology.

Coal Creek quartzite, pre-Cambrian: Fraser, G. D.

Coal deposits, Minnesota Creek area: Toenges, A. L., 2. 
Colorado-Continued

Historical geology-Continued

Dodge City Basin, pre-Pennsylvanian: Maher, J. C., 1; U. S. G. S., 1, no. 101.

Durango area: U. S. G. S., 1, no. 109; Zapp, A. D.

Geodes, Garden Park: Scott, G. R., 3.

Green, Yampa River Canyons, Dinosaur Natl. Monument: Untermann, G. E., 2.

Hugoton Embayment, Anadarko Basin, pre-Pennsylvanian: Maher, J. C., 4.

La Plata district: Eckel, E. B., 1.

Lyons sandstone, Front Range: Maher, J. C., 2; Thompson, W. O.

MeCoy area: Donner, H. F.

Pennsylvanian: Murray, H. F.

Naval Oil Shale Reserves 1 and 3, Garfield Co.: Duncan, D. C.; U. S. G. S., 1, no. 94 .

Pando area: Tweto, O. L.

Piedra River Canyon, Archuleta Co.: Read, C. B.; U. S. G. S., 1, no. 96.

Paleozoic and Mesozoic: Wood, G. H., Jr.

Pierre formation, Cretaceous, zones: Griffitts, M. O., 2.

Radium area: Gates, 0.

San Juan Basin structure: Barnes, F. C., 1.

San Juan Mts.: Bejnar, W.

Sangre de Cristo Mts., Paleozoic: Butler, C. $\mathbf{R}$.

Sawatch sandstone, Cambrian: Addy, R. V.

South Park: Stark, J. T.

Mineralogy.

Geodes, Garden Park: Scott, G. R., 3.

La Plata district: Galbraith, F. W., 1.

Melonite: Wahlstrom, E. E.

Pyrite, crystal structure, Leadville: Wasserstein, $\mathbf{B}$.

Paleontology.

Dinosaur National Monument: Stokes, W. L., 1.

Durania, rudistid, Niobrara formation: Griffitts, M. O., 1.

Fossil tracks, Flag Ridge, Lower Jurassic: Faul, H., 2.

Insecta, Miocene, Florissant beds: Melander, A. L.

La Plata district, Carboniferous: Williams, J. Steele, 1.

Pierre formation, Cretaceous, faunal lists: Griffitts, M. O., 2.

Rodents, Oligocene, White River area: Wilson, R. W., 2.

South Park: Stark, J. T.

Taeniodonts, Lampadophorus, DeBeque area, Paleocene: Patterson, B., 2.

\section{Petrology.}

Aggregate, petrography: Mielenz, R. C., 7.

Continental Divide tunnel rocks, petrography: Haff, J. C., 2, 3; Mielenz, R. C., 2.
Colorado-Continued
Petrology-Continued

Granby tunnel cores, petrography: Irwin, W. H., 1.

Irwin district: Socolow, A. A.

Laramide structure, northwestern Sawatch Range: Gabelman, J. W., 3.

Lyons sandstone, Front Range: Thompson, W. 0 .

Maroon formation, Pennsylvanian-Permian: Robb, G. L., 2.

Wagon Wheel Gap area, clays, petrography: McConnell, D., 2.

Physical geology.

Denver Mtn. Parks quadrangle, pre-Cambrian structure: Boos, M. F.

Green, Yampa River Canyons, Dinosaur Natl. Monument: Untermann, G. E., 2.

Laramide structure, northwestern Sawatch Range: Gabelman, J. W., 3.

Lyons sandstone, Front Range: Thompson, W. 0 .

Radium area, Laramide structures: Gates, 0 .

San Juan Basin structure: Barnes, F. C., 1.

San Juan Mts., Tertiary volcanism: Larsen, E. S., Jr., 3.

South Park: Stark, J. T.

Stylolites, origin: Blake, D. B.

Physiographic geology.

South Park: Stark, J. T.

Valley-widening processes, Rocky Mtn. area: Tator, B. A., 1.

Concretions.

Glacial clay: Bassler, R. S.

New England, glacial clay: Bassler, R. s. South Dakota, Missouri Valley manganese deposits: Pesonen, P. E., 1.

Conglomerate.

New Mexico, Ogallala formation west of Llano Estacado: Bretz, J H., 2.

New York, Deepkill conglomerate, Ordovician, origin: Ross, M. H.

Nova Scotia: Keating, B. J.

Texas, trans-Pecos area: Smith, J. F., Jr., 2.

Connate water.

Resistivity determinations: Wyllie, M. R. J.

Connecticut.

Gillette quarry, Haddam Neck, pegmatites: Stobbe, H. R., 2.

Haddam Neck area, geoiogic sketch map: Stobbe, H. R., 2.

Rocks and minerals: Stone, S. W.

Conodonts.

Correlation by: Branson, E. B., 1.

Iowa, Pella beds, Mississippian: Youngquist, W. L., 4.

Pennsylvanian: Youngquist, W. L., 2.

Prospect Hill, Mississippian: Youngquist, W. L., 1.

Southeast, Devonian, Mississippian: Thomas, I. A. 
Conodonts-Continued

Ohio, eastern, Allegheny formation: Sturgeon, M. T., 2.

Construction materials.

Alabama, Gilbertsville aggregate, petrography: Holland, W. Y., 5.

Guntersville aggregate, petrography: Holland, W. Y., 5.

Wheeler aggregate, petrography: Holland, W. Y., 5 .

Arizona, Davis dam area, aggregate: Rhoades, R. F., 1.

California, Friant dam, aggregate, petrography: Rhoades, R. F., 4.

Keswick quartz diorite, petrography: Haff, J. C., 1.

Shasta dam, aggregate, petrography: Rhoades, R. F., 4.

Colorado: Argall, G. O., Jr.

Aggregate, petrography: Mielenz, R. C., 7.

Crushed stone: Goldbeck, A. T.

Idaho, Anderson Ranch dam, petrography: Mielenz, R. C., 3.

Indiana: Patton, J. B.

Industrial minerals: Am. Inst. Min. Met. Eng.

Kansas, Ellis County: Byrne, F. E., 3. Norton County: Byrne, F. E., 1.

Rooks County: Byrne, F. E., 2.

Mineral aggregates: Am. Soc. Testing Materials.

Distribution: Woods, K. B.

Mineralogy: Rhoades, R. F., 6.

Petrography: Rhoades, R. F., 6.

Mississippi Valley, gravel: Waterways Expt. Sta.

Montana, gypsum: Perry, E. S., 1.

Limestone: Perry, E. S., 1.

Nevada, Davis dam area, aggregate: Rhoades, R. F., 1.

New Mexico, Tucumcari project, petrography: Irwin, W. H., 5.

North Carolina: Broadhurst, S. D.

Pozzolan materials: Mielenz, R. C., 16.

Prince Edward Island: Picher, R. H.

South Dakota, Sioux quartzite: Baldwin, W. B.

Tennessee, Chickamauga aggregate, petrography: Holland, W. Y., 5.

Pickwick aggregate, petrography: Holland, W. Y., 5.

Texas, Marshall Ford dam aggregate, petrography: Holland, W. Y., 6.

Utah, Newton dam, tuff, petrography: Rhoades, R. F., 2.

Newton dam area, riprap, petrography: Irwin, W. H., 4.

Virginia, Alleghany County: Parrott, W. T.

Washington, Columbia Basin, aggregate, petrography: Cook, R. H.; Mielenz, R. C., 6, 8 .

Pasco district, aggregate, petrography: Holland, W. Y., 7; Rhoades, R. F., 3.
Construction materials-Continued

Wyoming, Eaglenest Creek aggregate, petrography: Mielenz, R. C., 1.

Contact metamorphism. See Metamorphism.

Continental drift.

Arctic America, investigations: Wegmann, C. E.

Continental shelf.

Shoreline processes: Evans, O. F., 1.

Continents.

Distribution: Escher, B. G.

Mammal migration: Simpson, G. G., 2.

Origin: Escher, B. G.; Wilson, J. T., 1, 3.

Blister hypothesis: Wolfe, C. W., 3, 4, 5.

Copper.

Arizona, Ajo quadrangle: Dehlinger, M. E. San Manuel, origin: Schwartz, G. M., 3.

Squaw Peak mine: Thacker, E.

Wallapai district: Thomas, B. E.

British Columbia, biogeochemical researches: Warren, H. V., 3.

California: Jenkins, O. P.

Big Bend mine, Butte Co.: Eric, J. H., 1.

Copperopolis deposits, Calaveras Co.: Heyl, G. R., 5.

Economic mineral map: Jenkins, O. P. Foothill deposits, Sierra Nevada: Heyl, G. R., 1.

Jesse Belle mine, Madera Co.: Cox, M. W., 3.

La Victoria mine, Mariposa Co.: Cox, M. W., 2.

Lilyama mines, El Dorado Co.: Cox, M. W., 1.

Newton mine, Amador Co.: Heyl, G. R., 2.

Penn mine, Calaveras County: Heyl, G. R., 3 .

Pioneer mine, El Dorado County: Cox, M. W., 1.

Quail Hill area mines, Calaveras Co.: Heyl, G. R., 6.

CoIorado, Bear Creek district: Goddard. E. N., 1.

La Plata district: Schwartz, G. M., 2.

Deposition, wall rock replacement: Dreyer, R. M.

Georgia, Lumpkin County: Kline, M. H.

Manitoba, Sherritt Gordon mine: Farley, W. J.

New Jersey, Bridgewater mine, collecting: Hayes, W. H.

New Mexico, Chino mines, Santa Rita area: Ballmer, G. J.

Ontario, Rex-Werner Lakes area: Chisholm, E. O., 2.

Precipitation, experimental: Garrels, R. M.,

Coral reefs. See Bioherms; Reefs.

Corals. See Anthozoa. 
Cores.

Analysis, interpretation: Edinger, W. M. Technique: Caran, J. G.

Caribbean Sea, submarine, Foraminifera: Phleger, F. B., Jr., 1.

Oil field, analyses: Crawford, J. G., 1.

Ontario, Sanborn township: Ontario Dept. Mines.

Pennsylvania, Coryville pool: Fettke, C. R., 1.

Texas, Llano iron region: Barnes, V. E., 1.

Well cuttings, examination: Hills, J. M.

Correlations. See also Geologic formations, lists, sections, tables; Historical geology.

Alaska, Healy River Valley: Wahrhaftig, C., 1.

Alberta, Athabaska River, Cretaceous: Wickenden, R. T. D.

Lea Park and Belly River formations: Shaw, E. W.

Peace River Plains, Cretaceous: Gleddie, $\mathbf{J}$.

Ribbon Creek area, Mesozoic: Crockford, M. B. B., 1.

Stimson Creek West of Fifth Meridian: Canada G. S., 14.

Arizona, Lower Cretaceous, and Texas, Caucasus: Stoyanow, A. A., 1.

Moenkopi formation, Sycamore Canyon: Price, W. E., Jr.

Biogeography, Pleistocene, Europe and North America: Deevey, E. S., Jr.

British Columbia, Selkirk Mts., pre-Cambrian-Paleozoic boundary: Okulitch, v. J.

Wapiti Lake area: Laudon, L. R., 3.

California, Coast Ranges, northern San Francisco Bay area: Weaver, C. E.

West central, Lower Tertiary: Stewart, R. B.; U. S. G. S., 2, no. 34 .

Cambrian, North America and China: Howell, B. F., 1.

Colorado, Lyons sandstone, Permian: Maher, J. C., 2; Thompson, W. 0 .

South Park: Stark, J. T.

Conodonts for: Branson, E. B., 1.

Devonian fossil zones, western Canada and Montana: Warren, P. S., 1.

Elasmosaurs, Upper Cretaceous, central North America: Welles, S. P.

Electron microscope, use: Moore, C. A.

Florida, Tertiary: Vernon, R. 0 .

Foraminifera, Franciscan formation, California, and Europe: Glaessner, M. F.

Greenland, Giesecke Mts., pre-Permian: Maync, W., 1.

Gulf Coast, post-Claiborne: Monsour, E. T.

Iowa-Missouri, Devonian-Mississippian: Thomas, L. A.

Jurassic, Alberta, British Columbia and Eưrope: Spivak, J.

Alberta and Montana: Weir, J. D.
Correlations-Continued

Kentucky, Big Six sandstone: Young, D. $M$.

Louisiana, Cane River formation: Hussey, K. $\mathrm{M}$.

De Soto, Red River Parishes: Murray, G. E., Jr., 1.

Wilcox formation: Robertson, D. A.

Manitoba-North Dakota: Kerr, L. B., 2.

Mexico, Poza Rica oil field: Salas, G. P.

Quaternary, with United States: De Terra, H., 2

Microfossils in: Wicher, C. A.

Midcontinent, upper Paleozoic: Wheeler, R. R., 1.

Mississippi, central, Tertiary: Miss. Geol. Soc., 1.

Post-Claiborne: Monsour, E. T.

Mississippian, Virginia, West Virginia, Kentucky: Wilpolt, R. H.; U. S. G. S., 2, no. 38.

Mollusca, Lower Cretaceous, fresh-water, North America: Yen, T.-C., 1.

Montana, Belt series: Ross, C. $\mathbf{P}$.

Melrose, Camp Creek, Hecla areas: Karlstrom, T. N. V.

Nevada, Paleozoic sections: Maxey, G. B., 3.

Nevada-West Coast, Pliocene: Macdonald, J. R., 2.

New Jersey-Pennsylvania, Martinsburg formation, Ordovician: Willard, B., 1.

New Mexico, Mississippian: Laudon, L. R., 1.

Southeastern, Paleozoic: Lloyd, E. R.

New York, central, Devonian: Stevenson, R. E., 2.

Chemung formation, Bradford-Richburg oil sands: Harding, R. W.

Long Island, Kings County, well logs: deLaguna, $W$.

New York-Pennsylvania, Tully clastics, Devonian: Stevenson, R. E., 3.

Newfoundland, Cambrian-Ordovician, with Canada, Europe: Hayes, A. O., 1.

North America, early Tertiary: Wilson, $\mathbf{R}$. W., 4.

North America-Europe, Pliocene-Pleistocene: Moore, R. C., 5.

North Dakota-Manitoba: Kerr, L. B., 2.

Oil-field water, use: Crawford, J. G., 2.

Oklahoma, Mill Creek-Ravia area, Cambrian: Ham, W. E., 1.

Upper Missourian, subsurface: Lukert, L. $\mathbf{H}$.

Oregon, Newport-Waldport area, Lincoln Co.: Vokes, H. E., 1; U. S. G. S., 1, no. 88.

Tertiary: Snavely, P. D., Jr.; U. S. G. S., 1 , no. 97.

Panama area, Tertiary: Woodring, W. P., 1.

Pennsylvania, Chemung formation: Harding, R. W. 
Correlations-Continued

Pennsylvania-Continued

Middle Ordovician: Craig, L. C. Metabentonites: Craig, L. C.

Southwest, Upper Devonian: Bayles, R. E.

Stratigraphic, methods: LeRoy, L. W., 3.

Tennessee, Brownsport formation, Silurian: Amsden, T. W., 1.

Texas, northeastern, Upper Jurassic: Swain, F. M., 3.

Woodbine formation: Bergquist, H. R.; U. S. G. S., 1, no. 98.

Time terms: Lowman, S. W., 1.

United States, Pennsylvanian system: Moore, R. C., 3.

Utah, Carboniferous: Williams, J. Stewart, 2.

Cretaceous: Bissell, H. J.

Paleozoic, Mesozoic: Hansen, G. H.

Permian: Williams, J. Stewart, 2.

Uinta Basin: Baker, A. A.

Wyoming, central, Upper Cretaceous: Thompson, Raymond M.; U. S. G. S. 2, no. 36 .

Powder River Basin: Wyo. Geol. Assoc. Mesozoic: Downs, G. R.

Paleozoic: Thomas, H. D., 2.

Corundum, Ontario, origin: Moyd, L., 1.

Cosmic sediments: Heilborn, G.

Craters, New Mexico: Perkins, A. M.

Cretaceous. See also Paleontology, Cretaceous.

Alabama, southeast: LaMoreaux, P. E., 2.

Alberta, Athabaska River sections: Wickenden, R. T. D.

Belly River formation: Shaw, E. W.

Callum Creek, west of Fifth Meridian: Canada G. S., 2.

Foremost formation: Crockford, M. B. B., 3.

Langford Creek area: Canada G. S., 8.

Lea Park formation: Shaw, E. W.

Moon Creek area, west of Sixth Meridian: Canada G. S., 12.

Oldman formation: Crockford, M. B. B., 3.

Peace River Plains: Gleddie, J.

Southwestern, Kootenay strata: Crockford, M. B. B., 2.

Stimson Creek, west of Fifth Meridian: Canada G. S., 14.

Arkansas, southwestern: Shreveport Geol. Soc.

California, Coast Ranges, northern San Francisco Bay area: Weaver, C. E.

Colorado, Minnesota Creek area: Toenges, A. L., 2.

Naval Oil Shale Reserves 1 and 3, Garfield Co.: Duncan, D. C.; U. S. G. S., 1 , no. 94 .

Pierre formation: Griffitts, M. O., 2.

Greenland, North-east: Maync, W., 4.

Trail Island: Donovan, D. T.
Cretaceous-Continued

Kansas, Edwards County: McLaughlin, T. G.

Fort Hays chalk: Runnels, R. T., 1.

Pawnee County: McLaughlin, T. G.

Louisiana, De Soto, Red River Parishes: Murray, G. E., Jr., 1.

Maryland, subsurface: Overbeck, R. M.

Mexico, Sierra de los Muertos area: Humphrey, W. E.

New Mexico, Colfax County: Griggs, R. L.

North America, paleotectonic, paleogeologic maps: Eardley, A. J., 2.

South Dakota, Fall River County: Rothrock, E. P.

Western: Petsch, B. C.

Texas, Colorado River Valley, geologic map: Moore, R. C., 2; U. S. G. S., 1, no. 80.

Fort Worth, Comanchean: Gray, J. H.

Southern Davis Mts.: Goldich, S. S., 1.

Trans-Pecos region: West Texas Geol. Soc., 1.

United States, Great Basin: Blackwelder, E., 1.

Utah: Bissell, H. J.

Facies: Spieker, E. M.

Wyoming, central, stratigraphic sections: Thompson, Raymond M.; U. S. G. S., 2 , no. 36 .

Crinoidea. See also Echinodermata.

Calceolispongia, Permian: Teichert, C.

Evolution, relation to paleogeography: Moore, R. C., 8.

Kansas, Pennsylvanian: Strimple, H. L., 4.

Iola limestone: Strimple, H. L., 3 . Wyandotte limestone: Strimple, H. L., 3.

Nebraska, Iatan formation, Pennsylvanian: Strimple, H. L., 7.

Oklahoma, Ardmore Basin, Pennsylvanian: Strimple, H. L., 5.

Brownville limestone, Pennsylvanian: Strimple, H. L., 6.

Fayetteville formation, Mississippian: Strimple, H. L., 8.

Mississippian: Strimple, H. ..., 1.

Ordovician: Strimple, H. L., 2.

Pennsylvanian: Strimple, H. L., 4, 9. Cross bedding.

Colorado, Lyons sandstone, Front Range: Thompson, W. 0 .

Types: Scott, G. R., 2.

Crustacea. See also Arthropoda; Cirripedia; Ostracoda: Trilobita.

New Jersey, Raninella testacea, Cretaceous: Kindle, C. H., 1.

Cryolite: Mudd, H. T.

Cryopedology. See Permafrost.

Crystal structure.

Aluminum fluorides: Ferguson, R. B.

Aluminum orthophosphate: Hummel, F. A.

Bismuth arsenate: Mooney, R. C. L. 
Crystal structure-Continued

Bornite: Tunell, G., 2.

Buergex precession method: Barnes, W. H., 4.

Childrenite: Barnes, W. H., 1.

Chloritoid, Quebec: Milne, I. H.

Disorder: Buerger, M. J., 2.

Frondelite-rockbridgeite series: Lindberg, M. L. L., 1.

Groutite: Collin, R. L.

Guanajuatite, Mexico: Ramdohr, $P$.

Hauchecornite: Peacock, M. A., 3.

Holdenite: Prewitt-Hopkins, J.

Kaolinite: Comeforo, J. E.

Klockmannite: Earley, J. W.

Lattice spacings for glancing angles, iron $x$-radiation: Kaiman, $\mathbf{S}$.

Lindgrenite: Barnes, W. H., 3.

Melilites, synthetic: Ervin, G., Jr.

Montmorillonite: Barshad, I.

Mooreite: Prewitt-Hopkins, J.

Muscovite, Washington: Axelrod, J. M., 1.

Owyheeite: Robinson, S. C.

Paraguanajuatite, Mexico: Ramdohr, P.

Phenacite: Morgan, R. A.

Probertite: Barnes, W. H., 2.

Pyrrhotite, artificial: Graham, A. R.

Rectorite: Bradley, W. F.

Rickardite: Forman, S. A.

Spangolite: Frondel, C., 1.

Svanbergite, Nevada: Switzer, G.

Telluride minerals: Thompson, Robert M., 1.

Torreyite: Prewitt-Hopkins, J.

Uranium: Lukesh, J. S.

Vauquelinite: Berry, L. G.

Vermiculite: Barshad, I.

Crystallization.

Ice: Schaefer, V. J.

Silicate systems: Barth, T. F. W., 3.

Crystallography.

Adularia: Laves, F.

Aluminum fluorides: Ferguson, R. B.

Bravais memoir, translation: Bravais, A.

Chloritoid, Quebec: Milne, I. H.

Crystals, one-dimensional: Donnay, J. D. H., 1.

Crystals, one-dimensional, computing structure factors: Donnay, G. H.

Dufrenite complex minerals: Frondel, C.

Law of rationality: Donnay, J. D. H., 2.

Pyrrhotite, artificial: Graham, A. R.

Retgersite: Frondel, C., 2.

Spangolite: Frondel, C., 1.

Svanbergite, Nevada: Switzer, G.

Symmetry definition: Bader, H., 2.

Screw axes: Bader, H., 3.

Teaching: Fisher, D. J., 1; Gordon, S. G.; Peacock, M. A., 2; Tunell, G.; 3.

Crystals.

Rutile, synthetic: Moore, C. H., Jr.

Symmetrical, Fourier summations: Buerger, M. J., 1.

Cuba. See also West Indies.

Foraminifer, Globorotalia: Cushman, J. A., 1 , no. 326 .
Cuba-Continued

Havana, Somorrostro hills, Miocene: Aguayo, C. G., 3.

Moliusca, Baracoa area, Miocene: Aguayo, C. G., 2.

Reptilia, Cryptocleidus, Jurassic: Torre Mandrazo, $\mathbf{R}$.

Tungsten, Isle of Pines: Bundy, P. A.

Dams and dam sites. See Engineering geology.

Dedolomitization: Faust, G. T., 2.

Definitions.

Arkose: Oriel, S. S.

Mineral: Winchell, A. N.

Reefs: Wilson, W. B., 2.

Species: Burma, B. H.; Mayr, E., 2.

Symmetry: Bader, H., 2.

Unconformities: Scott, G. R., 1; Stewart, W. A.

Deformation.

Greenland, Franz Joseph Fiord area: Bütler, H., 1.

Lithosphere, and supporting magma: Gunn, R.

Marble, experimental: Knopf, E. B.

Mathematical solution: Heaps, H. S.

Montana, Hecla mining district: Karlstrom, T. N. V.

New Mexico, Sacramento Mts., Paleozoic: Pray, L. C.

South Dakota, northern Black Hills, Tertiary: Noble, J. A.

Texas, Grand Saline dome: Balk, R.

United States, north-central area: Hager, D., 1.

Vermont, east-central, cleavage: White, W. s. Deltas.

Mississippi River: Baulig, H.

Depositional environment: Fisk, H. N. Desert, Maine: Trefethen, J. M., 4.

Devonian. See also Paleontology, Devomian.

Alberta, Leduc oil field: Layer, D. B.

Moon Creek area, west of Sixth Meridian: Canada G. S., 12 .

Paleozoic pre-Waterways strata, Plains area: McGehee, J. R.

Rocky Mtn. Front Ranges, Bow River area: Clark, L. M., 2.

British Columbia, Alaska Highway: Laudon, L. R., 2.

Wapiti Lake area: Laudon, L. R., 3.

Greenland, Giesecke Mts.: Bütler, H., 3; Maync, W., 1.

Franz Joseph Fiord area: Bütler, H, 1.

Indiana, Sullivan and Vigo Counties: Bieberman, D. F.

Iowa, southeast: Thomas, L. A.

New York, central: Stevenson, R. E., 2. Chemung formation, Bradford-Richburg oil sands: Harding, R. W.

Otsego County, folding: Stevenson, $\mathbf{R}$. E., 1.

Tully clastics: Stevenson, R. E., 3.

North America, paleotectonic, paleogeologic maps: Eardley, A. J., 2. 
Devonian-Continued

Northwest Territories, Fort Good Hope area: Warren, P. S., 2.

Pennsylvania, Chemung formation, Bradford-Richburg oil sands: Harding, R. W.

Schuylkill County: Mills, J. R.

Southwest: Bayles, R. E.

Tully clastics: Stevenson, R. E., 3.

Tennessee, central: Wilson, C. W., Jr.

Utah: Hintze, F. F., 2.

Diabase, Pennsylvania, schist inclusions: Tomlinson, W. H.

Diamonds. See also Gems and gem materials.

Appalachian region: Holden, R. J.

Indiana: Wade, F. B.

Radioactive: Hardy, J. A.

Virginia, "Punch" Jones: Holden, R. J.

Diastrophism.

Appalachian, effect on bedding thickness: Gair, J. E.

Nevada, Hawthorne quadrangle, Jurassic: Ferguson, H. G.

Tonopah quadrangle, Jurassic: Ferguson, H. G.

Paleontologic relation: Henbest, L. G.

Periodicity theory: Gilluly, J., 3.

Relation to sedimentation: Lawson, A. C., 2.

Utah, upper Cretaceous: Spieker, E. M.

Wyoming, central-western: Horberg, C. L., 1.

Diatomaceae, Massachusetts, Boylston Street Fishweir II, Pleistocene: Conger, P. S.

Diatomaceous earth.

California, Lompoc area: Cook, R. B.

General: Cummins, A. B.

Differentiation. See Magmas and magmatic differentiation.

Diffusion, ionic, in rocks: Garrels, R. M., 1.

Dikes. Sèe also Intrusions.

Arkansas, central: Hildebrand, F. A.

California, Turtle Mts.: Chesterman, C. W.

Northwest Territories, Lac de Gras area: Canada G. S., 7.

Quebec, New Glasgow, anorthosite: Osborne, F. F.

Washington, Corkscrew Mountain, spiral: Dysart, A.

Dinosauria. See Reptilia.

Diorama, geological, of United States: Lobeck, A. K., 2.

Directory, geology departments, American colleges: Johnson, $\mathbf{D}$.

District of Columbia.

Liquid inclusions in crystalline rocks: Tuttle, 0. F., 1.

Dolomite.

Hydrothermal alteration: Faust, G. T., 2.

Nittany, porosity, petrography: Folk, R. L., 1.

Oklahoma, Mill Creek-Ravia area: Ham, W. E., 1.

\footnotetext{
$904979^{\circ}-51-13$
}

Domes. See also Salt domes.

Arizona, Crater Mound, origin: Hager, D., 2.

Ohio, Mayfield gas and oil pool: Rothrock, H. E., 3.

Dominican Republic. See also West Indies.

Foraminifera, Tertiary: Bermúdez y Hernández, P. J., 2.

Mollusca, Miocene: Aguayo, C. G., 1.

Tertiary: Bermúdez y Hernández, P. J., 2. Drainage changes. See also Glacial geology; Physiographic geology.

Appalachian Mts., relation to structure: Thompson, H. D., 2.

Colorado, Rocky Mtn. area, valley-widening processes: Tator, B. A., 1 .

Kentucky, Eagle Creek piracy, Pliocene: Jillson, W. R., 7.

Louisiana, De Soto, Red River Parishes: Murray, G. E., Jr., 1.

Massachusetts, Pawtucket quadrangle: Chute, N. E., 2.

Minnesota-Ontario, Quetico Superior area: Atwood, W. W.

Oregon, Long Tom River, history: Baldwin, E. M.

Pennsylvania, Appalachian Mts.: Thompson, H. D., 1.

Lehigh Valley: Myers, R. E.

Rhode Island, Pawtucket quadrangle: Chute, N. E., 2.

United States, Great Basin: Blackwelder, E., 1; Hubbs, C. L.

Utah, Markagunt Plateau, eastern: Gregory, H. E.

Drainage patterns: Carlston, c. W.

Dunes.

California, brush fires, geologic effect: Patton, M. M.

Clay, origin, Corpus Christi, Texas: Huffman, G. G., 2.

Maine: Trefethen, J. M., 4.

Michigan, Grand Marais Embayment: Tague, G. C.

Nebraska: Smith, H. T. U., 3.

Dynamic geology. See Physical geology. Eanth.

Atmosphere evolution, geological evidence: Chamberlin, R. T., 4.

Magnetic field, history: Johnson, E. A.

Origin: Wilson, J. T., 1.

Seismicity: Gutenberg, B., 2.

Crust.

Continent origin, blister hypothesis: Wolfe, C. W., $3,4,5$.

Deformation under pressure, experiments: Goranson, R. W.

Elements, new: De Ment, J. A., 4.

General: Gutenberg, B., 3.

Isostatic adjustment and magma origin: Wahl, W.

Microseisms: Gilmore, M. $\mathbf{H}$.

Mid-Atlantic Ridge, structure: Ewing, W. M., 2.

Moonscar: Kuehn, $\mathbf{H}$. 
Earth-Continued

Crust-Continued

Movements, origin: Urey, H. C.

Ocean floor, structure: Hersey, J. B., 2.

Origin: Escher, B. G.

Orogenetic movements: Rutten, L. M. R.

Orogeny, kinetic theory: Fisher, J. E., 3.

Oxygen distribution: Barth, T. F. W., 1.

Radioactivity: Slack, H. A.

Seismic waves, form: Ricker, N., 1.

Structure, gravity anomalies: Woollard, G. P., 1.

Suboceanic, properties: Gutenberg, B., 6.

Temperature, radioactivity effect: Urry, W. D.

Vibration from delay blasting: Leet, L. D., 1.

Interior.

General: Gutenberg, B., 3.

Oxygen distribution: Barth, T. F. W., 1. Temperature.

Radioactivity effect: Urry, W. D.

Rate of cooling, radioactivity: Ingersoll, L. $\mathbf{R}$.

Temperatures, geologic, measurement: Friedman, I. I., 2.

Earthquake craters, Carolina Bays, origin: Bailey, E. B.

Earthquakes. See also Seismology.

Activity periods, Pacific Basin area: Perrine, C. D.

California, northern, 1948: Romney, C. F., 1, 2, 3 .

San Andreas-San Jacinto rift zones: Sprotte, E. C.

Southern: Richter, C. F.; Warner, S. E.

Walker Pass, southern Sierra Nevada: Chakrabarty, S. K.

General: Earthquake Notes.

Intensity rating: Voigt, D. S.

Missouri, Ozarks, 1945-47: Heinrich, R. R. Nevada, Verdi: Byerly, P., 3; Gianella, V. P.

New York, Cornwall-Massena earthquake, 1944 : Milne, W. G., 2.

Ontario, Cornwall-Massena earthquake, 1944: Milne, W. G., 2.

Records, electric computor: Housner; G. W.

Rock creep: Benioff, H., 1.

Submarine, Airy phase: Press, F.

“T” phase: Tolstoy, I., 3.

Echinodermata. See also Crinoidea; Echinoidea; Invertebrata.

British Columbia, Wapiti Lake area, faunal lists: Laudon, L. R., 3.

Limestones, organic: Johnson, J. H., 1.

New York, ophiurans, Devoniaf: Johnson, R. B.

Echinoidea. See also Echinodermata.

California, Dendraster elsmerensis, Pliocene: Durham, J. W., 1.

Genera comparisons: Durham, J. W., 1.

Guatemala, Pygurostoma, Cretaceous: Cooke, c. W.
Echinoidea-Continued

Mexico, La Peña formation, Sierra de los Muertos: Humphrey, W. E.

Economic geology (general). For areal, see the various states and countries; See also Mineral deposits and the particular products.

Alteration, ore guide, East Tintic district, Utah: Lovering, T. S., 1.

Bibliography, annotated, 1948: Townsend, H. G.

Biogeochemical investigations, ore search: Warren, H. V., 1.

Coal, fields of research: Cady, G. H.

Economic geologist, training, duties: Broderick, T. M. .

Epithermal deposits, origin: Schmitt, $\mathbf{H}$. A., 2.

Geochemical prospecting: Hawkes, H. E., Jr., 2.

Geophysical investigations: Massé, L.

Industrial mineral exploration: Dawson, A. $\mathbf{S}$.

Mineral deposits, location, relation to orogeny: Reinhardt, E. V.

Mineralization, zoning theories: Schmitt, H. A., 1.

Ore deposition, lithologic control, Colorado: Bejnar, W.

Ore deposits and granitization: Edwards, A. B.

Ore exploration: Broderick, T. $\mathbf{M}$.

Gravimetric methods: Innes, M. J. S.

Magnetometric methods: Innes, M. J. S.

Thermal spring study: White, D. E., 3.

Ore genesis, theory: Brown, J. S.

Ore minerals, laboratory study: Smith, F. G., 3.

Reflectivity: Folinsbee, R. E.

Petroleum geology, textbook: Lalicker, C. $\mathbf{G}$.

Placer deposits, logarithmic - pattern: Wertz, J. B.

Ribbon structure in gold-quartz veins: McKinstry, H. E., 1.

Scope: Danloux-Dumesnils, M.

Stratigraphic convergence, petroleum accumulation: Wheeler, R. R., 2.

Uranium, occurrence: Joubin, F. R.

Vein formation, Butte, Montana: Sales, R. H.

Elements.

Accessory, relation to pegmatite origin: Holland, H. D.

Determination by polarographic method: Claffy, E. W.

Gallium, in iron meteorites: Brown, H. S., 3.

Igneous rock content: Sandell, E. B.

Metallic, distribution: Buddhue, J. D., 4.

Meteorites, distribution: Brown, H. S., 3.

Minor, in garnet: Jaffe, H. W., 2.

New: De Ment, J. A., 4.

Oxidation and reduction: Mason, B. H., 1.

Oxygen, distribution in lithosphere: Barth, T. F. W., 1. 
Elements-Continued

Oxygen-Continued

In rocks, reference for petrographic calculations: Barth, T. F. W., 2.

Palladium, in iron meteorites: Brown, H. S., 3.

Quebec, Landrienne Canton, rock analysis: Tousignant, $\mathbf{C}$.

Radium, content of ultramafic rocks: Davis, G. $\mathbf{L}$.

Selenium: Trelease, S. F.

Spectroscopic determination: Jaffe, H. W., 1.

Strontium, measurement of geologic time: Ahrens, L. H., 2.

Thallium, geochemistry: Rankama, K. K.

Uranium, content of ultramafic rocks: Davis, G. L.

Engineering geology.

California, Isabella project: Treasher, $\mathbf{R}$. C., 1.

Matilija Dam problem: Southworth, J. S. Civil engineering, application of geology: Trefethen, J. M., 5.

Crushed stone: Goldbeck, A. T.

Engineering maps: Sokoloff, V. P.

Geologic techniques: Robb, G. L., 1 .

Ground water measurement: Irwin., W. H., 6.

Highway design, geology applied to: Dobrovolny, $\mathbf{E}$.

Indiana, drainage mapping from airphotos: Parvis, $M$.

Airphoto patterns, Illinoian drift: Stevens, J. C.

Cagle's Mill reservoir site: McGrain, P., 1.

Kansas, Ellis County, construction materials: Byrne, F. E., 3.

Norton County, construction materials: Byrne, F. E., 1.

Rooks County, construction materials: Byrne, F. E., 2.

Loess: Mielenz, R. C., 17.

Manhattan schist, foundation rock: Feld, J.

Marble, oriented specimens, compression tests: Lepper, H. A., Jr.

Mineral aggregates: Am. Soc. Testing Materials.

Oregon, Malheur Siphon displacement: Rhoades, R. F., 5 .

Pozzolan materials: Mielenz, R. C., 16 .

Quarrying, geologic factors: Glover, S. L., 1.

Rockbursts, sedimentary strata: Wuerker, R. G.

Rocks, behavior under stress: McCutchen, W. $R$.

Soil mechanies-geology relation, foundation exploration: Turnbull, W. J.

Stream studies, flood control projects, California: Holdredge, C. P.

Textbook: Trefethen, J. M., 1.

Underground construction: Kiersch, G. A.,
Engineering geology-Continued

U. S. Geological Survey: Eckel, E. B., 2.

Virginia, Fairfax quadrangle: Sokoloff, V. $P$.

Eocene. See Tertiary.

Eolian action. See Wind work.

Erosion. See also Floods.

Alpine glaciation: Ray, L. L., 3.

Beaches: Caldwell, J. M.

California, brush fires, geologic effect: Patton, M. M.

Colorado, Rocky Mtn. area, valley-widening processes: Tator, B. A., 1.

Glacial: Holmes, C. D., 2.

Hawaii, Oahu: White, S. E., 1.

Maryland, shores: Singewald, J. T., Jr.: Slaughter, T. H.

Mexico, Chiapas: Mullerried, F. K. G., 6.

New Mexico, Ogallala formation west of Llano Estacado: Bretz, J. H., 2.

Soils: Ellison, W. D.

Utah, Bryce Canyon: Spitznas, R. L., 1.

Water-drop sand movement: Ekern, P. C., Jr.

Erosion surfaces, New Mexico, Carlsbad Caverns area: Horberg, C. L., 3.

Eurypterida. See also Arachnida.

Illinois, Mazon Creek: Kjellesvig-Waering, E. N.

Lepidoderma, genus revision: KjellesvigWaering, E. N.

Evolution.

Adaptation, fossil record: Colbert, E. H., 1.

Angiosperms: Chaney, R. W., 2.

Animal, rate: Simpson, G. G., 4.

Corals, ontogenetic stages: Durham, J. W., 2.

Crinoid, Calceolispongia: Teichert, C.

Delocrinus to Paradelocrinus: Strimple, H. L., 3.

Dinosaurs, growth: Colbert, E. H., 3.

Dipnoi: Westoll, T. S.

Invertebrate, periodicity: Newell, N. D., 4. Relation to geologic time computation: Sloss, L. L., 2.

Size increase: Newell, N. D., 3.

Mammalia, ancestors: Colbert, E. H., 2.

Early Tertiary, North America: Wilson, R. W., 4.

Orthogenesis: Jepson, G. L., 3.

Paleontological evidence: Romer, A. S., 1.

Paleontology and genetics, problems: Jep. son, G. L., 1.

Paleontology, biology, geology, relations: Rama Rao, L.

Plant: Just, T. K.

Rate: Stebbins, G. L., Jr.

Reptilia, phytosaurs, Triassic, adaptation: Colbert, E. H., 1.

Procolophonids, Triassic, adaptation: Colbert, E. H., 1.

Rhinoceros: Wood, H. E., 1.

Selection: Jepson, G. L., 3.

Significance: Simpson, G G., 3.

Speciation and systematics: Mayr, E., 1. 
Evolution-Continued

Speciation, successional, Cubitostrea sellaeformis: Stenzel, H. B., 1.

Taeniodonts: Patterson, B., 1.

Theories: Simpson, G. G., 6 .

Vertebrate, comparative anatomy: Davis, D. D.

Fossil evidence: Watson, D. M. S.

Periodicity: Simpson, G. G., 7.

Exfoliation, California, brush fires, geologic effect: Patton, M. M.

Experimental investigations.

Appalachian deformation: Straley, H. W., 1.

Aragonite-calcite differentiation, differential analysis: Faust, G. T., 1.

Bentonite, grinding reaction: Perkins, A. $\mathbf{T}$.

BeO. $\mathrm{Al}_{2} \mathrm{O}_{3}-\mathrm{Al}_{2} \mathrm{O}_{3}$ system, new compound: Foster, W. R., 1.

Biogeochemical prospecting, analytical methods: Warren, H. V., 1.

Calcite, linear thermal expansion: Rosenholtz, J. L.

Clay minerals, erystal forms by electron microscope: Mackie, W. Z.

Segregation: Pennington, R. P.

Clays, grinding reaction: Perkins, A. T.

Weathering sequence and $\mathrm{X}$-ray diffraction analysis: Willis, A. L.

Copper mineral precipitation: Garrels, $\mathbf{R}$. M., 2.

Deformation under pressure: Goranson, R. W.

Diffusion in rocks: Garrels, R. M.,' 1 .

Enargite, hydrothermal synthesis: Gaines, R. V.

Enstatite-orthoferrosilite series, solution heats: Sahama, T. G., 3.

Forsterite-fayalite series, solution heats: Sahama, T. G., 3.

Garnet, composition determination: Levin, s. B., 4.

Geologic mapping, high frequency electromagnetic waves: Kerwin, $L$.

Gold and silver content of plants, British Columbia: Warren, H. V., 5.

Ground vibrations near explosions: Howell, B. F., Jr.

Hematite-goethite relations under pressure: Smith, F. G., 2.

Ice crystals, formation: Schaefer, V. J.

Kaolinite, crystal structure, thermal behavior: Comeforo, J. E.

Thermal analysis: Gruver, R. M.

Liquid immiscibility, hydrous silicate systems: Friedman, I. I., 3.

Liquid inclusions, granite thermometry: Bailey, S. W.

Marble, deformation: Knopf, E. B.

Linear thermal expansion: Rosenholtz, J. L.

Oriented specimens, compression tests: Lepper, H. A., Jr.

Measurement, permeability of glacial material: Knodle, $\mathbf{R} . \mathbf{D}$.
Experimental investigations-Continued

Mica, decomposition and resynthesis: Roy, R., 1.

Grinding reaction: Perkins, A. T.

Missouri River sediments: Keller, W. D., 3.

Nepheline - carnegieite transformation: Washken, E.

Olivine, orthopyroxene, thermochemical study: Sahama, T. G., 2.

Ore minerals, laboratory advances: Smith, F. G., 3.

Placer deposits, logarithmic pattern: Wertz, J. B.

Porosity, cementation factor: Rosenfeld, M. A.

Measurement, petrographic control: Griffiths, J. C., 1.

Relation to diffusion: Garrels, R. M., 1. Quartz, crystal growth from sphere: Hale, D. $\mathbf{R}$.

Crystallization: Bailey, D. A.

Synthesis: Buehler, E. J.; Friedman, I. I., 1.

Hydrothermal: Swinnerton, A. C., 2.

Quartzite, formation: Fairbairn, H. W., 2.

Radioactivity, mineral content: Marble, J. P., 5.

Rhodochrosite, thermal study: Kulp, J. L., 1.

Rock age, $\mathrm{Pb} / \mathrm{U}$ ratio of accessory minerals: Larsen, E. S., Jr., 2.

Sand mixtures, synthesis: Menard, H. W., $\mathrm{Jr}$.

Serpentine and talc equilibria: Bowen, N. L., 3 .

Serpentinization: Bowen, N. L., 1.

Silicate system $\mathrm{MgO}-\mathrm{SiO}_{2}-\mathrm{H}_{2} \mathrm{O}$ : Bowen, N. L., 1.

Silver minerals, synthesis: Béland, R., 4.

Stability relations, geikielite and ilmenite: Sahama, T. G., 1.

System, $\mathrm{Al}_{2} \mathrm{O}_{3}-\mathrm{SiO}_{2}-\mathrm{H}_{2} \mathrm{O}$ : Roy, R., 3.

Fe-Ni-S: Hawley, J. E., 2.

$\mathrm{K}_{2} \mathrm{O}-\mathrm{MgO}-\mathrm{Al}_{2} \mathrm{O}_{3}-\mathrm{SiO}_{2}$, phase equilibrium: Schairer, J. F.

$\mathrm{Li}_{2} \mathrm{O}-\mathrm{Al}_{2} \mathrm{O}_{3}-\mathrm{SiO}_{2}$ : Roy, R., 2.

$\mathrm{NaAlSi}_{3} \mathrm{O}_{8}-\mathrm{KAlSi}_{3} \mathrm{O}_{8}-\mathrm{H}_{2} \mathrm{O}$ : Bowen, N. L., 4.

$\mathrm{NaAlSiO}_{4}-\mathrm{CaO} . \mathrm{Al}_{2} \mathrm{O}_{3}$ : Goldsmith, J. R., 1.

Tennantite, hydrothermal synthesis: Gaines, R. V.

Thermal analysis, siderite: Rowland, R. A.

Thermochemistry applied to petrology: Sahama, T. G., 3.

Tourmaline, synthesis: Smith, F. G., 1.

Vein mineral deposition: Smith, F. G., 6.

Vibrations from delay blasting: Leet, L. D., 1.

Water-drop sand movement: Ekern, P. C., Jr.

Zirconium minerals, synthesis: Maurice, o. D., 2.

Exploration.

British Columbia, ore: Riley, C.

Uranium: Stevenson, J. S. 
Exploration-Continued

Canadian Shield, aerial photographs, use: Russell, G. A., 2.

Geophysics, geology and oil finding: Nettleton, L. 'L.

Ground water, geologic methods: Fent, o. $\mathrm{s}$.

Industrial minerals: Dawson, A. S.

Maine, Moosehead Lake area: Hurley, P. M., 2.

Mineral, Geiger counter: Bateman, J. D., 1.

Geophysics: Jakosky, J. J.

Mineralogical methods: Kerr, P. F., 5. Radio waves: Barret, W. M.

Uranium: Joubin, F. R.; U. S. Atomic Energy Comm.

Petroleum, aerial mapping: Mott, G. P.

Geophysics: Jakosky, J. J.

Yukon, mineral areas; Bonham, W. M.; Bostock, H. S., 2, 3.

Facies.

Alaska, Kuskokwim area: Cady, W. M.

Analysis: Sloss, L. L., 1.

Basin and Range province: Muller, S. W.

Bituminous shales: Roth, R. I., 1.

Colorado Plateau: McKee, E. D., 1.

Gulf Coast area: Lowman, S. W., 1, 2.

Illinois, Niagaran strata: Lowenstam, H. A., 2.

Interpretation: McKee, E. D., 1.

Mississippi, Cretaceous: MeGlothin, J. T., Jr.

New Mexico, Permian: Wheeler, R. R., 3.

New York, Trenton limestones, statistical analysis: Chenoweth, P. A.

Nomenclature: Kay, G. M., 1.

Rocky Mtn. region, Eocene: Van Houten, F. B.

Sedimentary: King, P. B. 5; Rodgers, J., 1.

Continental, White River, Oligocene: Wood, H. E., 2.

Meaning: Moore, R. C., 4.

Mississippi Delta: Fisk, H. N.

Symposium: Longwell, C. R., 2.

Tectonics, relation: Sloss, L. L., 1.

Tertiary, western United States, paleobotanical interpretation: Axelrod, D. I., 1.

Texas, Permian: Wheeler, R. R., 3.

Time scales: Griffiths, J. C., 2.

Utah, upper Cretaceous: Spieker, E. M.

Faulting. See also Thrusts and thrusting.

Alaska, Iniskin Peninsula: Kirschner, C. E.; U. S. G. S., 1, no. 95 .

Alberta, Foothills: Link, T. A., 3.

Rocky Mtn. Front Ranges, Bow River area: Clark, L. M., 2.

Arizona, Artillery Mts.: Lasky, S. G., 2. Bright Angel quadrangle: Maxson, J. H. Empire Mts.: Galbraith, F. W., 2. Seventy Nine mine: Kiersch, G. A., 1.

British Columbia, McConnell Creek maparea: Lord, C. S., 1.

Wapiti Lake area: Laudon, L. R., 3.
Faulting-Continued

California, Black Mts.: Curry, H. D.

Coast Ranges, northern San Francisco Bay area: Weaver, C. E.

Cuyama Valley: Hoylman, H. W.

Devil's Punchbowl area: Laurie, A. M.

Grayhouse area, Amador Co.: Heyl, G. R., 4.

Haywards fault, impounding effect: Forbes, $\mathbf{H}$.

Kern County: Treasher, R. C., 2.

Puente Hills: Daviess, S. N.; U. S. G. S., 1, no. 83 .

San Andreas rift area, southern: Wallace, R. E., 1.

San Andreas-San Jacinto rift zones: Sprotte, E. C.

San Jacinto fault, Lytle Creek area: Arnett, G. R.

Santa Maria district: Regan, L. J., Jr. Southern, Kingston thrust: Hewett, D. F.

Canada, St. Lawrence Lowland: Dufresne, c.

Canadian Shield, relation to ore deposits: Wilson, J. T., 2.

Colorado, Green River Canyon: Untermann, G. E., 1.

San Juan Basin: Barnes, F. C., 1.

South Park: Stark, J. T.

Yampa River Canyon: Untermann, G. E., 1.

Detection with reflection seismograph: Kelsey, M. C.

General: LeRoy, L. W., 3.

Kentucky, Jessamine Creek area: Jillson, W. R., 5.

Manitoba, Dunphy Lakes area: Stanton, M. S.

File-Tramping Lakes area: Harrison, J. M., 1.

Montana, Hecla mining district: Karlstrom, T. N. V.

Nevada, Candelaria district: Page, B. M.

Hawthorne quadrangle, Jurassic: Ferguson, H. G.

Muddy Mtn. area: Longwell, C. R., 1.

Tonopah quadrangle, Jurassic: Ferguson, H. G.

New Hampshire, Keene-Brattleboro area: Moore, G. E., Jr., 2.

New Mexico, Manzanita Mts. area: Reiche, $P$.

North Manzano Mts. area: Reiche, $\mathbf{P}$.

San Juan Basin: Barnes, F. C., 1.

New York, Hudson Valley, Paleozoic: Flower, R. H., 3.

Oriskany sandstone: Finn, F. H.

Newfoundland, Lewis Hills-Bay St. George area: Walthier, T. N., 2.

Northwest Territories, Carp Lakes area: Miller, M. L.

Nova Scotia: Cameron, H. L., 3.

Lismore area, sub-sea: Cameron, H. L., 2.

Oklahoma, Anadarko Basin: Jacobsen, C. L., 2. 
Faulting-Continued

Ontario, Hearst and McFadden townships: Thomson, J. E.

Kirkland Lake area: Hopkins, $H$.

Oregon: Allison, I. S.

Kerby quadrangle: Wells, F. G., 2.

Newport-Waldport area, Lincoln Co.: Vokes, H. E., 1; U. S. G. S., 1, no. 88 .

Pennsylvania, Clearfield-Philipsburg area: Joesting, $\mathbf{H}$. $\mathbf{R}$.

Oriskany sandstone: Finn, F. H.

Southern, Triassic border fault: Stose, G. W., 2 .

Quebec, Hébécourt Lake area, Abitibi-West County: Graham, R. B., 2.

Logan's line: Clark, T. H., 3.

Texas, Culverson-Hudspeth Counties area: King, P. B., 1; U. S. G. S., 1, no. 90

Interpretation from seismic reflections: Quarles, M. W., Jr.

United States, Appalachian structure, middle and southern: Rodgers, J., 2.

Great Basin: Blackwelder, E., 1.

North-central area: Hager, D., 1.

Utah, Basin Range: Marsell, R. E., 2. Green River Canyon: Untermann, G. E. 1.

Uinta Basin: Baker, A. A.

Yampa River Canyon: Untermann, G. E., 1.

Vermont, Keene-Brattleboro area: Moore, G. E., Jr., 2.

Wyoming, central-western: Horberg, C. L. 1.

Feldspar.

Albite, synthetic: Tuttle, O. F., 4.

General: Burgess, B. C.

Maine, Topsham pegmatites: Shainin, V. E., 1.

Optics, investigations: Köhler, A.

Synthetic, structure, atom replacement: Goldsmith, J. R., 2.

Thermal history investigations: Köhler, A.

Floods, Colorado, Rocky Mtn. area, valleywidening processes: Tator, B. A., 1.

Fishes. See Pisces.

Flint. See Chert.

Florida.

Economic geology.

Clays: Calver, J. L., 2.

Kaolins: Calver, J. L., 2.

Natural gas, developments, 1948: Harris, R. $M$.

Exploration: Gunter, H., 1.

Petroleum, developments, 1948: Harris, R. M.

Exploration: Gunter, H., 1, 2.

Titanium minerals: Thoenen, J. R.

Historical geology.

Mesozoic, cross section: Southeastern Geol. Soc., Mesozoic Comm., 1, 2, 3, 4.

Pre-Mesozoic, subsurface: Applin, P. L.

Tertiary, correlation: Vernon, R. $O$.

Paleontology.

Lingulepis floridaensis, new species: Howell, B, F., 3.

Florida-Continued

Physical geology.

Landslide, Greensboro area: Jordan, R. H.

Physiographic geology.

Abandoned valley, High Springs: Edwards, R. A.

Fluorescence.

Bentonite: Hseung, $\mathbf{Y}$.

Wyoming: Brown, B. W.

Gems, handbook: DeMent, J. A., 1.

General: Flagg, A. L.

Minerals, handbook: DeMent, J. A., 1. Fluorite.

Colorado, St. Peters Dome area: Steven, T. A.

General: Mudd, H. T.

Illinois, Cave in Rock district, structures: Grogan, R. M., 1.

Douglas property: Bishop, O. M.

Hardin County: Grawe, O. R.

Nevada, Daisy mine: Thurston, W. R.

Utah, Topaz Mountain: Fitch, C. A., Jr. Folding.

Alaska, Iniskin Peninsula: Kirschner, C. E.; U. S. G. S., 1, no. 95.

Alberta, Foothills: Link, T. A., 3.

Rocky Mtn. Front Ranges, Bow River area: Clark, L. M., 2.

Appalachian, distortion of stratigraphic thickness: Gair, J. E.

British Columbia, Wapiti Lake area: Laudon, L. R., 3.

California, Coast Ranges, northern San Francisco Bay area: Weaver, C. E.

Devil's Punchbowl area: Laurie, A. M.

Grayhouse area, Amador Co.: Heyl, G. R., 4.

Colorado, Green River Canyon: Untermann, G. E., 1.

Piedra River Canyon: Read, C. B.; U. S. G. S., 1, no. 96 .

South Park: Stark, J. T.

Yampa River Canyon: Untermann, G. E., 1.

Manitoba, Dunphy Lakes area: Stanton, M. S.

File-Tramping Lakes area: Harrison, J. M. 1.

Wanipigow Lake area: Davies, J. F.

Mexico: Alvarez, M., Jr.

Sierra de los Muertos area: Humphrey, W. E.

Sierra Madre: Mullerried, F. K. G., 1.

Mountain, origin: Fisher, J. E., 2.

Nevada, Hawthorne quadrangle, Jurassic: Ferguson, H. G.

Tonopah quadrangle, Jurassic: Ferguson, H. G.

New Hampshire, Keene-Brattleboro area: Moore, G. E., Jr., 2.

New Mexico, Permian: Wheeler, R. R., 3.

New York, central, Devonian: Stevenson, R. E., 2.

Otsego County, Middle Devonian: Stevenson, R. E., 1.

Oklahoma, Haskell County: Oakes, M. C. 


\section{Folding-Continued}

Pennsylvania, Clearfield-Philipsburg area: Joesting, H. R.

South Dakota, Fall River County: Rothrock, E. P.

Homestake mine: Noble, J. A.

Northern Black Hills: Noble, J. A.

Texas, Grand Saline dome: Balk, $R$.

Permian: Wheeler, R. R., 3.

United States, Appalachian structure, middle and southern: Rodgers, J., 2.

Great Basin: Blackwelder, E., 1.

North-central area: Hager, D., 1.

Utah, Green River Canyon: Untermann, G. E., 1.

Yampa River Canyon: Untermann, G. E., 1.

Vermont, Keene-Brattleboro area: Moore, G. E., Jr., 2.

Washington, Lewiston basin: Graham, C. E.

Wisconsin arch, structural trends: Bieber, C. $\mathbf{L}$.

Wyoming, central-western: Horberg, C. L., 1.

Glendo area: Love, J. D., 2; U. S. G. S., 1, no. 92.

Footprints. See Tracks and trails.

Foraminifera.

Alabama, Black Warrior Basin, Mississippian: Thompson, M. L.

Tertiary: Bandy, O. L., 1, 2.

Allomorphina, Jurassic to Recent: Cushman, J. A., 1, no. 329.

Arkansas, Arkadelphia marl, Upper Cretaceous: Cushman, J. A., 3.

Bibliography, index, 1931-1947: Thalmann, H. E., 3.

New genera, species, 1947: Thalmann, H. E., 2.

1948: Thalmann, H. E., 4.

California, Elphidium, Tertiary: Graham, J. J., 2.

Franciscan formation, Santa Clara County: Glaessner, M. F.

Puente Hills: Daviess, S. N.; U. S. G. S., 1 , no. 83.

Wildcat coast section, Pliocene: Stewart, R. E.

Caribbean Sea, submarine core, Pleistocene fauna: Phleger, F. B., Jr., 1.

Chapmanininae, rotaliid, Tertiary: Frizzell, D. L., 2.

Chilostomellidae, Jurassic-Tertiary: Cushman, J. A., 1, no. 331.

Cibicides, nomenclature: Stainforth, R. M., 2.

Dominican Republic, Tertiary: Bermúdez y Hernández, P. J., 2.

Eponides, generic definition: Redmond, C. $\mathrm{D}$.

Eponides mexicanus: Bandy, O. L", 3.

Fusulinids, Pennsylvanian: Moore, R. C., 3.

Globigerina, ecologic interpretation, West Indies: Bronniman, $\mathbf{P}$.
Foraminifera-Continued

Globigerina oozes, ages: Stainforth, R. M., 1.

Globorotalia, Tertiary and Cretaceous, Cuba: Cushman, J. A., 1, no. 326.

Homonyms, 1947: Thalmann, H. E., 1. 1948-1949: Thalmann, H. E., 5.

Kansas, Cretaceous: Loeblich, A. R., Jr., 1. Limestones, organic: Johnson, J. H., 1.

Louisiana, Cane River formation, Eocene: Hussey, K. M.

De Soto, Red River Parishes: Murray, G. E., Jr., 1.

Harang formation, Miocene: Pope, D. E.; Smith, D. J.

Terrebonne Parish: Israelsky, M. C., 1.

Massachusetts, Boylston Street Fishweir II, Pleistocene: Phleger, F. B., Jr., 2.

Mexico, Tampico embayment, Upper Cretaceous: Wicher, C. A.

Mississippi, Black Warrior Basin, Mississippian: Thompson, M. L.

Covington County well, Tertiary: Alexander, C. I.

Nautilus becarii Linné, generic position: Frizzell, D. L., 1.

Oklahoma, Walnut formation, Cretaceous : Loeblich, A. R., Jr., 2.

Orbulina, good Tertiary index fossils: Tromp, S. W.

Oregon, Toledo formation, Eocene: Cushman, J. A., 6.

Panama Canal Zone, large Eocene: Cole, W. S.

Pavoninoides, Oligocene, Panama: Bermúdez y Hernández, P. J., 1.

Pliocene-Pleistocene boundary problem: Thalmann, H. E., 7.

Pullenia, nomenclature: Stainforth, R. M. 2.

Quadrimorphina, Jurassic to Recent: Cushman, J. A., 1, no. 329.

Rotaliidae, revision: Frizzell, D. L., 1.

Sphaeroidina, Tertiary: Cushman, J. A., 1 , no. 325.

Systematic descriptions: Ellis, B. F., 1.

Texas, Walnut formation, Cretaceous: Loeblich, A. R., Jr., 2.

Virginia, Yorktown, Eocene: Cushman, J. A., 2.

Washington, Astoria formation, Miocene: Rau, W. W.

Quinault formation, Pliocene: Cushman, J. A., 5.

West Indies, Paleocene: Davies, L. $\mathbf{M}$.

Forestry, relation to geology: Warren, H. V., 4.

Formations. See Geologic formations, lists, sections, tables; also Geologic formations.

Fossils. See Paleobotany; Paleontology.

Fracture.

Clay, characteristics: Ingram, R. L.

New Jersey, quantitative study: Pincus, H. J. 
Fracture-Continued

New Mexico, potash beds: Cathcart, J. B., Jr.

Fumaroles.

Alaska, Great Sitkin Island: Byers, F. M., Jr.

Umnak Island: Byers, F. M., Jr.

Fusulinidae. See Foraminifera.

Gabbro, Massachusetts, Norfolk County: Chayes, F., 4 .

Garnet.

Composition determination: Levin, S. B., 4.

Minor elements: Jaffe, H. W., 2.

New York, Adirondacks, petrogenesis: Levin, S. B., 3.

' North Creek, paragenesis: Shaub, B. M., 3.

Gastroliths.

Alzadasaurus, elasmosaur, Cretaceous, South Dakota: Welles, S. P.

Gastropoda. See also Mollusca; Invertebrata.

Alberta, faunal lists, Peace River Plains: Gleddie, J.

California, Kern County, Eocene: Hanna G. D.

Cancellariidae, Miocene: Marks, J. G.

Haliotidae, distribution: Sorensen, A.

Manitoba, Devonian: La Rocque, A., 2.

Mexico, Nuevo Léon, Cretaceous: Mullerried, F. K. G., 4.

Michigan, Devonian: La Rocque, A., 2.

Vermont, Monkton formation, Lower Cambrian: Tasch, $\mathbf{P}$.

Gems and gem materials.

Arizona, Sauceda Mts., chalcedony: Weight, H. 0., 2.

Color: Hurlbut, C. S., Jr., 2.

Fluorescent, handbook: DeMent, J. A., 1.

Opals: Anonymous, 9.

Washington, origin, occurrence: Glover, S. L., 2.

Genesis of ores. See Mineral deposits, origin.

Genesis of rocks. See Petrogenesis.

Genetics, relation of paleontology and evolution: Jepson, G. L., 1.

Geochemistry.

Albite-water system in gravitational field: Ramberg, H., 3.

Alumina, oak leaves, Missouri: Keller, W. D., 2.

Biochemical investigations, ore search: Warren, H. V., 1.

Biogeochemical investigations on copper, British Columbia: Warren, H. V., 3.

Carbon: Hutchinson, G. E.

Coal: Miller, H. P.

Gallium in igneous rocks: Sandell, E. B.

Gold and silver content of plants, British Columbia: Warren, H. V., 5.

Isostasy, effect on: Wahl, W.

Oxidation and reductions Mason, B. H., 1.

Prospecting, methods: Hawkes, H. E., Jr., 2.

Tennessee, Friends Station zinc deposit: Hawles, H. E., Jr., 1.

Thallium: Rankama, K. K.
Geochemistry-Continued

Thermal springs, ore discovery: White, D. E., 3.

Trace elements, polarographic method of determination: Claffy, E. W.

Zinc, content of soil, field determination: Lakin, H. W.

Determination in plants, field method: Reichen, L. E.

In leaf samples: Starr, C. C. Geodes.

Arizona, Kofa area: Weight, H. O., 1.

Sauceda Mts.: Weight, H. O., 2.

Colorado, Garden Park: Scott, G. R., 3.

Illinois, Tyson Creek area, petroliferous: Spitznás, R. L., 2.

Geologic formations.

Amsden, Carboniferous: Williams, J. Steele, 2.

Berea sand, Mississippian, Ohio: De Witt, W., Jr.; U. S. G. S., 1, no. 99.

Big Six sandstone, Kentucky: Young, D. $M$.

Brownsport, Silurian, Tennessee: Amsden, T. W., 1.

Chickahominy, Virginia, Eocene: Cushman, J. A., 2.

Elk Point, Silurian, Alberta: McGehee, J. $R$.

Foremost, Cretaceous, Alberta: Crockford, M. B. B., 3.

Frio, Tertiary, Texas: Reedy, M. F., Jr.

Garden City, Utah, Ordovician: Ross, R. J., Jr.

Greenbrier, Mississippian, West Virginia: Rittenhouse, G., 5., Hall, G. H.

Eastern Kentucky: Sonnenberg, F. P.

Lowell, Lower Cretaceous, Arizona: Stoyanow, A. A., 1.

Martinsburg, Pennsylvania, Ordovician: Craig, L. C.

Mayes, Mississippian, Oklahoma: Selk, E. $\mathbf{L}$.

McCoy, Colorado, Pennsylvanian: Donner, H. F.

Mercersburg, Pennsylvania, Ordovician: Craig, L. C.

Moenkopi, Triassic, Arizona: Price, W. E., Jr.

Morgan, Pennsylvanian, Utah: Untermann, G. E., 2.

Ogallala, Tertiary, southeastern New Mexico: Bretz, J H., 2.

Oldman, Cretaceous, Alberta: Crockford, M. B. B., 3.

Oranda, Pennsylvania, Ordovician: Craig, L. C.

Phosphoria, Permian: McKelvey, V. E.

Pierre, Cretaceous, Colorado: Griffitts, $M$. o., 2.

Queenston shale, Ordovician, northern Appalachian Basin: Rittenhouse, G., 2.

Shippensburg, Pennsylvania, Ordovician: Craig, L. C.

Supai, Permian, Black Mesa, Arizona: Hughes, P. W. 
Geologic formations-Continued

Swan Park, Utah, Ordovician: Ross, R. J., Jr.

Trivoli sandstone, Pennsylvanian, Illinois: Siever, R.

Woodbine, Cretaceous, Texas: Bergquist, H. R.; U. S. G. S., 1, no. 98.

Geologic formations, lists, sections, tables. See also Correlations; Historical geology.

Alabama: Mississippi Geol. Soc., 2.

Coosa coal field: Rothrock, H. E, 1, 2.

Little Stave Creek, Tertiary: Bandy, o. L., 1.

Mesozoic: Southeastern Geol. Soc., Mesozoic Comm., 4.

Southeast: LaMoreaux, P. E., 3.

Tertiary area: LaMoreaux, P. E., 1.

Alaska, Iniskin Peninsula: Kirschner, C. E.; U. S. G. S., 1, no. 95.

Alberta, Athabaska River: Wickenden, R. T. D.

Bow River-Crowsnest Pass area: Crockford, M. B. B., 2.

Cardston area: Williams, E. P.

Cretaceous: Shaw, E. W.

Leduc oil field: Link, T. A., 1.

Moon Creek area, west of Sixth Mrridian: Canada G. S., 12.

Ribbon Creek area: Crockford, M. B. B., 1.

Rocky Mtn. Front Ranges, Bow River area: Clark, L. M., 2.

Appalachians, southern, Cambrian, preCambrian: King, P. B., 6.

Ocoee series, pre-Cambrian: Stose, G. W., 1.

Arizona, Artillery Mts.: Lasky, S. G., 2. Bright Angel quadrangle: Maxson, J. H. Moenkopi formation, Sycamore Canyon: Price, W. E., Jr.

Southeastern, Lower Cretaceous: Stoyanow, A., 1.

Arkansas, eastern: Renfroe, C. A.

British Columbia, Alliford Bay area, Queen Charlotte Islands, Jurassic: McLearn, F. $\mathrm{H}$.

Fort St. James area: Armstrong, J. E. McConnell Creek map-area: I.ord, C. S., 1.

Maude Island, Jurassic: McLearn, F. H. Middle River Range: Little, H. W., 2.

Paleozoic, Alaska Highway: Laudon, L. R., 2.

Selkirk Mts.: Okulitch, V.J.

Wapiti Lake area: Laudon, L. R., 3.

California, Coast Ranges, northern San

- Francisco Bay area: Weaver, C. E.

Copper deposits: Jenkins, O. P.

San Andreas rift area, southern: Wallace, R. E., 1.

Santa Maria district: Regan, L. J., Jr.

West central, Lower Tertiary: Stewart, R. B.; U. S. G. S., 2, no. 34 .

Wilmington oil field: Gilluly, J., 2.

Colorado, Bonanza district, Tertiary lavas: Bejnar, W.
Geologic formtions, lists, etc.-Continued

Durango area: U. S. G. S., 1, no. 109;

Zapp, A. D.

Garden Park: Scott, G. R., 3.

La Plata district: Eckel, E. B., 1.

McCoy area: Donner, H. F.

Naval Oil Shale Reserves 1 and 3, Garfield Co.: Duncan, D. C.; U. S. G. S., 1, no. 94 .

Pando area: Tweto, O. L.

Piedra River Canyon: Read, C. B.; U. S. G. S., 1 , no. 96 .

Pierre formation: Griffitts, M. O., 2.

South Park: Stark, J. T.

El Salvador: Stirton, R. A.

Florida, Mesozoic: Southeastern Geol. Soc., Mesozoic Comm., 1, 2, 3, 4.

Georgia, Mesozoic: Southeastern Geol. Soc. Mesozoic Comm., 3.

Greenland, Devonian: Maync, W., 1.

Idaho, Avery district: Wagner, W. R., 1.

Illinois, southern: Bell, A. H., 1.

Indiana: Patton, J. B.

Mill Creek Valley: McGrain, P., 1.

Sullivan and Vigo Counties, Devonian: Bieberman, D. F.

Iowa, coal fields: Averitt, P., 1.

Southeast, Devonian, Mississippian: Thomas, L. A.

Waukon area: Pesonen, P. E., 2.

Kansas, Barber County-Saline County, subsurface cross section: Lee, $W$.

Chase County: O'Connor, H. G.

Eastern: Jewett, J. M., 1.

Ellis County: Byrne, F. E., 3.

Lower Kansas River Valley: Kans. Geol. Soc.

Meade, Clark Counties: Hibbard, C. W., 1.

Norton County: Byrne, F. E., 1; Frye, J. C., 1.

Pennsylvanian: Moore, R. C., 6.

Phillips County: Frye, J. C., 1.

Rooks County: Byrne, F. E., 2.

Saw Rock Canyon area, Pliocene: Hibbard, C. W., 2.

South-central: Williams, C. C.

Southern, Paleozoic subsurface: Lukert, L. H.

Western, Mississippian: Clair, J. R.

Kentucky, Big Six sandstone: Young, D. M.

Eastern, Upper Mississippian: Wilpolt, R. H.; U. S. G. S., 2, no. 38.

Louisiana, De Soto, Red River Parishes: Murray, G. E., Jr., 1.

Maine, northwestern: Wing, L. A.

Manitoba: Kerr, L. B., 2.

Dunphy Lakes area: Stanton, M. S.

English Brook area: Russell, G. A., 1.

File-Tramping Lakes area: Harrison, J. M., 1.

Sickle Lake area: Fawley, A. P.

Maryland, Anne Arundel County: Brookbart, J. W. 
Geologic formtions, lists, etc.-Continued

Maryland-Continued

Eastern, subsurface: Anderson, J. L., 1.

Georges Creek coal basin: Waage, K. M.

Massachusetts, Mount Grace quadrangle: Hadley, J. B., 1.

Mexico, oil and gas fields: García Rojas, A., 2.

Santa Clara coal district, Sonora: Wilson, I. F., 1.

Sierra de los Muertos area: Humphrey, W. $\mathbf{E .}$

Valley of Mexico, Quaternary: De Terra, H., 2.

Midcontinent, Upper Paleozoic: Wheeler, R. R., 1.

Minnesota, Duluth area: Schwartz, G. M., 1.

Mississippi, central, Tertiary: Miss. Geol. Soc., 1.

Tertiary, post-Claiborne: Monsour, E. T.

Mississippi Valley, Pleistocene: Leighton, M. M., 1.

Missouri, Vernon County, pre-Upper Cambrian: Skillman, M. W.

Montana, Centennial region: Honkala, F. S., 3.

Gage Dome: Perry, E. S., 2.

Hecla mining district: Karlstrom, T. N. V.

Gypsum-bearing formations: Perry, E. S., 1.

Philipsburg area: Cole, J. W., 2.

West Fork, Madison River: Honkala, F. S., 2.

Nebraska, Lower Platte River valley: Waite, H. A.

Nevada, Muddy Mtn. area: Longwell, C. R., 1.

New Hampshire, Keene-Brattleboro area: Moore, G. E., Jr., 1, 2.

Monadnock area: Fowler-Billings, K., 1, 2.

Percy quadrangle: Chapman, R. W., 1.

New Jersey: Wolfe, P. E., 3.

New Mexico: Kelley, V. C.

Central mining district: Lasky, S. G., 1.

Northeastern: Stobbe, H. R., 1.

Northwestern: Tatum, J. L.

Sacramento Mts., Deadman Canyon: West Texas Geol. Soc., 6.

Silver City region: Hernon, R. M.; West Texas Geol. Soc., 4.

Southeastern, Paleozoic: Lloyd, E. R.

Southwestern, Mississippian: Laudon, $\mathbf{L}$. R., 1.

New York, Albany County: Arnow, T.

Central, Devonian: Stevenson, R. E., 2.

Long Island, Mesozoic, Cenozoic: deLaguna, W.

Otsego County, Middle Devonian: Stevenson, R. E., 1.

Southern, Paleozoic: Finn, F. H.

Western: Pittsburgh Geol. Soc.

Newfoundland, Corner Brook-Stephenville area: Walthier, T. N., 1.
Geologic formtions, lists, etc.-Continued

Newfoundland-Continued

Eastern: Hayes, A. 0., 1.

Lewis Hills-Bay St. George area: Walthier, T. N., 2.

Placentia Bay area: Rose, E. R.

North America, Pleistocene biogeography: Deevey, E. S., Jr.

North Carolina, Coastal Plain: Berry, E. W., 1.

Yadkin-Pee Dee River Basin: Mundorff, M. J.

North Dakota: Laird, W. M., 1.

Tokio quadrangle: Easker, D. G.

Northwest Territories, Norman Wells area, Devonian: Warren, P. S., 2.

Ohio: Alkire, R. L., 1, 2.

Allegheny formation: Sturgeon, M. T., 1.

Coshocton County: Lamborn, R. E., 1.

Holmes County: White, G. W., 1 .

Perry County: Flint, N. K.

Southeastern: Dunn, O. C., Jr.

Oklahoma, Mill Creek-Ravia area: Ham, W. E., 1.

Northern, Paleozoic subsurface: Lukert, L. H.

Velma pool, Pennsylvanian: Mallory, W. W., 2.

Ontario, Beatty Township: Satterly, J., 1. Michaud Township: Satterly, J., 2.

Southwestern, Cambrian-Devonian: Roliff, W. A., 1.

Oregon, coastal area, Cape Kiwanda-Cape Foulweather: Snavely, P. D., Jr.; U. S. G. S., 1, no. 97.

Panama, Tertiary: Woodring, W. P.

Pennsylvania, Clearfield County: Sanford, R. $\mathbf{S}$.

Middle Ordovician: Craig, L. C.

Northern, Paleozoic: Finn, F. H.

Schuylkill County, Silurian-Devonian: Mills, J. R.

Southwest, Upper Devonian: Bayles, R. E.

Western: Pittsburgh Geol. Soc.

Quebec, Albanel Lake area: Mistassini Territory: Neilson, J. M.

Belleterre area, Témiscamingue County: Auger, P. E., 1, 2, 3.

Bourget area, Chicoutimi County: Jooste, R. F.

Canimiti River area, Pontiac County: Gillies, N. B.

Duparquet Township, Abitibi-West County: Graham, R. B., 1.

Duverny Township, Abitibi-East County: Weber, W. W.

Forget Lake area, Saguenay County: Longley, W. W., 2.

Gaspé limestone series: Russell, L. S., 1.

Hébécourt Lake area, Abitibi-West County: Graham, R. B., 2.

Lac des Trente-et-un-milles area: Aubert de la Rüe, E., 1. 
Geologic formtions, lists, etc.-Continued Quebec-Continued

McGill Township area: Aubert de la Rüe, E., 2.

Portneuf area: Clark, T. H., 2.

St. Lawrence Lowlands: Clark, T. H., 1.

Témiscamie River area, Mistassini Territory: Wahl, W. G., 2.

Upper Romaine River area: Claveau, J., 4.

Val des Bois area: Mauffette, $P$.

Wakeham Lake area: Claveau, J., 3.

Saskatchewan, Goldfields area: Christie, A. M., 1.

Martin Lake area: Christie, A. M., 1.

South Carolina, Mesozoic: Southeastern Geol. Soc., Mesozoic Comm., 2.

South Dakota, Fall River County: Rothrock, E. P.

Missouri Valley: Pesonen, P. F., 1.

Western: Petsch, B. C.

Tennessee: Mississippi Geol. Soc., 2.

Bumpass Cove: Clayton, A. B.

Central, pre-Chattanooga: Wilson, C. W., Jr.

Silurian, western: Amsden, T. W., 1.

Texas, Beach Mtn.: West Texas Geol. Soc., 6.

Big Bend region: Maxwell, R. A., 1. Buck Hill quadrangle: Goldich, S. S., 3 . Buck Hill volcanics: Goldich, S. S., 2.

Colorado River Valley Permian (?) rocks: Moore, R. C., 2; U. S. G. S., 1, no. 80. Fort Worth, Comanchean: Gray, J. H.

Frio formation, Orange, Jefferson Cos.: Reedy, M. F., Jr.

Glass Mts. area: West Texas Geol. Soc., 5.

Gulf Coastal Plain: Hill, H. B., 1.

Hueco Mts., pre-Permian: West Texas Geol. Soc., 6.

Marathon Basin, pre-Permian: West Texas Geol. Soc., 6.

Marathon region: Graves, R. W., Jr.

Montezuma-Chinati area: McMillan, W. D.

New Hope oil field: Carpenter, C. B.

Northeastern, Upper Jurassic: Swain, F. M., 3.

Panhandle: Roth, R. I., 2.

Sierra Blanca area: Smith, J. F., Jr., 1.

South Permian Basin, cross section: West Texas Geol. Soc., Strat. Prob. Comm.

Southern Davis Mts.: Goldich, S. S., 1.

Southern High Plains: Barnes, J. R. Cenozoic: Evans, G. L.; West Texas Geol. Soc., 3.

Southwest: West Texas Geol. Soc., 2.

Trans-Pecos region: West Texas Geol. Soc., 1.

Well section: DeFord, R. K.

Van Horn uplift, pre-Permian: West Texas Geol. Soc., 6.
Geologic formtions, lists, etc.-Continued

Texas-Continued

Western: West Texas Geol. Soc., 5.

Simpson group. Ordovician: Schweers, R. H.

Woodbine formation: Bergquist, H. R.: U. S. G. S., 1, no. 98 .

United States, Great Basin: Blackwelder, E., 1.

Pennsylvanian system: Moore, R. C., 3.

Western, Phosphoria formation: McKelvey, V. E.

Utah, Cambrian: Schneider, $\mathbf{H}$.

Carboniferous: Williams, J. Stewart, 2.

Cretaceous: Bissell, H. J.

Devonian: Hintze, F. F., 2.

Garden City and Swan Park formations, Ordovician: Ross, R. J., Jr.

Jurassic: Stokes, W. L., 2.

Markagunt Plateau, eastern: Gregory, H. E.

Northern: Williams, J. Stewart, 1.

Ordovician: Hintze, L. F.

Permian: Williams, J. Stewart, 2.

Silurian: Hintze, F. F., 1.

Tooele Valley: Thomas, H. E.

Triassic: Stokes, W. L., 2.

Uinta Basin: Baker, A. A.

Upper Cretaceous: Spieker, E. M.

Utah-Colorado, Green, Yampa River Canyons, Dinosaur Natl. Monument: Untermann, G. E., 1.

Salt-dome region: Tatum, J. L.

Vermont, Keene-Brattleboro area: Moore, G. E., Jr., 1, 2.

Virginia, Elkton area, bedrock and surface: King, P. B., 2 ,

Southwestern, Upper Mississippian: Wilpolt, R. H.; U. S. G. S., 2, no. 38.

West Virginia, southern, Upper Mississippian: Wilpolt, R. H.; U. S. G. S., 2, no. 38 .

Wyoming: Thomas, H. D., 1.

Bighorn River Canyon: Wyo. Geol. Assoc.

Central, Upper Cretaceous: Thompson, Raymond M.; U. S. G. S., 2, no. 36. Central-western: Horberg, C. L., 1.

Church Buttes field: Carlion, R. F.

Glendo area: Love, J. D., 2; U. S. G. S., 1 , no. 92 .

Gros Ventre Mts.; Swenson, F. A.

Hartville Uplift: Denson, N. M., 1; U. S. G. S., 1, no. 102.

Lance Creek-Little Buck Creek oil field: McCanne, R. W.

Mush Creek and Osage oil fields: Dobbin, C. E., 1; U. S. G. S., 1, no. 103.

Powder River Basin, Mesozoic: Downs, G. R.

Red Fork-Powder River area: Carlson, C. E.

Salt Creek field: Mallory, R. W.

Sheep Mtn., Auer Ranch area: Honkala, F. S., 1. 
Geologic history. See also Paleoclimatology; Paleogeography.

Appalachians, southern, Cambrian, preCambrian: King, P. B., 6.

Arizona, Upper Verde Valley, Cenozoic: Mahard, R. H.

British Columbia, Selkirk Mts.: Okulitch, V. J.

California, Coast Ranges, northern San Francisco Bay area: Weaver, C. E.

Colorado, South Park: Stark, J. T.

Evolution, significance: Simpson, G. G., 3. Glacier National Park, Montana: Dyson, J. L., 2.

Greenland: Maync, W., 2.

Labrador, pre-Cambrian: Bruet, E., 1.

Minnesota, Duluth area: Schwartz, G. M., 1.

Montana, pre-Jurassic: Perry, E. S., 2.

New Mexico, southeastern, Paleozoic: Lloyd, E. R.

Northwest Territories, McMurray area: Williams, M. Y.

Quebec, northern, pre-Cambrian: Bruet, E., 1.

United States, Appalachian structure, middle and southern: Rodgers, J., 2.

Great Basin: Blackwelder, E., 1.

Utah: Williams, J. Stewart, 1.

Bryce Canyon: Spitznas, R. L., 1.

Uinta Basin: Baker, A. A.

Utah-Colorado, Green, Yampa River Canyons, Dinosaur Natl. Monument: Untermann, G. E., 1.

Wyoming: Thomas, H. D., 3.

Yellowstone National Park: Chittenden, H. $\mathbf{M}$.

Geologic mapping.

Compilation, Sketchmaster aid: Sohn, I. G., 1.

Electromagnetic waves, high frequency, use: Kerwin, L.

Great Smoky Mts. National Park: Hadley, J. B., 4 .

Symbols: Goddard, E. N., 2.

United States, status: Boardman, L., 10. Geologic maps.

Alabama, Coosa coal field: Rothrock, H. E., 2.

Northeast, crystalline area: Harrell, D. C.

Shelby limonite area: Allen, R. M., Jr., 2.

Southeast, Upper Cretaceous, Tertiary: LaMoreaux, P. E., 2; U. S. G. S., 39.

Alasla, Healy River Valley: Wahrhaftig, C., 1.

Iniskin Peninsula: Kirschner, C. E.; U. S. G. S., 1, no. 95 .

Jumbo Dome: Wahrhaftig, C., 2.

Kenai field, southern: Barnes, F. F.

Alberta, A la Pêche area: Irish, E. J. W.

Bow River-Crowsnest Pass area: Crockford, M. B. B., 2.

Callum Creek, west of Fifth Meridian: Canada G. S., 2.
Geologic maps-Continued

Alberta-Continued

Cardston area: Williams, E. $\mathbf{P}$.

Gap, west of Fifth Meridian: Canada G. S., 5 .

Langford Creek area: Canada G. S., 8.

Leduc oil fields: Link, T. A., 1.

Moberly Creek, west of Sixth Meridian: Canada G. S., 11.

Moon Creek area, west of Sixth Meridian: Canada G. S., 12.

Ribbon Creek area: Crockford, M. B. B., 1.

Rocky Mtn. Front Ranges, Bow River area: Clark, L. M., 2.

Oldman, Foremost formations: Crockford, M. B. B., 3.

Stimson Creek, west of Fifth Meridian: Canada G. S., 14.

Appalachian region, northern: Pittsburgh Geol. Soc.

Southern, Cambrian, pre-Cambrian: King, P. B., 6; Stose, G. W., 1.

Arizona, Artillery Mts.: Lasky, S. G., 2. Chloride district: Thomas, B. E.

Ninety One Hills area: Stoyanow, A. A,. 1.

Seventy Nine mine area: Kiersch, G. A., 1.

Arkansas, Batesville manganese district: Wells, C. J.

British Columbia, Alliford Bay area, Queen Charlotte Islands: McLearn, F. H.

Carp Lake area: Canada G. S., 3. Surface deposits: Canada G. S., 4.

Fort St. James area: Armstrong, J. E.

Glacier Park area, sketch map: Okulitch, V. J.

Lead Empire group: Patmore, W. H.

McConnell Creek: Canada G. S., 10; Lord, C. S., 1.

Maude Island: McLearn, F. H.

Middle River Range: Little, H. W., 2.

Mining areas: British Columbia Dept. Mines.

Nelson area, Kootenay district: Little, H. W., 1.

Smithers-Fort St. James area: Canada G. S., 13.

Wapiti Lake area: Laudon, L. R., 3.

California, Antioch quadrangle: Weaver, C. E.

American Eagle-Blue Moon area: Eric, J. H., 2.

Big Bend mine, Butte County: Eric, J. H., 1

Carquinez quadrangle: Weaver, C. E.

Copper deposits: Jenkins, O. P.

Copperopolis area, Calaveras Co.: Heyl, G. R., 5 .

Foothill copper-zinc belt, Sierra Nevada: Heyl, G. R., 1.

Gazelle region: Heyl, G. R., 8.

Grayhouse area, Amador County: Heyl, G. R., 4 . 
Geologic maps-Continued

California-Continued

Jesse Belle copper mine, Madera County: Cox, M. W., 3.

June Lake district: Putnam, W. C.

La Victoria copper mine, Mariposa Co.: Cox, M. W., 2.

Lilyama and Pioneer copper mines, El Dorado Co.: Cox, M. W., 1.

Lytle Creek area: Arnett, G. R.

Mare Island quadrangle: Weaver, C. E. Mt. Vaca quadrangle: Weaver, C. E.

Newton copper mine, Amador Co.: Heyl, G. R., 2.

Oakville district, mercury mines: Fix, P. F., 1.

Penn zinc-copper mine, Calaveras Co.: Heyl, G. R., 3.

Petaluma quadrangle: Weaver, C. E.

Point Reyes quadrangle: Weaver, C. E.

Puente Hills: Daviess, S. N.; U. S. G. S. 1 , no. 83.

Quail Hill area mines, Calaveras Co.: Heyl, G. R., 6.

San Andreas rift area, southern: Wallace, R. E., 1.

Santa Rosa quadrangle: Weaver, C. E.

Siskiyou County, chromite: Wells, F. G., 1.

Sonoma quadrangle: Weaver, C. E.

Sonora region: Heyl, G. R., 7.

Vacaville quadrangle: Weaver, C. E.

Canada: Reed, F. R. C., 2.

Maritime Provinces: Canada G. S., 9.

North Pacific region: Canada G. S., 1.

Colorado, Cripple Creek area: Koschmann, A. H., 1.

Dodge City basin: Maher, J. C., 1; U. S. G. S., 1, no. 101.

Durango area: U. S. G. S., 1, no. 109 ; Zapp, A. D.

Gunnison Forks sulfur deposit: Dings, M. G.

La Plata district: Eckel, E. B., 1.

McCoy area: Donner, H. F.

Naval Oil Shale Reserves 1 and 3, Garfield Co.: Duncan, D. C.; U. S. G. S., 1 , no. 94.

Pando area: Tweto, O. L.

Piedra River Canyon: Read, C. B.; U. S. G. S., 1 , no. 96 .

St. Peters Dome area: Steven, T. A.

San Juan Mtn. area: Bejnar, W.

South Park: Stark, J. T.

Southwestern, vanadium region: Fischer, R. P., 1.

Connecticut, Haddam Neck area, sketch map: Stobbe, H. R., 2.

Georgia, Atlanta area: Herrick, S. M. Index: Boardman, L., 1.

Jasper County, pegmatites, sketch map: Warriner, L. $\mathbf{P}$.

Gulf Coastal Plain, northern: Moody, C. L. Haiti, Gonaives plain: Taylor, G. C., Jr., 2.
Geologic maps-Continued

Hawaii

Hawaii: Macdonald, G. A., 1.

Kauai: Macdonald, G. A., 4.

Maui: Macdonald, G. A., 4.

Molokai: Macdonald, G. A., 4.

Niihau: Macdonald, G. A., 4.

Oahu: Macdonald, G. A., 4.

Idaho, Avery district: Wagner, W. R,, 1.

Deer Creek-Wells Canyon phosphate area: Deiss, C. F.

Index: Boardman, L., 2.

Yankee Fork district: Anderson, A. L., 1.

Interpretation, ground conditions from geologic maps: U. S. G. S., 40.

Iowa coal fields: Averitt, P, 1.

Kansas: Schoewe, W. $\mathbf{H}$.

Dodge City basin: Maher, J. C., 1; U. S. G. S., 1, no. 101 .

Edwards County: McLaughlin, T. G.

Ellis County: Byrne, F. E., 3.

Norton County: Byrne, F. E., 1; Frye, J. C., 1.

Pawnee County: McLaughlin, T. G.

Pennsylvanian, sketch maps: Moore, $\mathbf{R}$. C., 6.

Phillips County: Frye, J. C., 1.

Rooks County: Byrne, F. E., 2.

Smoky Hill Valley: Latta, B. F.

South-central: Williams, C. C.

Louisiana, De Soto, Red River Parishes: Murray, G. E., Jr., 1.

Maine, Franklin County: Pratt, E. S. Index: Boardman, L., 3.

Jim Pond area, sketch map: Wing, L. A. Moosehead Lake area, sketch map: Hurley, P. M., 2.

Parmachenee area, sketch map: Wing, L. A.

Red Hill, Rumford: Shainin, V. E., 2.

Spencer serpentine area, sketch map: Wing, L. A.

Stony Brook Mtn, serpentine, sketch map: Wing, L. A.

Stover Cove, shore sediments: Donohue, J. J.

Topsham pegmatites: Shainin, V. E., 1.

Manitoba, Bird River area: Chisholm, E. O., 2.

Brochet area: Gadd, N. R.

Cat Lake-Winnipeg River area: Springer, G. D., 1.

Collins Point area: Frarey, M. J.

Dunphy Lakes area: Stanton, M. S.

English Brook area: Russell, G. A., 1.

File-Tramping Lakes area: Harrison, J. M., 1.

Kississing area: Canada G. S., 6.

Moody Lake area: Robertson, D. S.

Sickle Lake area: Fawley, A. P.

Southern: Kerr, L. B., 2.

Wanipigow Lake area: Davies, J. F. Weldon Bay: Kalliokoski, J. 
Geologic maps-Continued

Massachusetts, Mount Grace quadrangle, bedrock: Hadley, J. B., 1.

Surficial geology: Hadley, J. B., 2.

Pawtucket quadrangle: Quinn, A. W., 1, 2.

Ground-water map: Allen, W. B., 2.

Surficial geology: Chute, N. E., 1, 2. Mexico: Garfias, V. R.

Guanajuato mining district: Guiza, R., Jr.

Lucifer district: Wilson, I. F., 2.

Poza Rica oil and gas field: Salas, G. P.

Santa Clara district, Sonora: Wilson, I. F., 1.

Sierra de los Muertos area: Humphrey, W. E.

Soyatal dictrict, antimony mines: White, D. E., 1.

Taxeo district: Fowler, G. M.

Tepexpan region: De Terra, H., 2.

Michigan, Benzie County, surface geology: Calver, J. L., 1.

Iron River district: Dutton, C. E. Southwestern, surface: Tague, G. C.

Stager area: Good, S. E.

Wexford County, glacial deposits: Stewart, D. P.

Ypsilanti area, surface geology: McGuinness, C. L.

Minnesota, central: Woyski, M. S.

Duluth area: Schwartz, G. M., 1.

Montana, Big Ben molybdenum deposit: Herdlick, J. A.

Blakely Creek area: Howland, A. L.

Gish chromite deposits: Howland, A. L.

Gypsum areas: Perry, E. S., 1.

Hecla mining district: Karlstrom, T. N. V.

Limestone areas: Perry, E. S., 1.

Pegmatites: Heinrich, E. W., 1.

Philipsburg area: Cole, J. W., 2.

Philipsburg quadrangle, Henderson Gulch tungsten deposit: Hundhausen, R. J.

Stillwater complex, western: Howland, A. L.

Nevada, Hawthorne quadrangle: Ferguson, H. G.

Index: Boardman, L., 4.

Muddy Mtn. area: Longwell, C. R., 1.

Pioche district: Young, E. B.

Southern, Daisy fluorite mine area: Thurston, W. R.

Tonopah quadrangle: Ferguson, H. G.

White River Valley: Maxey, G. B., 3.

New Brunswick, Chipman area: Muller, J. E., 2.

Minto area: Muller, J. E., 1.

New Hampshire, Blister mica mine: Levin, S. B., 1.

Keene-Brattleboro area: Moore, G. E., Jr., 1, 2.

Monadnock quadrangle: Fowler-Billings, K., 1, 2.

Percy quadrangle: Chapman, R. W., 1.
Geologic maps-Continued

New Jersey, Franklin-Sterling area, sketch maps: Pinger, A. W.

New Jersey-Pennsylvania, Hunterdon Plateau: McLaughlin, D. B.

New Mexico, Central mining district: Lasky, S. G., 1.

Chino mines, Santa Rita area: Ballmer, G. J.

Colfax County: Griggs, R. L.

Iron deposits: Kelley, V. C.

Kilbourne Hole: West Texas Geol. Soc., 3.

Manzanita Mts, area: Reiche, $P$.

Northeastern: Collins, R. F.

North Manzano Mts. area: Reiche, $P$.

Ogallala formation west of Llano Estacado: Bretz, J H., 2.

Sacramento Mts.: West Texas Geol. Soc., 6.

Silver City region: West Texas Geol. Soc., 4.

Southeastern, caliche: Bretz, J H., 3.

New York Adirondack Mts., Grenville series: Engel, A. E. J., 3.

Albany County: Arnow, T.

Parker zinc deposit, St. Lawrence County: Hermance, $\mathbf{H}$. P.

Newfoundland: Reed, F. R. C., 2.

Clarenville area: Hayes, A. O., 1; Rose, E. R.

Corner Brook-Stephenville area: Walthier, T. N., 1.

Donn Brook, sketch map: Walthier, $\mathbf{T}$. N., 1.

Dormston quarry, sketch map: Walthier, T. N., 1.

Grand Lake area: Hayes, A. O., 2.

Lewis Hills-Bay St. George Bay area: Walthier, T. N., 2.

Port au Port Peninsula: Wolfe, P. E., 1.

St. Georges coalfields, sketch map: Hayes, A. O., 2.

North America, paleotectonic, paleogeologic maps: Eardley, A. J., 2.

North Carolina, Buck Creek area: Hadley, J. B., 3.

Coastal Plain: Berry, E. W., 1.

Corundum Knob area: Hadley, J. B., 3.

Deep River coal field: Reinemund, J. A.

Southwestern, Murphy marble belt: Van Horn, E. C., 1.

Yadkin-Pee Dee River Basin: Mundorff, M. J.

North Dakota, Oberon quadrangle: Tetrick, P. R.

Sodium sulfate deposits: Grossman, I. G.

Tokio quadrangle: Easker, D. G.

Northwest Territories, Aylmer Lake area: Lord, C. S., 2.

Carp Lakes area: Miller, M. L. Indin Lake area: Fortier, Y. $\sigma$.

Lac de Gras area: Canada G. S., 7.

McAlpine Channel area: Feniak, M. W. 
Geologic maps-Continued

Northwest Territories-Continued

Pitchblende between Beaverlodge and Hottah Lakes: Henderson, J. F., 1.

Wecho River area, east half: Yardley, D. H.

Yellowknife, Con-Rycon mine: Campbell, N.

Ohio, Coshocton County: Lamborn, R. E., 1.

Holmes County: White, G. W., 1.

Index: Boardman, L., 5.

Mayfield gas and oil pool: Rothrock, H. E., 3.

Perry County: Flint, N. K.

Oklahoma, Anadarko Basin: Jacobsen, C. L., 2.

Haskell County: Oakes, M. C.

Kingfisher County: Schoff, S. L.

Mill Creek-Ravia area: Ham, W. E., 1. Dodge City basin: Maher, J. C., 1.; U. S. G. S., 1, no. 101.

Ontario, Beatty Township: Satterly, J., 1.

Capreol-Milnet area, Pleistocene: Prest, V. K.

Dickenson Red Lake gold mine: Holbrooke, G. L.

Garrison Township: Satterly, J., 3.

Hearst and McFadden Townships: Thomson, J. E.

Kirkland Lake area: Hopkins, $\mathrm{H}$.

Michaud Township: Satterly, J., I.

Rex-Werner Lakes area: Chisholm, E. o., 2.

Southeastern, Potsdam sandstone distribution: Keith, M. L.

Oregon, coastal area, Cape Kiwanda-Cape Foulweather: Snavely, P. D., Jr.; U. S. G. S., 1, no. 97.

Index: Boardman, L., 6.

Kerby quadrangle: Wells, F. G., 2.

Newport-Waldport area, Lincoln Co.: Vokes, H. E., 1; U. S. G. S., 1, no. 88.

Pegmatites, United States: Cameron, E. N.

Pennsylvania, Clearfield-Philipsburg area: Joesting, H. R.

Southern, Triassic: Stose, G. W., 2.

Southwest, Upper Devonian: Bayles, R. E.

Wissahickon schist at Philadelphia: Weiss, J.

Prince Edward Island, O'Leary area: Owen, E. B.

Quebec, Albanel Lake area, Mistassini Territory: Neilson, J. M.

Allard River area, Abitibi-East County: Bêland, R., 2.

Bachelor Lake area, Abitibi-East County: Longley, W. W., 1.

Belleterre area, Témiscamingue County: Auger, P. E., 1, 2, 3.

Bourget area, Chicoutimi County: Jooste, R. F.

Branssat-Kreighoff area, Abitibi-East County: Gilbert, J. E., 2.
Geologic maps-Continued

Quebec-Continued

Canimiti River area, Pontiac County: Gillies, N. B.

Capsisit Lake area, Abitibi-East County: Gilbert, J. E., 1.

Cawatose area, Pontiac County: Wahl, W. G., 1.

Chaste area, Abitibi-East County: Tiphane, $M$.

Chertsey map-area: Côté, P. E.

Duparquet Township, Abitibi-West County: Graham, R. B., 1.

Duverny Township, Abitibi-East County: Weber, W. W.

Forget Lake area, Saguenay County: Longley, W. W., 2.

Forillon Peninsula, sketch map: Russell, L. S., 1.

Goéland Lake area, Abitibi-East County: Imbault, P. E., 2.

Hébécourt Lake area, Abitibi-West County: Graham, R. B., 2.

Iserhoff River area, Abitibi-East County : Claveau, J., 1.

Lac des Trente-et-un-milles area: Aubert de la Rüe, E., 1.

McGill Township area: Aubert de la Rüe, E., 2.

Nominingue region: Jérémine, $\mathrm{E}$.

Olga Lake area, Abitibi-East County: Imbault, P. E., 1.

Peribonca River area: Ross, S. H.

Portneuf area: Clark, T. H., 2.

Rawdon area: Béland, R., 3.

Razilly Township, Abitibi-East County: Maurice, O. D., 1.

St. Lawrence Lowlands: Clark, T. H., 1.

Taibi Lake area: Béland, R., 1.

Témiscamie River area, Mistassini Territory: Wahl, W. G., 2.

Upper Romaine River area: Claveau, J., 4.

Val des Bois area: Mauffette, $P$.

Wakeham Lake area: Claveau, J., 3.

Waswanipi Lake area, Abitibi-East County: Claveau, J., 2.

Rhode Island, Pawtucket quadrangle: Quinn, A. W., 1, 2.

Ground-water map: Allen, W. B., 2. Surficial geology: Chute, N. E., 1, 2.

Saskatchewan, Goldfields area: Christie, A. M., 1; Conybeare, C. E. B., 2. Sketch maps: Christie, A. M., 2.

Kississing area: Canada G. S., 6.

Martin Lake area: Christie, A. M., 1.

Snake Rapids area: Eastwood, G. E. P.

Southern: MacKay, B. R., 2.

South Dakota, Angostura irrigation: Littleton, R. T.

Northern Whitewood anticline: Petsch, B. C.

Pleasant Valley, pegmatites: Burns, R. E.

Tennessee, index: Boardman, I., 7. 
Geologic maps-Continued

Texas, Barrilla Mts.: Eifler, G. K., Jr. Big Bend region: Maxwell, R. A., 1.

Borden County: Ellis, W. C.

Buck Hill quadrangle: Goldich, S. S., 3.

Ceramic materials: Pence, F. K., 2.

Coal Creek serpentine, Blanco and Gillespie Counties: Romberg, F., 2.

Colorado River Valley Permian (?) rocks: Moore, R. C., 2; U. S. G. S., 1 , no. 80 .

Culberson-Hudspeth Counties area: King, P. B., 1; U. S. G. S., 1, no. 90 .

Davis Mts., southern: Goldich, S. S., 1, 2.

Elephant Mtn. area: Goldich, S. S., 3.

Glass Mts.: West Texas Geol. Soc., 5.

Gulf Coast: Sundstrom, R. W.

High Plains: Barnes, J. R.

Hueco Mts.: West Texas Geol. Soc., 5, 6.

Iron Mtn. area, Llano County: Barnes, V. E. 1,.

Maravillas Creek area: Graves, R. W., Jr.

Montezuma-Chinati area: McMillan, W. D.

North-central, Pennsylvanian clay outcrops: Plummer, F. B.

Northeastern, Cretaceous: Bergquist, H. R.; U. S. G. S., 1, no. 98 .

Panhandle: Roth, R. I., 2.

Rich Lake playa: West Texas Geol. Soc., 3.

Sierra Blanca area: Smith, J. F., Jr., 1.

Southwest: West Texas Geol. Soc., 2.

Tinija Range area: Graves, R. W., Jr.

Trans-Pecos region: West Texas Geol. Soc., 5.

Van Horn uplift: West Texas Geol. Soc., 6.

United States, Rocky Mts, and Plains, $\mathrm{Pa}=$ leocene: Brown, R. W., 2.

Utah, Bingham area, sketch map: Hunt, R. $\mathbf{N}$.

Markagunt Plateau, eastern: Gregory, H. E.

Southeastern, vanadium region: Fischer, R. P., 1 .

Three Peaks laccolith: Mackin, J. H.

Tooele Valley: Thomas, H. E.

Vermont, Carleton talc quarry, Chester: Billings, M. P.

East-central area: White, W. S.

Keene-Brattleboro area: Moore, G. E., Jr., 1, 2.

Mad River tale mine, Fayston: Billings, M. $\mathbf{P}$.

Rousseau talc prospect, Cambridge: Billings, M. P.

Virginia, Alleghany County: Parrott, W. $\mathrm{T}$.

Washington, Gladstone Mtn. area, Stevens County: Cole, J. W., 1.

Index: Boardman, L., 8.
Geologic Maps-Continued

Washington-Continued

Skagit River silica deposits, sketch maps: Popoff, C. C., 2.

Wenatchee perlite area: Huntting, $M$. T.

West Virginia, index: Boardman, L., 9.

Wyoming, central-western: Horberg, C. L., 1.

Glendo area: Love, J. D., 2; U. S. G. S., 1 , no. 92.

Gros Ventre Mts.: Swenson, F. A.

Hartville Uplift: Denson, N. M., 1; U. S. G. S., 1, no. 102 .

Mush Creek oil field: Dobbin, C. E., 1; U. S. G. S., 1, no. 103.

Powder River Basin: Love, J. D., 1; Wyo. Geol. Assoc.

Red Fork Powder River area: Carlson, C. E.

Sherman quadrangle, cordierite deposits: Newhouse, W. H., 2.

Tongue River area: Osterwald, F. W., 1. Yukon, McQuestion area: Bostock, H. S., 1.

Geologic reports.

Illustrations: LeRoy, L. W., 9.

Maps, subsurface: Low, J. W.

Subsurface geology: Crain, H. M.

Geologic systems, United States, areal exposure, relation to time: Higgs, D. V.

Geologic terms, origin: Burt, F. A., 2.

Geologic thermometry.

Decrepitation geothermometer: Peach, P. A., 1.

Liquid inclusions, granite thermometry: Bailey, S. W.

Halite: Peach, P. A., 2.

Quartz, inversion temperature: Tuttle, 0 . F., 2.

Temperatures, measurement: Friedman, $I$. I., 2.

Geologic time

Distribution of mountain building in: GilIuly, J., 3.

Evolution, significance: Simpson, G. G., 3. Geologic systems, areal exposure, relation to time: Higgs, D. V.

Leaching of carbonates, in loess and glacial drift, age correlation: Flint, $R$. F., 2.

Measurement: Marble, J. P., 1, 3.

A/K ratio in rocks: Farrar, R. L., Jr.

Bibliography: Marble, J. P., 2, 4.

Calcium method: Ahrens, L. H., 3.

Canada, Ontario-Manitoba gold belt: Furley, P. M., 1.

Lead method: Marble, J. P., 6.

Magnetite: Hurley, P. M., 3.

Methods: Knopf, A.

Ontario uraninite: Holmes, A.

$\mathrm{Pb} / \mathrm{U}$ ratio of accessory minerals: Larsen, E. S., Jr., 2.

Strontium method: Ahrens, L. H., 2, 3.

Pegmatite age determination, Manitoba: Ahrens, L. H., 1. 
Geologic time-Continued

Relation to rate of evolution: Sloss, L. L. 2.

Geologist.

Career: Koschmann, A. H., 3.

Indiana, before 1600: Malott, C. A., 3.

Geology and forest growth, relationship: Warren, H. V., 4.

Geomorphology, New Mexico, Carlsbad Caverns area: Horwerg, C. L., 3.

Geophysical abstracts: Rabbitt, M. C.; Skitsky, V. L.

Geophysical investigations.

Activity, 1948: Eckhardt, E. A.

Alaska, Adak Island: Alldredge, L. R.

Appalachians: Branham, C. A.

Anticlines: Straley, H. W., 1.

Gravity study: Woollard, G. P., 2.

Magnetic surveying: Branham, C. A.

Basement reflection correlation: Cortright, W. D.

California, Cuyama Valley, magnetic profiles: Hoylman, H. W.

Sacramento Va.iey, reflection correlation: Cohick, K. S.

San Joaquin valiey, gravity anomalies: Clement, P. F.

Well velocity shooting, seismic data: Wells, R. J.

Colorado, Georgetown district, Anglo Saxon vein, self potential survey: Gabelman, J. W., 2.

Composite reflections: Ricker, N. H., 2.

Connate-water resistivity determinations: Wyllie, M. R. J.

Correlation of seismic events and geological horizons: Clayton, $\mathrm{N}$.

Exploration, airborne magnetometer: Jensen, H., 2.

Fault detection with reflection seismograph: Kelsey, M. C.

Gravitational quantities, derivation by surface integration: Skeels, D. C.

Ground vibrations near explosions: Howell, B. F., Jr.

Ground water development by seismic methods: Linehan, $D$.

Indiana, Benton County, aeromagnetic map: U. S. G. S., 3.

Fulton County, aeromagnetic map: U. S. G. S., 4 .

Jasper County, aeromagnetic map: U. S. G. S., 5 .

Lake County, aeromagnetic map: U. S. G. S., 6.

La Porte County, aeromagnetic map: U. S. G. S., 7.

Newton County, aeromagnetic map: U. S. G. S., 8.

Posey County, aeromagnetic map: U. S. G. S., 9.

Pulaski County, aeromagnetic map: U. S. G. S., 10.

Starke County, aeromagnetic map: U. S. G. S., 11.
Geophysical investigations-Continued

Indiana-Continued

White County, aeromagnetic map: U. S. G. S., 12 .

Limestone reefs: Agnich, F. J.

Magnetic interpretation, application of field data: Peters, L. J.

Magnetic profile, Colorado-Indiana: Jensen, $\mathbf{H} ., 1$.

Magnetic quantities, derivation by surface integration: 'Skeels, D. C.

Magnetometer exploration: Peters, J. W.

Maine, Moosehead Lake area, magnetic survey: Hurley, P. M., 2.

Mexico, gravimetric surveys: De la 0 . Carreño, A.

Michigan, aeromagnetic survey, Bara a, Iron, Hudspeth Cos.: Balsley, J. R, Jr.

Iron County: Zinner, $\mathbf{P}$.

Siazer area, magnetic survey: Good, S. E.

Mineral exploration: García Rojas, A., 1.

Minnesota, Beltrami County, aeromagnetic profiles: U. S. G. S., 13.

Cass County, aeromagnetic map: U. S. G. S., 14, 17 .

Aeromagnetic profiles: U. S. G. S., $15,16,18$.

Crow Wing County, aeromagnetic map: U. S. G. S., 19, 21.

Aeromagnetic profiles; U. S. G. S., 20, 22.

Hubbard County, aeromagnetic map: U. S. G. S., $23,25$.

Aeromagnetic profiles: U. S. G. S., $24,26$.

Itasca County, aeromagnetic map: U. S. G. S., 27.

Aeromagnetic profiles: U. S. G. S., 28.

Morrison County, aeromagnetic map: U. S. G. S., $29,31$.

Aeromagnetic profiles: U. S. G. S., 30.

Todd County, aeromagnetic map: U. S. G. S., 32 .

Aeromagnetic profiles: U. S. G. S., 33.

Wadena County, aeromagnetic map: U. S. G. S., 25 .

Aeromagnetic profiles: U. S. G. S., 26.

Missouri, Coldwater quadrangle, aeromagnetic map: U. S. G. S., 34.

Crystal City quadrangie, aeromagnetic map: U. S. G. S., 37.

De Soto quadrangle, aeromagnetic map: U. S. G. S., 36 .

Des Arc quadrangle, aeromagnetic map: U. S. G. S., 35.

Farmington quadrangle, aeromagnetic map: U. S. G. S., 37.

Fredericktown quadrangle, aeromagnetic map: U. S. G. S., 38.

New Mexico, Houston-Thomas lead-ziric prospect: Barnes, V. E., 2.

$904979^{\circ}-51-14$ 
Geophysical investigations-Continued

New Mexico-Continued

Lead-zinc discovery, gravity meter survey: Romberg, F., 1.

Southeastern, seismic velocity maps: Dahm, C. G.

New York, Russell quadrangle, magnetic anomalies: Shaub, B. M., 2.

Petroleum exploration: Nettleton, L. L.

Resistivity method: Guyod, H. C.

Quebec, Allard Lake district, aeromagnetic survey: Bourret, $\mathrm{W}$.

East Sullivan area: Innes, M. J. S.

Radio waves, earth penetration: Anonymous, 2.

Mineral exploration: Barret, W. M.

Reefs, location: Agnich, F. J., 1, 2.

Salt-dome boundary determination by seismograph: Gardner, L. W.

Second vertical derivatives and magnetic anomalies: Henderson, R. G.

Seismic exploration, integration of geology and geophysics: Beebe, B. W.

Poulter method: Kastrop, J. E.; Novelly, W. O.; Poulter, T. C.

Seismic methods, ground water development: Linehan, D.

Seismic pulses, oscillatory: Dix, C. H.

Seismic surveying: Heroy, W. B., Jr.

Seismic wave propagation: Clewell, D. H.

Submarine, Atlantic Ocean, seismic studies : Ewing, W. M., 1, 3.

California, offshore, seismic: Johnson, C. $\mathrm{H}$.

Gulf of Mexico, offshore, seismic: Frowe, E. W.; Teufel, V. W.

Ocean bottom, seismic reflections: Hersey, J. B., 1, 2.

Sea bottom, slope determination, seismic reflections: Agoes, W. B., 1.

Texas, Coal Creek serpentine, Blanco and Gillespie Counties: Romberg, F., 2.

Fault interpretation from seismic reflections: Quarles, M. W., Jr.

Jameson area, gravity survey: Brown, H.

Llano iron region: Barnes, V. E., 1.

Trinidad, multiple reflections, difficulties: Higgins, G. E.

United States, magnetometer exploration: Peters, J. W.

Velocity intervals, calculation: Agocs W. B., 2.

Wells shot for velocity, index: Swan, B. G. Wyoming, Powder River Basin: Fenwick W. H., 1, 2.

Geophysics.

Approximations: Gutenberg, B., 1.

Colorado, application in mining: Wantland, $\mathrm{D}$.

General: Gutenberg, B., 3.

Gravimetric exploration for minerals: Garcia Rojas, A., 1.

Gravitational exploration: Fenwick, W. H. 2.

Investigations, need: Massé, L.
Geophysics-Continưed

Magnetic exploration: Fenwick, W. H., 2.

Mineral exploration: Jakosky, J. J.

Ore exploration: Koschmann, A. H., 2.

Petroleum exploration: Jakosky, J. J.

Refiections: Handley, E. J., 2.

Correlation with geologic horizons:

Handley, E. J., 1.

Review, 1948: Tolman, C.

Seismic data, interpretation: Terry, B. E.

Subsurface geologic methods: Stommel, H. E.

Water exploration: Kelly, S. F.

Georgia.

Economic geology.

Barite, Cartersville: Kesler, T. L.

Copper pyrite, Lumpkin County: Kline, M. $\mathbf{H}$.

Natural gas, developments, 1948: Harris, R. $M$.

Pegmatites, Jasper County: Warriner, L. $P$.

Petroleum, developments, 1948: Harris, R. $\mathbf{M}$.

Geologic maps.

Atlanta area: Herrick, S. M.

Index: Boardinan, L., 1.

Pegmatites, Jasper County, sketch map: Warriner, L. $\mathbf{P}$.

Ground water.

Atlanta area: Herrick, S. M.

Sheet structure in granites, effect: Le grand, $\mathbf{H}$. E.

Historical geology.

Mesozoic, cross section: Southeastern Geol. Soc., Mesozoic Comm., 3.

Pre-Mesozoic, subsurface: Applin, P. L.

Mineralogy.

Anatase: Nagelschmidt, G.

Kaolin: Nagelschmidt, G.

Staurolite: Furcron, A. S.

Paleontology.

Ostracode, leperditiid, Paleozoic: Swartz, F. M., 2.

Petrology.

Granites, sheet structure: Legrand, H. E.

Pegmatites, Jasper County: Warriner, L. $P$.

Geosynclines.

Alaska, Kuskolkwim area, deposition: Cady, W. $M$.

Appalachian, stratigraphy and structure: Lafferty, R. C., Jr.

Development, relation to isostatic adjustment: Wahl, Walter.

Ensialic: Wells, F. G., 3.

Ensimatic: Wells, F. G., 3.

General: Field, R. M.

Mexico: Alvarez, M., Jr.

Nomenclature: Kay, G. M., 1.

Paleozoic, and island ares: Kay, G. M., 2.

Geothermal gradients.

General: Ingersoll, L. $\mathbf{R}$.

Ontario, Kirkland Lake area: Misener, A. D. 
Geothermal gradients-Continued

Ontario-Continued

Sudbury area: Misener, A. D.

Timmins area: Misener, A. D.

Yellowstone National Park: Bloss, F. D.; Chittenden, H. M.; Muench, J. R.

Norris Basin, geyser development: Turner, D. $S$.

Old Faithful, regularity: Fix, P. F., 2.

Glacial geology. See also Glacial lakes: Glaciation; Glaciers; Quaternary.

Alaska, Jumbo Dome: Wahrhaftig, C., 2.

Alpine glaciation: Ray, L. L., 3.

Biogeography, Pleistocene, Europe and North America: Deevey, E. S., Jr.

British Columbia, Carp Lake area: Canada G. S., 3 .

Surface deposits: Canada G. S., 4.

Canada, North Pacific region: Canada G. S., 1.

Wisconsin ice sheet and marine seaway: La Rocque, A., 1.

Cirques, origin: Fisher, J. E., 2.

Colorado, South Park: Stark, J. T.

Continental glaciation, deposits: Hobbs, W. H., 3.

Forbes' dirt bands, origin: Fisher, J. E., 2.

Great Lakes area: Flint, R. F., 1.

Greenland, Holsteinsborg district: Milthers, $\mathrm{K}$.

West, landforms, effect of jointing: Jahn, A.

Gulf of Maine: Chadwick, G. H.

Illinois, till wedge, Wisconsin age: Horberg, C. L., 2.

Indiana, Henry County: McGrain, P., 2. Scottsburg area: Wickwire, G. T.

Interrelations, Pleistocene geology and soil science: Thorp, J., 1.

Iowa, Shelby County: Ruhe, R. V.

Southwest, loess-derived soils: Hutton, C. $\mathbf{E}$.

Wisconsin drift area soils: Riecken, F. F.

Wisconsin stage: Leighton, M. M., 2 .

Kansas, northeastern, Pleistocene loess: Frye, J. C., 6.

Leaching of carbonates in loess and glacial drift, age correlation: Flint, R. F., 2.

Massachusetts, Fitchburg rollstone: $\mathrm{Pa}$ lache, $C$.

Mount Grace quadrangle: Hadley, J. B., 2.

Pawtucket quadrangle: Chute, N. E., $1,2$.

Mexico, Tepexpan area: De Terra, H., 1. Valley of Mexico: De Terra, H., 2.

Michigan, Benzie County: Calver, J. L., 1. Grand Marais Embayment: Tague, G. C. Iron River district: Stanley, G. M., 1.

Wexford County: Stewart, D. P.

Ypsilanti area: McGuinness, C. L.

Minnesota, Duluth area: Schwartz, G. M., 1.

Minnesota-Ontario, Quetico Superior area: Atwood, W, W.
Glacial geology-Continued

Mississippi Valley, Pleistocene: Leighton, M. M., 1.

Missouri, gumbotil, formation, relation to overlying loess: Krusekopf, H. H.

Montana, Glacier National Park: Dyson, J. L., 1.

Periglacial features, origin: Schafer J. P., 1.

Teton River valley: Schafer, J. P., 2.

Neives Penitentes, origin: Fisher, J. E., 2.

New England, clay concretions: Bassler, R. S.

New Jersey, Wisconsin drift: MacClintock, $P$.

New York, Croton Point moraine: Kindle. C. H., 2.

Mohawk Valley: Kay, G. M., 3.

North America-Eurasia, continental glaciers: Hobbs, W. H., 4.

North Dakota, boulders: Waring, G. A.

Lake Agassiz Plain, ridges: Horberg, C. L., 4 .

Oberon quadrangle: Tetrick, P. R.

Tokio quadrangle: Easker, D. G.

Northwest Territories, Indin Lake area: Fortier, Y. $O$.

Lac de Gras area: Canada G. S., 7.

Ohio, Holmes County: White, G. W., 1. Northern, sand, gravel: Smith, W. H.

Ontario, Vermilion River area: Prest, V. K.

Glacier recession: Chapman, L. J.

Pebble distribution, outwash plain: Hawkins, A. C.

Pennsylvania, Susquehanna River terraces: Peltier, L. C.

Periglacial phenomena: Wolfe, C. W., 2.

Pleistocene biogeography: Deevey, E. S., $\mathrm{Jr}$.

Pleistocene climatology: Landsberg, $\mathbf{H}$.

Pleistocene problems: Ray, L. L., 2.

Pleistocene research: Flint, R. F, 3, 4.

Prince Edward Isiand, O'Leary area: Owen, E. B.

Quebec, Shickshock Mts., Gaspé: Carbonneau, C.

Rhode Island, Exeter area: Allen, W. B., 1. Pawtucket quadrangle: Chute, N. E., 1, 2.

South Dakota, boulders: Waring, G. A.

Submarine geology and Pleistocene: Phieger, F. B., Jr., 4.

United States, Great Basin: Antevs, E. V., 1; Blackwelder, E., 1.

South Mississippi Valley: Wascher, H. L.

Wisconsin, driftless area, periglacial features: Smith, H. T. U., 1.

Wyoming, Wind River Mts.: Holmes, G. W.; Moss, J. H., 2.

Moraines: Moss, J. H., 3.

Glacial lakes.

British Columbia, Carp Lake area, surface deposits: Canada G. S., 4.

Lake Barlow-Ojibway, Ontario: Satterly, J., 1. 
Glacial lakes-Continued

Lake Lahontan shore lines, elevations: Stanley, G. M., 2.

Lake Minnewankon, Tokio quadrangle North Dakota: Easker, D. G.

Michigan, Benzie County: Calver, J. L., 1. Grand Marais Embayment: Tague, G. C. New York, Mohawk valley: Kay, G. M., 3.

North Dakota, Tokio quadrangle: Easker, D. $\mathbf{G}$.

United States, Great Basin: Antevs, E. V., 1; Blackwelder, E., 1; Hubbs, C. L.

Glaciation.

Canada, Seward firn field: Sharp, R. P., 5.

Cirque formation, meltwater function: Lewis, W. V.

Continental: Hobbs, W. H., 3, 4.

Greenland, Clavering Island: Ahlmann, H. W.

Idaho, Coeur d'Alene district: Dort, W., Jr.

Origin: Morris, F. K.

Quebec, Shickshock Mts., theories: Carbonneau, C.

Valley: Sharp, R. P., 1

Glaciers.

Alaska: Miller, M. M.

Prince William Sound: Field, W. O., Jr., 1.

Alpine glaciation: Ray, L. L., 3.

British Columbia, Llanberis Glacier, Lloyd George Mts.: Odell, N. E., 2.

Lloyd George Mts., stagnant glacier: Odell, N. E., 1, 2.

Sentinel Glacier: Mathews, W. H.

Canada, Rockies, 1948: Field, W. O., Jr., 2. Classification: Ahlmann, H. W.

Continental: Robbs, W. H., 1, 3, 4 .

Glacial erosion, sedimentation: Holmes, C. D., 2.

Greenland, Fröya Glacier, Clavering Island: Ahlmann, H. W.

Mechanies: Chamberlin, R. T., 1.

Montana, Glacier National Park: Dyson, J. L., 1.

Palisade Glacier, California: Heald, W. F., 1.

Periglacial phenomena: Wolfe, C. W., 2.

Study techniques: Sharp, R. P., 2.

Temperature, cutting power: Fisher, J. E., 4.

United States, vanishing: Heald, W. F., 2.

Valley, compound: Sharp, R. P., 1.

Superglacial debris: Sharp, R. P., 4.

Wolf Creek glacier, Yukon, superglacial debris: Sharp, R. P., 4.

Glass, cellular structures, compared to lavas: Osborn, E. F.

Glossary, scientific names: Northrop, S. A.

Gneiss.

Classification: Alcock, F. J., 2.

Greenland, Holsteinsborg district, skarn minerals: Pauly, $\mathbf{H}$.

West, petrogenesis: Ramberg, H., 1.
Gold.

Colorado, Cripple Creek area, structural control: Koschmann, A. H., 1.

La Plata district: Eckel, E. B., 1.

Idaho, Yankee Fork district: Anderson, A. L., 1.

Manitoba, File-Tramping Lakes area: Harrison, J. M., 1.

Northwest Territories, Giant Yellowknife property: Dadson, A. S.

Yellowknife, Con-Rycon mine: Campbell, N.

Ontario, Central Patricia mine: Tigert, T. T.

Dickenson Red Lake mine: Holbrooke, G. $\mathbf{L}$.

Garrison Township: Satterly, J., 3.

Hard Rock mine: Morrow, H. F.

Hearst and McFadden townships: Thomson, J. E.

Kirkland Lake area: Hopkins, $\mathbf{H}$.

Michaud Township: Satterly, J., 2.

Pickle Crow mine: Monette, H. $\mathrm{H}$.

Oregon, Kerby quadrangle: Wells, F. G., 2.

Quebec, Belleterre area, Témiscamingue County: Auger, P. E., 1, 2.

Duparquet Township, Abitibi-West County: Graham, R. B., 1.

Duverny Township, Abitibi-East County: Weber, W. W.

South Dakota, Homestake mine: McLaughlin, D. H.

Granite. See also Construction materials.

Crystallization temperatures from liquid inclusions: Bailey, S. W.

Georgia, sheet structure, effect on ground water: Legrand, H. E.

Liquid inclusions, granite thermometry: Bailey, S. W.

Massachusetts, Norfolk County: Chayes, F., 4.

New York, Hudson Highlands: Lowe, K. E.

Oklahoma, Spavinaw: Strachan, C. G.

Origin: Daly, R. A.; Perrin, R.

Granitization.

General: Lowe, K. E.

Metasomatic, relation of synkinematic and static: Misch, P., 1.

Mineralization: Goodspeed, G. E., 3.

Oregon, Cornucopia area: Goodspeed, G. E., 1.

Relation to ore deposits: Edwards, A. B.

Washington, Okanogan County: Misch, P., 3.

Riverside-Conconully area, Paleozoic sediments: Misch, P., 1.

Swauk formation: Coombs, H. A.

Graptolitoidea.

Tennessee, Athens shale, Ordovician:

Decker, C. E.

Virginia, Athens shale, Ordovician: Decker, C. $\mathbf{E}$.

Gravel. See also Construction materials.

Mississippi Valley, lower: Waterways Expt. Sta. 
Gravel-Continued

New Mexico, Ogallala formation west of Llano Estacado: Bretz, J H., 2.

Ohio, northern, resources: Smith, W. H.

Prince Edward Island, O'Leary area Owen, E. B.

Texas, Hamilton Dam, petrography: Holland, W. Y., 2.

Virginia, Elkton area: King, P. B., 2.

Washington, Columbia River: Cary, A. S. Cowlitz River, petrography: Haff, J. C., 4.

Grand Coulee damsite, Brett Pit gravel, petrography: Holland, W. Y., 1.

Wyoming, Glendo area: Love, J. D., 2; U. S. G. S., 1, no. 92 .

Greenland.

Meteorites, Cape York, area: Graham, R. P.

Historical geology.

East Greenland, Jurassic: Maync, W., 3.

Franz Joseph Fiord area: Bütler, H., 1.

Geographical Society Island, Jurassic, Cretaceous: Donovan, D. T.

Giesecke Mts., Gauss Peninsula, pre-Permian: Maync, W., 1.

Middle Devonian: Bütler, H., 3.

Jørgen Brønlunds Fjord area, Paleozoic: Troelsen, J. C.

Pleistocene: Troelsen, J. C.

North-east Greenland, Cretaceous: Maync, W., 4.

Permian: Maync, W., 2.

Qapiarfik, Disko Bay, pre-Cambrian: Malaurie, J. N., 2.

Trail Island, Jurassic, Cretaceous: Donovan, $D$. T.

Wegener Peninsula, East Greenland: Bütler, H., 2.

Mineralogy.

Allanite, Godhaab: Boucot, A. J., 1.

Aluminum fluorides: Ferguson, R. B.

Calcite, Holsteinsborg district: Pauly, H.

Skarn minerals, Holsteinsborg district: Pauly, H.

Paleontology.

Cape Stosch coast: Nielsen, E., 1.

Cephalopoda, Permoteuthis groenlandica: Rosenkrantz, A.

East Greenland, Jurassic: Maync, W., 3. Trails, Triassic: Nielsen, E., 2.

Geographical Society Island, Cretaceous: Donovan, D. T.

Jørgen Brønlunds Fjord area, Pleistocene: Troelsen, J. C.

North-east Greenland, Cretaceous: Maync, W., 4.

Pisces, Bothriolepinae, Upper Devonian: Stensiö, E. A.

Strobitus, selaginelloid, Triassic: Lundblad, $\mathrm{B}$.

\section{Petrology.}

Facies classification of rocks: Ramberg, H., 2.

Gneiss complexes, West Greenland: Ramberg, H., 1.
Greenland-Continued

Fhysical geology.

Beach deposit, submarine: Malaurie, J. N., 1.

East Greenland, Watkins Mts., origin: Wager, L. R.

Franz Joseph Fiord area, deformation: Bütler, H., 1.

Jointing, effect on landform: Jahn, A.

Lava flows and changes of level: Eardley, A. J., 1.

Orogeny, pre-Cambrian: Noe-Nygaard, A. Qapiarfik, Disko Bay, pre-Cambrian: Malaurie, J. N., 2.

F hysiographic geology.

Fröya Glacier, Clavering Island: Ahlmann, H. W.

Glacial landforms, effect of jointing: Jahn. A.

Holsteinsborg district, glacial reconnaissance: Milthers, $\mathbf{K}$.

Ground water. For areal, see names of states and countries. See also Geysers; Springs; Thermal waters.

Alabama, fluoride in: LaMoreaux, P. E., 1.

Southeast: LaMoreaux, P. E., 3; U. S. G. S., 39.

Arizona, Big Sandy Valley: Morrison, R. B.

California: Bartz, P. M.

Haywards fault, impounding effect: Forbes, $\mathrm{H}$.

Caves, hydrology: Hamilton, D. K.

Exploration, electric logging: Jones, P. H. Geophysical methods: Kelly, S. F.

General: Broadhurst, W. L., 2.

Georgia, Atlanta area: Herrick, S. M.

Effect of sheet structure in granites: Legrand, H. E.

Haiti, Cul-de-Sac plain: Taylor, G. C., Jr.,

Gonaives plain: Taylor, G. C., Jr., 2.

Illinois, Peoria area: Larson, T. E.

Winnebago County: Smith, H. F.

- Indiana, Henry County: MeGrain, P., 2. Scottsburg area: Wickwire, G. T.

Iowa, hillside seepage, Iowan drift, Howard County: Kirkham, D.

Kansas, Chase County: O'Connor, H. G.

Edwards County: McLaughlin, T. G.

Norton County: Frye, J. C., 1.

Pawnee County: McLaughlin, T. G.

Phillips County: Frye, J. C., 1.

Prospecting: Fent, O. S.

Smoky Hill Valley: Latta, B. F.

South-central: Williams, C. C.

Southwestern: Frye, J. C., 2.

Limestone terranes, hydrology: Swinnerton, A. C., 1.

Louisiana, Natchitoches area: Maher, J. C., 3.

Maine: Trefethen, J. M., 3.

Maryland, Anne Arundel County: Brookhart, J. W. 
Ground Water-Continued

Massachusetts, Cambridge area, glacial deposits: Halberg, H. N.

Pawtucket quadrangle: Allen ,W. B., 2. Measurement device: Irwin, W. H., 6.

Michigan, Iron River district: Stuart, W. T. Ypsilanti area: MeGuinness, C. L.

Minnesota, Clay County: Dennis, P. E.

Nebraska, Lower Platte River valley: Waite, H. A.

Nevada, Goshute-Antelope Valley: Eakin, T. E.

Las Vegas artesian basin: Maxey, G. B., 1.

Las Vegas Valley: Maxey, G. B., 2.

Pahrump Valley: Maxey, G. B., 2.

Paradise Valley, Humboldt County: Loeltz, O. J.

White River Valley: Maxey, G. B., 3.

New Hampshire, artesian wells: Goldthwait, R. P.

New Mexico, Colfax Co.: Griggs, R. L.

New York, Albany area: Arnow, T.; Simpson, E. S.

Long Island, Kings County. deLaguna, W.

North Carolina, Yadkin-Pee Dee River Basin: Mundorff, M. J.

North Dakota, Cass County: Dennis, P. E. Oberon quadrangles: Tetrick, P. R.

Ohio, Canton area: Kazmann, R. G.

Stream flow and ground-water geology: Cross, W. P.

Oklahoma, Kingfisher County: Schoff, S. L.

Oklahoma City area: Jacobsen, C. L., 1.

Pacific Coast beaches, level: Isaacs, J. D.

Pennsylvania, Allegheny County, valley-fill deposits: Adamson, J. H., Jr., 1.

Pittsburgh area: Adamson, J. H., Jr., 2.

Prospecting, geologic methods: Fent, O.S.

Rhode Island, Exeter area: Allen, W. B., 1.

Pawtucket quadrangle: Allen, W. B., 2.

Rocky Mountain region, oil-field waters, characteristics: Crawford, J. G., 2.

Seismic reconnaissance: Linehan, D.

South Dakota, Angostura irrigation profect: Littleton, R. T.

Texas, Borden County: Ellis, W. C.

El Paso region: Sayre, A. N., 3; Scalapino, R. A.

High Plains: Alexander, W. H., Jr., 1, 2; Broadhurst, W. L., 1, 3.

Southern: Barnes, J. R.

Linn-Faysville area: Follett, C. R.

Matagorda County: Sundstrom, R. W.

United States, areas: Millis, J. B.

Utah, Jordan Valley: Taylor, G. H.

Tooele Valley: Thomas, H. E.

Washington, Spokane area: McMacken, J. G.

West Virginia: Johnston, H. F.

Yellowstone National Park, geyser development, Norris Basin: Turner, D. $\mathrm{S}$.

Guatemala, echinoid, Cretaceous: Cooke, C. W.
Guidebooks.

Alabama, northern, pre-Cambrian, Paleozoic: Mississippi Geol. Soc., 2.

Appalachian Basin, northern: Pittsburgh Geol. Soc.

Arkansas, southwestern, Cretaceous: Shreveport Geol. Soc.

Kansas, Lower Kansas River Valley: Kans. Geol. Soc.

Mississippi, central, Tertiary: Mississippi Geol, Soc., 1.

Tennessee, south-central, Paleozoic: Mississippi Geol. Soc., 2.

Wyoming, Powder River Basin: Wyo. Geol. Assoc.

Gulf Coast.

Geosynclinal sedimentation: Murray, G. E., Jr., 2.

Petroleum: Deegan, C. J., 2.

Sedimentary facies: Lowman, S. W., 2.

Gulf of Mexico.

Geophysical exploration, offshore: Frowe, E. W.

Ostracod distribution, paleoecology criterion: Rothwell, W. T., Jr.

Petroleum exploration, offshore: McGee, D. A.

Sediments: Stetson, H. C.

Recent, petroleum source beds: Trask, P. D.

Seismic exploration, offshore: Teufel, V. W.

Gumbotil, Missouri, formation from glacial deposits: Krusekopf, H. H.

Gypsum.

Montana: Perry, E. S., 1.

Selenite crystals: Carpenter, A. C.

Wyoming, Glendo area: Love, J. D., 2; U. S. G. S., 1, no. 92 .

Haiti. See also West Indies.

Geologic maps.

Gonaives plain: Taylor, G. C., Jr., 2.

Ground water.

Cul-de-Sac plain: Taylor, G. C., Jr., 1.

Gonaives plain: Taylor, G. C., Jr., 2.

Physical geology.

Cul-de-Sac plain, rivers, springs: Taylor, G. C., Jr., 1.

Halite.

California, Bristol Dry Lake cave: Hicks, F.

Identification, with sylvite: Roberts, C. $\mathbf{N}$. Salt dome structures: Balk, $\mathbf{R}$.

Hawaii.

Geologic maps.

Hawaii: Macdonald, G. A., 1, 4.

Kauai: Macdonald, G. A., 4.

Maui: Macdonald, G. A., 4.

Molokai: Macdonald, G. A., 4.

Niihau: Macdonald, G. A., 4.

Oahu: Macdonald, G. A., 4.

Petrology.

General: Macdonald, G. A., 4.

Island of Hawaii: Macdonald, G. A., 1. 
Hawaii-Continued

Physical geology.

Mauna Loa, activity, Apr.-June 1949: Macdonald, G. A., 3.

Eruption, January 1949: Macdonald, G. A., 2.

Oahu, erosion: White, S. E., 1.

Steam blast eruptions: Jaggar, T. A. Volcanic tremor: Finch, R. H.

Heat, conduction, geological applications: Ingersoll, L. R.

Heavy minerals.

Methods of study: Rittenhouse, G., 3 .

Pennsylvania, Wissahickon schist at Philadelphia: Weiss, J.

Soil minerals: Jeffries, C. D., 1.

Texas, northeastern, Upper Jurassic: Swain, F. M., 3.

West Virginia, Greenbrier formation: Rittenhouse, G., 5.

Hematite-goethite, experimental investigations: Smith, F. G., 2.

Historical geology. For areal, see names of states and countries. See also the different systems; Correlations; Geologic formations, etc.

Facies, meaning: Moore, R. C., 4 .

Sedimentary: Longwell, C. R., 2.

Gulf Coast: Lowman, S. W., 2.

Overlap and nonconformity: Lahee, F. H., 2.

Pennsylvanian system, divisions: Moore, R. C., 3.

Kansas: Moore, R. C., 6.

Plant and animal interdependence: Taylor, W. $\mathbf{P}$.

Soils, old, geologic significance: Branson, E. B., 2.

Stratigraphic convergence: Wheeler, R. R., 2.

Textbook: Dunbar, C. O.; Moore, R. C., 1. United States, maps: Lobeck, A. K., 1, 2. History. See also Surveys.

Alaska, U. S. Geological Survey work: Reed, J. C., 2.

Canada, geology, 1841-1941: Morin, L. G. 1849-1949: Aleock, F. J., 1.

Laval University, Quebec, museum: Bureau, R., 1.

Leonardo da Vinci: Clements, T. D.

New York, Staten Island rocks and minerals, early references: Coles, R. S.

Honduras. See also Central America.

Osteoborus, Pliocene, Gracias area: McGrew, P. 0 .

Hydrology. See Ground water.

Hydrothermal alteration.

Arizona, Silver Bell area: Kerr, P. F., 6.

California, Grayhouse area, Amador Co.: Heyl, G. R., 4.

Zinc-copper deposits, Big Bend mine, Butte Co.: Eric, J. H., 1.

Dedolomitization: Faust, G. T., 2.

Silicates, magnesian: Bowen, N. L., 1.

Utah, East Tintic district: Lovering, T. S., 1.
Hydrozoa, New York, Schenectady formation, new species, Ordovician: Howell, B. F., 2.

Ice.

Crystals, formation: Schaefer, V. J.

Giacier, pressure melting point: Fisher, J. E., 4.

Idaho.

Economic geology.

Avery district, Shoshone County: Wagner, W. R., 1.

Cobalt, Blackbird district: Douglas, E. B.

Lead-zinc, Coeur d'Alene district: Shenon, P. J.

Phosphate rock: Butner, D. W.; McKelvey, V. E.

Deer Creek-Wells Canyon area: Deiss, C. F.

Placer minerals: Staley, W. W.

Yankee Fork district, Custer County: Anderson, A. L., 1.

Geologic maps.

Avery district, Shoshone County: Wagner, W. R., 1.

Deer Creek-Wells Canyon phosphate area: Deiss, C. F.

Index: Boardman, L., 2.

Yankee Fork district, Custer County: Anderson, A. L., 1.

Historical geology.

Avery district, Shoshone County: Wagner, W. R., 1.

Deer Creek-Wells Canyon area: Deiss, C. F.

Yankee Fork district, Custer County: Anderson, A. L., 1.

Mineralogy.

Ludlamite, Blackbird district: Glass, J. J.

Paleontology.

Tree ferns, Cretaceous: Andrews, H. N., Jr., 1.

Petrology.

Construction materials, Anderson Ranch dam: Mielenz, R. C., 3.

Monzonite intrusion, Coeur d'Alene district: Anderson, A. L., 2.

Palisades dam site, andesite, petrography: Mielenz, R. C., 15.

Physiographic geology.

Coeur d'Alene district, glaciation: Dort, W, $\mathrm{Jr}_{\mathrm{r}}$.

Igneous rocks. See also Batholiths; Dikes: Intrusions; Magmas; Petrology; Rock descriptions; Stocks.

Accessory minerals, paragenesis: Moorhouse, W. W.

Arizona, Canelo Hills, tuff, spheroids: Feth, J. H., 1.

British Columbia, Middle River Range, ultrabasics: Little, H. W., 2.

California, Grayhouse area, Amador Co.: Heyl, G. R., 4.

June Lake district: Putnam, W. C.

Quail Hill area mines, Calaveras Co.: Heyl, G. R., 6. 
Igneous rocks--Continued

California-Continued

Siskiyou County, chromite: Wells, F. G., 1.

Canada, North Pacific region: Canada G. S., 1.

Classification: Mielenz, R. C., 10.

Colorado, Continental Divide tunnel, petrography: Haff, J. C., 2; Mielenz, R. C., 2.

McCoy area: Donner, H. F.

Dunite, origin: Bowen, N. L., 1.

El Salvador, volcanics: Stirton, R. A.

Gallium: Sandell, E. B.

Gulf Coastal Plain, northern: Moody, C. L.

Hawaii: Macdonald, G. A., 1, 4.

Idaho, Palisades dam site, andesite, petrography: Mielenz, R. C., 15.

Illinois, pre-Cambrian: Grogan, R. M., 2.

Manitoba, Brochet area: Gadd, N. R.

Cat Lake-Winnipeg River area: Springer, G. D., 1.

Dunphy Lakes area: Stanton, M. S.

English Brook area: Russell, G. A., 1.

File-Tramping Lakes area: Harrison, J. M., 1.

Kississing area: Canada G. S., 6.

Moody Lake area: Robertson, D. S.

Sickle Lake area: Fawley, A. P.

Wanipigow Lake area: Davies, J. F.

Massachusetts, Mount Grace quadrangle: Hadley, J. B., 1.

Mid-Atlantic Ridge: Shand, S. J.

Minnesota: Woyski, M. S.

Missouri, St. Francois Mts., pre-Cambrian volcanics: Robertson, F. S.

Montana, Canyon Ferry project, metaandesite, petrography: Mielenz, R. C., 12.

Nevada, Candelaria district, volcanics: Barksdale, J. D., 2.

New Hampshire, Monadnock area: FowlerBillings, K., 2.

New Mexico, Capitan quadrangle: Patton, L. T.

Colfax Co.: Griggs, R. L.

Northeastern, volcanics: Stobbe, H. R., 1.

Northwest Territories, Carp Lakes area: Miller, M. L.

Indin Lake area: Fortier, Y. 0.

Lac de Gras area: Canada G. S., 7.

McAlpine Channel area: Feniak, M. W.

Pitchblende between Beaverlodge and Hottah Lakes: Henderson, J. F., 1.

Wecho River area, east half: Yardley, D. $\mathbf{H}$.

Oregon, Deschutes project, petrography: Mielenz, R. C., 9.

Kerby quadrangle: Wells, F. G., 2.

Peridotite, origin: Bowen, N. L., 1.

Quebec, Forget Lake area, Saguenay County: Longley, W. W., 2.

Mt. Laurier region: Jérémine, E.

Peribonca River area: Ross, S. H.
Igneous rocks-Continued

Quebec-Continued

Upper Romaine River area: Claveau, J., 4.

Wakeham Lake area: Claveau, J., 3. Rhode Island, northern: Quinn, A. W., 3. Saskatchewan, Kississing area: Canada G. S., 6.

Snake Rapids area: Eastwood, G. E. P. Texas, Big Bend National Park: Lonsdale, J. T., 2.

Big Bend region: Maxwell, R. A., 1. Brewster County: Lonsdale, J. T., 1.

Buck Hill quadrangle: Goldich, S. S., 3. Buck Hill volcanics: Goldich, S. S., 2.

Sierra Blanca area: Smith, J. F., Jr., 1. Ultramafic, radium content: Davis, G. L. Utah: Bullock, K. C.

Washington, Methow quadrangle: Barksdale, J. D., 1.

Weathering, spheroidal: Chapman, R. W., 2.

Wyoming, peridotite, Laramie Mts.: Albanese, J. $P$.

Illinois.

Bibliography, Chicago region: Isfort, L. G.

Loess, properties, distribution: Smith, G.D.

Economic geology.

Coal, southern: Doerr, A. H.

Fluorspar, Cave in Rock district, structures: Grogan, R. M., 1.

Douglas property: Bishop, O. M.

Natural gas, developments, 1948: Bell, A. H., 2,3 .

Petroleum, developments, 1948: Bell, A. H., $2,3$.

Niagaran reefs: Lowenstam, H. A., 1.

Possibilities: Bell, A. H., 1.

Ground water.

Water analyses, geologic correlations, hydrologic interpretation: Larson, T. E.

Winnebago County: Smith, H. F.

Historical geology.

Niagaran reefs, oil accumulation: Lowenstam, H. A., 1.

Niagaran strata, facies analyses: Lowenstam, H. A., 2.

Mineralogy.

Fluorite, Hardin County: Grawe, O. R.

Loess, X-ray studies: Whiteside, E. P.

Strontianite, Hardin County: Grawe, O. R.

Witherite, Hardin County: Grawe, O. R.

Paleontology.

Botryopteris: Mamay, S. H.

Euryterid, Mazon Creek: Kjellesvig-Waering, E. $\mathbf{N}$.

Pteridosperms, Pennsylvanian: Baxter, $\mathbf{R}$. W.; Schopf, J. M., 2.

Petrology.

Coal, analyses: Parks, B. C.

Geodes, petroliferous, Tyson Creek area: Spitznas, R. L., 2.

McClosky sand, Mississippian, Passport oil pool: Connolly, F. T.

Pre-Cambrian crystallines: Grogan, R. M., 2. 
Illinois-Continued

Petrology-Continued

Ste. Genevieve formation, insoluble residues: Hoover, W. F.

Oolite: Shrode, R. S.

Trivoli sandstone, Williamson County: Siever, $\mathbf{R}$.

Physical geology.

Cave in Rock district, fluorspar deposits, structures: Grogan, R. M., 1.

Structure, southern: Doerr, A. H.

Physiographic geology.

Till wedge, Wisconsin age: Horberg, C. L., 2.

Ilmenite, Quebec, Allard Lake: Hammond, P. Index fossils.

Calceolispongiae, Permian: Teichert, C.

California, Miocene giant oysters, Shell Peak: Martin, L.

Cuba, Somorrostro hills, Havana area, Miocene: Aguayo, C. G., 3.

Foraminifera, Pliocene-Pleistocene boundary problem: Thalmann, H. E., 7.

Mexico, Reynosa area, Gulf Coast: Guzmán, E. J.

Orbulina, Tertiary time indicators: Tromp, S. W.

United States, Pennsylvanian system: Moore, R. C., 3.

Indiana.

Aeromagnetic maps, Benton County: U. S. G. S., 3.

Fulton County: U. S. G. S., 4.

Jasper County: U. S. G. S., 5.

Lake County: U. S. G. S., 6.

La Porte County: U. S. G. S., 7.

Newton County: U. S. G. S., 8.

Posey County: U. S. G. S., 9.

Pulaski County: U. S. G. S., 10.

Starke County: U. S. G. S., 11.

White County: U. S. G. S., 12.

Airphoto patterns, Illinoian drift: Stevens, J. C.

Cagle's Mill reservoir site, geological features: McGrain, P., 1.

Drainage mapping from airphotos: Parvis, M.

Geologists, before 1900: Malott, C. A., 3.

Economic geology.

Crushed stone: Patton, J. B.

Natural gas, developments, 1948: Bell, A. H., 2.

Petroleum, developments, 1948: Bell, A. H., 2.

Ground water.

Henry County: McGrain, P., 2.

Scottsburg area: Wickwire, G. T.

Historical geology.

Henry County: MeGrain, P., 2.

Limestone: Patton, J. B.

Sullivan, Vigo Counties, Devonian: Bieberman, $D$. $F$.

\section{Mineralogy.}

Diamond: Wade, F. B.
Indiana-Continued

Paleontology.

Calamite, new, Pennsylvanian: Reed, F. D., 2.

Petrology.

Oolitic facies, Ste. Genevieve formation, Mississippian: Leith, C. J.

Physiographic geology.

Henry County, glacial geology: McGrain, P., 2.

Hudelson cavern: Malott, C. A., 1, 2.

Lost River drainage: Malott, C. A., 1.

Mill Creek Valley: McGrain, P., 1.

Scottsburg area, glacial geology: Wickwire, G. T.

Industrial minerals.

Alaska, southeastern, limestone: Roehm, J. C.

Canada, silica deposits: MacPherson, A. R.

Colorado: Argall, G. O., Jr.

Exploration: Dawson, A. S.

General: Am. Inst. Min. Met. Eng.

Manitoba, bibliography: Kerr, L. B., 1.

Missouri: Forrester, J. D., 1.

Montana: Perry, E. S., 1.

New Jersey: Tyler, P. M.; Wolfe, P. E., 3. Glass sand: Wilkerson, A. S., 1, 2.

Vincentown area, lime marl: Bader, $\mathbf{H}$., 1.

North Carolina, eastern: Berry, E. W., 1. Ohio, Holmes County: White, G. W., 1.

Oklahoma, southwestern: Funnell, J. E.

Ontario, silica, Potsdam sandstone: Keith, M. L.

United States, bibliography: Ries, H., 3. Occurrence: Ries, H., 3.

Washington, nonmetallic minerals: Valentine, G. M.

Perlite: Huntting, M. T.

West Virginia, salt resources: Price, P. H., 2.

Insecta. See also Arthropoda.

California, asphalt deposits: Pierce, W. D., 2.

Colorado, Florissant beds, Miocene: Melander, A. L.

Insoluble residues.

Chickamauga limestone, Tennessee : Schlocker, J.

Kansas, Fort Hays chalk: Runnels, R. T. 1.

Minnewasta limestone, South Dakota: Schlocker, J.

Missouri, Fredericktown area, Bonneterre formation: James, J. A.

Paleozoic: Grohskopf, J. G.

Preparation, recording, symbols: Grohskopf, J. G.

Ste. Genevieve formation: Hoover, W. F. Study techniques: Ireland, H. A., 1.

Uses: Ireland, H. A., 1.

West Virginia, Greenbrier formation: Rittenhouse, G., 5.

Intrusions. See also Batholiths; Dikes, Igneous rocks; Magmas; Stocks. 
Intrusions-Continued

British Columbia, Middle River Range, ultrabasics: Little, H. W., 2.

California, Coast Ranges, northern San Francisco Bay area: Weaver, C. E.

Copper deposits, Copperopolis, Calaveras Co.: Heyl, G. R., 5.

Grayhouse area, Amador Co.: Heyl, G. R., 4.

Jesse Belle copper mine, Madera Co.: Cox, M. W., 3.

Penn zinc-copper mine, Calaveras Co.: Heyl, G. R., 3.

Quail Hill area mines, Calaveras Co.: Heyl, G. R., 6.

Zinc-copper deposits, Big Bend mine, Butte Co.: Eric, J. H., 1.

Gulf Coastal Plain, northern: Moody, C. L. Idaho, Coeur d'Alene district, monzonite: Anderson, A. L., 2.

Maine, northwestern: Wing, L. A.

Manitoba, Dunphy Lakes area: Stanton, M. S.

File-Tramping Lakes area: Harrison, J. M., 1.

Wanipigow Lake area: Davies, J. F.

Minnesota: Woyski, M. S.

Montana, pegmatites: Heinrich, E. W., 2.

New Hampshire, Keene-Brattleboro area: Moore, G. E., Jr., 2.

Northwest Territories, Carp Lakes area: Miller, M. L.

Lac de Gras area: Canada G. S., 7.

Pitchblende between Beaverlodge and Hottah Lakes: Henderson, J. F., 1.

Oregon, Kerby quadrangle: Wells, F. G., 2. Newport-Waldport area, Lincoln Co.: Vokes, H. E., 1; U. S. G. S., 1, no. 88.

Pennsylvania, southern, post-Triassic: Stose, G. W., 2.

Wissahickon schist at Philadelphia: Weiss, J.

Quebec, upper Romaine River area: Claveau, J., 4.

Wakeham Lake area: Claveau, J., 3.

South Dakota, northern Black Hills, Tertiary: Noble, J. A.

Utah, Iron Springs district: Mackin, J. H.

Vermont, Keene-Brattleboro area: Moore, G. E., Jr., 2.

Invertebrata (general). See also Porifera; Echinodermata; Mollusca; Paleontology; Evolution.

California, San Francisco Bay area, faunal lists: Weaver, C. E.

Colorado, La Plata district, Carboniferous: Williams, J. Steele, 1.

South Park: Stark, J. T.

Evolution, significance: Simpson, G. G., 3.

Favositidae, Devonian, types: Stumm, E. C., 1.

Glossary: Northrop, S. A.

Greenland, Geographical Society Island, Cretaceous: Donovan, D. T.
Invertebrata-Continued

Mexico, Reynosa area, Gulf Coast, faunal lists: Guzmán, E. J.

North Carolina, Harrellsville, Miocene: Berry, E. W., 2.

Ohio, Dorr Run shale, Pennsylvanian: Sturgeon, M. T., 1.

Oregon, Newport-Waldport area, faunal lists: Vokes, H. E., 1; U. S. G. S., 1, no. 88 .

Quebec, St. Lawrence Lowlands: Clark, T. H., 1.

Size increase in fossils: Newell, N. D., 3. Tennessee, Brownsport formation, Silurian: Amsden, T. W., 1.

Central, pre-Chattanooga: Wilson, C. W., Jr.

Texas, microfossils in plesiosaur matrix, Lake Waco: Graham, J. J., 1. Iowa.

Soil classification, Wisconsin drift area: Riecken, F. F.

\section{Eeonomic geology.}

Coal fields: Averitt, P., 1.

Iron, Waukon deposit: Pesonen, P. E., 2.

Geologic maps.

Coal fields: Averitt, P., 1.

Ground water.

Seepage, hillside, Iowan drift, Howard County: Kirkham, D.

\section{Historical geology.}

Coal fields: Averitt, P., 1.

Devonian, Mississippian: Thomas, I. A.

Exline limestone, Pennsylvanian, paleoecology: Cline, L. M.

Shelby County, Pleistocene: Ruhe, R. V.

\section{Mineralogy.}

Loess-derived soils, southwest: Hutton, C. E.

Mapleton meteorite: Roy, S. K., 1.

Paleontology.

Brachiopoda, Maquoketa shale, Ordovician: Wang, $Y$.

Cephalopod coquina, Maquoketa shale, Ordovician: Miller, A. K., 1.

Conodonts, Devonian, Mississippian: Thomas, L. A.

Pella beds, Mississippian: Youngquist, W. L., 4.

Pennsylvanian: Youngquist, W. L., 2.

Prospect Hill, Mississippian: Youngquist, W. L., 1.

Cordaites, fructifications, Pennsylvanian: Fry, W. I.

Fossil seeds, Pennsylvanian, Urbandale coal mine: Andrews, H. N., Jr., 2.

Pteridosperms, Pennsylvanian: Baxter, R. W.

Physical geology.

Iowa, southwest, loess-derived soils: Hut-ton, C. E.

Physiographic geology.

Glacial geology: Leighton, M. M., 2.

Loess-derived soils, southwest: Hutton, C. E. 
Iowa-Continued

Physiographic geology-Continued

Soil classification, Wisconsin drift area: Riecken, F. F.

Iron.

Alabama, Shelby, limonite ores, origin: Allen, R. M., Jr., 2.

California, Iron Mtn. mine, Redding: Kinkel, A. R., Jr.

Iowa, Waukon deposit: Pesonen, P. E., 2.

Lake Superior soft ores, origin: Tyler, S. A.

Mexico, origin: Flores, $T$.

Michigan, Iron River district: Dutton, C. E.; James, H. L.

Montana, Sheep Creek deposits: Reed, G. C.

New Mexico, deposits: Kelley, V. C.

Newfoundland, Wabana, oolitic ores: Caillère, $\mathrm{S}$.

Oxidation and reduction: Mason, B. H., 1 .

Quebec, Allard Lake district, aeromagnetic survey: Bourret, W.

Tennessee, limonite layers, Tertiary strata, origin: Schneider, $\mathbf{R}$.

Texas, Llans region: Barnes, V. E., 1.

Iron oxides, hematite-goethite relations under pressure: Smith, F. G., 2.

Isostasy.

General: Gunn, $\mathbf{R}$

Geochemical effect: Wahl, Walter.

Lithosphere, and supporting magma: Gunn, R.

Jade.

Alaska, Kobuk River area: Anderson, F., 2.

Wyoming, Long Creek: Cobb, H. S.

Jointing.

California, Jesse Belle copper mine, Madera Co.: Cox, M. W., 3.

Greenland, West: Jahn, A.

Mine roof: Holland, C. T.

Oregon, Kerby quadrangle: Wells, F. G., 2.

Washington, Rock Island, basalt: Fuller, R. E.

Jurassic. See also Paleontology, Jurassic.

Alberta, foothills sections: Spivak, J.

Southern Plains: Weir, J. D.

British Columbia, Alliford Bay area, Queen Charlotte Islands: McLearn, F. H.

Carp Lake area: Canada G. S., 3.

Foothills sections: Spivak, J.

Maude Island: McLearn, F. H.

California, Coast Ranges, northern San Francisco Bay area: Weaver, C. E.

Penn zinc-copper mine, Calaveras Co.: Heyl, G. R., 3.

Greenland, East: Maync, W., 3.

Geographical Society Island: Donovan, D. T.

Trail Island: Donovan, D. T.

Louisiana, De Soto, Red River Parishes: Murray, G. E., Jr., 1.

Mexico, Sierra de los Muertos area: Humphrey, W. E.

New Mexico, Colfax Co.: Griggs, R. L.
Jurassic-Continued

North America, paleotectonic, paleogeologic maps: Eardley, A. J., 2.

United States, Great Basin: Blackwelder, E., 1.

Utah: Stokes, W. L., 2 Kansas.

Loess, Pleistocene: Frye, J. C., b̆.

Meteorites, list: Nininger, H. H., 1.

Norton meteorite: Nininger, H. H., 2.

Scenic natural features: Landes, K. K., 3. Economic geology.

Construction materials, Ellis County: Byrne, F. E., 3.

Norton County: Byrne, F. E., 1.

Rooks County: Byrne, F. E., 2

Natural gas: Jewett, J. M., 2.

Developments, 1948: Berg, J. R.; Ver Wiebe, W. A., 2.

Eastern: Jewett, J. M., 1.

Map: Jacobson, E. C.

Petroleum: Jewett, J. M., 2.

Developments, 1948: Berg, J. R.; Ver Wiebe, W. A., 2.

Dodge City Basin: Maher, J. C., 1; U. S. G. S., 1, no. 101.

Eastern: Jewett, J. M., 1.

Map: Jacobson, E. C.

Shales, phosphate-bearing: Runnels, R. T. 2.

Tri-State zinc-lead district, reserves: Ruhl, O.

Geologic maps.

Dodge City Basin, pre-Pennsylvanian: Maher, J. C., 1; U. S. G. S., 1, no. 101.

Edwards County McLaughlin, T. G.

Ellis County: Byrne, F. E., 3.

General: Schoewe, W. H.

Norton County: Byrne, F. E., 1; Frye, J. C., 1.

Pawnee County: McLaughlin, T. G.

Pennsylvanian system, sketch maps: Moore, R. C., 6.

Phillips County: Frye, J. C., 1.

Rooks County: Byrne, F. E., 2.

Smoky Hill Valley: Latta, B. F.

South-central: Williams, C. C.

Ground water.

Chase County: O'Connor, H. G.

Edwards County: MeLaughlin, T. G.

Norton County: Frye, J. C., 1.

Pawnee County: McLaughlin, T. G.

Phillips County: Frye, J. C., 1.

Prospecting: Fent, O. S.

Smoky Hill Valley: Latta, B. F.

South-central: Williams, C. C.

Southwestern: Frye, J. C., 2.

Historical geology.

Cross section, subsurface, Barber CountySaline County: Lee, W.

Dodge City Basin, pre-Pennsylvanian: Maher, J. C., 1; U. S. G. S., 1, no. 101.

Eastern: Jewett, J. M., 1.

Edwards County: McLaughlin, T. G.

Ellis County: Byrne, F. E., 3. 
Kansas-Continued

Historical geology-Continued

Fort Hays chalk, Cretaceous: Runnels, $\mathbf{R}$. T., 1.

Hugoton Embayment, Anadarko Basin, pre-Pennsylvanian: Maher, J. C., 4.

Lower Kansas River valley: Kansas Geol. Soc.

Meade County, Pleistocene: Hibbard, C. W., 1.

Norton County: Byrne, F. E., 1; Frye, J. C., 1.

Paleozoic, subsurface cross sections: Lukert, L. $\mathbf{H}$.

Pawnee County: McLaughlin, T. G.

Pennsylvanian system, divisions: Moore, R. C., 6.

Phillips County: Frye, J. C., 1.

Pleistocene, northeastern: Frye, J. C., 6. Fossil soils: Frye, J. C., 4.

Rooks County: Byrne, F. E., 2.

Saw Rock Canyon area, Pliocene: Hibbard, C. W., 2.

South-central: Williams C. C. Mineralogy.

Meteorites, Kimberly Ranch, Haviland: Anonymous, 8.

Norton County: Beck, C. W., 1.

Selenite crystals: Carpenter, A. C.

Wathena meteorite: Henderson, E. P., 4. Paleontology.

Aves, Pleistocene: Downs, T.

Crinoids, Iola limestone, Pennsylvanian: Strimple, H. L., 3.

Pennsylvanian: Strimple, H. L., 4.

Wyandotte limestone, Pennsylvanian: Strimple, H. L., 3.

Foraminifera, Lower Cretaceous, Kiowa Co.: Loeblich, A. R., Jr., 1.

Meade County, Pleistocene, faunal list: Hibbard, C. W., 1.

Reptilia, pelycosaurs, Pennsylvanian: Peabody, F. E.

Saw Rock Canyon, Pliocene: Hibbard, C. W., 2.

Tremarctotherium, Meade County, Pleistocene: Rinker, G. C.

Vertebrata, upper Pliocene, Keefe Canyon, Meade Co.: Hibbard, C. W., 3.

Petrology.

Fort Hays chalk, Cretaceous: Runnels, $\mathbf{R}$. T., 1.

Mississippian strata, lithology: Clair, J. R.

Physical geology.

Structure, eastern: Jewett, J. M., 1.

Physiographic geology.

General: Schoewe, W. H. Kaolin.

Plains Border section: Frye, J. C., 3.

Florida: Calver, J. L., 2.

Georgia: Nagelschmidt, G.

Thermal analysis: Gruver, R. M.

Kentucky.

Economic geology.

Natural gas, Big Six sandstone: Young, D. M.
Kentucky-Continued

Economic geology-Continued

Natural gas-Continued

Development: Hunter, C. D. 1948: Wood, E. B.

Petroleum, deep wells: Jillson, W. R., 3.

Development: Hunter, C. D. 1948: Wood, E. B.

Historical geology.

Big Six sandstone: Young, D. M.

Cambrian subsurface: Freeman, L. B.

Greenbrier formation, Mississippian: Sonnenberg, F. $P$.

Jessamine Creek area: Jillson, W. R., 5.

Mississippian strata: Clair, J. R.

Ordovician, subsurface: Freeman, L. B.

Owen County: Jillson, W. R., 4.

Salt sand (Pottsville conglomerate), Pennsylvanian: Thomas, R. N.

Upper Mississippian, eastern: Wilpolt, $\mathbf{R}$. H.; U. S. G. S., 2, no. 38.

Paleontology.

Edestus, Carboniferous shark: Jillson, W. R., 6.

Vertebrates, Lower Blue Licks, Pleistocene: Jillson, W. R., 1, 2.

\section{Petrology.}

Salt sand (Pottsville conglomerate), Pennsylvanian: Thomas, R. N.

Physical geology.

Jessamine Creek area, faults: Jillson, W. R., 5.

Physiographic geology.

Eagle Creek piracy, Pliocene: Jillson, W. R., 7.

Labrador.

Manganese: Tanton, T. L., 2.

Pre-Cambrian: Bruet, E., 1.

Synclinal structure: Douglas, G. V., 1.

Laccoliths, rate of cooling: Ingersoll, $L . R$.

Lakes.

Alaska, oriented, origin: Black, R. F.

California, Lake Elsinore, bottom sampling: Mann, J. F., Jr.

Lake Michigan, origin: Thwaites, F. T.

Lake Superior, origin: Schwartz, G. M., 1.

North Carolina, Coastal Plain: Frey, D. G.

Oregon, Crater Lake, origin: Eisenberg, $\mathbf{J}$. M., 2.

Lakes, extinct. See also Glacial lakes.

United States, Great Basin, fish distribution and Pleistocene hydrography: Hubbs, C. L.

Landforms, erosional, quantitative analysis: Strahler, A. N., 1.

Landslides.

Florida, Greensboro area: Jordan, R. H.

New Mexico, Colfax County: Griggs, R. L.

Panama Canal: MacDonald, D. F.

Lava. See also Igneous rocks.

Cellular structures: Osborn, E. F.

El Salvador: Stirton, R. A.

Greenland: Eardley, A. J., 1. 
Lava-Continued

Hawaii, petrography: Macdonald, G. A., $1,4$.

Mexico, Parícutin eruption: James, C. C. New Mexico, Colfax County: Griggs, R. L.

Quebec, Bolton lavas, age: Ambrose, J. W.

Washington, basaltic, jointing: Fuller, R. E.

Lead.

Arizona, Seventy Nine mine: Kiersch, G. A., 1.

British Columbia, Lead Empire group: Patmore, W. $\mathbf{H}$.

Sullivan mine: Swanson, C. O., 1.

California, Big Bend mine, Butte Co.: Eric, J. H., 1.

Cerro Gordo mine area: Merriam, C. W. 1.

Canada, occurrences: McClelland, W. R.

Colorado, Mineral Point district: Hazen, S. W., Jr.

Poughkeepsie district: Hazen, S. W., Jr.

Idaho, Coeur d'Alene district: Shenon, P. J.

Kansas, Tri-State district: Ruhl, 0 .

Mexico: Gonzaléz Reyna, J., 2.

Pachuca ores: Geyne, A. R.

Taxco district: Fowler, G. M.

Mississippi Valley: Behre, C. H., Jr., 1.

Missouri, Fredericktown area: James, J. A.

Tri-State zinc-lead district: Ruhl, 0 .

Nevada, Pioche district: Young, E. B.

New Mexico, Houston-Thomas prospect, gravity exploration: Barnes, V. E., 2; Romberg, F., 1.

Oklahoma, Tri-State zinc-lead district: Ruhl, 0.

Pennsylvania, Ecton mine, abandoned: Boucot, A. J., 2.

Symposium: Dunham, K. C.

Texas, Montezuma-Chinati area: McMillan, W. D.

Tri-State region: Behre, C. H., Jr., 1.

Utah, Bingham area: Hunt, R. N.

Washington, Stevens County: Cole, J. W., 1.

Leucoxene: Allen, V. T., 2.

Lignite. See also Coal.

North Dakota: Roe, W. B.

Origin: Parks, B. C.

Petrography: Parks, B. C.

Saskatchewan, southern, map: McKay, B. R., 2.

United States, petrography: Parks, B. C.

Western, reserves: Bryson, R. P.

Vermont, Brandon, Tertiary, origin: Barghoorn, E. S., Jr., 5.

Limestone. See also Construction materials.

Alaska, southeastern: Roehm, J. C.

California, Gazelle region: Heyl, G. R., 8.

Sonora region: Heyl, G. R., 7.

General: Rockwood, N. C.

Limestone-Continued

Indiana: Patton, J. B.

Maine, Franklin County: Pratt, E. S.

Mexico, Papaloapan Basin, solution: Moneymaker, B. C.

Montana: Perry, E. S., 1.

New Jersey: Wolfe, P. E., 3.

North Carolina, eastern: Berry, E. W., 1.

Nova Scotia Glen Morrison: Goudge, M. F.

Organic: Johnson, J. H., 1.

Reserves, metallurgical use: Landes, K. K., 4.

South Dakota, Minnesota, petrography: Schlocker, J.

Tennessee, Chickamauga, petrography: Holland, W. Y., 3; Schlocker, J.

Graysville area, petrography: Holland, W. Y., 4.

Texas, Pennsylvanian, eastern Permian basin: Conley, J. N.

Washington, Oroville, silicification: Crosby, J. W.

Snohomish County: Popoff, C. C., 1.

Wyoming, Glendo area: Love, J. D., 2; U. S. G. S., 1, no. 92 .

Limonite.

Forms: Albrecht, H. O.

Michigan, Van Buren County: Hill, J.

Nova Scotia, Bridgeville deposit: Weeks, L. J.

Tennessee, Tertiary strata, origin: Schneider, $\mathbf{R}$.

Liquid inclusions.

Apparatus for measurement: Peach, $P$. A., 1.

Geothermometry: Peach, P. A., 2.

Granite thermometry: Bailey, S. W.

Ore deposit formation, temperature gauge: Smith, F. G., 5.

Planes of, orientation: Tuttle, O. F., 1.

Lithology.

Correlation with seismic events: Clayton, N.

Kansas, Mississippian strata: Clair, J. R.

Oklahoma, Viola formation rock types, correlation with specific gravity: Wengerd, S. A.

Loess.

Engineering petrography: Mielenz, R. C., 17.

Illinois, properties, distribution: Smith, G. $D$.

Iowa, southwest, soils from glacial deposits: Hutton, C. E.

Kansas, Pleistocene: Frye, J. C., 5, 6.

Mississippi Valley: Leighton, M. M., 3.

Petrography: Doeglas, D. J.

Missouri, gumbotil, relation to overlying glacial deposits: Krusekopf, H. H.

Nebraska, Trenton dam area, petrography: Holland, W. Y., 8.

United States, South Mississippi Valley: Wascher, H. L. 
Loess-Continued

X-ray studies of Illinois deposits: Whiteside, E. $P$.

Louisiana.

Areas described.

De Soto, Red River Parishes: Murray, G. E., Jr., 1.

Economic geology.

De Soto, Red River Parishes: Murray, G. E., Jr., 1.

Natural gas, continental shelf exploration: McGee, D. A.

Developments, 1948: McBee, W. S., Jr.; Williams, J. R.

Petroleum, continental shelf exploration: MeGee, D. A.

Developments, 1948: McBee, W. S., Jr.; Williams, J. R.

Geologic maps.

De Soto, Red River Parishes: Murray, G. E., Jr., 1.

Ground water.

Natchitoches area: Maher, J. C., 3.

Historical geology.

Cane River formation, Eocene: Hussey, K. M.

De Soto, Red River Parishes: Murray, G. E., Jr., 1.

Harang formation, Miocene: Pope, D. E.

Natchitoches area: Maher, J. C., 3.

Pliocene-Pleistocene boundary: Russell, $\mathbf{R}$. J., 2.

Wilcox formation, surface and subsurface correlation: Robertson, D. A.

Paleontology.

De Soto, Red River Parishes: Murray, G. E., Jr., 1.

Foraminifera, Cane River formation, Eocene: Hussey, K. M.

Harang formation, Miocene: Smith, D. J.

Harang fauna, Miocene: Pope, D. E.

Physiographic geology.

De Soto, Red River Parishes: Murray, G. E., Jr., 1.

Shoreline, Recent: Russell, R. J., 1.

Magmas and magmatic differentiation. See also Igneous rocks; Intrusions.

Facies classification of rocks: Ramberg, H., 2.

Granite and metasomation: Daly, R. A.

Granite origin: Perrin, R.

Gulf Coastal Plain, northern: Moody, C. $\mathbf{L}$.

Hawaii: Macdonald, G. A., 1, 4.

New Hampshire, Keene-Brattleboro area: Moore, G. E., Jr., 2.

Origin, effect of isostatic adjustment: Wahl, Walter.

Palisade diabase sill, New Jersey, differentiation: Guimarães, D.

Silicate, immiscibility and crystallization: Barth, T. F. W., 3.

Titaniferous, differentiation: Evrard, P.

Vermont, Keene-Brattleboro area: Moore, G. E., Jr., 2.

Maine.

Magnetic survey, Moosehead Lake area: Hurley, P. M., 2.

Shore sediments, Stover Cove: Donohue, J. J.

Economic geology.

Asbestos: Wing, L. A.

Beryl, Black Mountain deposit: Maillot, E. E.

Manganese, Aroostook County: Trefethen, J. M., 2.

Pegmatites, Topsham: Shainin, V. E., 1.

Serpentine: Wing, L. A.

Geologic maps.

Franklin County: Pratt, E. S.

Index: Boardman, L., 3.

Jim Pond area, sketch map: Wing, L. A.

Moosehead Lake area, sketch map: Hurley, P. M., 2.

Parmachenee area, sketch map: Wing, L. A.

Red Hill, Rumford: Shainin, V. E., 2.

Spencer serpentine area, sketch map: Wing, L. A.

Stony Brook Mtn. serpentine, sketch map: Wing, L. A.

Stover Cove, shore sediments: Donohue, J. J.

Topsham pegmatites: Shainin, V. E., 1.

Ground water.

General: Trefethen, J. M., 3.

Historical geology.

Clay deposits: Goldthwait, L.

Limestone strata, Franklin County: Pratt, E. S.

Northwestern: Wing, L. A.

Mineralogy.

Beryl, Mt. Mica: Hurlbut, C. S., Jr., 3.

Collecting localities: Seaman, D. M.

Roscherite: Frondel, C., 4.

Petrology.

Pegmatites, Red Hill: Shainin, V. E., 2.

Topsham, age determination: Shainin, V. E., 3.

Physiographic geology.

Desert of Maine: Trefethen, J. M., 4.

Gulf of Maine: Chadwick, G. H.

Mammalia.

Alaska, frozen mammoth, Pleistocene: Anthony, H. E.

Ancestors: Colbert, E. H., 2.

California, La Brea tar pits, Los Angeles: Curtin, G.

San Diego, pinniped, Pliocene: Burleson, G. L.

Titus Canyon formation: Stock, C., 1.

Colorado, Debeque area, taeniodont: Patterson, B., 2.

Continental migration: Simpson, G. G., 2.

El Salvador, Pleistocene: Stirton, R. A.

Elephants, Pleistocene, Manitoba: Leith, E. I.

Equus, Pliocene, phylogenetic significance: Lance, J. F. 
Mammalia-Continued

Hoplophoneus, Tertiary, Wyoming: Hough, J. $\mathbf{R}$.

Kansas, Keefe Canyon, Pliocene: Hibbard, C. W., 3 .

Meade County, Pleistocene: Hibbard, C. W., 1.

Saw Rock Canyon, Pliocene: Hibbard, C. W., 2.

Tremarctotherium, Pleistocene: Rinker, G. C.

Megalonyx tooth, Northwest Territories, Pleistocene: Stock, C., 2.

Mexico, horses, Pliocene, Pleistocene: Arellano, A. R. V., 2.

Missouri, St. Louis cave, Pleistocene: Simpson, G. G., 5 .

Nevada, Chalk Spring, Tertiary, Clarendonian: Macdonald, J. R., 1.

Pliocene: Macdonald, J. R., 2.

New Mexico, Nacimiento formation, Eocene: Wilson, R. W., 6.

Oregon, Silverton, mammoth bones, age: Hansen, H. P., 3.

Osteoborus, Pliocene, Honduras: McGrew, P. 0 .

Panama, Tertiary migration: Woodring, W. $\mathbf{P}$.

Promerycochoerinae, Tertiary, oreodonts: Schultz, C. B.

Rhinoceros, evolution: Wood, H. E., 1. Mold in Miocene basalt, Blue Lake, Washington: Chappell, W. M.

Rodents, Eocene, southern California: Wilson, R. W., 1.

Lagomorphs, upper Sespe, California: Wilson, R. W., 3.

Oligocene, White River area, Colorado: Wilson, R. W., 2.

Rincon fauna, Chihuahua, Mexico: Wilson, R. W., 5.

Tertiary: Wilson, R. W., 4.

Taeniodonts, evolution: Patterson, B., 1.

Wyoming, Bridger formation, Eocene: Gazin, C. L.

Upper Eocene fauna, Wind River Basin: Wood, A. E.

Man, fossil.

California, La Jolla: Carter, G. F.

Evolution, significance: Simpson, G. G., 3.

Mexico, Tepexpan man: De Terra, 1, 2; Mullerried, F. K. G., 2.

Oregon, Odell Lake paleo-Indian site: Cressman, L. S.

Texas, Clear Fork, Pleistocene: Ray, C. $\mathbf{N}$.

United States, Great Basin: Antevs, E. V., 1.

\section{Manganese.}

Arizona, Artillery Mts.: Lasky, S. G., 2.

Labrador: Tanton, T. L., 2.

Maine, Aroostook County: Trefethen, J. M., 2.
Manganese-Continued

Mexico: Rodriguez Cabo, J., Jr.

Lucifer district, manganese: Wilson, I. F., 2.

Quebec: Tanton, T. L., 2.

Manitoba.

Economic geology.

Bibliography, nonmetallic mineral resources: Kerr, L. B., 1.

File-Tramping Lakes area: Harrison, $J$. M., 1.

Natural gas: Kerr, L. B., 2.

Petroleum: Kerr, L. B., 2.

Salt, potash, phosphate: Cameron, E. L.

Sherritt Gordon mine: Farley, W. J.

Southeastern, mineral deposits: Springer, G. D., 2.

Zinc, Flin Flon mine: Tanton, T. L., 1.

Sherritt Gordon mine: Tanton, T. L., 1. Geologic maps.

Bird River area: Chisholm, E. O., 2.

Brochet area: Gadd, N. R.

Cat Lake-Winnipeg area: Springer, G. D., 1.

Collins Point area: Frarey, M. J.

Dunphy Lakes area: Stanton, M. S.

English Brook area: Russell, G. A., 1.

File-Tramping Lakes area: Harrison, J. M., 1.

Kississing area: Canada G. S., 6.

Moody Lake area: Robertson, D. S.

Sickle Lake area: Fawley, A. P.

Southern: Kerr, L. B., 2.

Wanipigow Lake area: Davies, J. F.

Weldon Bay: Kalliokoski, J.

Historical geology.

Dunphy Lakes area: Stanton, M. S.

File-Tramping Lakes area: Harrison, J. M., 1.

Kississing area: Canada G. S., 6.

Stratigraphy, southern: Kerr, L. B., 2.

Wanipigow Lake area: Davies, J. F.

Paleontology.

Elephants, Pleistocene: Leith, E. I.

Gastropoda, Middle Devonian: La Rocque, A., 2.

Petrology.

Brochet area: Gadd, N. R.

Cat Lake-Winnipeg River area: Springer, G. D., 1 .

English Brook area: Russell, G. A., 1.

Kississing area: Canada G. S., 6.

Moody Lake area: Robertson, D. S.

Pegmatites, age determination: Ahrens, L. H., 1.

Sickle Lake area: Fawley, A. P.

Physical geology.

Kississing area: Canada G. S., 6.

Maps (excluding Geologic maps, which see). See also Cartography.

Aeromagnetic.

Indiana, Benton County: U. S. G. S., 3.

Fulton County: U. S. G. S., 4.

Jasper County: U. S. G. S., 5.

Lake County: U. S. G. S., 6. 
Maps-Continued

Aeromagnetic -Continued

Indiana-Continued

La Porte County: U. S. G. S., 7.

Newton County: U. S. G. S., 8.

Posey County: U. S. G. S., 9.

Pulaski County: U. S. G. S., 10.

Starke County: U. S. G. S., 11

White County: U. S. G. S., 12.

Maine, Moosehead Lake area, sketch map: Hurley, P. M., 2.

Minnesota, Cass County: U. S. G. S., 14, 17.

Crow Wing County: U. S. G. S., 19, 21.

Hubbard County: U. S. G. S., 23, 25. Itasca County: U. S. G. S., 27.

Morrison County: U. S. G. S., 29, 31.

Todd County: U. S. G. S., 32.

Wadena County: U. S. G. S., 25.

Missouri, Coldwater quadrangle: U. $\mathbf{S}$. G. S., 34 .

Crystal City quadrangle: U. S. G. S., 37.

De Soto quadrangle: U. S. G. S., 36 .

Des Arc quadrangle: U. S. G. S., 35.

Farmington quadrangle: U. S. G. S., 37.

Fredericktown quadrangle: U. S. G. S., 38.

Mineral.

British Columbia, Smithers-Fort St. James area: Canada G. S., 13.

California: Calif. Dept. Nat. Res., Div. Mines.

Butte County: O'Brien, J. C.

California, copper: Jenkins, O. P.

Kern County, mines and minerals: Tucker, W. B.

Colorado, industrial minerals: Argall, G. O., Jr.

New Brunswick, Chipman area, coal deposits: Muller, J. E., 2.

Pennsylvania, resources: Pa. State College.

Saskatchewan, southern, coal and lignite: Mackay, B. R., 2.

Washington, nonmetallic minerals: Valentine, G. $M$.

Miscellaneous.

Ceramic materials, distribution, United States: Ries, H., 3.

Engineering geology: Sokoloff, V. P.

Eolian deposits, North America: Thorp J., 2.

Geologic report illustrations: Low, J. W.

Gravity anomalies, United States, eastern coast: Woollard, G. P., 1.

Indiana, drainage mapping from airphotos: Parvis, $M$.

Oil and gas.

Alberta: Anonymous, 15.

Arkansas, southern: Ark. Res. Dev. Comm., Div. Geology.

California, Kern County, Tucker, W. B.

Kansas: Jacobson, E. C.
Maps-Continued

Oil and gas-Continued

New Mexico: Lloyd, E. R.; Northup, R. C.

Ohio: Alkire, R. L., 1.

Saskatchewan: Anonymous, 15.

Paleogeographic.

Arctic America: Maync, W., 2.

Greenland: Maync, W., 2.

North America: Eardley, A. J., 2.

Texas, Panhandle: Roth, R. I., 2.

United States: Lobeck, A. K., 1.

Tectonic.

Wyoming, Hartville Uplift: Denson, N. M., 2.

Marble.

Calcite, preferred orientation: Turner, F. J.

Compression tests, oriented specimens: Lepper, H. A., Jr.

Deformation, experimental: Knopf, E. B. Thermal expansion: Rosenholtz, J. L. Marl.

New Jersey, Vincentown area: Bader, H., 1.

North Carolina, eastern: Berry, E. W., 1. Martinique, Mt. Pelée eruption: Jaggar, T. A. Maryland.

Economic geology.

Coal, Georges Creek basin, analyses: Cooper, H. M., 2.

Reserves: Toenges, A. L., 3.

Upper Potomac basin, analyses: Cooper,

H. M., 2.

Reserves: Toenges, A. L., 3.

Natural gas, exploration: Anderson, J. L., 1.

Petroleum exploration: Anderson, J. I., 1. Ground water.

Anne Arundel County: Brookhart, J. W. Historical geology.

Cretaceous, subsurface: Overbeck, R. M.

Georges Creek coal basin, stratigraphy:

Waage, K. M.

Tertiary, subsurface: Overbeck, R. M.

Paleontology.

Dinosaurs, Cretaceous: Vokes, H. E., 2.

Petrology.

Coal, Georges Creek basin, petrography. Smith, H. L.

Upper Potomac Basin, petrography: Smith, H. L.

Pseudotachylite, Antietam. quartzite: Anderson, J. L., 2.

Physiographic geology.

Potholes: Schreiber, J. F., Jr.

Shore erosion: Singewald, J. T., Jr.

Measurements: Slaughter, T. $\mathbf{H}$.

Massachusetts.

Geologic maps.

Mount Grace quadrangle, bedrock geology: Hadley, J. B., 1.

Surficial geology: Hadley, J. B., 2.

Pawtucket quadrangle, bedrock: Quinn. A. W., 1, 2 .

Surficial deposits: Chute, N. E., 1, 2. 
Massachusetts-Continued

Ground water.

Cambridge area, glacial deposits: Halberg, H. N.

Pawtucket quadrangle: Allen, W. B., 2.

Historical geology.

Boston area, Boylston Street Fishweir, Pleistocene: Judson, S. S., Jr.

Boylston Street Fishweir II, Pleistocene: Barghoorn, E. S., Jr., 1; Johnson, F.

Mount Grace quadrangle: Hadley, J. B.,

Narragansett Basin: Thurston, A. W.

Pawtucket quadrangle, bedrock: Quinn, A. W., 1,2 .

Paleontology.

Boylston Street Fishweir II, Pleistocene: Barghoorn, E. S., Jr., 1.

Diatoms: Conger, P. S.

Foraminifera: Phleger, F. B., Jr., 2.

Lower Peat, microfossils: Wilson, L. R., 1.

Paleobotany: Barghoorn, E. S., Jr., 2.

Fish, chimaeroid, egg capsules, Triassic: Bock, W.

Petrology.

Gabbro-granite transition, Norfolk Coun ty: Chayes, F., 4.

Mount Grace quadrangle: Hadley, J. B., 1.

Physical geology.

Shoreline changes, Boston Harbor, Shirley Gut: Nichols, R. L.

\section{Physiographic geology.}

Fitchburg rollstone, glacial boulder: $\mathrm{Pa}$ lache, $C$.

Mount Grace quadrangle: Hadley, J. B., 2.

Pawtucket quadrangle: Chute, N. E., 1, 2.

Melilites, synthetic, X-ray data: Ervin, G., Jr.

Mercury.

California, Oakville district, Napa County: Fix, P. F., 1.

Texas, Terlingua district: Yates, R. G.

\section{Mesozoic.}

Alabama, cross section: Southeastern Geol Soc., Mesozoic Comm., 4.

Central America, facies: Mullerried, F. K. G., 10.

Florida, cross section: Southeastern Geol. Soc., Mesozoic Comm., 1, 2, 3, 4.

Georgia, cross section: Southeastern Geol. Soc., Mesozoic Comm., 3.

Igneous rocks, northern Gulf Coastal Plain: Moody, C. L.

Mexico, facies: Mullerried, F. K. G., 9.

Montana, southwestern: Moritz, C. A.

New York, Long Island, Kings County: deLaguna, W.

Nicaragua, facies: Mullerried, F. K. G., 7.

Tehuantepec Isthmus: Mullerried, F. K. G., 10.

South Carolina, cross section: Southeastern Geol. Soc., Mesozoic Comm., 2.
Mesozoic-Continued

Wyoming, Powder River Basin: Downs, G. R.

Metals, native, distribution: Buddhue, J. D., 4. Metamorphic rocks.

California, Grayhouse area, Amador Co.: Heyl, G. R., 4.

Jesse Belle copper mine, Madera Co.: Cox, M. W., 3.

Lilyama and Pioneer copper mines, El Dorado Co.: Cox, M. W., 1.

Siskiyou County, chromite: Wells, F. G. 1.

Solorado, Coal Creek quartzite, pre-Cambrian: Fraser, G. D.

Continental Divide tunnel, petrography: Haff, J. C., 2, 3; Mielenz, R. C., 2.

Gneiss, classification: Alcock, F. J., 2.

Manitoba, Kississing area: Canada G. S., 6.

Wanipigow Lake area: Davies, J. F.

Massachusetts, Mount Grace quadrangle: Hadley, J. B., 1.

Montana, Dillon area, pre-Beltian: Heinrich, E. W., 3.

New Hampshire, Monadnock area: FowlerBillings, K., 2.

New York, Adirondack Mts., Grenville series: Engel, A. E. J., 3.

North Carolina, Hiwassee dam cores, pe. trography: Irwin, W. H., 2.

Ocoee series, southern Appalachians, preCambrian: Stose, G. W., 1.

Pennsylvania, southeastern, mineral isograds: McKinstry, H. E., 2.

Wissahickon schist at Philadelphia: Weiss, J.

Quebec, Mt. Laurier region: Jérémine, $\mathbf{E}$. Rhode Island, northern: Quinn, A. W., 3.

Saskatchewan, Kississing area: Canada G. S., 6 .

Serpentine, origin: Bowen, N. L., 1.

South Dakota, Sioux quartzite: Baldwin, W. B.

Washington, Methow quadrangle: Barksdale, J. D., 1.

Wyoming, structural control in formation: Newhouse, W. H., 1.

Metamorphism.

Alaska, Kuskokwim region: Wallace, $\mathbf{R}$ E., 2.

California, American Eagle-Blue Moon area: Eric, J. H., 2.

Newton copper mine, Amador Co.: Heyl, G. R., 2.

Dedolomitization by intrusion: Faust, G. T., 2.

Facies classification of rocks: Ramberg, H., 2.

Manitoba, File-Tramping Lakes area: Harrison, J. M., 1.

New Hampshire, Keene-Brattleboro area: Moore, G. E., Jr., 2.

Oregon, Cornucopia area: Goodspeed, G. E., 1. 
Metamorphism-Continued

Pennsylvania, Wissahickon schist at Philadelphia: Weiss, J.

Vermont, Keene-Brattleboro area: Moore, G. E., Jr., 2.

Washington, Okanogan County: Misch, P., 3.

Metasomatism.

California, Lucerne Valley, dolomite: Campbell, I.

Granite, origin: Daly, R. A.

Replacement reactions, equating volume and weight: Ridge, J. D.

South Dakota, Black Hills pegmatites: Higazy, R. A.

Meteor craters.

Arizona, Barringer, magnetometer survey: Nininger, H. H., 3.

Crater Mound, origin: Hager, D., 2.

Moon and earth craters: Baldwin, R. B.

New Mexico: La Paz, L.

\section{Meteorites.}

Alaska, Aggie Creek: Henderson, E. P., 5; Olivier, C. P.

Arizona, Barringer meteorite crater: $\mathrm{Ni}$ ninger, H. H., 4.

Canyon Diablo crater, sandstone: Buddhue, J. D., 1.

Canyon Diablo, iron oxide, oxygen content: Buddhue, J. D., 2.

Holbrook: Buddhue, J. D., 3.

Mt. Eldon: Buddhue, J. D., 3.

Navajo: Roy, S. K., 2.

Pima County: Henderson, E. P., 2.

Composition and origin: Brown, H. S., 1. Elements, distribution: Brown, H. S., 3 . General: Henderson, E. P., 1.

Greenland, Cape York area: Graham, R. $\mathbf{P}$.

Iowa, Mapleton: Roy, S. K., 1.

Iron, etching method: Reberholt, B. O.

Gallium content: Brown, H. S., 2.

Palladium content: Brown, H. S., 2.

Kunsas, Kimberly Ranch: Anonymous, 8.

List: Nininger, H. H., 1.

Norton County: Beck, C. W., 1; Nininger, H. H., 2.

Wathena: Henderson, E. P., 4.

Nebraska, Furnas County: Beck, C. W., I.

Linwood: Henderson, E. P., 3.

Mexico, Xiquipilco: Buddhue, J. D., 3.

Micrometeorites: Whipple, F. L.

Minerals exclusively meteoritic: Neuc G. J.

Nomenclature: Leonard, F. C.

North Carolina, Moore County: Hess, H. H., 1.

North Dakota, Richardton: Buddhue, J. D., 3.

Oklahoma, Weatherford: Beck, C. W., 2.

Relation, with similar composition: Olivier, C. $\mathbf{P}$.

Willamette, discovery: Sears, P. M.
Mexico.

Gravimetric investigation in Mexico: De la 0 . Carreño, $\mathbf{A}$.

Economic geology.

Antimony, Soyatal district: White, D. E., 1.

Coal, Santa Clara district, Sonora: Wilson, I. F., 1.

Guanajuato mining district: Guiza, R., Jr. Iron deposits, origin: Flores, T.

Lead: González Reyna, J., 2.

Lead-zinc, Pachuca ores: Geyne, A. R.

Taxco district: Fowler, G. M.

Manganese: Rodriguez Cabo, J., Jr.

Lucifer district: Wilson, I. F., 2.

Natural gas, fields: García Rojas, A., 2.

Poza Rica field: Salas, G. P.

Ore provinces: Behre, C. H., Jr., 3.

Petroleum: Cumming, J. L.

Developments, northeast, Gulf Coast: Guzmán, E. J.

Fields: García Rojas, A., 2; Ver Wiebe, W. A., 1.

Poza Rica field: Salas, G. P.

Zinc: González Reyna, J., 2.

\section{Geologic maps.}

General: Garfias, V. R.

Guanajuato mining district, Veta Madre: Guiza, R., Jr.

Lucifer district: Wilson, I. F., 2.

Poza Rica oil and gas field, Veracruz: Salas, G. P.

Santa Clara district, Sonora: Wilson, I. F., 1.

Sierra de los Muertos area: Humphrey, W. E.

Soyatal district: White, D. E., 1.

Taxco district: Fowler, G. M.

Historical geology.

Baja California, Cretaceous: Popenoe, W. P., 1.

Becerra formation, Pleistocene: Arellano, A. R. V., 1.

Facies, Mesozoic: Mullerried, F. K. G., 9.

General: Garfias, V. R.

Lucifer district: Wilson, I. F., 2.

Sierra de los Muertos area: Humphrey, W. E.

Soyatal district: White, D. E., 1.

Subsurface formations, northeast Gulf Coast: Guzmán, E. J.

Tampico embayment, Upper Cretaceous: Wicher, C. A.

Tepexpan area, Quaternary: De Terra, H., 1, 2.

Zacatecas, Triassic: Maldonado-Koerdell, M., 3.

\section{Mineralogy.}

Apatite, Durango: Vance, L. W.

Clay minerals, Gulf of California, bottom sediments: Grim, R. E., 2.

Guanajuatite, Guanajuato area: Ramdohr, P. 
Mexico-Continued

Mineralogy-Continued

Paraguanajuatite, Guanajuato area: Ramdohr, $\mathbf{P}$

Xiquipilco meteorite: Buddhue, J. D., 3.

Paleontology.

Diatoms, Tepexpan: De Terra, H., 2.

Equus, Pliocene, phylogenetic significance: Lance, J. F.

Foraminifera, Tampico embayment, Cretaceous: Wicher, C. A.

Gastropoda, Cretaceous, Nuevo León: Mullerried, F. K. G., 4.

Horses, Pliocene, Pleistocene: Arellano, A. R. V.

Man, fossil, Tepexpan: De Terra, H., 1, 2; Mullerried, F. K. G., 2.

Pisces: Maldonado-Koerdell, M., 2.

Poza Rica oil and gas field, Veracruz: Salas, G. P.

Ptychomya: Mullerried, F. K. G., 3.

Rodents, Rincon fauna, western Chihuahua: Wilson, R. W., 5 .

Rudistid, Tabasco area: Mullerried, F. K. G., 5.

Sierra de los Muertos area: Humphrey, W. E.

Vertebrates, Quaternary: Maldonado-Koerdell, M., 1.

Zacatecas, brachiopods, Triassic: Maldonado-Koerdell, M., 3.

Pelecypods, Triassic: Maldonado-Koerdell, M., 3.

Physical geology.

Erosion, Chiapas: Mullerried, F. K. G., 6.

Gulf of Mexico, submarine geology: Treadwell, T. K., Jr.

Papaloapan Basin, limestone solution: Moneymaker, B. C.

Parícutin volcano: González Reyna, J., 1; Holtedahl, H.; James, C. C.; Martin, G. P. R.

Sierra Madre Oriental, orogeny: Mullerried, F. K. G., 1.

Tectonics: Alvarez, M., Jr.

Physiographic geology.

East central: Behre, C. H., Jr., 4.

Popocatepetl volcano: White, S. E., 2.

Tepexpan area, Quaternary: De Terra, H., 1, 2.

Mica.

Decomposition and resynthesis: Roy, R., 1.

Grinding rcaction: Perkins, A. T.

Index of refraction measurement: Girault, J. P., 1.

Muscovite: Axelrod, J. M., 1.

New Hampshire, Big mine: Levin, S. B., 2.

Blister mine: Levin, S. B., 1.

Thermal analysis: Roy, R., 1 .

Michigan.

Aeromagnetic survey, Baraga, Iron, Hudspeth Counties: Balsley, J. R., Jr.
Michigan-Continued

Geophysical investigation, Iron County: Zinner, $P$.

Magnetic survey, Stager area: Good, S. E. Economic geology.

Iron River district, central: Dutton, C. E.

Uranium prospecting, Upper Peninsula: Kemp, C. E.

Geologic maps.

Benzie County, northwestern, surface geology: Calver, J. L., 1.

Iron River district, central: Dutton, C. E.

Stager area: Good, S. E.

Surface geology, southwestern: Tague, G. C.

Wexford County, glacial deposits: Stewart, D. $\mathbf{P}$.

Ypsilanti area, surface geology: McGuinness, C. I.

Ground water.

Iron River district: Stuart, W. T.

Ypsilanti area: McGuinness, C. L.

Historical geology.

Iron River district: James, H. L.

Mineralogy.

Limonite, Van Buren County: Hill, J.

Paleontology.

Corals, Traverse group, Devonian: Ehlers, G. M., 1.

Gastropoda, Middle Devonian: La Rocque, A., 2.

Michigan coal basin, flora: Arnold, C. A., 2.

Mierocyclus, Devonian: Stumm, E. C., 3.

Stromatolites, Randville dolomite, Lower Huronian: Richardson, E. S., Jr., 2.

Physiographic geology.

Benzie County: Calver, J. L., 1.

Grand Marais Embayment, Berrien County: Tague, G. C.

Iron River district, glacial geology: Stanley, G. M., 1.

Lake Michigan Basin, origin: Thwaites, F. T.

Wexford County, glacial deposits: Stewart, D. $\mathbf{P}$.

Micropaleontology.

Bibliography, paleoecology: Malkin, D. S.

Collecting, microvertebrates: Hibbard, C. W., 5.

Correlation: Wicher, C. A.

Eponides, generic definition: Redmond, C. D.

Petroleum exploration: LeRoy, L. W., 4.

Petroleum geology, application: Thalmann, H. E., 6 .

Microseisms, relation to meteorology: Gilmore, M. $\mathbf{H}$.

Mine rock, mineralogy, petrography: Windes, S. $\mathrm{L}$.

Mineral aggregates: Am. Soc. Testing Materials.

Distribution: Woods, K. B.

Mineralogy: Rhoades, R. F., 6.

Petrography; Rhoades, R. F., 6. 
Mineral collecting.

Connecticut, Haddam Neck, Gillette quar. ry: Stobbe, H. R., 2.

General: Dake, H. C., 1.

Maine: Seaman, D. M.

Mexico, apatite: Vance, L. W.

New Hampshire: Seaman, D. M.

New Jersey, Bridgewater copper mine: Hayes, W. H.

New York, Russell, danburite: Clark, W.

Ohio, Flint Ridge: Schiefer, H. V.

Oregon: Dake, H. C., 2.

Pennsylvania, Ecton lead mine, abandoned: Boucot, A. J., 2.

Utah, Clayton Peak: Field, V. W.

Mineral deposits.

Alaska, Ch.chagof Island: Twenhofel, W. S.

Kobuk River area, asbestos: Anderson, E., 2; Heide, H. E.

Kuiu Island: Twenhofel, W. S.

Northwestern: Anderson, E., 1.

Prince of Wales Island: Twenhofel, W. S.

Southeastern: Twenhofel, W. S.

Arizona, Squaw Peak copper mine: Thacker, $\mathbf{E}$.

British Columbia, exploration: Riley, C.

Nelson area, Kootenay district: Little, H. W., 1.

California: Calif. Dept. Nat. Res., Div. Mines; Murdoch, J., 1.

Butte County: O'Brien, J. C.

Copper: Jenkins, O. P.

Oakville district, mercury: Fix, P. F., 1.

Tuolumne County: Logan, C. A.

Canada, lead occurrences: McClelland, W. R.

Colorado, Caribou mine, silver: Ridland, G. C.

Industrial minerals: Argall, G. O., Jr.

Lead-zinc-silver, Mineral Point district: Hazen, S. W., Jr.

Poughkeepsie district: Hazen, S. W., Jr.

Vanadium: Fischer, R. P., 1.

Cuba, Isle of Pines, tungsten: Bundy, P. A.

Florida, titanium: Thoenen, J. R.

. Georgia, Cartersville, barite: Kesler, T. L.

Lumpkin County, copper pyrite: Kline, M. $\mathbf{H}$.

Idaho, Blackbird district, cobalt: Douglas, E. B.

Deer Creek-Wells Canyon area: Deiss, C. F.

Southeastern, phosphate rock: Butner, D. W.

Maine, Aroostook County, manganese: Trefethen, J. M., 2.

Manitoba, southeastern: Springer, G. D., 2. Mexico, Santa Clara district, coal: Wilson, I. F., 1.

Missouri: Forrester, J. D., 1.

Montana, Big Ben deposit, molybdenum: Herdlick, J. A.
Mineral deposits-Continued

Montana-Continued

Boulder River area, chromite: Howland, A. $\mathbf{L}$.

Gypsum: Perry, E. S., 1.

Henderson Gulch tungsten deposit: Hundhausen, R. J.

Limestone: Perry, E. S., 1.

Pegmatites: Heinrich, E. W., 1.

Philipsburg area: Cole, J. W., 2.

Sheep Creek, iron: Reed, G. C.

Nevada, Daisy mine, fluorite: Thurston, W. $R$.

New Hampshire, Big mica mine: Levin, S. B., 2.

Blister mica mine: Levin, S. B., 1.

New Jersey, Vincentown area, lime marl: Bader, H., 1.

New Mexico, Harding tantalum-lithium pegmatite: Berliner, M. H.

Iron: Kelley, V. C.

Silver City region: Hernon, R. M.; West Texas Geol. Soc., 4.

New York, St. Lawrence County, zinc: Hermance, H. P.

Talc: Engel, A. E. J., 2.

North Carolina, barite: Van Horn, E. C., 3.

Oklahoma, voleanic ash: Ham, W. E., 2.

Ontario, Garrison Township, gold: Satterly, J., 3.

Ontario, Theano Point, pitchblende: Satterly, J., 4.

South Carolina, barite: Van Horn, E. C., 3.

South Dakota, Missouri Valley, manganese: Pesonen, P. E.

Tennessee, Bumpass Cove, zinc: Clayton, A. B.

Texas, Montezuma-Chinati area, zinc-lead: McMillan, W. D.

United States, reference clay localities: Kerr, P. F., 2.

Western phosphate: McKelvey, V. E.

Utah, Topaz Mountain, fluorite: Fitch, C. A., Jr.

Vaṇadium: Fischer, R. P., 1.

Washington, Mackinaw nickel mine: Milton, C., 2.

Nonmetallic minerals: Valentine, G. $\mathbf{M}$.

Stevens County, lead-zinc: Cole, J. W., 1.

Wyoming, Casper Mtn., chromite: Horton, F. W.

Yukon: Bonham, W. M.

Mineral deposits, origin.

Alabama, Shelby, limonite ores: Allen, R. M., Jr., 2.

Arizona, Ajo quadrangle: Dehlinger, M. E. Artillery Mts., manganese: Lasky, S. G., 2.

Helvetia district: Johnson, V. H.

San Manuel, copper: Schwartz, G. M., 3.

Seventy Nine mine, lead: Kiersch, G. A., 1.

Wallapai district, copper: Thomas, B. E. 
Mineral deposits, origin-Continued

Bauxite: Goldman, M. I., 1; Harder, E. C., $1,2$.

British Columbia, Fort St. James area: Armstrong, J. E.

Lead Empire group: Patmore, W. $H$.

Mining areas: British Columbia Dept. Mines.

Sullivan mine, lead-zinc: Swanson, C. O., 1.

California, Cerro Gordo mine area, lead: Merriam, C. W., 1.

Copper deposits, Copperopolis, Calaveras Co.: Heyl, G. R., 5 .

Foothill copper-zinc belt, Sierra Nevada: Heyl, G. R., 1.

Grayhouse area, Amador Co.: Heyl, G. R., 4.

Iron Mtn. mine, Redding, iron: Kinkel, A. R., Jr.

La Victoria copper mine, Mariposa Co.: Cox, M. W., 2.

Newton copper mine, Amador Co.: Heyl, G. R., 2.

Penn zinc-copper mine, Calaveras Co.: Heyl, G. R., 3.

Quail Hill area mines, Calaveras Co.: Heyl, G. R., 6.

Siskiyou County, chromite: Wells, F. G., 1.

Zine deposits, American Eagle-Blue Moon area: Eric, J. H., 2.

Zinc-copper deposits, Big Bend mine, Butte Co.: Eric, J. H., 1.

Canadian Shield, structural factors: Wilson, J. T., 2.

Clay: Ries, H., 1.

Colorado, Bear Creek district, copper: Goddard, E. N., 1.

Cripple Creek area, gold: Koschmann, A. H., 1.

La Plata district: Eckel, E. B., 1.

Copper: Schwartz, G. M., 2.

San Juan Mts.: Bejnar, W.

Vanadium: Fischer, R. P., 2.

Epithermal deposits: Schmitt, H. A., 2.

Formation, temperature measurement, liquid inclusions: Smith, F. G., 5.

Idaho, Avery district: Wagner, Wr. R., 1.

Coeur d'Alene district, lead-zinc: Shenon, P. J.

Yankee Fork district: Anderson, A. L., 1.

Iron, Lake Superior soft ores: Tyler, S. A.

Lead, symposium: Dunham, K. C.

Manitoba, File-Tramping Lakes area: Harrison, J. M., 1.

Flin Flon mine, zinc: Tanton, T. L., 1. Sherritt Gordon mine, copper: Farley, W. J.

Zinc: Tanton, T. L., 1.

Mexico, Guanajuato mining district: Guiza, R., Jr.

Iron: Flores, T.

Lead-zinc: González Reyna, J., 2.
Mineral deposits, origin-Continued

Mexico-Continued

Lucifer district, manganese: Wilson, I. F., 2.

Ore provinces: Behre, C. H., Jr., 3.

Soyatal district: White, D. E., 1.

Taxco district, lead-zinc: Fowler, G. M. Mississippi Valley, zinc-lead: Behre, C. H., Jr., 1.

Missouri, Fredericktown area, lead: James, J. A.

Montana, Butte, vein formation: Sales, R. H.

Hecla mining district: Karlstrom, T. N. $\mathrm{V}$.

Nevada, Comstock Lode: McBride, G. B. Pioche district, lead-zinc: Young, E. B.

New Jersey, Franklin-Sterling area, zinc: Pinger, A. W.

New Mexico, Central mining district, zinc: Lasky, S. G., 1.

Santa Rita area, copper: Ballmer, G. J. North Carolina, barite: Van Horn, E. C., 2.

Buck Creek area, corundum: Hadley, J. B., 3.

Southwestern, talc: Van Horn, E. C., 1. Talc and soapstone: Stuckey, J. L.

North Dakota, sodium sulfate: Grossman, I. G.

Northwest Territories, Giant Yellowknife property, gold: Dadson, A. S.

Nova Scotia, Bridgeville limonite deposits: Weeks, L. J.

Ontario, Berens River suifide mine: Oliver, T. A.

Central Patricia mine, gold: Tigert, T. T.

Hard Rock gold mine, quartz stringer ore zones: Morrow, H. F.

Kirkland Lake area: Hopkins, $\mathbf{H}$.

Miller Lake-O'Brien mine, silver: Bastin, E. $\mathbf{S}$.

Nepheline and corundum rocks: Moyd, L., 1.

Pickle Crow mine, gold: Monette, H. H. Rex-Werner Lakes area: Chisholm, E. o., 2.

Theano Point, uranium: Lang, A. H., 2. Ore deposits and granitization: Edwards, A. B.

Ore genesis, theory: Brown, J. S.

Oregon, garnierite: Pecora, W. T., 1.

Origin, pneumatolytic, liquid inclusions: Smith, F. G., 5.

Orogeny, location: Reinhardt, E. V.

Oxidation and reduction: Mason, B. F., 1. Pegmatites: Holland, H. D.

Quebec, Allard Lake, ilmenite: Hammond, $\mathrm{P}$.

Saskatchewan, Flin Flon mine, zinc: Tanton, T. L., 1.

Goldfields area, pitchblende: Christie, A. M., 1, 2.

South Dakota, Homestake mine, gold: McLaughlin, D. H.

Tennessee, eastern, zinc: Brokaw, A. L. 
Mineral deposits, origin-Continued

Texas, Terlingua district, mercury: Yates, R. G.

Titanium ores: Gillson, J. L.

Tri-State region, zinc-lead: Behre, C. H., Jr., 1.

Uranium: Everhart, D. L.

Utah, Bingham area, lead-zinc: Hunt, R. N.

East Tintic district: Lovering, T. S., 1. Gilsonite, Uinta Basin: Murray, A. N. Iron Springs district: Mackin, J. H.

Washington, Northport district, ore zones: Campbell, C. D.

Wyoming, cordierite: Newhouse, W. H., 2. Long Creek jade deposit: Cobb, H. S.

Zinc, symposium: Dunham, K. C.

Mineral descriptions. See also Mineralogy.

Adularia, crystallography: Laves, F.

Optics: Chaisson, U.

Allanite, Greenland: Boucot, A. J., 1.

Anatase, Georgia: Nagelschmidt, G.

Antimony oxides: Mason, B. H., 2.

Arrojadite, South Dakota: Lindberg, M. L. L., 2.

Bastnäsite, optics: Foster, W. R., 2.

Beraunite: Frondel, C., 3.

Bodenbenderite, discredited: Milton, C., 1.

Bornite, structure: Tunell, G., 2.

Calcite, Holsteinsborg district, Greenland: Pauly, $\mathbf{H}$.

California minerals: Murdoch, J., 1.

Cancrinite, Blue Mt., Ontario: Phoenix, R.

Childrenite, crystal structure: Barnes, W. H., 1.

Chloritoid, Quebec: Milne, I. H.

Colorado, La Plata district: Galbraith, F. W., 1.

Dolomite, New Mexico: Rogers, A. F., 1.

Dufrenite: Frondel, C., 3.

Enstatite, Nebraska-Kansas meteorite: Beck, C. W., 1.

Eudialyte, New Mexico: Clabaugh, E. E.

Fluorescent: Flagg, A. L.

Frondelite: Lindberg, M. L. L., 1.

Garnierite, Oregon: Pecora, W. T., 1.

Geikielite, California: Murdoch, J., 2.

Graftonite, South Dakota: Lindberg, M. L. L., 2.

Hauchecornite: Peacock, M. A., 3.

Holdenite: Prewitt-Hopkins, J.

Jadeite: Yoder, H. S., Jr.

Jarlite: Ferguson, R. B.

Josephinite, Oregon: Morley, R. A.

Kaolin, Georgia: Nagelschmidt, G.

Kempite, California: Rogers, A. F., 2.

Klockmannite: Earley, J. W.

Laubmannite: Frondel, C., 3.

Lindgrenite, crystal structure: Barnes, W. H., 3.

Ludlamite, Idaho: Glass, J. J.

New Hampshire: Wolfe, C. W., 1.

Metajarlite: Ferguson, R. B.

Mooreite: Prewitt-Hopkins, J.

Morenosite: Frondel, C., 2.

Muscovite, Washington: Axelrod, J. M., 1.
Mineral descriptions-Continued

Owyheeite: Robinson, S. C.

Priceite, Oregon: Staples, L. W., 1.

Probertite, crystal strưcture: Barnes, W. H., 2.

Prosopite: Ferguson, R. B.

Pyrrhotite, artificial: Graham, A. R.

Ralstonite: Ferguson, R. B.

Retgersite: Frondel, C., 2.

Rickardite: Forman, S. A.

Rockbridgeite: Frondel, C., 3; Lindberg, M. L. L., 1.

Scorzalite, South Dakota: Pecora, W. T., 2.

Skarn minerals, Holsteinsborg district, Greenland: Pauly, H.

Spangolite: Frondel, C., 1.

Staurolite: Furcron, A. S.

Strontianite, Hardin County, Illinois: Grawe, 0. R.

Svanbergite, Nevada: Switzer, G.

Tellurides: Thompson, Robert M., 1.

Torreyite: Prewitt-Hopkins, J.

Vauquelinite: Berry, L. G.

Weberite: Ferguson, R. B.

Whitlockite, Palermo mine, New Hampshire: Frondel, C., 4.

Witherite, Hardin County, nllinois: Grawe, o. $R$.

Wolfeite, Palermo mine, New Hampshire: Frondel, C., 4.

Xanthoxenite, Palermo mine, New Hampshire: Frondel, C., 4.

Xenotime, optics: Foster, W. R., 2.

Mineral resources. See also sub-heading Economic Geology under the various states and countries.

Alberta, fuel: Lang, W. A.

British Columbia: British Columbia Dept. Mines.

California: Calif. Dept. Nat. Res., Div. Mines.

Butte County: O'Brien, J. C.

Kern County: Tucker, W. B.

Tuolumne County: Logan, C. A.

Canada, North Pacific region: Canada G. S., 1 .

Coal: Ashley, G. H.

Colorado, industrial minerals: Argall, G. o., Jr.

Kansas, Tri-State zinc-lead district: Ruhl, 0 .

Limestone, metallurgical use: Landes, K. K., 4 .

Mexico, petroleum: Cumming, J. L.

Missouri: Forrester, J. D., 1.

Tri-State zinc-lead district: Ruhl, 0 .

New Jersey: Tyler, P. M.

Northwest Territories, Lac de Gras area: Canada G. S., 7.

Oklahoma: Dott, R. H.

Haskell County, nonmetallic: Oakes, M. C.

Tri-State zinc-lead district: Ruhl, 0 .

Oregon, Kerby quadrangle: Wells, F. G., 2.

Pennsylvania, index map: Pa. State College. 
Mineral resources-Continued

Petroleum: Levorsen, A. I.

Problems: Lasky, S. G., 3.

Quebec: Denis, B. T.

United States, annual review, 1948: Davidson, D. $M$.

Coal: Fieldner, A. C. Western: Bryson, R. P.

Lignite, western: Bryson, R. P.

Natural gas: Oberfell, G. G.

Petroleum: Pratt, W. E.

Uranium: Gustafson, J. K.

West Virginia, salt: Price, P. H., 2.

Mineralization, zoning theories: Schmitt, H. A., 1.

Mineralogy.

Aluminum fluorides, Greenland: Ferguson, R. B.

Aragonite-calcite differentiation, differential thermal analysis: Faust, G. T., 1.

California minerals: Murdoch, J., 1.

Caves: Foster, W. J.

Charting 5 and 6 variables on bounding tetrahedra of hypertetrahedra: Mertie, J. B., Jr.

Clays: Marshall, C. E.

Clinopyiroxenes, chemical and optical analyses: Hess, H. H., 2.

Color photography: Fisher, L. W.

Copper minerals, deposition: Dreyer, R. M.

Precipitation: Garrels, R. M., 2.

Crystallization temperatures from liquid inclusions: Bailey, S. W.

Definition of mineral: Winchell, A. N.

Development survey: Peacock, M. A., 1.

Disorder in sulfides: Frueh, A. J., Jr.

Dufrenite complex: Frondel, C., 3.

Feldspar investigations: Köhler, A.

Fluorescence, gems and minerals, handbook: DeMent, J. A., 1.

Fragment section study: Gabelman, J. W., 1.

Frondelite-rockbridgeite series: Lindberg, M. L. L., 1.

Geikielite, ilmenite, stability relation, occurrence: Sahama, T. G., 1.

Goongarrite discredited: Thompson, Robert M., 2.

Hematite-goethite relations under pressure: Smith, F. G., 2.

Hydrous silicate systems, liquid immiscibility: Friedman, I. I., 3.

Index of refraction measurement, micas and chlorites: Girault, J. P., 1.

Liquid inclusions, granite thermometry: Bailey, S. W.

Quartz, orientation: Tuttle, O. F., 1.

Meteoritic minerals: Neuerburg, G. J.

Mine rock, types: Windes, S. L.

Mineral aggregates: Rhoades, R. F., 6.

Mineral exploration, use: Kerr, P. F'., 5.

Olivine, orthopyroxene, thermochemical study: Sahama, T. G., 2.

Optical, teaching aids: von Huene, R., 1.

Pegmatitic stage, phase relations: Smith, F. G., 6.
Mineralogy-Continued

Pleochroic haloes, mineral age: Rogers, D. $\mathrm{H}$.

Porosity and petroleum accumulation: Krynine, P. D., 1.

Quartz twinning: Gault, H. R., 2.

Reflectivity, ore minerals: Folinsbee, R. E.

Replacement reactions, equating volume and weight: Ridge, J. D.

Rhodochrosite, thermal study: Kulp, J. L., 1.

Scope: Casperson, W. C.

Soils, relation between composition and properties: Grim, R. E., 1.

Spectrochemical analysis of minerals: Strock, L. W., 1.

Spectroscopic determination of elements: Jaffe, H. W., 1.

Stain analysis: LeRoy, L. W., 7.

Subsurface samples, study methods: Rittenhouse, G., 3 .

Telluride minerals, Canada: Thompson, Robert M., 1.

Textbook: Hurlbut, C. S., Jr., 1.

Thin section study: Gabelman, J. W., 1.

Uranium: Savage, W. S.

Vein minerals, nonsulfide transport and deposition: Maurice, O. D., 2; Smith, F. G., 1.

Warthaite discredited: Thompson, Robert M., 2.

Water in minerals: Keller, W. D., 6.

Mining geology.

Coal beds, roof characteristics: Am. Min. Cong., Coal Div., Comm. on Roof Action.

Colorado, application of geophysics: Wantland, $D$.

Development, review: Swanson, C. O., 2.

Geophysics, use: Koschmann, A. H., 2.

Review, 1948: Davidson, D. M.; Tolman, C.

Roof structure: Holland, C. T.

Scope, engineering aspects: Forrester, J. D., 2.

Subsurface geologic methods: Kuhn, T. H. Minnesota.

Aeromagnetic maps, Cass County: U. S. G. S., 14, 17.

Crow Wing County U. S. G. S., 19, 21.

Hubbard County: U. S. G. S., 23, 25.

Itasea County: U. S. G. S., 27.

Morrison County: U. S. G. S., 29, 31.

Todd County: U. S. G. S., 32.

Wadena County: U. S. G. S., 25.

Aeromagnetic profiles, Beltrami County: U. S. G. S., 13.

Cass County: U. S. G. S., 15, 16, 18.

Crow Wing County: U. S. G. S., 20, 22.

Hubbard County: U. S. G. S., 24, 26.

Itasca County: U. S. G. S., 28.

Morrison County: U. S. G. S., 30.

Todd County: U. S. G. S., 33.

Wadena County: U. S. G. S., 26.

Areas described.

Duluth area: Schwartz, G. M., 1. 
Minnesota-Continued

Geologic maps.

Central: Woyski, M. S.

Duluth area: Schwartz, G. M., 1.

Ground water.

Clay County: Dennis, P. E.

\section{Petrology.}

Intrusives: Woyski, M. S.

Physiographic geology.

Quetico-Superior area: Atwood, W. W.

Miocene. See Tertiary.

Mississippi.

Bibliography: Braunstein, J., 1.

Northeastern, Paleozoic, pre-Cambrian: Braunstein, J., 2.

Economic geology.

Natural gas, developments, 1948: Harris, R. M.

Petroleum: Mellen, F. F.

Brookhaven field: Womack, R., Jr. Developments, 1948: Harris, R. M.

La Grange field: Sherwin, M. W.

Historical geology.

Central, Tertiary: Miss. Geol. Soc., 1.

Covington County well, core log: Alexander, C. I.

Cretaceous, facies: MeGlothlin, J. T., Jr.

General: Mellen, F. F.

Tertiary, post-Claiborne: Monsour, E. T. Northeastern Wayne County: Hendy, W. J.

West-central: Thomas, E. P.

Paleontology.

Central, Tertiary: Miss. Geol. Soc., 1.

Covington County well, fossil lists: Alexander, C. I.

Foraminifera, Black Warrior Basin, Mississippian: Thompson, M. L.

Mississippi River.

Delta, depositional environments: Fisk, H. N.

Pleistocene history: Hobbs, W. H., 5.

Mississippi Valley.

Cenozoic geology, field conference: Leighton, M. M., 1.

Gravel deposits: Waterways Expt. Sta.

Lead deposits: Behre, C. H., Jr., 1.

Loess: Leighton, M. M., 3.

Petrography: Doeglas, D. J.

Soil mechanics-geology relation, foundation exploration: Turnbull, W. J.

Zine deposits: Behre, C. H., Jr., 1.

Mississippian. See Carboniferous.

Missouri.

Aeromagnetic maps, Coldwater quadrangle: U. S. G. S., 34 .

Crystal City quadrangle: U. S. G. S., 37 .

De Soto quadrangle: U. S. G. S., 36 .

Des Arc quadrangle: U. S. G. S., 35.

Farmington quadrangle: U. S. G. S., 37.

Fredericktown quadrangle: U. S. G. S., 38.

Alumina, oak leaves: Keller, W. D., 2.

\section{Missouri-Continued}

Economic geology.

Fredericktown area, ore deposits: James, J. A.

Mineral resources: Forrester, J. D., 1.

Tri-State zinc-lead district, reserves: Ruhl, 0 .

Historical geology.

Exline limestone, Pennsylvanian, palesecology: Cline, L. M.

Vernon County, pre-Upper Cambrian: Skillman, M. W.

Mineralogy.

Paleozoic shales: Allen, V. T., 1.

Paleontology.

Athyris, Burlington limestone, Columbia area: Unklesbay, A. G.

Dolichoharpes, Kimmswick formation, Ordovician: Whittington, H. B.

Mammalia, St. Louis cave: Simpson, G. G., 5.

Spores, Pennsylvanian: Schemel, M. P.

Petrology.

Insoluble residues, Paleozoic: Grohskopf, J. G.

Paleozoic shales: Allen, V. T., 1.

Pre-Cambrian volcanics, St. Francois Mts.: Robertson, F. S.

Vernon County, pre-Upper Cambrian: Skillman, M. W.

Physical geology.

Ozark earthquakes, 1945-47: Heinrich, R. R.

Physiographic geology.

Gumbotil, formation, relation to overlying loess: Krusekopf, H. H.

Mollusca. See also. Cephalopoda; Gastropoda; Invertebrata; Pelecypoda; Scaphopoda.

Arizona, Buell Park, Recent: Drake, R. J.

Southeastern, Lower Cretaceous: Stoyanow, A. A., 1.

California, Cretaceous, genetic lines: Popenoe, W. P., 2.

Miocene giant oysters, Shell Peak: Martin, L.

Wildcat coast section, Pliocene: Stewart, R. E.

Carinulorbis for Carinorbis: Yen, T.-C., 2.

Cuba, Baracoa area, Miocene: Aguayo, C. G., 2.

Dominican Republic, Miocene: Aguayo, C. G., 1 .

Limestones, organic: Johnson, J. H., 1.

Louisiana, De Soto, Red River Parishes, faunal lists: Murray, G. E., Jr., 1.

Mexico, La Peña formation, Sierra de los Muertos: Humphrey, W. E.

Morrison formation, correlation with $\mathrm{Eu}$ rope: Yen, T.-C., 4.

New York, Mytilarea knappi, holotype, Devonian: Smith, $B$.

North America, Lower Cretaceous, freshwater: Yen, T.-C., 1.

Nuculoidea, genotype, hinge and margin: Vokes, H. E., 3. 
Mollusca-Continued

Panama, Isla Escudo de Veragua, Pleistocene: Aguayo, C. G., 2.

Tertiary: Woodring, W. P.

Stratigraphic importance: Yen, T.-C., 3. Molybdenum, Montana, Big Ben deposit: Herdlick, J. A.

\section{Montana.}

Glacier National Park: Dyson, J. L., 2.

Economic geology.

Chromite, Boulder River area: Howland, A. L.

Coal reserves: Combo, J. X.

Gypsum: Perry, E. S., 1.

Hecla mining district: Karlstrom, T. N. V. Iron, Sheep Creek deposits: Reed, G. C.

Limestone: Perry, E. S., 1.

Molybdenum, Big Ben deposit: Herdlick, J. A.

Philipsburg area: Cole, J. W., 2.

Phosphate: McKelvey, V. E.

Tungsten, Henderson Gulch deposit: Hundhausen, R. J.

Vein formation, Butte: Sales, R. H.

Geologic maps.

Big Ben molybdenum deposit: Herdlick, J. A.

Blakely Creek area: Howland, A. L.

Gish chromite deposits: Howland, A. L.

Gypsum areas: Perry, E. S., 1.

Hecla mining district: Karlstrom, T. N. V.

Limestone areas: Perry, E. S., 1.

Pegmatites: Heinrich, E. W., 1.

Philipsburg area: Cole, J. W., 2.

Philipsburg quadrangle, Henderson Gulch tungsten deposit: Hundhausen, R. J.

Stillwater complex, western: Howland, A. L.

Historical geology.

Belt series: Ross, C. P.

Centennial region: Honkala, F. S., 3.

Eocene conglomerate: Pecora, W. T., 3.

Geologic section, West Fork, Madison River: Honkala, F. S., 2

Hecla mining district: Karlstrom, T. N. V. Mesozoic, southwestern: Moritz, C. A.

Paleozoic: Sloss, L. L., 3.

Pre-Jurassic: Perry, E. S., 2.

\section{Paleontology.}

Faunal homonyms, synonyms, Upper Cambrian: Lochman, C.

Teleost, Livingston formation: Schaeffer, B.

\section{Petrology.}

Canyon Ferry project, petrography: Mielenz, R. C., 12, 13.

Pegmatites: Heinrich, E. W., 1, 2.

Pre-Beltian, metamorphic: Heinrich, E. W., 3.

Tiber damsite, sediments, petrosraphy: McConnell, D., 3.

Physiographic geology.

Glaciation, Glacier National Park: Dyson, J. L., 1

Periglacial features, origin: Schafer, J. P.,
Montana-Continued

Physiographic geology-Continued

Teton River Valley, Pleistocene: Schafer, J. P., 2.

Montmorillonite, crystal structure: Barshad, I.

Monzonite, Idaho, Coeur d'Alene district: Anderson, A. L., 2.

Moraines. See also Glacial geology.

Alpine glaciation: Ray, L. L., 3.

New York, Croton Point: Kindle, C. H., 2.

North Dakota, Oberon quadrangle: Tetrick, P. R.

Tokio quadrangle: Easker, D. G.

Ontario, southern: Chapman, L. J.

Wyoming, Wind River Mts.: Moss, J. H., 3.

Mounds.

Louisiana, De Soto, Red River Parishes: Murray, G. E., Jr., 1.

Mima, origin: Price, W. A., 1.

Origin: Krinitzsky, E. L.

Mountain building. See Orogeny.

Natural gas. See also Oil and gas fields.

Accumulation, time: Levorsen, A. I.

Alabama, developments, oil and gas, 1948: Harris, R. M.

Alaska, Iniskin Peninsula: Kirschner, C. E.; U. S. G. S., 1, no. 95.

Alberta, Leduc oil field: Layer, D. B.

Moberly Creek, West of Sixth Meridian: Canada G. S., 11.

Northern: Nauss, A. W.

Reserves: Lang, W. A.

Appalachian Basin, northern: Pittsburgh Geol. Soc.

Northern, Silurian: Rittenhouse, G., 1; U. S. G. S., 1, no. 100.

Arkansas, developments, 1948: Williams, J. R.

Southern, map: Ark. Res. and Dev. Comm., Div. of Geology.

Basins, reserves: Moulton, G. F.

California, developments, 1948: Moody, G. B.

Kern. County: Tucker, W. B.

Canada, developments, 1948: Gray, J. G.

Interior Plains, stratigraphy and structure: Link, T. A., 5.

Western: Link, T. A., 4. Exploration: Deegan, C. J., 3.

Colorarlo, Dodge City Basin: Maher, J. C., 1; U. S. G. S., 1, no. 101.

Pied:a River Canyon: Read, C. B.; U. S. G. S., 1, no. 96.

San Juan Basin: Barnes, F. C., 1, 2.

U. S. Geological Survey, investigations: Dane, C. $\mathrm{H}$.

Composition, properties, Appalachian fields: Headlee, A. J. W.

Exploratory wells, geological interpretation: Weaver, $\mathbf{P}$.

Florida, developments, 1948: Harris, R. M.

Exploration: Gunter, H., 1.

Geophysical activity, 1948: Eckhardt, E. A. 
Natural gas-Continued

Georgia, developments, 1948: Harris, R. M.

Gulf of Mexico, continental shelf exploration: McGee, D. A.

Illinois, developments, 1948: Bell, A. H., $2,3$.

Indiana, developments, 1948: Bell, A. H., 2.

Kansas: Jewett, J. M., 2.

Developments, 1948: Berg, J. R.; Ver Wiebe, W. A., 2.

Dodge City basin: Maher, J. C., 1; U. S. G. S., 1, no. 101 .

Eastern: Jewett, J. M., 1. Map: Jacobson, E. C.

Kentucky, Big Six sandstone: Young, D. M.

Developments, 1948: Wood, E. B.

Eastern, Upper Mississippian: Wilpolt, R. H.; U. S. G. S., 2, no. 38 .

South-central, development: Hunter, C. D.

Louisiana, De Soto, Red River Parishes: Murray, G. E., Jr., 1.

Developments, Gulf Coast, 1948: McBee, W. S., Jr.

Northern, 1948: Williams, J. R.

Magnetometer exploration, fields: Peters, J. W.

Manitoba, bibliography: Kerr, L. B., 1.

Maryland, exploration: Anderson, J. L., 1.

Mexico, fields: García Rojas, A., 2.

Poza Rica oil and gas field: Salas, G. P.

Reynosa area, Gulf Coast: Guzmán, E. J.

Mid-Continent region, Arbuckle and Ellenburger formations: Bartram, J. G.

Mississippi, developments, 1948: Harris, R. M.

New Mexico, developments, 1948: Henderson, C. F.

Map: Northup, R. C.

San Juan Basin: Barnes, F. C., 1, 2.

Southeastern, Paleozoic stratigraphy: Lloyd, E. R.

New York, Cambro-Ordovician: Swartz, F. M., 3.

Oriskany sandstone: Finn, F. H.

Ohio: Alkire, R. L., 2.

Berea sand: De Witt, W., Jr.; U. S. G. S., 1 , no. 99 .

Fields, map: Alkire, R. L., 1.

Holmes County: Lamborn, R. E., 2.

Mayfield pool: Rothrock, H. E., 3 .

Southeast: Dunn, O. C., Jr.

Oklahoma, developments, 1948: Wellman, D. C.

Dodge City basin: Maher, J. C., 1; U. S. G. S., 1, no. 101 .

Ontario, Salina-Guelph fields:, Roliff, W. A., 1.

Pennsylvania, Cambro-Ordovician: Swartz, F. M., 3.

Natural gas-Continued

Pennsylvania-Continued

Developments, 1948: Fettke, C. R., 2.

East Fork-Wharton field: Ebright, J. R.

Oriskany sandstone: Finn, F. H.

Southwest, Devonian oil and gas fields: Bayles, R. E.

Texas, developments, 1948: Ammon, W. L., 2; Clark, G. C., 1; Henderson, C. F.; Mettner, F. E.; Scrafford, J. B.

Resources: Culberson, 0 .

Textbook: Lalicker, C. G.

United States, exploratory drilling, 1948: Lahee, F. H., 1.

Reserves: Oberfell, G. G.

Rocky Mtn. region, developments, 1948: Dorn, C. L.

Western, exploration: Tatum, J. L.

Utah: Hansen, G. H.

Clay Basin field: Fidlar, M. M.

Virginia, southwestern, Upper Mississippian: Wilpolt, R. H.; U. S. G. S., 2, no. 38.

West Virginia: Price, P. H., 1; Tollefson, E. H.

Jackson-Kanawha field: McClain, A. H. Southern, Upper Missippian: Wilpolt, R. H.; U. S. G. S., 2, no. 38 .

Wyoming, central, Upper Cretaceous: Thompson, Raymond M.; U. S. G. S., 2, no. 36.

Church Buttes field: Carlson, R. F.

Fields, map: Keefer, E. K.

Glendo area: Love, J. D., 2; U. S. G. S., 1, no. 92.

Hartville Uplift, potential: Denson, N. M., 1; U. S. G. S., 1, no. 102.

Newcastle sandstone, facies: Summerford, H. E., 1.

Nautiloidea. See Cephalopoda.

Nebraska.

Ground water.

Lower Platte River valley: Waite, H. A. Historical geology.

Lower Platte River Valley: Waite, H. A. Mineralogy.

Meteorite, Furnas County: Beck, C. W., 1.

Linwood: Henderson, E. P., 3.

Paleontology.

Crinoids, Iatan formation, Pennsylvanian: Strimple, H. L., 7.

\section{Petrology.}

Trenton dam area, loess: Holland, W. Y., 8.

Physical geology.

Dunes: Smith, H. T. U., 3.

Nepheline.

Ontario, origin: Moyd, L., 1.

Transformation to carnegieite: Washken, E.

Nevada.

Economic geology.

Aggregate, Davis dam: Rhoades, R. F., 1. Comstock Lode: McBride, G. B. 
Nevada-Continued

Economic geology-Continued

Fluorite, Daisy mine, Beatty: Thurston, W. $R$.

Lead-zinc, Pioche district: Young, E. B. Geologic maps.

Daisy fluorite mine area: Thurston, W. R.

Hawthorne quadrangle: Ferguson, H. G.

Index: Boardman, L., 4.

Muddy Mtn. area: Longwell, C. R., 1.

Pioche district: Young, E. B.

Tonopah quadrangle: Ferguson, H. G.

White River Valley: Maxey, G. B., 3.

Ground water.

Las Vegas artesian basin: Maxey, G. B., 1.

Las Vegas Valley: Maxey, G. B., 2.

Goshute-Antelope Valley, Elko County: Eakin, T. E.

Pahrump Valley: Maxey, G. B., 2.

Paradise Valley, Humboldt County: Loeltz, O. J.

White River VaHey: Maxey, G. B., 3.

Historical geology.

Antelope Valley, Paleozoic: Merriam, C. W., 2.

Antler Peak quadrangle: Roberts, R. J.

Basin and Range province, facies: Muller, S. W.

Candelaria district, volcanics: Baxksdale, J. D., 2.

Eastern: Humphrey, F. L.

Mesozoic, northeastern: Wheeler, I. E.

Muddy Mtn. area: Longwell, C. R., 1.

Permian, northeastern: Wheeler, H. E.

Tonopah quadrangle: Ferguson, H. G.

Mineralogy.

Svanbergite: Switzer, G.

Paleontology.

Cephalopoda, White Pine shale, Mississippian: Youngquist, W. L., 3.

Mammalia, Clarendonian Tertiary, Chalk Spring: Macdonald, J. R., 1.

Pliocene: Macdonald, J. R., 2.

Physical geology.

Antler Peak quadrangle: Roberts, R. J.

Candelaria district, structure: Page, B. M.

Earthquake, Verdi: Gianella, V. P.

Goodsprings district, Monte Cristo limestone, structure: Albritton, C. C., Jr., 2.

Hawthorne quadrangle, structure: Ferguson, H. G.

Muddy Mtn. area: Longwell, C. R., 1.

Structure: Humphrey, F. L.; Longwell, C. R., 3.

Tonopah quadrangle, structure: Ferguson, H. G.

Verdi earthquake: Byerly, P., 3.

Physiographic geology.

Lake Lahontan shore lines, elevations: Stanley, G. M., 2.

New Brunswick.

Economic geology.

Coal, Chipman area: Muller, J. E., 2.

Minto area, map: Muller, J. E., 1.
New Brunswick-Continued

Geologic maps.

Chipman area: Muller, J. E., 2.

Minto area: Muller, J. E., 1.

Historicai geolggy.

Chipman area: Muller, J. E., 2.

New England, concretions, glacial varved clays Bassler, R. S.

New Hampshire.

Economic geology.

Mica, Big mine: Levin, S. B., 2.

Blister mine: Levin, S. B., 1.

Geologic maps.

Blister mica mine: Levin, S. B., 1.

Keene-Brattleboro area: Moore, G. E., Jr., $1,2$.

Monadnock quadrangle: Fowler-Billings, K., $1,2$.

Pexcy quadrangle: Chapman, R. W., 1.

Ground water.

Artesian wells: Goldthwait, R. P.

Historical geology.

Keene-Brattleboro area: Moore, G. E., Jr., $1,2$.

Monadnock quadrangle: Fowler-Billings, K., $1,2$.

Percy quadrangle: Chapman, R. W., 1.

Mineralogy.

Collecting localities: Seaman, D. M.

Ludlamite, Palermo mine, North Groton: Wolfe, C. W., 1.

Whitlockite, Palermo mine: Frondel, C., 4.

Wolfeite, Palermo mine: Frondel, C., 4.

Xanthoxenite, Palermo mine: Frondel, C., 4.

Petrology.

Keene-Brattleboro area: Moore, G. E., Jr., $1,2$.

Monadnock quadrangle: Fowler-Billings, $\mathrm{K} ., 1,2$.

Percy quadrangle: Chapman, R. W., 1.

Physiographic geology.

Flume: McNair, A. H., 1.

Franconia Notch: McNair, A. H., 1.

Kinsman Notch: MeNair, A. H., 2.

Lost River Gorge: McNair, A. H., 2.

New Jersey.

Economic geology.

Agricultural minerals: Wolfe, P. E., 3.

Glass sand: Wilkerson, A. S., 1, 2.

Lime-marl deposit, Vincentown: Bader, $\mathbf{H}$., 1.

Limestone: Wolfe, P. E., 3.

Mineral resources: Tyler, P. M.

Zinc, Franklin-Sterling area: Pinger, A. W.

Historical geology.

Martinsburg formation, Ordovician, correlation: Willard, B., 1.

Triassic facies, Delaware Valley: McLaughlin, D. B.

Geologic maps.

Franklin-Sterling area, sketch maps: Pinger, A. W.

Hunterdon Plateau: McLaughlin, D. B. 
New Jersey-Continued

Mineralogy.

Bridgewater copper mine, collecting: Hayes, W. $\mathbf{H}$.

Glass sand: Wilkerson, A. S., 2.

Quartz crystals, Prospect Park: Lisle, T. 0.

Paleontology.

Crustacea, Raninella testacea, Cretaceous: Kindle, C. H., 1.

Martinsburg formation, Ordovician, fossil list: Willard, B., 1.

Petrology.

Palisade sill diabase, rhombic pyroxenes: Guimarães, D.

Physical geology.

Fractures, quantitative analysis: Pincus, H. J.

Physiographio geology.

Glacial drift: MacClintock, P.

New Mexico.

Meteorite crater: La Paz, L.

Seismic maps, velocity data: Dahm, C. G.

Economic geology.

Barite: Clippinger, D. M.

Copper, Santa Rita area, Chino mines: Ballmer, G. J.

Harding tantalum-lithium pegmatite: Berliner, $\mathbf{M}$. $\mathbf{H}$.

Iron deposits: Kelley, V. C.

Lead-zinc, Houston-Thomas prospect: Romberg, F., 1.

Gravity exploration: Barnes, V. E., 2.

Natural gas, developments, 1948: Henderson, C. F.

Map: Northup, R. C.

Pools, southeastern: Lloyd, E. R.

Petroleum, developments, 1948: Henderson, C. F.

Map: Northup, R. C.

Pools, southeastern: Lloyd, E. R.

San Juan Basin: Barnes, F. C., 2.

Silver City region: Hernon, R. M.; West Texas Geol. Soc., 4.

Zinc, Central mining district: Lasky, S. G., 1.

Geologic maps.

Caliche, southeastern: Bretz, J. H., 3.

Central mining district: Lasky, S. G., 1.

Chino mines, Santa Rita area: Ballmer, G. J.

Colfax County: Griggs, R. L.

Iron deposits: Kelley, V. C.

Kilbourne Hole: West Texas Geol. Soc., 3. Manzanita Mts. area: Reiche, $\mathbf{P}$.

North Manzano Mts. area: Reiche, $\mathbf{P}$.

Northeastern: Collins, R. F.

Ogallala formation west of Llano Estacado: Bretz, J H., 2.

Sacramento Mts.: West Texas Geol. Soc., 6. Silver City region: West Texas Geol. Soc., 4.

Ground water.

Colfax County: Griggs, R. L.

Historical geology.

Colfax County : Griggs, R. L.

Manzanita Mts.: Reiche, $\mathbf{P}$.

\section{New Mexico-Continued}

Historical geology-Continued

Mississippian: Laudon, L. R., 1.

North Manzano Mts.: Reiche, $P$.

Ogallala limestone, Union County: Van Tuyl, F. M., 1.

Ogallala formation west of Llano Estacado: Bretz, J H., 2.

Permian facies: Wheeler, R. R., 3.

Salado formation, Permian, deposition cycle: Lang, W. T. B.

San Juan Basin structure: Barnes, F. C., 1.

Simpson group, Ordovician: Bartley, J. H. Southeastern, oil-producing zones, Paleozoic: Lloyd, E. R.

Southern: West Texas Geol. Soc., 6.

Woodford black shale, Devonian: Ellison, S. P., Jr., 2.

Mineralogy.

Dolomite crystals, Lake Arthur: Rogers, A. F., 1.

Eucolite: Clabaugh, S. E.

Eudialyte: Clabaugh, S. E.

Talc, in halite, Carlsbad: Bailey, $\mathbf{R}$. K. Paleontology.

Amphibia, Abo formation, Permian: Langston, W., Jr., 2.

Mammalia, Nacimiento formation, Eocene: Wilson, R. W., 6.

Petrology.

Caliche, southeastern: Bretz, J H., 3.

Eudialyte-bearing dikes, Otero County: Clabaugh, S. E.

Igneous rocks, Capitan quadrangle: Patton, L. T.

Laughlin Peak, dacite: Stobbe, H. R., 3.

Tucumcari project, construction materials, petrography: Irwin, W. H., 5.

Volcanics, northeastern: Collins, R. F.; Stobbe, H. R., 1

Physical geology.

Caliche, southeastern: Bretz, J H., 3.

Carlsbad Caverns, origin: Bretz: J H., 1.

Caves, Guadalupe Range, origin: Bretz, J $H ., 1$.

Folding, Permian: Wheeler, R. R., 3.

Fracture, Salado formation potash beds, near Carlsbad: Cathcart, J. B., Jr.

Sacramento Mts., Paleozoic deformation: Pray, L. C.

San Juan Basin structure: Barnes, F. C., 1.

Volcanic ash from Valle Grande crater, Great Plains, Pleistocene: Swineford, A.

Physiographic geology.

Carlsbad Caverns, origin: Bretz: J H., 1. Geomorphic history: Horberg, C. L., 3.

Caves, Guadalupe Range, origin: Bretz, J H., 1.

Craters: Perkins, A. M.

Ogallala formation west of Llano Estacado: Bretz, J H., 2.

Pluvial lakes, age: Antevs, E. V., 2.

Sink holes; Perkins, A, M. 
New York.

Engineering geology, Manhattan schist, foundation rock: Feld, $J$.

Magnetic anomalies, Russell quadrangle: Shaub, B. M., 2.

Staten Island rocks and minerals, early references: Coles, R. S.

Economic geology.

Natural gas, Oriskany sandstone: Finn, F. $\mathbf{H}$.

Petroleum, Cambro-Ordovician: Swartz, F. M., 3.

Deep wells: Jillson, W. R., 3.

Exploration: Donnerstag, $P$.

Tale deposits: Engel, A. E. J., 2.

Zinc, St. Lawrence County: Hermance, H. $\mathbf{P}$.

Geologic maps.

Adirondack Mts., Grenville series: Engel, A. E. J., 3.

Albany County: Arnow, T.

Parker zinc deposit, St. Lawrence County: Hermance, $H$. $P$.

Western: Pittsburgh Geol. Soc.

Ground water.

Albany area, preglacial buried channels: Simpson, E. S.

Albany County: Arnow, T.

Long Island, Kings County, well log correlation: deLaguna, $\mathrm{W}$.

Historical geology.

Albany County: Arnow, T.

Cambro-Ordovician, subsurface: Swartz, F. M., 3.

Chemung formation, Bradford-Richburg oil sands, Devonian: Harding, R. W.

Deepkill conglomerates, Ordovician: Ross, M. $\mathbf{H}$.

Devonian strata, structures: Stevenson, R. E., 2.

Hudson Valley, Cambro-Ordovician: Flower, R. H., 3.

Long Island, Kings County, well $\log$ correlation: deLaguna, $W$.

Oriskany sandstone, Devonian: Finn, F. H.

Otsego County, Middle Devonian, structures: Stevenson, R. E., 1.

Paleozoic strata: Swartz, F. M., 1 .

Trenton limestones, statistical analysis: Chenoweth, P. A.

Tully clastics, Devonian: Stevenson, R. E., 3.

Mineralogy.

Danburite, near Russell: Clark, W.

Garnet minerals, paragenesis, North Creek: Shaub, B. M., 3.

Quartz, Ravena: Hamilton, H. V.

Paleontology.

Appalachian Basin, northern: Pittsburgh Geol. Soc.

Mytilarca knappi, Devonian, Skaneateles Lake, holotype: Smith, B.

Ophiurans, Ithaca formation, Devonian: Johnson, R. B.

Pachyphyllum vagabundum, Upper Devonian: Ehlers, G. M., 2.
New York-Continued

Paleontology-Continued

Schenectady formation, near Rexford, invertebrates: Howell, B. F., 2.

Petrology.

Adirondack Mts., garnets: Levin, S. B., 3.

Grenville metasediments, cleavage: Engel, A. E. J., 3.

Titaniferous ores: Evrard, P.

Granitization, Hudson Highlands: Lowe, K. E.

Physical geology.

Cornwall-Massena earthquake, 1944 : Milne, W. G., 2.

Hudson Valley, Paleozoic faulting: Flower, R. H., 3 .

Oriskany sandstone, structure: Finn, F. H. Physiographic geology.

Beach features, Fire Island: Rosalsky, M. B.

Croton Point moraine: Kindle, C. H., 2.

Finger Lake region: Durham, F.

Mohawk Valley, Pleistocene lakes: Kay, G. M., 3 .

Preglacial buried channels, Albany area: Simpson, E. S.

Newfoundland.

Land planning, geological methods: Wolfe, P. E., 4.

Port au Port Peninsula: Wolfe, P. E., 1.

Upper Humber Valley: Wolfe, P. E., 2.

Economic geology.

Coal: Hayes, A. O., 2.

Geologic maps.

Clarenville area: Hayes, A. O., 1; Rose, E. R.

Corner Brook-Stephenville area: Walthier, T. N., 1.

Donn Brook, sketch map: Walthier, $\mathbf{T}$. N., 1.

Dormston quarry, sketch map: Walthier, T. N., 1.

General: Reed, F. R. C., 2.

Grand Lake area: Hayes, A. O., 2.

Lewis Hills-Bay St. George area: Walthier, T. N., 2.

Port au Port Peninsula: Wolfe, P. E., 1.

St. Georges coalfields: Hayes, A. O., 2.

Historical geology.

Clarenville area, eastern: Hayes, A. O., 1.

Corner Brook-Stephenville area, Paleozoic: Walthier, T. N., 1.

General: Reed, F. R. C., 2.

Lewis Hills-Bay St. George area, Paleozoic: Walthier, T. N., 2.

Placentia Bay area: Rose, E. R.

Mineralogy.

Iron ores, oolitic, Wabana: Caillère, $\mathrm{S}$.

Petrology.

Corner Brook-Stephenville area, pre-Cambrian: Walthier, T. N., 1.

Placentia Bay area: Rose, E. R.

Physical geology.

Corner Brook-Stephenville area, orogeny: Walthier, T. N., 1. 
Newfoundland-Continued

Physical geology-Continued

Lewis Hills-Bay St. George area, structure: Walthier, T. N., 2.

Nicaragua.

Historical geology.

Facies, Mesozoic: Mullerried, F. K. G., 10.

Mesozoic stratigraphy, Tehuantepec Isthmus: Mullerried, F. K. G., 7.

Paleontology.

Mesozoic strata, fauna: Mullerried, F. K. G., 7.

Nickel.

Oregon, garnierite: Pecora, W. T., 1

Washington, Mackinaw mine: Milton, C., 2.

Nodules, coal, Pennsylvania: Schopf, J. M., 3. Nomenclature.

Absaroka sequence: Sloss, L. L., 1.

Acrocrinus, new species, Oklahoma, Pennsylvanian: Strimple, H. L., 9.

Arkose: Oriel, S. S.

Bancroftina, name revision: Sinclair, G. W., 2.

Basin, depositional: Kay, G. M., 1.

Belt series, Montana: Ross, C. P.

Brachiopoda, Iowa, Ordovician, new genera: Wang, $\mathbf{Y}$.

Bryozoa, Paleozoic, genotypes: Duncan, $\mathrm{H}$. Cambrian, eastern Pennsylvania: Willard, B., 3.

Southern Appalachians: King, P. B., 6.

Cancellariidae, Miocene Gastropoda, tropical America: Marks, J. G.

Carinulorbis for Carinorbis: Yen, T.-C., 2.

Chickahominy formation, Virginia, Eocene: Cushman, J. A., 2.

Clay minerals, glossary: Kerr, P. F., 1.

Conodonts, Iowa, new species: Thomas, L. A.

Dalmanites oklahomae, Silurian: Richardson, E. S., Jr., 1.

Dolichoharpes, generic description: Whittington, H. B.

Dorr Run shale, Allegheny formation, Ohio: Sturgeon, M. T., 1.

Dufrenite complex minerals: Frondel, C., 3.

Elk Point formation, Silurian, Alberta: McGehee, J. R.

Eobronteidae for Scutellidae, Ordovician Trilobita: Sinclair, G. W., 1.

Eolian gravity cones: Patton, M. M.

Eponides, generic definition: Redmond, C. $D$.

Facies: McKee, E. D., 1.

Foraminifera: Stainforth, R. M., 2. Alabama, new names: Bandy, O. L., 2. Fomonymns: Thalmann, H. E., 1, 5. Rotaliid, Chapmanininae: Frizzell, D. L., 2.

Garnierite: Pecora, W. T., 1.

Geologic terms, origin: Burt, F. A., 2.

Geosynches: Kay, G. M., 1; Wells, F. G., 3.

\section{Nomenclature-Continued}

Homonyms, synonyms: Haas, O., 3.

Upper Cambrian faunas, Montana: Lochman, C..

Hoplophoneus, subspecies: Hough, J. R.

Hybocrinus crinerensis, n. sp., Oklahoma, Ordovician: Strimple, H. L., 2.

Hypodigm specimens: Newell, N. D., 1.

Insoluble residues: Ireland, H. A., 1.

Intercontinental genera and species: Newell, N. D., 2.

Kaskaskia sequence: Sloss, L. L., 1.

Laosaurus Gilmore, dinosaur: Russell, L. S., 2.

Lithostrotion, Mississippian, British Columbia: MeLaren, D. J.

Loganopeltoides, Loganopeltis: Raw, F.

Meteorites, subclasses: Leonard, F. C.

Mooreocrinus bowsheri, n. sp., Oklahoma, Mississippian: Strimple, H. L., 1.

Nautilus becarii Linné, generic position: Frizzell, D. L., 1.

Nucellangium, fossil seed, Iowa, Pennsylvanian: Andrews, H. N., Jr., 2.

Ohio, geological place-names: Cottingham, $\mathbf{K}$.

Oniscoidichnus for Isopodichnus Brady, 1947: Brady, L. F.

Onlap, offlap, overstep and overlap as geologic terms: Swain, F. M., 2.

Overlap and nonconformity: Lahee, F. H., 2.

Paleontologic classification: Weller, J. M. Panama, Tertiary strata: Woodring, W. P.

Pavoninoides, n. sp., Panama, Oligocene: Berrinúdez y Hernández, P. J., 1.

Pedioceras, synonym of Crioceras (Pseudocrioceras): Yenne, K. A.

Pennsylvanian system, divisions: Moore, R. C., 3.

Plant names: Haas, O., 2.

Pleistocene problems: Ray, L. L., 2.

Prosopon, proposed term for ornament: Gill, E. D.

Pteridosperm male fructifications of $\mathrm{Do}$ lerotheca, Illinois: Schopf, J. M., 2.

Raymondella, name revision: Sinclair, G. W., 2.

Reedaspis, name revision: Sinclair, G. W., 2.

Rotaliidae, revision: Frizzell, D. I., 1.

Sauk sequence: Sloss, L. L., 1.

Scaphites morrowi: Jeletzky, J. A.

Stratigraphic, correlation, time terms: Lowman, S. W., 1.

Subsurface units: American Comm. Strat. Nomenclature.

Texas: Israelsky, M. C., 2.

Taxonomy, procedure: Schenk, E. T.

Texas, Colorado River Valley Permian (?) rocks: Moore, R. C., 2; U. S. G. S., 1, no. 80.

Tippecanoe sequence: Sloss, L. L., 1.

Type specimens: Newell, N. D., 1. 
Nomenclature-Continued

Unconformities: Stewart, W. A.

Utah, upper Cretaceous: Spieker, E. M.

North America.

Bibliography, 1946-47: Thom, E. M.

Economic geology.

Geophysical activity, 1948: Eckhardt, E. A.

Petroleum fields: Ver Wiebe, W. A., 1.

Historical geology.

Cambrian, correlation with China: Howell, B. F., 1.

Climatology, Pleistocene: Landsberg, $\mathrm{H}$.

Geosynclines, Paleozoic, and island ares: Kay, G. M., 2.

Paleotectonic, paleogeologic maps, central, western: Eardley, A. J., 2.

Pliocene-Pleistocene boundary: Moore, R. C., 5.

Tertiary: Wilson, R. W., 4.

Mineralogy.

Sandstone types, cementing agents: Tallman, S. L.

Paleontology.

Biogeography, Pleistocene: Deevey, E. S., Jr.

Ecotones, Tertiary, western: Chaney, R. W., 4.

Eobronteus, Trilobita, Ordovician: Sinclair, G. W., 1 .

Favositidae, Devonian, types: Stumm, E. C., 1.

Foraminifera, rotaliid, Chapmanininae, ef. Dictyoconus: Frizzell, D. L., 2.

Mollusca, fresh-water, Lower Cretaceous: Yen, T.-C., 1.

Morrison formation: Yen, T.-C., 4.

Nautiloidea, Devonian, new genera: Flower, R. H., 1.

Permian: Miller, A. K., 2.

Pelecypoda, Pacific Coast: Parker, P. E.

Rodents, early Tertiary: Wilson, R. W., 4.

Vertebrata, Pleistocene: Hibbard, C. W., 4.

Petrology.

Sandstone types, cementing agents: Tallman, S. L.

Physical geology.

Crustal movement, Great Lakes area: Hobbs, W. H., 2.

Tectonics, eastern: Shatsky, N. S.

Textbook: Miller, W. J.

Physiographic geology.

Biogeography, Pleistocene: Deevey, E. S., Jr.

Climatology, Pleistocene: Landsberg, $H$.

Eolian deposits, map: Thorp, J., 2.

Glacial erosion, sedimentation: Holmes: C. D., 2 .

Glaciation, continental: Hobbs, W. H., 4.

Glaciers, continental, America-Eurasia: Hobbs, W. H., 1.

Greas Lakes area, glacial geology: Flint, R. F., 1.

North Carolina.

Great Smoky Mts. National Park, geologic mapping: Hadley, J. B., 4.
North Carolina-Continued

Economic geology.

Barite: Van Horn, E. C., 2; 3.

Clay, halloysite: Hunter, C. E.

Coal, Deep River field: Reinemund, J. A.

Corundum, Buck Creek area: Hadley, J. B., 3.

Halloysite: Hunter, C. E.

Limestone: Berry, E. W., 1.

Marl: Berry, E. W., 1.

Silica resources: Broadhurst, S. D.

Soapstone: Stuckey, J. L.

Talc: Stuckey, J. L.

Southwestern: Van Horn, E. C., 1.

Geologic maps.

Buck Creek area: Hadley, J. B., 3.

Coastal Plain: Berry, E. W., 1.

Corundum Knob area: Hadley, J. B., 3 .

Deep River coal field: Reinemund, J. A.

Murphy marble belt: Van Horn, E. C., 1.

Yadkin-Pee Dee River Basin: Mundorff, M. J.

Ground water.

Yadkin-Pee Dee River Basin: Mundorff, M. J.

Historical geology.

Deep River coal field: Reinemund, J. A.

Eocene outlier: Parker, J. M.

Mineralogy.

Moore County meteorite: Hess, H. H., 1.

Paleontology.

Fauna, Harrellsville, Miocene: Berry, F. W., 2.

Petrology.

Hiwassee dam cores, petrography: Irwin, W. H., 2.

Pegmatites, Spruce Pine area: Jones, W. H., 2.

Quartzites, analyses: Broadhurst, S. D.

Physical geology.

Durham Triassic Basin, structure: Harrington, J. W.

Physiographic geology.

Carolina Bays, ellipticity: Prouty, W. F. Origin: Bailey, E. B.: Wells, B. W.

Lakes and "Carolina Bays", Coastal Plain: Frey, D. G.

North Dakota.

Richardton meteorite: Buddhue, J. D., 3.

Economic geology.

Lignite: Roe, W. B.

Petroleum possibilities: Laird, W. M., 1.

Sodium sulfate deposits: Grossman, I. G.

Geologic maps.

Oberon quadrangle: Tetrick, P. R.

Sodium sulfate deposits: Grossman, I. G.

Tokio quadrangle: Easker, D. G.

Ground water.

Cass County: Dennis, P. E.

Oberon quadrangle: Tetrick, P. R.

Historical geology.

Golden Valley formation, Eocene: Benson, W. E. B.

Stratigraphy: Laird, W. M., 1.

Tokio quadrangle: Easker, D. G. 
North Dakota-Continued

Physiographic geology.

Glacial boulders: Waring, G. A.

Oberon quadrangle: Tetrick, P. R.

Ridges, Lake Agassiz plain: Horberg, C. L., 4 .

Tokio quadrangle, glacial geology: Easker, D. G.

Permafrost, Giant Yellowknife area: Dateman, J. D., 2; Jenness, J. L.

Northwest Territories.

Economic geology.

Con-Rycon mine, Yellowknife: Campbell, N.

Gold, Giant Yellowknife property: Dadson, A. S.

Petroleum, Athabaska tar sands: Williams, M. $\mathbf{Y}$.

Pitchblende, between Beaverlodge and Hottah Lakes: Henderson, J. F., 1.

Eldorado mine: Merritt, P. L.

Geologic maps.

Aylmer Lake area: Lord, C. S., 2.

Beaverlodge and Hottah Lakes: Henderson, J. F., 1.

Carp Lakes area: Miller, M. L.

Indin Lake area, eastern: Fortier, Y. $O$.

Lac de Gras area: Canada G. S., 7.

MeAlpine Channel area: Feniak, M. W.

Wecho River area, east half: Yardley, D. $\mathbf{H}$.

Yellowknife, Con-Rycon mine: Campbell, N.

Historical geology.

Aylmer Lake area: Lord, C. S., 2.

Beaverlodge and Hottah Lakes: Henderson, J. F., 1.

Carp Lakes area: Miller, M. L.

Devonian, Fort Good Hope area: Warren, P. S.,.2.

Lac de Gras area: Canada G. S., 7.

McMurray area: Williams, $\mathbf{M}$. $\mathbf{Y}$.

Mineralogy.

Berthierite: Warren, H. V., 2.

Bismuth: Warren, H. V., 2.

Paleontology.

Megalonyx tooth, Pleistocene: Stock, C., 2.

Petrology.

Beaverlodge and Hottah Lakes: Henderson, J. F., 1.

Indin Lake area: Fortier, Y. 0.

McAlpine Channel area: Feniak, M. W.

Wecho River area, east half: Yardley, D. $\mathbf{H}$.

Physical geology.

Lac de Gras area: Canada G. S., 7.

Structural mapping: Henderson, J. F., 2.

Physiographic geology.

Lac de Gras area: Canada G. S., 7.

Nova Scotia.

Mapping from aerial photos, Cape Breton Island: Cameron, H. L., 1.

Economic geology.

Limestone, Glen Morrison: Goudge, M. F.
Nova Scotia-Continued

Economic geology-Continued

Limonite deposits, Bridgeville: Weeks, I. J.

Peat: Leverin, H. A.

Historical geology.

Conglomerates, basal: Keating, B. J.

Mineralogy.

Limonite deposits, Bridgeville: Weeks, L. J.

Physical geology.

Bras d'Or lakes, origin: Douglas, G. V., 2.

Faulting: Cameron, H. L., 3.

Lismore area, faulting, sub-sea: Cameron, H. L., 2.

Strait of Canso, origin: Douglas, G. V., 2.

Oceans. See also Submarine geology.

Arctic Basin, bottom topography: Emery, K. 0 .

Atlantic, Mid-Atlantic Ridge area: Tolstoy, I., 1.

Seismic studies: Ewing, W. M., 3.

Earth's crust beneath, properties: Gutenberg, B., 6.

Floor, tectonics: Bucher, W. H.

Pacific, bottom sediments, clay minerals: Grim, R. E., 2.

Sea mounts: Carsola, A.

Sediments, deposition: Phleger, F. B., Jr., 3.

Ohio.

Geological place-names: Cottingham, K.

Economic geology.

Ceramic minerals: Everhart, J. 0.

Holmes County: White, G. W., 1.

Natural gas: Alkire, R. L., 2.

Berea sand: De Witt, W., Jr.; U.S.G.S., 1 , no. 99.

Fields, map: Alkire, R L., 1.

Holmes County: Lamborn, R. E., 2.

Mayfield pool: Rothrock, H. E., 3.

Petroleum: Alkire, R. L., 2.

Berea sand: De Witt, W., Jr.; U.S.G.S., 1 , no. 99 .

Clinton sand: Lockett, J. R.

Deep wells: Jillson, W. R., 3.

Fields, map: Alkire, R. L., 1.

Holmes County: Lamborn, R. E., 2.

Mayfield pool: Rothrock, H. E., 3.

Petroliferous formations: Dunn, O. C., Jr.

Sand and gravel resources, northern: Smith, W. H.

Geologic maps:

Coshocton County: Lamborn, R. E., 1.

Holmes County: White, G. W., 1.

Index: Boardman, L., 5.

Mayfield gas and oil pool: Rothrock, H. E., 3.

Perry County: Flint, N. K.

Ground water.

Canton area: Kazmann, R. G.

Stream flow and ground-water geology: Cross, W. P.

Historical geology.

Allegheny formation, Dorr Run shale member: Sturgeon, M. T., 1 . 
Ohio-Continued

Historical geology-Continued

Berea sand, Mississippian: De Witt, W., Jr.; U.S.G.S., 1, no. 99.

Cambro-Ordovician: Alkire, R. L.., 2.

Clinton sand: Lockett, J. R.

Dunkard series, cycles: Cross, A. T., 3.

Holmes County: White, G. W., 1.

Monongahela series, cycles: Cross, A. T., :

Petroliferous formations: Dunn, O. C., Ji:

Mineralogy.

Flint Ridge, mineral collecting: Sch:efer, H. V.

Paleontology.

Conodonts, Allegheny formation: Sturgeon, M. T., 2.

Dorr Run shale, faunal list: Sturgeon, M. T., 1.

Petrified logs, Pennsylvanian, tissue preservation: Cross, A. T., 1.

Sigillaroid stump, Permian: Cross, A. T., 2.

Physical geology.

Blue Hole spring: Stout, W. E.

Physiographic geology.

Holmes County: White, G. W., 1.

Oil. See Petroleum.

Oil and gas fields. (Alphabetically by name). Arick oil field, Texas: Shepherd, G. F.

Assumption North pool, Illinois: Bell, A. H., 1.

Assumption pool, Illinois: Bell, A. H., 1. Atlanta oil field, Arkansas: Riggs, C. H.

Benedum oil field, Texas: Deegan, C. J., 1.

Blackfoot oil field, Texas: Branson, D. 0 .

Brookhaven oil field, Mississippi: Womack, R., Jr.

Cairo oil field, Arkansas: Goebel, I. A.

Church Buttes gas field, Wyoming: Carlson, R. F.

Clay Basin gas field, Utah: Fidlar, M. M. Coryville pool, Pennsylvania: Fettke, C. R., 1.

Cuyama oil field, California: Eckis, R.

East Fork-Wharton gas field, Pennsylvania: Ebright, J. R.

East Lance Creek oil field, Wyoming: McCanne, R. W.

Guijarral Hills oil field, California: Loofbourow, J. S., Jr.

Jackson-Kanawha gas field, West Virginia: MeClain, A. H.

Jameson oil field, Texas: Brown, $H$.

La Grange oil field, Mississippi: Sherwin, M. W.

Lance Creek oil field, Wyoming: McCanne, R. W.

Leduc oil field, Alberta: Layer, D. B. Link, T. A., 1.

Little Buck Creek oil field, Wyoming: McCanne, R. W.

Lost Soldier field, Wyoming: Krampert, E. W.

Marine pool, Illinois: Bell, A. H., 1.

Mayfield pool, Ohio: Rothrock, H. E., 3.
Oil and gas fields-Continued

MeDonald oil field, Pennsylvania: Ingham, A. I., 1.

Merigale-Paul oil field, Texas: Moore, H. Mush Creek oil field, Wyoming: Dobbin, C. E., 1; U. S. G. S., 2, no. 103.

New Hope oil field, Texas: Carpenter, C. $B$.

North Sulphur Mtn. oil field, California: Schwade, I. T.

Northwest Sulphur oil pool, Oklahoma: Swirezynski, R. P.

Osage oil field, Wyoming: Dobbin, C. E. 1; U.S.G.S., 1, no. 103.

Passport oil pool, Illinois: Connolly, F. T.

Placerita Canyon oil field, California: Willis, $R$.

Poza Rica oil and gas field, Mexico: Salas, G. P.

Russell Ranch oil field, California: Eckis, $R$.

Salina-Guelph, Ontario: Roliff, W. A., 1.

Salt Creek oil field, Wyoming: Mallory, R. W.

San Ardo oil field, California: Baldwin, T. A.

Sheridan oil field, Texas: Hill, H. B., 1.

Sholem Alechem oil field, Oklahoma: Billingsley, H. R.

Southeast Ceres oil field, Oklahoma: Neal, E. P.

Squire oil field, Texas: Huffman, G. G., 1 . Strake oil field, Texas: Huffman, G. G., 1 . Todd oil field, Texas: Imbt, R. F.

Velma oil pool, Oklahoma: Mallory, W. W. $1,2$.

West Red River field, Oklahoma: Hill, H. B., 2.

Wilmington oil field, California: Gilluly, J., 2.

Oil shale. See also Bituminous rocks; Petroleum.

Classification: Schopf, J. M., 4.

Colorado, Green River: Eisenberg, J. M., 1.

Naval Oil Shale Reserves 1 and 3: Duncan, D. C.; U.S.G.S., 1 , no. 94.

Utah, Green River: Eisenberg, J. M., 1. Oklahoma.

Director's report, Oklahoma Geological Survey, 1947-48: Dott, R. H.

Economic geology.

Ceramic materials: Funnell, J. E.

Dolomite, Mill Creek-Ravia area: Ham, W. E., 1.

Haskell County: Oakes, M. C.

Natural gas, developments, 1948: Wellman, D. C.

Petroleum, developments, 1948: Wellman, D. C.

Dodge City Basin: Maher, J. C., 1; U.S.G.S., 1, no. 101.

Northwest Sulphur pool: Swirczynski, R. P.

Sholem Alechem field: Billingsley, H. R. 
Oklahoma-Continued

Economic geology-Continued

Petroleum-Continued

Southeast Ceres field: Neal, E. P.

West Red River field: Hill, J. B., 2.

Tri-State zinc-lead district, reserves: Ruhl, 0 .

Volcanic ash: Ham, W. E., 2.

Geologic maps.

Anadarko Basin: Jacobsen, C. L., 2.

Dodge City Basin, pre-Pennsylvanian: Maher, J. C., 1; U.S.G.S., 1, no. 101

Haskell County: Oakes, M. C.

Kingfisher County: Schoff, S. L.

Mill Creek-Ravia area: Ham, W. E., 1.

Ground water.

Kingfisher County: Schoff, S. L.

Oklahoma City area: Jacobsen, C. L., 1. Historical geology.

Anadarko Basin: Jacobsen, C. L., 2; Wheeler, R. R., 1.

Arbuckle limestone, Cambro-Ordovician: Ham, W. E., 3.

Des Moines series, east-central: Jackson, N. A.

Dodge City Basin, pre-Pennsylvanian: Maher, J. C., 1; U.S.G.S., 1, no. 101.

Haskell County: Oakes, M. C.

Hugoton Embayment, Anadarko Basin, pre-Pennsylvanian: Maher, J. C., 4.

Mayes formation, Mississippian: Selk, E. $\mathbf{L}$.

Mill Creek-Ravia area: Ham, W. E., 1.

Morrow series, east-central: Jackson, N. A.

Paleozoic, subsurface cross sections: Lukert, L. $\mathrm{H}$.

Velma oil pool, Pennsylvanian: Mallory, W. W., 1, 2.

Verden sandstone, origin: Evans, O. F., 3.

Mineralogy.

Resources: Dott, R. H.

Weatherford meteorite: Beck, C. W., 2.

\section{Paleontology.}

Brachiopoda, Henryhouse formation, Silurian: Amsden, T. W., 2.

Crinoids, Ardmore Basin, Pennsylvanian: Strimple, H. L., 5.

Brownville limestone, Pennsylvanian: Strimple, H. L., 6.

Fayetteville formation, Mississippian: Strimple, H. L., 8.

Hybocrinus crinerensis, Ordovician: Strimple, H. L., 2.

Mooreocrinus bowsheri, Mississippian: Strimple, H. L., 1.

Pennsylvanian: Strimple, H. L., 4, 9. Foraminifera, Walnut formation, Lower Cretaceous: Loeblich, A. R., Jr., 2.

Nautiloids, Pennsylvanian, microstructure: Fischer, A. G.

Trilobita: Frederickson, E. A., Jr., 2.

Dalmanites oklahomae, Silurian: Richardson, ₹. S., Jr., 1.
Oklahoma-Continued

Paleontology-Continued

Honey Creek formation, Cambrian: Frederickson, E. A., Jr., 1.

Petrology.

Spavinaw granite: Strachan, C. G.

Viola formation, rock types, specific gravity: Wengerd, S. A.

Volcanic ash: Ham, W, E., 2.

Physical geology.

Anadarko Basin, structure: Jacobsen, C. L., 2.

Haskell County: Oakes, M. C.

Velma pool: Mallory, W. W., 1, 2.

Physiographic geology.

Caddo canyons, Pleistocene: Ireland, H. A., 2.

Oligocene. See Tertiary.

Olivine, thermochemical study: Sahama, T. G., 2.

Ontario.

Geothermal gradients, Kirkland Lake area: Misener, A. D.

Sudbury area: Misener, A. D.

Timmins area: Misener, A. D.

Radioactivity, rocks: Keevil, N. B.

Economic geology.

Beatty Township: Satterly, J., 1.

Berens River mine, ore minerals: Oliver, T. A.

Dickenson Red Lake gold mine, Balmer Township: Holbrooke, G. L.

Garrison township: Satterly, J., 3.

Gold, Central Patricia mine: Tigert, T. T. Pickle Crow mine: Monette, H. H.

Hard Rock gold mine, Little Longlac district: Morrow, H. F.

Hearst and McFadden Townships: Thomson, J. E.

Kirkland Lake area: Hopkins, H.

Michaud Township, pre-Cambrian: Satterly, J., 2.

Petroleum, Salina-Guelph fields: Roliff, W. A., 1.

Rex-Werner Lakes area: Chisholm, E. O., 2.

Silica, Potsdam sandstone: Keith, M. L.

Silver ores, Miller Lake-O'Brien mine, Gowganda district: Bastin, E. S.

Tin, Linklater Lake, Thunder Bay area: Chisholm, E. O., 1.

Uranium, Theano Point: Lang, A. H., 3. Camray deposit: Lang, A. H., 2.

Geologic maps.

Beatty Township: Satterly, J., 1.

Capreol-Milnet area, Pleistocene: Prest, V. $\mathbf{K}$.

Dickenson Red, Lake gold mine: Holbrooke, G. I.

Garrison Township: Satterly, J., 3.

Hearst and McFadden Townships: Thomson, J. E.

Kirkland Lake area: Hopkins, $H$.

Michaud Township, pre-Cambrian: Satterly, J., 2. 
Ontario-Continued

Geologic maps-Continued

Potsdam sandstone distribution, southeastern: Keith, M. L.

Rex-Werner Lakes area: Chisholm, E. O., 2.

Historical geology.

Beatty Townsh:p: Satterly, J., 1.

Garrison Township, pre-Cambrian: Satterly, J., 3.

Hearst and McFadden townships: Thomson, J. E.

Kirkland Lake area: Hopkins, $H$.

Michaud Township, pre-Cambrian: Satterly, J., 2.

Pleistocene, Capreol-Milnet area, Vermilion River: Prest, V. K.

Sanborn Township, drill core: Ontario Dept. Mines

Seine series, East Shoal Lake: Bruce, E. L.

Silurian strata, southwestern: Roliff, W. A., 1.

Mineralogy.

Berens River mine, ore minerals: Oliver, T. A.

Cancrinite, Blue Mt.: Phoenix, $\mathrm{R}$.

Pitchblende, Theano Point, Lake Superior: Satterly, J., 4.

Pyrite, Kirkland Lake, spectrography: Hawley, J. E., 3.

Silver ore, antimonial: Wells, R. C.

Miller Lake-O'Brien mine, Gowganda district: Bastin, E. S.

Uraninite, geologic age: Holmes, A.

Paleontology.

Microcyclus, Devonian: Stumm, E. C., 3.

Paleobotany, bogs: Potzger, J. E., 2.

Sanborn Township, drill core: Ontario Dept. Mines

Petrology.

Beatty Township: Satterly, J., 1.

Corundum rocks: Moyd, L., 1.

Kirkland Lake area, radioactivity: Slack, H. A.

Nepheline rocks: Moyd, L., 1.

Physical geology.

Cornwall-Massena earthquake, 1944: Milne, W. G., 2.

Hearst and McFadden Townships: Thomson, J. E.

Kirkland Lake area: Hopkins, $H$.

Physiographic geology.

Quetico-Superior area: Atwood, W. W.

Wisconsin glacier recession: Chapman, L. J.

Oolites.

Illinois, Ste. Genevieve formation, Mississippian: Shrode, R. S.

Indiana, Ste. Genevieve formation, Mississippian: Leith, C. J.

Opal. See Gems and gem materials.

Ordovician. See also Paleontology, Ordovician.

Alberta, Paleozoic pre-Waterways strata, Plains area: McGehee, J. R.
Ordovician-Continued

Greenland, Jørgen Brønlunds Fjord area:

Troelsen, J. C.

Kentucky, subsurface: Freeman, L. B.

Manitoba, File-Tramping Lakes area: Harrison, J. M., 1.

Kississing area: Canada G. S., 6.

New York, Hudson Valley: Flower, R. H., 3.

Subsurface: Swartz, F. M., 3.

Trenton limestones, statistical analysis: Chenoweth, P. A.

Newfoundland, eastern: Hayes, A. O., 1.

Pennsylvania, formations: Craig, L.' C. Subsurface: Swartz, F. M., 3.

Saskatchewan, Kississing area: Canada G. S., 6 .

Tennessee, central: Wilson, C. W., Jr.

Facies: Rodgers, J., 1.

Utah: Hintze, L. F.

West Virginia: Woodward, H. P.

Ore deposits, origin. See Economic geology; Mineral deposits, origin. Oregon.

Malheur Siphon displacement, engineering geology: Rhoades, S. F., 5.

Geologic maps.

Coastal area, Cape Kiwanda-Cape Foulweather, Tertiary: Snavely, P. D., Jr.; U.S.G.S., 1, no. 97.

Index: Boardman, L., 6.

Kerby quadrangle: Wells, F. G., 2.

Newport-Waldport area, Lincoln County: Vokes, H. E., 1; U.S.G.S. 1, no. 88.

Historical geology

Coastal area, Cape Kiwanda-Cape Foulweather, Tertiary: Snavely, P. D., Jr.; U.S.G.S., 1, no. 97.

Kerby quadrangle: Wells, F. G., 2.

Newport-Waldport area, Lincoln County: Vokes, H. E., 1; U.S.G.S., 1, no. 88.

Mineralogy.

Garnierite, Riddle: Pecora, W. T., 1.

Josephinite: Morley, R. A.

Priceite, Curry County: Staples, L. W., 1.

Quartz pseudomorphs after halite: Staples, L. W., 2.

Rare minerals, collecting: Dake, H. C., 2. Paleontology.

Ancient forests: Chaney, R. W., 1.

Coal, fossils, Coos Bay field: Schopf, J. M., 1.

Faunal lists, coastal area, Cape KiwandaCape Foulweather, Tertiary: Snavely, P. D., Jr; U.S.G.S., 1, no. 97.

Foraminifera, Toledo formation, Eocene: Cushman, J. A., 6.

Koelreuteria, Oligocene: Arnold, C. A., 3. Mammoth bones, Silverton, age: Hansen, H. P., 3.

Newport-Waldport area, Lincoln County: Vokes, H. E., 1; U.S.G.S., 1, no. 88.

Odell Lake site, paleo-Indians: Cressman, L. S.

Osmundites oregonensis: Arnold, C. A., 1. 
Oregon-Continued

Paleontology - Continued

Sequoia, Miocene, John Day Basin area: Chaney, R. W., 3.

\section{Petrology.}

Alteration, granitization, rheomorphism: Goodspeed, G. E., 1.

Deschutes project, rock samples, petrography: Mielenz, R. C., 9, 11.

Kerby quadrangle: Wells, F. G., 2.

Winona dam, Rogue River, serpentine: Mielenz, R. C., 4.

\section{Physical geology.}

Faulting: Allison, I. S.

Newport-Waldport area, Lincoln Co.: Vokes, H. E., 1; U.S.G.S., 1, no. 88.

\section{Physiographic geology}

Crater Lake, origin: Eisenberg, J. M., 2. Long Tom River, history: Baldwin, E. M.

\section{Orogeny.}

Axis shifting theory: Fisher, J. E., 2.

Blister hypothesis: Wolfe, C. W., 3, 4, 5.

Canadian Shield: Gill, J. E., 2; Wilson, J. T., 2.

Colorado, South Park: Stark, J. T.

Compressional mountains, tectonic history: Rich, J. L., 1.

Distribution in geologic time: Rutten, L. M. R.

Frequency, periodicity: Rutten, L. M. R.

Greenland, East, Watkins Mts., origin: Wager, L. R.

Pre-Cambrian: Noe-Nygaard, A.

Qapiarfik, Disko Bay area: Malaurie, J. N., 2.

Isostatic adjustment, geochemical effect: Wahl, Walter.

Kinetic theory: Fisher, J. E., 3.

Mexico: Alvarez, M., Jr.

Sierra Madre: Mullerried, F. K. G., 1.

Mineral deposits, origin, location: Reinhardt, E. V.

Nevada, Muddy Mtn. area: Longwell, C. R., 1.

Newfoundland, Corner Brook-Stephenville area: Walthier, T. N., 1.

Paleozoic geosynclines and island ares: Kay, G, M., 2.

Periodicity theory: Gilluly, J., 3.

Stress directions: Misch, P., 2.

United States, Great Basin: Blackwelder, E., 1.

Utah: Eardley, A. J., 3.

Ostracoda. See also Crustacea.

California, southern, Pliocene: Crouch, R. W.

Wildcat coast section, Pliocene: Stewart, R. E.

Eucytherura, Cretaceous, Tertiary, Gulf Coast, U. S.: Weingeist, L.

Gulf of Mexico, criterion for paleoecology: Rothwell, W. T., Jr.

Hinge mechanism, Paleozoic: Sohn, I. G., 2.
Ostracoda-Continued

Leperditiidae, classification: Swartz, F. M., 2.

Louisiana, De Soto, Red River Parishes: Murray, G. E., Jr., 1.

Paleozoic, species fluctuation: Warthin, A. $\mathbf{S}$.

Texas, northeastern, Upper Jurassic: Swain, F. M., 3.

United States, western interior, early Tertiary: Swain, F. M.; 1.

Oxidation and reduction in geochemistry: Mason, B. H., 1.

Overthrusts. See Thrusts and thrusting.

Paleobotany. See also Algae; Paleontology.

Alberta, glacial forests: Hansen, H. P., 1. Cretaceous: Bell, W. A.

Paleocene: Bell, W. A.

Peat bogs, pollen analysis: Hansen, H. P., 2.

Algae, Medicine Bow Mts., Wyoming: Fenton, C. L.

Organic limestones: Johnson, J. H., 1. Algal nodules, Lower Cambrian, Marble Mts., California: Riccio, J. F.

Angiosperms, evolution: Chaney, R. W., 2.

British Columbia, McConnell Creek maparea, list: Lord, C. S., 1.

California, San Francisco Bay area, Pleistocene: Weaver, C. E.

Coal, research since 1943: Schopf, J. M., 5.

Colorado, South Park flora: Stark, J. T.

Cycadeoidea, Cretaceous, Black Hills, South Dakota: McIntosh, A. C.

Diatomite, Lompoc area, California: Cook, R. B.

Ecotones, Tertiary, North America: Chaney, R. W., 4.

Facies interpretation, Tertiary, western United States: Axelrod, D. I., 1.

Great Basin, Tertiary: Axelrod, D. I., 2.

Greenland, East, selaginelloid strobilus, Triassic: Lundblad, B.

Idaho, tree ferns: Andrews, H. N., Jr., 1.

Illinois, Botryopteris: Mamay, S. H.

Indiana, calamite, new, Pennsylvanian: Reed, F. D., 2.

Iowa, cordaitean fructifications, Pennsylvanian: Fry, W. L.

Fossil seeds, Urbandale coal mine, Des Moines, new genus: Andrews, H. N. Jr., 2.

Lepidocarpon: Andrews, H. N., Jx., 3.

Louisiana, De Soto, Red River Parishes: Murray, G. E., Jr., 1.

Lycopods, Devonian-Mississippian: Koskins, J. H., 2.

Magothy formation, Cretaceous: Penny, J. $\mathrm{S}$.

Massachusetts, Boston area, Boylston Street Fishweir II, Pleistocene: Barghoorn, E. S., Jr., 1, 2; Conger, P. S.; Johnson, F.; Wilson, L. R., 1. 
Paleobotany-Continued

Medullosae, new species, Iowa, Illinois, Pennsylvanian: Baxter, R. W.

Mexico, Tepexpan, diatoms: De Terra, H., 2.

Michigan coal basin: Arnold, C. A., 2. Missouri, spores, Pennsylvanian: Schemel, M. $P$.

New Albany shale, Devonian: Hoskins, J. H., 1.

New Mexico, Ogallala algal limestone, Pliocene: Van Tuyl, F. M., 1.

Ohio, sigillaroid stump: Cross, A. T., 2.

Ontario, bogs: Potzger, J. E., 2.

Oregon, coal fossils, Coos Bay field: Schopf, J. M., 1.

Forests: Chaney, R. W., 1.

Koelreuteria, Oligocene: Arnold, C. A., 3.

Silverton, peat beds, age: Hansen, H. P., 3.

Organic sediments, palececology: Breger, I. A.

Osmundites oregonensis, Oregon Eocene: Arnold, C. A., 1

Petrified logs, tissue preservation: Cross, A. T., 1.

Pinus remorata: Mason, $\mathrm{H}$. L.

Plant and animal interdependence: Taylor, W. P

Plant evolution, rate: Stebbins, G. L., Jr. Plant morphology, evolution: Just, T. K.

Plant remains in organic sediments: Barghoorn, E. S., Jr., 4.

Pleistocene biogeography: Deevey, E. S., Jr.

Pollen analysis, paleoclimatology determination: Knox, A. S.

Paleoecology: Cain, S. A.

Pollen grains and spores, classification: Erdtman, G.

Pteridosperm male fructifications of Dolerotheca, Illinois: Schopf, J. M., 2.

Pteridosperms, Pennsylvanian, Iowa, Illinois: Baxter, $R$. W.

Quebec, bogs: Potzger, J. E., 1.

Sequoia, Miocene, John Day Basin area, Oregon: Chaney, R. W., 3.

South Carolina, Santee Valley: Berry, E. W., 3.

South Dakota, Black Hills, Cretaceous, Tertiary flora: McIntosh, A. C.

Speciation and systematics: Mayr, E., 1.

Sphenophyllum, Psaronius, Carboniferous: Reed, F. D., 1.

United States, Western Interior, Tertiary: Wilson, L. R., 2.

Utah, Cache Valley, Pliocene: Brown, R. W., 4.

Vermont, Brandon lignite, Tertiary: Barghoorn, E. S., Jr., 3, 5; Spackman, W., Jr.

Washington, Russell Forest, petrified wood: Bateman, E. S.
Paleobotany-Continued

Washington-Continued

Puget Lowland, pollen analyses: Hansen, H. P., 4.

Paleocene. See Tertiary.

Paleoclimatology. See also Geologic history.

Determination by pollen analysis: Knox, A. $\mathbf{S}$.

General: Brooks, C. E. P.

Leaching of carbonates in loess and glacial drift, age correlation: Flint, R. F., 2.

New Mexico, southeastern, caliche: Bretz, J H., 3.

Pacific Coast, Tertiary climate: Durham, J. W., 3.

Pennsylvania, Pleistocene: Peltier, L. C.

Physical effects, Pleistocene climate changes: Smith, H. T. U., 2.

Pleistocene: Deevey, E. S., Jr.; Landsberg, $\mathrm{H}$.

United States, Great Basin: Antevs, E. V., 1.

Paleoecology

Exline limestone, Pennsylvanian, Iowa and Missouri: Cline, L. M.

Great Basin, Pleistocene: Hubbs, C. L.

Gulf of Mexico, ostracodes as criteria: Rothwell, W. T., Jr.

Massachusetts, Boylston Street Fishweir II, Lower Peat: Wilson, L. R., 1.

Organic sediments: Breger, I. A.

Pollen analysis: Cain, S. A.

Ripple marks: Evans, O. F., 2.

Tectonics and environments, sedimentary: Krumbein, W. C.

West Indies, fossil Globigerina, ecologic interpretation: Bronniman, $\mathbf{P}$.

Paleogeographic maps. See Maps.

Paleogeography. See also Geologic history; Paleoclimatology.

Appalachian Basin, northern, Silurian: Rittenhouse, G., 1, 6; U. S. G. S., 1, no. 100 .

Arizona, southeastern, Lower Cretaceous: Stoyanow, A. A., 1

British Columbia, Selkirk Mts., pre-Cambrian-Paleozoic boundary: Okulitch, V. J.

Canada, Churchill area: Richards, H. G., 2.

Post-Pleistocene seaway, James Bay to Gulf of St. Lawrence: La Rocque, A., 1.

Crinoid evolution: Moore, R. C., 8. Faunal migration: Newell, N. D., 2.

Illinois, McClosky sand, Mississippian: Connolly, F. T.

Mammal migration: Simpson, G. G., 2.

Panama, Tertiary: Woodring, W. P.

Pennsylvania, Middle Ordovician: Craig, L. C.

Texas, Panhandle: Roth, R. I., 2.

West Virginia, Greenbrier formation: Rittenhouse, G., 5 . 
Paleontology. For areal see sub-heading $\mathrm{Pa}-$ Paleontology-Continued leontology under the various states and countries. See also the classes of animals; Evolution; Invertebrata; Paleobotany; Restorations.

Analysis of variance, application: Miller, R. L.

Arachnida, Paleozoic: Petrunkevitch, A.

Biogenetic laws, stratigraphic application: Mathews, A. A. L.

Bryozoa, Paleozoic, genotypes: Duncan, $\mathbf{H}$.

Cancellariidae, Miocene Gastropoda, tropical America: Marks, .J. G.

Cephalopoda, nautiloids, Tertiary development: Miller, A. K., 4.

Classification: Weller, J. M.

Coralliochama, siphon: Mullerried, F. K. G., 8.

Crinoid evolution, relation to paleogeography: Moore, R. C., 8.

Dinosaur National Monument, ColoradoUtah: Stokes, W. L., 1.

Dipnoi, evolution: Westoll, T. S.

Dolichoharpes, generic description: Whittington, $\mathrm{H} . \mathrm{B}$.

Evolution: Simpson, G. G., 4, 6.

Fossil evidence: Romer, A. S., 1.

Significance: Simpson, G. G., 3.

Fauna distribution, intercontinental: Wolfson, $A$.

Faunal range and migration: Newell, N. D., 2.

Faunal succession: Camp, C. L., 2.

Fossil collecting: Dondlinger, P. T.

Northern Canada: Richards, H. G., 2.

Fossils, early ideas on: Ley, W.

Genera distribution, relation to diastrophism: Henbest, L. G.

Geneties and evolution, common problems: Jepson, G. L., 1.

Haliotidae, distribution: Sorensen, A.

Hypodigm specimens: Newell, N. D., 1.

Invertebrate evolution, periodicity: Newell, N. D., 4.

Limestones, organic: Johnson, J. H., 1.

Mammal migration: Simpson, G. G., 2.

Mollusca, stratigraphic importance: Yen, T.-C., 3.

Nautiloidea, Devonian, new genera: Flower, R. H., 1.

Nomenclature, type specimens: Newell, N. D., 1.

Orthogenesis: Jepson, G. L., 3.

Paleontology, biology, geology, relations: Rama Rao, L.

Phyletic studies, relation to stratigraphy: Flower, R. H., 2.

Plant and animal interdependence: Taylor, W. $\mathbf{P}$.

Prosopon, proposed term for ornament: Gill, E. D.

Ptychomya, Mexico: Mullerried, F. K. G., 3.

Reptilia, Ceratopsia, growth patterns, deformed coordinate system: Lull, R. S,

Reptilla-Continued

Phytosaurs, adaptation: Colbert, E. H., 1.

Procolophonids, adaptation: Colbert, E. H., 1.

Rhinoceros, evolution: Wood, H. E., 1.

Scientific names, glossary: Northrop, S. A. Selection: Jepson, G. L., 3.

Size increase in fossil invertebrates: Newell, N. D., 3.

Speciation and systematics: Mayr, E., 1. Successional: Stenzel, H. B., 1.

Species concept: Burma, B. H.; Mayr, E., 2.

Stereophotography, paleontological tool: Evitt, W. R.

Taeniodonts, evolution: Patterson, B., 1.

Taxonomy, procedure: Schenk, .E. T.

Type specimens: Newell, N. D., 1.

Vertebrate evolution: Watson, D. M. S.

Comparative anatomy: Davis, D. D.

Periodicity: Simpson, G. G., 7 .

Vertebrates, bibliography, 1939-43: Camp, C. L., 1 .

Cambrian.

Appalachians, stratigraphy and paleontology: Wilson, J. L., 2.

Arizona, trilobite sequence: Stoyanow, A. A., 2.

California, Marble Mts.: Riccio, J. F.

Oklahoma, Honey Creek formation, trilobites: Frederickson, E. A., Jr., 1.

Texas, Trilobita, Elvinia zone, Wilberns limestone: Wilson, J. L., 1.

Vermont, Monkton formation: Tasch, $\mathbf{P}$.

Carboniferous.

Alabama, Black Warrior Basin, Foraminifera, Mississippian: Thompson, M. L.

British Columbia, Lithostrotion, Mississippian: McLaren, D. J.

Colorado, La Plata district: Williams, J. Steele, 1.

Corals, cuneate, Mississippian: Easton, W. $\mathrm{H}$.

Illinois, eurypterid, Mazon Creek: Kjellesvig-Waering, E. N.

Pteridosperm male fructifications of $\mathrm{Do}$ lerotheca: Schopf, J. M., 2.

Indiana, calamite, new: Reed, F. D., 2.

Iowa, conodonts, Mississippian: Thomas, L, A.

Pella beds, Mississippian: Youngquist, W. L., 4 .

Pennsylvanian: Youngquist, W. L., 2.

Prospect Hill formation, Mississippian: Youngquist, W. L., 1.

Fossil seeds, new genus: Andrews, $H$. N., Jr., 2.

Kansas, crinoids, Pennsylvanian: Strimple, H. L., 3, 4 .

Pelycosaurs, Pennsylvanian: Peabody, F. E.

Kentucky, Edestus, shark: Jillson, W. R., 6. 
Paleontology-Continued

Carboniferous-Continued

Michigan coal basin, flora: Arnold, C. A., 2.

Mississippi, Black Warrior Basin, Foraminifera, Mississippian: Thompson, M. L.

Missouri, Athyris, Burlington limestone: Unklesbay, A. G.

Spores, Pennsylvanian: Schemel, M. P.

Nebraska, crinoids, Iatan formation, Pennsylvanian: Strimple, H. L., 7.

Nevada, White Pine shale, Cephalopoda: Youngquist, W. L., 3.

Ohio, conodonts, Allegheny formation: Sturgeon, M. T., 2.

Dorr Run shale, Pennsylvanian: Sturgeon, M. T., 1.

Oklahoma, crinoids, Ardmore Basin, Pennsylvanian: Strimple, H. L., 5.

Brownville limestone, Pennsylvanian: Strimple, H. I., 6.

Fayetteville formation, Mississippian: Strimple, H. L., 8.

Mississippian: Strimple, H. L., 1.

Pennsylvanian, new species: Strimple, H. L., 4, 9.

Nautiloids, microstructure: Fischer, A. G.

Oregon, forests: Chaney, R. W., 1.

Pennsylvanian system: Moore, R. C., 3.

Pteridosperms, Pennsylvanian, Iowa, Illinois: Baxter, R. W.

Texas, Scaphopoda, Pennsylvanian: Miller, A. K., 3 .

United States, Cephalopoda: Miller, A. K., 5.

Sphenophyllum, Psaronius, anatomy: Reed, F. D., 1.

\section{Cretaceous.}

Alberta, Athabaska River: Wickenden, R. T. D.

Flora: Bell', W. A.

Laosaurus, dinosaur: Russell, L. S., 2.

Peace River Plains: Gleddie, J.

Allomorphina: Cushman, J. A., 1, no. 329.

Arizona, southeastern, Mollusca: Stoyanow, A. A., 1.

Arkansas, Arkadelphia marl, Foraminifera: Cushman, J. A., 3.

California, Foraminifera, Franciscan, Santa Clara County: Glaessner, M. F.

Mollusea, genetic lines: Popenoe, W. P., 2.

San Francisco Bay area, faunal and floral lists: Weaver, C. E.

Chilostomellidae: Cushman, J. A., 1, no. 331.

Colorado, Pierre formation, faunal lists: Griffitts, M. O., 2.

Cuba, Globorotalia: Cushman, J. A., 1, no. 326.

Durania, rudistid, Niobrara formation: Griffitts, M. O., 1.

Greenland, North-east: Maync, W., 4.
Paleontology-Continued

Cretaceous-Continued

Guatemala, echinoid: Cooke, C. W.

Idaho, tree ferns: Andrews, H. N., Jr., 1. Kansas, Foraminifera: Loeblich, A. R., $\mathrm{Jr} ., 1$.

Maryland, dinosaurs: Vokes, H. E., 2.

Mexico, Gastropoda, Nuevo León: Mullerried, F. K. G., 4.

La Peña formation, Sierra de los Muertos: Humphrey, W. E.

Pisces: Maldonado-Koerdell, M., 2.

Tampico embayment: Wicher, C. A.

Mollusca, fresh-water: Yen, T.-C., 1.

Montana, teleost, Livingston formation: Schaeffer, B.

New Jersey, Raninella testacea: Kindle, C. H., 1 .

Oklahoma, Walnut formation, Foraminifera: Loeblich, A. R., Jr., 2.

Oregon, forests: Chaney, R. W., 1.

Quadrimorphina: Cushman, J. A., 1, no. 329.

South Dakota, Alzadasaurus, elasmosaur, Iona: Welles, S. P.

Black Hills, flora: McIntosh, A. C.

Texas, microfossils in plesiosaur matrix, Lake Waco: Graham, J. J., 1.

Walnut formation, Foraminifera: Loeblich, A. R., Jr., 2.

United States, eastern, Magothy formation, conifers: Penny, J. S.

Gulf Coast, Ostracoda, Eucytherura: Weingeist, $L$.

Wyoming, Ammonoidea, Greybull area: Haas, 0., 1.

\section{Devonian.}

Alberta, fossil zones: Warren, P. S., 1.

Favositidae, types: Stumm, E. C., 1.

Flora, New Albany shale: Hoskins, J. H., 1.

Greenland, East, Pisces, Bothriolepinae: Stensiö, E. A.

Iowa, conodonts: Thomas, L. A.

Manitoba, Gastropoda: La Rocque, A., 2.

Michigan, corals, Traverse group: Ehlers, G. M., 1 .

Gastropoda: La Rocque, A., 2.

Microcyclus: Stumm, E. C., 3.

Nautiloidea: Flower, R. H., 1.

New York, Mytilarca knappi, holotype, Devonian: Smith, B.

Ophiurans, Ithaca formation: Johnson, R. B.

Pc.chyphyllum vagabundum: Ehlers, G. M., 2.

Ontario, Microcyclus: Stumm, E. C., 3.

Tetracorals, revision: Stumm, E. C., 2.

\section{Jurassic.}

Chilostomellidae: Cushman, J. A., 1, no. 331.

Cuba, Reptilia, Cryptocleidus: Torre Mandrazo, R., de la.

Greenland, East; Maync, W., 3. 
Paleontology-Continued

Jurassic-Continued

Mexico, La Peña formation, Sierra de los Muertos: Humphrey, W. E.

Mollusca, Morrison formation, correlation with Europe: Yen, T.-C., 4.

Oregon, forests: Chaney, R. W., 1.

Texas, northeastern, Ostracoda: Swain, F. M., 3.

Mesozoic.

Nicaragua: Mullerried, F. K. G., 7.

Ordovician.

Iowa, Maquoketa shale, brachiopods: Wang, Y.

Cephalopod coquina: Miller, A. K., 1.

Missouri, Dolichoharpes, Kimmswick formation: Whittington, H. B.

New Jersey, Martinsburg formation: Willard B., 1.

New York, Schenectady formation, invertebrates: Howell, B. F., 2.

North America, Eobronteus, Trilobita: Sinclair, G. W., 1.

Oklahoma, crinoid: Strimple, H. L., 2.

Pennsylvania, fossil lists: Craig, L. C.

Quebec, Trilobita, Loganopeltoides, Loganopeltis: Raw, $\mathrm{F}$.

Tennessee, graptolites, Athens shale: Decker, C. E.

Utah, Garden City formation, trilobite zones: Ross, R. J., Jr.

Virginia, Dolichoharpes, Edinsburg formation: Whittington, H. B.

Graptolites, Athens shale: Decker, C. E.

Paleozoic.

Arachnida: Petrunkeviteh, A.

Florida, Lingulepis floridaensis, well cores: Howell, B. F., 3.

Ostracoda, hinge mechanism: Sohn, I. G., 2.

Species fluctuation: Warthin, A. S.

Tennessee, central, pre-Chattanooga: Wilson, C. W., Jr.

Permian.

Arizona, ammonoids, Mustang Mts.: Stoyanow, A. A., 3.

Calceolispongia: Teichert, $\mathbf{C}$.

Greenland, Permoteuthis groenlandica: Rosenkrantz, A.

Mammalia, ancestors: Colbert, E. H., 2.

Mexico, pisces: Maldonado-Koerdell, M., 2.

Nantiloidea: Miller, A. K., 2.

New Mexico, Abo formation, amphibians: Langston, W., Jr., 2.

Oniscoidichnus for Isopodichnus Brady, 1947: Brady, L. F.

Texas, amphibian spine: Lundelius, $\mathbf{E}$.

Apache Mts., algae: Johnson, J. H., 2.

Vale formation, fish tooth plates: Wilson, J. A.

Pre-Cambrian.

Michigan, stromatolites, Lower Huronian: Richardson, E. S., Jr., 2.
Paleontology-Continued

Quaternary.

Alaska, frozen mammoth, Pleistocene: Anthony, H. E.

Alberta, peat bogs, pollen analysis: Hansen, H. P., 2.

Arizona, Buèll Park, nonmarine mollusks: Drake, R. J.

Calciphilus, Black Mesa: Chamberlin, R. V.

California, asphalt deposits, Insecta: Pierce, W. D., 2.

Cathartid vulture skulls: Fisher, H. I. McKittrick asphalt pit: Pierce, W. D., 1 . Pinus remorata: Mason, H. L.

Puente Hills, Foraminifera: Daviess, S. N.; U. S. G. S., 1, no. 83.

San Francisco Bay area, faunal and floral lists: Weaver, C. E.

Vertebrates: Savage, D. E.

Southern, marine Pleistocene Aves: Howard, H., 1.

El Salvador, mammals, Pleistocene: Stirton, R. A.

Foraminifera, Pleistocene submarine core, Caribbean Sea: Phleger, F. B., Jr., 1.

Pliocene-Pleistocene boundary problem: Thalmann, H. E., 7.

Kansas, Aves, Pleistocene: Downs, T. Meade County: Hibbard, C. W., 1.

Tremarctotherium, Pleistocene: Rinker, G. C.

Kentucky, Lower Blue Licks, Pleistocene vertebrates: Jillson, W. R., 1, 2.

Manitoba, Pleistocene elephants: Leith, E. I.

Massachusetts, Boston area, Boylston Street Fishweir II, Pleistocene: Barghoorn, E. S., Jr., 1, 2.

Diatoms: Conger, P. S.

Foraminifera: Phleger, F. B., Jr., 2.

Lower Peat: Wilson, L. R., 1.

Megalonyx tooth, Northwest Territories: Stock, C., 2.

Mexico, horses: Arellano, A. R. V., 2.

Reynosa area, Gulf Coast, faunal lists: Guzmán, E. J.

Tepexpan man: De Terra, H., 1, 2; Mullerried, F. K. G., 2.

Vertebrates: Maldonado-Koerdell, M., 1.

Missouri, St. Louis, Cherokee cave, mammals: Simpson, G. G., 5.

Oregon, forests: Chaney, R. W., 1.

Odell Lake paleo-Indian site: Crossman, L. S.

Silverton, mammoth bones: Hansen, H. P., 3.

Panama, Pleistocene, Isla Escudo de Veragua: Aguayo, C. G., 2.

Pelecypoda, Pacific Coast: Parker, P. E. Pleistocene biogeography: Deevey, E. S., Jr.

Pleistocene research: Flint, R. F., 3.

Texas, Clear Fork, Pleistocene man:* Ray, c. $\mathbf{N}$. 
Paleontology-Continued

Quaternary-Continued

Vertebrata, Pleistocene: Jibbard, C. W., 4. Silurian.

Oklahoma, Brachiopoda, Henryhouse formation, Pontotoc (lounty: Amsden, T. W., 2.

Dalmanites oklahomae: Richardson, E. S., Jr., 1.

Tennessee, Brownsport formation: Amsden, T. W., 1.

Tertiary.

Alabama, Foraminifera: Bandy, O. L., $1,2$.

Alberta, flora, Paleocene: Bell, W. A.

Allomorphina: Cushman, J. A., 1, no. 329.

California, Aves, Pliocene, San Diego area: Howard, H., 2.

Cathartid vulture skulls: Fisher, H. I.

Dendraster elsmerensis: Durham, J. W., 1.

Elphidium: Graham, J. J., 2.

Gastropoda, Eocene: Hanna, G. D.

Mammalia, Titus Casıyon formation: Stock, C., 1.

Mancalla, Pliocene fligh tless bird: Miller, L. $\mathbf{H}$.

Miocene giant oysters, Shell Peak: Martin, $\mathrm{L}$.

Mount Diablo, Marysville Butte area, faunal lists: Stewar, R. B.; U. S. G. S., 2 , no. 34 .

Mytilus, Pliocene: Manılra, Y. T.

Pinniped, San Diego, Pliocene: Burleson, G. L.

Puente Hills, Foraminifera: Daviess, S. N.; U. S. G. S., 1. no. 83 .

Rodents, lagomorphs, u:per Sespe: Wilson, R. W., 3.

San Francisco Bay a ea, faunal and floral lists: Weaver, C. E.

Vertebrates: Savage, D. E.

Southern, Eocene rodents: Wilson, R. W., 1.

Pliocene Ostracoda: Srouch, R. W.

Wildeat coast section, Foraminifera, Pliocene: Stewart, R. E.

Mollusca, Pliocene: S :ewart, R. E. Ostracoda, Pliocene: Stewart, R. E.

Chilostomellidae: Cushma1,, J. A., 1, no. 331.

Colorado, Florissant bed:;, Insecta, Miocene: Melander, A. I.

Rodents, Oligocene, White River area: Wilson, R. W., 2.

Taeniodonts, Lampadophorus, DeBeque area, Paleocene: Patterson, B., 2.

Cuba, Globorotalia: Cushnıan, J. A., 1, no. 326.

Mollusca, Miocene Baracoa area: Aruayo, C. G., 2.

Somorrostro Hills, Harana area, Miocene: Aguayo, C. G., 3.

Cubitostrea, speciation, erolution: Stenzel, H. B., 1.
Paleontology-Continued

Tertiary-Continued

Dominican Republic, Foraminifera: Bermúdez y Hernández, P. J., 2.

Miocene Mollusca: Aguayo, C. G., 1.

Foraminifera, Pliocene-Pleistocene boundary problem: Thalmann, H. E., 7.

Rotaliid, Chapmanininae: Frizzell, D. L., 2.

Honduras, Osteoborus, Pliocene, Gracias area: McGrew, P. 0.

Kansas, Saw Rock Canyon, Pliocene: Hibbard, C. W., 2.

Vertebrata, upper Pliocene, Keefe Canyon, Meade Co.: Hibbard, C. W., 3.

Louisiana, De Soto, Red River Parishes: Murray, G. E., Jr., 1.

Foraminifera, Cane River formation, Eocene: Hussey, K. M.

Harang formation, Miocene: Pope, D. E. Foraminifera: Smith, D. J.

Mexico, Equus, Pliocene: Lance, J. F.

Horses: Arellano, A. R. V., 2.

Pisces: Maldonado-Koerdell, M., 2.

Reynosa area, Gulf Coast, faunal lists: Guzmán, E. J.

Rincon fauna rodents, western Chihuahua: Wilson, R. W., 5.

Rudistid, Tabasco area: Mullerried, F. K. G., 5.

Mississippi, central: Miss. Geol. Soc., 1.

Covington County well, Foraminifera, Tertiary: Alexander, C. I.

Montana, teleost, Livingston formation: Schaeffer, B.

Nautiloidea, development: Miller, A. K., 4.

Nevada, Chalk Spring, Clarendonian fauna: Macdonald, J. R., 1.

Mammalia: Macdonald, J. R., 2.

New Mexico, Mammalia, Nacimiento formation, Eocene: Wilson, R. W., 6.

North America, western, ecotones: Chaney, R. W., 4.

North Carolina, Harrellsville, Miocene fauna: Berry, E. W., 2.

Orbulina, index fossils: Tromp, S. W.

Oregon, coastal area, Cape Kiwanda-Cape Foulweather, faunal lists: Snavely, P. D., Jr.; U. S. G. S., 1, no. 97.

Forests: Chaney, R. W., 1.

John Day Basin area, Miocene Sequoia: Chaney, R. W., 3.

Koelreuteria, Oligocene: Arnold, C. A., 3.

Newport-Waldport area, faunal lists: Vokes, H. E., 1; U. S. G. S., 1, no. 88 . Osmundites oregonensis, Eocene: Arnold, C. A., 1.

Toledo formation, Foraminifera, Eocene: Cushman, J. A., 6.

Panama, Mollusca: Woodring, W. P.

Nomenclature, Miocene Cancellariidae: Marks, J. G.

Pavoninoides, Oligocene: Bermúdez y Hernández, P. J., 1. 
Paleontology-Continued

Tertiary-Continued

Panama-Continued

Foraminifera, Eocene: Cole, W. S. Pelecypoda, Pacific Coast: Parker, P. E.

Quadrimorphina: Cushman, J. A., 1, no. 329.

Rodents: Wilson, R. W., 4.

South Dakota, Black Hills fiora: McIntosh, A. C.

Texas, Frio formation, faunal lists: Reedy, M. F., Jr.

Trinidad, nomenclature, Miocene Cancellariidae: Marks, J. G.

Sphaeroidina: Cushman, J. A., 1, no. 325.

United States, Gulf Coast, Ostracoda, Eucytherura: Weingeist, $\mathrm{L}$.

Promerycochoerinae, oreodonts: Schultz, C. $B$.

Sphaeroidina: Cushman, J. A., 1, no. 325.

Western Interior, paleobotany: Wilson, L. R., 2.

Ostracoda: Swain, F. W., 1.

Utah, Pliocene flora, Cache Valley: Brown, R. W., 4.

Vermont, Brandon lignite, flora: Barghoorn, E. S., Jr., 3; Spackman, W., Jr.

Virginia, Yorktown, Foraminifera, Eocene: Cushman, J. A., 2.

Washington, Astoria formation, Foraminifera, Miocene: Rau, W. W.

Blue Lake, rhinoceros mold in Miocene basalt: Chappell, W. M.

Quinault formation, Foraminifera, Pliocene: Cushman, J. A., 5.

West Indies, fossil Globigerina, ecologic interpretation: Bronniman, $\mathbf{P}$.

Nomenclature, Miocene Gancellariidae: Marks, J. G.

Wyoming, Eocene insectivore, Bridger formation: Gazin, C. L.

Hoplophoneus, Brule formation: Hough, J. $\mathbf{R}$.

Upper Eocene mammals, Wind River Basin: Wood, A. E.

Triassic.

Greenland, East, trails: Nielsen, E., 2.

Selaginelloid strobilus: Lundblad, B.

Mammalia, ancestors: Colbert, E. H., 2.

Massachusetts, Turner's Falls, chimaeroid egg capsules: Bock, W.

Mexico, Zacatecas: Maldonado-Koerdell, M., 3.

Phytosaurs, adaptation: Colbert, E. H., 1.

Pisces, Prince William County, Virginia: Baer, F. M.

Procolophonids, adaptation: Colbert, E. H., 1.

Texas, Camp Springs, Paleorhinus: Langston, W., Jr., 1.

Wyoming, nothosaurs, Alcova limestone: Zangerl, $\mathbf{R}$.
Paleozoic.

Alabama, northern: Mississippi Geol. Soc., 2.

Subsurface: Applin, P. L.

Anadarko Basin, Hugoton Embayment, mid-Continent: Maher, J. C., 4.

Appalachian geosyncline, central basin, stratigraphy: Lafferty, R. C., Jr.

Facies, sequences: Sloss, L. L., 1.

Florida, subsurface: Applin, P. L.

Georgia, subsurface: Applin, P. L.

New Mexico, southeast: Lloyd, E. R.; West Texas Geol. Soc., 6.

Tennessee, south central: Mississippi Geol. Soc., 2.

Texas, trans-Pecos area: West Texas Geol. Soc., 6.

Utah, Uinta Basin: Baker, A. A.

Wyoming, Powder River Basin: Thomas, H. D., 2.

Panama. See also Central America.

Historical geology.

General: Rubio, A.

Tertiary strata: Woodring, W. P.

Paleontology.

Cancellariidae, Miocene Gastropoda: Marks, J. G.

Foraminifera, large, Eocene: Cole, W. S.

Mammal migration, Tertiary: Woodring, W. $P$.

Mollusca, Pleistocene, Isla Escudo de Veragua: Aguayo, C. G., 2.

Tertiary: Woodring, W. P.

Pavoninoides, Oligocene: Bermúdez y Hernández, P. J., 1.

Physical geology.

Landslides, Canal Zone: MacDonald, D. F.

Seismology: Rubio, A.

Structure: Rubio, A.

Paragenesis.

California, Penn zinc-copper mine, Calaveras County: Heyl, G. R., 3.

Garnet minerals, North Creek, New York: Shaub, B. M., 3.

Silver ores, Miller Lake-O'Brien mine, Gowganda district: Bastin, E. S.

Utah, East Tintic district: Lovering, T. S., 1.

Peat. See also Bogs; Paleobotany; Pollen analysis.

Alberta, pollen analyses: Hansen, H. P., $1,2$.

Massachusetts, Boston area, Boylston Street Fishweir II, analyses: Barghoorn, E. S., Jr., 2.

Nova Scotia: Leverin, H. A.

Oregon, Silverton, pollen analyses, age of elephant bones: Hansen, H. P., 3.

Pollen analysis and paleoecology: Cain, S. A.

Washington, Puget Lowland, pollen analyses: Hansen, H. P., 4.

Pebbles.

New Mexico, Ogallala formation west of Llano Estacado: Bretz, J H., 2.

Southeastern, caliche: Bretz, J H., 3. 
Pedology. See Soils.

Pegmatites.

Accessory elements, relation to origin: Holland, H. D.

Arizona, Wickenburg: Jahns, R. H., 1.

Connecticut, Haddam Neck, Gillette quarry: Stobbe, H. R., 2.

Facies classification of rocks: Ramberg, H., 2.

Georgia, Jasper County: Warriner, L. P. Granitic, structure: Cameron, E. N.

Maine, Black Mountain beryl deposit: Maillot, E. E.

Red Hill: Shainin, V. E., 2.

Topsham: Shainin, V. E., 2.

Age determination: Shainin, V. E., 3.

Manitoba, age: Ahrens, L. H., 1.

Montana: Heinrich, E. W., 1, 2.

New Hampshire, Big mica mine: Levin, S. B., 2.

Blister mica mine: Levin, S. B., 1.

New Mexico, Harding dike: Berliner, M. $\mathbf{H}$.

North Carolina, Spruce Pine area: Jones, W. H., 2.

Quebec, lithium-bearing: Derry, D. R.

South Dakota, beryl pegmatite: Gries, J. P.

Black Hills, perthite: Higazy, R. A.

Pleasant Valley, map: Burns, R. E.

Structure: Cameron, E. N.

Pelecypoda. See also Mollusca.

Alberta, faunal lists, W. Peace River Plains: Gleddie, J.

Chione and Securella, Pacific Coast, North America, Tertiary, Quaternary: Parker, P. E.

Coralliochama, siphon: Mullerried, F. K. G., 8.

Durania, Niobrara formation, Colorado: Griffitts, M. O., 1.

Mexico, Ptychomya: Mullerried, F. K. G., 3.

Tabasco area, rudistid: Mullerried, F. K. G., 5.

Zacatecas: Maldonado-Koerdell, M., 3.

Mytilus, Pliocene, California: Mandra, Y. T.

Speciation, successional, Cubitostrea sellaeformis: Stenzel, H. B., 1.

Peneplains. See also Erosion surfaces.

Shenandoah Valley, age of Harrisburg: King, P. B., 2.

\section{Pennsylvania.}

Clearfield-Philipsburg area, aeromagnetic survey: Joesting, H. R.

U. S. Geological Survey work, anthracite fields: Rothrock, H. E., 4

\section{Economic geology.}

Clay, high-alumina: Sanford, R. S.

Coal, U. S. Geological Survey work: Rothrock, H. E., 4.

Mineral resources, index map: Pa. State College.

Natural gas, developments, 1948: Fettke, C. R., 2 .
Pennsylvania-Continued

Economic geology-Continued

Natural gas-Contınued

East Fork-Wharton field: Ebright, J. R.

Oriskany sandstone: Finn, F. $\mathbf{H}$.

Petroleum, Cambro-Ordovician: Swartz, F. M., 3.

Coryville pool, core: Fettke, C. R., 1.

Deep wells: Jillson, W. R., 3.

Development, 1948: Fettke, C. R., 2.

McDonald field: Ingham, A. I., 1.

Geologic maps.

Clearfield-Philipsburg area: Joesting, H. R.

Devonian, Upper: Bayles, R. E.

Southern, Triassic: Stose, G. W., 2.

Western: Pittsburgh Geol. Soc.

Wissahickon schist at Philadelphia: Weiss, J.

Ground water.

Allegheny County, valley-fill deposits: Adamson, J. H., Jr.; 1.

Pittsburgh area: Adamson, J. H., Jr., 2. Historical geology.

Appalachian Basin, northern: Pittsburgh Geol. Soc.

Cambrian terminology: Willard, B., 3.

Cambro-Ordovician, subsurface: Swartz, F. M., 3.

Chemung formation, Bradford-Richburg oil sands, Devonian: Harding, R. W.

Devonian, Upper, subsurface, southwest: Bayles, R. E.

East Fork-Wharton gas field: Ebright, J.R.

McDonald oil field: Ingham, A. I., 1.

Middle Ordovician, south-central: Craig, L. C.

Oriskany sandstone, Devonian: Finn, F. H.

Paleozoic strata: Swartz, F. M., 1.

Silurian-Devonian, Schuylkill County: Mills, J. $R$.

Triassic facies, Delaware Valley: McLaughlin, D. B.

Tully clastics, Devonian: Stevenson, R. E., 3.

Mineralogy.

Coal, natural briquettes: Schopf, J. M., 3.

Ecton lead mine, abandoned: Boucot, A. J., 2.

Wissahickon schist at Philadelphia: Weiss, J.

Paleontology.

Middle Ordovician strata, fossil lists: Craig, L. C.

Petrology.

Chert, Ordovician: Folk, R. L., 2.

Nittany dolomite: Folk, R. L., 1.

Philadelphia area, mineral isograds: McKinstry, H. E., 2.

Wissahickon schist: Weiss, $\mathbf{J}$.

Schist inclusions in diabase: Tomlinson, W. $\mathbf{H}$.

Physical geology.

Oriskany sandstone, structure: Finn, F. H.

Triassic border fault, southern: Stose, G. W., 2. 
Pennsylvania-Continued

Physiographic geology.

Appalachians, drainage evolution: Thompson, H. D., 1.

Lehigh Valley, drainage changes: Myers, R. E.

Leibert's gap, origin: Myers, R. E.

Terraces, Susquehanna River: Peltier, L. C. Highspire, origin: Moss, J. H., 1.

Pennsylvanian. See Carboniferous.

Perlite, Washington: Huntting, M. T.

Permafrost.

Alaska, Dunbar area: Péwé, T. I.

Seward Peninsula, thaw lakes: Hopkins, D. $M$.

Canada: Jenness, J. L.

Northwest Territories, Giant Yellowknife area: Bateman, J. D., 2; Jenness, J. L.

Origin: Jenness, J. L.

Significance: Bryan, K.

Washington, Spokane area: McMacken, J. G.

Permeability.

Determination, methods: Buell, A. W.

Glacial material, laboratory measurement: Knodle, R. D.

Oil field cores, determination: Crawford, J. G., 1.

Reservoir rocks, resistivity gradient: Tixier, M. $\mathbf{P}$.

Permian. See also Carboniferous; Paleontology, Permian.

Arctic America: Maync, W., 2.

Arizona, Supai formation: Hughes, P. W.

British Columbia, Carp Lake area: Canada G. S., 3.

Colorado, Lyons sandstone, Front Range: Thompson, W. $O$.

Greenland: Maync, W., 2.

Kansas, Edwards County: McLaughlin, T. G.

Pawnee County: McLaughlin, T. G.

Kansas-Oklahoma, subsurface cross sections: Lukert, L. H.

North America, paleotectonic, paleogeologic maps: Eardley, A. J., 2.

Oklahoma, Anadarko Basin: Wheeler, R. R., 1.

Texas, Colorado River Valley: Moore, R. C., 2; U. S. G. S., 1, no. 80 .

Marfa Basin: Albritton, C. C., Jr., 1.

Trans-Pecos region: West Texas Geol. Soc., 5.

Utah: Williams, J. Stewart, 2.

Perthites, South Dakota, Black Hills pegmatites: Higazy, R. A.

Petrofabrics.

Marble, calcite, preferred orientation: Turner, F. J.

Pre- and post-deformation: Knopf, E. B.

Structural petrology of deformed rocks: Fairbairn, H. W., 1.

Use in structural geology: Wagner, W. R., 2.
Petrogenesis.

Feldspar investigations: Köhler, A.

Granite, origin: Perrin, R.

Greenland, West, gneiss complexes: Ramsberg, H., 1.

Hawaii: Macdonald, G. A., 4.

Lake Superior soft iron ores: Tyler, S. A.

New York, Adirondacks, garnet evidence: Levin, S. B., 3.

Ontario, nepheline and corundum rocks: Moyd, L., 1.

Sedimentary rocks: Rittenhouse, G., 4.

South Dakota, Black Hills pegmatites: Higazy, R. A.

Temperatures, geologic, measurement: Friedman, I. I., 2.

Petrography.

Mine rock, types: Windes, S. L.

Mineral aggregates: Rhoades, R. F., 6.

Nittany dolomite: Folk, R. L., 1.

Oxygen in rocks, reference for petrographic calculations: Barth, T. F. W., 2.

Sedimentary rocks, porosity, cementation factor: Rosenfeld, M. A.

Porosity and composition: Griffiths, J. C., 1.

Petroleum. See also Bituminous rocks; Oil shale; Oil and gas fields.

Accumulation, stratigraphic convergence: Wheeler, R. R., 2.

Time: Levorsen, A. I.

Alabama, developments, 1948: Harris, R. M.

Alaska, Iniskin Peninsula: Kirschner, C. E.; U. S. G. S., 1, no. 95 .

Northern, exploration: Kotick, O. F.

Oil fields: Ver Wiebe, W. A., 1.

Alberta, Foothills structures: Link, T. A., 3.

Leduc oil fièld: Layer, D. B.; Link, T. A., 1.

Moberly Creek, West of Sixth Meridian: Canada G. S., 11.

Reserves: Lang, W. A.

Appalachian Basin, northern: Pittsburgh Geol. Soc.

Silurian: Rittenhouse, G., 1; U. S. G. S., 1, no. 100 .

Arkansas, Atlanta field: Riggs, C. H.

Cairo field: Goebel, L. A.

Developments, 1948: Williams, J. R.

Eastern, exploration, well logs: Renfroe, C. A.

Northwest: Burns, K. R.

Southern, map: Ark. Res. Dev. Comm., Div. Geology.

Atlantic Coastal Plain: Straley, H. W., 2. Basins, reserves: Moulton, G. F.

California, cementation, Tertiary reservoir sands: Gilbert, C. M., 1.

Cuyama field: Eckis, R.

Developments, 1948: Moody, G. B.

Guijarral Hills field: Loofbourow, J. S., Jr.

Kern County: Tucker, W. B. 
Petroleum-Continued

California-Continued

North Sulphur Mtn. field: Schwade, I. T.

Placerita Canyon field: Willis, $R$.

Puente Hills: Daviess, S. N.; U. S. G. S., 1 , no. 83 .

Russell Ranch field: Eckis, R.

San Ardo field: Baldwin, T. A.

Santa Maria district reservoirs: Regan, L. J., Jr.

Wilmington oil field: Gilluly, J., 2.

Canada, developments: Gray, J. G.; Gustafson, J. D.

Oil fields: Ver Wiebe, W. A., 1.

Western: Link, T. A., 2, 4.

Interior Plains, stratigraphy and structure: Link, T. A., 5.

Possibilities: Deegan, C. J., 3.

Colorado, Dodge City basin: Maher, J. C., 1; U. S. G. S., 1, no. 101.

Naval Oil Shale Reserves 1 and 3, Garfield Co.: Duncan, D. C.; U. S. G. S., 1 , no. 94 .

Piedra River Canyon: Read, C. B.; U. S. G. S., 1, no. 96 .

San Juan Basin: Barnes, F. C., 1. Developments: Barnes, F. C., 2.

U. S. Geological Survey, investigations: Dane, C. $\mathrm{H}$.

Connate-water resistivity determinations: Wyllie, M. R. J.

Core analysis: Edinger, W. M.

Exploration: Cumming, J. L.

Aerial mapping: Mott, G. P.

Aerial photographs, structure interpretation: Wasem, A. R.

Geophysics: Jakosky, J. J.

Integration of geology and geophysics: Beebe, B. W.

Micropaleontology: LeRoy, L. W., 4; Thalmann, H. E., 6.

Mineralogical research: Krynine, P. D. 3.

Photogeology: Brundall, L., 2.

Relation of geophysics and geology: Nettleton, L. L.

Resistivity method: Guyod, H. C.

Submarine: Chase, J. L.

Radio surveying: Soske, J. L.

Techniques: DeGolyer, E. L.

Wells, geological interpretation: Weaver, $P$.

Florida: Gunter, H., 2.

Developments, 1948: Harris, R. M.

Exploration: Gunter, H., 1.

Formation, active-surface catalysts: Brooks, B. T.

Geophysical activity, 1948: Eckhardt, E. A. Georgia, developments, 1948: Harris, R. M. Gulf Coast, offshore seismic exploration: Teufel, V. W.

Sedimentary deposits, oil formation: Link, W. K.

Gulf of Mexico, continental shelf exploration: McGee, D. A.
Petroleum-Continued

Gulf of Mexico-Continued

Offshore exploration: Frowe, E. W.

Recent sediments as source beds: Trask, P. D.

Illinois, developments, 1948: Bell, A. H., 2,3 .

Geodes, petroliferous, Tyson Creek area: Spitznas, R. L., 2.

Niagaran reefs: Lowenstam, H. A., 1.

Possibilities: Bell, A. H., 1.

Indiana, developments, 1948: Bell, A. H., 2.

Kansas: Jewett, J. M., 2.

Developments, 1948: Berg, J. R.; Ver Wiebe, W. A., 2.

Dodge City Basin: Maher, J. C.; U. S. G. S., 1, no. 101.

Eastern: Jewett, J. M., 1.

Map: Jacobson, E. C.

Kentucky, deep wells: Jillson, W. R., 3 . Developments, 1948: Wood, E. B.

Owen County: Jillson, W. R., 4.

South-central: Hunter, C. D.

Limestone reefs, geophysical exploration: Agnich, F. J.

Louisiana, De Soto, Red River Parishes: Murray, G. E., Jr., 1.

Developments, Gulf Coast, 1948: McBee, W. S., Jr.

Northern, 1948: Williams, J. R.

Terrebonne Parish oil-well oscillation chart: Israelsky, M. C., 1.

Magnetometer exploration, field: Peters, J. W.

Manitoba, bibliography: Kerr, L. B., 1.

Maryland, exploration: Anderson, J. L., 1.

Mexico, fields: García Rojas, A., 2; Ver Wiebe, W. A., 1.

Poza Rica field: Salas, G. P.

Reserves: Cumming, J. L.

Reynosa area, Gulf Coast: Guzmán, E. J.

Mid-Continent region, Arbuckle and Ellenburger formations: Bartram, J. G.

Migration: Wilson, W. B., 1.

Mississippi: Mellen, F. F.

Brookhaven field: Womack, R., Jr.

Developments, 1948: Harris, R. M.

La Grange field: Sherwin, M. W.

New Mexico, developments, 1948: Henderson, C. F.

Map: Northup, R. C.

San Juan Basin: Barnes, F. C., 1.

Developments: Barnes, F. C., 2.

Southeastern, Paleozoic stratigraphy: Lloyd, E. R.

New York, Cambro-Ordovician: Swartz, F. M., 3.

Chemung formation, Bradford-Richburg oil sands, correlation: Harding, R. W.

Deep wells: Jillson, W. R., 3.

Exploration: Donnerstag, $\mathbf{P}$.

Nittany dolomite, reservoir potentiality: Folk, R. L., 1.

North America, oil fields: Ver Wiebe, W. A., 1. 
Petroleum-Continued

North Dakota, possibilities: Laird, W. M., 1.

Northwest Territories, Athabaska tar sands, origin: Williams, M. Y.

Ohio: Alkire, R. L., 2.

Berea sand: De Witt, W., Jr.; U. S. G. S., 1, no. 99 .

Clinton sand: Lockett, J. R.

Deep wells: Jillson, W. R., 3.

Fields, map: Alkire, R. L., 1.

Holmes County: Lamborn, R. E., 2.

Mayfield pool: Rothrock, H. E., 3.

Southeast: Dunn, O. C., Jr.

Oil fields, core analyses: Crawford, J. G., 1.

Water analyses: Crawford, J. G., 1. Oil sand, porosity: Ryder, H. M.

Oklahoma, developments, 1948: Wellman, D. C.

Northwest Sulphur pool: Swirczynski, R. $\mathbf{P}$.

Dodge City Basin: Maher, J. C., 1; U. S. G. S., 1, no. 101 .

Sholem Alechem field: Billingsley, H. R.

Southeast Ceres field: Neal, E. P.

Velma pool: Mallory, W. W., 1, 2.

West Red River field: Hill, H. B., 2.

Ontario, Salina-Guelph fields: Roliff, W. A., $1 . \quad$ -

Origin: Cox, B. B.; Cumming, J. L.; Fash, R. H.; Link, W. K.; Nevin, C. M., 1 .

Bacteria role: ZoBell, C. E.

Reef development: Link, T. A., 6 .

Pennsylvania, Cambro-Ordovician: Swartz, F. M., 3.

Chemung formation, Bradford-Richburg oil sands, correlation: Harding, R. W.

Coryville pool: Fettke, C. R., 1.

Deep wells: Jillson, W. R., 3.

Developments, 1948: Fettke, C. R., 2.

McDonald field: Ingham, A. I., 1.

Southwest, Devonian fields: Bayles, R. E.

Poulter method, oil exploration: Kastrop, J. E.

Reserves: Levorsen, A. I.

Reservoir theory of accumulation: Krynine, P. D., 1.

Texas, Arick field, structure: Shepherd, G. F.

Benedum field: Deegan, C. J., 1.

Blackfoot field: Branson, D. 0 .

Colorado River Valley Permian (?) rocks: Moore, R. C., 2; U. S. G. S., 1, no. 80.

Developments, 1948: Ammon, W. L., 2; Clark, G. C., 1; Henderson, C. F.; Mettner, F. E.; Serafford, J, B.

Merigale-Paul field: Moore, $\mathbf{H}$.

New Hope field: Carpenter, C. B.

Northeastern, Woodbine formation: Bergquist, H. R.; U. S. G. S., 1, no. 98.

Resources: Culberson, 0 .

Sheridan field: Hill, H. B., 1.

Squire field: Huffman, G. G., 1.
Petroleum-Continued

Texas-Continued

Strake field: Huffman, G. G., 1.

Strand-line oil fields, Jim Hogg County: Freeman, J. C.

Todd field, Pennsylvanian: Imbt, R. F.

West, Simpson group, Ordovician: Schweers, R. H.

Textbook: Lalicker, C. G.

United States, exploratory drilling, 1948: Lahee, F. H., 1.

Fields: Ver Wiebe, W. A., 1.

Gulf Coast, active-surface catalysts in oil formation: Brooks, B. T.

Exploration: De Blieux, C. W.

Fields: Deegan, C. J., 2.

Resources: Culberson, O.; Pratt, W. E.

Rocky Mtn. region developments, 1948: Dorn, C. L.

Western, exploration: Tatum, J. L.

Utah: Hansen, G. H.

Well cuttings, examination: Hills, J. M.

West Virginia: Price, P. H., 1.

Wyoming, central, Upper Cretaceous: Thompson, Raymond M.; U. S. G. S., 2, no. 36.

East Lance Creek field: McCanne, R. W.

Fields, map: Keefer, B. K.

Glendo area: Love, J. D., 2; U. S. G. S., 1 , no. 92.

Hartville Uplift, potential: Denson, N. M., 1; U. S. G. S., 1, no. 102.

Lance Creek field: McCanne, R. W.

Little Buck Creek field: McCanne, R. W.

Lost Soldier field: Krampert, E. W.

Newcastle sandstone, facies: Summerford, H. E., 1, 2.

Powder River Basin, geophysical exploration: Fenwick, W. H., 1.

Resources: Thomas, H. D., 1.

Salt Creek field: Mallory, R. W.

Petrology (general). For areal see sub-heading Petrology under the various states and countries. See also Igneous rocks; Metamorphic rocks; Meteorites; Rock deseriptions; Sedimentary rocks; Technique.

Accessory minerals, paragenesis: Moorhouse, W. W.

Albite-water system in gravitational field: Ramberg, H., 3.

Dedolomitization by intrusion: Faust, G. T., 2.

Enstatite-orthoferrosilite series, solution heats: Sahama, T. G., 3.

Facies classification of rocks: Ramberg, H., 2.

Feldspar investigations: Köhler, A.

Forsterite-fayalite series, solution heats: Sahama, T. G., 3.

Fragment section study: Gabelman, J. W., 1.

Geikielite, ilmenite, stability relation, occurrence: Sahama, T. G., 1. 
Petrology-Continued

Gradational transitions: Chayes, F., 4.

Granitization: Lowe, K. E.

Intrusives, basic origin: Bowen, N. L., 1.

Liquid inclusions in quartz, orientation: Tuttle, 0. F., 1.

Mineralization related to granitization: Goodspeed, G. E., 3.

Olivine, orthopyroxene, thermochemical study: Sahama, T. G., 2.

Pegmatites, distribution of accessory elements: Holland, H. D.

Granitic, structure: Cameron, E. N.

Pennsylvania, southeastern, mineral isograds: McKinstry, H. E., 2

Ratio correlation in petrography: Chayes, F., 2.

Replacement reactions, equating volume and weight: Ridge, J. D.

Ribbon structure in gold-quartz veins: McKinstry, H. E., 1.

Rocks of the mid-Atlantic Ridge: Shand, S. J.

Sedimentology, trends: Russell, R. D.

Spectrochemical analysis of minerals: Strock, L. W., 1.

Structural petrology of deformed rocks: Fairbairn, H. W., 1.

Thermochemistry, applied to: Sahama, T. G., 3.

Thin section study: Gabelman, J. W., 1.

Titaniferous magmas, differentiation: Evrard, $P$.

Phosphate.

Arkansas, Hickory Valley: Wells, C. J.

Determination, contact printing: Gault, H. R., 1.

Idaho, Deer Creek-Wells Canyon area: Deiss, C. F.

Southeastern: Butner, D. W.

Kansas, Pennsylvanian shales: Runnels, R. T., 2.

Manitoba: Cameron, E. L.

United States, western: McKelvey, V. E.

Photogeology.

General: Brundall, L., 2.

Petroleum exploration, application: Wasem, A. $\mathbf{R}$.

United States, Gulf Coast exploration: De Blieux, C. W.

University instruction: Tator, B. A., 2.

Physical geology (general). For areal see sub-heading Physical geology under the various states and countries.

Algal pillars, Wyoming: Brown, R. W., 1 . Bars and troughs, formation: Shepard, F. P., 3.

Beach erosion: Caldwell, J. M.

Caves, origin: Stone, R. W.

Continental shelves, shoreline processes: Evans, 0. F., 1.

Diffusion in rocks: Garrels, R. M., 1.

Fault detection with reflection seismograph: Kelsey, M. C.
Physical geology-Continued

Lithosphere and supporting magma: Gunn, R.

New Mexico, potash beds, open fracture: Catheart, J. B., Jr.

Oklahoma, Verden sandstone, origin: Evans, O. F., 3.

Reefs, characteristics, geologic distribution: Twenhofel, W. H.

Ripple marks: Evans, O. F., 2.

Seismicity of the earth, Gutenberg, B., 2.

Shallow structures over reefs: Brodie, G. $\mathrm{H}$.

Shore line formation, absence of wave action: Keulegan, G. H.

Soil erosion: Ellison, W. D.

Spheroidal weathering, igneous rocks: Chapman, R. W., 2.

Stone nets, stripes, Wyoming, origin: Richmond, G. $M$

Stylolites, development: Shaub, B. M., 1

Tectonics and environments, sedimentary: Krumbein, W. C.

Textbook: Landes, K. K., 1, 2; Miller, W. J.

Volcanic sublimates, concentration and distribution: De Ment, J. A., 3.

Water-drop sand movement: Ekern, P. C., $\mathrm{Jr}$.

Weathering, chemical, low temperature: Williams, J. E.

Physiographic geology (general). For areal see sub-heading Physiographic geology under the various states and countries. See also Drainage changes; Glacial geology; Geomorphology.

Alpine glaciation: Ray, L. L., 3.

Caves, origin: Stone, R. W.

Drainage patterns: Carlston, C. W.

Kansas: Schoewe, W. H.

Landforms, erosional, quantitative analysis: Strahler, A. N., 1.

Limestone terranes: Swinnerton, A. C., 1.

Pennsylvania, Susquehanna River terraces: Peltier, L. C.

Pimple mounds, origin: Krinitzky, E. L.

Pleistocene problems: Ray, L. L., 2.

-Slopes, frequency-distribution analysis: Strahler, A. N., 2.

Piezoelectric minerals: Waesche, H. H.

Pimple mounds, origin: Krinitzky, E. L.

Pioneers in geology: Burt, F. A., 1. Pisces.

Alberta, Peace River Plains: Gleddie, J.

Dipnoi, evolution: Westoll, T. S.

Edestus, Carboniferous shark, Kentucky: Jillson, W. R., 6.

Egg capsules, chimaeroid, Triassic, Massachusetts: Bock, W.

Greenland, East, Bothriolepinae, genera revision: Stensiö, E. A.

Oregon, Newport-Waldport area, faunal lists: Vokes, H. E., 1; U. S. G. S., 1 , no. 88

Mexico: Maldonado-Koerdell, M., 2. 
Pisces-Continued

Teleost, Livingston formation, Montana: Schaeffer, B.

Texas, Vale formation, tooth plates, Permian: Wilson, J. A.

Virginia, Triassic, Prince William County: Baer, F. $M$.

Pitchblende.

General: Merritt, P. L.

Northwest Territories, Beaverlodge to Hottah Lakes: Henderson, J. F., 1.

Saskatchewan, Goldfields area: Christie, A. M., 2.

Placers.

Idaho, minerals: Staley, W. W.

Oregon, Kerby quadrangles: Wells, F. G., 2.

River, logarithmic pattern: Wertz, J. B. Plants, fossil. See Paleobotany.

Pleistocene. See Glacial geology; Quaternary. Pliocene, See Tertiary.

Pollen analysis. See also Bogs; Paleobotany; Peat.

Alberta, peat bogs: Hansen, H. P., 1, 2.

Classification, spores and grains: Erdtman, G.

Massachusetts, Boston area, Boylston Fishweir II, Lower Peat: Wilson, L. R., 1.

Oregon, Silverton, age of elephant bones: Hansen, H. P., 3.

Paleoecology : Cain, S. A.

Pleistocene biogeography: Deevey, E. S., Jr.

Washington, Puget Lowland, peat beds: Hansen, H. P., 4.

Popular and elementary.

Alaska, frozen mammoth, Pleistocene: Anthony, H. E.

California, Alverson Canyon, fossil shell collecting: Weight, H. O., 3.

Connecticut, rocks and minerals: Stone, S. W.

Dinosaur National Monument, ColoradoUtah: Stokes, W. L., 1.

Fluorescent minerals: Flagg, A. L.

Fossils, collecting: Dondlinger, P. T.

Early ideas: Ley, W.

Glacier National Park, Montana: Dyson, J. L., 1, 2.

Kansas, natural features: Landes, K. K., 3.

New Hampshire, artesian wells: Goldthwait, R. P.

Flume: McNair, A. H., 1.

Franconia Notch: McNair, A. H., 1.

Keene-Brattleboro quadrangle : Moore, G. E., Jr., 1.

Kinsman Notch: McNair, A. H., 2.

Lost River Gorge: McNair, A. H., 2.

Monadnock quadrangle: Fowler-Billings, K., 1.

Percy quadrangle: Chapman, R. W., 1.

Vermont, Keene-Brattleboro quadrangle: Moore, G. E., Jr., 1.

Virginia, rare minerals: Jones, W. H., 1. Volcanoes, Central America: Griffin, N. J.
Popular and elementary-Continued

Washington, Russell Forest, petrified wood: Bateman, E. S.

Willamette meteorite discovery: Sears, $P$. M.

Yellowstone National Park: Chittenden, H. M.

Geysers and springs: Muench, J. R.

Porifera, limestones, organic: Johnson, J. H., 1.

Porosity.

Cementation factor: Rosenfeld, M. A.

Determination, methods: Buell, A. W.; Rall, C. G.

Glacial material, laboratory measurement: Knodle, R. D.

Nittany dolomite: Folk, R. L., 1.

Oil sand: Rall, C. G.; Ryder, H. M.

Petrographic control: Griffiths, J. C., 1.

Petroleum reservoirs: Krynine, P. D., 1.

Relation to diffusion in rocks: Garrels, $\mathbf{R}$. M., 1.

Potash.

General: Smith, H. I.

Manitoba: Cameron, E. I.

Potholes, Maryland: Schreiber, J. F., Jr.

Pre-Cambrian. See also Paleontology, preCambrian.

Alabama, northern: Mississippi Geol. Soc., 2.

Alberta, Paleozoic pre-Waterways strata, Plains area: McGehee, J. R.

Appalachian, southern: King, P. B., 6.

Arizona: Anderson, C. A.

British Columbia, Glacier-Rogers Pass area: Cox, A. H.

California, Crystal Spring formation: Wright, L. A., 2.

Canadian Shield, origin: Wilson, J. T., 1. Colorado, Coal Creek quartzite: Fraser, G. D.

South Park: Stark, J. T.

Continent origin: Wilson, J. T., 1.

Greenland, orogeny : Noe-Nygaard, A.

Qapiarfik, Disko Bay area: Malaurie, J. N., 2.

Labrador: Bruet, E., 1.

Manitoba, Dunphy Lakes area: Stanton, M. $\mathbf{S}$.

File-Tramping Lakes area: Harrison, $\mathbf{J}$. M., 1.

Kississing area : Canada G. S., 6.

Wanipigow Lake area: Davies, J. F.

New Mexico, Manzanita Mts. area: Reiche, P.

North Manzano Mts. area: Reiche, $\mathbf{P}$.

Northwest Territories, Carp Lakes area: Miller, M. L.

Lac de Gras area: Canada G. S., 7.

Ocoee series, southern Appalachians: Stose, G. W., 1.

Ontario, Beatty Township: Satterly, J., 1. Quebec, Allard River area, Abitibi-East County: Béland, R., 2. 
Pre-Cambrian-Continued

Quebec-Continued

Northern: Bruet, E., 1.

Wakeham Lake trough: Claveau, J., 5. Saskatchewan, Athabaska series: Conybeare, C. E. B., 2.

Kississing area: Canada G. S., 6. Utah, Blackwelder, E., 2.

Prince Edward Island.

Economic geology.

Road materials: Picher, R. H.

Geologic maps.

O'Leary area: Owen, E. B.

Historical goology.

Pleistocene deposits, O'Leary area: Owen, E. B.

Prospecting. See Exploration.

Pseudomorphs, quartz after halite, Oregon: Staples, L. W., 2.

Pumice, California, Friant Dam, petrography: Mielenz, R. C., 14.

Pyrite.

Colorado, Leadville, crystal structure: Wasserstein, $\mathbf{B}$.

Georgia, Lumpkin County: Kline, M. H.

Ontario, Kirkland area, spectrography: Hawley, J. E., 3.

\section{Pyroxene.}

Clinopyroxenes, chemical and optical analyses: Hess, H. H., 2.

Palisade diabase sill, New Jersey, rhombic pyrozene development: Guimarâes, D.

Thermochemical study: Sahama, 'T. G., 2. Quarrying; geologic factors: Glover, S. L., 1.

Quartz.

Crystal growth from sphere: Hale, D. R.

Crystallization from amorphous silica: Bailey, D. A.

Crystals, synthesis: Buehler, E. J.

Inversion temperature: Tuttle, O. F. 2.

Liquid inclusions, planes, orientation: Tuttle, O. F., 1.

New Jersey, Prospect Park: Lisle, T. O.

New York, Ravena: Hamilton, H. V.

Petrographic determination: Foster, W. D.

Piezoelectric: Waesche, H. H.

Pseudomorphs after halite, Oregon: Staples, L. W., 2.

Synthesis: Friedman, I. I., 1.

Hydrothermal: Swinnerton, A. C., 2.

Twinning: Gault, H. R., 2.

Quartzite.

Laboratory synthesis : Fairbairn, H. W., 2.

Nortb Carolina: Broadhurst, S. D.

Quaternary. See also Glacial geology; Paleontology, Quaternary.

Arizona, Upper Verde Valley development: Mahard, R. $\mathbf{H}$.

British Columbia, Carp Lake area, surface deposits: Canada G. S., 4.

California, Coast Ranges, northern San Francisco Bay area: Weaver, C. E.

June Lake district: Putnam, W. C.

Puente Hills : Daviess, S. N.; U. S. G. S., 1 , no. 83.
Quaternary-Continued

California-Continued

Santa Barbara, coastal changes: Upson, J. E., 1.

Canada, post-Pleistocene seaway, James Bay to Gulf of St. Lawrence: La Rocque, A., 1.

Colorado, Naval Oil Shale Reserves 1 and 3. Garfield Co.: Duncan, D. C.; U. Ś. G. S., 1 , no. $\$ 4$.

Great Basin: Blackwelder, E., 1.

Greenland, Jørgen Broniunds Fjord area: Troelsen, J. C.

Iowa, Shelby County, Pleistocene till: Ruhe, R. V.

Kansas, Edwards County: McLaughlin, T. G.

Meade County: Hibbard, C. W., 1.

Northeastern: Frye, J. C., 6.

Pleistocene loess: Frye, J. C., 5.

Pleistocene strata, fossil soils: Frye, J. C., 4.

Leaching of carbonates in loess and glacial drift, age correlation : Flint, R. F., 2 .

Louisiana, Natchitoches area: Maher, J. C., 3.

Pliocene-Pleistocene boundary: Russell, R. J., 2

Massachusetts, Boston area, Boylston Street F'ishweir II, Pleistocene: Barghoorn, E. S., Jr., 1; Johnson, F.; Judson, S. S., Jr.

Pawtucket quadrangle, surficial deposits: Chute, N. E., 1, 2.

Mexico, Becerra formation, Pleistocene: Arellano, A. R. V., 1.

Tepexpan area: De Terra, H., 1.

Valley of Mexico: De Terra, H., 2.

Michigan, Benzie County: Calver, J. L., 1.

Grand Marais Embayment, post-glacial: Tague, G. C.

Ypsilanti area: McGuinness, C. L.

Mississippi Valley, field conference: Leighton, M. M., 1.

New Mexico, Colfax Co.: Griggs, R. L.

New York, Mohawk Valley, Pleistocene lakes: Kay, G. M., 3.

North America-Europe, Pliocene-Pleistocene deposits: Moore, R. C., 5 .

North Daknta, Tokio quadrangle: Easker, I). $\mathbf{G}$.

Ontario, Vermilion River area, Pleistucene: Prest, V. K.

Pennsylvania, central, Pleistocene: Peltier, J. C.

Pleistocene, interrelation with soil science: Thorp, J., 1.

Problems: Ray, L. L., 2.

Research: Flint, R. F., 3, 4.

Prince Edward Island, O'Leary area : Owen, E. B.

Rhode Island, Pawtucket quadrangle, surficial deposits: Chute, N. E., 1, 2.

Subrnarine geology and Pleistocene: Phleger, F. B., Jr., 4. 
Quaternary-Continued

Texas, Colorado River Valley, geologic map: Moore, R. C., 2; U. S. G. S., 1, no. 80.

Utah : Marsell, R. E., 1.

Washington, Puget Lowland, peat beds, pollen analyses: Hansen, H. P., 4.

Quebec.

- East Sullivan area, geophysical prospecting: Innes, $M$. J. S.

Laval University, mineralogical museum: Bureau, R., 1.

Areal geology.

Wakeham Lake area: Claveau, J., 3.

\section{Economic geology.}

Allard Lake district, aeromagnetic survey: Bourret, W.

Belleterre area, Témiscamingue County: Auger, P. E., 1, 2.

Duparquet Township, Abitibi-West County: Graham, R. B., 1.

Duverny Township, Abitibi-East County : Weber, W. W.

IImenite, Allard Lake: Hammond, P.

Iron, titaniferous magnetite, Chicoutimi area: Jooste, R. F.

Manganese: Tanton, T. L., 2.

Mineral resources, undeveloped: Denis, B. T.

Geologic maps.

Albanel Lake area, Misstassini Territory: Neilson, J. M.

Allard River area, Abitibi-East County: Béland, R., 2.

Bachelor Lake area, Abitibi-East County: Longley, W. W., 1.

Belleterre area, Témiscamingue County: Auger, P. E., 1, 2, 3.

Bourget area, Chicoutimi County: Jooste, R. F.

Branssat-Kreighoff area, Abitibi-East County: Gilbert, J. E., 2.

Canimiti River area, Pontiac County: Gillies, N. B.

Capsisit Lake area, Abitibi-East County: Gilbert, J. E., 1.

Cawatose area, Pontiac County: Wahl, W. G., 1.

Chaste area, Abitibi-East County: Tiphane, $M$.

Chertsey map-area: Côté, P. E.

Duparquet Township, Abitibi-West County: Graham, R. B., 1.

Duverny Township, Abitibi-East County: Weber, W. W.

Forget Lake area, Saguenay County: Longley, W. W., 2.

Forillon Peninsula, sketch map: Russell, L. S., 1.

Goéland Lake area, Abitibi-East County : Imbault, P. E., 2.

Hébécourt Lake area, Abitibi-East County: Graham, R. B., 2.

Iserhoff River area, Abitibi-East County: Claveau, J., 1.
Quebec-Continued

Gcologic maps-Continued

Lac des Trente-et-un-milles area: Aubert de la Rüe, E., 1.

McGill Township area: Aubert de la Rüe, E., 2.

Nominingue region: Jérémine, $E$.

Olga Lake area, Abitibi-East County: Imbault, P. E., 1.

Peribonca River area: Ross, S. $H$.

Portneuf area: Clark, T. H., 2

Rawdon area: Béland, R., 3.

Razilly Township, Abitibi-East County : Maurice, O. D., 1

Romaine River, upper area, Saguenay County: Claveau, J., 4.

St. Lawrence Lowlands: Clark, T. H., 1.

Taibi Lake area: Béland, R., 1.

Témiscamie River area, Misstassini Territory: Wahl, W. G., 2.

Val des Bois area: Mauffette, $P$.

Wakeham Lake area: Claveau, J., 3.

Waswanipi Lake area, Abitibi-East County: Claveau J., 2.

Historical geology.

Aibanel Lake area, Misstassini Territory: Neilson, J. M.

Allard River area, Abitibi-East County : Béland, R., 2.

Bachelor Lake area, Abitibi-East County : Longley, W. W., 1.

Belleterre area, Têmiscamingue County: Auger, P. E., 1, 2, 3.

Bolton lavas, age: Ambrose, J. W.

Bourget area, Chicoutimi County: Jooste, R. F.

Branssat-Kreighoff area, Abitibi-East County: Gilbert, J. E., 2.

Canimiti River area, Pontiac County: Gillies, N. B.

Capsisit Lake area, Abitibi-East County: Gilbert, J. E., 1.

Cawatose area, Pontiac County: Wahl, W. G., 1.

Chaste area, Abitibi-East County: Tiphane, M.

Chertsey map-area: Côté, P. E.

Duparquet Township, Abitibi-West County: Graham, R. B., 1.

Duverny Township, Abitibi-East County: Weber, W. W.

Forget Lake area, Saguenay County : Longley, W. W., 2.

Gaspé limestone series: Russell, L. S., 1.

Goéland Lake area, Abitibi-East County: Imbault, P. E., 2.

Hébécourt Lake area, Abitibi-East County: Graham, R. B., 2

Iserhoff River area, Abitibi-East County: Claveau, J., 1.

Lac des Trente-et-un-milles area: Aubert de la Rüe, E., 1.

Lévis area, Middle Cambrian: Laverdière, J. W. 
Quebec-Continued

Historical geology-Continued

McGill Township area: Aubert de la Rüe, E., 2.

Olga Lake area, Abitibi-East County: Imbault, P. E., 1.

Portneuf area: Clark, T. H., 2.

Pre-Cambrian: Bruet, E., 1.

Rawdon area: Béland, R., 3.

Razilly Township, Abitibi-East County: Maurice, O. D., 1.

Romaine River, upper area, Saguenay County: Claveau, J., 4.

St. Lawrence Lowlands: Clark, T. H., 1.

Taibi Lake area: Béland, R., 1.

Témiscamie River area, Misstassini Territory: Wahl, W. G., 2.

Val des Bois area: Mauffette, $P$.

Wakeham Lake area: Claveau, J., 3.

Wakeham Lake trough, pre-Cambrian: Claveau, J., 5.

Waswanipi Lake area, Abitibi-East County: Claveau, J., 2.

Mineralogy.

Chloritoid, Megantic County: Milne, I. H.

Minerals, Quebec City: Bureau, R., 2.

Paleontology.

Bogs, paleobotany : Potzger, J. E., 1.

St. Lawrence Lowlands, fossil lists : Clark, T. $\mathbf{H} ., 1$.

Silicified fossils: Bureau, R., 3.

Trilobita, Loganopeltoides, Loganopeltis: Raw, $\mathbf{F}$.

Petrology.

Allard River area, metasediments, strueture: Béland, J.

Anorthosite dikes, New Glasgow: Osborne, F. F.

Batholith, Duverny : Bruet, E., 2.

Forget Lake area, Saguenay County: Longley, W. W., 2.

Intrusive rocks, $\mathrm{Mt}$. Laurier region: Jérémine, E.

Landrienne Canton, rock analysis, minor elements: Tousignant, $\mathrm{C}$.

Metamorphic rocks, Mt. Laurier region: Jérémine, $\mathbf{E}$.

Pegmatites, lithium-bearing: Derry, D. R.

Peribonca River area: Ross, S. H.

Pre-Cambrian: Bruet, E., 1.

Romaine River, upper area, Saguenay County: Claveau, J., 4.

Wakeham Lake area: Claveau, J., 3.

Physical geology.

Logan's line fault zone: Clark, T. H., 3.

Wakeham Lake area: Claveau, J., 3.

Physiographic geology.

Shickshock Mts., Gaspé, glaciation: Carbonneau, $\mathbf{C}$.

Radiation, infrared, absorption by silica minerals: Keller, W. D., 4.

Radio surveying, petroleum exploration, submarine: Soske, J. L.

Radioactive minerals.

Arizona, Hillside mine: Axelrod, J, M., 2.
Radioactive minerals-Continued

Atlantic Coast, monazite sand: Jones, W. H., 3.

British Columbia, prospecting: Stevenson, J. $\mathrm{s}$.

Canada, prospecting: Lang, A. H., 1.

General: Savage, W. S.; White, D. J.

Inclusions, measurements : Yagoda, $\mathrm{H}$.

Michigan, Upper Peninsula, prospecting: Kemp, C. E.

Ontario, Theano Point: Lang, A. H., 2; Satterly, J., 4.

Pitchblende: Merritt, P. L.

Prospecting: U. S. Atomic Energy Comm.: White, D. J.

Geiger counter: Bateman, J. D., 1.

Saskatchewan, Goldfields area: Christie, A. M., 1, 2.

Martin Lake area: Christie, A. M., 1.

Texas, Barringer Hill, uranium: Dake, H. C., 3.

Uranium: Everhart, D. L.; Joubin, F. R.; Muilenberg, G. A.

Radioactivity.

Diamonds : Hardy, J. A.

Earth, cooling, rate: Ingersoll, $\mathbf{L}$. $\mathbf{R}$. Crust: Slack, H. A.

Crustal movements, origin: Urey, H. C. Temperature effect: Urry, W. D.

Field determination in ores: Senftle, F. E.

Measurement, beta activity, density correction: Faul, H., 1.

Inclusions in minerals and rocks: $\mathrm{Ya}$ goda, $\mathrm{H}$.

Mineral content: Marble, J. P., 5.

Ontario, Kirkland area: Slack, H. A.

Rucks: Keevil, N. B.

Saskatchewan, Goldfields area, red rocks : Conybeare, C. E. B., 3.

Thermoluminescence, test for: Davis, W.

Rare earths, spectroscopic determination Jaffe, H. W., 1.

Ratio correlation in petrography: Chayes, F. 2.

Red beds.

Color: Robb, G. L., 2.

Origin: Krynine, P. D., 2.

Reefs.

Alberta, Leduc oil field: Layer, D. B.; Link, T. A., 1.

Canada, western, petroleum: Link, T. A., 2.

Characteristics, geologic distribution : Twenhofel, W. H.

Coral reefs, problem: Ladd, H. S., 1.

Definition: Wilson, W. B., 2.

Development: Ladd, H. S., 2.

Geophysical exploration: Agnich, F. J.

Illinois, Niagaran, relation to oil accumulation: Lowenstam, H. A., 1.

Petroleum, origin: Link, T. A., 6.

Texas, Lawson-Chapman area, Pennsylvanian: Ammon, W. L., 1.

Scurry County: Stormont, D. H. 
Reefs-Continued

Texas-Continued

Todd oil field, Pennsylvanian: Imbt, R. F.

West-central, shallow structures: Brodie, G. H.

Refractories, sillimanite group: Riddle, F. H. Reptilia.

Alzadasaurus, elasmosaur, Cretaceous, South Dakota: Welles, S. P.

Ancestors of mammals : Colbert, E. H., 2.

Ceratopsia, growth patterns, deformed coordinate system: Lull, R. S.

Cuba, Cryptocleidus, Jurassic: Torre Mandrazo, $\mathbf{R}$.

Dinosaurs, Dinosaur National Monument, Colorado-Utah: Stokes, W. L., 1.

Evolutionary growth: Colbert, E. H., 3. Laosaurus: Russell, L. S., 2.

Kansas, Keefe Canyon, Pliocene: Hibbard, C. W., 3.

Pelycosaurs, Pennsylvanian: Peabody, F. E.

Maryland, dinosaurs, Cretaceous: Vokes, H. E., 2 .

Nothosaurs, Alcova limestone, Wyoming: Zangerl, $\mathbf{R}$.

Phytosaurs, Triassic, adaptation: Colbert, E. H., 1.

Procolophonids, Triassic, adaptation: Colbert, E. H., 1.

Texas, Camp Springs, Paleorhinus, TriResearch. assic: Langston, W., Jr., 1.

Canada, geological projects : Hawley, J. E., 1.

Coal: Cady, G. H.

Coal sedimentation: Dapples, E. C., 1.

Flectron microscope, geological application: Bates, T. F., 1.

Minerulogical, oil exploration: Krynine, P. D., 3.

Rhode Island.

Geologic maps.

Pawtucket quadrangle, bedrock: Quinn, A. W., 1, 2 .

Ground-water map: Allen, W. B., 2.

Surficial deposits : Chute, N. E., 1, 2.

Ground water.

Exeter area: Allen, W. B., 1.

Pawtucket quadrangle: Allen, W. B., 2. Historical geology.

Narrangansett Basin: Thurston, A. W.

Pawtucket quadrangle, bedrock: Quinn, A. W., 1, 2.

Petrology.

Intrusives: Quinn, A. W., 3.

Metamorphic rocks: Quinn, A. W., 3.

Physiographic geology.

Exeter area, glacial deposits : Allen, W. B., 1.

Pawtucket quadrangle: Chute, N. E., 1, 2. Rhodochrosite, thermal analysis: Kulp, J. L., 1.
Rift valleys, California, San Andreas rift area, southern: Wallace, R. E., 1.

Ripple marks: Evans, O. F., 2.

Arizona, Moenkopi formation, Triassic: McKee, E. D., 3.

Colorado, Lyons sandstone, Front Range: Thompson, W. 0 .

Utah, Moenkopi formation, Triassic: MeKee, E. D., 3 .

Rivers.

Haiti, Cul-de-Sac plain: Taylor, G. C., Jr., 1.

Indiana, Lost River drainage: Malott, C. A., 1.

Mississippi, delta deposition: Fisk, H. N. Pleistocene history: Hobbs, W. H., 5.

Valley and delta: Baulig, $\mathbf{H}$.

Missouri, Illinoian age: Warren, C. R.

Oregon, Long Tom: Baldwin, E. M.

Susquehanna, Pennsylvania, terraces: Peltier, L. C.

Road materials. See Construction materials. Rock analysis, spectrochemical: Strock, L. W., 2.

Rock creep, earthquakes : Benioff, H., 1.

Rock cycle: Keller, W. D., 1.

Rock descriptions. See also Igneous rocks; Metamorphic rocks; Petrology; Sedimentary rocks.

Anorthosite, Quebec: Osborne, F. F.

Dacite, Laughlin Peak, New Mexico: Stobbe, H. R., 3.

Igneous, ultramafic: Davis, G. I.

Intrusives, central Minnesota: Woyski, M. $\mathbf{S}$.

Missouri, Vernon County, pre-Upper Cambrian : Skillman, M. W.

Newfoundland, Placentia Bay area: Rose, E. $R$.

Peridotite, Laramie Mts., Wyoming: Albanese, J. P.

Pseudotachylite, Antietam quartzite, Maryland: Anderson, J. L., 2.

Quebec, Mt. Laurier region: Jérémine, $\mathrm{E}$.

Suzorite: Girault, J. P., 2.

Volcanics, Hawaii : Macdonald, G. A., 1, 4.

New Mexico: Collins, R. F.; Stobbe, H. R., 1.

Rockbursts, sedimentary : Wuerker, R. G.

Rocky Mountains, oil-field waters, characteristics : Crawford, J. G., 2.

Rubble, Alaska, Jumbo Dome: Wahrhaftig, C., 2.

Rutile, synthetic crystals, formation, properties : Moore, C. H., Jr.

Salt.

Manitoba: Cameron, E. L.

North Dakota, sodium sulfate deposits: Grossman, 1. G.

Texas, occurrence: Bartlett, z. W.

West Virginia, resources: Price, P. H., 2.

Salt domes.

Boundary determination by seismograph: Gardner, I. W. 
Salt domes-Continued

Texas, eastern : Clark, G. C., 2.

Grand Saline dome: Balk, R.

Salvador, El. See also Central America.

Historical geology.

General: Stirton, R. A.

Paleontology.

Mammalia, Pleistocene: Stirton, R. A. Sand.

Examination, economic use: Ries, H., 2.

Iowa, Wisconsin drift area soils: Riecken, F. F.

New Jersey, glass sand: Wilkerson, A. S., $1,2$.

Ohio, northern, resources: Smith, W. H. Sand mixtures, synthesis: Menard, H. W., Jr.

Wyoming, Glendo area: Love, J. D., 2; U. S. G. S., 1, no. 92.

Sand dunes. Sce Dunes.

Sandstone. See also Construction materials.

Arizona, Canyon Diablo meteorite crater, size analysis: Buddhue, J. D., 1.

California, cementation, Tertiary reservoir sands: Gilbert, C. M., 1.

Colorado, Lyons sandstone, Front Range: Thompson, W. 0 .

Illinois, Trivoli formation, Williamson County: Siever, R.

Types, abundance, cementing agents: Tallman, S. L.

Saskatchewan.

Economic geology.

Coal, map: Mackay, B. R., 2.

Lignite, map: Mackay, B. R., 2.

Natural gas, fields, map: Anonymous, 15.

Petroleum, fields, map: Anonymous, 15.

Radioactive minerals, Goldfields area: Christie, A. M., 1, 2.

Martin Lake area: Christie, A. M., 1.

Zine, Flin Flon mine: Tanton, T. 1., 1.

Geologic maps.

Athabaska series, Goldfelds: Conybeare, C. E. B., 2.

Goldfields area: Christie, A. M., 1.

Sketch maps: Christie, A. M., 2.

Kississing area: Canada G. S., 6.

Martin Lake area: Christie, A. M., 1.

Snake Rapids area: Eastwood, G. E. P.

Southern area: MacKay, B. R., 2.

Historical geology.

Athabaska series, Proterozoic: Conybeare C. E. B., 2 .

Goldfields area: Christie, A. M., 1.

Kississing area: Canada G. S., 6.

Martin Lake area: Christie, A. M., 1.

Southern area: MacKay, B. R., 2.

Petrology.

Goldfields area, red radioactive rocks: Conybeare, C. E. B., 3.

Kississing area: Canada G. S., 6.

Snake Rapids area: Eastwood, G, E. P.

Stylolites in pre-Cambrian quartzite, Alice Iake area: Conybeare, C. E. B., 1
Saskatchewan-Continued

Physical geology.

Kississing area: Canada G. S., 6.

Scaphopoda. See also Mollusca.

Dentalium, Pennsylvanian, Texas: Miller, A. K., 3.

Schist, Pennsylvania, Wissahickon schist at Philadelphia: Weiss, J.

Sedimentary facies. See Facies.

Sedimentary petrography, universal stage, use: Gilbert, C. M.; 2.

Sedimentary petrology.

General: Rittenhouse, G., 4.

Red bed coloration: Robb, G. L., 2.

Ste. Genevieve formation, oolite: Shrode, R. S.

Sedimentary rocks. See also Petrology; Rock descriptions; Limestone; Sandstone, etc.

Canada, North Pacific region: Canada G. S., 1.

Classification: Dapples, E. C., 2.

Cross-bedding: Scott, G. R., 2.

Facies: McKee, E. D., 1; Moore, R. C., 4. Magnetic polarization: Torreson, $\mathrm{O}$. W.

Magnetism: Graham, J. W.

Manitoba, File-Tramping Lakes area, Harrison, J. M., 1.

Wanipigow Lake area: Davies, J. F.

Mid-Atlantic Ridge: Shand, S. J.

Montana, Tiber damsite, petrography : MeConnell, D., 3.

New Mexico, Colfax Co.: Griggs, R. L.

Northwest Territories, Carp Lakes area: Miller, M. L.

Beaverlodge and Hottah Lakes: Henderson, J. F., 1.

Oklahoma, Verden sandstone, origin: Evans, O. F., 3.

Oregon, Kerby quadrangle: Wells, F. G., 2.

Oscillation chart, by oil-well Foraminifera, Terrebone Parish, La.: Israelsky, M. C., 1.

Petrography, universal stage: Gilbert, C. M., 2.

Petrology: Rittenhouse, G., 4.

Porosity, cementation factor: Rosenfeld, M. A.

Nittany dolomite: Folk, R. L., 1.

Petrographic control: Griffiths, J. C., 1 .

Quebec, Forget Lake area, Saguenay County : Longley, W. W., 2.

Wakeham Lake area: Claveau, J., 3.

Red beds, origin: Krynine, P. D., 2.

Ripple marks : Evans, O. F., 2.

Rockbursts: Wuerker, R. G.

Sandstone: Tallman, S. L.

Sedimentology, trends: Russell, R. D.

South Dakota, Angostura dam, petrography: Berman, J.

Texas, northeastern, Upper Jurassic: Swain, F. M., 3.

Textbook: Pettijohn, F. J.

Unconformities, origin: Stewart, W. A. 
Sedimentary structures.

Illinois, Cave in Rock district, fluorspar beds: Grogan, R. M., 1.

Stylolites, Saskatchewan: Conybeare, C. E. B., 1.

Sedimentation. See also Erosion.

Bauxite deposits, stratigraphy, origin: Harder, E. C., 2.

California, Lake Elsinore, bottom sampling: Mann, J. F., Jr.

Coal, lines of research: Dapples, E. C., 1.

Cyclic, Paleozoic: Moore, R. C., 7; Wanless, $\mathbf{H}$. $R$.

Alaska Highway area, British Columbia : Laudon, L. R., 2.

Appalachians : Willard, B., 2.

Determination by pollen analysis: Knox, A. $\mathbf{S}$.

Environments, criteria: Rich, J. L., 2.

Glacial: Holmes, C. D., 2.

Gulf Coust, geosynclinal: Murray, G. E., Jr., 1.

Sedimentary deposits, oil formation: Link, W. K.

Gulf of Mexico: Trask, P. D.

Louisiana, Terrebonne Parish, oil-well oscillation chart: Israelsky, M. C., 1

Missouri River sediments: Keller, W. D., 3.

New Mexico, Salado formation, Permian, deposition cycle: Lang, W. T. B.

Ohio, Dunkard series, cycles: Cross, A. T., 3.

Monongahela series, cycles: Cross, A. T., 3.

Organic sediments, paleoecology: Breger, I. A.

Pleistocene problems: Ray, L. L., 2.

Relation to diastrophism: Lawson, A. C. 2.

Sediment sorting: Inman, D. L., 1.

Soil particles, settling time: Tanner, C. B.

Submarine geology and Pleistocene: Phleger, F. B., Jr., 4.

Tectonies and environments, sedimentary : Krumbein, W. C.

Texas, Salado formation, Permian deposition cycle: Lang, W. T. B.

Textbook: Pettijohn, F. J.

Water-drop sand movement: Ekern, P. C., Jr.

Sedimentology, trends: Russell, R. D.

Sediments.

Arctic Basin, origin: Emery, K. O.

Cosmic: Heilborn, G.

Deep sea, age determinations: Kulp, J. L., 3.

Origin and deposition: Phleger, F. B., Jr., 3.

Gulf of California, clay minerals: Grim, R. F., 2.

Gulf of Mexico, western: Stetson, H. C. Maine, Stover Cove: Donohue, J. J. Missouri River: Keller, W. D., 3. New York, Paleozoic: Swartz, F. M., 1.
Sediments-Continued

Pacific Ocean, clay minerals: Grim, R. E., 2.

Pennsylvania, Paleozoic: Swartz, F. M., 1. Sand mixtures, synthesis: Menard, H. W., Jr.

Screen analysis: LeRoy, L. W., 5.

Settling analysis: LeRoy, L. W., 6.

Shape analysis: LeRoy, L. W., 8.

Seismology. See also Earthquakes.

Bibliography: Milne, W. G.

Deep-focus earthquakes, travel-time curves: Stechschulte, V. C.

Earthquake shocks, first motion: Byerly, P., 2.

Earthquake study, southern California: Gutenberg, B., 5.

General: Earthquake Notes.

Hawaii, volcanic tremor: Finch, R. H.

Microseisms, tripartite measurements: Leet, L. D., 2.

PP/P waves, ratio of amplitude variation: Byerly, P., 1

Seismic waves, form: Ricker, N., 1.

Seismicity of the earth: Gutenberg, B., 2.

Seismograms, interpretation: Gutenberg, B., 4.

Strain seismograph pairs: Benioff, H., 2.

Volcanic tremors: Finch, R. H.

Selenium, geological occurrence: Trelease, S. F.

Serpentine.

Equilibrium relations: Bowen, N. L., 3.

Maine, northwestern, Spencer area: Wing, L. A.

Oregon, Winona dam, Rogue River, petrography: Mielenz, R. C., 4.

Shale. See also Oil shale.

California, Santa Maria district: Regan, L. J., Jr.

Kansas, phosphate-bearing, Pennsylvania : Runnels, R. T., 2.

Missouri, Paleozoic, mineral content: Allen, V. T., 1.

Sampling procedure: Prince, A. T.

Washington, North Dam, Grand Coulee, petrography: Irwin, W. H., 3.

Shenandoah Valley, Virginia, Elkton area, floor: King, P. B., 2.

Shore lines. See also Beaches; Changes of level; Glacial lakes; Terraces.

Bars and troughs, formation: Shepard, F. P., 3.

California, Gaviota quadrangle: Upson, J. E., 2.

Mugu Lagoon area: Inman, D. L., 2.

Santa Barbara, Quaternary: Upson, J. E., 1.

Continental shelves, processes: Evans, 0 . F., 1.

Formation, absence of wave action: Keulegan, G. $H$.

Greenland, Franz 'Joseph Fiord area: Bütler, H., 1.

Louisiana, Recent: Russell, R. J., 1. 
Shore lines-Continued

Maryland, erosion: Singewald, J. T., Jr, Erosion measurements: Slaughter, T. H.

Massachusetts, Boston Harbor, Shirley Gut, changes: Nichols, R. L.

Michigan, Benzie County: Calver, J. L., 1. Grand Marais Embayment: Tague, G. C. Texas, strand-line oil fields, Jim Hogg County: Freeman, J. C.

Siderite, thermal analysis: Rowland, R. A. Silica.

Canada, deposits: MacPherson, A. R.

Minerals, absorption of infrared radiation: Keller, W. D., 4.

North Carolina, resources: Broadhurst, S. $D$.

Ontario, Potsdam sandstone: Keith, M. L.

Washington, Skagit River deposits: Popoff, C. C., 2.

Silica structure, $\mathrm{AlPO}_{4}$, isostructural: Hummel, F. A.

Silicates.

Crystallization, melts and magmas: Barth, T. F. W., 3.

Micas, decomposition and resynthesis: Roy, R., 1.

Structure: Marshall, C. E.

Sillimanite, general: Riddle, F. H.

Sills. See also Intrusions.

Palisade diabase, New Jersey: Guimarães, D.

Silurian. See also Paleontology, Silurian.

Alberta, Paleozoic pre. Waterways strata, Plains area: McGehee, J. R.

Appalachian Basin, northern: Rittenhouse, G., 1; U. S. G. S., 1, no. 100.

Paleography: Rittenhouse, G., 6 .

British Columbia, Alaska Highway: Laudon, L. R., 2.

Illinois, Niagaran facies: Lowenstam, $H$. A., 2.

Pennsylvania, Schuylkill County: Mills, J. $R$.

Tennessee, Brownsport formation: Amsden, T. W., 1.

Central:, Wilson, C. W., Jr.

Utah: Hintze, F. F., 1.

Silver.

Antimonial, Cobalt, Ontario: Wells, R. C.

California, Quail Hill area mines, Calaveras Co.: Heyl, G. R., 6 .

Colorado, Caribou mine: Ridland, G. C.

La Plata district: Eckel, E. B., 1.

Mineral Point district: Hazen, S. W., Jr. Poughkeepsie dictrict: Hazen, S. W., Jr.

Idaho, Yankee Fork district: Anderson, A. L., 1.

Mexico, Guanajuato mining district: Guiza, R., Jr.

Minerals, synthesis: Bêland, R., 4 .

Ontario, Miller Lake-O'Brien mine, mineralization: Bastin, E. S.

Sink holes, New Mexico: Perkins, A. M.

Slate, general: Behre, C. H., Jr., 2.
Sodium sulfate, North Dakota: Grossman, I. G.

Soils.

Classification: Hunt, C. B., 1.

Clays, weathering sequence and X-ray diffraction analysis: Willis, A. L.

Erosion: Ellison, W. D.

Genesis: Hunt, C. B., 1.

Gumbotil, formation, relation to overlying loess: Krusekopf, H. H.

Illinois loess, properties, distribution: Smith, G. D.

lowa, classification, Wisconsin drift area: Riecken, F. F.

Loess-derived: Hutton, C. E.

Kansas, Pleistocene strata, fossil soils: Frye, J. C., 4.

Mineral analyses by X-ray spectrometer: Jeffries, C. D., 2.

Mineralogical composition, properties: Grim, R. E., 1.

Minerals: Jeffries, C. D., 1.

Mississippi Valley, soil mechanics and foundation exploration: Turnbull, $\mathrm{W}$. J.

Newfoundland, Port au Port Peninsula: Wolfe, P. E., 1.

Upper Humber valley: Wolfe, P. E., 2. Old, geologic significance: Branson, E. B., 2.

Pleistocene geology and soil science: Thorp, J., 1.

Utah, Lake Bonneville area: Hunt, C. B., 1.

Zinc content, field determination: Lakin, H. W.

Solifluction, periglacial: Wolfe, C. W., 2.

South Carolina.

Barite: Van Horn, E. C., 3.

Carolina Bays, ellipticity: Prouty, W F.

Mesozoic, cross section: Southeastern Geol. Soc., Mesozoic Comm., 2.

Paleobotany, Santee Valley: Berry, E. W., 3.

South Dakota

Economic geology.

Beryl, Helen pegmatite: Gries, J. P.

Gold, Homestake mine: McLaughlin, D. $\mathbf{H}$.

Manganese, Missouri Valley: Pesonen, $\mathbf{P}$. E., 1

Sioux quartzite: Baldwin, W. B.

Geologic maps.

Angostura irrigation project: Iittleton, R. T.

Pleasant Valley, pegmatites: Burns, R. E.

Whitewood anticline area, northern: Petsch, B. C.

Ground water.

Angostura irrigation project: Littleton, R. T.

Historical geology.

Fall River County: Rothrock, E P.

Missouri Valley manganese deposits: Pesonen, P. E., 1. 
South Dakota-Continued

Historical geology-Continued

Pierre formation, Upper Cretaceous: Welles, S. P.

Whitewood anticline area, northern: Petsch, B. C.

Mineralogy.

Arrojadite, Nickel Plate mine: Lindberg, M. L. L., 2.

Graftonite, Nickel Plate mine: Lindberg, M. L. L., 2.

Scorzalite: Pecora, W. T., 2.

Paleontology.

Alzadasaurus, elasmosaur, Cretaceous, Iona: Welles, S. P.

Floras, Black Hills, Cretaceous, Tertiary: MeIntosh, A. C.

I'etrology.

Angostura Dam, sediments, petrography: Berman, J.

Minnewasta limestone: Schlocker, J.

Pegmatites, perthite, petrogenesis, Black Hills: Higazy, R. A.

Sioux quartzite: Baldwin, W. B.

Physical geology.

Black Hills, northern, structure: Noble, J. A.

Fall River County, structures: Rothrock, E. $P$.

Homestake mine, structure: Noble, J. A.

Physiographic geology.

Glacial boulders: Waring, G. A.

Missouri River, age: Warren, C. R.

Speleology. See Caves.

Spongiae. See Porifera.

Springs. See also Ground water; Thermal waters.

Geochemistry and ore discovery: White, D. E., 3.

Haiti, Cul-de-Sac plain: Taylor, G. C., Jr., 1.

Gonaives plain: Taylor, G. C., Jr., 2.

Manitoba, salt: Cameron, E. L.

New Mexico, Colfax Co.: Griggs, R. L.

Ohio, Blue Hole: Stout, W. E.

Thermal, utilization, geochemical and geophysical approach: White, D. E., 2.

Yellowstone National Park: Chittenden, H. M.; Muench, J. R.

Stalactites.

California, Bristol Dry Lake cave: Hicks, F.

Virginia, Skyline Caverns: Henderson, E. P., 6.

Staurolite, Georgia: Furcron, A. S.

Stereophotography, paleontological tool: Evitt, W. R.

Stocks. See Intrusions.

Stone nets, stripes, Wind River Mts., Wyoming: Richmond, G. M.

Stratigraphy. See also Historical geology.

Mexico: Garfias, V. R.

Petroleum exploration, importance, methods: LeRoy, L. W., 3.
Stratigraphy-Continued

Submarine geology, relation: Shepard, F. P., 5 .

Unconformities, origin: Stewart, W. A.

Stream capture. See also Drainage changes.

Kentucky, Eagle Creek, Pliocene: Jillson, W. R., 7.

Oregon, Long Tom River: Baldwin, E. $\mathbf{M}$.

Pennsylvania, Appalachian: Thompson, H. D., 1.

Streams. See Rivers.

Stress, rock behavior: McCutchen, W. R.

Strontium, geologic time measurement: Ahrens, L. H., 2.

Structural geology. See also Physical geology.

Appalachians: Rodgers, J., 2.

Canadian Shield, orogenic development: Wilson, J. T., 2.

Interpretation by aerial photographs: Henderson, J. F., 2.

Mexico: Garfias, V. R.

Pennsylvania, Wissahickon schist at Philadelphia: Weiss, J.

Petrofabrics analysis, application: Wagner, W. R., 2.

Symbols, mapping: Wagner, W. R., 2.

Textbooks: Nevin, C. M., 2.

Utah, Iron Springs district: Mackin, J. H. Structures, mine roof: Holland, C. T.

Study and teaching.

Colorado School of Mines, geological engineering: Van Tuyl, F. M., 2.

Crystallography: Fisher, D. J., 1; Peacock, M. A., 2; Tunell, G., 3.

Law of rationality: Donnay, J. D. H., 2. Museum role: Gordon, S. G.

Economic geologist, training: Broderick, T. $M$.

Field courses, University of Southern California: Holwerda, $\mathrm{J}$.

Geology departments, American colleges, directory: Johnson, D.

Geology, scope: Danloux-Dumesnils, M.

Laval University, Quebec, museum: Bureau, R. I.

Optical mineralogy, teaching aids: von Huene, R., 1.

Photogeology: Tator, B. A., 2.

Rock cycle: Keller, W. D., 1.

Stadia rod, miniature: Ellison, S. P., Jr., 1.

Virginia, geologic study: Allen, R. M., Jr., 1.

Stylolites.

Colorado, origin: Blake, D. B.

Development: Shaub, B. M., 1.

Saskatchewan, Alice Lake area, pre-Cambrian quartzite: Conybeare, C. E. B., 1.

Submarine geology.

Atlantic Ocean, floor: Tolstoy, I., 2.

Mid-Atlantic Ridge: Ewing, W. M., 2; Shand, S. J.; Tolstoy, I., 1.

Northwest of Bermuda, seismic study: Ewing, W. M., 1.

Seismic study: Ewing, W. M., 3. 
Submarine geology-Continued

California, offshore ocean-bottom structure: Raitt, R. W.

Santa Barbara coast, submarine topography: Thompson, W. C.

Earthquakes: Press, F.; Tolstoy, I., 3.

Faulting, Nova Scotia: Cameron, H. L., 2. Gulf of Maine: Chadwick, G. H.

Gulf of Mexico: Treadwell, T. K., Jr.

Ocean floors: Gutenberg, B., 6.

Seismic reflections: Hersey, J. B., 1, 2.

Tectonics: Bucher, W. H.

Pacific Ocean, sea mounts: Carsola, A.

Petroleum exploration: Chase, J. L.

Pleistocene research: Phleger, F. B., Jr., 4.

Relation to stratigraphy: Shepard, F.P., 5 .

Sea bottom slope determination, seismic reflection: Agocs, W. B., 1.

Sediments, deep sea, age determination: Kulp, J. L., 3.

Origin, deposition: Phleger, F. B., Jr., 3.

Pacific Ocean, clays: Grim, R. E., 2.

Submarine canyons: Shepard, F. P., 2.

California, La Jolla area: Shepard, F. P., 4.

Monterey: Shepard, F. P., 1.

Canyon heads, depth changes: Shepard, F. P., 6.

Subsidence. See also Changes of level.

California, Long Beach Harbor area: Gilluly, J., 2.

Subsurface geologic methods: LeRoy, L. W., 1. Sulfur.

Colorado, Gunnison Forks: Dings, M. G.

Texas, occurrence: Bartlett, Z. W.

Surveys.

State geological, directory: Melvin, J. H., 2.

Scope and activities: Laird, W. M., 2. U. S. Geological Survey: Wrather, W. E.

Alaska work: Reed, J. C., 2.

1949: Reed, J. C., 3.

Coal work: Averitt, P., 2.

Pennsylvania, anthracite fields: Rothrock, H. E., 4.

Colorado work: Dane, C. H.

Engincering geology: Eckel, E. B., 2.

Great Smoky Mts. National Park, gcologic mapping: Hadley, J. B., 4.

Sylvite, identification with halite: Roberts, C. N. Symbols for geologic maps: Goddard, E. N., 2. Symmetry, definition: Bader, H., 2.

Symposia.

Alberta: Clark, L. M., 1.

Boylston Street Fishweir II, Boston, Massachusetts: Barghoorn, E. S., Jr., 1.

Genetics, paleontology, and evolution: Jepson, G. L., 1.

Lead: Dunham, K. C.

Mineral aggregates: Am. Soc. Testing Materials.

Pleistocene research: Flint, R. F., 3.

Sedimentary facies: Longwell, C. R., 2.
Symposia-Continued

Subsurface geologic methods: Lekoy, L W., 1.

Zinc: Dunham, K. C.

Synclines, California, Devil's Punchbowl area: Laurie, A. M.

Systems.

Albite-water, gravitational field: Ramberg, H., 3.

$\mathrm{Al}_{2} \mathrm{O}_{3}-\mathrm{SiO}_{2}-\mathrm{H}_{2} \mathrm{O}$ : Roy, R., 3.

BeO. $\mathrm{Al}_{2} \mathrm{O}_{3}-\mathrm{Al}_{2} \mathrm{O}_{3}$ : Foster, W. R., 1.

$\mathrm{CaO}-\mathrm{CO}_{2}-\mathrm{H}_{2} \mathrm{O}$ : Faust, G. T., 2.

Fe-Ni-S: Hawley, J. E., 2.

$\mathrm{H}_{2} \mathrm{O}-\mathrm{CO}_{2}$ : Faust, G. T., 2.

$\mathrm{H}_{2} \mathrm{O}-\mathrm{Na}_{2} \mathrm{O}-\mathrm{SiO}_{2}$, saturation curve: Morey, G. W.

$\mathrm{K}_{2} \mathrm{O}-\mathrm{MgO}-\mathrm{SiO}_{2}$ : Roedder, E. W., 1.

$\mathrm{K}_{2} \mathrm{O}-\mathrm{MgO}-\mathrm{Al}_{2} \mathrm{O}_{3}-\mathrm{SiO}_{2}$, phase equilibrium: Schairer, J. F.

Leucite-SiO ${ }_{2}-\mathrm{FeO}$ : Roedder, E. W., 2.

$\mathrm{Li}, 2-\mathrm{Al}_{2} \mathrm{O}_{3}-\mathrm{SiO}_{2}$, phase equilibria: $\mathrm{Roy}, \mathrm{R}$. 2.

$\mathrm{MgO}-\mathrm{CaO}-\mathrm{CO}_{2}-\mathrm{H}_{2} \mathrm{O}$ : Faust, G. T., 2.

MgO- $\mathrm{H}_{2} \mathrm{O}$ : Faust: G. T., 2.

$\mathrm{MgO}-\mathrm{SiO}_{2}-\mathrm{H}_{2} \mathrm{O}$ : Bowen: N. L., 1.

$\mathrm{NaAlSiO}_{4}$-CaO.Al $\mathrm{O}_{2} \mathrm{O}_{3}$ : Goldsmith, J. R., 1.

$\mathrm{NaAlSi}_{3} \mathrm{O}_{8}-\mathrm{KAlSi}_{3} \mathrm{O}_{8}-\mathrm{H}_{2} \mathrm{O}$ : Bowen, N. L., 4.

$\mathrm{Na}_{2} \mathrm{O}-\mathrm{SiO}_{2}-\mathrm{H}_{2} \mathrm{O}$ : Friedman, I. I., 4.

Silicate, crystallization: Barth, T. F. W., 3.

Hydrous, liquid immiscibility: Friedman, I. I., 3.

Tables of formations. See Geologic formations, lists, sections, tables.

Tale.

California, Silver Lake area: Wright, L. A., 1.

Equilibrium relations: Bowen, N. L., 3. General: Engel, A. E. J., 1.

New Mexico, Carlsbad: Bailey, R. K.

New York: Engel, A. E. J., 2.

North Carolina: Stuckey, J. L.

Southwestern: Van Horn, E. C., 1.

Vermont, Carleton quarry, Chester, geologic map: Billings, M. P.

Mad River mine, Fayston, geologic map: Billings, $\mathbf{M}$. $\mathbf{P}$.

Rousseau prospect, Cambridge, geologic map: Billings, $\mathbf{M}$. $\mathbf{P}$.

Tantalum, New Mexico, Harding deposit: Berliner, $\mathbf{M}$. H.

Taxonomy, procedure: Schenk, E. T.

Technique.

Apparatus.

Chromograph, element determination: Stevens, R. E.

Computor, earthquake records: Housner, G. W.

Decrepitation apparatus: Smith, F. G., 4. Decrepitation geothermometer: Peach, $P$. A., 1.

Electron microscope in geological research: Bates, T. F., 1

Ground water, measurement device: Irwin, W. H., 6 . 
Technique-Continued

Apparatus-Continued

Microscope for infrared light: Bailly, R. J.

Ore minerals, laboratory study: Smith, F. G., 3.

Petrographic microscope: Winchell, $\mathbf{H}$.

Point counter for thin sections: Chayes, F., 1.

Polarograph, quantitative determination of trace elements: Claffy, E. W.

Pressure vessels, high temperature investigations: Tuttle, O. F., 3 .

Refractometer, for infrared light: Bailly, R. J.

Silicon carbide, gem identification: De Ment, J. A., 2.

Rock slicing machine: Anonymous, 3.

Slide rule, road log mileage computation: Ingham, A. I., 2.

Thermal analysis: Kulp, J. L., 2.

Clay specimens: Kerr, P. F., 3.

Geophysical.

Airborne magnetometer: Jensen, H., 2.

Poulter method, seismic exploration: Novelly, W. 0 .

Radio waves, earth penetration: Anonymous, 2.

Second vertical derivatives and maynetic anomalies: Hendersen, R. G.

Seismic reflections from beneath the ocean floor: Hersey, J. B., 1.

Seismic surveying: Heroy, W. B., Jr.

Subsurface geologic methods: Stommel, H. E.

Mapping.

Sketchmaster, geologic map compilation from aerial photographs: Sohn, I. G., 1.

Mineral exploration.

Gravimetric exploration: García Rojas, A., 1.

Mineralogical methods: Kerr, P. F., 5 .

Ore value determination, narrow veins: Kruger, F. C.

Prospecting, Geiger counters: Bateman, J. D., 1; Faul, H., 1; Stead, F. W.

Radio waves: Barret, W. M.

\section{Mineralogic.}

Aragonite-calcite differentiation, differential thermal analysis: Faust, G. T., 1.

Charting five and six variables on bound-: ing tetrahedra of hypertetrahedra: Mertie, J. B., Jr.

Clays and shales, sampling procedure: Prince, A. T.

Clays, crystal forms by electron microscope: Mackie, W. Z.

Crystal models, preparation: Gude, A. J.

Crystals, one-dimensional, computing structure factors: Donnay, G. H.

Etching iron meteorites: Reberholt, B. $O$.

Fragment sections: Gabelman, J. W., 1.

Heavy mineral study: Rittenhouse, G., 3.

Mounting cement: von Huene, R., 2.
Technique-Continued

Mineralogic-Continued

Ore minerals, laboratory study: Smith, F. G., 3 .

Phosphates, contact printing: Gault, H. R., 1.

Pleochroic haloes, phase contrast microscope: Rogers, D. H.

Polished sections of ores: Sampson, E.

Quartz determination: Foster, W. D.

Reflectivity, ore minerals: Folinsbee, R. E.

Refractive indices, micas and chlorites, measurement: Girault, J. P., 1.

High index liquids, prism method, twocircle goniometer: Wolfe, C. W., 6.

Soil clays, analysis, X-ray diffraction: Willis, A. L.

Soil minerals, analysis, X-ray spectrometer: Jeffries, C. D., 2.

Stain analysis: LeRoy, L. W., 7.

Subsurface samples: Rittenhouse, G., 3.

Thermal analysis, multiple differential: Kerr, P. F., 4.

Thermoluminescence, radioactivity test: Davis, W.

Thin sections: Gabelman, J. W., 1.

Grains: von Huene, R., 1.

Uranium, field analysis: Senftle, F. E.

X-ray analysis: Schieltz, N. C.

Misccllaneous.

Connate water, resistivity determinations: Wyllie, M. R. J.

Engineering geology, application: Robb, G. L., 1 .

Geologic temperatures, measurement: Friedman, I. I., 2.

Geologic time, measurement, strontium method: Ahrens, L. H., 2.

Glacier study: Sharp, R. P., 2.

Interpretation, ground conditions from geologic maps: U. S. G. S., 40.

Permeability of glacial material, measurement: Knodle, R. D.

Preservation of wet specimens: Arthur, M. A.

Spectrochemical analysis: Strock, L. W., 1.

Structural plane plotting: Biemesderfer, G. $\mathbf{K}$.

Subsurface geologic methods: LeRoy, L. W., 1.

Well cuttings; examination: Hills, J. M.

Zinc determination in plants, field method: Reichen, L. $\mathbf{E}$.

Zine in soils, field method: Lakin, H. W. Paleontologic.

Microfossils, slide mount: Fllis, B. F., 2.

Microvertebrate collecting: Hibbard, C. W., 5.

Paleobotanical: Andrews, H. N., Jr., 1.

Plant compressions, removal from rock surface: Abbott, M. L.

Petrographic.

Coal: Parks, B. C.

Electron microscopy: McCartney, J. T.

Fragment sections: Gabelman, J. W., 1. 
Technique-Continued

Petrographic-Continued

Insoluble residues: Grohskopf, J. G., Ireland, H. A., 1.

Mineral separator, electromagnetic: Frautschy, J. D.

Permeability analysis: Buell, A. W.

Petrofabric analysis: Fairbairn, H. W., 1.

Screen analysis: LeRoy, L. W., 5 .

Settling analysis: LeRoy, L. W., 6.

Shape analysis: LeRoy, L. W., 8.

Spectrochemical rock analysis: Strock, L. W., 2.

Stain analysis: LeRoy, L. W., 7.

Thin sections: Gabelman, J. W., 1.

Universal stage: Gilbert, C. M., 2.

Petroleum exploration.

Core analysis: Caran, J. G.; Edinger, W. M.

General: DeGolyer, E. L.

Magnetometer: Peters, J. W.

Micropaleontology: LeRoy, L. W., 4.

Photogeology: Brundall, L., 2; De Blieux, C. W.

Porosity determination: Rall, C. G.

Radio surveying, offshore areas: Soske, J. L.

Subsurface methods: LeRoy, L. W., 2.

Photographic.

Minerals, color photography: Fisher, L. W.

Rocks, thin sections: Anonymous, 3.

Stereoscopic photographs: Evitt, W. R.: Moyd, L., 2.

Stratigraphic.

Correlation, electric logs: Claurlet, $\Lambda$.

Electron microscope: Moore, C. $A$.

Water analysis: Crawford, J. G., 2.

Tectonics. See also Faulting; Folding; Orogeny; Structural geology.

Mexico: Alvare\%, M., $J_{i}$.

North America, eastern: Shatsky, N. S.

Orogenetic movements: Rutten, L. M. R.

United States, tectonic map, comments: Béthune, P. F., de.

Tektites: Von Gliszczynski, S.

Telluriries.

British Columbia: Warren, H. V., 2.

Canada: Thompson, Robert M., 1 .

Colorado, La Plata district: Eckel, F. B., 1.

Mineral descriptions: Thompson, Robert M., 1.

Temperature. Sce Earth, Tempcrature.

Tennessee.

Bibliography, west-central, Paleozoic, preCambrian: Braunstein, J., 2.

Geochemical investigation, Friends. Station zinc deposit: Hawkes, H. E., 1.

Great Smoky Mts. National Park, geologic mapping: Hadley, J. B., 4.

Economic geology.

Zinc, Bumpass Cove: Clayton, A. B.

Eastern: Brokaw, A. L.
Tennessec-Continued

Geologic maps.

Central, pre-Chattanooga: Wilson, C. W., $\mathrm{Jr}$.

Index: Boardman, L., 7.

Historical geology.

Brownsport formation, Silurian: Amsden, T. W., 1.

Facies, Ordovician: Rodgers, J., 1.

Mascot formation, Ordovician: Oder, C. R. L.

Paleozoic, south-central: Mississippi Geol. Soc., 2.

Pre-Chattanooga central: Wilson, C. W., $\mathrm{Jr}$.

Tertiary strata, limonite, origin: Schneider, $\mathbf{R}$.

Mineralogy.

Limonite layers, Tertiary strata, origin: Schneider, R.

I'alcontology.

Brownsport formation, Silurian: Amsden, T. W., 1.

Central, pre-Chattanooga: Wilson, C. W., Jr.

Graptolites, Athens shale, Ordovician: Decker, C. E.

retrology.

Chickamauga aggregatc, petrography: Holland, W. Y., 5.

Chickamauga limestone: Schlocker, J.

Petrography: Holland, W. Y., 3.

limestone, Graysville area: Holland, W. Y., 4.

Pickwick aggregate, petrography: Holland, W. Y., 5.

Terraces. Sce also Beaches; Shore lines.

Atlantic, north, and mid-Atlantic Ridgc area: Tolstoy, I., 1.

Louisiana, De Soto, Red River Parishes: Murray, G. E., Jr., 1.

New Mexico, Carlsbad Caverns area: Horberg, C. L., 3.

North Dakota, Oberon quadrangle: Tetrick, $P$. R.

Pennsylvania, Highspire, Susquehanna River, origin: Moss, J. H., 1.

Susquehanna River area: Peltier, L. C.

Physical effects, Pleistocene climate changes: Smith, H. T. U., 2.

Tertiary. Sce also Paleontology, Tertiary.

Alabama, Little Stave Creck: Bandy, $O$, L., 1.

Southeast: LaMoreaux, P. E., 1, 2.

Alberta, Callum Creek, West of Fifth Meridian: Canada G. S., 2.

Langford Creek area: Canada G. S., 8. Moon Creek area, West of Sixth Meridian: Canada G. S., 12.

Arizona, Upper Verde Valley development: Mahard, R. H.

British Columbia, Carp Lake area: Canada G. S., 3.

California, Coast Ranges, northern San Francisco Bay area: Weaver, C. E. 
Tertiary-Continued

California-Continued

Devil's Punchbowl area: Laurie, A. M.

Mount Diablo, Marysville Butte area: Stewart, R. B.; U. S. G. S., 2, no. 34 .

Penn zinc-copper mine, Calaveras County: Heyl, G. R., 3.

Puente Hills: Daviess, S. N.; U. S G. S., 1 , no. 83 .

Wildcat series: Stewart, R. E.

Colorado, Minnesota Creek area: Toenges, A. L., 2.

Naval Oil Shale Reserves 1 and 3, Garfield County: Duncan, D. C.; U. S. G. S. 1, no. 94 .

South Park: Stark, J. T.

Cuba, Somorrostro hills, Havana area, Miocene: Aguayo, C. G., 3.

Facies, Oligocene, White River formation: Wood, H. E., 2.

Western United States, relation to paleobotany: Axelrod, D. I., 1.

Florida, correlation: Vernon, R. $O$.

Great Basin: Axelrod, D. I., 2; Blackwelder, E., 1.

Gulf Coast, facies: Lowman, S. W., 1.

Kansas, Edwards County: McLaughlin, T. G.

Pawnee County: McLaughlin, T. G.

Kentucky, Eagle Creek piracy, Pliocene: Jillson, W. R., 7 .

Louisiana, De Soto, Red River Parishes: Murray, G. E., Jr., 1.

Natchitoches area: Maher, J. C., 3.

Pliocene-Pleistocene boundary: Russell, R. J., 2.

Maryland, subsurface: Overbeck, R. M.

Mexico, Reynosa area, Gulf Coast: Guzmán, E. J.

Mississippi, central: Mississippi Geol. Soc., 1.

Post-Claiborne: Monsour, E. T.

Wayne County: Hendy, W. J.

West-central: Thomas, E. P.

New Mexico, Colfax Co.: Griggs, R. L.

Ogallala algal limestone, Pliocene: Van Tuyl, F. M., 1.

North America: Wilson, R. W., 4.

North America-Europe, Pliocene-Pleistocene deposits: Moore, R. C., 5.

Oregon, coastal area, Cape Kiwanda-Cape Foulweather: Snavely, P. D., Jr.; U. S. G. S., 1 , no. 97 .

Newport-Waldport area, Lincoln Co.: Vokes, H. E., 1; U. S. G. S., 1, no. 88.

Pacific Coast, climate: Durham, J. W., 3. Panama: Woodring, W. P.

Rocky Mtn. region, Eocene facies: Van Houten, F. B.

Plains, Paleocene, map: Brown, R. W., 2.

Sedimentary facies, Gulf Coast: Lowman, S. W., 2.

Texas, Frio formation, Orange, Jefferson Counties: Reedy, M. F., Jr,
Tertiary-Continued

Texas-Continued

Southern Davis Mts.: Goldich, S. S., 1.

Squire field: Huffman, G. G., 1.

Strake field: Huffman, G. G., 1.

Trans-Pecos region: West Texas Geol. Soc., 1.

Utah: Kay, J. L.

Vermont, Brandon lignite: Barghoorn, E. S., Jr., 5.

Virginia, Yorktown: Cushman, J. A., 2.

Washington, Pend Oreille County: Schroeder, M. C.

Texas.

Geophysical investigation, Coal Creek serpentine, Blanco and Gillespie Counties: Romberg, F., 2.

Jameson area, gravity survey: Brown, $\mathbf{H}$. Economic geology.

Bentonite, south-central, Eocene: Pence, F. K., 1.

Ceramic materials: Pence, F. K., 2.

Clay, north-central, Cisco group: Plummer, F. B.

Coal: Stenzel, H. B., 2.

Grand Saline salt dome, structure: Balk, $\mathbf{R}$. Iron, Llano region: Barnes, V. E., 1.

Mercury, Terlingua district: Yates, R. G.

Natural gas, developments, 1948: Ammon, W. L., 2; Clark, G. C., 1; Henderson, C. F.; Mettner, F. E.; Scrafford, J. B.

Continental shelf exploration: McGee, D. A.

Resources: Culberson, 0 .

Permian (?) rocks, Colorado River Valley: Moore, R. C., 2; U. S. G. S. 1, no. 80.

Petroleum, Arick field: Shepherd, G. F. Benedum field: Deegan, C. J., 1. Blackfoot field: Branson, D. 0 .

Continental shelf exploration: McGee, D. A.

Developments, 1948: Ammon, W. L., 2; Clark, G. C., 1; Henderson, C. F.; Mettner, F. E.; Serafford, J. B.

Merigale-Paul field: Moore, $\mathbf{H}$.

New Hope field: Carpenter, C. B.

Resources: Culberson, 0 .

Sheridan field: Hill, H. B., 1.

Squire field: Huffman, G. G., 1 .

Strake field: Huffman, G. G., 1.

Strand-line oil fields, Jim Hogg County: Freeman, J. C.

Todd field: Imbt, R. F.

Salt, occurrence: Bartlett, Z. W.

Salt domes, eastern: Clark, G. C., 2.

Scurry County, limestone-reef development: Stormont, D. $\mathbf{H}$.

Sulfur, occurrence: Bartlett, Z. W.

Zinc-lead, Montezuma-Chinati deposits, Presidio County: McMillan, W. D.

\section{Geologic maps.}

Barrilla Mts.: Eifler, G. K., Jr.

Big Bend region: Maxwell, R. A., 1.

Borden County: Ellis, W. C. 
Texas-Continued

Geologic maps-Continued

Buck Hill quadrangle, Brewster County: Goldich, S. S., 3.

Ceramic materials: Pence, F. K., 2.

Coal Creek serpentine, Blanco and Gillespie Counties: Romberg, F., 2.

Colorado River Valley, Permian: Moore, R. C., 2; U. S. G. S. 1, no. 80 .

Culberson-Hudspeth Counties area: King, P. B., 1; U. S. G. S. 1, no. 90 .

Davis Mts., southern: Goldich, S. S., 1, 2.

Elephant Mtn. area, Brewster County: Goldich, S. S., 3.

Glass Mts.: West Texas Geol. Soc., 5.

Gulf Coast: Sundstrom, R. W.

High Plains: Barnes, J. R.

Hueco Mts.: West Texas Geol. Soc., 5, 6. Iron Mtn. area, Llano County: Barnes, V. E., 1.

Maravillas Creek area: Graves, R. W., Jr. Montezuma-Chinati area: MeMillan, W. D. Northeastern, Cretaceous: Bergquist, $\mathbf{H}$. R.; U. S. G. S. 1, no. 98.

Panhandle, paleogeology: Roth, R. I., 2.

Pennsylvanian clay outcrops, north-central: Plummer, F. B.

Permian(?) rocks, Colorado River Valley: Moore, R. C., 2; U. S. G. S. 1, no. 80.

Rich Lake playa: West Texas Geol. Soc., 3.

Sierra Blanca area: Smith, J. F., Jr., 1.

Southwest: West Texas Geol. Soc., 2.

Tinija Range area: Graves, R. W., Jr.

Trans-Pecos region: West Texas Geol. Soc., 5.

Van Horn uplift: West Texas Geol. Soc., 6.

Ground water.

Borden County: Ellis, W. C.

El Paso region: Sayre, A. N., 3; Scalapino, R. A.

General: Broadhurst, W. L., 2.

High Plains: Alexander, W. H., Jr., 1, 2; Broadhurst, W. L., 1, 3.

Southern: Barnes, J. R.

Linn-Faysville area: Follett, C. R.

Matagorda County: Sundstrom, R. W.

Historical geology.

Big Bend National Park: Maxwell, R. A., 2.

Big Bend region: Maxwell, R. A., 1.

Buck Hill quadrangle, Cretaceous, Tertiary: Goldich, S. S., 3.

Comanchean, Fört Worth: Gray, J. H.

Connell sandstone, Simpson group, Ordovician: Schweers, R. H.

Culbersor.-Hudspeth Counties area: King, P. B., 1; U. S. G. S. 1, no. 90 .

Ellenburger group, Ordovician: Hendricks, L.

Frio formation, Orange, Jefferson Cos.: Reedy, M. F., Jr.

High Plains, Upper Cenozoic: Evans, G. I.
Texas-Continued

Historical geology-Continued

Hueco Mts., pre-Permian: West Texas Geol. Soc., 6.

Jurassic, Upper, northeastern: Swain, F. M., 3.

Lawson-Chapman area, Pennsylvanian reef: Ammon, W. L., 1.

Marathon region: Graves, R. W., Jr.

Marathon uplift, pre-Permian: West Texas Geol. Soc., 6.

Marfa Basin, Permian: Albritton, C. C., Jr., 1.

Panhandle, paleogeology: Roth, R. I., 2.

Pennsylvanian, limestone distribution, eastern Permian Basin: Conley, J. N.

Permian facies: Wheeler, R. R., 3.

Permian (?) rocks, Colorado River Valley: Moore, R. C., 2; U. S. G. S., 1, no. 80.

Salado formation, Permian, deposition cycle: Lang, W. T. B.

Sierra Blanca area: Smith, J. F., Jr., 1.

Simpson group, Ordovician: Bartley, J. H.

South Permian Basin, cross section: West Texas Geol. Soc., Strat. Prob. Comm.

Southwest: West Texas Geol. Soc., 2 .

Southwest, Cenozoic: West Texas Geol. Soc., 3.

Squire oil field: Huffman, G. G., 1.

Strake oil field: Huffman, G. G., 1.

Stratigraphic units, subsurface, nomenclature: Israelsky, M. C., 2.

Trans-Pecos area, conglomerates: Smith, J. F., Jr,, 2.

Cretaceous: West Texas Geol. Soc., 1.

Davis Mts.: Goldich, S. S., 1.

Green Valley, Paradise Valley: Goldich, S. S., 1, 2.

Permian: West Texas Geol. Soc., 5.

Tertiary: West Texas Geol. Soc., 1.

Well section: DeFord, R. K.

Van Horn uplift, pre-Permian: West Texas Geol. Soc., 6.

Woodbine formation, Cretaceous: Bergquist, H. R.; U. S. G. S., 1, no. 98 .

Woodford black shale, Devonian: Ellison, S. P., Jr., 2.

Word series, Permian, facies change: Roth, R. I., 1.

Mineralogy.

Uranium, Barringer Hill: Dake, H. C., 3.

Paleontology.

Algae, Apache Mts., Permian: Johnson, J. H., 2.

Amphibian spine, Permian: Lundelius, E. Foraminifera, Walnut formation, Lower Cretaceous: Loeblich, A. R., Jr., 2.

Frio formation, Orange, Jefferson Counties: Reedy, M. F., Jr.

Man, Clear Fork, Pleistocene: Ray, C. N.

Microfossils in plesiosaur matrix, Lake Waco, Cretaceous: Graham, J. J., 1.

Ostracoda, Upper Jurassic: Swain, F. M., 3. 
Texas-Continued

Paleontology-Continued

Paleorhinus, Camp Springs, Triassic: Langston, W.. Jr., 1.

Pisees, tooth plates, Vale formation, Permian: Wilson, J. A.

Scaphopoda, Pennsylvanian: Miller, A. K., 3.

Trilobita, Wilberns limestone, Cambrian: Wilson, J. L.

Woodbine formation, Cretaceous: Bergquist, H. R.; U. S. G. S. 1, no. 98.

Petrology.

Alkalic rocks, Brewster County: Lonsdale, J. T., 1.

Big Bend National Park: Lonsdale, J. T., 2.

Buck Hill quadrangle: Goldich, S. S., 3.

Ellenburger group, Ordovician: Hendricks, L.

Hamilton Dam gravel: Holland, W. Y., 2. Heavy minerals, Upper Jurassic: Swain: F. M., 3.

Marshall Ford dam aggregate, petrography: Holland, W. Y., 6.

Trans-Pecos region, Buck Hill volcanics: Goldich, S. S., 2.

Physical geology.

Dunes, clay, origin, Corpus Christi: Huffman, G. G., 2.

Faults, interpretation from seismic reflections: Quarles, M. W., Jr.

Folding, Permian: Wheeler, R. R., 3.

Grand Saline salt dome, structure: Balk, $R$.

Shallow structures, west-central: Brodie, G. $\mathrm{H}$.

Physiographic geology.

Petroleum, strand-line oil fields, Jim Hogg County: Freeman, J. C.

Pluvial lakes, age: Antevs, E. V., 2.

Textbooks:

Evolution: Simpson, G. G., 3.

Geology: Emmons, W. H.

Geology and man: Landes; K. K., 1.

Geology for engineers: Trefethen, J. M., 1.

Historical geology: Dunbar, C. O.; Moore, R. C., 1.

Introduction to college geology: Holmes, C. D., 1.

Mineralogy: Hurlbut, C. S., Jr., 1.

Petroleum geology: Lalicker, C. G.

Physical geology: Miller, W. J.

Physical geology and man: Landes, K. K., 2.

Physical geology, laboratory manual: Bloomer, R. 0 .

Sedimentary rocks: Pettijohn, F. J.

Structural geology: Nevin, C. M., 2.

Structural petrology of deformed rocks: Fairbairn, H. W., 1.

Thallium, geochemistry: Rankama, K. K.

Thaw lakes, Alaska, Seward Peninsula: Hopkins, D. M.
Thaw sinks, Alaska, Seward Peninsula: Hopkins, D. $M$.

Thermal analysis.

Aragonite-calcite differentiation: Faust, G. T., 1.

Clay, reference specimens: Kerr, P. F., 3.

Equipment, technique: Kerr, P. F., 4.

Kaolinite: Gruver, R. M.

Miea: Roy, R., 1.

Rhodochrosite: Kulp, J. L., 1.

Siderite: Rowland, R. A.

Thermal waters. See also Springs.

Alaska, Great Sitkin Island: Byers, F. M. Jr.

Umnak Island: Byers, F. M., Jr.

Utilization, geochemical and geophysical approach: White, D. E., 2.

Yellowstone National Park, geyser development, May 22, 1946, Norris Basin: Turner, D. S.

Thermoluminescence, radioactivity test: Davis, W.

Thrusts and thrusting. See also Faulting; Physical geology.

Alberta, Foothills structures: Link, T. A., 3.

Appalachian Mts.: Rodgers, J., 2.

Nevada, Muddy Mtn. area: Longwell, C. R., 1.

Thunder eggs, origin: Reed, M. F.

Till.

California, June Lake district: Putnam, W. C.

Illinois, Wisconsin age: Horberg, C. L., 2.

Iowa, hillside seepage, Iowan drift, Howand County: Kirkham, D.

Shelby County: Ruhe, R. V.

Wisconsin drift area soils: Riecken, F. F.

Massachusetts, Boston area: Judson, $\mathrm{S}$. S., Jr.

Tin, Ontario, Linklater Lake, Thunder Bay area: Chisholm, E. O., 1.

Titanium.

Florida, deposits: Thoenen, J. R.

General: Gillson, J. L.

Quebec, Allard Lake district: Hammond, $P$.

Aeromagnetic survey: Bourret, $\mathrm{W}$ Tourmaline, synthesis, stability: Smith, F. G., 1.

Tracks and trails.

Coloredo, Flag Ridge, Lower Jurassic: Faul, H., 2.

Lyons sandstone, Front Range: Thompson, W. 0 .

Greenland, East, Triassic: Nielsen, E., 2.

Oniscoidichnus for Isopodichnus Brady, 1947: Brady, L. F.

Triassic. See also Paleontology, Triassic.

Alberta, Rocky Mtn. Front Ranges, Bow River area: Clark, L. M., 2.

Arizona, Moenkopi formation, Sycamore Canyon: Price, W. E., Jr.

Atlantic Coastal Plain, subsurface: Richards, H. G., 1. 
Triassic-Continued

British Columbia, Carp Lake area: Canada G. S., 3.

Greenland, East, trails: Nielsen, E., 2.

Mexico, Zacatecas: Maldonado-Koerdell, M., 3.

Nevada, Basin and Range province, facies: Muller, S. W.

New Jersey, Delaware Valley: McLaughlin, D. B.

New Mexico, Colfax Co.: Griggs, R. I.

North America, paleotectonic, paleogeologic maps: Eardley, A. J, 2.

Pennsylvania, Delaware Valley: McLaughlin, D. B.

Southern: Stose, G. W., 2.

Utah: Stokes, W. L., 2.

Trilobita. See also Crustacea; Arthropoda.

Arizona, Cambrian: Stoyanow, A. A., 2.

California, Lower Cambrian, Marble Mts.: Riccio, J. F.

Dolichoharpes, generic description: Whittington, $\mathbf{H}$. $B$.

Eobronteidae, Ordovician: Sinclair, G. W., 1.

Loganopeltoides, Loganopeltis, facial sutures: Raw, F.

Montana, homonyms, synonyms, Unper Cambrian faunas: Lochman, $C$.

Missouri, Dolichoharpes, Ordovician: Whittington, H. B.

Oklahoma: Frederickson, E. A., Jr., 2. Dalmanites oklahomae, Silurian: Richardson, E. S., Jr., 1.

Honey Creek formation, Upper Cambrian: Frederickson, E. A., Jr., 1.

Texas, Wilberns limestone, Cambrian: Wilson, J. L., 1.

Utah, Garden City formation, Ordovician: Ross, R. J., Jr.

Vermont, Monkton formation, Lower Cambrian: Tasch, $\mathbf{P}$.

Virginia, Dolichoharpes, Ordovician: Whittington, H. B.

Trinidad. See also West Indies.

Cancellariidae, Miocene Gastropoda: Marks, J. G.

Globigerina oozes, fossil, ages: Stainforth, R. M., 1.

Multiple reflections: Higgins, G. E.

Sphaeroidina, Tertiary: Cushman, J. A., 1 , no. 325 .

Tuff, Arizona, Canelo Hills, spheroids: Feth, J. II., 1.

\section{Tungsten.}

California, Bishop district: Bateman, P. C.

Cuba, Isle of Pines: Bundy, P. A.

Twinning, quartz: Gault, H. R., 2.

Unconformities.

Alberta, Langford Creek area: Canada G. S., 8 .

California, Puente Hills: Daviess, S. N.; U. S. G. S., 1, no. 83 .

Classification: Scott, G. R., 1.

Criteria: LeRoy, L. W., 3; Seott, G. R., 1.
Unconformities-Continued

Definition: Scott, G. R., 1.

Field determinations: Scott, G. R., 1.

New Mexico, Mississippian rocks: Laudon, L. R., 1.

Nomenclature: Stewart, W. A.

Northwest Territories, Fort Good Hope area, Devonian: Warren, P. S., 2.

Origin: Stewart, W. A.

Overlap and nonconformity: Lahee, $\mathbf{F}$. H., 2.

Soil beds, significance: Branson, E. B., 2.

Utah-Colorado, Green, Yampa River Canyons, Dinosaur Natl. Monument: Untermann, G. E., 1.

Underground water. Sce Ground water.

United States. See also the various states.

Geologic mapping, status: Boardman, L., 10.

Geologic systems, areal exposure, relation to time: Higgs, D. V.

Magnetic profile, Colorado-Indiana: Jensen, H., 1.

Meteorites: Henderson, E. P., 1.

Mississippi Valley, field conference, Cenozoic geology: Leighton, M. M., 1.

Soil mechanics-geology relation, foundation exploration, lower Mississippi Valley: Turnbull, W. J.

State geological surveys, directory: Melvin, J. H., 2.

Scope and activities: Laird, W. M., 2.

Economic geology.

Atlantic Coastal Plain, petroleum: Straley, H. W., 2.

Ceramic materials, occurrence, bibliography: Ries, H., 3.

Clay, reference localities: Kerr, P. F., 2.

Coal, reserves: Bryson, R. P.; Fieldner, A. C.

Western: Parry, V. F.

Gravel, lower Mississippi Valley: Waterways Expt. Sta.

Lead, Mississippi Valley: Behre, C. H., Jr., 1.

Lignite, reserves, western: Bryson, R. P.

Magnetometer exploration: Peters, J. W.

Mineral resources, 1948 review: Davidson, D. $M$.

Problems: Lasky, S. G., 3.

Natural gas, Appalachian fields, composition, properties: Headlee, A. J. W.

Exploration, 1948: Lahee, F. H., 1. Western: Tatum, J. L.

Mid-Continent region, Arbuckle and Ellenburger formations: Bartram, J. G.

Reserves: Moulton, G. F.; Oberfell, G. G.

Rocky Mts., developments, 1948: Dorn, C. $\mathrm{L}$.

Petroleum, exploration, 1948: Lahee, F. H., 1.

Western: Tatum, J. L.

Fields: Ver Wiebe, W. A., 1. Gulf Coast: Deegan, C. J., 2. 
United States-Continued

Economic geology-Continued

Petroleum-Continued

Formation, active-surface catalysts, Gulf Coast: Brooks, B. T.

Mid-Continent region, Arbuckle and Ellenburger formations: Bartram, J. G.

Photogeology, Gulf Coast exploration: De Blieux, C. W.

Reserves: Culberson, O.; Moulton, G. F.; Pratt, W. E.

Roeky Mts., developments, 1948: Dorn, C. $\mathbf{L}$.

Phosphate: McKelvey, V. E.

Reefs, limestone, geophysical exploration: Agnich, F. J.

Zinc, Mississippi Valley: Behre, C. H., Jr., 1.

Geologic maps.

Appalachians, southern, Cambrian, preCambrian: King, P. B., 6.

Igneous rocks, Mesozoic, northern Gulf Coastal Plain: Moody, C. L.

Pegmatites: Cameron, E. N.

Rocky Mts. and Plains, Paleocene: Brown, R. W., 2.

Ground water.

Areas: Millis, J. B.

Limestone terranes, hydrology and physiography: Swinnerton, A. C., 1.

Pacific Coast beaches, level: Isaacs, J. D. Historical geology.

Appalachian Basin, northern, early Silurian: Rittenhouse, G., 1; U. S. G. S. 1 , no. 100

Silurian: Rittenhouse, G., 6.

Appalachians, southern, Cambrian, preCambrian: King, P. B., 6.

Mississippian: Stockdale, P. B.

Ocoee series, pre-Cambrian: Stose, $G$. W., 1.

Basin and Range province, facies: Muller, . S. W.

Colorado Plateau, facies: McKee, E. D., 1. Cyclic sedimentation, Paleozoic: Moore, $\mathbf{R}$. C., 7; Wanless, H. R.

Appalachians: Willard, B., 2.

Diorama, geological: Lobeck, A. K., 2.

Facies, sequences: Sloss, L. L., 1.

Fish distribution and Pleistocene hydrography: Hubbs, C. L.

General, maps: Lobeck, A. K., 1.

Great Basin: Blackwelder, E., 1.

Climatic changes: Antevs, E. V., 1.

Tertiary: Axelrod, D. I., 2.

Gulf Coast, sedimentary facies: Lowman, S. W., 1,2 .

Gulf region, geosynclinal sedimentation: Murray, G. E., Jr., 2.

Mid-Continent, Missouri series, Pennsylvanian, facies change: Roth, R. I., 1.

Oligocenè facies, White River formation: Wood, H. E., 2.

Pacific Coast, Tertiary climate: Durham, J. W.., 8.
United States-Continued

Historical geology-Continued

Pennsylvanian system, divisions: Moore, R. C., 3 .

Phosphoria formation: McKelvey, V. E.

Queenston shale, Ordovician, northern Appalachian Basin: Rittenhouse, G., 2.

Rocky Mtn. region, Eocene facies: Van Houten, F. B.

Tertiary facies, Far West: Axelrod, D. I. 1.

Mineralogy.

Appalachian region, diamonds: Holden, R. J.

Monazite sand, Atlantic Coast: Jones, W. H., 3 .

Paleontology.

Cephalopoda, Mississippian, central and western: Miller, A. K., 5.

Cubitostrea, speciation, Gulf Coast, Tertiary: Stenzel, H. B., 1.

Fish distribution and Pleistocene hydrography: Hubbs, C. L.

Magothy formation, Cretaceous, conifers: Penny, J. S.

Ostracoda, Eueytherura, Gulf Coast, Cretaceous, Tertiary: Weingeist, $L$.

Western interior, early Tertiary: Swain, F. M., 1.

Promerycochoerinae, Tertiary oreodonts: Schultz, C. B.

Sphaeroidina, Tertiary: Cushman, J. A., 1, no. 325.

Sphenophyllum, Psaronius, anatomy, Carboniferous: Reed, F, D., 1.

Tetracorals, Devonian, revision: Stumm, E. C., 2.

Western Interior, paleobotany, Tertiary: Wilson, L. R., 2.

\section{Petrology.}

Igneous rocks, Mesozoic, northern Gulf Coastal Plain: Moody, C. L.

Lake Superior soft ixon ores: Tyler, S. A. Lignite, petrography: Parks, B. C.

Pegmatites, structure: Cameron, E. N.

Physical geology.

Appalachian structure: Rodgers, J., 2

Coastal areas, sea level changes: Marmer, H. A.

Great Basin: Blackwelder, E., 1.

Great Lakes area, crustal movement: Hobbs, W. H., 2.

Mounds, mima, origin: Price, W. A., 1.

Tectonic map, comments: Béthune, P. F., de.

Tectonics, Interior coal basin, north-central: Hager, D., 1.

Physiographic geology.

Diorama, geological: Lobeck, A. K., 2.

Drainage, Appalachian Mts., relation to structure: Thompson, H. D., 2.

Glaciers, vanishing: Heald, W. F., 2.

Great Basin: Blackwelder, E., 1.

Leaching of carbonates in loess and glacial drift, age correlation: Flint, R. F., 2, 


\section{United States-Continued}

Physiographic geology-Continued

Limestone terranes, hydrology and physiography: Swinnerton, A. C., 1.

Loess, south Mississippi Valley: Wascher, H. L.

Mississippi River, valley and delta: Baulig, H.

Photogeology, Gulf Coast exploration: De Blieux, C. W.

Pimple mounds, origin: Krinitzky, E. L.

Pleistocene hydrography: Hubbs, C. L.

United States Geological Survey. See Surveys.

Universal stage, sedimentary petrography, application: Gilbert, C. M., 2.

Uranium. See also Radioactive minerals; Radioactivity.

Arizona, Hillside mine, minerals : Axelrod, J. M., 2.

British Columbia, prospecting: Stevenson, J. $\mathrm{s}$.

Canada: Lang, A. H., 3 .

Crystal structure: Lukesh, J. S.

Field analysis: Senftle, F. E.

General: Savage, W. S.

Igneous rocks, ultramafic, content: Davis, G. L.

Minerals : Muilenberg, G. A.

Occurrence: Everhart, D. L.; Gustafson, J. K.; Joubin, F. R.

Ontario, Theano Point: Lang, A. H., 2, 3. Prospecting: U. S. Atomic Energy Comm.; White, D. J.

Canada: Lang, A. H., 1.

Geiger-Muller equipment: Stead, F. W.

Resources: Gustafson, J. K.

Texas, Barringer Hill: Dake, H. C., 3. Utah.

Soil genesis, Utah Valley: Hunt, C. B., 1. Eeonomic geology.

Clay deposits, pre-Bonneville: Hunt, C. B., 2.

East Tintic district, alteration, ore guide: Lovering, T. S., 1.

Fluorite, Topaz Mountain: Fitch, C. A., Jr.

Gilsonite: Crawford, A. L.

Uinta Basin: Murray, A. N.

Hydrocarbons: Crawford, A. L.

Lead-zinc, Bingham area: Hunt, R. N.

Natural gas: Hansen, G. H.

Clay Basin field: Fidlar, M. M.

Oil shales, Green River: Eisenberg, J. M., 1.

Petroleum: Hansen, G. H.

Phosphate: McKelvey, V. E.

Geologic maps.

Bingham area, sketch map: Hunt, R. N.

Iron Springs district, intrusions: Mackin, J. $H$.

Markagunt Plateau, eastern: Gregory, H. E.

Southwestern, vanadium region: Fischer, R. P., 1.

\section{Utah-Continued}

Geologic maps-Continued

Three Peaks laccolith, Iron Springs district: Mackin, J. H.

Tooele Valley: Thomas, H. E.

Ground water.

Jordan Valley: Táylor, G. H.

Tooele Valley: Thomas, H. E.

Histerical geology.

Basin and Range area: Granger, A. E.

Bryce Canyon: Spitznas, R. L., 1.

Cambrian: Schneider, $\mathrm{H}$.

Carboniferous: Williams, J. Stewart, 2.

Cretaceous: Bissell, H. J.

Upper, facies: Spieker, E. M.

Devonian: Hintze, F. F., 2.

Garden City formation, Ordovician: Ross, R. J., Jr.

General: Hansen, G. H.; Williams, J. Stewart, 1.

Green, Yampa River Canyons, Dinosaur Natl. Monument: Untermann, G. E., 1.

Jurassic: Stokes, W. L., 2.

Markagunt Plateau, eastern: Gregory, H. E.

Moenkopi formation, ripple marks: McKee, E. D., 3.

Morgan formation, Pennsylvanian: Untermann, G. E., 2.

Ordovician: Hintze, L. F.

Permian: Williams, J. Stewart, 2.

Pre-Cambrian: Blackwelder, E., 2.

Quaternary: Marsell, R. E., 1.

Silurian: Hintze, F. F., 1.

Tertiary: Kay, J. L.

Tooele Valley: Thomas, H. E.

Triassic: Stokes, W. L., 2.

Uinta Basin, Paleozoic: Baker, A. A.

Mineralogy.

Clay deposits, pre-Bonneville: Hunt, C. B., 2.

Clayton Peak, collecting: Field, V. W.

Nontronite, Ringham: Stringham, B. F. Paleontology.

Dinosaur National Monument: Stokes, W. L., 1.

Flora, Pliocene, Cache Valley: Brown, R.

Trilobite zones, Garden City formation, Ordovician: Ross, R. J., Jr.

\section{Petrology.}

Igneous rocks: Bullock, K. C.

Iron Springs district, intrusions: Mackin, J. $\mathrm{H}$.

Newton Dam area, riprap, petrography: Irwin, W. H., 4.

Volcanic tuff: Rhoades, R. F., 2.

Three Peaks Iaccolith, Iron Springs district: Mackin, J. H.

Physical geology.

Basin and Range area: Granger, A. E.

Basin Range faulting: Marsell, R. E., 2.

Green Yampa River Canyons, Dinosaur Natl. Monument: Untermann, G. E., 1 .

Structure, orogeny: Eardley, A. J., 3.

Wasatch fault zone: Marsell, R. E., 2. 
Utah-Continued

Physiographic geology.

Bryce Canyon, Utah: Spitznas, R. L., 1. General: Buss, W. R.

Valleys, Popocatepetl Volcano, Mexico: White, S. E., 2.

Vanadium.

Colorado: Fischer, R. P., 1.

Origin: Fischer, R. P., 2.

Utah: Fiseher, R. P., 1.

Veins.

Arkansas, Ouachita Mts. : Engel, A. E. J., 4

Colorado, Cripple Creek area, gold veins: Koschmann, A. H., 1.

Gold quartz, ribbon structure: McKinstry, H. E., 1.

Mineralization, zoning theories: Schmitt, H. A., 1 .

Montana, Butte, formation: Sales, R. H.

Uranium-bearing: Everhart, D. L.

Ventifacts.

Physical effects, Pleistocene climate changes: Smith, H. T. U., 2.

Wyoming, Big Horn Mt. area, Pleistocene: Sharp, R. P., 3.

Vermiculite.

Crystal structure: Barshad, I.

Wyoming, Glendo area: Love, J. D., 2; U. S. G. S., 1, no. 92.

Vermont.

Carleton tale quarry, Chester: Billings, M. $P$.

East-central area: White, W. S.

Keene-Brattleboro area: Moore, G. E., Jr., $1,2$.

Mad River talc mine, Fayston: Billings, M. $P$.

Rousseau talc prospect, Cambridge: Billings, $M . P$.

Historical geology.

Brandon lignite, Tertiary: Barghoorn, E. S., Jr., 5; Spackman, W., Jr.

Keene-Brattleboro area: Moore, G. E., Jr., $1,2$.

Paleontology.

Brandon lignite, flora: Barghoorn, E. S., Jr., 3; Spackman, W., Jr.

Monkton formation, Lower Cambrian: Tasch, P.

Petrology.

Keene-Brattleboro area: Moore, G. E., Jr., $1,2$.

Physical geology.

Cleavage, east-central: White, W. S.

Physiographic geology.

Physical features: Jacobs, E. C.

Vertebrata (general). See also Amphibia; Aves, etc.

Bibliography, 1939-1943: Camp, C. L., 1. California, San Francisco Bay region, late Cenozoic: Savage, D. E.
Vertebrata-Continued

Collecting, microvertebrates: Hibbard, c. W., 5 .

Colorado, South Park: Stark, J. T.

El Salvador, Pleistocene: Stirton, R. A.

Evolution: Simpson, G. G., 3; Watson, D. M. S.

Comparative anatomy: Davis, D. D.

Hoplophoneus, Tertiary, Wyoming : Hough, J. $\mathbf{R}$.

Kentucky, Lower Blue Licks, Pleistocene: Jillson, W. R., 1, 2.

Mexico, Quaternary: Maldonado-Koerdell, M., 1.

Pleistocene: Hibbard, C. W.. 4.

Virginia.

Field for geologic study: Allen, R. M., Jr., 1.

Economic geology.

Construction materials, Alleghany County: Parrott, W. T.

Geologic maps.

Alleghany County: Parrott, W. T.

Historical geology.

Chickahominy formation, Eocene: Cushman, J. A., 2.

Upper Mississippian, southwestern: Wilpolt, R. H.; U. S. G. S., 2, no. 38 , Mineralogy.

"Punch" Jones diamond: Holden, R. J.

Rare minerals: Jones, W. H., 1 .

Paleontology.

Dolichoharpes, Edinsburg formation, Ordovician: Whittington, $\mathrm{H}$. $\mathrm{B}$.

Foraminifera, York County, Eocene: Cushman, J. A., 2.

Graptolites, Athens shale, Ordovician: Decker, C. E.

Pisces, Triassic, Prince William County: Baer, F. M.

Physiographic geology.

Shenandoah Valley, Elkton area: King, P. B., 2.

Skyline Caverns, stalactites: Fienderson, E. P., 6.

Volcanic ash.

Oklahoma: Ham, W. E., 2.

Valle Grande crater, Great Plains, Pleistocene, source: Swineford, A.

Volcanic rocks. See Igneous rocks.

Volcanism.

Alaska, Great Sitkin Island: Byers, F. M. Jr.

Umnak Island: Byers, F. M., Jr.

Colorado, San Juan Mts.: Larsen, E. S., Jr., 3.

General : Escher, B. G.

Great Basin: Blackwelder, E.,

Gulf Coastal Plain, northern: Moody, c. $\mathbf{L}$.

Hawaii, steam blast eruptions: Jaggar, T. A.

Tremors: Finch, R. H.

Martinique, steam blast eruptions: Jaggar, T. A. 
Volcanism-Continued

Paleozoic geosynelines and island ares: Kay, G. M., 2.

Steam blast eruptions: Jaggar, T. A.

Tremors: Finch, R. H.

Volcanoes.

Alaska, Akutan Volcano: Anonymous, 5.

California, Lassen Volcano, eruptions: Loomis, B. F.

Central America: Griffin, N. J.

Huwaii, rock types, petrography: Mncdonald, G. A., 1.

Mauna Loa, activity: Macdonald, G. A., 3.

Eruption: Macdonald, G. A., 2.

Martinique, Mt. Pelée: Jaggar, T. A.

Mexico: González Reyna, J., 1.

Paricutin: González Reyna, J., 1; Holtedahl, H.; James, C. C.; Martin, G. P. R.

Popocatepetl: White, S. E., 2.

Oregon, Crater Lake, origin: Eisenberg, J. M., 2.

Sublimate concentration and distribution : De Ment, J. A., 3.

Washington.

ficonomic geology.

Lead-zinc, Stevens County: Cole, J. W., 1.

Limestone, Snohomish County: Popoff, C. C., 1.

Nonmetallic minerals: Valentine, G. M. Northport district, ore zones: Campbell, C. D.

Perlite: Huntting, M. T.

Silica deposits, Skagit River: Popoff, C. C., 2.

Geologic maps.

Gladstone Mtn. area, Stevens County: Cole, J. W., 1.

Index: Boardman, L., 8.

Silica deposits, Skagit River, sketch maps: Popoff, C. C., 2.

Wenatchee perlite area: Huntting, M. T.

Ground water.

Spokane area: McMacken, J. G.

Historical geology.

Methow quadrangle: Barksdale, J. D., 1.

Pend Oreille County, Tertiary: Schroeder, M. C.

Pleistocene, Puget Lowland, peat beds: Hansen, H. P., 4.

\section{Mineralogy.}

Gems, origin, occurrence: Glover, S. L., 2. Mackinaw nickel mine: Milton, C., 2.

Muscovite, Snohomish County: Axelrod, J. M., 1.

\section{Paleontology.}

Foraminifera, Astoria formation, Miocene: Rau, W. W.

Quinault formation, Pliocene: Cushman, J. A., 5.

Rhinoceros mold in basalt, Blue Lake: Chappell, W. M.
Washington-Continued

Petrology.

Columbia Basin, aggregate, petrography : Cook, R. H.; Mielenz, R. C., 6, 8.

Cowlitz River gravel, petrography: Haff, J. C., 4.

Grand Coulee damsite, Brett pit gravel: Holland, W. Y., 1.

Granitization, Okanogan County: Misch, P., 3.

Paleozoic sediments, Riverside-Conconully area: Misch, P., 1.

Swauk formation: Coombs, H. A.

Limestone silicification, Oroville area: Crosby, J. W.

North Dam, Grand Coulee, basalt, shale, petrography: Irwin, W. H., 3.

Pasco district, aggregate, petrography: Holland, W. Y., 7; Rhoades, R. F., 3.

Ross Dām abutment, Seattle, petrography: McConnell, D., 1.

Physical geology.

Gravel deposit, clay-filled, Columbia River: Cary, A. S.

Jointing, basalt, Rock Island : Fuller, R. E.

Lewiston Basin, structure: Graham, C. E.

Russell Forest, petrified wood: Bateman, E. S.

Snoqualmie Pass region, chemical weathering, low temperature: Williams, J. E.

Physiographic geology.

Corkscrew Mountain : Dysart, A.

Water, underground. See Ground water.

Water and wind gaps.

Pennsylvania, Appalachian: Thompson, H. D., 1.

Leibert's gap, origin: Myers, R. E.

Water resources, Alabama, southeastern: $U$. S. G. S., 39 .

Weathering. See also Erosion.

Bauxite deposits, origin: Harder, E. C., 2.

Chemical, low temperature: Williams, J. E.

Iowa, southwest, loess-derived soils: Hutton, C. E.

Soil clays, X-ray diffraction analysis: Willis, A. L.

Spheroidal, igneous rocks: Chapman, $R$. W., 2.

Well cuttings, examination: Hills, J. M.

West Indies. See also the various islands and countries.

Historical geology.

General: Butterlin, J.; Reed, F. R. C., 1.

Paleontology.

Cancellariidae, Miocene Gastropoda: Marks, J. G.

Foraminifera, Paleocene: Davies, L. M.

Pleistocene submarine core, Caribbean Sea: Phleger, F. B., Jr., 1.

Globigerina, ecologic interpretation: Bronniman, $P$.

Physical geology.

Greater Antilles, structure: Butterlin, J.

Mt. Pelée eruption, Martinique: Jaggar, T. A. 
West Virginia.

Geological Survey collection of drill cuttings: Martens, J. H. C.

Economic geology.

Natural gas: Price, P. H., 1; Tollefsor, E. H.; Woodward, H. P.

Jackson-Kanawha field: MeClain, A. H.

Petroleum: Price, P. H., 1; Woodward, H. $\mathbf{P}$.

Salt resources: Price, P. H., 2.

Geologic maps.

Index: Boardman, L., 9.

Ground water.

General: Johnston, H. F.

Historical geology.

Cambrian: Woodward, H. P.

Greenbrier formation: Rittenhouse, G., 5. Ordovician: Woodward, H. P.

Southern: Tollefson, E. H.

Upper Mississippian, southern: Wilpolt, R. H.; U. S. G. S. 2 , no. 38 .

Petrology.

Greenbrier formation: Hall, G. H.; Rittenhouse, G., 5 .

Physiographic geology.

Caves: Davies, W. E., 1.

Wind gaps. See Water and wind gaps.

Wind work.

California, brush fires, geologic effect: Patton, M. M.

Iowa, southwest, loess-derived soils: Hutton, C. E.

Mexico, Chiapas, erosion: Mullerried, F. K. G., 6 .

Periglacial: Wolfe, C. W., 2.

Physical effects, Pleistocene climate changes: Smith, H. T. U., 2.

Wyoming, Pleistocene ventifacts, Big Horn Mts, area: Sharp, R. P., 3.

Wisconsin.

Lake Michigan Basin, origin: Thwaites, F. T.

Periglacial features, Driftless Area: Smith, H. T. U., 1

Wisconsin arch, structural trends: Bieber, C. $\mathrm{L}$.

Worms, New York, Schenectady formation, Ordovician, new genus: Howell, B. F., 2. Wyoming.

Powder River Basin, geophysical investigations: Fenwick, W. H., 2.

Photogeology: Brundall, L., 1.

Economic geology.

Chromite, Casper Mtn.: Horton, F. W.

Glendo area: Love, J. D., 2; U. S. G. S., 1 , no 92 .

Natural gas, Church Buttes field: Carlson, R. F.

Fields, map: Keefer, E. K.

Newcastle sandstone, Mush Creek and Skull Creek area: Summerford, H. E., 1.

Oil shales, Green River: Eisenberg, J. M., 1.

Petroleum: Thomas, H. D., 1.

East Lance Creok field: McCanne, R. W.
Wyoming-Continued

Economic geology-Continued

Petroleum-Continued

Exploration, Powder River Basin, geophysical methods: Fenwick, W. H., 1 .

Fields, map: Keefer, E. K.

Lance Creek field: McCanne, R. W.

Little Buck Creek field: McCanne, R. W.

Lost Soldier field, Cambrian: Kampert, E. W.

Newcastle sandstone, lithofacies problems: Summerford, H. E., 2.

Mush Creek and Skull Creek area: Summerford, H. E., 1.

Salt Creek field: Mallory, R. W.

Phosphate: McKelvey, V. E.

Geologic maps.

Central western: Horberg, C. L., 1.

Cordierite deposits, Sherman quadrangle: Newhouse, W. H., 2.

Glendo area: Love, J. D., 2; U. S. G. S., 1, no. 92.

Gros Ventre Mts.: Swenson, F. A.

Hartville uplift: Denson, N. M., 1; U. S. G. S., no. 102 .

Mush Creek oil field: Dobbin, C. E., 1; U. S. G. S., 1, no. 103.

Osage oil field: Dobbin, C. E., 1; U. S. G. S., 1, no. 103 .

Powder River Basin: Love, J. D., 1; Wyo. Geol. Assoc.

Red Fork Powder River area: Carlson, C. $\mathrm{E}$.

Tongue River area: OsterwaIa, F. W., 1.

Ground water.

Glendo area: Love, J. D., 2; U. S. G. S., 1 , no. 92.

Historical geology.

Central-western: Horberg, C. L., 1.

Cretaceous, Upper, stratigraphic sections: Thompson, Raymond M.; U. S. G. S., 2, no. 36.

Ferris Mts. region: Heisey, E. L.

Ceneral: Thomas, H. D., 3.

Glendo area: Love, J. D., 2; U. S. G. S., 1, no. 92.

Gros Ventre Mts.: Swenson, F. A.

Hartville uplift: Denson, N. M., 1; U. S. G. S., 1 , no. 102 .

Powder River Basin: Fenwick, W. H., 2; Wyo. Geol. Assoc.

Mesozoic: Downs, G. R.

Paleozoic: Thomas, H. D., 2.

Sheep Mtn.: Honkala, F. S., 1.

Mineralogy.

Bentonite, fluorescence: Brown, B. W.

Jade, Long Creek: Cobb, H. S.

Paleontology.

Algae, Medicine Bow Mts.; Fenton, C. L. Ammonoidea, Greybull area, Upper Cretaceous: Haas, $0 ., 1$.

Hoplophoneus, subspecies: Hough, J. R.

Insectivore, Eocene Bridger formation: $\mathrm{Ga}$ zin, C. L. 
Wyoming-Continued

Paleontoloyy-Continued

Mammals, upper Eocene, Wind River Basin: Wood, A. E.

Nothosaurs, Alcova limestone: Zangerl, R. Petrology.

Bighorn Mts.: Osterwald, F. W., 2.

Cordierite deposits, Laramie Range: Newhouse, W. H., 2.

Eaglenest Creek aggregate, petrography: Mielenz, R. C., 1.

Gneisses, metamorphic rocks, structure control in formation: Newhouse, W. H., 1.

Long Creek jade deposit: Cobb, H. S.

Peridotite, Laramie Mts.: Albanese, J. P.

Physical geology.

Algal pillars: Brown, R. W., 1.

Bighorn Mts., structure: Osterwald, F. W., 2.

Hartville uplift, tectonic map: Denson, N. M., 2.

Old Faithful Geyser, regularity: Fix, P. F., 2 .

Powder River Basin, structure: Blackstone, D. L., Jr.

Structure: Thomas, H. D., 3.

Central-western: Horberg, C. L., 1.

Tongue River area, structure: Osterwald F. W., 1 .

Ventifacts, Pleistocene, Bighorn Mts, area: Sharp, R. P., 3.

Physiographic geology.

Gros Ventre Mts.: Swenson, F. A.

Wind River Mts., glacial geology: Holmes, G. W.; Moss, J. H., 2.

Moraines: Moss, J. H., 3.

Stone nets, stripes: Richmond, G. M.

$\mathrm{X}$-ray investigations.

Analysis, technique: Schieltz, N. C.

Cone-axis diffraction patterns: Fisher, D. J., 2.

Kaolin, Georgia: Nagelschmidt, G.

Lattice spacings for glancing angles, iron $x$-radiation: Kaiman, $S$.

Loess, Illinois: Whiteside, E. P.

Yellowstone National Park.

General: Chittenden, H. M.

Geysers: Bloss, F. D.; Muench, J. R.

Development, Norris Basin: Turner. D. $S$.

Old Faithful, regularity: Fix, P. F., 2 . Yukon

Springs: Muench, J. K.

McQueston area, geologic map: Bostock, H. S., 1 .

Mineral areas: Bonham, W. M.

Prospecting: Bostock, H. S., 2, 3.

Wolf Creek glacier, superglacial debris: Sharp, R. P., 4 .
Zeolites, colloidal properties: Marshall, C. E. Zinc.

British Columbia, Lead Empire group: Patmore, W. H.

Sullivan mine: Swanson, C. O., 1.

California, American Eagle-Blue Moon area: Eric, J. H., 2.

Big Bend mine, Butte Co.: Eric, J. H., 1.

Cerro Gordo mine area: Merriam, C. W. 1.

Foothill belt, Sierra Nevada: Heyl, G. R., 1.

Quail Hill area mines, Calaveras Co.: Heyl, G. R., 6.

Colorado, Mineral Point district: Hazen, S. W., Jr.

Poughkeepsie district: Hazen, S. W., Jr.

Idaho, Coeur d'Alene district: Shenon, P. J.

Kansas, Tri-State zinc-lead district: Ruhl, O.

Manitoba, Flin Flon mine: Tanton, T. L., 1.

Sherritt Gordon mine: Tanton, T. L., 1.

Mexico: González Reyna, J., 2.

Pachuca ores: Geyne, A. R.

Taxco district: Fowler, G. M.

Mississippi Valley: Behre, C. H., Jr., 1.

Missouri, Tri-State zinc-lead district: Ruhl, 0 .

Nevada, Pioche district: Young, E. B.

New Jersey, Franklin-Sterling area: Pinger, A. W.

New Mexico, Central mining district: Lasky, S. G., 1.

Houston-Thomas prospect, gravity exploration: Barnes, V. E., 2.

New York, St. Lawrence County: Hermance, $H$. $P$.

Oklahoma, Tri-State zinc-lead district: RuhI, $O$.

Plant content, field determination: Reichen, L. E.; Starr, C. C.

Saskatchewan, Flin Flon mine: Tanton, T. I., 1.

Soil content, field determination: Lakin, H. W.

Symposium: Dunham, K. C.

Tennessee, Bumpass Cove: Clayton, A. B. Eastern: Brokaw, A. I.

Friends Station: Hawkes, H. E., 1.

Texas, Montezuma-Chinati area: McMillan, W. D.

Tri-State region: Behre, C. H., Jr., 1.

Utah, Bingham area: Hunt, R. N.

Washington, Stevens County: Cole, J. W., 1.

Zirconium, minerals, synthesis, stability: Maurice, O. D., 2. 


